UNIVERSIDADE DE SÃO PAULO

FACULDADE DE FILOSOFIA, LETRAS E CIÊNCIAS HUMANAS

DEPARTAMENTO DE SOCIOLOGIA

PROGRAMA DE PÓS-GRADUAÇÃO EM SOCIOLOGIA

\title{
Mercado de trabalho e região: a articulação de duas problemáticas na perspectiva de um estudo de caso
}

Guilherme Gaspar de Freitas Xavier Sobrinho

\begin{abstract}
Tese apresentada ao Programa de Pós-Graduação em Sociologia do Departamento de Sociologia da Faculdade de Filosofia, Letras e Ciências Humanas da Universidade de São Paulo, para a obtenção do título de Doutor em Sociologia.
\end{abstract}

Orientadora: $\operatorname{Prof}^{\mathrm{a}} \operatorname{Dr}^{\mathrm{a}}$ Nadya Araujo Guimarães 

Mãe, esta tese é para ti, e deu mais trabalho do que aquela caixinha de goiabada revestida de palitos de fósforo, que fiz na aula de artes (parece que foi ontem, e o amor é o mesmo).

Ah, e a boa notícia é que não precisas ler-nem depois de terminar o Calvino!

Pae, aquela cerveja na "confeitariazinha da Duque" vai fazer uma baita falta, mas nesses vinte anos (já!), o sinal não se perdeu; teu contentamento é o meu contentamento, e assim por diante, como na latinha do sapóleo. 



\section{RESUMO}

Esta tese apóia-se em um estudo de caso realizado na Grande Santa Rosa, Rio Grande do Sul, Brasil, para discutir a categoria analítica "mercado de trabalho". Restrições ao conceito emergem em um tratamento teórico inspirado na nova sociologia econômica e se evidenciam na abordagem empírica. O trabalho de campo desenvolveu-se em 2002 e, a seguir, entre 2006 e 2007. Foram realizadas observações de inspiração etnográfica e entrevistas em profundidade; dados censitários, registros administrativos e pesquisa de documentação histórica constituíram-se em fontes complementares. Na região - autodenominada o "Berço Nacional da Soja", expressando o peso econômico e simbólico do produto -, a elevada participação da agricultura familiar na ocupação, a grande parcela de trabalho não-remunerado e as pequenas populações dos municípios que a integram seriam características suficientes para interpelar o caráter mercantil do uso do trabalho, bem como as ferramentas analíticas consagradas nas pesquisas sobre mercados de trabalho. O quadro regional, entretanto, se torna ainda mais desafiador pois abriga um setor industrial moderno, nucleado por duas empresas multinacionais, que empregam grande número de trabalhadores, influenciam fortemente a vida institucional da região e a inserem em circuitos de interações globais. A interconexão entre essas duas formas de circulação e uso do trabalho não sustenta uma interpretação dualista, e só adquire coerência quando se traz a problemática espacial para o centro da análise. Os nexos, historicamente tecidos, entre os múltiplos fatores - sociais, culturais e institucionais -, tão pertinentes na análise sociológica de um mercado de trabalho, associam-se às especificidades de uma configuração espacial concreta, atravessada pelas múltiplas escalas (local, nacional, global) que se sobrepõem e se articulam para constituí-la.

Palavras-chave: mercados / mercados de trabalho / região / sociologia econômica / Rio Grande do Sul (Brasil) 


\begin{abstract}
This thesis explores a case study in the "Grande Santa Rosa" region (Rio Grande do Sul, Brazil) aiming to contribute to recent discussions on the pertinence and heuristic value of "labor market" as an analytical tool in sociological analysis. Weaknesses of this concept grow from both a theoretical approach inspired in the new economic sociology, and the empirical results. Field research has been conducted in two periods: 2002 and 2006-2007 based upon ethnographic observation and in-depth interviews; census and administrative data as well as primary documents and historical information completed the collection of data sources. In this region - known as the "National Cradle of Soya Beans", evidence of the economic and symbolic importance of the product - some characteristics like the high labor force engagement on family based agriculture, the weight of non-paid work and the very small size of population in the municipalities would confront interpretations on the mercantile character of work relations and would challenge the pertinence of analytical tools currently used on sociological analysis of labor market. The nature of its social reality, however, looks even more challenging due to the presence of a modern industrial sector, driven by two large transnational corporations, employing a significant contingent of regional workers; those firms are major players on regional institutional life, brokering Grande Santa Rosa connections with global circuits. The links between those two different forms of labor circulation and economic insertion do not stand for dualistic interpretation. Coherence to be reached requires the spatial dimension to be brought to the center of analysis. The historical intertwine of social, cultural or institutional factors, crucial for the sociology of labor markets, requires the analysis to be grounded in the uniqueness of concrete spatial configuration, taking into account the overlapping and interaction of its multiple scales (local, national and global).
\end{abstract}

Key words: markets / labor markets / region / economic sociology / Brazil 


\section{AGRADECIMENTOS}

Ao concluir este trabalho, estou convencido de que os agradecimentos que devo ultrapassam em muito a convenção, pois contei não apenas com uma decisiva rede institucional de apoios, mas com o engajamento generoso de muitas pessoas.

À Fundação de Economia e Estatística (FEE), em que trabalho, presto meu agradecimento institucional, sem deixar de individualizar meu reconhecimento ao ex-presidente Aod Cunha de Moraes Jr., que se empenhou para viabilizar a autorização pelo Governo do Estado do Rio Grande do Sul para que eu realizasse essa formação; ao atual presidente, Adelar Fochezatto, e aos demais integrantes de ambas as gestões, que, nos sucessivos níveis hierárquicos, garantiram as condições para que eu desenvolvesse esta tese. Aos dois coordenadores que tive no Núcleo de Desenvolvimento Regional (NDR) da FEE, Carlos Águedo Paiva e Ivan Gerardo Tartaruga, agradeço a permanente e generosa atenção e apoio. Tantos colegas contribuíram e incentivaram este trabalho que não posso nominá-los, mas são amigos a quem, felizmente, terei muitas oportunidades de expressar minha gratidão. Destaco, pelo laço mais cotidiano, os colegas do Núcleo de Estudos do Trabalho (NET), que deixei ao sair, e os do NDR, que encontrei ao retornar.

Aos Programas de Pós-Graduação (PPG) em Economia, da Faculdade de Economia, Administração e Contabilidade da USP (FEA-USP), e em Geografia, da Faculdade de Filosofia, Letras e Ciências Humanas (FFLCH), em que cursei disciplinas que convergiam com meus interesses de pesquisa, agradeço a acolhida e a qualidade do trabalho que desenvolvem. Quanto ao nosso PPG em Sociologia da FFLCH, agradeço ao competente time de professores e à eficiente Secretaria, não podendo deixar de salientar a dedicação afetuosa da Ângela Ferraro de Souza.

Ao CNPq, agradeço a concessão da bolsa de estudos que me permitiu cursar o doutorado nessa Universidade um tanto "fora de mão" para um porto-alegrense, além de contribuir para a viabilização da pesquisa de campo.

Aos Professores Maria Cristina Cacciamali, do Departamento de Economia, e Alvaro Comin, do Departamento de Sociologia, agradeço as valiosas críticas e sugestões que apresentaram, em meu exame de Qualificação, e a disposição permanente a compartilhar seus conhecimentos e a incentivar este trabalho. Meu reconhecimento também ao Prof. Ricardo Abramovay, do Departamento de Economia, interlocutor arguto e generoso, na disciplina que com ele cursei, na FEA, e nas oportunidades em que a ele recorri, fora delas. Ao Prof. Bernardo Campolina Diniz, agradeço a orientação que me deu para superar algumas dúvidas, na metade da estrada.

Ter sido orientado pela Profa. Nadya Araujo Guimarães não foi uma sorte. A sorte contribuiu, é claro, para que se viabilizasse essa que era uma meta minha, estabelecida nove anos antes de eu ingressar no doutorado. Conhecia, já então, a qualidade de seus escritos, mas, ao 
presenciar as intervenções da Nadya ao longo de um GT da ANPOCS, pressenti nela as qualidades que eu gostaria de ver reunidas em um orientador, as quais vieram a se comprovar, sobejamente, nesses quatro anos (e pouco) de trabalho conjunto. Um pensamento rápido e original, solidamente fundamentado e rigoroso; generosidade, entusiasmo, caráter, bom humor e uma capacidade de trabalho impressionantes - parece bom? O resultado, claro, traz as minhas limitações, mas o processo não poderia ter sido melhor. Muitíssimo obrigado.

Quem diz que o processo da tese é muito solitário não foi orientado pela Nadya, que consagrou, e mantém com extremo zelo, a tradição de reunir regularmente seus alunos e colaboradores, para uma discussão dos resultados de pesquisa de cada um. Essa íntima convivência intelectual é muito produtiva e foi muito prazerosa. Eu não conseguiria recuperar os nomes de todos os parceiros que passaram por essa universidade dentro da Universidade, nos quatro anos em que dela tomei parte, tampouco dos muitos convidados especialíssimos que estiveram conosco para ajudar a resolver inquietações teóricas do momento. Agradeço muito especialmente às minhas colegas, Ana Cláudia Moreira Cardoso, Ana Lúcia Ferraz, Gisela Tartuce, Rosileide Rosendo e Sirlei Márcia de Oliveira, que encontrei ao ingressar, que muito contribuíram para a concepção e avanço desta tese, e com quem criei laços de cumplicidade e afeto que muito prezo. Do resto dessa variada turma, agradeço, com risco de omissões, a alguns interlocutores, com diversas entradas institucionais, que me ajudaram a apurar meu percurso, com suas idéias: Flávia Consoni, Jonas Bicev, Luís Felipe Hirano, Maria Carla Corrochano, Milena Estorniolo, Mônica Pedro, Monise Picanço, Murillo Alves de Brito, Nathalia Coelho, Priscila Faria Vieira e Uvanderson da Silva.

Muita gente querida, no Sul e no Sudeste - só para ir entrando no clima regional da tese me estimulou, me agüentou, quebrou galhos, torceu e, sobretudo, me alegrou. Uma seleção dos "paulistas" (de todos os cantos, inclusive do Rio Grande do Sul) não pode abrir mão dos supracitados, tampouco desses aqui: Altair Garcia, Andrei Koerner, Cícero Araújo, Cida Moreira, Eduardo Fragoaz, Giovanna Xavier, Inês Caetano, João Egydio Neto, João Saldanha e Leonardo Mello e Silva.

Na ponte lá-e-cá, portanto com merecida dupla contagem (para minha alegria): o Helio Alves e o quarteto Henrique Lessa, Kalinka Kaminski e suas (nossas!) pequenas Victória e Amanda*.

Nos pampas e seus "complementos" (parodiando Wilson Cano, mas isso só faz sentido no capítulo 3), este seleto time esteve bem perto: Ana Backes e Ingo Luger; Annie Wautier; Áurea e Lauro Breitbach; Denise Jardim** e Edu Neumann; Flávia Rieth, Paulo Huf e sua (nossa!) Paula*; Gabriela Andreucci; Graça Bulhões; Iara Ducceschi; Jurema Brites, Francisco Pereira da Silva, e seus (nossos!) Elisa* e Ramiro; Isabel Jornada e Flávio Fligespan; Lucrécia Calandro; Marilis

\footnotetext{
** Obrigado por me tirar parte do medo da antropologia, com tuas preciosas dicas para o trabalho de campo.

* Precioso trio de afilhadas!
} 
Almeida; Naira e Ricardo Franzoi; Paulo Roberto Pereira; Roberto Marcantonio e Eudoxia Machado; Sheila Borba; Silvia Balestreri e Alexandre Quadros; Sônia Reichel Pereira; Vasco Piva da Silva. [Não estar nessa lista não é desprestígio, certo?, a tantas outras pessoas não menos estimadas! É que esse grupinho aí padeceu mais com os meus humores de estudante grisalho].

A "familhada" ganha parágrafo próprio. Gente que não acaba mais, perguntando pela tese; chateando, como é próprio dos parentes; mimando, como também é. A Mãe já ganhou a tese toda, lá na primeira página. Meus irmãos e irmãs, cunhadas, a sobrinha Aurora e o Tio Willy me julgaram um tanto desaparecido, eu sei, mas é bom que eu lhes diga que, de minha parte, os tive sempre comigo, como deve ser, ou pelo menos é, carne da minha carne que são. E vamos pôr tudo em dia [inclusive as aulas de francês, Monsieur Le Aîné (tá certo?)]! O resto da árvore ganha um obrigado coletivo, em nome da concisão e da isonomia.

$\mathrm{O}$ último agradecimento é também coletivo e também muito sincero: às dezenas de pessoas que entrevistei e incontáveis com que conversei, ao longo da minha pesquisa na Grande Santa Rosa, expresso uma gratidão que é profissional, mas, igualmente, humana. A receptividade e a generosa disposição de contribuir com meu estudo foram a tônica dessa população, com quem passei a me sentir definitivamente ligado (e se eu contar que não cancelei a assinatura do jornal de lá?). 



\section{SUMÁRIO}

INTRODUÇ̃̃O

PARTE I - O TRABALHO SOCIAL E A SUA TERRITORIALIDADE ANTE A NOCC̃̃O DE MERCADO

1. A CATEGORIA "MERCADO" APLICADA AO TRABALHO: LIMITES E IMPLICAÇÕES

CONCEITUAIS

1.1. Uma agenda emergente: a abordagem sociológica dos mercados...................

1.2. O trabalho em sua forma emprego e a categoria mercado.............................21

1.3. Trabalho não-assalariado, não-trabalho e o alcance da matriz teórica...........33

2. A DIMENSÃO ESPACIAL: COMPLEXIDADE E REVALORIZAÇÃO ANTE O DECLÍNIO

DO "NACIONALISMO METODOLÓGICO" .....................................................................43

2.1. A globalização e o tensionamento do "nacional" desde fora.....................47

2.2. A (re)afirmação das instâncias subnacionais - o espaço regional e local....53

2.2.1. Algumas referências conceituais sobre "lugar" e "região".............................54

2.2.2. A "ortodoxia" dos distritos industriais e a preocupação com as grandes cidades

2.2.3. Uma tipologia das possíveis evoluções dos espaços locais...........................68

3. LEGADOS E LACUNAS: UM SELETIVO DIÁLOGO COM A REFLEXÃO BRASILEIRA733

3.1. Juarez Brandão Lopes: particularidades no nível local e uma generalização dualista..................................................................................................75

3.2. Francisco de Oliveira: uma leitura marxista em diferentes escalas...............80

3.3. Wilson Cano: "núcleo" e "periferia" na abordagem econômica das articulações regionais................................................................88

PARTE II - POSSÍVEIS LIÇÕES DE UM CASO “LONGÍNQUO”.......................................101

4. RUMO À FRONTEIRA: A ESTRATÉGIA METODOLÓGICA DA PESQUISA ....................102

4.1. A relevância de estudos em profundidade de mercados regionais de trabalho, para além das metrópoles e dos distritos......................102

4.2. A região estudada: uma escolha induzida pelo interesse analítico...............107

4.3. Um risco assumido....................................................................................110

4.4. O desenho da investigação - fontes e procedimentos.................................113 ANEXO 117

5. A GRANDE SANTA ROSA: A CONSTRUCCÃO HISTÓRICA E A CONSTRUCC̃̃O

ANALÍTICA DE UMA REALIDADE REGIONAL ..........................................................119

5.1. O contraste com a metrópole ..................................................................120

5.2. A constituição de uma população: colonização e etnias................................122

5.2.1. O processo da ocupação do território e seus personagens .........................122

5.2.2. Manifestações presentes da clivagem étnica.........................................125

5.3. A vida econômica: a base agrícola e um peculiar tecido industrial...............134

5.3.1. Uma trajetória econômica em "ciclos" ......................................................135

5.3.2. O quadro econômico presente. ........................................................142

5.4. A dinâmica demográfica ............................................................................157

5.5. A Grande Santa Rosa como região e sua institucionalidade...........................165

5.5.1. Aglutinação a partir da diversidade................................................166

5.5.2. Uma articulação real, convergente e - por que não? - hierárquica .............170

5.5.3. Alguns recursos institucionais e um traço da auto-imagem.......................173 ANEXO 182

6. O TRANSBORDAMENTO DO MERCADO: NEXOS SOCIAIS DO TRABALHO NA

EXPERIÊNCIA ESTUDADA................................................................................................. 185

6.1. O mercado de trabalho delineado pelos indicadores estatísticos.................186

6.1.1. Volume, distribuição espacial e setorial do emprego formalizado................186

6.1.2. A ocupação no Censo Demográfico de 2000 ............................................190

6.1.3. Atributos dos trabalhadores: gênero......................................................194

6.1.4. Atributos dos trabalhadores: idade ..................................................198

6.1.5. Atributos dos trabalhadores: escolaridade ...........................................201 


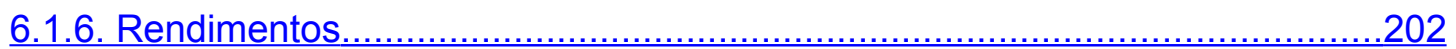

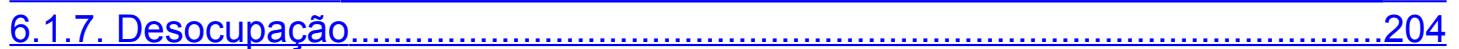

6.2. Algumas características do mercado de trabalho, à luz da pesquisa de

A FORJA DE UM MERCADO LOCAL DE TRABALHO: INSTITUIÇÕES, ESPAÇO E OPORTUNIDADES OCUPACIONAIS EM HORIZONTINA..................................................222

7.1. Diferenciação (articulada) de uma localidade, no contexto regional............2222

7.2. A cidade e a empresa: uma imbricação genética........................................226

7.3. A mudança patrimonial da fábrica na percepção dos atores locais.............2229

7.4. A grande empresa e seu entorno produtivo e institucional............................232

7.5. A pessoalização das relações sociais..........................................................2.235

7.6. 0 trabalho na (ou para a) John Deere: sonhos, "quebras".........................241

7.7. Mecanismos de controle da oferta e da demanda de trabalho....................247

8. O CAMINHO DA ROCA E SEUS SENTIDOS: AGRICULTURA FAMILIAR VERSUS EMPREGO URBANO, NA PERSPECTIVA DOS MINIFUNDIÁRIOS ................................2254

8.1. Agricultura familiar e sua relação com alguns outros mercados..................254

8.2. A "opção" de ficar ou sair do minifúndio e as especificidades do trabalho e do mercado na agricultura familiar..................................................258

8.3. Formas e conteúdos do trabalho na agropecuária, e um pouco das representações a respeito do rural.................................................262

8. 4. O gosto pela atividade rural, estímulos versus dificuldades e os trânsito ocupacionais.............................................................................................271

8. 5. O caráter familiar da vida econômica e dos projetos.....................................277

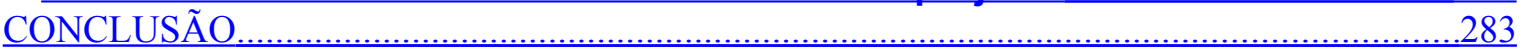

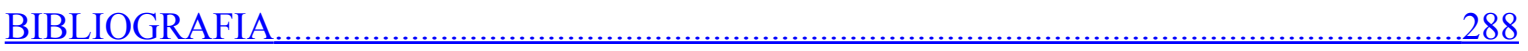




\section{INTRODUÇÃO}

Para elaborar esta tese, dediquei-me a estudar pormenorizadamente uma região composta por vinte municípios, vários dos quais com menos de três mil habitantes, em uma faixa extrema do território do Rio Grande do Sul, que o Rio Uruguai separa da Argentina. As razões de minha escolha não foram pessoais, no sentido em que nenhum laço biográfico ou familiar preexistia entre mim e a "Grande Santa Rosa", objeto empírico da pesquisa cujos resultados aqui exponho. Tenho a consciência de que parte não desprezível de meu desafio, aqui, é convencer quem venha a ler este trabalho que alguma sensatez marcou a minha aposta, sobretudo quando enuncio que minha temática central são mercados de trabalho, vertente copiosa de estudos, no campo das ciências sociais em sentido amplo, que raramente põe no foco de sua preocupação configurações sócioespaciais com as características dessa que tentei dissecar, em diversas e longas estadas, valendome do maior número de fontes e técnicas possível, mas valorizando especialmente a palavra dos sujeitos sociais que nela vivem.

Nessa redobrada necessidade de justificar a localização de meu campo anuncia-se já um elemento que motivou esse trabalho. Procurarei desenvolver, nesta tese, uma abordagem algo detida sobre a categoria analítica "mercado de trabalho", para trazer à discussão e procurar sistematizar uma série de insuficiências teóricas que a ela se associam. O elemento a completar o binômio que dá título a esta tese está na idéia de região, vale dizer, na dimensão espacial das formações sociais, por uma dupla razão: num primeiro nível, alguns limites das ferramentas analíticas consagradas nos estudos de mercado de trabalho são particularmente nítidos quando elas são chamadas a alcançar espaços que carregam diferenças qualitativas relevantes frente às configurações territoriais que historicamente serviram de base para a forja desses instrumentos. Num segundo nível, um diálogo eminentemente teórico indica que a perspectiva de tornar mais densa, de uma perspectiva sociológica, a reflexão sobre mercados de trabalho encontra nas teorizações sobre a dimensão espacial um campo de convergência e aportes dignos de interesse.

A noção de mercado de trabalho aparece associada geneticamente ao período de afirmação e reinado inconteste do salariado, mesmo quando aplicada, pela negação, a realidades sociais como a brasileira, em que a forma típica do emprego com vínculo contratualizado, em que pese à trajetória de expansão relativa mantida ao longo de décadas, sempre "relutou" em se universalizar como padrão de estruturação da ocupação da força de trabalho.

Essa associação - mais ou menos imediata, explícita ou implícita, mas inegavelmente cristalizada - que se operou, na vida e na teoria social, entre trabalho e emprego condensa-se na matriz de um mercado de trabalho. Tal construto naturaliza-se, por muito tempo, mas vê aumentada a carga de tensões analíticas que o cercam no atual contexto histórico, em que se acumulam evidências de uma inflexão, assinalando, nos mais diversos contextos societais, uma 
retração relativa na participação dessa forma social que se consagrou como referência simbólica e institucional para a idéia mesma de trabalho.

Uma vertente da discussão sociológica contemporânea afigura-se especialmente afinada com o enfrentamento dessa (renovada) problemática. A sociologia econômica vem adquirindo crescente vigor e visibilidade, freqüentemente precedida do adjetivo "nova", para indicar um corpo emergente de pressupostos e problemas de pesquisa. Para muitos de seus intérpretes, com que dialogo neste trabalho, ela pode ser compreendida, essencialmente, como uma "sociologia dos mercados". Curiosamente, os mercados de trabalho não têm sido objeto destacado dessa vertente, mas a reflexão sobre mercados em geral vai progressivamente se adensando e oferece bem-vindo apoio para que se interpele essa construção que consagrou, no cerne da reflexão sobre o trabalho social, a matriz mercantil de interpretação de relações sociais.

Dela decorre a necessidade, a que um estudo de caso como o que empreendi parece servir, de se questionar em que medida a noção de mercado de trabalho se propõe como uma ferramenta analítica que exaure a realidade do trabalho social ou, em caso negativo, qual é o alcance que se lhe atribui, quais os fenômenos de que se exime e qual o instrumental teórico que deve servir de alternativa para que se dê conta dos aspectos que não abrange. São muito escassas as ocasiões em que essas balizas recebem a atenção e o debate devidos, o que parece indicar uma reificação dos conceitos e das categorias, protegidos por uma aura de "tecnicalidade" que lhes retira o conteúdo propriamente social, o que vem sendo progressivamente questionado.

São muitos os caminhos potenciais para esse esforço de aprimoramento do tratamento sociológico de mercados de trabalho. Privilegio o eixo da territorialização, ou espacialização, dos fenômenos sociais. Reconheço nas duas problemáticas homologias e possibilidades de mútua fertilização. Presentemente, essa dimensão da vida social passa por transformações reconhecidamente acentuadas, que têm na idéia de "globalização" sua epítome, cercada de controvérsias mas instalada no senso comum e na bibliografia técnica. A ela, muitos dos intérpretes de pertencimento acadêmico articulam uma retomada da importância e uma ressignificação das dimensões local e regional do espaço, reivindicando a irredutibilidade das configurações sócio-territoriais concretas.

Ann Tickamyer (2000) é uma das vozes a reivindicar que a sociologia enfrente com maior empenho a tarefa de incorporar a dimensão espacial em sua produção:

A história reivindica o tempo como seu domínio, e a geografia teoriza o espaço (Friedland and Boden, 1994). A sociologia, alternando-se entre a arrogância de ser a 'rainha' das ciências sociais e a confusão sobre seu status científico, tem uma trajetória inconstante relativamente a ambos esses conceitos analíticos (Tickamyer, 2000:807).

$\mathrm{Na}$ agenda de problemas de pesquisa potencialmente relevantes com que finaliza seu artigo, a autora inclui os mercados de trabalho e defende a importância de estudos de locais 
"periféricos, pobres, remotos e explorados", apontando os ganhos analíticos de estudar-se "tanto os lugares mais poderosos quanto os menos, e a conexão entre eles" (p.811).

Essa tentativa de articular a problemática do mercado de trabalho à dimensão espacial, a partir de um recorte regional, foi motivada por desafios surgidos em meu exercício profissional, que me puseram diante de uma realidade que julgo crescentemente corriqueira. Frente a uma entre tantas experiências de regionalização do planejamento público, há alguns anos, a instituição em que trabalho - Fundação de Economia e Estatística (FEE), em Porto Alegre, vinculada à Secretaria de Planejamento e Gestão do Governo do Estado do Rio Grande do Sul - viu-se instada a contribuir com subsídios para que atores sociais nessas diferentes porções do Estado elaborassem diagnósticos de sua realidade sócio-econômica, com vistas a propor ações estratégicas e investimentos. Com alguma experiência no estudo de "mercados de trabalho", vimo-nos despreparados para analisar configurações sociais, territoriais e produtivas muito diferentes do paradigma metropolitano, o qual, sem que nos déssemos conta, parecia condicionar nossa reflexão, mesmo quando ela se projetava para territórios plurais, como a totalidade de um Estado, por meio de dados estatísticos.

Esta tese nasce com a perspectiva de avançar no enfrentamento de tais insuficiências, e a Grande Santa Rosa ${ }^{1}$ demonstrou-se um suporte pródigo, em sua "tarefa" de aportar elementos que provocassem ruído, no confronto com as ubíquas referências metropolitanas. Nesse sentido, algumas características mostraram-se especialmente relevantes, na experiência concreta: uma forte participação do trabalho agropecuário no total da ocupação de força de trabalho; a presença de localidades com populações muito reduzidas e "tecidos empresariais" praticamente nulos; uma estrutura fundiária e uma organização social da produção primária calcadas na pequena produção familiar, com o conseqüente peso do trabalho não remunerado na estrutura ocupacional; uma dinâmica demográfica tendente à estagnação ou mesmo à retração populacional, com a emigração "deslocando" a problemática do desemprego; uma alegada pluralidade "étnica" (categoria amplamente difundida nas falas dos atores locais) convivendo com inequívoca predominância dos descendentes de alemães; um acanhado tamanho da cidade-pólo (menos de 70 mil habitantes) e a percepção, muitas vezes manifesta pela população, de isolamento frente a qualquer "grande centro".

Por outro lado, uma série de elementos desaconselha que uma formação regional como essa seja simplesmente descartada - por "insuficiência" ou falta de pertinência - de um tratamento analítico que procure dar conta da realidade do trabalho social na sua complexidade, quando se tem presente que, aos traços "negativos" antes mencionados, combinam-se outros dos quais uma teoria de mercado de trabalho, mesmo restritiva, não pode se eximir com facilidade. A região possui um histórico de êxitos produtivos e econômicos, como a deflagração do cultivo da soja em

\footnotetext{
${ }^{1}$ Eventualmente designada, nesta tese, como "Fronteira Noroeste" (denominação que recebe em outra regionalização do Rio Grande do Sul, absolutamente coincidente neste caso), meramente para aliviar o texto de exageradas repetições do mesmo (e central) sujeito.
} 
grande escala no país ao longo dos anos 70, que deu impulso a uma considerável expansão de sua economia urbana, ou a criação, em período ainda anterior, de grandes empresas industriais que se tornaram muito pujantes, incluindo duas firmas produtoras de máquinas agrícolas que há alguns anos se encontram sob o controle de companhias norte-americanas, líderes no mercado nacional e grandes exportadoras, mas mantêm aquelas plantas enraizadas naquela região. Uma simples visita ao município de Horizontina - sede de uma dessas plantas, hoje pertencente à John Deere permite captar em que medida uma pequena localidade de menos de 20 mil habitantes pode estar fortemente integrada a um circuito propriamente "global" de negócios, em uma inserção com todos os traços a que se associa o qualificativo "moderno", em termos de gestão e logística.

Considerem-se ainda, entre outros fatores, os desempenhos positivamente diferenciados na evolução do emprego formal ou sua destacada performance em índices de tipo "desenvolvimento humano", e ter-se-á uma configuração sócio-territorial que, se não adere facilmente às ferramentas ou ao estilo de análise mais corrente de mercados de trabalho, tampouco presta-se a ser desdenhada como um fenômeno que só pode ser afirmado pelo negativo, pela "falta".

Esse pertencimento a circuitos globais coexiste com uma articulação estreita dos vinte municípios, em uma configuração tipicamente regional, ao mesmo tempo em que as diferentes cidades preservam fisionomias e identidades que as "localizam" no interior do arranjo, o que prenuncia também a riqueza do caso escolhido do ponto de vista espacial. Nele, a circulação física da mão-de-obra e uma série de outros "trânsitos" identitários e institucionais reforçam a vinculação das duas problemáticas que servem de eixo a este estudo.

A tese se desdobra em duas partes, além desta introdução e da conclusão. Na primeira, desenvolvo a discussão com a bibliografia, em três capítulos. No primeiro deles, busco interpelar a noção de mercados de trabalho a partir de sua matriz de pensamento - não raro "recalcada" sobre "mercados". Pavimento ali o caminho para buscar, inspirado pela nova sociologia econômica, as dimensões de análise que, na configuração estudada, podem dar mais consistência a uma abordagem sociológica do mercado de trabalho. Do contrário, ter-se-ia a mera recusa ao pensamento econômico (neo)clássico, ou a reiteração de críticas a ele que são feitas há muitas décadas no interior mesmo daquela corrente.

No segundo capítulo dedico-me à discussão sobre a territorialidade e suas configurações contemporâneas, a qual aporta elementos para pensar os laços não apenas entre porções fisicamente recortadas do espaço ou unidades definidas por meros critérios políticoadministrativos, mas também entre fenômenos sociais, culturais, institucionais, que se articulam para compor a noção mesma de espaço.

No terceiro capítulo, trato de começar a pôr em uma relação mais direta os dois eixos teóricos dessa tese, remetendo-os à forma como eles foram conjugados na obra de estudiosos brasileiros de diferentes formações e orientações teóricas, em um passado recente. Isso contribui 
para identificar alguns traços de uma tradição de pesquisa, com seus legados e lacunas. Juarez Brandão Lopes, Francisco de Oliveira e Wilson Cano são os autores selecionados para esse exercício.

$\mathrm{Na}$ segunda parte, trago os resultados de minha pesquisa de campo, dedicando-me a esmiuçar a realidade do trabalho na Grande Santa Rosa de forma integrada a uma série de outros planos da vida social, cujas articulações são exploradas a partir de uma perspectiva espacial.

Inicialmente, no capítulo 4, faço uma descrição dos procedimentos de minha investigação, começando por defender a validade que atribuo a um estudo de caso com esse desenho, e relatando, a seguir, em grandes linhas, o trabalho que realizei.

No quinto capítulo, esforço-me por "descrever" a região pesquisada, partindo de eixos analíticos intencionalmente selecionados - com base na discussão realizada na primeira parte da tese -, como a história da formação regional, sua composição étnica, sua economia e sua vida institucional.

Afirmado nessa contextualização, o sexto capítulo enfrenta a análise desse mercado regional de trabalho, explorando permanentemente a tensão entre o alcance e os limites dos dados estatísticos disponíveis no país para municípios não metropolitanos - essencialmente a Relação Anual de Informações Sociais (RAIS) do Ministério do Trabalho, restrita ao emprego formal, e os Censos Demográficos, decenais. De modo o mais articulado possível, busco no material colhido em campo a expansão desse repertório de referências e nexos sociais, que confrontam e dão um alcance compreensivo a muitos fenômenos que escapam às fontes secundárias tradicionais.

Os dois capítulos finais decorrem da necessidade que senti de apresentar com maior detalhamento e aprofundar a reflexão sobre dois dos tantos aspectos analíticos que me pareceram de central importância no trabalho de campo.

No capítulo 7, fecho o foco "espacial", dentro da Grande Santa Rosa, sobre uma localidade específica - o município de Horizontina -, o que permite um destaque ao tratamento propriamente territorial de minha pesquisa, por evidenciar o "trânsito" necessário - e riquíssimo em trama social - entre as instâncias local, regional, nacional e global. Ademais, esse município me oferece um exemplo extremo de "incrustação" de uma empresa transnacional (que tenderíamos a considerar apátrida) em uma formação sócio-territorial específica, com todas as "negociações" e vínculos que isso significa e que, tento demonstrar, são inextrincáveis de uma perspectiva teórica sobre mercados de trabalho.

No capítulo final, dedico-me a uma categoria social, tanto quanto a um setor de atividade, que há muito encontram-se eclipsados na produção brasileira especializada em mercados de trabalho. Fora do campo específico da sociologia rural e das linhas de pesquisa a que ela se articula, a temática da produção familiar rural tem sido muito pouco contemplada. Neste meu esforço de reflexão, trata-se de um objeto de extremo interesse - especialmente por não poder ser desconsiderado em uma visão que pretenda abarcar o mercado de oferta de mão-de-obra de uma 
formação regional, ao mesmo tempo em que não se enquadra sem violência na perspectiva que só reconhece como trabalho os vínculos monetarizados, mercantilizados, maximizadores e impessoais.

A conclusão tem o tradicional caráter de uma síntese seletiva que é ao mesmo tempo o momento de peneirar as ênfases e dar mais clareza aos nexos analíticos encontrados: retomo na experiência da Grande Santa Rosa as evidências que, em meu entender, ajudam a reforçar a necessidade de vigilância contra a apropriação acrítica da matriz de mercados para o entendimento da realidade do trabalho social; procuro destacar, ademais, enfatizando a dimensão territorial que o enraíza em experiências sociais concretas, um elenco de dimensões que esse caso permitiu identificar como pertinentes, em uma perspectiva na qual a reivindicação de que mercados são construções sociais, mais do que um contra-dogma, aponte para um aprimoramento da reflexão e do enfrentamento das questões que cercam a realidade laboral contemporânea.

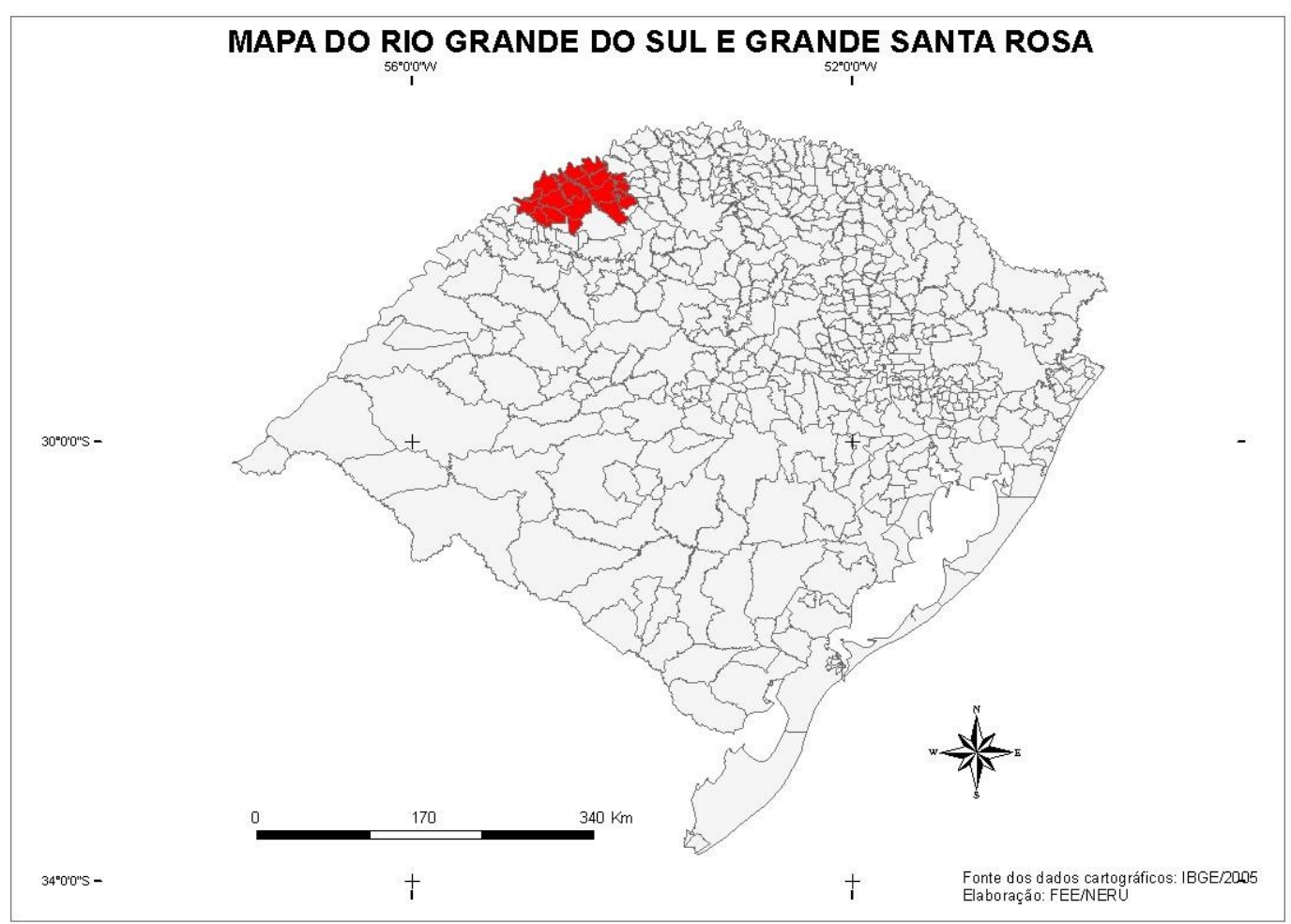




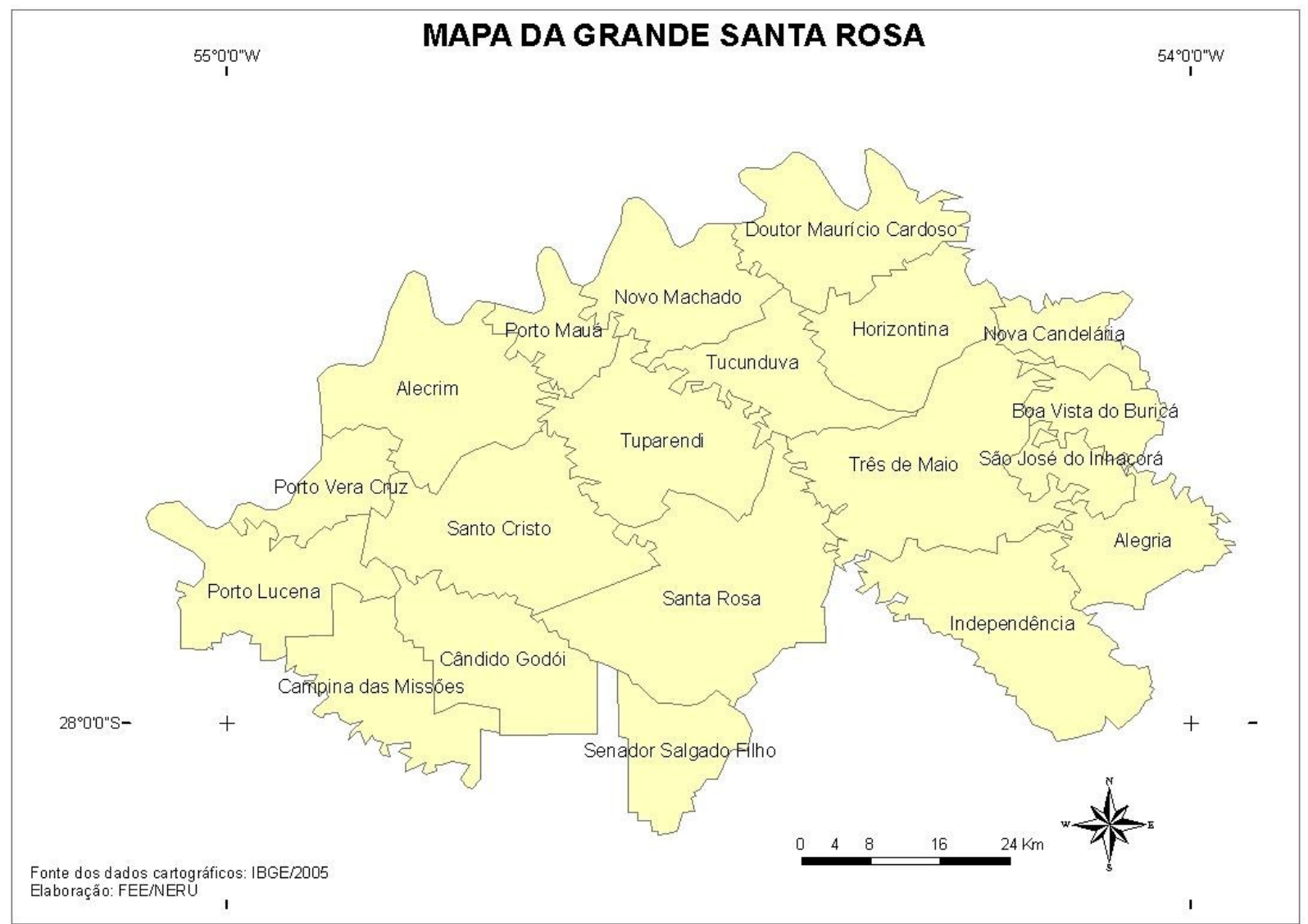




\section{PARTE I - O TRABALHO SOCIAL E A SUA TERRITORIALIDADE ANTE A NOÇÃO DE MERCADO}




\section{A CATEGORIA "MERCADO" APLICADA AO TRABALHO: LIMITES E IMPLICAÇÕES CONCEITUAIS}

Não deixa de ser surpreendente a pouca atenção que tem sido dada, desde a consolidação da "sociedade salarial", a algumas questões como: qual o estatuto teórico da categoria mercado de trabalho? Em que medida ela recobre as questões relevantes que cumpre investigar no que tange ao trabalho social em sociedades capitalistas? Que vieses a consagração dessa ferramenta conceitual como representação hegemônica da dinâmica da ocupação pode ter imposto à agenda de pesquisa da sociologia?

Como já enunciei, o objeto de minha investigação leva-me a recuperar essas preocupações, conduzindo-me a me aproximar de um programa de pesquisa mais amplo, "a sociologia econômica, conhecida sob a denominação de construção social dos mercados" (Steiner, 2004:01 - grifo meu), que tem submetido à sua perspectiva disciplinar numerosas esferas da vida econômica. Discuto, a seguir, alguns aspectos referentes a essa linha de análise, a qual, rapidamente, conquista terreno. Ao mesmo tempo que encontro nela um campo importante de interlocução e pontos de apoio analítico muito bem-vindos, ressalto também alguns aspectos que ainda não parecem ter sido equacionados de modo satisfatório.

Desse tratamento dos mercados em geral, vou ao encontro da problemática específica dos mercados de trabalho: na seção 1.2., exploro o quanto as "idiossincrasias" da mercadoria trabalho assalariado põem em xeque, mais do que qualquer outra, a idéia convencional, tributária das ciências econômicas, de "mercado"; na seção 1.3., destaco o quanto a "franja" de trabalho social não contida na forma emprego aporta limites, quando não fragilidades adicionais a um esquema explicativo restrito à contratação mercantil de força de trabalho.

\subsection{Uma agenda emergente: a abordagem sociológica dos mercados}

É forçoso reconhecer a visibilidade e a influência que vem conquistando um corpo de literatura que se articula ao redor da proposta de constituição de uma "nova sociologia econômica".

O qualificativo "novo/a", quando aplicado a correntes de pensamento, tende a despertar reserva: por um lado, ele é, ao menos em um primeiro momento, ambíguo quanto ao grau em que uma tradição é recuperada ou descartada; por outro, presta-se muitas vezes a estratégias que visam primariamente a valorizar posições no campo científico ${ }^{3}$. Ainda assim, merecem ser consideradas, tanto a originalidade dos problemas empíricos com que se defronta essa produção emergente,

${ }^{2}$ Castel (1995/2001) fala de uma sociedade salarial, como momento distinto (e subseqüente) ao da "sociedade industrial". Nessa categorização, há um interessante deslocamento de ênfase analítica, da dimensão produtiva para a dimensão societal. 
como a presumível dificuldade de identificar-se, com univocidade, uma versão "clássica" de "sociologia econômica" que desfrute de um mínimo de consenso ${ }^{4}$. A expressão já é utilizada em autores como Max Weber (1922/1969:46-50 et passim), mas nem por isso constituiu uma vertente que se possa despregar dos esquemas teórico-conceituais mais amplos das (divergentes) tradições sociológicas. A dispersão de filiações e alinhamentos na nova sociologia econômica, de resto, é um dos elementos que condicionam seu caráter teoricamente incipiente, como indicam alguns de seus expoentes, como Richard Swedberg (2004:17-18) ou Neil Fligstein (2001b:08).

É, por certo, demasiado ampla uma definição de sociologia econômica como "a aplicação de idéias, conceitos e métodos sociológicos aos fenômenos econômicos", tal qual Swedberg formula ${ }^{5}$. O autor acrescenta, evocando Max Weber, que o interesse não se restringe aos "fenômenos econômicos", mas se estende aos "fenômenos economicamente condicionados" (2004:02).

É este mesmo Weber que, após recomendar a incorporação do conceito de "bens" numa "teoria sociológica da economia", afirma: "De outro modo pode proceder (talvez) a teoria econômica, cujos conhecimentos teóricos constituem o fundamento da sociologia econômica mesmo que esta, em alguns casos, tenha que criar seus próprios conceitos" (1922/1969: 50).

Sob essa forma de entender a articulação entre os dois campos disciplinares, não é surpreendente, por exemplo, que Trigilia (2002:197) recorra a uma subdivisão da "nova sociologia econômica" entre os níveis "macro" e "micro" e diferencie ainda estudos "pelo lado da oferta" daqueles "pelo lado da demanda" - clivagens tradicionais das ciências econômicas.

Muitos critérios são propostos para organizar a produção da sociologia econômica, como é o caso da de Fligstein (2001a), que subdivide a sociologia dos mercados em uma vertente orientada aos "macroprocessos" e outra aos "microprocessos" (p. 6-7). Steiner (2004: 10-11), por sua vez, faz um corte homólogo, mas com outro foco. Parte de duas concepções de mercado: na

\footnotetext{
${ }^{3}$ Alude-se à dinâmica que Bourdieu imputa ao campo científico, no qual "a fissão das disciplinas permite que se assegure uma dominação mais completa sobre um domínio mais restrito" (1989/2004:131). Essa perspectiva ressalta da leitura de Swedberg (2004), que, em sua abalizada caracterização da "sociologia econômica hoje", detém-se a avaliar a "institucionalização" deste "sub-campo" da sociologia, destacando a existência de livros de referência (Readings) - sendo um deles co-editado pelo próprio autor -; a constituição de seção própria na American Sociological Association; o número de disciplinas oferecidas, de docentes e de estudantes vinculados, nas universidades dos Estados Unidos; a produção em outros países, especialmente europeus, entre outros indicadores.

${ }^{4}$ Quanto à tradição teórica da Sociologia Econômica, um esforço de sistematização encontra-se em Trigilia (2002). O autor elege, de uma forma que reconhece "arbitrária" (p.119), seis pensadores, como "pais fundadores" (sic) da Sociologia Econômica clássica, circunscrevendo ao período 1890-1940 tal geração. Esse conjunto de estudiosos mescla sociólogos e economistas, sendo composto por Sombart, Weber, Schumpeter, Durkheim, Veblen e Polanyi. Neles, Trigilia encontra "extraordinária convergência", sobretudo pelo fato de que "partilham uma abordagem dos fenômenos econômicos que é, a um só tempo, consistente com o marginalismo e dele diferenciada" (p.119). Já Steiner (1999) se concentra em Weber e Durkheim, adicionando a essa genealogia a contribuição de Pareto. Smelser e Swedberg (1996), por sua vez, elegem outro sexteto, com direito a auto-referência: Marx, Weber, Durkheim, Schumpeter, Polanyi, e a dupla Parsons-Smelser.

${ }^{5}$ Outra definição semelhante no conteúdo e na abrangência poderia ser a de Fligstein: "A sociologia econômica é o estudo de como a produção e o consumo materiais de populações humanas dependem de processos sociais para sua estrutura e para sua dinâmica" (2001b:06).
} 
primeira, ele é visto como "arena" para a troca, que "filtra" a formação dos "pares", dentre os atores que buscam transacionar; a segunda não se restringe à troca, mas incorpora a produção e, com isso, as firmas e seu comportamento, o que implica um grau de compromisso e de fluxo nos processos sociais implicados. A essas duas formas de abordar o mercado estarão associadas, respectivamente, uma sociologia econômica "relacional" e outra mais propriamente "estrutural"6.

$\mathrm{O}$ acerto de contas - ora mais cordial, ora mais exaltado; aqui tácito, ali explícito - entre duas disciplinas científicas marca claramente a constituição da nova sociologia econômica. A proposição segundo a qual ela tem "como principal característica (...) estudar os mercados não como mecanismos abstratos de equilíbrio, mas como construções sociais" (Abramovay, 2004:01) circunscreve, de certa maneira, a arena desse confronto entre tradições acadêmicas. Textos tão diferenciados como Hollingsworth, Boyer (1997a); Garcia-Parpet (2003); Müller (2003) respaldam, como ilustrações, tal percepção ${ }^{7}$.

Num artigo que se consagrou como pedra fundamental da reemergência da sociologia econômica, nos anos 1980, Granovetter afirma:

(...) os sociólogos furtaram-se de estudos sérios sobre qualquer tema já reivindicado pela economia neoclássica. Aceitaram, implicitamente, a presunção dos economistas de que 'processos de mercado' não são objetos apropriados de estudo sociológico, porque as relações sociais detêm apenas um papel friccional e diruptivo, e não um papel central, nas sociedades modernas (1985:504).

Logo a seguir, na conclusão de seu texto, o autor afirmará ter tentado demonstrar que "todos os processos de mercado são adequados à análise sociológica" e que "tal análise revela traços centrais, e não periféricos, desses processos" (p.505).

Economista bastante próximo à nova sociologia econômica, Robert Boyer (1997:62-65), repertoria seis possíveis acepções para o emprego da categoria "mercado". Sintetizando-as, são elas:

- à maneira do vocábulo francês marché: contratos bilaterais, para a entrega de um bem por um preço fixado, em prazo predeterminado. A exemplificação de Boyer é próxima ao que no Brasil seria chamado de licitação. "Nesse caso, o mercado não coordena estratégias independentes ex post, mas organiza o levantamento (screening) das várias ofertas e ajuda a selecionar a melhor (...)" (p.62). O contrato final é bilateral e assegurado pelo sistema legal, em contraste com a definição convencional de mercado "como o locus onde ofertas e demandas anônimas interagem, com pouca ou nenhuma coerção legal” (p. 62).

\footnotetext{
${ }^{6}$ Essa subdivisão que Steiner apresenta, em verdade, já é um recorte adicional a uma primeira distinção que o autor faz entre três formas de sociologia econômica. Na primeira, de que ele se ocupa, está em jogo um "confronto" (sic) entre duas disciplinas acadêmicas, a sociologia econômica e a economia política. O autor visualiza uma segunda vertente, "puramente sociológica", que "não busca se confrontar diretamente com as questões colocadas pela teoria econômica". Por fim, há uma terceira linha que ele qualifica como "présociologia econômica contemporânea", pois reivindica uma "exterioridade" frente à teoria econômica e assume que a teoria do mercado é atribuição dessa última (2004:01-2).

${ }^{7}$ De qualquer modo, se a delimitação da sociologia econômica como uma "sociologia dos mercados" faz ou não justiça ao conjunto da produção desta "corrente" é questão que não tem, aqui, implicações relevantes, já que a apropriação que faço é assumidamente "interessada".
} 
- marketplace - Boyer resgata a definição que, na Inglaterra de 1891, fundamenta sua regulamentação: "uma afluência pública autorizada de compradores e vendedores de mercadorias, os quais se encontram em um local delimitado ou definido de modo mais ou menos estrito, em um momento previamente acordado (an appointed time)" (p.62 - grifo meu). Evoca Polanyi para frisar que o nascimento dos mercados se deu a partir de uma vida econômica altamente regulada e institucionalizada e afirma que "os mercados globais contemporâneos são os mais recentes seguidores dessa forma embrionária de mercado, que foi conquistando uma fração cada vez maior das mercadorias e, por fim, alguns mercados de fatores, como o trabalho" (p.63).

- uma agregação, para uma área geográfica e/ou para um produto, em que vendedores competem pelos consumidores. Boyer considera esta uma expansão do conceito - a qual tributa aos economistas "clássicos ou neoclássicos", remetendo a uma obra de Marshall de 1890 - em que a noção de mercado vai perdendo seu conteúdo intuitivo (“já não é mais o marketplace"), e pode indicar até mesmo a demanda efetiva agregada (p.64).

- mecanismo "para tornar compatível uma série de ofertas e demandas individuais" (p.64). O mercado estaria operando quando se chega ao preço de equilíbrio. Boyer recorre novamente a Alfred Marshall, que sustenta que o mercado não se resume ao marketplace, mas engloba "a totalidade de qualquer região na qual compradores e vendedores estão em uma interação (intercourse) tão livre uns com os outros que o preço dos mesmos bens tende à igualdade, fácil e rapidamente" (Marshall apud Boyer, 1997: 64). Boyer sublinha que esta é uma propriedade nova e mais abstrata atribuída ao mercado, distante da concretude do marketplace: "um tipo ideal de mecanismos de mercado puros e perfeitos" (p. 64).

- sistema econômico no qual a competição de mercado é dominante, mesmo que não exclusiva - Boyer exemplifica essa não-exclusividade com a produção industrial francesa durante a II Guerra, em que o planejamento centralizado teve um papel excepcional. Disso deriva que, embora, num tal sistema, o mercado prevaleça "para bens duráveis e bens finais, terra, trabalho e capital" (p.65), há um espectro de assim chamadas "economias de mercado", segundo a extensão que esse mecanismo de coordenação atinge. Implícita ou explicitamente a expressão "economia de mercado" equivale, para alguns autores, a capitalismo, propriedade privada e competição - "termos que [entretanto] não são logicamente equivalentes" (p.65). Nessa visão, só o dinheiro não é fornecido e ofertado, já que é simples numerário, e os mecanismos macroeconômicos são abolidos. "As instituições realmente existentes são implicitamente comparadas com o ideal de uma sociedade coordenada por mercados puros e perfeitos sobre os quais nenhum indivíduo isolado tem qualquer influência, mas dentre os quais os indivíduos são livres para escolher" (p. 65).

- metáfora para situações em que "atores sociais competem uns com os outros para obter recursos escassos, ou algumas posições ou status restritos" (p. 65). Sob esse ponto de vista, 
seriam "quase-mercados" o casamento, o crime, ou doações a igrejas, por exemplo. Esse é um uso "até mesmo imperialista" do conceito. Por um lado, afirma Boyer, Marx e Veblen, entre outros, chamaram a atenção, com acerto, para o fato de que, sob o capitalismo, tudo se mercantiliza; por outro, o conceito de mercado torna-se tão frouxo que corre o risco de mistificar mais do que ilumina (p.65-6).

Num contexto histórico em que o debate social sobre as liberdades de mercado ou as restrições a ele recupera uma importância de que, possivelmente, não desfrutava desde os anos 1930, o foco da investida de Boyer são as acepções de mercado como "mecanismo" e como "sistema econômico". A zona de maior "fricção" entre a sociologia e a economia, "clássica ou neoclássica" (acompanhando-se Boyer nessa fusão oportunamente simplificadora), é justamente a associação que esta opera entre mercados e "concorrência perfeita", tendo por base as pressuposições ontológicas cristalizadas na imagem do homo economicus, relativamente às motivações e ao comportamento do indivíduo, tomado como autônomo, racional e maximizador.

Em sua "Sociologia da Vida Econômica", Mingione (1997/2003) afirma:

\begin{abstract}
$\mathrm{Na}$ base de tudo está o velho paradigma do mercado, que acompanhou, em versões diversas, as etapas da história industrial, como instrumento de condicionamento e de interpretação distorcida da vida econômica. É a idéia de que a competição entre indivíduos livres de restrições seja suficiente por si mesma para produzir colaboração e organização, um tecido denso de ligações sociais indispensáveis a fim de que todos possam melhorar as próprias condições de vida sem prejudicar as dos outros. Essa mesma idéia tem também, muitas vezes, um conteúdo moral e político, no qual a eficiência econômica e a ordem meritocrática coincidem: têm sucesso aqueles que se empenham, enquanto quem se encontra em dificuldades é culpado, preguiçoso ou pouco motivado; tudo isso em uma máquina que não pode ser detida, a qual, puxada pelos meritórios e eficientes, produz crescentes oportunidades para todos. Enquanto a primeira parte do paradigma é a que consente aos economistas uma interpretação formal universalística que prescinde das diversidades e da variabilidade das condições sociais, a segunda parte é a alma política do desenvolvimento do capitalismo. A duplicidade do paradigma do mercado é um dos elementos que complicaram a história intelectual dos últimos dois séculos, com implicações arrebatadoras sobre a vida econômica e social (Mingione, 1997/2003:12).
\end{abstract}

Efetivamente, esse poderoso e resistente paradigma, no interior das ciências econômicas, repousa em hipóteses restritivas e irrealistas. Em uma versão que escolho, propositalmente, pelo didatismo e pelo caráter de "difusão", já que se trata de um manual (Rossetti, 2002:401-02), as "condições" que devem ser preenchidas para que "uma estrutura de mercado" corresponda, rigorosamente, a um estado de "concorrência perfeita" podem ser assim resumidas:

a. atomização - um número de agentes compradores e vendedores suficientemente grande para que nenhum deles tenha poder de influenciar o mercado, o qual é "totalmente despersonalizado".

b. homogeneidade - "O produto [ou fator de produção] vindo de qualquer produtor é um substituto perfeito do que é ofertado por quaisquer outros produtores". 
c. mobilidade - inclui a livre circulação no território e a liberdade de ingressar ou retirarse do circuito de transações, expandir ou reduzir as instalações produtivas. "Nada impede que se tomem quaisquer decisões alocativas".

d. permeabilidade - "Não há quaisquer barreiras para entrada ou saída dos agentes que atuam ou querem atuar no mercado. Barreiras técnicas, financeiras, legais, emocionais ou de qualquer outra ordem não existem sob situação de perfeita concorrência".

e. preço-limite - trata-se do preço de equilíbrio. A formulação, lapidar, de Rossetti: "O preço-limite é dado pelo mercado. Define-se impessoalmente. Ninguém o estabeleceu. Ele resulta de forças que nenhum agente é capaz de comandar".

f. transparência - nenhum agente detém informações privilegiadas ou diferentes das que todos detêm.

Por certo, formulações simplificadas como essa realçam o caráter implausível das condições para a "concorrência perfeita" e, portanto, para que uma determinada concepção de mercado se sustente. Ainda assim, é na contraposição a alguns desses pressupostos que Trigilia sintetiza os "aspectos metodológicos" que caracterizariam a sociologia econômica - já em sua primeira geração, anteriormente aludida ${ }^{8}$.

Dentre os muitos pontos que estimulam a reflexão, elejo, aqui, umas poucas questões referentes à contraposição entre as duas vertentes disciplinares e a sua forma de conceber a natureza e o funcionamento dos mercados.

\section{QUADRO 1}

\begin{tabular}{lll}
\hline \multicolumn{2}{l}{ Aspectos metodológicos da economia neoclássica e da sociologia econômica } \\
\hline Concepção de economia & Economia neoclássica & Sociologia econômica \\
& $\begin{array}{l}\text { Alocação racional de recursos } \\
\text { escassos para fins alternativos } \\
\text { (economizing) }\end{array}$ & $\begin{array}{l}\text { Atividade voltada para a busca } \\
\text { dos meios de subsistência }\end{array}$ \\
Ação econômica & $\begin{array}{l}\text { Atomismo e utilitarismo. } \\
\text { Persecução racional dos }\end{array}$ & $\begin{array}{l}\text { Ação econômica como ação } \\
\text { interesses individuais, por }\end{array}$ \\
& social. \\
& Motivações utilitaristas e não-
\end{tabular}

${ }^{8}$ A formulação de Trigilia é bastante semelhante à de Smelser e Swedberg (1996:04). 
indivíduos agindo

independentemente uns dos outros

Regras (Rules)

Método de investigação

Método dedutivo-axiomático

Modelos abstratos

Alto grau de generalização utilitaristas influenciadas pelas

instituições

Mercado

Instituições sociais (p.ex., reciprocidade)

Instituições políticas (p.ex., redistribuição)

Método indutivo

Modelos empiricamente

embasados

Generalizações limitadas

Extraído de Trigilia (2002:125)

\section{A economia neoclássica como um oponente construído}

Os "fundadores" eleitos por Trigilia necessitaram, certamente, de muita energia combativa para contrapor-se aos dogmas da economia clássica e neoclássica. Mas é desconfortável identificar-se, mais de 60 anos depois, na produção da sociologia econômica, uma representação do pensamento das ciências econômicas em que esse parece ter ficado no mesmo lugar, a esperar a segunda "geração" de críticas sociológicas, de resto não muito distintas daquelas da primeira.

Seguramente, a avassaladora hegemonia do neoliberalismo, nos anos 80 , e sua incidência nas ciências econômicas ajudam a explicar certo grau de "radicalização" do debate, o que não raro tem como efeito colateral a simplificação.

Embora a economia neoclássica se mantenha como o mainstream em seu campo disciplinar, ela vem sofisticando e superando muitos dos seus pressupostos mais restritivos. Hollingsworth e Boyer (1997b, 1997c) admitem que boa parte das críticas que eles formulam a uma visão mecânica do funcionamento dos mercados e aos pressupostos referentes ao indivíduo auto-interessado e à racionalidade maximizadora encontra respaldo e apoio em avanços recentes da microeconomia neoclássica.

Ademais, os economistas neoclássicos mostram uma histórica ambivalência quanto à extensão em que assumem seus próprios pressupostos. Há mais de 50 anos, em seu célebre "manual", Paul Samuelson afirmava, com incontida ironia:

Um cínico diria da perfeita competição o que Bernard Shaw disse do cristianismo: o único defeito é que nunca foi experimentado na realidade. Os historiadores já discutiram muito a questão sobre se houve jamais uma idade de ouro da competição livre. Certamente, na opinião do economista, a competição tal como ela existe na realidade econômica não é perfeita (1955:47).

É uma barreira para qualquer controvérsia a ausência de um interlocutor que sustente abertamente a posição que se quer contestar. Ainda assim, o programa da sociologia econômica parece retirar muito de sua força e de sua justificação desse embate, o que a leva, 
permanentemente, a reconstruir e a "reapresentar" o campo adversário de uma forma que valorize, de forma contrastiva, sua própria contribuição.

\section{As ciências econômicas para além do paradigma neoclássico}

Não tenho qualquer pretensão de me aproximar, aqui, de uma história do pensamento econômico. Entretanto, ante o risco de distorção que implica tomar apenas a vertente neoclássica para o diálogo com o pensamento econômico, vale fazer uma simples menção a um autor como Keynes. Na nova sociologia econômica, são raras as referências ao impacto prático e teórico das críticas desse pensador à tradição (neo)clássica, já nas décadas de 1920 e 1930. No registro "técnico", a sua "Teoria Geral do Emprego, do Juro e da Moeda" (Keynes, 1936/1983) nunca deixa de ser reconhecida como revolucionária (Prebisch, 1998). Numa embocadura política, textos como "O fim do 'laissez-faire"” (Keynes, 1926/1978b) não soam menos atuais do que boa parte das críticas recentes aos automatismos do mercado. Para dar um exemplo: após associar as hipóteses dos economistas neoclássicos ao darwinismo e mimetizar um raciocínio em que a competição econômica é comparada aos mecanismos evolutivos que fizeram com que as girafas de pescoços mais longos fossem "selecionadas", Keynes afirma:

(...) muitos dos que reconhecem que as hipóteses simplificadas não correspondem precisamente aos fatos concluem, apesar disso, que elas representam o que é 'natural' e, portanto, ideal. Eles consideram saudáveis as hipóteses simplificadas, e doentias as demais complicações.

Todavia, além desta questão de fato, existem outras considerações, suficientemente conhecidas, que trazem corretamente ao cálculo o custo e o caráter da própria luta competitiva, e a tendência para que a riqueza seja distribuída aos que mais a apreciam. Se levarmos a sério o bem-estar das girafas, não devemos menosprezar o sofrimento das de pescoços mais curtos, que morrem de fome, ou as folhas doces que caem no chão e são pisadas na luta, ou a superalimentação das de pescoços compridos, ou o mau-olhado de angústia ou cobiça agressiva que anuvia os semblantes suaves da multidão (1926/1978b: $117-18)$.

Outra formulação que se confundiria com a de muitos sociólogos recentes:

Na Europa (...) existe uma reação latente, um pouco difundida, contra a fundamentação da sociedade, até o ponto em que o fazemos, no favorecimento, no encorajamento e na proteção dos motivos monetários individuais. (...) Nosso problema é o de criar uma organização social tão eficiente quanto possível, sem ofender nossas noções de um modo satisfatório de vida" (p. 124-126).

Tais excertos são suficientes para exemplificar o risco que correm alguns sociólogos contemporâneos quando tratam economia neoclássica, ideologia (neo)liberal e teoria econômica como uma unidade, postura exemplificada por Swedberg: "a ação econômica, em suma, não segue os caminhos curtos e diretos da maximização, como defendem os economistas" (2004:09).

Por certo, autores como Trigilia ou Boyer irão aludir ao papel de Keynes, e, no caso do primeiro, também a outros economistas como Joan Robinson ou Edward Chamberlin, que já na década de 1930 sofisticavam a versão "primitiva" do paradigma neoclássico, a qual tantos sociólogos, hoje, julgam necessário "desmascarar" como irrealista. Mas a imagem de Keynes 
parece ter ficado irreversivelmente associada ao Estado de Bem-Estar, ao fordismo e a toda uma era que não soa atrativa para uma agenda que almeja ser reconhecida como renovadora. É possivelmente o mesmo tipo de "recusa" que sofre Marx, nas duas linhas que Swedberg lhe dedica no texto "Sociologia Econômica: hoje e amanhã". Após relembrar que, "quando a sociologia econômica foi reanimada, nos Estados Unidos, em meados dos anos 1980, os sociólogos estavam basicamente perdidos quando se tratava de teoria", e repassar algumas "alternativas", sentencia: "Basear-se no trabalho de Marx não parecia uma opção, tampouco, uma vez que os dias da sociologia radical estavam encerrados" (2004:09).

O quanto a sociologia econômica já "se achou" sob esse ponto de vista teórico é difícil afirmar. No que tange ao diálogo interdisciplinar com as correntes mais recentes do pensamento econômico, o trabalho de Abramovay (2004) traz um sólido apanhado. Essa, de qualquer modo, é apenas uma faceta do campo de alianças teóricas da sociologia econômica, que interage intensamente com outras áreas do conhecimento, como a ciência política, a antropologia, o direito, etc. E nesse movimento, o leque de objetos de estudo se expande, abrangendo desde relações interfirmas em cadeias produtivas específicas até o mercado para fotografias de moda, ou a saúde.

\section{Racionalidade(s) x valores: especializações disciplinares?}

Nesse misto de disputa e "divisão do trabalho" entre sociologia e economia, um ponto nodal diz respeito à racionalidade e aos valores que presidem uma organização social, aí incluída a sua "vida econômica". Segundo Baron e Hannan (1994), Pareto consagrou uma distinção segundo a qual a economia seria o estudo do comportamento "racional", enquanto a sociologia, do comportamento "não racional" - divisão que Parsons teria contribuído para consolidr (Baron, Hannan, 1994:116). É bastante vívida, no debate da nova sociologia econômica, a problemática dos fundamentos e motivações da ação individual que não se enquadram na racionalidade típica do homo economicus.

Ilustrando uma visão dicotômica como a referida, sob a perspectiva da economia, encontramos novamente em Samuelson uma referência muito pertinente:

Mesmo que o sistema funcionasse perfeitamente, tal como foi descrito, o que todo o mundo sabe estar longe da realidade, muitos ainda não o considerariam ideal. Em primeiro lugar as mercadorias se orientam no sentido do remate mais alto em dinheiro. $\mathbf{O}$ cão do rico beberá o leite que faltará ao filho do pobre. Por quê? Por que o mecanismo de oferta e procura não funciona? Longe disto. A procura e a oferta não fazem mais do que colocar a mercadoria nas mãos daqueles que podem pagar por ela a maior soma em dinheiro (...).

Ou, para tomarmos outro exemplo, suponhamos que a invenção de máquinas automáticas causasse a queda do preço competitivo do trabalho, reduzindo desse modo a renda do pobre. Há algo necessariamente justo nisso? (...) Se as rendas devem ou não ser completamente determinadas pela luta competitiva, pela sobrevivência dos sobreviventes, é uma questão de ordem ética que ultrapassa a mecânica da pura economia (Samuelson: 1955:50 - grifo meu). 
Em que medida essa dissociação entre a "ética" e a "mecânica da economia" é recusada pela sociologia? Enquanto Karl Marx tem sido muito pouco evocado, Max Weber é certamente o "representante" de maior envergadura dentre os sociólogos elencados por Trigilia (supra) como "fundadores" da nova sociologia econômica. Abramovay (2004:17) afirma que, "sob o ângulo do que Schumpeter chama de teoria econômica, Max Weber era um pensador neoclássico". Mais do que essa classificação, interessa reter a sugestão de que Weber possa ter "uma teoria econômica" a ser considerada em separado de sua teoria sociológica. Embora a complexidade de uma questão como essa extrapole meus propósitos, aqui, quero relembrar a forma como Weber conceitua a racionalidade de uma "gestão econômica".

Weber diferencia uma "racionalidade formal" de uma "racionalidade material", ao tratar da gestão econômica. No primeiro caso, está em questão o fundamento em "reflexões sujeitas a número e cálculo", e, por isso, ainda que de modo "relativo", o conceito é "inequívoco" (1922/1969: 64). Em contraste,

(...) o conceito de racionalidade material é completamente equívoco. Significa apenas esse conjunto de coisas: que a consideração não se satisfaz com o fato inequívoco (relativamente) e puramente formal de que se proceda e calcule de modo 'racional', em conformidade com fins, lançando mão dos meios factíveis tecnicamente mais adequados, mas, isso sim, que se colocam exigências éticas, políticas, utilitárias, hedonistas, estamentais, igualitárias ou de qualquer outra natureza, e que, dessa forma, se medem as conseqüências da gestão econômica - ainda que ela seja plenamente racional do ponto de vista formal, ou seja, calculável - com referência a valores ou a fins materiais. Os pontos de vista valorativos, neste sentido racionais, são em princípio ilimitados, e entre eles os comunistas e socialistas, de forma alguma congruentes entre si e sempre éticos e igualitários em algum grau, são apenas, evidentemente, um grupo entre os muitos possíveis (articulação estamental, fins políticos, especialmente de guerra, e quaisquer outros pontos de vista imagináveis são, nesse sentido, igualmente 'materiais') (Weber, 1922/1969:64-5).

Nessa segunda forma, a "interferência" de valores éticos ou políticos não compromete o caráter racional da gestão econômica, e o alicerce da calculabilidade é ainda a base de avaliação, ou de validação. Mas o autor contempla uma terceira possibilidade, a de uma crítica "ética, ascética e estética da consciência econômica, bem como dos meios econômicos. Para todas elas, a função 'puramente formal' do cálculo em dinheiro pode aparecer como subalterna, ou mesmo como inimiga de seus postulados (...)" (p. 65).

Essas três "possibilidades" formalizadas por Weber parecem reforçar a interpretação de que, em seu pensamento, há lugar, analiticamente, para um "reino" da economia eminentemente destituído de considerações ou interferências valorativas. Estas podem penetrá-lo, subordinando os fins que o orientam, ao mesmo tempo em que se subordinam à sua racionalidade; alternativamente, podem recusá-lo e combatê-lo.

Em síntese, algumas tradições, seja da sociologia, seja da economia, tendem a abordar os fenômenos econômicos como dotados de certa independência analítica frente a outros condicionantes sociais, especialmente aqueles de natureza ética. Esse é um dos primeiros pontos a sofrer a rediscussão e a crítica, em trabalhos que alimentam a discussão da nova sociologia 
econômica (Sen, 1987/1999; Dumont 1977/2000); porém, como discuto a seguir, produz ainda ambivalência no tratamento analítico dos mercados como objeto.

\section{Mercado criatura e mercado criador}

Duas abordagens diferenciadas convivem no terreno que se identifica com a sociologia econômica. De um lado, há o esforço de demonstrar que os mercados são "construções sociais", e, como tais, subordinam-se, inapelavelmente, às motivações, interesses e conflitos, à historicidade, às formas de simbolização e a todos os demais elementos que conformam a ordem social mais ampla, da qual são apenas uma instância.

Steiner (2004) recorre a Swedberg ao defender que os mercados sejam encarados como um tipo específico de estrutura social - "interações de determinado tipo, recorrentes e padronizadas, entre agentes, mantidas através de sanções" (Swedberg, apud Steiner, 2004:02) -, para, em seguida, afirmar: "a sociologia econômica contemporânea se interessa pela origem dessa estrutura social, das regras que lhe permitem funcionar; ela estuda suas diferentes formas e pesquisa as razões de suas evoluções. É o que chamamos hoje em dia a construção social dos mercados" (grifo Steiner).

Na mesma perspectiva, Granovetter declara:

(...) a produção e a distribuição de bens e serviços é apenas um complexo institucional de atividades, e (que) os argumentos aplicáveis a elas deve ter alguma similaridade genérica com os argumentos que se podem desenvolver para explicar a ação política, a ciência e o conhecimento, família e parentesco, e outros padrões sociais persistentes (2001:01).

Dificilmente algum teórico identificado com a corrente deixaria de subscrever tal ponto de vista. Entretanto, não é raro que ele sofra, nessa bibliografia, a hibridação com uma segunda linha de análise, que acarreta tensões teóricas, se não lógicas. Em alguns estudos, opera-se uma espécie de reificação e autonomização do(s) mercado(s) frente à sociedade, que em geral fundamenta uma atitude prescritiva de autores que advogam, implícita ou explicitamente, o controle das forças que a "entidade" mercado emana, ou, ao menos, uma restrição ao seu alcance como mecanismo de "coordenação".

Para esclarecer esse ponto, recuo rapidamente ao trabalho de Karl Polanyi (1944/1980), totemizado na produção da "nova sociologia econômica".

Polanyi construiu, na década de 1940, uma interpretação sobre a "civilização específica" que teve como "fonte e matriz" o "mercado auto-regulável". À visão de que o ser humano teria uma "predileção inata” por "ocupações lucrativas" (p.60) irá opor: “(...) anteriormente à nossa época, nenhuma economia existiu, mesmo em princípio, que fosse controlada por mercados. Apesar da quantidade de fórmulas cabalísticas acadêmicas, tão persistentes no século XIX, o ganho e o lucro feitos nas trocas jamais desempenharam um papel importante na economia humana" (p.59). Os esteios historicamente efetivos para garantir "a ordem na produção e na

\footnotetext{
${ }^{9}$ A dedicatória do livro organizado por Hollingsworth e Boyer (1997a), por exemplo, é "Para Karl Polanyi, por ter nos ensinado sobre a dinâmica do capitalismo".
} 
distribuição" estariam, isso sim, nos princípios - "não associados basicamente à economia" (p.63) - de reciprocidade e de redistribuição, apoiados, respectivamente, pelos padrões de simetria (social) e centralidade (política). Em poucas palavras: "Na verdade, o sistema econômico é mera função da organização social" (p.64). Alternativamente: "A descoberta mais importante nas recentes pesquisas históricas e antropológicas é que a economia do homem, como regra, está submersa em suas relações sociais" (p.61). ${ }^{10}$

"A Grande Transformação" é escrito em meio à II Guerra Mundial, e é manifesta a motivação de Polanyi em interpretar o conflito. A primeira frase do livro é: "A civilização do século XIX ruiu". E esse movimento é a derrocada de uma "utopia" (sic) do mercado autoregulável.

Uma tal instituição [o mercado auto-regulável] não poderia existir em qualquer tempo sem aniquilar a substância humana e natural da sociedade; ela teria destruído fisicamente o homem e transformado seu ambiente num deserto. Inevitavelmente, a sociedade teria que tomar medidas para se proteger, mas quaisquer que tenham sido essas medidas, elas prejudicaram a auto-regulação do mercado, desorganizaram a vida industrial e, assim, ameaçaram a sociedade em mais de uma maneira. Foi esse dilema que forçou o desenvolvimento do sistema de mercado numa trilha definida e, finalmente, rompeu a organização social que nele se baseava (p.23).

Esse excerto sintetiza (ou sincretiza) as duas abordagens indicadas. Em Polanyi, "a sociedade" institui o mercado, e, nesse sentido, ela é "criador" e este é "criatura". A criatura, porém, se autonomiza e se torna um "moinho satânico" (p.51), o que, com o perdão do mau trocadilho, pode gerar uma confusão dos diabos. Diferentemente da imagem marxiana do fetiche da mercadoria (Marx, 1867/1988: 70-78), não se trata, em Polanyi, de um fenômeno circunscrito à consciência dos sujeitos engajados em uma "economia de mercado". O "econômico" e o "social", depois de declarados indissociáveis, distanciam-se, e suas trajetórias podem mesmo ser tratadas como paralelas: "Calculamos que uma avalanche de desarticulação social, superando em muito a que ocorreu no período dos cercamentos, desabou sobre a Inglaterra; que esta catástrofe foi simultânea a um vasto movimento de progresso econômico (...)” (Polanyi: 1944/1980: p.56-7 grifo meu).

No debate mais recente, é reconhecível essa labilidade no tratamento das relações entre "os mercados" e "a sociedade".

De um lado, há quem considere, como Boyer (1997:70) que, “de um modo mais geral, cada forma de mercado é completada por ou enraizada em uma série de mecanismos de coordenação, que se baseiam na obrigação (e não no auto-interesse) e/ou na coordenação vertical, alianças, hierarquias, comunidades, redes e autoridades públicas". Nesse sentido, a tarefa fundamental torna-se estabelecer a melhor "combinação" entre mecanismos de mercados e demais

\footnotetext{
${ }^{10}$ Neste excerto, a palavra "submersa", grifada, é a tradução de "embedded" - metáfora retomada por Mark Granovetter no seu já referido artigo de 1985 (sobre a relevância desta obra, cfe. Swedberg, 2004). Várias outras traduções são utilizadas em português para o substantivo embeddedness, como incrustação (Lisboa, 2000) ou enraizamento.
} 
instituições. Esse "balanceamento" não poderia jamais ser feito a priori, entre outras razões porque o grau de legitimidade do mercado (Trigilia, 2002: 126) varia de uma sociedade para outra.

Uma sociedade [a norte-americana] fortemente caracterizada pelo individualismo liberal, marcada, historicamente, pelo papel central ocupado pela imigração e pela busca de sucesso através da mobilização individual pode aceitar níveis de desigualdade superiores àqueles tolerados em sociedades com uma tradição cultural ou uma herança institucional diferentes, como as européias ou a japonesa (Trigilia, 2002: 247).

De outro lado, tem-se abordagens mais radicalmente "sociologizantes" dos próprios "mecanismos" de mercado. Um exemplo de uma perspectiva auto-proclamada como durkheimniana é o texto de Wolfgang Streeck (1997) sobre "restrições benéficas". No que diz respeito à relação mercado (associado à perspectiva individualista e voluntarista) x "sociedade" (representada pelas restrições), Streeck pugna pela necessidade de "governança do comportamento social e econômico por instituições sociais - ou seja, elas próprias não constituídas racional ou contratualmente - que limitem as opções, excluam escolhas e sobreponham-se à 'vontade livre' dos atores, contra a resistência deles" (1997:199).

Assentadas, ainda que sumariamente, algumas características e questões que cercam a produção recente de uma "sociologia dos mercados", busco a seguir tomá-la como inspiração para levantar elementos teóricos pertinentes a uma leitura sociológica dos mercados de trabalho.

\subsection{O trabalho em sua forma emprego e a categoria mercado}

Inicio essa discussão dos mercados de trabalho pelas posições "polarizadas" no tratamento de mercados em geral, que venho de apresentar. Não somente no interior do paradigma neoclássico, as visões mais correntes da economia fazem uma distinção entre os mercados de bens e os mercados de fatores de produção.

Os fatores de produção são os insumos usados para produzir bens e serviços. Terra, capital e trabalho são os três fatores de produção mais importantes (...). Embora sob muitos aspectos os mercados de fatores se assemelhem aos mercados de bens (...), eles têm uma diferença importante: a demanda por um fator de produção é uma demanda derivada. Isto é, a demanda da empresa por um fator de produção deriva de sua decisão de oferecer um bem em outro mercado (Mankiw, 1999:390- grifo no original).

Muito embora esteja em jogo uma "demanda derivada", a tendência natural do sistema econômico ao equilíbrio sustentaria uma plena utilização dos fatores produtivos, o que incluiria, nessa concepção, o pleno emprego da força de trabalho, com a condição de que o ajuste possa se dar pela livre flutuação dos salários ${ }^{11}$, análogos nesse sentido aos preços dos bens e serviços.

\footnotetext{
${ }^{11}$ Segundo Mingione, até a contribuição dos fundadores da economia neoclássica, o paradigma de mercado era uma visão filosófica sem densidade. "É com o 'dogma do fundo salarial fixo', assumindo que o mercado de trabalho funcione a despeito das modalidades de vida dos trabalhadores, que é elaborado um paradigma lógico propriamente dito, que permite universalizar os conhecimentos econômicos e considerá-los autônomos de fatores sociais e culturais, locais e particulares" (1997/2003: 23-24)
} 
O que determina o quanto vai para os trabalhadores? Para os donos da terra? Para os donos do capital? Por que alguns trabalhadores ganham salários mais altos do que outros, alguns proprietários de terra, aluguéis mais altos que outros e alguns proprietários de capital, lucros mais altos? Por que, em particular, os programadores [de computadores] ganham mais do que os frentistas?

A resposta, como a maior parte das coisas em economia, depende da oferta e da demanda (Mankiw, 1999:389).

Voltarei a mencionar esse papel conferido aos salários como elemento de equilíbrio nos mercados de trabalho. Neste momento, para contrapor à abordagem neoclássica os questionamentos da sociologia econômica (e seus "fundadores"), o trabalho de Polanyi configurase como um bom ponto de partida.

Ao tratar da construção da "civilização" ocidental do século XIX, Polanyi reconhece que, sendo "elementos essenciais da indústria", trabalho, terra e dinheiro - trinômio que se mostra muito próximo aos "fatores de produção" que acabo de citar, no enfoque neoclássico - tinham de ser organizados em mercados. É neste ponto que Polanyi formula uma das concepções mais centrais de sua obra. Esses três "elementos", sustenta, não são mercadorias (Polanyi, 1944/1980: 84-5).

Para defender esse ponto de vista, Polanyi avança, em verdade, duas ordens de argumento. De um lado, há uma consideração lógica: "O postulado de que tudo o que é comprado e vendido tem que ser produzido para a venda é enfaticamente irreal no que diz respeito a eles [trabalho, terra e dinheiro]" (p.84-5). Um dos aspectos fundamentais é que não há, nesses casos, um ajuste da oferta com base em uma racionalidade maximizadora: "Nenhum deles é produzido para a venda. A descrição do trabalho, da terra e do dinheiro como mercadorias é inteiramente fictícia" ${ }^{12}$ (p.85). Entretanto, o autor não desconhece - ao contrário, dá especial ênfase - ao fato de que, fictícias ou não, essas "mercadorias" são lançadas, com base na "utopia" do mercado auto-regulável, ao jugo dos mecanismos de mercado. Dessa forma, a segunda vertente do seu argumento pode ser considerada prescritiva, moral:

Ao dispor da força de trabalho de um homem, o sistema disporia também, incidentalmente, da entidade física, psicológica e moral do 'homem' ligado a essa etiqueta. Despojados da cobertura protetora das instituições culturais, os seres humanos sucumbiriam sob os efeitos do abandono social; morreriam vítimas de um agudo transtorno social, através do vício, da perversão, do crime e da fome (...). Os mercados de trabalho, terra e dinheiro são, sem dúvida, essenciais para uma economia de mercado. Entretanto, nenhuma sociedade suportaria os efeitos de um tal sistema de grosseiras ficções, mesmo por um período de tempo muito curto, a menos que a sua substância humana e natural, assim como a sua organização de negócios, fosse protegida contra os assaltos desse moinho satânico (Polanyi, 1944/1980: 85-6).

\footnotetext{
${ }^{12}$ No caso específico da terra - tomada como simbolização dos recursos naturais, de modo geral -, esse aspecto é retomado em uma discussão bastante diferenciada da que aqui se prioriza, mas que guarda com ela interessante homologia. Boyer procura demonstrar que os mecanismos de mercado não são eficazes para a coordenação do suprimento e do consumo de "bens públicos" - aqueles cuja apropriabilidade, pelo comprador, não pode ser total. "Se o ar ou a água limpos são considerados bens gratuitos, as firmas e os indivíduos preferirão economizar recursos que têm custos ao invés de preservar o ambiente (...) não se trata absolutamente de um ajuste convencional de oferta e demanda, uma vez que a natureza não reage de acordo com objetivos econômicos (...)" (1997:80).
} 
Independentemente desse conteúdo axiológico, tal diferenciação do trabalho assalariado frente ao universo das transações mercantilizadas é, inquestionavelmente, uma pedra de toque da abordagem sociológica. Na construção marxiana, é uma das linhas mestras de "O Capital". Apenas para ilustrar, em um dos muitos momentos em que é tratada sistematicamente - no capítulo IV do Livro I - encontram-se formulações como esta, plena da ironia de Marx:

A modificação [do valor do dinheiro em capital] só pode originar-se, portanto, do seu valor de uso enquanto tal, isto é, do seu consumo. Para extrair valor do consumo de uma mercadoria, nosso possuidor de dinheiro precisaria ter a sorte de descobrir dentro da esfera da circulação, no mercado, uma mercadoria cujo próprio valor de uso tivesse a característica peculiar de ser fonte de valor, portanto, cujo verdadeiro consumo fosse em si objetivação de trabalho, por conseguinte, criação de valor. E o possuidor de dinheiro encontra no mercado tal mercadoria específica - a capacidade de trabalho ou a força de trabalho (1867/1988: 134-5 - grifo meu).

Segue-se a esse excerto toda uma análise eminentemente sociológica da condição do trabalhador livre como "ofertante" de força de trabalho. O fato de a contribuição de Marx ser pouco recuperada no debate da "nova sociologia econômica" poderia ser atribuído à falta de uma elaboração mais detida desse autor sobre os "mecanismos de mercado", se se acompanhar a interpretação de Abramovay (2004).

Quando se direciona a atenção para Max Weber, evidenciam-se dois contrastes. Em primeiro lugar, o tratamento que este autor recebe, no debate atual, é muito mais reverente; em segundo, a distinção é teórica. Quando se põe a dissecar, formalmente, "as normas típicas da economia racional", Weber recusa-se a conferir um estatuto diferenciado para o trabalho assalariado:

Para nossos fins, podemos considerar como troca, em seu sentido amplo, toda oferta, baseada em um pacto formal e livre, de utilidades de qualquer sorte, atuais, contínuas, presentes, futuras, contra determinadas contraprestações, qualquer, também, que seja a espécie dessas. Assim, por exemplo, (...) ou a prestação de serviços de qualquer tipo contra um salário ou soldo. O fato de que, hoje em dia, sociologicamente considerado, esse último processo signifique para os 'trabalhadores' a entrada em uma associação de dominação, fica, neste momento, tão fora de nossa preocupação como a distinção entre 'empréstimo' e 'compra', etc (Weber, 1922/1969: 54 - grifo meu).

Se sua estratégia analítica não recomenda, no momento da formulação conceitual, excetuar o trabalho assalariado da categoria "troca" - e esta, por sua vez, das "normas típicas da economia racional" -, Weber não deixa de antecipar a natureza diferenciada dessa "transação", de que se ocupará em outros momentos de sua obra. Essa distinção é reposta, recentemente, em outros termos, pela nova sociologia econômica. Em uma de suas abordagens, na qual a "relação de emprego" é analiticamente subordinada à dimensão contratual, o contraste é estabelecido com o "mercado aberto", no qual se inclui a oferta de bens e serviços fornecidos por trabalhadores autônomos ${ }^{13}$ :

${ }^{13} \mathrm{O}$ trabalho não assalariado, incluído o "auto-emprego" a que se refere Marsden, será tratado na próxima seção. 
Fazer cumprir contratos que se originam no mercado aberto, como no caso do autoemprego, torna-se relativamente fácil, uma vez que os termos do contrato são acordados antecipadamente, e as partes têm interesse em assegurar que seu grau de ambigüidade seja pequeno. A situação é bastante diferente no caso da relação de emprego por tempo indeterminado, que se assemelha mais a um acordo para trabalhar junto, ainda que sob a direção do empregador, do que a uma troca mercantil (Marsden, 2004: 228).

As especificidades reconhecidas na mercadoria trabalho não impedem que uma categoria como a de "mercados de trabalho" se consagre, passando por um processo que beira a naturalização, se for considerada, de um lado, a disseminação de seu uso no senso comum, e, de outro, a raridade de exercícios de vigilância epistemológica empreendidos por cientistas sociais.

Cumpre analisar um pouco melhor como essa categoria é definida, para prosseguir nesse esforço de problematização, no qual - com as ressalvas já apresentadas - acompanho a inspiração da sociologia econômica ao tomar a concepção neoclássica de mercado como um ponto extremo de referência contrastiva. Nesse sentido aponta Mingione, ao afirmar:

O conceito de mercado de trabalho é submetido à mesma impostação crítica discutida no primeiro capítulo a propósito do paradigma do mercado em geral. Não se trata de um subsistema sócio-organizativo com um equilíbrio próprio derivado da competição atomizada, mas, isso sim, de tensões que continuam a produzir formas de desorganização e de reorganização dos âmbitos sócio-organizativos (Mingione, 1997/2003:164).

Ao final da década dos 1970, numa revisão sobre a produção sociológica a respeito dos mercados de trabalho, Kalleberg e Sorensen assim os conceituam:

Definimos mercados de trabalho, abstratamente, como as arenas em que os trabalhadores negociam (exchange) sua força de trabalho tendo por retorno salários, status e outras recompensas derivadas do trabalho (other job rewards). O conceito, portanto, refere-se amplamente às instituições e práticas que regem a compra, a venda e a formação dos preços dos serviços do trabalho. Essas estruturas incluem os meios pelos quais os trabalhadores são distribuídos entre os postos (jobs) e as regras que regem o emprego, a mobilidade, a aquisição de qualificações e de treinamento e a distribuição de salários e outras recompensas obtidas em função da participação no sistema econômico (1979:351 grifo meu).

Indiscutivelmente ampla, essa formulação já estabelece uma clara ruptura com os atributos apontados pelos neoclássicos. As condições para que se tenha um mercado "perfeito" (de "concorrência perfeita") - que apresentei na primeira seção deste capítulo, com base em Rossetti (1999) -, servem-me, agora, para organizar, por oposição, a apresentação de alguns pontos da discussão sobre mercados de trabalho, de um ponto de vista sociológico.

a) Atomização - Kalleberg e Sorensen recuperam em Parnes (1968) a posição de que os mercados de trabalho envolvem cinco atores principais: o trabalhador individual, o empregador individual, as associações de trabalhadores, as associações de empregadores e o governo (Kalleberg, Sorensen, 1979:353). Muitas outras formulações sociológicas, com outros desenhos, irão apontar no mesmo sentido: a importância central de que a ação coletiva e o poder público desfrutam, na 
construção social dessa forma específica de "mercado", em clara oposição ao princípio da atomização.

Recentemente, Streeck dedicou-se à problemática sindical a partir de uma ótica afinada com a sociologia econômica, à qual, entretanto, reputa uma "relutância" em enfrentar a análise "da dinâmica da construção de instituições e da mudança institucional dentro dos mercados", em favor da perspectiva das "redes sociais"14 (Streeck, 2005:256). Seu tratamento busca correlacionar perfis de sindicatos, estruturas dos mercados de trabalho e a ação política.

Já no século XIX, Stuart Mill mostrava, no âmbito das ciências econômicas, que "grupos não competitivos" atuavam no mercado de trabalho, controlando a oferta de trabalho para determinadas ocupações consideradas positivamente diferenciadas e, portanto, desejáveis, lembram Kalleberg e Sorensen. Assimetrias de poder sobre o conteúdo substantivo da relação de emprego eram destacados na década dos 1950 por Phelps, que distinguia os mercados de trabalho em que empregadores têm poder (rules) unilateral, aqueles em que os governos têm o principal papel regulador e aqueles caracterizados por vários acordos entre sindicatos de trabalhadores e gerências (Kalleberg, Sorensen, 1979:360). Uma abordagem análoga derivou da sociologia das profissões, que assinalou a diferença entre os níveis de controle que diferentes categorias ocupacionais detêm sobre os mercados de trabalho e sobre os termos das relações de emprego. "Ocupações representam grupos de indivíduos que desempenham atividades similares e, portanto, têm qualificações e treinamento semelhantes, bem como quantidades (amounts) similares de poder social derivados dessas posições na divisão social do trabalho" (Kalleberg, Sorensen, 1979:361).

Abbott (2005), sobre este ponto específico, defende que "ocupações" sejam entendidas como "coisas" (things) sociais, e não estatísticas, o que implica, além de "áreas de tarefas" similares, grupos de pessoas e um pertencimento sustentado por indivíduos particulares a esses grupos, conduzindo-as a institucionalizar-se (p. 322-23).

A vertente marxista, com sua ênfase nas classes sociais, é evocada por Kalleberg e Sorensen a partir dos esforços de E. Wright, nos anos 1970, no sentido de produzir, com base em dados de surveys, um quadro da estrutura de classes dos Estados Unidos, dimensionando, relativamente, as diferentes "posições de classe" (p.361).

Dois autores da nova sociologia econômica ajudam a cercar essa idéia de atomização. Fligstein (2001a:45-56) constrói uma tipologia de mercados de trabalho a partir de situações de dominação. Seu interesse é afirmar que as instituições do mercado de trabalho são estruturadas politicamente - como, de resto, ocorre em qualquer mercado, na sua visão. As quatro dimensões com que caracteriza o perfil institucional desses mercados de trabalho - "estruturas de governança", "regras de troca", "direitos de propriedade" e "concepções de controle" - serão diretamente influenciadas pela definição de qual(is) grupo(s) social(is) detém(êm) a posição

${ }^{14} \mathrm{O}$ autor acredita que ambas as abordagens possam convergir, uma vez que "a construção de instituições requer redes sociais para dar suporte à mobilização de recursos e para impor (enforce) padrões específicos de ação" (p.256) 
dominante. Esses grupos seriam os trabalhadores, os capitalistas e o Estado (quando rent seeker, isto é, um Estado cuja atuação é auto-interessada). Além dos três cenários de prevalência "pura", qualquer um dos dois primeiros grupos pode formar uma coalizão com o Estado, e pode haver ainda uma sexta situação em que o equilíbrio de poder entre trabalhadores e capitalistas conduza a um impasse (stand-off) que conferiria ao Estado uma importância fundamental como mediador ${ }^{15}$. Em síntese, na "arquitetura" de Fligstein, a força conferida às estruturas macrossociais ${ }^{16}$ é, evidentemente, incompatível com uma concepção atomista de mercado de trabalho.

Granovetter, por sua vez - que, cotejado com Fligstein representaria a outra linha da nova sociologia econômica, na perspectiva de Steiner (2004) - contrapõe-se por um outro caminho ao caráter "despersonalizado" das "transações" no mercado de trabalho. O autor percorre vários eixos relativos às relações sociais nos ambientes de trabalho para destacar a influência de laços sociais especialmente relações interpessoais - sobre práticas tão variadas quanto as promoções de empregados em uma empresa, a obtenção de trabalho ou a percepção que um trabalhador tem do estabelecimento para o qual é contratado, a qual influi em sua disposição à "lealdade" para com o empregador. Relembrando a expressão de Arthur Okun, que fala de "contratos implícitos de trabalho" como um "aperto de mão invisível" entre trabalhadores e empregadores, Granovetter sustenta que "há evidências empíricas substantivas de que empregadores e empregados não encaram um ao outro como estranhos" (2001:244).

b) Homogeneidade - Uma extensa produção sociológica explorou a heterogeneidade do "fator" trabalho, a qual pode ser desdobrada em dois planos. No primeiro, destaca-se que os processos de produção e de trabalho recriam, permanentemente, a diferenciação da força de trabalho segundo requisitos operatórios, de qualificação, de treinamento, etc. Essa tradição encontra novos desenvolvimentos na sociologia econômica, em pesquisas que abordam estratégias nacionais ou regionais de inserção competitiva nos mercados mundiais de produtos e serviços, vinculando-as aos aspectos de aprendizado tecnológico e gerencial, ao posicionamento em "cadeias de valor" e a estratégias de gestão e qualificação da força de trabalho (Gereffi, 2003). A problemática do treinamento desfruta, ainda, de grande destaque em estudos que priorizam dilemas - em muito tributários à teoria dos jogos - relativos aos seus custos e externalidades, ganhando destaque a

\footnotetext{
${ }^{15}$ Embora meu objetivo, neste momento, passe ao largo de uma aplicação a circunstâncias históricas concretas, a introdução do Estado nessa equação da construção social de mercados de trabalho evoca o tradicional debate sobre o peso que o poder público jogou na institucionalização do "estatuto da relação de emprego" (Cacciamali, 2005) no Brasil. A formulação de Fligstein não parece confortável para entender tal trajetória: não seria plausível caracterizar o Estado brasileiro - no primeiro período Vargas, especialmente como "rent seeker"; tampouco se observa uma "coalizão" entre governo e uma classe trabalhadora ou empresarial historicamente madura e politicamente organizada, que dirá um equilíbrio de poder entre essas duas que coubesse ao Estado simplesmente mediar. A especificidade de uma ação estatal geralmente classificada como populista e/ou corporativista reivindica um tratamento mais complexo de suas bases políticas e da natureza de sua intervenção.

${ }^{16} \mathrm{O}$ autor não se furta ao uso de expressões como "luta de classes" (2001a:39), embora sua perspectiva seja assumidamente inspirada no interacionismo simbólico (2001b:04).
} 
consideração sobre fatores institucionais que estimulam empresas a bancar ou participar do financiamento de ações de qualificação ou que, inversamente, favorecem comportamentos oportunistas ou free-rider (Marsden, 2004; Boyer, 1997).

Em um segundo registro, as pesquisas evidenciam que a diferenciação dos indivíduos segundo características socialmente investidas de prestígio ou status diferenciados manifesta-se, necessariamente, na "arena" das "transações" entre vendedores e compradores de força de trabalho. Nesta linha, Kalleberg e Sorensen recuperam uma vasta literatura, da qual priorizam as dimensões racial e de gênero. Numa formulação sintética, que enfoca os rendimentos, mais do que as oportunidades de trabalho, sustentam: "Existe discriminação quando trabalhadores de igual produtividade não recebem iguais recompensas pelo trabalho" (p.369). Dois exemplos da literatura resenhada pelos autores: Baron (1975) defende que, sob o capitalismo avançado, uma nova forma de reforço mútuo se exerce entre a opressão racial e a segmentação dos mercados de trabalho; Burawoy (1976), por sua vez, sustenta que o racismo é uma forma de suprir uma necessidade de força de trabalho, e que a falta de poder dos grupos migrantes é uma condição necessária para o racismo. Muitas análises sobre essa problemática terminam por indicar a existência de diferentes mercados de trabalho para grupos populacionais específicos (Kalleberg, Sorensen, 1979:370-72).

A par dessa tradição mais longa de estudos sobre formas de segmentação da força de trabalho segundo características individuais e sobre discriminação, o caráter pessoalizado que passa a ser reconhecido nas relações sociais nos locais de trabalho - que já ilustrei com Granovetter - assinala, também, de uma forma cara à nova sociologia econômica, a ausência de homogeneidade nos mercados de trabalho.

c) Permeabilidade - Na perspectiva de segmentação do mercado de trabalho, que já se anunciou no ponto anterior, Reich, Gordon e Edwards afirmavam, no início da década de 1970, a partir do campo das ciências econômicas:

\footnotetext{
Um corpo crescente de pesquisa empírica tem documentado divisões persistentes entre os trabalhadores norte-americanos: divisões por raça, sexo, nível de escolaridade, ramo industrial e assim por diante (...). Esses grupos parecem operar em diferentes mercados de trabalho, com diferentes condições de trabalho, diferentes oportunidades promocionais e diferentes instituições. (...) A teoria ortodoxa sustenta que empregadores maximizadores de lucro avaliam os trabalhadores em termos de suas características individuais e prognostica que as diferenças no mercado de trabalho entre grupos declinarão no transcorrer do tempo por causa de mecanismos competitivos (...). Todavia (...) as diferenças no mercado de trabalho não têm desaparecido. [sustentamos que] (...) forças políticas e econômicas dentro do capitalismo americano têm promovido e perpetuado mercados de trabalho segmentados, e é incorreto conceber as origens dos mercados segmentados como exógenas ao sistema econômico (Reich, Gordon, Edwards, 1973:359-60).
}

De grande impacto à sua época, a teoria do mercado de trabalho dual, que teve em Michael Piore seu principal "porta-voz" (Kalleberg, Sorensen, 1979: 356), colide frontalmente com a noção de permeabilidade e com a ausência de barreiras nos circuitos de transação que ela supõe. 
Mercados duais se subdividem em, de um lado, um setor primário - o qual abriga empregos que "requerem e desenvolvem hábitos de trabalho estáveis" (Reich, Gordon, Edwards, 1973:360), costumam estar associados a qualificações adquiridas no posto de trabalho, a salários relativamente elevados e a vias de ascensão na empresa - e, de outro, um setor secundário, cujas características são simétricas e inversas. A par da distribuição desigual dos grupos de trabalhadores entre esses setores, registrada no ponto anterior, o elemento que interessa, aqui, é a restrição de acesso ao segmento positivamente diferenciado, que, conforme o excerto transcrito, seria endógena ao sistema econômico, possuindo fundamentos políticos e sociais. A interpretação de Reich, Gordon e Edwards, ao enfatizar como causalidade as estratégias do capital monopolista para combater o poder político de uma classe operária tendente à homogeneização, perdeu seu apelo, mas, de qualquer modo, a teoria dos mercados de trabalho duais animou, na economia e na sociologia, um rico manancial de pesquisas que documentaram empiricamente a fragmentação dessa "arena" supostamente aberta, bem como as restrições (expressas em seletividade) à circulação entre seus segmentos (Kalleberg, Sorensen, 1979). Parte das críticas que fizeram avançar essa perspectiva analítica desviou a ênfase conferida ao dualismo para repô-la na lógica de funcionamento dos "mercados internos de trabalho".

d) Mobilidade - O conceito de "mercados internos de trabalho", originado na economia institucional dos anos 1950, se refere às "regras complexas que determinam o movimento dos trabalhadores entre classificações de cargos no interior de unidades administrativas, como empresas, companhias ou centros de intermediação de mão-de-obra" (Dunlop, 1966, apud Kalleberg, Sorensen, 1979:359). A contraposição aos mercados externos de trabalho se dá na medida em que, nesses últimos, "as decisões quanto à formação de preços, à alocação e ao treinamento são controladas diretamente pelas forças de mercado" (Kalleberg, Sorensen, 1979:359). Esta abordagem foi associada por Doeringer e Piore (1971) à "teoria do mercado de trabalho dual": o "setor primário" seria composto de uma série de mercados internos de trabalho. Estes se subdividem em dois tipos: circunscrevem-se a uma firma ou são compostos por um grupo ocupacional qualificado. Nesse segundo caso, há mobilidade do trabalhador individual entre empregadores, mas ele desfruta de maior segurança do que ocorreria no "mercado externo", o que é garantido pelas suas habilidades, cuja oferta competitiva é controlada pelo grupo (Kalleberg, Sorensen, 1979: 359).

A hipótese dos mercados internos de trabalho sugere que a "renúncia" à mobilidade pode corresponder aos interesses de agentes que transacionam em um mercado (de trabalho). Da perspectiva dos trabalhadores: de um lado, os "interesses" no sentido estrito da "maximização" (ganhos monetários, ou "calculáveis", na esteira de Weber) podem, numa situação de estabilização do vínculo de trabalho, ser potenciados; de outro, são expressivas as evidências de que ganhos 
simbólicos e de gratificação associados a uma relação de confiança e lealdade tendem a se misturar ou até a se sobrepor às motivações tipicamente mercantis ${ }^{17}$.

Numa esteira paralela, Sabel (1997) explora o conceito de "ordens constitucionais", estruturas de coordenação de processos econômicos diferenciadas, a um só tempo, da atomização de indivíduos auto-interessados, atribuída às relações de mercado, e da padronização de procedimentos baseados na assimetria de poder de decisão, associada a hierarquias. No centro de seu argumento está a eficiência que, potencialmente, arranjos baseados na confiança podem adquirir, como mecanismos de coordenação. Nos anos 1980 e 1990, o caso do emprego vitalício japonês se converteu na referência, levada ao paroxismo, dos mercados internos de trabalho, e devolveu a práticas dessa natureza grande atenção da sociologia do trabalho.

Granovetter (2001:235) observa um movimento pendular no pensamento econômico, relativamente à estabilidade dos vínculos de trabalho: a uma visão originalmente favorável, sucede-se, nos anos 1920, uma preocupação com os custos elevados da rotatividade, quando estudos chegam a estimar entre $54 \%$ e $86 \%$ a parcela de "trocas de trabalho" "desnecessárias". No pós II Guerra, os longos tempos de permanência no emprego voltam a ser malvistos, considerados "um novo feudalismo industrial". Com base na "nova economia institucional", os anos 1970 trazem nova valorização da estabilidade. Granovetter propõe-se, ainda, a inovar a abordagem das "propensões individuais" à mobilidade, destacando seu enraizamento (embeddedness) em constrangimentos da estrutura social. Valoriza, nesse sentido, as redes sociais que podem favorecer a (re)inserção no mercado de trabalho, bem como os efeitos negativos que sucessivos episódios de desemprego tendem a impor à "reputação" do indivíduo, neutralizando parte dos ganhos que seus contatos pessoais poderiam trazer à sua trajetória no mercado (2001:239-43).

No bojo dessa discussão, Granovetter insurge-se contra a classificação binária entre situações de "emprego" e "desemprego". Matiza, nesse sentido, o significado de tais categorias: "o desemprego que deriva do fechamento de uma planta em uma firma de uma cidade pequena impinge perdas mais sérias do que as suspensões (lay-offs) temporárias em uma grande cidade". Essa problematização quanto à multiplicidade de situações sociais, institucionais e subjetivas que se configuram nos diferentes mercados de trabalho, e aos processos que as convertem em categorias do pensamento e da vida quotidiana (Guimarães, 2002), abre um leque de desdobramentos de pesquisa com o qual meu estudo se comunica de forma bastante direta.

Essa referência ao desemprego traz à baila um aspecto essencial à reflexão sobre a especificidade de um mercado de trabalho. Se a mobilidade significa "liberdade de ingressar ou retirar-se do circuito de transações", o ofertante de força de trabalho não é um agente de mercado

17 Sobre essas motivações mercantis, é cristalina a formulação de Weber: "Toda troca racionalmente orientada pressupõe a conclusão por compromisso de uma luta de interesses prévia, aberta ou latente. A luta dos interessados através da troca, cuja conclusão supõe o compromisso, conduz-se sempre, por um lado, como luta pelo preço, contra os que se encontram interessados na troca na condição de partes (meio típico: o regateio), mas, por outra, como competição, contra os terceiros, reais ou possíveis (atuais ou futuros), na condição de concorrentes pela obtenção (meio típico: encarecer ou rebaixar)" (Weber, 1922/1969: 53). 
como outro qualquer - e, por extensão, esse mercado não é um mercado como outro qualquer -, dada a natureza da mercadoria transacionada. As formulações de Marx são, nesse sentido, especialmente elucidativas:

Para transformar dinheiro em capital, o possuidor de dinheiro precisa encontrar, portanto, o trabalhador livre no mercado de mercadorias, livre no duplo sentido de que ele dispõe, como pessoa livre, de sua força de trabalho como sua mercadoria, e de que ele, por outro lado, não tem outras mercadorias para vender, solto e solteiro, livre de todas as coisas necessárias à realização de sua força de trabalho (p.136).

Quem diz capacidade de trabalho não abstrai dos meios necessários à sua subsistência. O valor deles é antes expresso no valor dela. Se não é vendida, de nada serve ao trabalhador, ele então a percebe muito mais como uma cruel necessidade natural que a sua capacidade de trabalho tenha exigido determinado quantum de meios de subsistência para sua produção e constantemente exige de novo para a sua reprodução. Ele descobre, então, com Sismondi: 'A capacidade de trabalho nada é se não é vendida' (Marx, 1867/1988: 139).

e) Preço-limite - A idéia (neo)clássica de um "preço de equilíbrio (...) que nenhum agente é capaz de comandar" (Rossetti, 2002:402) não deixou de ser estendida, por essa vertente de pensamento, aos salários, como já registrei. Esse debate, na economia, teve uma centralidade inquestionável, especialmente no contexto da depressão dos anos 1930, e é um dos eixos das preocupações de Keynes, na "Teoria Geral". Keynes refuta o postulado clássico segundo o qual o desemprego seria sempre voluntário e resultaria da "desutilidade do trabalho" - a recusa de indivíduos a trabalhar por uma remuneração considerada a tal ponto baixa que não traria vantagem, na comparação com a alternativa de não-trabalho ${ }^{18}$ (sendo que essa remuneração não poderia ser alterada, pois corresponderia à produtividade marginal do trabalho). Esta passagem guarda muita semelhança com críticas da nova sociologia econômica à teoria neoclássica:

Contudo, se a teoria clássica é apenas aplicável ao caso do pleno emprego, torna-se obviamente enganoso aplicá-la aos problemas de desemprego involuntário - supondo-se que tal coisa exista (e quem o negará?). Os teóricos da escola clássica são comparáveis aos geômetras euclidianos em um mundo não euclidiano, os quais, descobrindo que, na realidade, as linhas aparentemente paralelas se encontram com muita freqüência, as criticam por não se conservarem retas (...). Precisamos desembaraçar-nos do segundo postulado da doutrina clássica e elaborar um sistema econômico em que o desemprego involuntário seja possível no seu sentido mais estrito (Keynes, 1936/1983: 24).

Considerada um desdobramento do enfoque neoclássico (Kalleberg, Sorensen, 1979:362), a teoria do capital humano e alguns desenvolvimentos correlatos, como o da "sinalização" no mercado de trabalho, também despertaram grande interesse no campo da sociologia. Baron e Hannan (1994), por sua vez, disparam contra os sociólogos, que ignorariam parte da estrutura teórica que estava em questão, embora utilizassem a linguagem. Para eles, o aspecto fundamental da teoria do capital humano foi encaixar a escolarização, a saúde e outros comportamentos em

18 Essa suposta decisão não diria respeito, apenas, ao trânsito do indivíduo entre a condição de "economicamente ativo" ou "inativo", nos termos mais recentes. Idealmente concebida, ela incluía a "alocação" de horas adicionais ao trabalho. 
termos de investimentos - envolvendo, portanto, considerações como taxas de retorno, custos de oportunidade, financiamento ou a problemática da apropriação dos retornos pelo investidor.

Os sociólogos empregaram a linguagem do capital humano para se referirem a características que têm valor nos mercados de trabalho, sem sempre especificar qualquer estrutura de investimento ou depreciação. Na prática, a idéia de capital humano tornou-se usada para re-rotular vários tipos de efeitos em modelos de regressão convencionais sobre a atribuição de status. (...) Muito dos insights teóricos de Becker se perdeu na tradução (Baron, Hannan, 1994: 1122-23).

A teoria do capital humano, bem ou mal apropriada pela sociologia, aponta para outra força explicativa na determinação dos salários, que se afasta da perspectiva de salários de equilíbrio derivados de uma "função de produção" em que o que está em jogo é, antes de mais nada, um quantum de trabalho - tratado "como se" homogêneo. Entre outras implicações, a teoria do capital humano atribui ao trabalhador individual uma parcela relevante de responsabilidade sobre o valor (ou preço) de seu trabalho.

Ainda mais pertinente, no que tange às remunerações do trabalho, é a diversificada literatura que aborda a dimensão das negociações coletivas e o decorrente caráter "convencional" dos níveis salariais. O pagamento de um "salário eficiência", por sua vez, dificilmente poderia ser analisado exclusivamente a partir dos pressupostos dos preços de equilíbrio. Quatro "versões" explicativas são resenhadas por Saygili:

Na versão da negligência (shirking), salários mais altos reduzem a negligência por aumentarem o custo de perder o emprego. Na versão da rotatividade, salários mais altos reduzem os custos da rotatividade. A versão da seleção adversa (adverse selection) sustenta que oferecer um salário mais alto elevará a qualidade média dos candidatos aos empregos, e, com isso, aumentará a qualidade média dos trabalhadores que a firma contrata. Finalmente, a versão sociológica propõe que um salário mais alto pode erigir lealdade entre os trabalhadores e, assim, aumentar o esforço dos trabalhadores (1998:01).

f) transparência - Embora esse aspecto não seja contemplado com especial destaque na bibliografia, cabe registrar a atenção que desfruta a problemática da informação no mercado de trabalho - relativamente a oportunidades de trabalho, a indivíduos que se candidatam a empregos, a firmas que recrutam -, na produção de alguns autores contemporâneos. Conforme já foi referido, Granovetter traz à frente da cena a interveniência das redes sociais, dos contatos pessoais e dos "laços fracos ou fortes" que conectam indivíduos - mecanismos que compartilham ou até superam o papel da circulação "pública” de informações.

Já num outro enfoque, que aborda o cotidiano da relação de emprego, Marsden (2004) destaca as assimetrias informacionais, no que tange aos procedimentos técnicos e produtivos, entre empregadores e gerências, de um lado, e os trabalhadores, de outro. Esse elemento se demonstra decisivo na configuração de sistemas de gestão de recursos humanos, os quais podem contemplar, em maior ou menor grau, a delegação de responsabilidades quanto à tomada de decisões, ou, inversamente, formas mais permanentes e restritivas de controle. 
A relação de emprego é a instituição social e econômica central nos mercados de trabalho e o alicerce da firma moderna como uma organização empregadora. Ela resolve um problema difícil de coordenação: assegurar os ganhos que derivam da cooperação entre partes auto-interessadas, dado que cada uma delas sabe mais do que a outra a respeito de aspectos importantes de seu trabalho comum, e que essa separação é custosa (Marsden, 2004: 226).

A par de ilustrar a ênfase que o autor atribui à dimensão informacional no funcionamento da firma moderna e, por extensão, na relação de emprego, o excerto acima permite-me destacar que a centralidade conferida ao trabalho assalariado, nas construções teóricas que enfocam os mercados de trabalho, não deixa de se fazer presente também na produção da "nova sociologia econômica", como se percebe em Granovetter (2001), Marsden (2004) e Neil Fligstein (2001a).

Dois outros autores identificados com essa perspectiva analítica, no entanto, dedicam muita atenção à problemática do trabalho para além da relação de emprego. Enzo Mingione e André Gorz oferecem-me a chave de entrada para a próxima seção, voltada para essa ampliação do escopo.

Antes, sintetizo o contraponto que a literatura citada ofereceu a uma concepção do trabalho assalariado subordinada à matriz (neo)clássica de entendimento das "relações de mercado". Processos sociais e políticos como negociações coletivas, conflitos de classe, cooperação no processo de trabalho, hierarquias de status, entre outros, evidenciam que os "agentes" não se encontram atomizados e não podem ser reduzidos, ontologicamente, à condição de indivíduos maximizadores em estado de concorrência. A "mercadoria" (força de) trabalho, ademais, não é homogênea no sentido de que seus ofertantes sejam "substitutos perfeitos" uns dos outros. Atributos pessoais, credenciais escolares e habilidades técnicas, por exemplo, tornarão muito diferenciada a atratividade de cada indivíduo diante de seus potenciais empregadores, o que reflete mecanismos eminentemente sociais de reconhecimento e seu inverso, a discriminação. Com isso, geram-se segmentos de mercado dissociados uns dos outros, os quais, contidos por barreiras de acesso, são destituídos da "permeabilidade" que deles se esperaria, modelarmente. Quanto à mobilidade, entendida como "a liberdade de ingressar ou retirar-se do circuito de transações", tampouco ela convive confortavelmente com a segmentação ou a segregação. Afora isso, em alguns contextos ela pode não ser desejada pelos "agentes" - empregadores e trabalhadores -, cujos interesses, quer materiais, quer simbólicos, apontam muitas vezes no sentido da estabilização de uma relação social. Os mecanismos de preço não têm condições de cobrir a realidade das determinações salariais, revestidas de um caráter convencional que historicamente refletiu os pactos políticos mais amplos da sociedade, atualizados, ademais, na barganha entre empregadores e trabalhadores nas mais diversas escalas de organização e representação de seus interesses coletivos, tendo os aparatos governamentais uma participação mais ou menos ativa, mas raramente desprezível, nesses dois planos. Por fim, a informação "perfeita", reconhecidamente uma das condições mais irrealistas dos modelos (neo)clássicos, parece inaplicável à realidade do trabalho 
assalariado, seja do ponto do vista da relação entre empregadores e empregados no processo mesmo de produção, seja no que se refere ao recrutamento de trabalhadores pelas firmas ou nas escolhas que os primeiros fazem entre oportunidades ocupacionais. Relações sociais e interpessoais mostram-se decisivas nessas tomadas de decisão, dotando os "agentes" de uma confiança que os mecanismos "universais" de circulação de informação não lhes transmitem.

Todas essas incongruências com uma perspectiva estritamente mercantil levam a que a sociologia conviva com uma ambivalência, ilustrada pelo texto de Streeck (2005), intitulado "Sociologia dos mercados de trabalho e dos sindicatos", em que o autor afirma: "De um modo geral, a pesquisa e a teoria sociológicas sustentam que o mercado de trabalho não é realmente um mercado, no sentido de um mecanismo universalista, impessoal, cego para a cor e para o gênero, que gere o encontro (match) da oferta de e da demanda por trabalho" (p. 254).

\subsection{Trabalho não-assalariado, não-trabalho e o alcance da matriz teórica}

Após coligir uma série de contribuições diversificadas que interpelam a aplicação de uma visão clássica de "mercado" para os atos de compra e venda de força de trabalho, preciso problematizar as formas assumidas pelo trabalho social quando não se enquadram na modalidade do assalariamento - imposição de meu objeto empírico, além de desdobramento lógico da discussão anterior. Afora a solidez, está em jogo o alcance da categoria "mercado de trabalho" para dar conta da problemática da "ocupação", da "atividade economicamente orientada", ou como quer que seja designada.

Aparentemente, a categoria "mercado de trabalho" tomou um sentido metafórico (Boyer, supra), com implicações sobre a visibilidade de situações não "modelares". Aos fenômenos contemporâneos do desemprego e do desassalariamento (Pochmann, 1998a) são atribuídas implicações societais de radical profundidade, como "a desconversão social, o individualismo negativo, a vulnerabilidade de massa, a desvantagem, a invalidação social, a desfiliação" (Castel, 1995/2001:23). Alternativamente, há interpretações que conferem um valor eminentemente positivo às mudanças que se processam, associando-lhes um maior grau de liberdade, eficiência e inovação (cfe. Mingione, 1997/2003:11). Mais do que enfrentar o conteúdo histórico e político substantivo dos processos em curso, nessa escala tão ampliada, colho a reflexão que alguns pensadores produzem por conta deles, para remetê-los à dimensão teórica do tratamento do trabalho não assalariado.

Enzo Mingione oferece contribuição muito relevante para essa discussão. A partir de uma extensa revisão teórica, contesta a "hipótese fantasiosa de que o mercado de trabalho funcione como o mercado de uma mercadoria qualquer" (p.162). Prioriza, então, o conceito de "regime de trabalho" - "um conjunto coerente e duradouro de regras de vida social que permite mobilizar as energias laborais em formas típicas" (p.158). Sob essa perspectiva, dedica-se a detalhar modalidades de trabalho que escapam à forma típica do emprego e, demonstra, nunca deixaram de 
desempenhar papel muito relevante na reprodução social. Em seu entender, "a ocupação assalariada nas grandes empresas assumiu um papel central, mas nunca uma dimensão quantitativa majoritária" (158). Nesse sentido, "as interpretações correntes do mercado de trabalho, para poder discutir competição e salários, fundam-se no pressuposto de que a população ativa não tenha outra alternativa para sobreviver se não a de encontrar um trabalho assalariado. Assim formulado, o pressuposto é fantasioso" (p.165).

Dois esteios da argumentação de Mingione merecem relevo. Primeiramente, a centralidade da idéia de reprodução social, que o autor insiste em "recuperar teoricamente" (p.88), e que, segundo ele, impõe a análise da diversidade, em oposição à pretensa universalidade do trabalho assalariado:

Nessa perspectiva, o trabalho doméstico, o auto-consumo, as atividades informais, as economias de subsistência, o desenvolvimento de combinações sempre mais complicadas de Estado e família nos serviços de cuidados pessoais, inovação e persistência nas pequenas empresas, tornam-se campos analíticos centrais da interpretação das economias industriais, tal qual são estruturadas socialmente. A diversificação histórica e local das estratégias e dos ambientes de reprodução se torna, assim, um dos campos complexos da interface entre a organização social e o sistema econômico, para além do paradigma do mercado (Mingione, 1997/2003:88).

Em segundo lugar, a persistência de atividades e "modalidades" de trabalho que não se enquadram nas relações de emprego é interpretada pelo autor a partir de uma perspectiva em que adquire muita relevância a motivação dos indivíduos:

(...) as modalidades não assalariadas de trabalho mantiveram um papel importante. Essas últimas, de fato, continuaram a se fazer portadoras de estratégias e respostas diferenciadas frente à tensão do mercado, na comparação seja com as dos outros trabalhadores, seja com as dos outros empreendedores: manter o controle das próprias modalidades de trabalho e de subsistência, tradicionais em maior ou menor grau, mais do que maximizar o rendimento imediato do trabalho e o próprio status de consumidor (tudo isto quer por escolha, quer por força da ausência de alternativas); reforçar o bem-estar familiar mais do que maximizar o lucro e promover a concentração econômica (p 178-9).

É difícil não observar a ambigüidade do raciocínio de Mingione, que, no mesmo movimento em que busca fincar as raízes do trabalho não assalariado em objetivos individuais distintos dos que imperariam no "paradigma do mercado" (o "controle das próprias modalidades de trabalho" funcionando como um equivalente da idéia não expressa de autonomia; o "bem-estar familiar" com prioridade sobre o lucro; a pouca importância atribuída ao status derivado do padrão de consumo), não deixa de contemplar a leitura alternativa, de que essas formas atípicas se devam à "ausência de alternativas". Com uma coloração teórica muito diferente, essa questão reaparecerá no rápido tratamento que reservo, adiante, ao debate brasileiro sobre o "setor informal" e a marginalidade. Neste momento, resta fazer justiça a Mingione, que - após caracterizar a crise contemporânea do trabalho e suas duas "síndromes negativas mais visíveis", a desocupação de massa e a ocupação precária com renda insuficiente (p.207) - afasta a hipótese de que o trabalho autônomo ou as microempresas possam ser vistos como "solução generalizável frente à 
necessidade de encontrar um equilíbrio entre a difusão de modalidades de trabalho mais flexíveis e o déficit de regulação social que essas modalidades mesmas comportam” (p.219). Essa posição contra-arresta certo romantismo que transpira em outros momentos de sua reflexão.

A contribuição de Mingione é muito rica ao dar visibilidade à multiplicidade de formas de trabalho - e de critérios analíticos para distingui-las - que se articulam nas sociedades contemporâneas, a qual ele sistematiza no quadro que reproduzo abaixo. 
QUADRO 2

Esquema analítico das atividades de trabalho em sentido amplo

\begin{tabular}{|c|c|c|c|c|c|c|c|}
\hline Formal & \multicolumn{7}{|c|}{ Informal } \\
\hline \multicolumn{2}{|c|}{ Legal } & \multicolumn{2}{|c|}{ Ilegal } & \multicolumn{4}{|c|}{ Não regulamentado } \\
\hline \multicolumn{5}{|c|}{ Monetário } & \multicolumn{3}{|c|}{ Não monetário } \\
\hline Público & & & & & & & Privado \\
\hline $\begin{array}{l}\text { I. atividades formais } \\
\text { puras }\end{array}$ & $\begin{array}{l}\text { II. atividades } \\
\text { mistas formais/ } \\
\text { informais }\end{array}$ & $\begin{array}{l}\text { III. Atividades } \\
\text { que burlam a } \\
\text { legislação fiscal, } \\
\text { previdenciária ou } \\
\text { trabalhistas }\end{array}$ & $\begin{array}{l}\text { IV. Atividades } \\
\text { criminosas }\end{array}$ & $\begin{array}{l}\text { V. Atividades } \\
\text { remuneradas por } \\
\text { transações não } \\
\text { regulamentadas }\end{array}$ & $\begin{array}{l}\text { VI. Atividades } \\
\text { não retribuídas de } \\
\text { reciprocidade ou } \\
\text { voluntárias }\end{array}$ & $\begin{array}{l}\text { VII. Auto- } \\
\text { produção (no } \\
\text { interior do } \\
\text { núcleo familiar) }\end{array}$ & $\begin{array}{l}\text { VIII. Trabalho } \\
\text { doméstico } \\
\text { 'normal' }\end{array}$ \\
\hline \multicolumn{8}{|c|}{ Exemplos } \\
\hline $\begin{array}{l}\text { Todas as atividades } \\
\text { produtivas } \\
\text { realizadas na } \\
\text { observância das } \\
\text { regulamentações } \\
\text { existentes }\end{array}$ & $\begin{array}{l}\text { Atividades } \\
\text { formais que } \\
\text { contêm } \\
\text { elementos } \\
\text { informais. Por } \\
\text { exemplo: } \\
\text { retribuições } \\
\text { parcialmente "por } \\
\text { fora" (in nero) }\end{array}$ & $\begin{array}{l}\text { Segundo trabalho } \\
\text { (informal [in } \\
\text { nero]); admissão } \\
\text { sem contrato; } \\
\text { auto-ocupação } \\
\text { informal }\end{array}$ & $\begin{array}{l}\text { Furto, tráfico de } \\
\text { drogas, } \\
\text { falsificação }\end{array}$ & $\begin{array}{l}\text { Escambo; lavagem } \\
\text { de carros por } \\
\text { crianças }\end{array}$ & $\begin{array}{l}\text { Trabalho baseado } \\
\text { em relações de } \\
\text { reciprocidade; } \\
\text { ajuda entre } \\
\text { vizinhos; vários } \\
\text { tipos de trabalho } \\
\text { voluntário ou } \\
\text { social }\end{array}$ & $\begin{array}{l}\text { Hortas para o } \\
\text { auto-consumo; } \\
\text { atividades faça- } \\
\text { você-mesmo }\end{array}$ & $\begin{array}{l}\text { Limpeza; } \\
\text { cuidado dos } \\
\text { filhos; } \\
\text { preparação das } \\
\text { refeições }\end{array}$ \\
\hline
\end{tabular}

Extraído de Mingione (1997/2003: 160) 
André Gorz, no cotejo com Mingione, oferece um exemplo lapidar de caminhos opostos cujos pontos de chegada são muito próximos. Ele caracteriza o momento presente não como uma crise da economia ou da sociedade, mas como uma crise da utopia ( e da promessa de que

(...) o desenvolvimento das forças produtivas e a expansão da esfera econômica liberariam a humanidade da penúria, da injustiça e do mal-estar; (...) fariam do trabalho a atividade demiúrgica e ao mesmo tempo autopoiética, na qual o aperfeiçoametno incomparavelmente singular de cada um seria reconhecido - direito e dever a um só tempo - como parte da emancipação de todos.

Desta utopia nada resta (Gorz, 1988/2003:20).

Gorz propõe-se, de modo explícito, a reforçar politicamente uma nova utopia, a de que o trabalho social que resta a ser feito (reduzido em razão do progresso técnico) seja compartilhado, gerando-se ocupação para todos com uma "duração do trabalho" mais restrita.

A mera garantia de renda está longe de satisfazer, em sua visão, o "déficit de sociedade" (p.205): nas atuais circunstâncias, os beneficiários de transferências monetárias formulariam uma auto-imagem terrível: “"Excluído de todos os grupos e de todas as empresas, puro consumidor de ar, de água, e do trabalho de outrem, reduzido ao tédio de viver, à consciência aguda de minha contingência', sou um 'supernumerário da espécie humana"' (p.204). Menos do que as proposições políticas de Gorz, é a sua discussão sobre qual trabalho é almejado como um direito que me abre janelas relevantes de diálogo.

O problema não é de hoje. Marx já empregava a noção de 'trabalho' de forma indiferenciada, colocando no mesmo plano o trabalho de um operário de fábrica e aquele do compositor ou do cientista (...).

Para demonstrar que a 'sociedade do trabalho' não está prestes a desaparecer, que o trabalho continuará a ser o cerne de nossas vidas, seus ideólogos vão ainda mais longe nessa indiferenciação: as atividades do técnico, do policial, do biscateiro, do entregador de pizza em domicílio, da empregada doméstica, da mãe, do engraxate, do padre, da prostituta etc, são todas atividades consideradas 'trabalho' (...) (p.132-133).

Gorz limita as alternativas aceitáveis de trabalho que inclui em sua utopia àquelas que configuram "trabalho no sentido econômico" e que sejam portadoras de "emancipação". Inicia por enunciar as características das atividades às quais a "racionalidade econômica parece aplicável". Essas atividades são definidas por quatro critérios, cuja combinação o autor usará de base para uma intricada tipologia:

a) criam valor de uso;

b) têm em vista uma troca mercantil;

c) realizam-se na esfera pública;

d) em um tempo mensurável e com um rendimento o mais elevado possível (p.137).

A partir desse elenco de características, Gorz aplica uma subdivisão entre atividades mercantis e atividades não mercantis. As primeiras delas, a seguir, são desagregadas em quatro tipos. O primeiro é "o trabalho no sentido econômico como emancipação". Aqui são obedecidos os 
quatro critérios (a, b, c, d). Este (e somente este) é o verdadeiro "fator de inserção social". "Um trabalho determinado em condições e preços determinados" na esfera pública é um direito indissociável do direito à cidadania (p.138-9). Não parece haver, ressalto, nessa formulação de Gorz, uma restrição ao trabalho assalariado. Ainda assim, acompanhando-se seu argumento, vê-se que rechaça boa parte das atividades que geralmente se associam ao trabalho por conta-própria.

No segundo tipo das atividades mercantis, estão as atividades "de serviçal". Embora cumpram os demais requisitos, elas não criariam valor de uso. A figura síntese é a do engraxate, cujos fregueses pagariam "não pela utilidade de seu trabalho, mas pelo prazer que têm em serem servidos" (p. 139). O imperativo de "agradar" que pesa sobre o trabalhador não permite que se considere plenamente pública a esfera em que se realiza a atividade. Nesse tipo, a argumentação de Gorz parece mais arbitrária e menos rigorosa: ele não apresenta, por exemplo, nenhuma evidência que sustente sua posição segundo a qual raramente "o tempo que os serviçais fazem seus patrões ganharem" é "empregado em atividades de uma utilidade social ou econômica muito maior".

"Funções, assistência, auxílios" compõem o terceiro tipo. A elas "falta" a condição "d": seu "rendimento é impossível (de) medir e, conseqüentemente, (de) maximizar" (p.140). É o caso de bombeiros que ficam de plantão, mas dos quais se espera que nada tenham a fazer - e aqui ele afirma a idéia de "função" como essa espécie de prontidão, a qual passa a compor o perfil de muitos postos, como o do operário que supervisiona instalações automáticas. Analogamente, a assistência - médica, por exemplo - não permite que se padronizem ou quantifiquem os tempos e o "rendimento" do trabalho. Nessas situações, ou no laço professor-aluno, a relação "é dissociada da relação mercantil e considerada em sua autonomia", o que inclui um componente de "dádiva" (p.143). O ideal, segundo Gorz, seria que atividades dessa natureza fossem executadas por voluntários, não como uma forma de substituir empregos "de verdade" por um "ofício de baixo preço", mas, isso sim, restituindo-as, parcialmente, à esfera da vida "não econômica", sob a lógica do auxílio mútuo, sem deixar de contar com os "serviços institucionalizados e centralizados" (p.144).

O quarto tipo de atividade mercantil causa inicialmente desconcerto, pela originalidade da abordagem: trata-se da prostituição. Aqui, atendem-se aos requisitos (a), (b) e (d), acima apresentados. Falta-lhe a inserção na esfera pública. Nessa forma como Goz a formula, "a prostituição não se limita, evidentemente, ao 'serviço sexual'. Há prostituição cada vez que permito a alguém comprar, para dispor a sua guisa, isso que eu sou, sem poder produzi-lo em virtude de uma competência técnica: por exemplo, o renome e o talento do escritor venal; ou a mãe que aluga seu ventre" (p.148).

Esses quatro tipos demonstram, segundo Gorz, que nem todas as atividades cumpridas em vista da troca mercantil respondem aos mesmos critérios de racionalidade; até por isso, não podem 
ser abrangidas indistintamente na "esfera econômica". Por tudo isso, "não são 'trabalho' no mesmo sentido do termo" (p. 151).

Menos ainda o são as atividades que não visam à troca mercantil. Nesse segundo grupo, Gorz distingue dois tipos. O "trabalho para si", primeiramente, gera "valor de uso do qual somos nós mesmos os artesãos e os únicos destinatários" (p.152), e sua profissionalização ou mercantilização (na perspectiva de gerar postos de trabalho, defendida por alguns) não traria qualquer ganho para a sociedade: geraria apenas mais serviçais, num processo de "sulafricanização da sociedade" (p.155), liberando tempo de um pequeno contingente (de clientes), quando muito, para "deleites privados" (p. 154). Num segundo tipo de atividades não mercantis encontram-se as "atividades autônomas", identificadas com "a busca do Bem, do Belo e do Verdadeiro" (p.164), em situações libertas da heteronomia e, também, da necessidade (p.166).

Claramente, para Gorz, o trabalho assalariado prossegue sendo uma forma insubstituível de "pertencimento" social (p. 205), cuja rarefação se constitui no fulcro da crise. Orientado para o futuro, recusa a indiferenciação das formas de atividade e as esquadrinha para repelir soluções que se baseiem em modalidades de trabalho ainda menos desejáveis do que o emprego. Num caminho diverso, Mingione externa uma valoração positiva das atividades que se despeguem do "paradigma do mercado" (embora não as proponha como panacéia). Numa abordagem mais histórica do que prospectiva, destaca o quantum de trabalho social que, não tomando a forma de emprego, circunda essa construção social, participando de sua reprodução.

Ambos os autores desafiam abordagens teóricas em que qualquer forma de trabalho se subordina à categoria emprego. Esta, ademais, contrai-se, nas sociedades contemporâneas, o que fragiliza ainda mais o constructo "mercado de trabalho". Essa tendência evoca uma das "inseguranças" com que Mattoso (1994) caracteriza o trabalho na atualidade. Refiro-me à "própria insegurança em pertencer ou não ao mercado de trabalho" (p.525). O estudo apresentado em Guimarães (2004) compara metrópoles de três países e detalha a "intensificação nas transições no mercado de trabalho", em que se destaca, no caso brasileiro, "um importante movimento de entrada e saída do mercado de trabalho, isto é, de transição em direção à inatividade; tal movimento, uma vez banalizado, põe em xeque as próprias fronteiras analiticamente consagradas para delimitação do mercado de trabalho" (p.05).

Uma expansão da inatividade (ou a intermitência desse estado, em trajetórias individuais) é uma das faces mais claras que a desestruturação do mercado de trabalho pode assumir. A "inatividade" é uma entre outras categorias que estruturam os levantamentos estatísticos sobre mercados de trabalho, as quais, evidentemente, se baseiam em critérios que expressam representações sociais historicamente (e, em decorrência, provisoriamente) consolidadas sobre o "funcionamento" do mundo do trabalho. O fato de que essas construções nada têm de inequívocas pode ser ilustrado pelo intenso debate que, especialmente nos anos 1960 e 1970, cercou a 
problemática do setor informal e da marginalidade nos países latino-americanos. No Brasil, a controvérsia envolveu diretamente o trabalho "por conta-própria" e tem homologias perturbadoras com a dinâmica presente do trabalho, mesmo nos países industrializados, como sugere a tese da “brasilianização", lançada por Beck (1999:277-79).

A idéia de "subemprego" condensou, naquele momento, uma série de significados sociais. Tomo apoio na revisão de Hoffmann (1977): o recorte setorial era relevante: o percentual do emprego industrial era tomado como um indicador de "saúde" das estruturas ocupacionais (p.44); inversamente, o terciário hipertrofiado apontava para desequilíbrios, para uma "urbanização sociopática", o que equivalia a dizer: crescendo a taxas mais elevadas do que o emprego industrial (p.56). Outros elementos de classificação eram o "caráter intermitente", "o tempo parcial", "baixa produtividade e remuneração menor ainda" (p.61). Ainda assim, era percebida a dificuldade conceitual de tomar os baixos rendimentos como indicador de subemprego, ou de ocupações de baixa produtividade, pela própria heterogeneidade tecnológica e pela característica incipiente do tecido produtivo nacional, que frustravam as expectativas de uma industrialização como alavanca de melhorias generalizadas no padrão de vida. Uma interpretação dualista e "funcional" dessas discrepâncias foi uma das vertentes:

(...) setores industriais mais modernos (...) são os que criam as novas necessidades, tanto pela difusão dos 'novos produtos' quanto pelas exigências de qualificação da 'sua' força de trabalho. Mas, essas condições exigem, para que possam perdurar, uma piora ainda maior das condições de vida de certas camadas da população (Camargo et alii, 1976:77).

Castro (1969/1972:) destaca que, ao longo da história brasileira, um contingente maior ou menor da força de trabalho teve de "contentar-se com os resultados ínfimos obtidos em formas várias de auto-emprego". Anuncia, entretanto, uma novidade: não serão mais as crises a deteriorar as condições do mercado de trabalho, mas, cada vez mais, "o avanço", no sentido da capitalização de atividades até então conduzidas de forma mais ou menos tradicional (p.161). A "força de trabalho excedente", entretanto, relembra o autor, por mais que esteja na raiz de problemas sociais e políticos de grande magnitude, não deixa por isso de se constituir em um fator produtivo. "De alguma forma buscará produzir", e o auto-emprego será a forma pela qual ocupará atividades deixadas ao largo pelas empresas capitalistas. "Nelas, o excedente inassimilável de trabalhadores busca encontrar as formas menos cruéis de exclusão". A imagem que o autor usará aqui é a de uma "franja" em torno dos centros urbanos (p.172), dialogando diretamente com a discussão que se travou sobre a "marginalidade social", no país.

Essa noção tomou apoio no conceito marxiano de exército de reserva. Nessa interpretação, ele não abarca toda a mão-de-obra excedente: uma parcela, apenas, cumpriria a função de estoque potencial de força de trabalho para substituição dos trabalhadores empregados ou expansão da 
produção. Um segundo grupamento representaria exatamente essa "massa marginal", "sobrante em relação às necessidades do sistema, apesar de gerada por sua dinâmica" (Paoli, 1974:25).

De dentro do campo da economia, Souza (1980/1999) assume uma posição que externa à perfeição uma das conseqüências desse entendimento, a qual me interessa mais diretamente nessas considerações sobre as fronteiras do mercado de trabalho, socialmente e analiticamente.

A análise dos problemas relacionados à força de trabalho deve necessariamente estar restrita aos seus integrantes, ou seja, aos proletários. (...) As categorias 'Exército de Trabalhadores em Atividade' e 'Exército Industrial de Reserva', portanto, englobam apenas os integrantes da força de trabalho. Logicamente, os ocupados em formas não tipicamente capitalistas de organização estão por definição excluídos desta conceituação.

[Nota] Ao contrário da conceituação corrente, entendo por força de trabalho o conjunto de assalariados nas formas tipicamente capitalistas de organização, mais as pessoas que estão procurando emprego. Em geral, as análises sobre a situação ocupacional tomam esse conceito como sinônimo de População Economicamente Ativa, que inclui todos os ocupados mais os desempregados 'abertos' (que estão procurando emprego) (Souza 1980/ 1999: 85).

O trabalho de Souza, que surge no momento em que o debate sobre a marginalidade está próximo de se esgotar, traz um argumento digno de interesse. Segundo ele, se a "massa marginal" não integra (sequer) o exército industrial de reserva, ela não toma parte no quadro que ele se propõe estudar (no caso, a determinação dos salários) (p.86). Um tratamento análogo é reservado à pequena produção: "os ocupados em tais atividades estão suficientemente distanciados do mercado de trabalho para que exista qualquer relação" (p.101 - grifo meu).

Sem qualquer intenção de debater a sua démarche, no quadro de suas preocupações sobre a determinação dos salários, o que me interessa reter é que Souza sugere que um amplo contingente de indivíduos que trabalham seja desconsiderado do tratamento analítico do mercado de trabalho.

Se, na seção anterior deste capítulo, procurei enfatizar a forma como um tratamento sociológico do universo do emprego assalariado transborda a matriz mercantil, nesta, outra ordem de questão ganhou relevo: há muitas modalidades do trabalho social que são executadas ao largo da compra e venda contratualizada de força de trabalho, o que aporta uma segunda ordem de insuficiências e tensionamentos.

Do ponto de vista das tradições disciplinares da sociologia, quando se assume uma definição restritiva de mercado de trabalho, proclamando-se que suas fronteiras não coincidem com as do trabalho social e recusando-se relevância analítica aos contingentes que não cumprem os requisitos estabelecidos, renuncia-se à possibilidade de avançar em uma construção analítica que reconheça a pluralidade e a extensão das relações que atravessam uma sociedade nos atos de produzir e trabalhar. 
A noção de mercado de trabalho está a carecer de exercícios de vigilância epistemológica, sendo especialmente oportuno que se debatam seus fundamentos e implicações. Essa tarefa teórica não se subordina a uma agenda "conjuntural", mas, certamente, tem sua importância acrescida por este momento histórico em que sinais claros de fratura afetam a construção institucional das "sociedades salariais", que vicejaram nos principais países capitalistas ao longo do século passado. Não é necessário assumir o partido de teóricos como Offe (1989), que há duas décadas foi uma das vozes a sinalizar a perda de centralidade da "categoria trabalho" para as ciências sociais. Mesmo se considerando que a ocupação ou o emprego seguem sendo decisivos para analisar a sociedade contemporânea, é difícil deixar de ver que seu tratamento analítico transborda cada vez mais uma compreensão - possivelmente metafórica, na origem, mas, posteriormente, reificada - calcada numa matriz de transações mercantis.

As ciências sociais tentam romper um longo silêncio diante da categoria mercados, a qual demonstra grande potencial de influenciar a realidade política, econômica e social. A nova sociologia econômica congrega uma pluralidade de esforços no sentido de recuperar a tessitura social das práticas mercantis, necessariamente fundadas em arranjos institucionais, em regras, em esteios culturais - vale dizer, em sociedades.

Nesse percurso ainda incipiente, a contraposição ao entendimento "modelar" de mercados, de corte neoclássico, consagra, algumas vezes, uma caricatura do campo "adversário". Ao mesmo tempo, expõe um nervo do problema: apesar de todas as críticas e refinamentos incrementalmente acumulados contra esse paradigma, não se constituiu uma alternativa teórica acabada e consistente para deslocá-lo. Dessa forma, ele segue imprimindo sua marca nos esquemas explicativos e nas interpretações, com efeitos possivelmente mais nocivos quando não assumido integral e explicitamente.

Mais do que em qualquer outra arena, quando se trata de mercados de trabalho é difícil sustentar princípios como a impessoalidade, a homogeneidade, a liberdade de ingresso e retirada do circuito de "transações" ou, ainda mais, a atomização dos "agentes". Uma literatura já clássica e as contribuições da nova sociologia econômica convergiram para cercar de "incômodos" o conceito. 


\section{A DIMENSÃO ESPACIAL: COMPLEXIDADE E REVALORIZAÇÃO ANTE O DECLÍNIO DO "NACIONALISMO METODOLÓGICO"}

No capítulo anterior, destaquei algumas insuficiências que cercam a categoria analítica "mercado de trabalho". A pesquisa que desenvolvi na Grande Santa Rosa teve o propósito de contribuir para o avanço da reflexão sobre essa problemática a partir do estudo de um mercado regional de trabalho, creditando à dimensão espacial não apenas uma necessária imbricação quanto um potencial aporte no enfrentamento dos impasses que venho de explorar. Nesse sentido, o percurso implicou a articulação de duas vertentes da produção das ciências sociais que, nas últimas décadas, embora tenham gerado confluências, vêm seguindo trajetórias relativamente afastadas.

Como externa Tickamyer (2000), a negligência da tradição sociológica quanto à dimensão espacial de suas análises vem sendo sentida e professada, no plano teórico. Ainda assim, desde os anos 1970, ao menos uma maior sensibilidade a essa lacuna parece estar se fortalecendo: a aceleração das transformações sociais e econômicas que se verifica a partir de então tem como uma de suas faces mais amplamente reconhecidas o processo que passou a ser designado, sinteticamente (mesmo na produção acadêmica, apesar de onipresentes ressalvas), como globalização. O tratamento desse fenômeno tem induzido a literatura sociológica e econômica (bem como a de outras disciplinas) a enfrentar - quando pouco, descritivamente - uma problemática eminentemente espacial. Nesse debate, costumam-se identificar dois movimentos, em aparente contradição - por vezes encabuladamente adjetivada de dialética ${ }^{19}$-, a desafiar a centralidade do Estado-nação, unidade sócio-territorial dominante no pensamento do século passado: de um lado, há a progressiva afirmação de agentes e relações transnacionais, atravessando as fronteiras políticas nacionais; de outro, revitalizam-se instâncias subnacionais regionais, locais -, que recuperam (ou vêem novamente reconhecido) seu potencial para articular forças sociais historicamente relevantes.

Numa expressão de A. D. Smith retomada por Beck (1999:48-9; 121-28), é o "nacionalismo metodológico" - segundo o qual "os contornos da sociedade devem se sobrepor gradualmente aos contornos do Estado" - que entra em xeque:

Não é somente uma nova variedade de conexões e de relações entre Estados e sociedades que surge com a globalização em todas as suas dimensões; é o conjunto das suposições fundamentais sob o qual todas as sociedades até hoje organizaram, viveram e apoiaram sua condição de unidades territoriais mutuamente separadas (Beck, 1999:49).

\footnotetext{
${ }^{19}$ Beck, por exemplo, refere-se à globalização "como um processo ('dialético', diríamos na moda passada) (...)" (1999: 31); também Bourdin utiliza aspas para falar de relações dialéticas (2001:64) e classifica o adjetivo como "fora de moda".
} 
Neste capítulo, discuto, numa primeira seção, a idéia de globalização, para, em seguida, priorizar o movimento de revitalização (e de revalorização teórica) dos espaços locais, o qual incide mais diretamente em meu objeto de pesquisa. $\mathrm{O}$ conceito de região é tratado em sua conexão com a escala local ${ }^{20}$.

Nesta pequena abertura, quero destacar de imediato alguns aspectos que estabelecem um diálogo mais imediato com as questões tratadas no primeiro capítulo.

Em primeiro lugar, das seis condições anteriormente apontadas para que um mercado opere em condições típicas, é a "mobilidade" a que mais diretamente se vincula ao problema da territorialização de um mercado de trabalho. Diferentemente da amplitude propriamente global da circulação de muitas mercadorias, o trabalho - e a "entidade física, psicológica e moral do 'homem' ligado a essa etiqueta", na formulação já citada de Polanyi (1944/1980: 85-6) - tem necessariamente uma relação diferenciada com o espaço, e a natureza de seu deslocamento é qualitativamente irredutível. Uma das razões para isso é que, ao menos na relação de emprego, o "consumo" da mercadoria força de trabalho implica a reiteração de contextos de co-presença, tendo por base um vínculo social distendido no tempo, "que se assemelha mais a um acordo para trabalhar junto (...) do que a uma troca mercantil”, reiterando Marsden (2004:228).

Quando um trabalhador se encontra a centenas de quilômetros de uma empresa que oferece vagas, é pouco proveitoso, do ponto de vista analítico, representá-los como dois "agentes" em um (mesmo) mercado. Em que pese ao histórico peso que as migrações exerceram e exercem na história de boa parte dos países $^{21}$, a oferta e a procura de oportunidades de trabalho são, necessariamente, referidas a um recorte espacial com algum grau de restrição. Sob esse ponto de vista, é lícito afirmar que um mercado de trabalho é intrínseca e necessariamente local (ou regional) - e parece adequado tomar a "geografia" da circulação de mão-de-obra como um dos critérios de delimitação de uma região (problema analítico por nada trivial, ao qual retorno adiante).

Por certo, o nível eminentemente físico da circulação da mão-de-obra é apenas a porta de entrada mais imediatamente reconhecível, na articulação que aqui persigo. A literatura sobre o local e o regional traz a forte presença das dimensões social, cultural e histórica, e boa parte dela tem claras afinidades com o enfoque da sociologia econômica - para além dos casos em que a esta se filia explicitamente.

Michael Piore e Charles Sabel exemplificam com destaque esses pontos de contato. Em sua clássica obra de 1984, que teve grande repercussão no debate sobre as rupturas no padrão de desenvolvimento capitalista, afirmam:

\footnotetext{
${ }^{20}$ A distinção entre "região" e "local", na bibliografia estudada, não é muito nítida - e, de um ponto de vista mais abstrato, em alguns momentos não é tão relevante quanto eu costumava considerar. Voltarei a esse ponto no presente capítulo.

${ }^{21}$ Essa dimensão volta a ser tratada, à luz de algumas contribuições sobre o caso brasileiro, no próximo capítulo.
} 
Dito de outra forma, a especialização flexível funciona violando um dos postulados básicos da economia política: o de que a economia é separada da sociedade. Tanto mercados quanto hierarquias - as duas categorias que dominam a teoria contemporânea e a reflexão prática sobre a organização da indústria - pressupõem que a firma seja uma entidade independente. Nos modelos de mercado, a firma está ligada pelas relações de troca a outras unidades; em modelos hierárquicos, a firma é tão autônoma que quase constitui uma indústria por si mesma. Em contraste, na especialização flexível é difícil dizer onde a sociedade (na forma de laços familiares e escolares ou celebrações comunitárias de identidade étnica e política) termina, e onde a organização econômica começa (Piore, Sabel, 1984: 275).

Percebe-se, neste excerto, um deslizamento da noção de sociedade para a de "comunidade", marca de uma representação dos espaços locais muito encontradiça. Embora Piore e Sabel fundamentem seu conceito de especialização flexível também em outras configurações ${ }^{22}$, os distritos industriais são, inequivocamente, a matriz da sua teorização. Os autores recuam aos distritos do século XIX, mas é claramente a experiência da Itália no pós II Guerra que fundamenta a caracterização dessa forma particular de configuração - a um só tempo territorial, social, cultural, produtiva -, em que se destacam: aglomeração, no espaço, de produtores independentes dedicados a fabricar mercadorias ou prestar serviços que se articulam em torno de um ou de um pequeno número de ramos industriais; combinação de cooperação e competição entre produtores; imbricação de vários planos da vida social, garantindo uma alta densidade de interações sociais, envolvendo fortes laços familiares, comunitários, étnicos e políticos, que por sua vez alimentam e estimulam a cooperação econômica; inovação permanente de produtos e processos produtivos, calcados em habilidades "craft" e em uso flexível de tecnologia multi-propósito; amplo leque de mercadorias produzidas para mercados diferenciados e por vezes efêmeros; e instituições capazes de equilibrar as relações entre as firmas (Piore e Sabel, 1984:29).

A conceituação de especialização flexível teve destacável influência na afirmação de um ponto de vista que (re)valorizou os espaços regionais, o qual extrapolou o circuito acadêmico, tendo sofrido também muitas e pertinentes críticas. Retomo esse debate na segunda seção deste capítulo.

Neste momento, na perspectiva de abrir os pontos de contato entre as duas problemáticas que tenciono articular, destaco a contribuição de um autor que vincula diretamente a problemática do "espaço local" e a "construção social do mercado". Bottazzi (1996) parte do esquema "ternário" de Polanyi, segundo o qual os princípios de integração da sociedade seriam a reciprocidade, a redistribuição e a troca. De maneira típica, a cada um desses princípios correspondem, segundo o autor, "instituições (ou mecanismos)" que possibilitam a integração social: comunidade, Estado e mercado, respectivamente. Bottazzi periodiza, especulativamente, o peso relativo que esses princípios e mecanismos tiveram na vida econômica das sociedades. Uma primeira fase teria como princípio dominante a reciprocidade, combinada a algum grau de

22 “Conglomerados regionais", “empresas federadas", “firmas solares" e "fábricas-ateliês". 
redistribuição e uma presença mínima da troca. Segundo o autor, nesse momento "os diferentes espaços locais, de dimensões muito restritas, não tinham entre si senão relações limitadas" (p.73).

O "espaço moderno" se desenharia com a gradativa afirmação do mercado e do Estado nacional, "que se opõem à comunidade" (p.73).

O mercado, no esquema de Bottazzi, tem seu florescimento e difusão na segunda fase, antes da consolidação dos Estados, em detrimento, portanto, da "reciprocidade" e em um estágio em que o princípio redistributivo - que, no esquema de Polanyi, vincula-se a uma autoridade central (1944/80:64) - ainda não adquiriu potência significativa. Nesse processo, consagram-se "novos espaços e novas identidades territoriais, baseadas na especialização ou na interdependência" (p.74). Consoante com a orientação da sociologia econômica, adverte Bottazzi:

De qualquer modo, são os homens que trocam, não os territórios, e os circuitos da troca são feitos por indivíduos inseridos em relações sociais, não pelo indivíduo atomizado do pensamento neoclássico. Enfim, desde o começo o mercado não se afirma num vazio social, quando mais não seja porque a troca (...) demanda, para ter lugar, um mínimo de laços sociais, de confiança e de garantia (p.74).

Uma terceira fase marca a institucionalização do "Estado moderno", que, de condição de possibilidade da economia de mercado, passa a sobrepor-se a ela e mesmo a superá-la como mecanismo de integração: "É o modelo 'fordista' ou do keynesianismo social" (p.76). É esse o auge da territorialidade nacional: "Todos os espaços locais, mesmo aqueles que tinham permanecido relativamente nas margens, se vêem cada vez mais inseridos, por razões estratégicas ou de ordem pública, na esfera dominante da regulação estatal" (p.76). O caráter não mercantil, redistributivo, da intervenção estatal na vida econômica se reflete não apenas ou principalmente em sua ação "econômica", mas em sua forma de arbitrar e regular, das relações de trabalho à concorrência.

Para Bottazzi, o processo de modernização é 'um processo de 'desterritorialização', no sentido de que as relações sociais são retiradas (disembedded) de contextos da interação (espaço local) e reestruturadas sobre dimensões espaço-temporais indefinidas" (p.76). Em todo esse processo, "o papel de perdedor" cabe à comunidade e aos espaços locais, que, progressivamente, são privados de toda a "especificidade" em favor do Estado e do mercado (p.75).

Na última fase de sua periodização, o autor identifica uma ascensão da dimensão local, associada à "crise do modelo fordista". Bottazzi rejeita a associação - que até então parecia encampar - entre "localidade" e "comunidade", por considerar que esta última noção "traz o risco de avalizar a idéia errônea de um estado societário tradicional, que teria sobrevivido em uma espécie de reserva natural, ao longo de séculos, e que hoje ressurge à vista de todos" (p.80).

Para ele, são incertas as configurações que se afirmarão, quanto ao peso relativo dos princípios de integração vinculados à redistribuição, às trocas e à reciprocidade. Diferentes combinações desses princípios servem de base a uma tipologia de realidades locais que o autor 
avança, a que retornarei adiante. Um de seus pressupostos, que prefiro lançar desde já, é que escalas espaciais diversas se associam, em tensão, a cada forma de integração: "a troca de mercado tende a abrir os espaços; a reciprocidade tende a fechá-los; a distribuição, a limitá-los, controlá-los e organizá-los" (p.86).

Esboçada essa zona de convergência entre a problemática espacial e essa sociologia dos mercados que abordei no capítulo anterior ${ }^{23}$, passo à discussão da noção de globalização, fundamento tanto da idéia de que "o mercado" está esgarçando as fronteiras nacionais - e, no mesmo movimento, todo um edifício político-institucional que repousa sobre elas -, quanto da alegada reemergência dos espaços locais.

\subsection{A globalização e o tensionamento do "nacional" desde fora}

A noção de globalização, talvez por não ter uma linhagem eminentemente acadêmica, é claramente desconfortável para boa parte dos teóricos que se dedicam a analisá-la. Não se trata, ao que tudo indica, de um preconceito: a falta de pedigree da noção se traduziria na sua imprecisão, como aponta Fligstein:

(...) a "globalização" econômica reúne uma série de tendências frouxamente relacionadas entre si, tais como o crescimento do comércio mundial, o crescente espraiamento internacional da produção, o aumento do tamanho e da complexidade das cadeias de fornecimento, o crescimento das chamadas organizações em rede, o uso de tecnologias de informação para expandir e alterar essas várias tendências, o crescimento da Internet como uma ferramenta para as vendas e para o marketing, a crescente integração dos mercados financeiros mundiais e a notável industrialização da Ásia (Fligstein, 2001a:192).

Nem por isso, Fligstein deixa de adotar o termo, cujo significado procura cercar reconstruindo a versão "corrente" e opondo-lhe contra-argumentos. Em todos esses, sua preocupação é ressaltar que não se está diante de uma "força impessoal", mas, que a globalização significa, em larga medida, "a construção social e política de mercados, pelas firmas e Estados" (p. 221-2).

Esse protagonismo conferido às firmas, mais freqüentemente às corporações multinacionais, no processo de globalização encontra-se em autores de variados matizes, dentre os quais Chesnais (1994/1996) - que em sua análise atribui a propulsão da globalização aos "grandes grupos oligopolistas", em especial os da "Tríade" (Estados Unidos, Alemanha e Japão, conforme construção que toma de Ohmae) -, e Gereffi (2003), que se auto-classifica como integrante da linha de estudos das "redes de produção global", vertente que, segundo ele, enfatiza aos "laços entre os países desenvolvidos e em desenvolvimento, criados pelas redes interfirmas e corporações transnacionais", tendo como eixo central de interesse a temática da governança (p.19).

${ }^{23}$ Essa convergência é tematizada com maior profundidade em Abramovay (2006), que toma em especial a reflexão de Neil Fligstein sobre mercados para avançar na proposição de uma "teoria dos estudos territoriais". 
Beck (1999:30) - que declara a "irreversibilidade" da globalização como elemento central da "transição da primeira para a segunda modernidade" - insiste sobre a pluralidade de dimensões que está em jogo, o que o leva a tratar de uma "globalização ecológica", de "uma globalização cultural", de uma "globalização econômica", e assim por diante, cada qual com sua "lógica particular", o que recomenda que sejam analisadas "uma a uma e em suas relações de interdependência". Sua preocupação é com a consagração de uma leitura ideológica do(s) processo(s), que conferiria à esfera econômica uma preeminência espúria. Fligstein insurge-se no mesmo sentido: "tanto a economia quanto o marxismo consideram as forças econômicas como estruturais, inevitáveis e dominando a ação em toda a parte", posição que ele reputa "monocausal" e "mercantilista" (2001a:195).

Beck (1999:27-30) utiliza o termo globalismo para, distinguindo-o da noção de globalização, designar uma ideologia (a qual tacha de "neoliberal", "ideologia do império do mercado mundial") que despolitizaria os processos de integração, descarnando-os de atores sociais interessados.

Também a globalização econômica - e sobretudo ela - não é um mecanismo, não é automática: ela é na verdade um projeto político praticado, numa constante renovação, por atores transnacionais, instituições e coalizões, Banco Mundial, OMC, OCDE, empresas multinacionais, além de outras organizações internacionais (Beck, 1999:212).

Do ponto de vista dos fluxos e processos eminentemente econômicos, Trigilia (2002:248) aponta três "componentes" fundamentais da globalização: primeiramente, a expansão do comércio mundial, violentamente superior, em termos relativos, ao crescimento do produto (considerados os países desenvolvidos, no período 1975 a 1995, a diferença de taxas seria de 20 vezes); em segundo lugar, a intensificação dos investimentos diretos estrangeiros (que se elevam quatro vezes mais do que a produção); em terceiro, os descomunais fluxos de capital nos mercados financeiros. Com base nesses três indicadores, o autor define a globalização econômica como "abertura crescente das economias individuais, bem como interdependência entre elas" (p.251).

Pode-se considerar, no entanto, que a caracterização de Trigilia prioriza aspectos de uma integração econômica internacional que é secular. Robertson (1990/1999:34-36) traça um "caminho histórico temporal rumo às circunstâncias atuais de um grau elevado de densidade e complexidade global" que ele inicia no século $\mathrm{XV}$, até chegar à fase presente (a quinta em seu esquema, caracterizada pela "incerteza”). Coriat (1997:242) defende que, para que se defina globalização, é necessário principiar distinguindo-a da internacionalização, "palavra-chave de uma era anterior". A internacionalização teria, historicamente, dois componentes: a difusão da produção em massa fordista e "respostas estilo 'espelho' para esses tipos de processo de produção por competidores localizados no exterior". A globalização traria "multiplicidade de métodos inovativos" oriundos das mais diversas nações (Coriat, 1997: 242). 
Fligstein (2001a) é um dos autores menos convencidos de qualquer descontinuidade significativa em escala mundial. Denomina "informacionalismo" a perspectiva que identifica convergência no comportamento das multinacionais, a partir da expansão das tecnologias da informação e das organizações em redes, tese que refuta, por não encontrar "evidências sistemáticas" de "mudança qualitativa" (p. 204-5). Do seu ponto de vista, a versão corrente da globalização é aplicável aos Estados Unidos, apenas, e envolve "um rápido crescimento do comércio (...) acompanhado por um rápido aumento na desigualdade, exacerbado por tendências políticas que favoreceram o capital frente ao trabalho" (p.209). O autor não minimiza, entretanto, o fato de que "a retórica conservadora da responsabilidade pessoal e a posição de que tudo o que o governo fazia era ruim, enquanto tudo que ocorresse ao redor dos mercados era bom, tornou-se dominante" (p.221).

Uma posição similar encontra-se em Hollingsworth e Boyer (1997c), que atribuem ao conceito de globalização uma dependência lógica da idéia de convergência entre os "sistemas sociais de produção", o que tendencialmente diluiria o próprio sentido de nação. A idéia de convergência aqui equivale a homogeneização e teria como força propulsora tão-somente os mecanismos de mercado, em detrimento de qualquer outra forma de "coordenação". Com isso, Hollingsworth e Boyer sustentam que os pressupostos "dessa interpretação ao gosto da moda" (p.461) seriam: uma completa globalização dos mercados de fatores (finanças, recursos naturais e trabalho qualificado); a integração dos mercados de produtos; a alta mobilidade e transferibilidade das modernas tecnologias (p.462). Dedicando-se a demonstrar que esses pressupostos são mais "utópicos" (sic) do que empiricamente verificáveis, afirmam "desafiar a relevância" do conceito de globalização.

Outros estudiosos encontram na idéia de uma globalização econômica a referência para transformações efetivas e profundas. Do ponto de vista produtivo, o ponto central para Gereffi é que: "a globalização (que) é qualitativamente distinta da internacionalização porque envolve a integração funcional de atividades internacionalmente dispersas" (2003:04). Kurz (2002/2004:27) toma o exemplo de uma revista alemã que, prestes a ser fechada, viabilizou-se transferindo o trabalho gráfico para Cingapura e a distribuição para o serviço postal de um país do Caribe, para dizer que a "coerência da economia nacional tradicional" estaria superada.

Nesta concepção, não é uma dissolução das diferenças que fundamenta a globalização, mas, inversamente, a afirmação de circuitos produtivos em que é possível às empresas atravessar e subverter as economias nacionais, explorando vantagens advindas da heterogeneidade - quer derivem da especialização produtiva, quer dos custos dos fatores, ou da dotação de recursos naturais, humanos ou institucionais. 
Longe de assumir uma posição que conferiria ao "mercado", como mecanismo de "coordenação", o condão desse processo, Chesnais ${ }^{24}$ afirma:

S. Amin (1990) lembrou que a expansão do sistema capitalista baseou-se na integração simultânea, no quadro dos Estados-nações "regulamentados", de três mercados: "o das mercadorias, o do capital e tecnologia, e o do trabalho". Em seu movimento de mundialização, o capital está mandando pelos ares essa integração, e tendo todo o cuidado em não reconstruí-la (1994/1996: 39).

Percebe-se, claramente, nesta afirmação, um primeiro nível das implicações políticas, aquele que envolve a correlação de forças entre o capital e o trabalho. Nessa linha, Rodrik lembra de um elemento poucas vezes recuperado no debate:

(...) as restrições à imigração não eram tão comuns durante o século XIX, e conseqüentemente a mobilidade internacional do trabalho era mais comparável àquela do capital. Conseqüentemente, a assimetria entre capital (físico e humano) móvel e trabalho 'natural' imóvel, que caracteriza a presente situação, é fenômeno relativamente recente (Rodrik, 1997:08).

Embora seja certeira a referência à diferença de mobilidade dos "fatores", deve-se evitar o equívoco de imaginar que em algum momento da história a migração tenha conferido ao trabalho uma "mobilidade" internacional significativa. Dificilmente um indivíduo ou uma família se desenraíza socialmente e arca com os custos de se transferir para outro país ao ritmo das oportunidades de maximização que a idéia de "mobilidade" evoca. De qualquer modo, como lembra Rodrik, barreiras regulatórias se multiplicam e reforçam os impedimentos materiais, físicos e sociais que sempre existiram para isso.

Este autor enuncia de modo sintético um fundamento teórico do desequilíbrio de forças entre capital e trabalho ante as facilidades de relocalização da produção e do que Gereffi (2003:12), entre outros, chamam de estratégia do outsourcing pelas empresas:

Em uma economia que está mais aberta ao comércio e ao investimento internacional, a demanda por trabalho será, de modo geral, mais sensível a mudanças no preço do trabalho, ou mais elástica. A razão é que os empregadores e os consumidores finais podem mais facilmente substituir trabalhadores domésticos por estrangeiros - seja investindo no exterior, seja importando os produtos feitos por trabalhadores estrangeiros. Já que a demanda por trabalho é uma demanda derivada, que varia proporcionalmente à elasticidade da demanda por bens, a integração dos mercados de bens, por si mesma, torna a demanda por trabalho doméstico mais elástica (Rodrik, 1997:16).

A idéia implícita nesse excerto é a de que a elasticidade da demanda por trabalho no contexto doméstico é alimentada pela facilidade de deslocar essa procura para outras áreas geográficas do planeta. Desse modo, não é a variação na magnitude da demanda, como tradicionalmente se concebe a idéia de elasticidade, que está em jogo, analiticamente, neste

\footnotetext{
${ }^{24}$ Embora este autor prefira o termo "mundialização" ao "globalização", justifica essa posição sustentando que o primeiro, em francês, corresponde mais fielmente ao uso anglo-saxão do vocábulo globalization (1994/1996:17).
} 
momento, mas, isso sim, o número e, sobretudo, a localização dos ofertantes, que adquirem uma abrangência incomparavelmente maior. Isso permite "contornar" os parâmetros de preço - e, por extensão, todas as formas de regulação que cercam as relações de trabalho e as relações interempresariais - do ambiente nacional, quando se trata de consumir "trabalho". Outro aspecto que deriva é que a demanda por força de trabalho e a demanda por produtos são, em última instância, indiscerníveis.

Chesnais é taxativo: "A tendência é para o alinhamento nas condições mais desfavoráveis aos assalariados" (1994/1996:40). Em seu entender, a nova facilidade para a deslocalização de atividades produtivas põe os países em concorrência pelo preço da força de trabalho. Esta redobrada mobilidade do capital não é meramente um fato econômico ou tecnológico, se a esses se atribuir uma neutralidade política.

\begin{abstract}
A perda, para a esmagadora maioria dos países capitalistas, de boa parte de sua capacidade de conduzir um desenvolvimento parcialmente autocentrado e independente; o desaparecimento de certa especificidade dos mercados nacionais e a destruição, para muitos Estados, da possibilidade de levar adiante políticas próprias, não são conseqüência mecânica da globalização, intervindo como processo 'externo', sempre mais coercitivo, impondo a cada país, a seus partidos e a seus governos uma determinada linha de conduta. Sem a intervenção política ativa dos governos Thatcher e Reagan, e também do conjunto dos governos que aceitaram não resistir a eles, e sem a implementação de políticas de desregulamentação, de privatização e de liberalização do comércio, o capital financeiro internacional e os grandes grupos multinacionais não teriam podido destruir tão depressa e tão radicalmente os entraves e freios à liberdade deles de se expandirem à vontade e de explorarem os recursos econômicos, humanos e naturais, onde lhes for conveniente (Chesnais, 1994/1996:34 - grifos no original).
\end{abstract}

Essas considerações de Chesnais introduzem o segundo eixo pelo qual o processo de extroversão das economias nacionais é politizado (e sociologizado). A bibliografia é ambivalente quando aponta os governos dos Estados nacionais, da década de 1980 em diante, como patrocinadores (mais ou menos ativos, dependendo da abordagem) do processo de globalização, ao mesmo tempo em que os expõe como agentes que têm seus recursos econômicos e políticos drasticamente reduzidos nessa trajetória. As duas idéias emergem com muita veemência da citação de Chesnais, acima.

Tendendo, inequivocamente, para a primeira vertente, Fligstein (2001a:95-96) insiste que o surgimento e a institucionalização de mercados globais depende "da cooperação entre firmas e Estados para produzir regras de troca, direitos de propriedade (isto é, garantias de que as firmas podem se apropriar dos lucros) e estruturas de governança (isto é, modos de competir)”, e especula, em função disso, que o aumento na intensidade do comércio mundial fará com que se demande cada vez mais que os governos nacionais celebrem acordos entre si, o que classifica como uma forma de cooperação. A "arquitetura dos mercados" de Fligstein não deixa margem a dúvidas: se os mercados são abertos, é porque elites econômicas e políticas operam deliberada e sistematicamente para que isso ocorra; mais do que isso, será um passo necessário - 
conceitualmente -, para que se consolidem mercados globais, que os arranjos que os constituem sejam monitorados e garantidos (enforced) (Fligstein, 2001a:192). Esse é o pressuposto fundamental para que esse autor tome a seguinte posição: "os Estados continuam sendo peças da criação da economia global, porque as suas elites dependem deles para preservar seu poder e garantir a entrada nos mercados globais" (p.96).

Trigilia (2002: 253) identifica certo consenso dos teóricos sobre o estreitamento da margem de manobra dos Estados nacionais. A seu ver, as controvérsias envolvem sobretudo as conseqüências desse quadro, mais do que seu diagnóstico. Os elementos que condicionam essas novas restrições são "a liberalização dos fluxos de capital e a crescente integração dos mercados financeiros", o que dificulta que "políticas macroeconômicas tradicionais de tipo keynesiano" possam ser implementadas em um único país. Governos que sinalizam a opção por políticas de expansão da economia que impliquem um comprometimento mais substantivo de fundos públicos criam expectativas negativas, por conta da possibilidade de geração de déficits públicos, o que afeta as taxas de câmbio e gera desequilíbrios macroeconômicos. Esses constrangimentos são reforçados pela integração comercial e pelos investimentos estrangeiros (p.253).

Rodrik (1997) e Beck (1999) acrescentam a isso um argumento fiscal. Segundo o primeiro (p.06), a crescente mobilidade do capital deixa escapar (torna footloose) uma significativa parcela da base tributária dos governos. A alternativa que restaria a esses seria aumentar desproporcionalmente o gravame sobre os rendimentos do trabalho, opção politicamente indigesta e, de resto, objetivamente limitada, sobretudo em contextos de elevação do desemprego e de evoluções desfavoráveis dos salários reais. Beck, por sua vez, sustenta que há um crescente conflito entre "contribuintes virtuais" - as empresas transnacionais - e "reais" - as pequenas e médias empresas, as quais, segundo o autor "sangram nas mãos dos novos entraves da burocracia estatal" (p.21). Isso o leva a concluir que "O humor negro da história entra em cena: são justamente os perdedores da globalização que deverão pagar tudo (...)” (p. 21).

Fligstein (2001a:214-16) opõe a esses argumentos mais peremptórios algumas considerações importantes. Primeiramente, põe em dúvida o dilema "eficiência versus eqüidade", segundo o qual uma condução da política econômica eficaz para atrair investimentos e conferir competitividade às empresas do país, de um lado, e a sustentação de mecanismos de proteção social e de políticas redistributivas, de outro, seriam incompatíveis. Em sua visão, esse argumento concebe o custo do trabalho como único fator de competição e imputa a qualquer política governamental efeitos negativos sobre o crescimento econômico. Fligstein repertoria estudos, especialmente de economistas da "nova economia institucional", para indicar que burocracias públicas competentes, políticas industriais, gastos em educação, saúde etc, podem ser altamente compatíveis e favoráveis ao crescimento. Ademais, a importância dos Estados encontra-se no 
provimento de estabilidade política, instituições legais, sistemas monetários estáveis e governos confiáveis.

Ainda que breve, essa recuperação de referências analíticas sobre a globalização deverá ter servido para evidenciar algumas pressões que se processam sobre os Estados nacionais - e, por extensão, sobre o "nacionalismo metodológico" -, associadas a uma lógica, nova ou renovada, de estruturação da economia capitalista. Essas forças são a um só tempo sociais, produtivas, políticas, culturais. Nas palavras de Beck:

O Estado nacional é um estado territorial, isto é, seu poder está baseado no vínculo com um determinado espaço (no controle sobre associações, determinação das leis vigentes, defesa das fronteiras, etc). A sociedade mundial que tomou uma nova forma no curso da globalização - e isto não apenas em sua dimensão econômica - relativiza e interfere na atuação do Estado nacional, pois uma imensa variedade de lugares conectados entre si cruza suas fronteiras territoriais, estabelecendo novos círculos sociais, redes de comunicação, relações de mercado e formas de convivência. Isto fica evidente em todas as colunas da autoridade do Estado nacional: impostos, atividades especiais da polícia, política externa, segurança militar (Beck, 1999:18).

Conforme as advertências referidas de Hollingsworth e Boyer ou de Fligstein, a hipótese de convergência, de uniformização, não encontra fundamento empírico tampouco a idéia de um ocaso dos Estados nacionais. Ainda assim, a afirmação de agentes e circuitos de interação eminentemente transnacionais é uma evidência, que tem como contrapartida (ou contraface) a reconhecida emergência da esfera regional ou local, à qual se pressagia uma centralidade impensável há um par de décadas.

\subsection{A (re)afirmação das instâncias subnacionais - o espaço regional e local}

A centralidade das empresas multinacionais na regulação do sistema "global", em detrimento dos Estados-nações, e a vinculação entre produção flexível e globalização produtiva são aspectos bastante destacados pela bibliografia. As facilidades aportadas com a microeletrônica para efetuar o controle à distância de etapas produtivas espacialmente descontínuas e uma redução de custos de transportes são indicadas como elementos facilitadores para que os grandes conglomerados aprofundem sua posição no comércio internacional, retirando de cada porção territorial as vantagens de custo e lucratividade que reúnam. Nesse sentido, houve mesmo quem apontasse no sentido de um mundo borderless (sem fronteiras, na formulação de Ohmae) e stateless - sem estado, ou sem nacionalidade, na expressão popularizada pela revista norteamericana Business Week (cf. Scherer, 2002).

No entanto, paralelamente a esse enfoque, a construção teórica a respeito de um novo paradigma de produção industrial assumia forte coloração regional, influenciada de forma decisiva pela formulação, por Piore e Sabel (1984), do conceito de especialização flexível, já aludido. 
Bourdin (2001) identifica a emergência de uma visão "hiperlocalista" da sociedade, sendo o local "definido como o baluarte da mundialização" (p.09), posição que o autor não endossa. Afirma que a localidade está necessariamente referida a "contextos que não são necessariamente locais" (p.12). Ainda assim, confere grande importância à categoria "proximidade", que reputa "antropológica", indicando, já aí, que se insere em um plano da discussão bem menos condicionado pela dimensão econômico-produtiva.

Bourdin insiste que, como princípio de percepção e organização da experiência, a "dupla proximidade/ distância" é uma construção social. Em contraste com a hipótese pós-moderna, que afirma a completa perda de significação dessa antinomia, o que se passa, no entender desse autor, é uma mudança nas condições de sua produção: "a relação proximidade/ distância conserva seu caráter estruturante, mas as coações da distância (e da proximidade) geográfica se tornam totalmente substituíveis".

São as condições da produção social da proximidade que se transformam, no entender de Bourdin, que aponta fenômenos como as facilidades de comunicação em tempo real entre dois pontos quaisquer do planeta, a rapidez e a intensidade dos fluxos de bens materiais, ou, em sentido oposto, a possibilidade de que pessoas que partilham a mesma posição no espaço não mantenham qualquer contato social (Bourdin, 2001:14).

Bourdin torna mais clara essa interpretação ao discutir o processo de mundialização, o qual poria em questão as concepções do território como "sistema estável de diferenças, associado a uma área geográfica dada, englobado em sistemas mais vastos em relação hierárquica" (p.61). As relações entre o próximo e o distante tornar-se-iam, assim, "instáveis e multidimensionais", sem, por isso, perderem importância. Esta chave da instabilidade, ou mesmo de uma certa labilidade, emerge da bibliografia sobre a "dimensão local”, que está no centro de meu interesse.

\subsubsection{Algumas referências conceituais sobre "lugar" e "região"}

Desde meus primeiros esforços para construir teoricamente esse "objeto regional" 25, observei que, na literatura consultada, das áreas de sociologia e economia, espaços subnacionais são tratados ora como configurações "locais", ora como "regionais", sem que fique clara a distinção entre essas categorias (ou recortes).

Tal preocupação é aplacada quando se encontra em Milton Santos, avatar da geografia brasileira, esta posição: "A distinção entre lugar e região passa a ser menos relevante do que antes, quando se trabalhava com uma concepção hierárquica e geométrica, onde o lugar devia ocupar uma extensão do espaço geográfico menor que a região" (Santos, 1996/2004:166).

\footnotetext{
${ }^{25}$ Parafraseio o título do primeiro capítulo de Bourdin (2001), “O objeto local”.
} 
Para que se possa compreender a concepção de "lugar" 26 com que Santos trabalha, é necessário fazer aproximações sucessivas de sua conceituação, a começar pela seguinte idéia: "Como um lugar se define como um ponto onde se reúnem feixes de relações, o novo padrão espacial pode dar-se sem que as coisas sejam outras ou mudem de lugar" (p. 96). Os "feixes de relações", por sua vez, associam-se à noção de "eventos", cujo "caráter principal (...) é "poder situar-se com precisão nas coordenadas do espaço e do tempo"” (p. 145). A unidade entre uma ordem temporal e uma ordem espacial em constante transformação condensa-se na noção de evento. "O lugar é o depositário final, obrigatório, do evento. Segundo Eddington, um evento é "um instante do tempo e um ponto do espaço"” (1996/2004, p. 144).

Prosseguindo nessa construção, para Santos, "evento e ação são sinônimos (...). Os eventos também são idéias e não apenas fatos" (p.148). Tem-se, a seguir, de considerar que o espaço geográfico é, para Milton Santos, "formado por um conjunto indissociável, solidário e também contraditório, de sistemas de objetos e sistemas de ações, não considerados isoladamente, mas como o quadro único no qual a história se dá” (1996/2004:63).

O sistema de ações como componente "indissociável" do objeto da geografia, o espaço geográfico, reveste-a de um radical comprometimento com a dimensão social e com a história. Em Benno Werlen (1993), Milton Santos irá recolher a seguinte formulação: "Se a ação, em lugar do espaço, se tornasse o conceito teórico central da geografia social, o arranjo espacial dos objetos seria relevante não como uma causa, mas como uma condição e uma conseqüência necessária da ação humana" (Werlen, apud Santos, 1996/2004:83). Mesmo não abraçando a "geografia social" na forma proposta por aquele autor, a quem atribui uma anulação do outro "termo" do binômio, o sistema de objetos, Santos se vale dessa vinculação necessária entre o meio material ou físico e a ação dos homens para definir o espaço geográfico como um "híbrido" (p.86).

Esse meio físico ou material - de um modo que recende a Bourdieu, de quem trato a seguir - nada tem a ver com uma "natureza" alheia ao social e ao humano, como afirma Santos em "Por uma Geografia Nova", ao final dos anos 1970:

Produzir e produzir espaço são dois atos indissociáveis. Pela produção o homem modifica a Natureza Primeira, a natureza bruta, a natureza natural, socializando, dessa forma, aquilo que T. de Chardin chama de 'ecossistema selvagem'. É por essa forma que o espaço é criado como Natureza Segunda, natureza transformada, natureza social ou socializada (1978/2002, p. 203)

Apreendido esse significado distintivo do "natural" em Santos, pode-se compreender a distinção que faz entre o espaço e a configuração territorial (da qual a "paisagem" é um recorte).

A configuração territorial é dada pelo conjunto formado pelos sistemas naturais existentes em um dado país ou numa dada área e pelos acréscimos que os homens superimpuseram a

\footnotetext{
${ }^{26}$ A equivalência entre "local" (substantivo) e "lugar" é, também, corrente.
} 
esses sistemas naturais. A configuração territorial não é o espaço, já que sua realidade vem de sua materialidade, enquanto o espaço reúne a materialidade e a vida que a anima. A configuração territorial, ou configuração geográfica, tem, pois, uma existência material própria, mas sua existência social, isto é, sua existência real, somente lhe é dada pelo fato das relações sociais. Esta é outra forma de apreender o objeto da geografia (Santos, 1996/2004:62).

Em um recurso extremo para transmitir essa idéia, Santos diz que, se uma bomba de nêutrons fosse lançada, "o que na véspera seria ainda o espaço, após a temida explosão seria apenas paisagem" (2004, p. 106 - grifos no original).

Recapitulando-se: ação e evento são "sinônimos"; o evento pode situar-se com precisão nas coordenadas do espaço e do tempo; o espaço é a unidade indissociável de sistemas de objetos e sistemas de ações. Essas referências permitem entender um pouco mais claramente a proposição, já citada, segundo a qual: "O lugar é o depositário final, obrigatório, do evento. (...) um evento é "um instante do tempo e um ponto do espaço"' (Santos, 1996/2004:144). Esta articulação espaçotemporal tem por conseqüência que o "lugar" será sempre uma realidade provisória, em permanente transformação, já que: “A base mesma da geografia é que o mundo está sempre redistribuindo-se, se regeografizando. Em cada momento, a unidade do mundo produz a diversidade dos lugares" (2004, p.158).

Dessa forma, o lugar não é apenas o depositário do(s) evento(s): é também um produto dele(s): "Podemos admitir que cada combinação de eventos ao mesmo tempo cria um fenômeno unitário, unitariamente dotado de extensão e se impõe sobre uma área, necessária a sua atuação solidária”27 (1996/ 2004:155).

Milton Santos associa a problemática da extensão dos eventos à noção de escala geográfica. A escala dos eventos é desdobrada, então, em duas "acepções": a escala de origem e a escala do impacto. A escala de origem vincula-se à "causa eficiente" do evento, especificamente à sua procedência. No caso da escala de impacto, trata-se de um tipo de solidariedade entre eventos, que, sobrepostos, ocorrendo em uma área comum, compõem a geografização destes eventos: “(...) no âmbito geográfico de uma região ou de um lugar, as escalas superiores de ação estão freqüentemente enviando vetores. Esses vetores de diferentes níveis hierárquicos se combinam para solidariamente constituir uma área comum de ocorrência, que é a sua escala de realização" (1996/2004:153 - grifo meu).

Segundo Santos, "a era da globalização" é uma época que torna os eventos, mais do que nunca, "globalmente solidários, pela sua origem primeira, seu motor último" (1996/2004:164). E prossegue: “A região e o lugar, aliás, definem-se como funcionalização do mundo e é por eles que o mundo é percebido empiricamente. A região e o lugar não têm existência própria. Nada mais são que uma abstração, se os considerarmos à parte da totalidade" (2004, p. 165). Porém,

${ }^{27}$ O adjetivo "solidário", em Santos, tem a manifesta filiação à formulação de Durkheim, não tendo o conteúdo moral da linguagem corrente. 
coerentemente com a matriz dialética que afirma adotar, o autor sustenta, também, que "para se tornar espaço, o Mundo depende das virtualidades do Lugar" (1996/2004: 338).

Santos, em síntese, rompe com qualquer postura metodológica que "reifique" a região como parcela autônoma do espaço geográfico. Subsumida na noção de lugar, a região, de forma inapelável, é uma realidade provisória, já que é tributária dos eventos e "só a totalidade em movimento cria novos eventos" (1996/2004:160).

Mas em Milton Santos não encontro endosso a uma posição em que o problema da escala geográfica simplesmente desapareça, supostamente "resolvido" por uma relação dialética entre os níveis local e global. Primeiramente, o autor é muito cioso da dimensão nacional: "A formação social nacional funciona, pois, como uma mediação entre o Mundo e a Região, o Lugar" (1996/2004:337). Mas não só o "país" é ressalvado como decisivo: “A situação intermediária entre o Mundo e o país é dada pelas regiões supranacionais, e a situação intermediária entre o país e o lugar são as regiões infranacionais, subespaços legais ou históricos” (1996/2004:338).

Assim, se "os dois níveis de existência" do "evento" são o global e o local (1996/2004:162), nem por isso desaparecem as mediações. Esse entendimento é coerente com o papel basilar atribuído aos "sistemas de ações" na concepção do espaço geográfico mesmo. No parágrafo anterior, a referência aos "subespaços legais ou históricos" indica o reconhecimento que Santos concede à institucionalidade, social e historicamente erigida. Aqui reside um ponto de contato entre ele e Bourdieu, com a licença desse sociólogo, que não nutria nenhuma predileção pela Geografia ${ }^{28}$.

Em um dos capítulos de "O Poder Simbólico", Bourdieu propõe-se a apresentar "elementos para uma reflexão crítica sobre a idéia de região". Seu objetivo é "uma crítica epistemológica" das noções comumente empregadas nas ciências sociais (1989:107). Nesse sentido, a "idéia" (sic) de região é tomada, praticamente, como um exemplo, sem que sua conceitualização apareça como uma meta do autor. É, antes, o seu objeto.

Liberto de qualquer vinculação "genética" de sua disciplina com as "ciências da natureza", o sociólogo reduz o meio físico a seu conteúdo social e histórico, inapelavelmente:

Ninguém poderia hoje sustentar que existem critérios capazes de fundamentar classificações 'naturais' em regiões 'naturais', separadas por fronteiras 'naturais'. (...) e as classificações mais 'naturais' apóiam-se em características que nada têm de natural e que são, em grande parte, produto de uma imposição arbitrária, quer dizer, de um estado anterior da relação de forças no campo das lutas pela delimitação legítima. (...). Nada há, nem mesmo as 'paisagens' ou os 'solos', caros aos geógrafos, que não seja herança, quer dizer, produtos históricos das determinações sociais (p.114-5).

\footnotetext{
${ }^{28}$ Em sua análise, a Geografia aparece como uma disciplina "dominada" (sic), "dada a contentar-se com aquilo que lhe é concedido, a isolar-se na região que as disciplinas mais 'ambiciosas', sociologia e economia, lhe dão em partilha, quer dizer, o pequeno, o particular, o concreto, o real, o visível, a minúcia, o pormenor, a monografia, a descrição (...)" (Bourdieu, 1989:109).
} 
A região é "uma 'realidade' que, sendo em primeiro lugar representação, depende (tão) profundamente do conhecimento e do reconhecimento" (p. 108, grifo no original).

Os critérios de identidade regional são, assim, objeto de representações de dois tipos: representações mentais - "actos de percepção e de apreciação, de conhecimento e de reconhecimento em que os agentes investem os seus interesses e os seus pressupostos" - e representações "objectais" - "emblemas, bandeiras, insígnias, etc" -, além de "actos, estratégias interessadas de manipulação simbólica" (p.112).

Esses processos de conhecimento e de reconhecimento aparecem, no pensamento de Bourdieu, indissociáveis das "lutas das classificações, lutas pelo monopólio de fazer ver e fazer crer, de dar a conhecer e de fazer reconhecer, de impor a definição legítima das divisões do mundo social e, por este meio, de fazer e de desfazer os grupos" (p. 113).

Bourdieu enfatiza o ato de instituir, ou de trazer à existência, uma região. Recorre à etimologia da palavra região (regio) para associá-la a um "decreto" (sic), como ato "propriamente social", que introduz "uma descontinuidade decisória na continuidade natural" (p. 113). Esse ato social - regere fines - é capaz de trazer à existência aquilo que é prescrito, e, "como todo o poder simbólico" (p.114), assenta-se no reconhecimento, originalmente associado à autoridade sagrada:

O auctor [o sujeito investido da auctoritas, ou autoridade], mesmo quando só diz com autoridade aquilo que é, mesmo quando se limita a enunciar o ser, produz uma mudança no ser: ao dizer as coisas com autoridade (...), publicamente e oficialmente, ele subtrai-as ao arbitrário, sanciona-as, santifica-as, consagra-as, fazendo-as existir como dignas de existir, como conformes à natureza das coisas, 'naturais' (p. 114).

Coerentemente com sua concepção de uma "economia do simbólico", Bourdieu desloca, de certa maneira, a problemática relativa à idéia de região para os movimentos regionalistas, os quais emergem para reivindicar o reconhecimento de uma identidade - "esse ser percebido que existe fundamentalmente pelo reconhecimento dos outros" (p.117). Demonstra-se interessado essencialmente no princípio de "maximização do ganho simbólico" que informaria as lutas das classificações (p.113), das quais os movimentos regionalistas constituiriam uma modalidade.

Atento para a hipótese de que "a mundialização da economia" possa ter "permitido caminho livre à lógica da diferenciação simbólica", criando as condições para "um separatismo quase sem limites econômicos" (p.129-130), Bourdieu associa a emergência de uma identidade regional - o que, levando-se ao limite o seu pensamento, é sinônimo de região - à reação a um estigma: "E de facto, se a região não existisse como espaço estigmatizado, como 'província' definida pela distância econômica e social (e não geográfica) em relação ao 'centro', quer dizer, pela privação do capital (material e simbólico) que a capital concentra, não teria que reivindicar a sua existência" (p.126). 
A possibilidade de eficácia de um discurso regionalista é, em Bourdieu, claramente condicionada pela "objetividade do grupo a que ele se dirige" - o que se associa ao reconhecimento e à crença que este grupo confere a quem evoca ou reivindica sua identidade -, e também pelas "propriedades econômicas ou culturais que eles têm em comum" (p.117).

Observa-se que a zona de contato do pensamento de Milton Santos com o de Bourdieu é bastante pontual. Sobressai a distância entre as tradições (e os estilos) disciplinares. Um aspecto que chama a atenção é a obliteração - ou, mesmo, recusa - da dimensão física ou material no tratamento desse sociólogo. Um segundo ponto é que a abordagem de Bourdieu, ao menos nesse texto, não contempla problemas de ordem operacional, que, numa investigação empírica, interpelam o pesquisador, no que diz respeito à delimitação de um recorte regional.

A região, como conceito e como recurso analítico, segue sendo um ponto a ser melhor compreendido pelos próprios geógrafos. Lencioni empreende uma revisão da história do pensamento geográfico tomando o conceito de região como fỉo condutor e conclui que a noção é ainda hoje, "problemática" (2002:15); "carece de rigor" (p. 26) e é "ambígua" (p.29), sofrendo a dificuldade adicional de se defrontar permanentemente com os usos do senso comum da palavra região (p. 16-7).

Apoiando-me nessa autora, assinalo alguns momentos da discussão da sua disciplina, que dizem respeito ao meu interesse analítico. O debate geográfico que atravessa o século XIX, opondo determinismo e possibilismo, colocava, de um lado, "uma busca das relações causais e de leis gerais, centrando-se na investigação dos aspectos da natureza"; de outro, "aspectos da vida social e cultural, (incorporando) a dimensão histórica, elaborando análises particulares em vez de construir explicações generalizadoras" (Lencioni, 2003:99). Esse divórcio de pontos de vista punha em xeque a geografia como campo específico do conhecimento.

A solução veio por meio do estudo regional, visto que este possibilitava combinar as duas perspectivas. As relações causais e as leis gerais, mais pertinentes ao estudo dos fenômenos naturais, combinadas à compreensão dos aspectos da vida social e cultural não tinham o objetivo de construir generalizações. A relação entre os fenômenos físicos e humanos de uma dada área aparecia como solução para o impasse teórico-metodológico. (...)

$\mathrm{O}$ objeto essencial de estudo da Geografia passou a ser a região, um espaço com características físicas e socioculturais homogêneas, fruto de uma história que teceu relações que enraizaram os homens ao território e que particularizou este espaço, fazendoo distinto dos espaços contíguos (p.100).

Com Vidal de La Blache, no século XIX, consagram-se as "monografias regionais" como trabalho geográfico por excelência. Uma posição desse precursor que mantém relevância no debate - como exemplifica Armand Frémont, nos anos 1970 (cf. Breitbach, 2003) - é a de que a região pode não ter limites bem determinados, ser concebida com uma circunscrição fluida, "como uma espécie de auréola" (Lencioni, 2003:108). 
É também em La Blache que ganha corpo a visão de uma região "nodal”, organizada a partir da força polarizadora de uma cidade. Nesse sentido, "é a cidade que cria a região", mas essas constituições são "dinâmicas", no sentido de que "se formam e se dissolvem" (Lencioni, 2003:108). Uma visão análoga emerge nos anos 1960, na França, no bojo da chamada Geografia Ativa (p. 141). Nesse momento, o fenômeno "metropolitano" dá o tom no tratamento do "urbano", em sua relação com o "regional".

Os seguidores de La Blache "esterilizaram sua proposta", condenando os estudos regionais à "mesmice" (p.109), ousando muito pouco para além das "monografias regionais". O próprio debate entre a Geografia Humana e a Geografia Física teria arrefecido, em função da alegada "síntese" oferecida pelos estudos regionais, privando a disciplina de discordâncias que a alimentavam.

Configurada essa estagnação, e dada a força que haviam adquirido a atitude descritiva e o "particularismo" - ou, recuperando-se Bourdieu, o "internalismo" (p.109) - nos estudos regionais, a discussão muda de ênfase, passando a questionar a Geografia do ponto de vista epistemológico. Cumpria estabelecer seu caráter como ciência idiográfica - voltada para o específico - ou como ciência nomotética - direcionada para a identificação de leis gerais dos fenômenos estudados (Lencioni, 2003:111). Uma vez mais, os estudos regionais buscaram constituir-se na solução do impasse, sendo Hettner (1859-1941) um dos exemplos dos esforços de síntese. Segundo ele, "a Geografia tem por objeto proporcionar a descrição e a interpretação, de maneira precisa, ordenada e racional, do caráter variável da superfície da Terra" (apud Lencioni, 2003:123).

Essa superfície, em seu entender, constituiria uma totalidade, sendo a região geográfica um "determinado espaço da superfície terrestre, cujas características possuíssem uma coerência fisionômica e funcional que permitissem configurar uma individualidade funcional" (Lencioni, 2003: 123).

Em Richard Hartshorne, por sua vez, a questão da escala do estudo regional - "um dos principais problemas teóricos e metodológicos da Geografia", no entendimento de Lencioni (p.125) - recebe mais atenção. Para ele, quanto mais complexos os fenômenos a serem analisados (de forma integrada), menores deverão ser as áreas investigadas (Lencioni, 2003:128).

Paralelamente à corrente que Lencioni reputa tributária ao neokantismo, e que os dois últimos autores referidos ilustram, desenvolveu-se a chamada Nova Geografia, com inspiração no positivismo lógico e fortemente calcada na modelagem matemática. Essa vertente esteve associada ao boom do planejamento regional, capitaneado pelos Estados nacionais, o qual teria transformado a região em "um instrumento técnico-operacional" (p.134). Lencioni considera que o determinismo geográfico, que marcou o início da disciplina, retorna, renovado em uma "versão matemática" (p. 137). 
As forças que se opõem metodologicamente ao avanço da Nova Geografia são fundamentalmente a fenomenologia e o marxismo. Na primeira, antropocêntrica e humanista, com forte valorização da história, novas preocupações se afirmam para a pesquisa geográfica - como é o caso da afetividade ou da percepção subjetiva, captada pelos "mapas mentais" -, e há uma forte valorização da noção de lugar. "Isso porque é o lugar, mais do que o espaço, que se relaciona à existência real e à experiência vivida" (p.154). A ênfase de Frémont para a idéia de "espaço vivido" é uma expressão clara dessa postura. O autor, entretanto, atenta para uma contradição dialética entre a regionalização que corresponde à experiência subjetiva (coletiva, inclusive) e aquela que, consagrando uma divisão administrativa, lhe é exterior (cfe. Lencioni, 2003:155).

Quanto à questão da escala, em Frémont, segundo Lencioni, a região é vista como ocupando uma posição intermediária entre o espaço da vivência cotidiana dos indivíduos (mais ligada à noção de "lugar") e "os grandes espaços" (p.155-6).

Uma das abordagens críticas aos autores inspirados na fenomenologia derivou do campo que, em trajetória paralela, se opunha à hegemonia da Nova Geografia: os teóricos marxistas combateram o que consideraram uma guinada da disciplina para o idealismo. Por sua vez, ganhando terreno, trouxeram consigo novos vieses. Lencioni recorre à posição de Edward Soja para afirmar que "foi excessiva a ênfase dada (pela geografia marxista) à história em detrimento do espaço" (p.163). Não menos dignos de nota teriam sido os deslizamentos na direção do essencialismo e do reducionismo econômico. Dentre os méritos dessa vertente, estaria o impulso à geografia urbana.

É um autor marxista, Yves Lacoste, que formula, a respeito da escala do estudo regional, a idéia de múltiplas regionalizações: "quando se altera a problemática, altera-se a escala" (cf. Lencioni, 2003:165). Insurge-se, ademais, contra a idéia de conceber a região a partir da área de influência de uma cidade, evocando as regiões em que essa polarização não se verifica, as quais seriam, no limite, desconsideradas (p.166).

Lacoste, como os demais marxistas, recusa também a associação direta entre região e o "espaço vivido" de Frémont e outros. A região seria "um conjunto espacial bem mais amplo que o espaço vivido. Para Lacoste, as regiões se constituem em conjuntos espaciais que se entrelaçam e se tornam objeto de investigação dos geógrafos" (p169).

O movimento recente, na geografia como nas demais ciências sociais, foi de dispersão, frente à erosão de paradigmas clássicos. A vertente pós-moderna adquire visibilidade nesse cenário de crise. Dentre seus traços conhecidos, a postura anti-essencialista leva-a defender que "nenhum aspecto do mundo social e natural merece um status ontológico especial" (Lencioni, 2003:180). Ainda assim, questões como a estética e a subjetividade são por ela bastante realçadas. No conjunto das ciências sociais, o pensamento pós-moderno dá renovado destaque ao espaço, que sobredeterminaria o tempo (p.183). A ênfase na heterogeneidade e na indeterminação do mundo 
pode levar a uma valorização dos estudos regionais, mas Lencioni reconhece aí o risco de uma atomização capaz de esterilizar os resultados de pesquisa (p.187).

Impossível deixar de associar o avanço de idéias pós-modernas ao contexto da chamada globalização e da reestruturação do capitalismo, em que se recompõem os pesos relativos do local, do regional e do global. Lobato Corrêa é um dos autores que afirma uma perda de autonomia da instância regional, acompanhada, por outro lado, de uma multiplicidade de possibilidades de recortar a superfície terrestre, o que tornaria as particularidades mais relevantes. Ele afirma a noção de região como condicionada pela diferenciação de áreas, a qual se vincularia à idéia de "particularidade", "isto é, uma mediação entre o universal (processos gerais advindos da globalização) e o singular (a especificação máxima do universal)" (Corrêa, apud Lencioni, p. 189). Sandra Lencioni subscreve essa mesma posição, e em seu balanço final afirma a crença na relevância dos estudos regionais, em uma perspectiva renovada da Geografia.

Essa breve seleção de pontos levantados por Lencioni, em sua panorâmica da problemática regional sob o ponto de vista da Geografia, sugere o dinamismo do debate, realçado pela abordagem retrospectiva da autora, e a quantidade de questões abertas.

Olhando-se de forma conjunta essas referências sobre o "local" e o "regional", amplificase, como que "cumulativamente", a dominância de uma orientação segundo a qual a delimitação a escala - do espaço que se irá "recortar" e definir (em qualquer um dos dois "níveis", se é lícito "contrapô-los") é fluida, imprecisa. Como ficou indicado, essa labilidade decorre tanto da própria dinâmica da territorialização dos fenômenos sociais quanto da intervenção, da intencionalidade, do próprio investigador, que "constitui" um objeto regional conforme a problemática que lhe interessa. Esse ponto de vista é consistente com uma interpretação como a de Bourdieu, que ressalta o papel das "lutas de classificação" na definição de identidades regionais - o que tem como motivação "trazer à existência" essas realidades. Em qualquer luta que tenha um caráter permanente, os resultados são sempre provisórios.

Outra impressão que registro é que, embora as obras abordadas nessa seção não tenham como problema central o fenômeno da globalização, convergem em identificar que ela tanto modifica a configuração quanto reforça a importância da problemática regional ou local.

Retomando-se a contribuição de Alain Bourdin (2001), é interessante a caracterização que ele faz desse renovado interesse pelo "objeto local", partindo do contexto francês. Segundo o autor, nos anos 1970 uma valorização dessa problemática orientava-se no sentido de contestar processos de homogeneização, ligados ao desenvolvimento do padrão de consumo fordista e à "administração generalizada da vida diária" pelo Estado, e significava uma "recusa do homem unidimensional", apontando para a "afirmação da liberdade e da responsabilidade coletiva", apoiando-se nas necessidades locais. No momento atual, Bourdin identifica que a situação é inversa. A diversificação do consumo, uma retração da presença do Estado em função da "onda 
neoliberal", e o "triunfo das cidades sobre os Estados" fazem com que a valorização do local assuma, em certo sentido, o caráter de um "relativismo tranqüilo para não dizer hipócrita", tomando o lugar de princípios universalistas. Em síntese, segundo o autor, "a localidade triunfa e perde sua capacidade crítica" (Bourdin, 2001: 19-20).

Mesmo recalcitrante frente à visão "hiperlocalista" - ou, talvez, até por isso - Bourdin oferece uma definição do local na qual se percebe uma afinidade com a posição de autores como Santos:

Desta forma, chegamos a uma definição do local que não faz dele nem uma necessidade antropológica nem um conteúdo herdado e inevitável, mas uma forma social que constitui um nível de integração das ações e dos atores, dos grupos e das trocas. Essa forma é caracterizada pela relação privilegiada com um lugar, que varia em sua intensidade e em seu conteúdo. A questão se desloca então da definição substancial do local à articulação dos diferentes lugares de integração, à sua importância, à riqueza de seu conteúdo (2001: $56)$.

Bourdin não recusa relevância ao "objeto local". Todavia, politiza claramente a questão, quando, por exemplo, adverte contra o caráter potencialmente "conservador" (sic) de uma corrente "primordialista", a qual advogaria a volta aos grupos primários como tendência da evolução da sociabilidade contemporânea.

Como venho sublinhando, uma parte importante desse debate foi animada pela onda de interesse que cercou as experiências produtivas "localizadas" dos distritos industriais, especialmente quando revestidas da aura de paradigma que lhe foi emprestada por Piore e Sabel na formulação do conceito de "especialização flexível".

\subsubsection{A "ortodoxia" dos distritos industriais e a preocupação com as grandes cidades}

As elevadas pretensões do conceito de especialização flexível conferiram à experiência dos distritos industriais uma notoriedade e um interesse que não haviam sido gerados por trabalhos importantes, que precederam o de Piore e Sabel (1984), como o de Bagnasco (1977), que cunha a expressão Terceira Itália, ou o de Brusco (1982).

Uma série de críticas foi feita a essa noção, das quais pode-se destacar: uma fé exagerada (e fragilmente fundamentada, do ponto de vista macroeconômico) na superação da importância das economias de escala no capitalismo contemporâneo (Coriat, 1992); a minimização de conflitos sociais inerentes ao modelo e às formações sociais concretas que o embasam (Souza, 1992); uma tensão (ou incoerência) entre a flexibilidade no uso da força de trabalho que o modelo propugna e o alto conteúdo de savoir-faire e capacitação que desta se espera (Leborgne, Lipietz, 1990). Talvez a principal insatisfação gerada pela tese da especialização flexível derive de sua ambição de agregar em um único conceito uma pluralidade qualitativamente muito heterogênea de arranjos produtivos e societais distintos entre si, que teriam em comum (pouco mais do que) a ruptura 
frente a algum traço "clássico" do paradigma da produção em massa (Xavier Sobrinho, 1997/ 2002a).

Essa controvérsia teve forte eco nos estudos de economia regional. Benko e Lipietz (1994) identificam "uma nova ortodoxia: tudo-para-o-distrito-industrial, expressão de um novo modelo de organização produtiva" (p.4). Propõem-se a fazer um contraponto a essa postulação, que consideram equivocada. Até por isso, procuram localizá-la num esquema de sucessivas visões dominantes da "economia espacial, economia regional ou internacional" (Lipietz, 1994, p.10).

A primeira ortodoxia, com origens na década de 1930, é fruto da microeconomia "desde então dominante" (p.10). As cidades se constituiriam em redes hexagonais de malhas cada vez mais largas, mantendo a eqüidistância dos "lugares centrais", os quais concentrariam a oferta de bens e serviços, atendendo as localidades no seu raio de abrangência. Isso "organizaria" e minimizaria a concorrência, através de uma hierarquia urbana. Essa visão deixa de contemplar os ganhos econômicos e a "emulação" (Lipietz, 1994, p.11) que a aglomeração oferece aos atores, do ponto de vista econômico e social: a suposta mão invisível que os distribuiria uniformemente no espaço não encontrou correspondência com a realidade.

(...) Considerando a cidade (e a região que a cerca e participa de sua prosperidade) como um 'sujeito coletivo', vemos então inverterem-se, como uma tira de Moebius, as duas faces opostas de toda a ciência social: holismo e individualismo, estrutura e trajetória, ou seja, na linguagem da análise espacial, o 'global' e o 'local'. É entre esses dois pólos que vão se confrontar as duas grandes 'ortodoxias' espaciais dos anos 1960 (Lipietz, 1994, p.12).

Dessas duas ortodoxias dos anos 1960, a primeira seria o esquema Clark-Rostow-Vernon (Lipietz, 1994, p.12), cujo entendimento, aqui simplificado, seria que regiões e países teriam à sua frente as mesmas etapas de desenvolvimento, embora houvesse defasagens temporais nessas trajetórias, sendo "o 'atraso' relativo de alguns em relação a outros (...) um efeito dos acasos da História" (Lipietz, 1994, p. 12). A metodologia individualista que embasou essa construção teórica (com os países ou regiões representando os indivíduos) foi contestada pela segunda "ortodoxia" desse período. A teoria da dependência vinculava causalmente o desenvolvimento de determinadas regiões ao subdesenvolvimento de outras. Em uma nova forma de divisão internacional do trabalho, países e regiões se distribuiriam entre "três funções sincrônicas da atividade produtiva dentro de um mesmo ramo: concepção; fabricação qualificada; fabricação/ montagem não qualificadas. Cada uma dessas funções tenderia a localizar-se nas regiões previamente mais dispostas a recebê-las (pelo grau de desenvolvimento, pelos níveis de sindicalização, de qualificação e de salários etc)" (Lipietz, 1994:13). A rigidez estruturalista desse esquema sobrevalorizaria o peso político das empresas multinacionais e menosprezaria as forças sociais e políticas de cada região ou país. A própria história teria interpelado a teoria, com a emergência dos novos países industrializados - os quais demonstraram a possibilidade de avançar sobre as "posições" a eles destinadas, superando, ainda que parcialmente, barreiras a entrada. 
Benko e Lipietz saúdam a superação do que classificam como "estruturalismo global" da teoria da dependência, por parte da geografia radical anglo-saxônica, citando a frase emblemática de D. Massey, em trabalho de 1985: "The Unique is back on the agenda" (Benko e Lipietz, 1994: $10)$.

A perspectiva de resgatar os aspectos particulares de cada formação social específica - em que a dimensão territorial se acresce de relevância - conduz à formulação das teorias do "desenvolvimento regional 'endógeno"”. Segundo Benko e Lipietz, trabalhos dispersos convergem para constituir essa linha de pensamento ao final dos anos 80 (1994:10). A perspectiva teórica do desenvolvimento endógeno é ligada umbilicalmente à experiência de distritos industriais, especialmente os da Terceira Itália, segundo Benko e Lipietz, que declaram:

(...) o golpe de gênio de Michael Piore e Charles Sabel (1984) consistiu em interpretar o êxito dos distritos industriais como um caso particular de uma tendência mais geral. (...) afirmaram que, à produção de massa fordista, rigidamente estruturada, sucederia um regime baseado na especialização flexível, cuja forma espacial seria o distrito (...) (Benko, Lipietz, 1994, p. 11).

Em trabalhos anteriores (Xavier Sobrinho, 1997/2002b, 1997/2002c), discuti o chamado modelo italiano e os distritos industriais - e conceitos muito próximos, como o de Sistemas Industriais Localizados (Courlet, 1993) -, na perspectiva dos estudos do trabalho. Benko e Lipietz, por sua vez, envoltos nas controvérsias da economia regional, levantam-se contra essa "nova ortodoxia" que põe os distritos industriais como horizonte ou modelo de configuração sócioespacial na economia contemporânea. Amin e Robins, em artigo da obra organizada por Benko e Lipietz (1994), priorizam a crítica à lógica interna da construção teórica que articula distritos e especialização flexível:

Mais do que a passagem de um período de centralização, concentração e integração, a uma nova era histórica de descentralização, disseminação e desintegração, o que se observa hoje são evoluções que constituem, de múltiplos pontos de vista, uma extensão das estruturas fordistas. (...) as actuais experiências efectuadas na economia das empresas tendem a confirmar que a produção descentralizada, quando se verifica, faz parte de um processo de intensificação e extensão da concorrência e do domínio oligopolístico, e não pode desligar-se dele (Amin, Robins, 1994: 97-8).

Já Lipietz propugna a substituição da idéia de distrito pela de rede, e "o retorno triunfante da política" (1994:17). A primeira idéia "alarga fantasticamente as potencialidades espaciais"; a segunda convoca a idéia de governança, sustentando que: "a escolha política de um modelo de desenvolvimento (...) (escolha que se origina na emergência de um novo bloco social territorial ao mesmo tempo que o solda) vai determinar o tipo de rede industrial e a bacia de emprego, portanto a direção do desenvolvimento do território" (p.18).

A seguir, o autor questiona-se sobre a "escala geográfica" em que essas escolhas se dão, para afirmar que, embora o quadro nacional (legislativo e "convencional") seja fortemente 
influente, “(...) tudo isto só tem interesse prático (e até teórico, aliás) se existir uma margem de manobra para os blocos sociais regionais, capazes de empregar modos de governança locais, independentemente da política nacional ou continental (pensamos na CEE) e da macroeconomia mundial" (Lipietz, 1994:18).

Quero destacar, com esses autores, que o debate sobre as regiões como "entes" relativamente autônomos, que empregam seus recursos políticos, sociais, culturais e econômicos para buscar uma "inserção" mais proveitosa num cenário de economia mundializada e de desverticalização produtiva, tem se nutrido de experiências bem sucedidas - base da construção de uma "ortodoxia". Porém, como afirma Barquero (2001), "a globalização e a reestruturação produtiva afetam os sistemas produtivos de regiões desenvolvidas e atrasadas, bem como os de cidades grandes, médias e pequenas" (p.16 - sem grifos no original).

No entanto, mesmo não se propondo um estudo dos distritos, mas do "paradigma do desenvolvimento endógeno", Barquero incorre na mesma vinculação que destaquei. Sua "industrialização endógena" tem clara identidade com a especialização flexível:

Os processos de industrialização endógena caracterizam-se pela produção de bens, em geral produtos industriais, que são transformados através da organização flexível da produção e da utilização intensiva do trabalho. As empresas especializam-se em etapas do processo produtivo ou na fabricação de componentes, os quais são posteriormente montados para chegar-se ao produto final. A força de trabalho utilizada é flexível, no sentido de ser capaz de realizar tarefas diversas no processo de produção. Da mesma forma, a oferta de mão-de-obra tem condições de se adaptar às necessidades das empresas mediante o trabalho em tempo parcial, a domicílio ou de caráter informal (Barquero, 2001:40).

Também Barquero dá "status" de modelo a características específicas atribuídas (ainda assim, sem unanimidade) a experiências produtivas concretas, particularmente a Terceira Itália. Essa "cunha", no debate teórico, traz o risco de reduzir a acuidade com que se analisam outras configurações, que poderiam aportar novos elementos para serem teorizados, ou ao menos (re)conhecidos. Por outro lado, tem o mérito de romper com visões economicistas: a maior parte da literatura sobre a Terceira Itália - destacando-se (uma vez mais) a obra de Piore e Sabel (1984), e agregando-se o célebre estudo de Putnam (1996) - dão muita ênfase aos aspectos culturais e ao capital social como fundamento do sucesso, seja este especialmente produtivo (Piore e Sabel), seja institucional (Putnam). Este último autor - cujo estudo priorizou a dimensão político-institucional mais do que a econômico-produtiva, mas influenciou diversas sub-áreas das ciências humanas declara: "Para a estabilidade política, para a boa governança e mesmo para o desenvolvimento econômico, o capital social pode ser mais importante até do que o capital físico ou humano" (Putnan, 1996, p.192). 
Esse tipo de abordagem encontra eco na reflexão de economistas institucionalistas, especialmente neo-schumpeterianos, que, por outros caminhos, recuperam a importância da cultura, dos laços e conflitos sociais na viabilização de novas trajetórias tecnológicas:

A importância de ativos sociais aumenta na medida em que a dinâmica inovativa está condicionada por uma mudança recente no paradigma tecno-econômico. Diante da falta de critérios padronizados para avaliar qual a melhor trajetória a ser adotada, mais relevante ficam os elementos subjetivos (como confiança mútua e até mesmo relações de amizade) nas relações usuários-produtores de inovação (Villaschi Filho, Campos, 2002, p. 27).

Outra vertente da discussão da territorialidade, por sua vez, merece referência. Ela enfatiza, não as condições de êxito de arranjos sócio-espaciais "emergentes", mas os efeitos sociais e econômicos dos processos de reestruturação e de globalização nas "unidades" geográficas mais claramente tributárias à "era" fordista: as metrópoles e as grandes cidades. Nesse enfoque, não se trata principalmente dos requisitos para que regiões se "constituam" como tais (na perspectiva de Bourdieu), já que sua existência e relevância social, cultural e produtiva é indisputada, mas de como elas recebem o impacto de mudanças sócio-econômicas profundas como as das últimas décadas.

Nesse processo de rearticulação, as grandes metrópoles mundiais, cidades globais, assumem papel fundamental, enquanto sedes dos organismos de gestão dos grandes capitais e dos centros de pesquisa e desenvolvimento tecnológico e pontos nodais dos novos circuitos do capital. Do ponto de vista social, essas cidades são descritas como lócus de um movimento crescente de polarização entre ricos e pobres, entre incluídos e excluídos, em que desapareceria a oposição de classes como fator central de segmentação social. Tal perfil estaria associado aos efeitos da reestruturação produtiva no mercado de trabalho, que produziria o crescimento do Setor Terciário, a modernização e retração do Secundário, e um 'encolhimento' das classes médias, tendendo a estrutura social a se polarizar entre camadas privilegiadas, qualificadas e bem remuneradas, e segmentos mal remunerados e sem qualificação, configurando uma estrutura social no formato de ampulheta (Barcellos, Mammarella, 2001, p. 248-9).

Barcellos e Mammarella (2001) revisam a discussão sobre polarização, exclusão e dualização espacial, de que Saskia Sassen e Edmond Préteceille são referências, dando espaço aos contrapontos a sua "inevitabilidade". Outro ponto controverso refere-se à extensão com que as metrópoles conservam, aumentam ou perdem centralidade na configuração contemporânea da economia internacional, e que eventuais mudanças "funcionais" se processam nesses espaços. Sobre esse ponto, Lipietz (1994) identifica uma posição segundo a qual: "hoje, a espontaneidade aparente dos agentes nas suas iniciativas concorrentes parece ter a primeira e a última palavra, e esta grande mudança parece ser a chave da nova geografia econômica. 'Desintegração vertical', 'divisão social do trabalho' são com certeza as principais ocorrências desses ensaios” (Lipietz, 1994, p.15). Mas o autor encarrega-se de contestar essa visão:

Da mesma maneira que nos tempos de Marx a 'cooperação simples', agrupamento de artesãos sob o teto do mesmo ateliê, foi a primeira etapa da hierarquia capitalista (...), da 
mesma forma a aglomeração, com o seu cortejo de oportunidades potenciais, atualizáveis a baixo custo, foi e permanece a primeira condição do mercado capitalista.

(...) telemática em nada faz recuar o desejo de aglomeração. Para agarrar as 'oportunidades' é preciso estar lá, estar no lugar, observar, com os seus próprios olhos, 'face a face' (Lipietz, 1994: 15)

Efetivamente, pode-se considerar que as aglomerações urbanas de larga escala seriam elementos de renovada importância no circuito da acumulação global, por concentrarem "massa crítica", serviços especializados, efeitos de aglomeração e de externalidade relacionados aos requisitos de feição terciária que, há muitos anos, vêm sendo apontados como a "nova infraestrutura facilitadora" (Pérez, 1989) da base técnica vinculada às tecnologias de informação.

O debate sobre as metrópoles envolve questões em certa medida "próprias" - o que, acompanhando-se Sassen, é uma diferença qualitativa que expressa "quantidades" (ou intensidades):

Por um lado, elas [as grandes cidades] concentram uma parcela desproporcional de poder corporativo e são um dos principais locais para a supervalorização da economia corporativa. Por outro, concentram uma participação desproporcional de contingentes humanos em situação de desvantagem e são um dos principais locais para a desvalorização desses contingentes (Sassen, 1994/1998:158)

Cabe registrar que a autora, embora não persiga essa hipótese, indica a possibilidade de que algumas das características e dos processos que ela identifica como a tônica das "grandes cidades" se "reproduzam", em escala "menor", em outros contextos sócio-espaciais: "Notamos fatos paralelos nas cidades que funcionam como eixos regionais, isto é, em escalas geográficas menores e em níveis mais baixos de complexidade do que nas cidades globais" (Sassen, 1994/1998:153).

Mesmo que "notem" as escalas menores, poucos autores tratam delas sistematicamente. Para além dos ideados distritos industriais e das metrópoles, uma faixa de incertezas (tanto teóricas quanto históricas) parece cobrir outras configurações sócio-espaciais. Esses espaços subnacionais não "modelares" deparam-se, também eles, com o desafio de fazer frente ao arrefecimento das formas de integração típicas da era do "nacionalismo metodológico", enfrentando as incertezas quanto aos seus próprios recursos para uma inserção virtuosa em uma nova ordenação regulatória e econômica.

Nessa perspectiva, em que a literatura é um tanto lacunar, interessou-me particularmente o exercício que Bottazzi realizou para tipologizar espaços locais. Sua contribuição tem, quando pouco, o mérito de conferir reconhecimento, mesmo que dedutivamente, a um leque mais amplo de arranjos e de situações históricas.

\subsubsection{Uma tipologia das possíveis evoluções dos espaços locais}


Bottazzi (1996) realiza um exercício sobre as configurações que pode assumir a "integração social" nos espaços locais, no contexto de crise do modelo marcadamente nacional. O autor parte dos três princípios de integração propostos por Polanyi, e seus respectivos mecanismos: troca-mercado, redistribuição-Estado, reciprocidade-comunidade ${ }^{29}$. A forma como cada um desses pares tende a se comportar - no sentido de uma intensificação $(+)$ ou de um retraimento (-) de sua importância no arranjo societário - dá base à construção que se segue.

O procedimento de Bottazzi é, como mencionei, dedutivo, uma vez que deriva de uma projeção formal e abstrata de padrões, descomprometida da ancoragem em realidades concretas. Os resultados, e esse é um segundo aspecto a ser destacado, são dinâmicos, ou, melhor dizendo, evolutivos. Trata-se de antecipar trajetórias de transformação de realidades locais, sem que se contemple, no exercício, o estágio em que esse caminho tem início - especificamente o "quantum" dos princípios de redistribuição, reciprocidade e troca com que cada espaço local dá a partida. Sua abordagem é, por fim, "relativa", vale dizer, ela se dedica a descrever situações em que cada um desses princípios avança (ou se retrai) comparativamente aos demais, no que se poderia entender como uma "ponderação" das formas de integração.

$\mathrm{O}$ autor não dedica a mesma atenção a todos os tipos, deixando perceber que prioriza aqueles com maior probabilidade de afirmação no atual contexto histórico e/ou os que vêm sendo mais "celebrados" na literatura.

O tipo 1 corresponde nitidamente ao modelo dos "distritos industriais". Bottazzi o descreve como "o espaço do desenvolvimento local". Se esse é o tipo que merece uma consideração mais detida do autor, a intenção é, claramente, evidenciar os seus limites e toda a mística que em torno dele se construiu. Bottazzi, afirma, ironicamente, que o tipo 1 representa o "mito dos políticos regionais". Como característica do primeiro tipo tem-se o crescimento relativo tanto da integração baseada em mecanismos de mercado quando da integração baseada em mecanismos "comunitários". A ação redistributiva do poder estatal, aqui, é o pólo que se retrai. Até por isso, as formas de "espontaneidade e informalidade" nas relações sociais triunfariam. Bottazzi expressa seu ceticismo sobre a possibilidade de difusão de experiências com esse formato, em que se reconhece claramente a feição de que Piore e Sabel dotam a "especialização flexível". Poucos exemplos concretos se enquadrariam nesse figurino, segundo Bottazzi, e, ademais, todos eles europeus (“ou, na pior das hipóteses, eles resultam da ramificação desse coração [sócio-econômico europeu]”, p. 87).

Bottazzi salienta, ainda sobre esse primeiro tipo, que sua existência - porquanto, de modo geral, dependente de um alto grau de especialização produtiva - é condicionada por uma

${ }^{29}$ Como já mencionei, Bottazzi rejeita a associação direta entre o conceito de comunidade e o de espaços locais, preferindo utilizar, para esses, o termo "sociedade local", ou, seguindo Bagnasco, "formações sociais regionais". Na sua tipologia, a idéia de comunidade tem assumida inspiração weberiana, indicando que "a disposição ao agir social repousa sobre um pertencimento comum, subjetivamente percebido (afetivo ou tradicional)" (Bottazzi, 1996:80). 
vinculação a "um global mais vasto, primeiramente nacional e em seguida internacional, no interior da divisão internacional do trabalho". Também o Estado nacional impõe necessariamente uma moldura legislativa e fiscal que não pode ser desprezada como fator de competitividade e, por isso, de viabilidade.

Como se isso não bastasse, modificações importantes estariam alterando a dinâmica desses espaços em que a forma "distrito" é reconhecível:

Os valores tipicamente 'comunitários' dão lugar a atitudes mais 'modernas' (ou pósmodernas), as estruturas sociais anteriormente muito integradas apresentam os sinais de desagregação. O controle local dos recursos e a regulação local do mercado de trabalho diminuem seu alcance diante de fenômenos de concentração financeira; e problemas tradicionais das sociedades industriais, da poluição ao aumento de categorias sociais marginais (os imigrados do Terceiro Mundo) aparecem cada vez mais (Bottazzi, 1996:87).

Bottazzi imagina um caminho pelo qual os espaços locais do "tipo 1" poderiam se transformar, em duas etapas sucessivas, cada qual dando origem a um novo tipo. Inicialmente, uma dessas configurações "distritais" poderia migrar para o "tipo 4". Nessa transição, o caráter "comunitário" se eclipsa, diante das pressões competitivas e das tendências de concentração, restando a dura lei do mercado, com suas conseqüências potencialmente desagregadoras. Num segundo momento, em função de uma reação da sociedade aos efeitos da (des)regulação pelo mercado, surgiriam reivindicações análogas às que, no passado, estiveram na origem dos Estadosnação, o que poderia levar à "reprodução, em uma escala menor, de algo semelhante ao velho protecionismo intra-estatal" - o que desemboca no "tipo 2" (p.88).

O próprio autor objeta que esse último percurso é improvável, diante da interdependência que a própria especialização produtiva do espaço local impõe. Para que algum grau de proteção tenha possibilidade de se afirmar, ele precisaria provir de um nível territorial "relativamente 'global', ou seja, de espaços supra-regionais e supra-estatais, que possam governar os efeitos deletérios da competição de mercado" (p.88).

\section{QUADRO 3}

As tipologias resultantes das combinações possíveis de formas de integração

\begin{tabular}{|l|l|l|l|l|l|l|}
\hline & \multicolumn{7}{l|}{ Combinações possíveis } \\
\cline { 2 - 8 } Formas de integração & 1 & 2 & 3 & 4 & 5 & 6 \\
\hline Troca-mercado & + & + & - & + & - & - \\
Redistribuição-Estado & - & + & + & - & + & - \\
Reciprocidade-comunidade & + & - & + & - & - & + \\
\hline
\end{tabular}

NOTA (G.Bottazzi) - "Excluímos o caso em que as três formas de integração aumentam ou diminuem ao mesmo tempo. A combinação das variações tem soma zero, já que se pode supor que troca, redistribuição e reciprocidade, juntas, atinjam 1. É, portanto, impossível ocorrer um aumento ou uma diminuição simultânea das três formas.

É interessante constatar que essa tipologia permite identificar os principais modelos de sociedade que se confrontam ainda hoje em dia:

1. O liberalismo católico ou de direita;

2. O solipsismo pós-moderno; 
3. O socialismo utópico;

4. O triunfo do mercado ou o liberalismo thatcheriano;

5. O coletivismo burocrático do 'socialismo real';

6. O comunitarismo romântico da 'self-reliance'."

FONTE: Extraído de Bottazzi (1996:86).

$\mathrm{Na}$ continuidade de sua análise, Bottazzi detém-se sobre o tipo 3, que classifica de "espaços periféricos, ou de fordização inacabada". Estes seriam espaços em que a industrialização foi limitada, frágil, e onde o trabalho assalariado teve difusão mais restrita. Ainda assim, um Estado mais ativo como princípio de integração garante à localidade uma transferência de recursos importante. Nesse sentido, a redistribuição é um princípio decisivo, ao mesmo tempo em que a reciprocidade de tipo 'comunitário' vigora por conta do "atraso da modernização" (p.88). O autor exemplifica esse tipo com regiões do sul da Itália, que ele classifica como "economias assistidas", em que o clientelismo é um importante traço de organização. Entretanto, divisa dificuldades crescentes para que se mantenham os aportes financeiros por parte de Estados nacionais cuja orientação keynesiana se fragiliza. Destarte, abrem-se, "teoricamente" (sic) caminhos para que o tipo 3 tenha um deslocamento rumo ao tipo 1 (o caminho dos "distritos"), ao tipo 4 (liberalismo econômico mais radical) ou ao tipo 6 (que ainda vou descrever, abaixo).

O tipo 1, como se viu, é de escassa capacidade de generalização. No caso dos espaços locais como os que estão em questão, do tipo 3, em que é forte o legado de um passado "clientelista" e "assistido", uma limitação adicional para a transição seria a resistência à difusão de uma "cumplicidade social" (sic, p.89). Esta seria um requisito não apenas para o "virtuoso" tipo 1, mas, igualmente, para a consagração de uma economia de mercado propriamente dita. Isso obstaculiza, então, também o tipo 4 ("thatcheriano"). Assim, não restaria que o tipo 6, "neoclânico", em que uma forte base de reciprocidade de tipo comunitário luta para compensar a ausência tanto de formas de integração mercantis quanto de processos redistributivos estatais.

As conclusões que Bottazzi enuncia a partir dessa tipologia são, singelamente, que: "os espaços locais são muito diferentes entre si”; que suas evoluções são diversas; que eles podem interpor, ao "global" que os enquadra, demandas opostas - "mais autonomia ou mais Estado para garantir sua permanência, marginal que seja, no âmbito do 'global'” (Bottazzi, 1996:89). Ainda que o alcance de tais proposições não seja exatamente dos mais amplos, ressalto que um exercício como este é bem-vindo quando se trata de enfrentar uma pesquisa sobre uma região que não se enquadra nos tipos modelares que dominam a bibliografia. A lacuna sobre outras modalidades de inserção num tabuleiro mundializado - não metropolitanas e não distritais - parece deixar apenas o ponto de fuga da "desconexão forçada" que ameaçaria regiões do planeta que deixam de ser atrativas para o capital (Chesnais, 1994/1996:18).

$* * * *$ 
Nas referências que encontro para a reflexão sobre a dimensão espacial de meu objeto, mostram seu peso as contribuições da economia e da geografia, mas é perceptível um crescente aporte da sociologia na tarefa de compreender transformações que, entre outros fenômenos, fragilizam a dominância dos Estados-nação como instância territorial de coordenação da vida social e como referência cognitiva das ciências sociais. Novas e surpreendentes conexões entre locais se impõem, à primeira vista a partir da lógica econômica e mercantil, que teria o condão de impor a adequação de arranjos normativos e institucionais. Nesse ponto, a sociologia (e a nova sociologia econômica parece ter um potencial interessante nesse movimento) encaminha-se para identificar no espaço uma dimensão nobre de seu programa de pesquisa, em que é preciso identificar e compreender os atores e processos sociais em que se "enraízam" fluxos materiais e imateriais territorialmente novos.

Uma politização que, também ela, sobrepõe escalas - envolvendo desde uma "denúncia" relativamente abstrata do poder das corporações transnacionais, até uma valorização "hiperlocalista" de formas "comunitárias" de vida social - é uma das primeiras manifestações de que essa tarefa começa a ser assumida, com as necessárias controvérsias. A relativa "libertação" de instâncias regionais e locais frente aos constrangimentos historicamente enfeixados na instância nacional é proclamada a partir de uma configuração muito precisa, analiticamente construída, que são alguns bem sucedidos distritos industriais contemporâneos, concentrados na Europa. O entusiasmo que geram tende a estabelecer uma "ortodoxia" na interpretação do que seria a dinâmica territorial contemporânea, mas a multiplicidade de caminhos possíveis para os espaços locais e regionais reemerge, em análises que enfatizam as variáveis sociais e institucionais que estão em jogo na perspectiva de (re)construir mecanismos de integração (mercantis, redistributivos, de reciprocidade) nessas formações concretas.

Neste capítulo, delineei a complexidade da dimensão espacial no seu estágio presente. Retomarei, na abertura do quarto capítulo, o laço mais direto entre essa problemática e a compreensão dos mercados de trabalho, já na perspectiva de pavimentar a análise que faço da experiência da Grande Santa Rosa.

Antes, reencontro um pequeno número de estudiosos nacionais que, em contextos intelectuais recentes mas diferenciados do atual, produziram reflexões sobre a realidade brasileira em que as problemáticas do trabalho e do espaço estiveram articuladas de modos particularmente ricos, constituindo um legado importante para inspirar o enfrentamento dessa questão, no presente. 


\section{LEGADOS E LACUNAS: UM SELETIVO DIÁLOGO COM A REFLEXÃO BRASILEIRA}

Nos capítulos precedentes, priorizei uma discussão mais estritamente conceitual dos dois eixos que confluem em minha problemática de pesquisa. Ainda assim, ao final do capítulo anterior, a remissão a alguns momentos do debate sobre marginalidade e auto-emprego demonstrava a relevância de recuperar alguns "marcadores" do debate sobre mercado de trabalho e sua espacialidade na experiência concreta do Brasil.

Nesse processo de retomada da literatura, não identifiquei autores que tenham posto no primeiro plano de seu interesse a conjugação que aqui me ocupa, entre a constituição de um mercado de trabalho e a dimensão espacial. A possibilidade de cercar as múltiplas vertentes de pesquisa que têm intersecções algo indiretas com minha problemática, seguramente, abriria um vasto potencial de diálogo. Foi preciso assumir, realisticamente, minha impossibilidade de empreender algo como uma história intelectual desse debate, e descartar, em seguida, um tratamento "catalográfico", que resultaria lacunar e inócuo.

Considerei mais proveitoso, para os meus propósitos, eleger, para com elas dialogar, as contribuições de três pesquisadores cuja obra se inicia e pontifica em uma geração anterior, os quais, pela reconhecida densidade intelectual, tornaram-se parte de um legado compartilhado pelos pesquisadores nacionais, o que é claramente reconhecível na produção contemporânea. Juarez Brandão Lopes, Francisco de Oliveira e Wilson Cano oferecem-me, assim, um leque manejável de referências destacáveis do debate brasileiro, já que seus trabalhos se demonstram representativos e influentes nas formas como questões concretas envolvendo os mercados de trabalho brasileiros e sua regionalização foram enfrentadas por diferentes linhagens teóricas, em contextos que são recentes e, ao mesmo tempo, oferecem um recuo histórico para que se os analisem com a vantagem que oferecem obras clássicas.

Nos trabalhos que selecionei desses estudiosos, reconhece-se de forma clara o binômio trabalho e território, que se apresentam como elementos inextrincavelmente associados na tessitura da realidade social sobre a qual se debruçam - movidos por diferentes agendas e munidos de diferentes ferramentas analíticas e teóricas.

Lopes e Oliveira, sociólogos, encarnam dois troncos distintos da produção disciplinar. O primeiro mantém uma orientação weberiana em suas buscas teóricas, ao longo das quais se verifica uma primeira aproximação com os chamados "estudos de comunidade", bem como um pioneirismo, na academia brasileira, no diálogo com a produção norte-americana das sociologias da modernização ou das relações industriais. Já Oliveira se posiciona firmemente no campo marxista, em que toma parte de acesos debates teóricos e epistemológicos, diante de questões que ganham ênfase em sucessivos momentos de sua obra, tais como a estrutura de classes 
contemporânea e o papel que o fundo público passa a assumir na reprodução do sistema capitalista; credencia-se, como poucos de seus pares, em uma interação muito próxima com a vertente disciplinar da Economia. Essa, por sua vez, neste exercício que inicio a seguir, comparece por intermédio de Wilson Cano, que acumula uma longa e reconhecida produção sobre economia regional brasileira. Na sua reflexão, a reconstrução histórica é um pilar que convoca permanentemente ao tratamento analítico as dimensões social e político-institucional, o que favorece seu diálogo com a sociologia.

A opção por esse pequeno número de intérpretes-tipo permite-me esboçar, com um mínimo de vagar, elementos que norteiam alguns de seus estudos, condição para que se visualizem as conexões analíticas que conformam suas visões sobre a espacialidade dos mercados de trabalho. Do ponto de vista das escalas, emergem assim, desde o aprofundado estudo de pequenas localidades, em Lopes, até as grandes clivagens de espaços fisicamente descontínuos, quer se trate da oposição entre áreas rurais e urbanas (igualmente central na interpretação de Lopes), quer diga respeito ao cotejo entre um "núcleo" do desenvolvimento brasileiro (o Estado de São Paulo) e uma periferia, constituída pelo restante do território - um dos construtos de Cano. Ambos, bem como Oliveira, transitam, como procurarei explorar, entre diferentes níveis de regionalização. Desse último autor são aqui evocadas tanto análises de abrangência nacional, quanto o estudo de uma "Grande Região" brasileira (o Nordeste) e outro com foco em uma capital estadual, Salvador.

Esse deslocamento entre escalas expressa a variedade de problemas de pesquisa e de preocupações analíticas que cada um dos autores combina. Isso não impede que se reconheça neles a dominância de condicionantes que ecoam o "nacionalismo metodológico" que venho de discutir, no capítulo precedente. Essa marca analítica e histórica da escala nacional se faz presente nas interpretações que constroem para questões que vão desde os valores, ideais e preconceitos apreendidos na etnografia de um "Brasil arcaico" (Lopes) até o tratamento estatístico de indicadores como o valor da transformação industrial por operário segundo as Unidades da Federação ou grupos delas (Cano), passando pela identificação de uma forma dominante de acumulação do capital que comporta estruturas "peculiares" de classes, regionalmente configuradas (Oliveira).

Com todas as diferenças metodológicas e teóricas entre os três estudiosos, eles compartilham preocupações que essa tese vem reencontrar, dentre as quais: os fatores institucionais que estão na base dos fenômenos econômicos e das oportunidades ocupacionais regionalmente delimitados; as especificidades que marcam os espaços da produção primária; o significado econômico e social das migrações internas; a heterogeneidade de configurações sociais, culturais e produtivas que os recortes territoriais trazem à tona. 


\subsection{Juarez Brandão Lopes: particularidades no nível local e uma generalização dualista}

Minha decisão de iniciar por Juarez Brandão Lopes este percurso vincula-se, especialmente, a um estudo que está completando 50 anos, por ele realizado em duas "comunidades" (sic) de Minas Gerais, no bojo de um extenso projeto coletivo destinado a subsidiar políticas educacionais, coordenado por Oracy Nogueira e Bertram Hutchinson. Sua abordagem eminentemente local e o diálogo com uma emergente literatura norte-americana o diferenciam de seus pares de mesma grandeza, na geração de sociólogos que ele integra, com a qual compartilha a tarefa de interpretar a industrialização e a urbanização brasileiras - a díade da "modernização" -, tendo como principais interrogantes teóricos a natureza do capitalismo no Brasil, suas particularidades e limites, e as perspectivas que se poderiam projetar para o (sub)desenvolvimento nacional.

Essa pesquisa de Lopes teve como foco as relações industriais em duas cidades vizinhas que dele receberam as designações fictícias de Sobrado e Mundo Novo -, no interior mineiro. O autor baseou-se fundamentalmente em entrevistas, mas também em questionários, documentos e jornais. Cada um desses municípios é abordado em suas especificidades - num tratamento eminentemente local - e, ao mesmo tempo, ganham relevo os aspectos de continuidade e semelhança entre ambos, que remetem à abordagem regional (a qual se estende, por vezes, ao território maior que essas duas "comunidades" integram, a Zona da Mata mineira).

A exposição mais completa de tal estudo é apresentada como tese de doutorado de Lopes e publicada em 1967 sob a forma de livro, intitulado "Crise do Brasil Arcaico". Lançado anteriormente, "Sociedade Industrial no Brasil" (Lopes, 1964) utiliza resultados dessas pesquisas na Zona da Mata mineira como parte das evidências que sustentam a argumentação.

Em "Crise...", Lopes enfatiza que é "mister (...) ver a comunidade no quadro mais geral do desenvolvimento econômico e social de toda a sociedade". E continua: "Nessa perspectiva, a mudança das relações de trabalho locais torna-se um componente do processo de desintegração de toda a ordem tradicional no Brasil, decorrente daquele desenvolvimento" (1967:15). Retornarei, pouco adiante, a esse aspecto crucial que é a expectativa de generalização que fundamenta (e/ou visa a legitimar) a metodologia aplicada. Desse mesmo excerto, quero destacar que a filiação dessa investigação de Lopes aos chamados "estudos de comunidade" não é aceita sem conflito pelo autor, que, como se vê, apressa-se em subscrever a principal crítica àquela linha de trabalhos: a escassa conexão, nessas análises, entre os fenômenos locais observados e a "sociedade global" - e uso aqui a expressão corrente na época, em que o "global" não se remetia à esfera internacional, mas à pluralidade de dimensões que dariam consistência e alcance a uma abordagem sociológica 
(o que, como exemplificam as advertências e as análises de Lopes, exigia uma escala fundamentalmente nacional) ${ }^{30}$.

Ainda assim, no prefácio de "Crise...", o autor afirma que se trata de um estudo de comunidade, que "examina apenas a parte do processo relativa a como o que ocorre no nível nacional incide sobre o local, sem cuidarmos das repercussões que se dão em sentido contrário" (1967:07).

E, talvez por isso, "Crise..." é uma pesquisa que se funda em um apurado e raro (sobretudo à sua época) tratamento da realidade "global" (nessa acepção acima referida) de um objeto local. Sua inspiração etnográfica é nítida, e a construção do relato avança de uma forma que aprofunda e valoriza as particularidades. Lopes principia por fornecer um histórico econômico e político da formação daquelas "comunidades" - termo que adota -, passando a descrever a evolução da estrutura fundiária, da exploração econômica da terra - aí compreendidas com destaque as relações de trabalho - e os processos de migração (fundamentalmente a transferência de população das 'roças' vizinhas para essas duas cidades). Seu interesse é preparar a análise das relações de trabalho no ambiente industrial estabelecendo que "trata-se de um operariado cuja origem rural é de ontem" (Lopes, 1967:36).

Ao adentrar o incipiente mundo fabril dessas duas localidades, Lopes explora as histórias das famílias proprietárias das unidades industriais e a "estrutura produtiva" das comunidades uma das quais conta com um único grande estabelecimento empregador; outra, com quatro. Apóiase, igualmente, em análises bastante detalhadas de questionários realizados com trabalhadores e tabulações especiais do Censo de 1950, embora, conforme já mencionei, considere como sua fonte básica as entrevistas ${ }^{31}(1967: 8-9)$.

É na análise das "relações industriais" (mais habitualmente denominadas relações de trabalho, no Brasil, conforme é tratado num apêndice) que o autor centra seus objetivos, animados teoricamente, como é informado na breve introdução do livro, pela oposição entre patrimonialismo e burocracia, tributária de Max Weber e afinada com os trabalhos de Kerr, Dunlop e outros.

\footnotetext{
${ }^{30}$ Em obra posterior a "Crise...", "Desenvolvimento e Mudança Social”, Lopes (1972/1968) refere-se aos muitos "esforços que já foram feitos para explicar o desenvolvimento do Brasil dos pontos de vista econômico, sociológico e político". Ao aludi-los, menciona - entre outras vertentes - que "uns têm o cunho monográfico, de estudos de comunidade", e então chama a seguinte nota: "Há limitações sérias ao uso dos resultados da vintena de estudos de comunidade realizados no Brasil nos últimos vinte anos; primeiro devido a problemas de comparabilidade; em segundo lugar porque quase nunca analisam, no dizer de IANNI, 'as conexões da comunidade com o sistema econômico-social, inclusivo, capitalista, em expansão' (Ianni, 1961, p. 113). Usamos os seus resultados, na medida do possível, conscientes desses percalços e procurando justamente inseri-los no quadro das mudanças da sociedade global" (Lopes, 1972/1968: XV).

31 "Colhemos principalmente em entrevistas os dados do nosso estudo. Foram entrevistados operários das fábricas, seus familiares, pessoas de nível sócio-econômico equivalente ao operário mas com outras ocupações, contramestres, mestres, pessoal administrativo das empresas e industriais. Ao todo foram realizadas mais de 350 entrevistas, a maioria com meia a uma hora e meia de duração, sendo, aproximadamente, $140 \mathrm{em}$ Sobrado e 220 em Mundo Novo. As entrevistas eram pouco estruturadas e seguiam roteiros, que variavam conforme o tipo de informante" (Lopes, 1967:8)
} 
Nessa tensão encontra-se o fio que Lopes explora em seus dois "casos" locais, estabelecendo - desde a "recolocação do problema" com que inicia a análise propriamente dita das relações industriais - que não se contenta com o aspecto formalmente contratual dos vínculos de trabalho:

\begin{abstract}
A abolição do regime escravista não quebrou a hegemonia da grande propriedade, o que propiciou a preservação, grosso modo, durante a Primeira República, embora com ajustamentos, da estrutura de dominação patrimonialista dos grandes fazendeiros. Certo, a liberdade de movimentação do trabalhador rural, e igualmente a introdução do vínculo monetário nas relações de trabalho, significaram relativo desvio da estrutura rural do tipo de organização tradicional. Entretanto, embora os trabalhadores viessem a ser empregados do fazendeiro e por conseguinte ficassem numa relação que, sob dado aspecto, era impessoal, a natureza tradicional da mesma permanecia de grande importância, preponderante até (1967:44).
\end{abstract}

A continuidade entre a propriedade das grandes fazendas e a dos estabelecimentos industriais locais vai ser identificada como fator para que se prolonguem as relações pessoais, tradicionais, patrimonialistas, consagradas entre patrões e empregados no ambiente rural, para dentro das fábricas. Ao mesmo tempo, inúmeros fatores técnicos, sociais e institucionais incidirão no sentido contrário, da instauração de uma racionalidade burocrática, impessoal. As pressões da eficiência produtiva, a constituição e a atuação dos sindicatos de trabalhadores ou a intervenção do governo federal em questões salariais e trabalhistas são aspectos bastante valorizados na reconstrução que Lopes realiza, sempre buscando pontos de semelhança e contrastes entre as duas "comunidades" que investigou (em que se destaca o menor alcance da atividade industrial em Sobrado).

Toda essa abordagem é bastante detalhada e valoriza, sobretudo por meio da transcrição de trechos de entrevistas, processos que ocorrem nas empresas e nas cidades, os quais, em outras tradições de pesquisa, poderiam soar prosaicos. Reproduz, por exemplo, depoimentos que expõem os conflitos de trabalhadores com a hierarquia da fábrica, eivados por exigências "tradicionais" de lealdade política e pessoal às famílias proprietárias e às chefias, ao poder onipresente dessas elites locais: "Aqui na cidade quem manda são os Machado [família dos industriais]; se a gente não vai bem com eles, pode mudar", relata um entrevistado de Sobrado.

A matriz analítica, como fica claro, longe de uma filiação materialista ou de qualquer forma de objetivismo, enfatiza as disposições individuais e aspectos culturais, como a "comunidade de hábitos, perspectivas, ideais e preconceitos" que Lopes identifica entre os proprietários rurais, independentemente das extensões de suas terras (1967:26).

$\mathrm{O}$ autor se volta especialmente para as implicações da tendência a que se recrie no meio urbano e industrial o padrão de relações sociais consagrado nas propriedades agrícolas daquelas comunidades: "Do campo, com padrões, valores e relações caracteristicamente patrimonialistas, provém a mão-de-obra industrial” (1967:29). 
Em obra de 1964, tematizando, precisamente, a sociedade industrial no Brasil, Lopes enfatiza, a partir da realidade do Estado de São Paulo, o caráter da produção manufatureira como principal fator de mudança estrutural nas "classes ocupacionais", pelo potencial de mobilidade que dela advém; o autor especifica que o interessa, especialmente:

(...) a passagem de lavrador (ou trabalhador de baixo status social e de comunidades semirurais) para operador de máquina em fábrica e a ascensão de indivíduos, em muitos casos de origem, em última instância, rural e outras vezes também de origem estrangeira, ao nível de operário qualificado, o que se dá em geral depois de duas ou três gerações de ajustamento à vida urbana (1964:22).

A forma como é pensada a tensão dessa passagem tem reconhecíveis traços evolucionistas: “(...) realizam muitas vezes uma mudança radical de ambiente, transpondo literalmente em poucos dias várias épocas de evolução sócio-econômica" (Lopes, 1964:23). Lopes, em um dos estudos que integra essa obra, realizado em uma grande empresa industrial de São Paulo, explora o perfil dos trabalhadores que migraram para essa metrópole, dentre os quais se destacam os de Estados do nordeste e os de outros municípios paulistas. Do ponto de vista das motivações desses indivíduos, o "espírito de aventura" é visto como comparável aos fatores econômicos ("tatu é que fica na terra", diz-lhe um informante). As diferenças culturais que cercam essas origens "geográficas" são amplamente exploradas pelo autor, que contrasta estruturas das famílias, valoração do trabalho autônomo, predisposição a realizar a migração de retorno, etc. As diferenças mais marcantes reforçam a oposição entre o urbano e o rural: "a orientação dos entrevistados de origem rural é claramente para fora do sistema industrial" (Lopes, 1964:44). Sua percepção é de que a mobilidade dentro da estrutura industrial poderia estabilizar esses indivíduos no sistema, mas essa ascensão ("qualificação em ofício industrial ou (com) a obtenção dos primeiros postos de supervisão") é rara para os trabalhadores procedentes do meio rural, e, em geral, só ocorre após duas gerações "afastados do trabalho agrícola" (1964:50).

As transições ocupacionais não se dão apenas de um ponto de vista objetivo. A pesquisa de Lopes nas localidades mineiras permite verificar que, mais do que um processo de "expulsão da terra", para muitos desses migrantes existem "hoje, no seu mundo mental, 'alternativas' aos movimentos de uma zona rural para outra, constituídas por empregos urbanos nas sedes dos municípios vizinhos" (1967:33 - grifo meu). Por outro lado, a problemática da "adaptação" nunca deixa de ser central na abordagem de Lopes, que destaca: "Freqüente é a menção a pessoas que 'não se acostumam à cidade', e retornam à roça, ou 'não conseguem aprender o trabalho da fábrica de jeito nenhum'. 'Ficar fechado o dia todo' e não tolerar o 'trabalho preso' são queixas de pessoas de mais idade que labutaram longos anos no meio rural" (1967:35).

É aqui que se evidencia uma tensão básica na obra de Lopes. De um lado, sua original abordagem local o leva a perceber que a problemática da adaptação dos trabalhadores, ou mesmo da "evolução" para um patamar de relações impessoais e burocráticas, assume colorações 
ricamente diferenciadas conforme os contextos culturais, históricos, sociais, econômicos, políticos, que particularizam experiências (que podem ser, e são, por ele, espacialmente delimitadas). Em obra anterior a "Crise...", o autor já apontava nessa direção de uma abertura à diversidade regional: “(...) pois o Brasil, como já foi dito muitas vezes, é, em certa medida, uma sociedade plural. Falar, portanto, de um único sistema de estratificação para as várias partes do país é interpretação demasiado simplista" (Lopes, 1964:178).

Numa linha de pensamento que precede em décadas reflexões como as de Marsden (2004), Lopes afirma que: "a relação empregador-operário é muito mais ampla do que uma simples relação de emprego. Como relação pessoal ela tende a ser total, especialmente numa pequena comunidade tradicional" (1967:70).

É por essa tentativa de generalização expressa no final do excerto - em que os fenômenos mais variegados terminam por adquirir seu sentido na oposição entre o tradicional e o moderno que temos o outro lado da moeda do pensamento de Lopes, o retorno de uma matriz dualista de entendimento. Em grande medida, ele termina por conceder a uma possibilidade de generalização a legitimidade dos "casos" que estuda. Nesse sentido "último", não são muito distintas as análises que faz da adaptação de trabalhadores rurais ao mundo fabril, seja no caso de Sobrado e Mundo Novo, seja no de migrantes nordestinos (ou paulistas) que se empregam em uma grande indústria da cidade de São Paulo, o que faz em "Sociedade Industrial no Brasil". Nessa obra, ao discutir, a "conduta econômica" e os limites da "solidariedade grupal" de operários provenientes do meio rural, evidencia a pouca confiança e o pouco reconhecimento com que esses se relacionam com o sindicato, e qualifica, assim, o seu achado: "atitude compreensível, quando nos lembramos que saíram de um mundo pequeno, familiar, de uma sociedade de folk, em que as relações eram pessoais, vindo para o mundo urbano, onde estão rodeados de instituições e grupos distantes, impessoais, alheios, até onde podem ver, aos seus interesses" (Lopes, 1964:59).

Como já antecipei, o autor entende seu estudo do "local" como uma "parte do processo", em que o "nacional" tem o caráter de "incidir" sobre a comunidade. Embora considere o caminho de volta, diz que não se ocupa dele. Assim, também no prefácio de "Crise...", justifica seus esforços buscando indicar que os resultados de sua observação e análise tenderiam a ser válidos para o país ou boa parte dele:

Em outras palavras, pretendemos ver a quebra do padrão patrimonialista de relações de trabalho em cidades industriais de Minas Gerais como componente de um processo global de desintegração da ordem tradicional no Brasil, provocado, a seu turno, pelo desenvolvimento social e econômico. Cremos que os mecanismos de mudança identificados são válidos, grosso modo, para as relações nas indústrias imersas no tradicionalismo de pequenas comunidades existentes por todo o Brasil. É provável que também o sejam para amplas áreas do campo brasileiro (...). Justifica-se, assim, a generalidade do título dado a este estudo monográfico: Crise do Brasil Arcaico - estudo da mudança das relações de trabalho na Sociedade Patrimonialista (Lopes, 1967:07 grifos meus). 
É com essa pressuposição que o autor embasa conclusões de grande alcance - territorial (nacional) e analítico -, a exemplo desta: "O Brasil novo está crescendo à custa do Brasil arcaico, tanto pela expansão das técnicas econômicas modernas, como pelos movimentos de migração interna" (Lopes, 1964:178). Encontram-se, aqui, sintetizadas as duas operações: de um lado, a cisão, dualista, entre o novo e o arcaico, que se projeta em uma divisão binária do país; de outro, a amalgamação de uma rica variedade de experiências e de formas sociais para "conformar" cada um desses dois pólos da antinomia.

$\mathrm{Na}$ presente tese, tantas décadas passadas, a problemática do local - suas possibilidades de articulação (simultânea e provisória) com diferentes escalas espaciais - não se coaduna facilmente com a idéia de que o "caso" exprime ou "manifesta" um (mesmo) "nacional", e que a este se chegaria por aquele. Nem por isso está ausente uma esperança de que os resultados da pesquisa possam se estender para além da atomicidade do "terreno" de campo. Aqui, a tentativa é de exercitar as possibilidades analíticas do tratamento de diferentes dimensões da vida social que se mostram pertinentes para a configuração - irrepetível, a cada caso - de "mercados de trabalho".

\subsection{Francisco de Oliveira: uma leitura marxista em diferentes escalas}

Não tenciono de forma alguma reconstituir o debate que leva Francisco de Oliveira a escrever sua "Crítica à razão dualista". Uma transcrição abreviada da "Breve colocação do problema" que abre esse clássico ensaio, entretanto, pode ser oportuna para reavivar o foco da intervenção do autor:

O esforço reinterpretativo que se tenta neste trabalho suporta-se teórica e metodologicamente em terreno completamente oposto ao do dual-estruturalismo: não se trata, em absoluto, de negar o imenso aporte de conhecimentos bebido diretamente ou inspirado no 'modelo Cepal' (...).

$\mathrm{O}$ anterior não deve ser lido como uma tentativa de contemporização: a ruptura com o que se poderia chamar o conceito do 'modo de produção subdesenvolvido' ou é completa ou apenas se lhe acrescentarão detalhes. No plano teórico, o conceito do subdesenvolvimento como uma formação histórico-econômica singular, constituída polarmente em torno da oposição formal de um setor 'atrasado' e um setor 'moderno' não se sustenta como singularidade: esse tipo de dualidade é encontrável não apenas em quase todos os sistemas, como em quase todos os períodos. Por outro lado, a oposição, na maioria dos casos, é tão somente formal: de fato, o processo real mostra uma simbiose e uma organicidade, uma unidade de contrários, em que o chamado 'moderno' cresce e se alimenta da existência do 'atrasado', se se quer manter a terminologia.

Com seus estereótipos (...), a teoria do subdesenvolvimento sentou as bases do 'desenvolvimentismo' que desviou a atenção teórica e a ação política do problema da luta de classes, justamente no período em que, com a transformação da economia de base agrária para industrial-urbana, as condições objetivas daquela se agravavam (Oliveira, 1981/1972: 11-13).

Estão aí anunciadas de modo muito evidente as dimensões política e teórica tanto da controvérsia quanto da posição que Oliveira vai desenvolver ao longo dessa obra. Meu interesse é 
tão-somente o de estabelecer os fundamentos que permitem entender a forma como o autor irá formular e operacionalizar, em dois outros trabalhos, a noção de região.

Ao romper com a visão acima sintetizada em suas próprias palavras, Oliveira articula diversas frentes de ataque: uma delas é setorial. Sua interpretação sobre a pretensa hipertrofia do Terciário no Brasil é contundente: ele não seria anômalo ou disfuncional, muito ao contrário: "a aparência de 'inchação' esconde um mecanismo fundamental da acumulação: os serviços realizados à base de pura força de trabalho, que é remunerada a níveis baixíssimos, transferem, permanentemente, para as atividades econômicas de corte capitalista, uma fração do seu valor, 'mais valia' em síntese" (1981/1972:33). Dessa afirmação, Oliveira deriva uma interpretação do fenômeno da urbanização do país, na qual o escasso crescimento relativo da ocupação industrial perde a importância ou o caráter "sociopático", como havíamos visto, que lhe eram atribuídos. Para o autor, o problema se resume à idéia de que "o incremento da urbanização no Brasil obedece à lei do decréscimo da participação da agricultura no Produto total” (1981/1972:35). Não serão, portanto, apenas os postos de trabalho industriais que terão o condão de promover o crescimento das cidades: as "necessidades da acumulação impõem um crescimento dos serviços horizontalizado, cuja forma aparente é o caos das cidades" (idem).

A obra prossegue reinterpretando a atípica - por contraste às experiências clássicas passagem da hegemonia, das "classes proprietárias rurais" para as "novas classes burguesas empresárias industriais", transferência que não ocorre até o "pacto populista" dos anos 1930 e que, mesmo com a articulação entre a "nascente burguesia industrial" e as "classes trabalhadoras urbanas", não se concretiza por completo, pois ainda "são as produções agropecuárias as únicas que geram divisas" (Oliveira, 1981/1972: 39-41).

A industrialização brasileira, por tardia, vale-se de tecnologia já disponível em escala mundial, o que faz com que o processo de reprodução do capital queime etapas: "o problema não é que o crescimento industrial não crie empregos - questão até certo ponto conjuntural - mas que, ao acelerar-se, ele pôs em movimento uma espiral que distanciou de modo irrecuperável os rendimentos do capital em relação aos do trabalho" (Oliveira, 1981/1972:42). Isso "também reduz o circuito de realização interna do capital", o que afeta negativamente "o efeito multiplicador real da inversão" (idem).

O "fosso abismal" que se cria na distribuição dos ganhos de produtividade leva à criação de "setores que funcionam como satélites das populações nucleadas nos subúrbios e, portanto, atendem a populações de baixo poder aquisitivo: por esta forma, os baixos salários dessas populações determinam o nível de ganho desses pseudo pequenos proprietários (...)” (p.44). A negativa cabal de qualquer dualismo é expressa por Oliveira, em decorrência dessa argumentação, em formulações como esta:

A 'especificidade particular' de um tal modelo consistiria em reproduzir e criar uma larga 'periferia' onde predominam padrões não-capitalísticos de relações de produção, como 
forma e meio de sustentação e alimentação do crescimento dos setores estratégicos nitidamente capitalistas, que são a longo prazo a garantia das estruturas de dominação e reprodução do sistema (Oliveira, 1981/1972:44)

A tentativa de superação das restrições estruturais à aceleração da acumulação capitalista será identificada por Oliveira na ação das "classes dirigentes", que, desde os anos 30, contam com um Estado fortemente engajado em "fazer a empresa capitalista industrial a unidade mais rentável do conjunto da economia (1981/1972:18-19). Nos anos 1950, o caráter planificador deste Estado se acentuará, e a estratégia envolverá fundamentalmente o engajamento de capitais estrangeiros (p.47-51) e um "aumento da taxa de exploração da força de trabalho". Mesmo que se verificasse uma aparente melhora de condições de vida - sobretudo para "as massas trabalhadoras" de extração rural que se tornavam urbanas -, é a comparação salário real-produtividade que expõe esse segundo e decisivo elemento, na interpretação de Oliveira. As perdas de valor real das remunerações para a inflação e a crescente mercantilização dos itens que compunham o custo de reprodução da força de trabalho teriam elevado crescentemente essa taxa de exploração (p.51-63). Este é um fator crucial para o gradual acirramento da contradição de classes, o qual desemboca na crise que dá origem ao golpe militar de 1964. Na compreensão desse processo, Oliveira persegue as alternativas para esses impasses econômicos, políticos e sociais que desembocaram na ditadura e as novas contradições que se abrem ante a gestão autoritária do Estado. Essa reflexão, aqui, não será abordada.

O que procurei recuperar na "Crítica..." são elementos que permitem situar com mais acuidade o tratamento que Oliveira dá à problemática regional em dois trabalhos posteriores, "Elegia para uma re(li)gião", de 1977, e "O elo perdido", de 1987.

O marxismo é, nesses trabalhos de Oliveira como em tantos outros daquela época, não apenas ferramenta teórica, mas também um objeto: em boa parte das análises que pontificaram na produção da sociologia brasileira dos anos 1970 a meados dos 1980, a utilização desse referencial serviu de base para exegese e disputa. Nessa arena, o posicionamento de Oliveira marca-se por uma invulgar ênfase à dimensão política da realidade - do abstrato nível da luta de classes a suas manifestações históricas concretas nos mais diversos níveis -, e às contradições inerentes ao curso dos processos históricos, em especial àquelas representadas pelo (renovado e variável) papel estrutural do Estado na reprodução. Essa perspectiva teórica é posta em marcha na análise que o autor faz da condição da região Nordeste no contexto brasileiro dos anos 1970, em "Elegia para uma re(li)gião".

Movido pelo "amor pelos milhões de nordestinos que pereceram, vítimas de um sistema de opressão e opróbrio" (1981/1977:17) e afirmando que "na década de 70 do século XX o socialismo é mais que uma previsão: é uma possibilidade concreta" (idem, ibidem), Oliveira toma como ponto de apoio sua experiência na Superintendência do Desenvolvimento do Nordeste (Sudene), nos anos 1960, para "oferecer uma versão e uma interpretação da história econômica, 
social e política do Nordeste e do Brasil dos dias da criação da Sudene - com o indispensável retrospecto e a também indispensável prospecção" (p.23). Nesse abrangente escopo, planejamento econômico (estatal, em especial) é um dos alicerces do estudo (porquanto "forma transformada do conflito social" - p.23). A idéia de região é o outro pilar, uma vez que é o "planejamento regional no Nordeste do Brasil" que servirá de objeto a Oliveira, numa análise que rejeita expressamente o enfoque dos "desequilíbrios regionais" para afirmar "a ótica da divisão regional do trabalho no Brasil, vale dizer (sob) a ótica do processo de acumulação de capital e de homogeneização do espaço econômico do sistema capitalista no Brasil” (p.25).

Oliveira busca na reflexão de Gramsci sobre o Mezzogiorno a principal referência marxista para o "tema regional” (p.40) e afirma: “(...) privilegia-se aqui um conceito de região que se fundamente na especificidade da reprodução do capital, nas formas que o processo de acumulação assume, na estrutura de classes peculiar a essas formas e, portanto, também nas formas da luta de classes e do conflito social em escala mais geral" (p.27).

Insiste que a problemática não "remete de volta à questão do modo de produção"; desautoriza qualquer debate sobre a existência de feudalismo no Brasil e repisa a sua crítica ao dualismo, contrapondo-se àqueles que quisessem ver nas "várias 'regiões' (...) pólos opostos da dualidade". Oliveira então reelabora, do ponto de vista espacial, a tese que já erigira na "Crítica..." : "sua inconsistência teórica [do dualismo] reside mais em não saber distinguir precisamente as várias formas que a produção do valor toma, subordinadas a uma dinâmica mais geral" (1981/1977:31).

Por tudo isso:

(...) as regiões são apenas espaços sócio-econômicos onde uma das formas do capital se sobrepõe às demais homogeneizando a 'região' exatamente pela sua predominância e pela conseqüente constituição de classes sociais cuja hierarquia e poder são determinados pelo lugar e forma em que são personas do capital e de sua contradição básica. E enfatiza-se, uma vez mais, que uma região assim tende a desaparecer (...) na mesma medida em que as várias formas do capital se fusionam (...) (1981/1977:30 - grifos no original)

Se a redação desse excerto poderia induzir a uma leitura algo mecanicista, ao ligar pelo adjetivo "conseqüente" a constituição de classes sociais às formas do capital, o aspecto político e a indeterminação desses conflitos são inequivocamente afirmados pelo autor logo a seguir.

Talvez a elaboração mais cuidadosa do conceito de 'região' que se queria introduzir seja a da dimensão política. Isto é, de como o controle de certas classes dominantes 'fecha' a região. Essa dimensão política não é uma instância separada da econômica; pelo contrário, é ou será da imbricação das duas instâncias que poderá surgir mais completo o conceito que aqui se propõe, pelo menos na tradição teórica do marxismo (Oliveira, 1981/1977:31 grifos no original).

O aspecto homogeneizador do desenvolvimento do capitalismo, no entanto, segue sendo um pressuposto de Oliveira, e por isso o "fechamento" que as classes dominantes conseguem imprimir a uma região é visto como transitório, enquanto aquelas conseguirem "reproduzir a 
relação social de dominação, ou mais claramente as relações de produção" (p.31). Quando esse processo se inviabiliza, a "substituição" com que acena Oliveira se dá por classes dominantes não mais locais, mas "outras, de caráter nacional e internacional" (p.32).

São essas "passagens" de hegemonia de (frações de) classes, compreendidas de forma decididamente espacial, que caracterizam a original interpretação de Oliveira sobre o Nordeste Brasileiro. De imediato, o autor enuncia o conflito entre sua abordagem e os limites "territoriaispolítico-administrativos das regiões". Repassando de forma ilustrativa os "vários "nordestes"” (p.32) que se identificam, nos diferentes momentos históricos, Oliveira dá ainda mais concretude à sua forma de pensar regiões a partir dessa matriz que privilegia as relações de produção e a acumulação. Em uma nota (p.41), ele revisita a imagem de "arquipélago", utilizada anteriormente, por outros autores, para representar a formação da economia brasileira. Salientando que essa idéia esfuma-se à medida que a realização do valor passa a ser de caráter fundamentalmente interno ao país, Oliveira, por outro lado, a reabilita, para destacar que as diferentes "regiões" - as aspas são dele - do país tinham tido, de fato, variadas formas de subordinação ao capitalismo mercantil e, em seguida, ao capitalismo imperialista (p.41). O exemplo do Maranhão e de seus laços com a França, nos tempos coloniais, serve para esclarecer o cerne do argumento: "Essa subordinação variada reflexiona-se dialeticamente com as forças produtivas de caráter local, para criar a 'região' no conceito aqui adotado. (...) Essa relação interna-externa é que dá o caráter de 'região' que depois o Maranhão assumiria (...)" (Oliveira, 1981/1977:41). Em outro caso, o estabelecimento de um circuito direto de ligação entre o algodão do Ceará e a indústria inglesa, no período da Secessão Norte-americana, permite que aquele Estado se libere dos "tênues laços de sua subordinação ao capital mercantil de Pernambuco" e avance no caminho de constituição de (sua) oligarquia (p.41).

Esse é o complexo caminho que o autor se propõem trilhar em sua análise regional: identificar formações suficientemente "fechadas" - nunca de forma total, ou estática, é evidente -, em que se possa reconhecer a especificidade de uma estrutura (social e política) de classes, associada, por definição, a circuitos particulares de realização e acumulação, a relações de produção.

Convergindo com essa percepção, constata-se que, ao logo do tratamento histórico que dá ao nordeste brasileiro, Oliveira termina por construir duas regiões - ambas definidas na sua relação com a região que desponta, a partir do século XIX como hegemônica, a "região do café" -: de um lado, o "Nordeste açucareiro", "semiburguês", é uma "região" (aspas de Oliveira) que é "excluída dos novos circuitos de produção e apropriação do valor gerado pela mercadoria café (...)"; simultaneamente, "um outro Nordeste emergia gradualmente, submetido e reiterado pelas mesmas leis de determinação de sua relação com o capital internacional: o Nordeste 'algodoeiropecuário"” (Oliveira, 1981/1977:34-45). 
Do ponto de vista do Nordeste como um todo, o trunfo da "região" oligárquica, pecuária alinhada com os "pressupostos da produção agro-exportadora da 'região' do café", subordinada por sua vez "aos interesses do capital comercial e financeiro inglês e norte-americano" - tem um efeito regressivo, forçando, inclusive, a recriação de "mecanismos de uma acumulação primitiva, que tomaram a forma do 'cambão' e de outros processos de relação de produção pré-capitalistas" ou o "abortamento da completa constituição de uma força de trabalho assalariada" (Oliveira, 1981/1977:36).

As transformações mais radicais se processam, entretanto, com a "conversão da 'região' do café em 'região' da indústria" (p.37). Uma nova "divisão regional do trabalho em todo o conjunto nacional" se estabelece. Nela, o Nordeste passa a ser

\begin{abstract}
a reserva do exército industrial de reserva: as migrações Nordeste-São Paulo chegam a constituir um formidável contingente que vai suprir os postos de trabalho criados pela industrialização, e contribuir para manter baixos os níveis de salário real de toda a massa trabalhadora; por outro lado, os diferenciais da taxa de lucros começam a drenar o capital que ainda se formava no Nordeste: e ainda sob outro aspecto, a mudança da política econômica (...) deu lugar a um mecanismo de triangulação das trocas de mercadorias Nordeste-Exterior-Centro-Sul-Nordeste que deprimia a taxa de realização do valor das mercadorias produzidas no Nordeste, inviabilizando ainda mais a reprodução do capital na região nordestina (1981/1977:37).
\end{abstract}

A estagnação do Nordeste e o conseqüente conflito que se articula é enfrentado pelo estabelecimento da SUDENE, forma institucional do planejamento regional, na qual a própria circunscrição do que era considerado Nordeste é ampliada, passando a estender-se do Maranhão à Bahia e englobando, ainda, uma pequena área de Minas Gerais. Segundo Oliveira, encontram-se nesse desenho "os contornos da ideologia da classe dominante da 'região' da indústria: desde que os movimentos migratórios do Nordeste para São Paulo ganharam força e intensidade, os migrantes de todos os Estados do Nordeste e mesmo os dos Estados do Norte são apelidados em conjunto de "baianos"' (p.38).

O percurso analítico que Oliveira desenvolve em "Elegia..." é vasto, e não caberia continuar, aqui, a reconstituí-lo, estabelecidas essas grossas linhas de sua construção. Elejo alguns elementos que merecem destaque:

a) a permanente atenção ao espaço, nessa análise, não se reflete em uma preocupação com delimitações fisicamente rígidas. A "região de São Paulo", a "região da indústria" "a região Sul" ou "Centro-Sul" aparecem, alternativamente, como sinônimos - de resto, o termo região vem quase sempre entre aspas -, e não há equívoco: alude-se ao pólo hegemônico da industrialização, da acumulação, e ao seu entorno mais diretamente articulado. Na análise da Sudene, esse "outro" não precisa ser dissecado com esmero, estabelecido seu significado estrutural e político. Já as diferenciações internas desse "Nordeste" - mesmo desses "dois nordestes" anteriormente referidos - têm lugar, quando o autor as julga pertinentes, e nesses 
momentos são utilizadas referências históricas, produtivas, político-eleitorais, conforme a pertinência (ver, por exemplo, páginas 108 a 110).

b) a centralidade da categoria "classes sociais" na matriz de pensamento de Oliveira o faz pôr o trabalho - as relações de trabalho, os mercados de trabalho - no cerne da sua regionalização. Os conflitos inter-regionais - que, na sua visão, são, em verdade, conflitos de (frações de) classe - passam pelo estabelecimento de regulações que representam os interesses de determinadas "áreas" do país; as perdas relativas de dinamismo (que são também e necessariamente perdas de poder) se expressam na migração e na própria (des)valorização simbólica da força de trabalho. Um item de seu capítulo IV intitula-se "O aumento das disparidades regionais como sinal e momento da integração nacional” (p.75), e nele Oliveira afirma:

Este processo de 'nacionalização' do capital estava parcialmente cumprido, seja porque a autonomia política dos Estados federados havia sido gradualmente reduzida, característica política mais marcante do pós-30, seja porque, do lado da força de trabalho, os movimentos migratórios que se intensificam no pós-guerra haviam transformado uma 'população para as regiões' em uma 'população para a nação' (1981/1977:77).

c) o planejamento regional é aqui a porta de entrada, neste momento de sua obra, da contínua reflexão de Oliveira sobre o papel do Estado e dos fundos públicos na configuração do capitalismo contemporâneo. Sua interpretação do Estado brasileiro (e do pacto populista, já referida), é aqui, também ela, regionalizada. O populismo é agora visto como "a forma de imposição da hegemonia da burguesia industrial do Centro-Sul”. Estavam ausentes, no nordeste brasileiro, os "conteúdos específicos do "populismo", que envolviam a hegemonia burguesa afirmada sem ruptura frontal com a oligarquia agrária, um proletariado que cresce sob a expansão das forças produtivas e "um Estado produtor que tornava-se gradual e crescentemente o próprio núcleo da contradição, pela ambigüidade de suas relações com as classes dominantes e dominadas" (p.95). Por isso, a luta de classes no nordeste teria sido mais “clássica" - "mas esse 'classicismo' é antes de tudo um arcaísmo, pois no capitalismo monopolista a presença do Estado muda as formas do conflito social básico" (p.95-96 - grifo no original).

Concluindo essa incursão por "Elegia...", interessa-me, aqui, externar uma implicação que sua abordagem teórica tem do ponto de vista da escala espacial. De acordo com Oliveira, nada menos fiel à reflexão marxiana do que certa literatura entrincheirada no plano mais abstrato da "lógica do sistema", que fracassa em enfrentar a compreensão da história. Para o autor, o principal risco da utilização do método marxista é "o de não alcançar-se a saturação histórica do concreto, isto é, de não saber apanhar a multiplicidade de determinações que fazem o concreto. A vulgata é precisamente essa recusa, é o recurso à abstração, que no marxismo é a forma elementar, mais primitiva e por isso menos rica" (Oliveira, 1987:09). 
Mesmo que no excerto acima Oliveira não aborde diretamente a dimensão territorial, mas a das classes sociais, a associação entre elas, que fundamenta o seu entendimento de região, permite identificar a relevância que empresta ao estudo de objetos histórica e espacialmente concretos, resgatando-os dos meros exercícios dedutivos. É um percurso como esse que o autor empreende em "O Elo Perdido", de 1987, em que as temáticas de "classe e identidade de classe" subtítulo do livro -, articuladas com o aprofundamento da problemática do Estado e do fundo público, reaparecem sob a forma do estudo minucioso de uma cidade. A análise que Oliveira faz de Salvador é perfeitamente fiel à orientação já bem assentada em seus trabalhos anteriores, mas chama a atenção pela riqueza de dimensões analíticas que me esforço para articular em minha própria investigação: aos elementos da história econômica e política, aos impasses estruturais da competição intercapitalista ou da valorização dos excedentes regionalmente gerados, virão se somar referências à religião, à questão racial, à "arrogância da oligarquia da Bahia, que se esconde nas grã-finas casas do Corredor da Vitória e da Barra-Avenida" (p.35), ao "acarajé para os turistas" (p.39), às duas polegadas a mais no quadril de Marta Rocha (p.36), ao discurso nacionalista da Petrobrás e as relações que essa empresa estatal estabelece com seu operariado (p.74), ou às canções de Dorival Caymmi (p.115), tanto quanto aos cinco empregados domésticos que, no mínimo, devem ter os ricos, para não dar sinal de pobreza (p.35).

Avesso ao dualismo, Oliveira apresenta um quadro em que o arcaísmo estrutural de uma sociedade em que $50 \%$ dos trabalhadores em atividade estavam no setor "informal" (p.87 - aspas de Oliveira) - índice muito elevado, para o padrão das metrópoles nacionais daquela década - ou os "mascaramentos ideológicos" do racismo e da luta de classes não condenam a capital baiana a um alijamento do processo nacional de desenvolvimento capitalista: condicionam, isso sim, a inserção de suas classes dominantes - "endógenas" (fortemente ligadas ao capital financeiro) ou "exógenas" (implantadas no bojo da industrialização "forçada" pelo poder público federal, a partir dos anos 1950, de que a Petrobrás é a epítome) - no tabuleiro do capitalismo brasileiro.

Por certo, em "O Elo Perdido", Oliveira não tem um interesse localista e mantém grande distância de abordagens como os "estudos de comunidade". Suas preocupações de fundo são nacionais e mesmo sistêmicas - sua reflexão sobre o capitalismo contemporâneo. Nem por isso deixa de recolher de um "caso" concreto - espacial, no sentido teoricamente mais pleno dessa idéia - o máximo de suas possibilidades analíticas. Especialmente importante é salientar que a experiência que escolhe para estudar o interessa não por ser (ou poder ser tomado como) representativa ou dianteira de tendências nacionais. São efetivamente os fatores que abortam para usar uma metáfora muitas vezes repetida nessa obra - a industrialização ou o amadurecimento das classes sociais em Salvador que melhor servem aos seus propósitos de pesquisa.

De qualquer forma, seu suporte empírico é um "local" - termo que Oliveira não utiliza que equivale ao sentido de "região" acima esboçado, quando tratei de "Elegia...": particulariza-se 
("fecha-se", no termo do autor) por uma configuração específica da estrutura de classes e das relações de produção. Nesse sentido, ao estudar Salvador, é - quando não esse grande agregado que seria o Nordeste brasileiro -, ao menos toda a Bahia que Oliveira põe sob mira.

\subsection{Wilson Cano: "núcleo" e "periferia" na abordagem econômica das articulações regionais}

Contemplando a contribuição de pesquisadores que intervêm no debate a partir do enquadramento disciplinar da economia, analiso agora o trabalho de Wilson Cano, que tem larga contribuição na produção brasileira sobre a "questão regional" - entre aspas, como ele costuma grafar, sugerindo que recolhe a formulação de uma órbita da discussão que extravasa o universo acadêmico.

Dos seus textos que examinei, interessa-me especialmente sua percepção da diversidade regional brasileira a partir de um ponto de vista, fundamentalmente econômico-produtivo, que eu arrisco chamar de sistêmico: a nação se constitui e se desenvolve a partir da integração de suas regiões, as quais se articulam e se hierarquizam dinamicamente. Mesmo que se reconheçam tendências duradouras, há um permanente movimento nesse arranjo. A concorrência intercapitalista e as complementaridades da estrutura produtiva (ou da oferta) das regiões aparecem como fatores centrais na interpretação de Cano, que nem por isso deixa de remetê-los recorrentemente às esferas da política e, sobretudo, da história.

Trabalho é uma categoria que emerge, em seus estudos, em vários níveis, ressaltando-se: o tratamento histórico da constituição de relações capitalistas de produção e da (indissociável) emergência de um mercado de trabalho; a ênfase às migrações inter-regionais, que aparecem como a expressão de fatores de atração e de expulsão presentes nas diferentes áreas da nação; a articulação analítica entre desempenhos econômicos regionais e variáveis como produtividade do trabalho, distribuição funcional da renda ou níveis salariais.

Sua reflexão guarda alguma afinidade teórica com a que vimos de examinar em Oliveira, na medida que Cano recorre em vários momentos à categoria classes sociais e a uma leitura da dinâmica capitalista que se afinam com a tradição marxista. No entanto, o cerne do seu interesse diferencia-se, por concentrar-se nesse agregado nacional que a cada momento é ponto de partida ou de chegada para sua análise de "desequilíbrios" (novamente, aspas dele) nos fluxos econômicos ou produtivos e nas relações de subordinação entre as regiões brasileiras.

Em "Desequilíbrios Regionais e Concentração Industrial no Brasil - 1930-1970" (Cano, 1985), o autor tenta situar historicamente a emergência da "questão regional brasileira", principiando por lastimar a escassez de estudos que apresentem "uma visão integrada do fenômeno regional, inserido na dinâmica social de toda a nação" (p.21). Essa característica do debate contribuiria para acirrar a disputa entre os Estados da Federação, acesa na cena política. 
Até o final dos anos 1950, na percepção de Cano, a única problemática reconhecidamente regional no Brasil referia-se à região Nordeste e suas secas. A instituição da CEPAL e a discussão que ela produz sobre as relações "centro-periferia" teriam favorecido abordagens que buscavam reeditar essa matriz para fenômenos intranacionais, o que ele considera impróprio:

a 'concepção centro-periferia' só é válida quando aplicada ao relacionamento entre Estados-Nações politicamente independentes, e não entre regiões de uma mesma nação, onde a diferenciação de fronteiras internas não pode ser formalizada por medidas de política cambial, tarifária e outras, salvo aquelas relacionadas às chamadas políticas de incentivos regionais. Os espaços regionais, quando muito, guardam marcadas diversidades culturais, historicamente determinadas, além, naturalmente, daquelas decorrentes de suas estruturas econômicas diferenciadas (Cano, 1985:23 - grifo W.C.).

Ainda dentre os fatores que teriam contribuído para avivar esse debate no país, nos anos 1950, o autor identifica a afirmação da "chamada 'Ciência Regional”" na França e Estados Unidos, cujos fundamentos, ainda que inadequados à nossa realidade, teriam estimulado que os "desequilíbrios regionais" fossem postos em pauta aqui. No plano doméstico, essa conjuntura é marcada por fortes secas no Nordeste e pela institucionalização de programas de apoio àquela região (já editados, episodicamente, ao sabor das estiagens, desde o final do século anterior), com especial destaque para a instauração da SUDENE. Outro elemento valorizado por Cano é a divulgação da série estatística, com recuo a 1939, de Contas Nacionais, desagregadas por Estado, que fomenta a comparação e reivindicações por eqüidade. Um último elemento relevante nesse tabuleiro são os elevados investimentos, privados e públicos, deflagrados no bojo do Programa de Metas: por se concentrarem no Centro-Sul do país, desencadeiam "grandes pressões políticas das demais regiões, reclamando tratamento prioritário de desenvolvimento" (Cano, 1985:25).

Cano enuncia e procura desfazer quatro visões, que classifica como mitos, no "trato da questão regional" (1985:27).

O primeiro deles é 'tomar como paradigma de 'desenvolvimento' as regiões industrializadas como São Paulo", pugnando pela reedição de sua experiência nas regiões mais pobres do país, com base na premissa de que a industrialização seria o "mecanismo redentor do sofrimento regional" e permitiria, por si mesma, enfrentar "o atraso, as disparidades, o desemprego e o subemprego" (p.28). Cano contrapõe a essa perspectiva a importância que teve, para o desenvolvimento de São Paulo (bem como de vários países avançados) uma agricultura moderna e uma "urbanização mais ampla". Frisando que os problemas da distribuição de renda e da pobreza não estão resolvidos em São Paulo, o autor afirma que "do ponto de vista do emprego não foi a indústria como setor diretamente produtivo, mas sim a industrialização em sentido amplo, com seus desdobramentos no setor terciário funcional e moderno, que ampliou o mercado de trabalho urbano" (p.30).

O segundo aponta a existência de um elevado potencial de expansão da fronteira agrícola como forma de canalizar a população que, tornada excedente em áreas rurais, lá permanece em 
precárias condições ou protagoniza o êxodo para as cidades. Cano reconhece a existência de áreas agricultáveis ociosas, mas procura demonstrar que as mesmas não estão efetivamente disponíveis para a exploração econômica desse contingente expulso do campo, mas tomadas pelo "capital especulativo" (p.31). Assinala os explosivos conflitos entre grileiros e posseiros, as mortes que se acumulam, e denuncia que essa proposição, em verdade, objetiva escamotear a "perversa estrutura fundiária do país" (p.32).

O terceiro é o mais minuciosamente debatido por Cano - possivelmente por ser mais complexo do ponto de vista político, mas, com tanto mais razão, por se aproximar do interesse analítico mais central do autor -: trata-se do "mito do "imperialismo paulista sanguessuga". Preparando-se para contestar, com o recurso a dados estatísticos e informações históricas, quatro argumentos em que se desdobra essa visão, o autor antecipa sua réplica de forma sintética:

(...) o verdadeiro problema do chamado 'imperialismo interno' é o da concentração automática de capital, através da concorrência capitalista que se processa em forma livre, num espaço econômico nacional internalizado, onde os interesses privados de maior porte não são efetivamente regionais. Há, em síntese, a concentração em um Centro Dominante, que imprime os rumos decisivos do processo de acumulação de capital à escala nacional (p.33 grifo W.C.).

Essa convicção de Cano espelha o eixo pelo qual, ao longo do livro, irá reconstituir historicamente a afirmação de São Paulo como pólo do desenvolvimento brasileiro, oposto a uma periferia $^{32}$.

Esse terceiro mito possui variantes, que Cano resgata do debate das duas ou três décadas que precedem esse seu estudo. O primeiro argumento sustenta que teria havido transferências, via sistema bancário, da periferia nacional para São Paulo. Cano diz que não há demonstração possível para essa tese, que considera simplória (p.31-32). O segundo assegura que São Paulo teria sido deficitário no seu comércio com o exterior, diferença financiada pela periferia nacional, superavitária. Cano contrapõe dados que indicam que esses "sinais" oscilam muito em uma série histórica; ademais os saldos "periféricos" raras vezes teriam tido monta que os capacitassem a cobrir desempenhos negativos paulistas. O terceiro eixo trata da política cambial e das tarifas de importação em sua relação com os preços internos. Dentre as posições que se articulam em torno dele, encontra-se a idéia de que a periferia pagaria preços mais altos pelos bens industrializados no "pólo" em razão da proteção aos produtos nacionais (majoritariamente fabricados no Centro-Sul). Cano admite que o argumento procede, mas lembra que essa suposta desvantagem não recai predominantemente sobre a periferia, distribuindo-se por todos os consumidores nacionais. E questiona: "fossem as tarifas reduzidas a zero, haveria viabilidade econômica para se instalar

\footnotetext{
${ }^{32} \mathrm{Sim}$, pois embora recuse, como assinalei, a transposição do modelo centro-periferia para o plano interno do país, o autor adota ao longo de todo esse estudo a noção de periferia para as porções do território que não compõem o pólo (designação que demonstra preferir a "centro") do desenvolvimento nacional. Este, por sua vez, algumas vezes é o "Centro-Sul", mas, boa parte das vezes, é, nomeadamente, São Paulo. Em tratamentos estatísticos, em vários momentos, compara os dados de São Paulo com o "resto do Brasil". O mesmo se verifica em outros trabalhos, como Cano (1991).
} 
indústrias no país? E na periferia, conseguir-se-ia atrair alguma indústria?" (p.37). Uma linha de raciocínio semelhante é usada pelo autor para refutar que o período em que taxas de câmbio diferenciadas vigoraram para importação e exportação teria representado perdas maiores para a periferia. Cano não desacredita Celso Furtado e o estudo que está nas origens da Sudene: teria havido "transferência de recursos implícita" do Nordeste para o Centro-Sul de 167 milhões de dólares, entre 1948-56; porém Cano apóia-se em períodos subseqüentes para assegurar que esse fluxo a seguir se inverte, e a ponderação resulta nula, ao menos entre 1948-1968. Cano recupera em Furtado o que lhe parece central: "a transferência (...) não se expressa em fluxo monetário. A rigor, não se trata de uma transferência de renda e sim de uma baixa de produtividade de caráter econômico" (Furtado apud Cano, 1985:40). Assim, é o diferencial econômico, de eficiência, de porte, para além de priorizações emanadas das instâncias político-institucionais, que Cano quer ressaltar.

O mesmo vale para a última variante do "terceiro mito": frente à posição segundo a qual São Paulo teria crescido à custa do excedente periférico, Cano insiste que foi o "seu potencial econômico" que permitiu a esse Estado desenvolver sua indústria, e que o lastro foi "o maior desenvolvimento de relações capitalistas de produção" (p. 40). "Certamente não às custas do excedente do Piauí, Minas Gerais ou do Rio de Janeiro é que se implantou a moderna indústria paulista" (p. 41). Consciente das implicações políticas de sua posição, acrescenta: "Não pretendo, com isto, afirmar que a atuação do Governo Federal no Nordeste seja suficiente e satisfatória. Acho que a região requer muito mais do que isso. Entretanto, o que desejo afirmar é que não procedem as alegações sobre sugamento periférico do excedente por São Paulo" (p. 44).

O quarto mito, enfim, é o de que o planejamento regional seria uma panacéia. Cano critica essa retórica e algumas características das políticas até ali predominantes, em especial a falta de coordenação entre elas e a proliferação de planos nas esferas nacional, regionais e estaduais ${ }^{33}$. O autor questiona ainda a sobrevalorização da "política de atração de indústrias", em detrimento de várias outras frentes que demandariam intervenção, e desacredita os que pretendem conferir "base técnica" aos planos de desenvolvimento:

Não será com uma postura 'técnica' e sim com uma firme posição política - explicitada por amplo respaldo democrático - que se poderá avançar na confecção de 'planos regionais' e principalmente na tomada de decisões políticas que tenham por objetivo uma efetiva melhoria das condições de vida das populações mais carentes, sejam elas de uma região 'x' ou 'y' (p. 46-7).

Com o foco direcionado à problemática do trabalho, Cano publicou, em 1994, o artigo "Industrialização, crise, ajuste e reestruturação: algumas questões sobre o emprego e suas repercussões sobre a distribuição da renda". Nesse trabalho, analisa "três momentos desse 'processo acumulativo de riqueza e miséria social', que se formou ao longo de nossa extraordinária

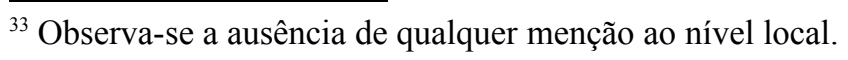


industrialização" (p.590): a industrialização restringida (1930-55) e a industrialização pesada (1956-80) - formulação de João M. Cardoso de Mello -, seguidas do período de "crise da dívida e políticas neoliberais" (1980-93). Em uma apreciação que atravessa todas essas fases, Cano afirma: "O que essas conservadoras elites sempre tentaram, na verdade, foi 'empurrar com a barriga' nossos problemas sociais, acreditando que a fronteira agrícola, a industrialização e a urbanização e, é bom lembrar, a repressão policial - e dariam conta dos males de nossa pobreza e miséria historicamente acumuladas" (1994:589).

A configuração de nosso capitalismo "duplamente retardatário" conseguiu, na primeira etapa de industrialização, desencadear um processo de acomodação social, cujos principais fatores teriam sido o crescimento do nível de emprego urbano, a concessão pelo Estado de alguns direitos sociais e a expansão da fronteira agrícola (Cano, 1994:590-592). A conjugação desses elementos possibilitou, segundo o autor, o adiamento de reformas estruturais (reformas agrária, urbana e tributária), embora já se avolumassem reivindicações sociais por educação, saúde e habitação e os rendimentos do trabalho consagrassem - apesar de uma melhoria dos padrões de sobrevivência dos migrantes rurais incorporados aos mercados de trabalho urbanos - uma "enorme regressividade" na distribuição de renda.

No ciclo da industrialização pesada, as vultosas taxas de crescimento do setor industrial e dos Serviços, bem como da construção civil, levaram a uma evolução do emprego urbano em taxas médias anuais superiores às do crescimento da população urbana, "enxugando parte da desocupação aberta e disfarçada do setor rural" (1994:593). Nesse período, esgotam-se fronteiras agrícolas do período anterior, e a agricultura passa a ser expulsora líquida de mão-de-obra; avança o processo de integração do mercado nacional, verificando-se descentralização e desconcentração industrial (que beneficiam especialmente o Norte e o Nordeste do país), graças, entre outros fatores, a uma política governamental de incentivos ao desenvolvimento regional; consolidam-se sete novas metrópoles regionais, que geram um grande volume de empregos urbanos, compensando o esgotamento das ocupações agrícolas, e vêm atenuar a concentração das atividades econômicas no Rio de Janeiro e em São Paulo. As políticas de incentivos, inclusive à exportação, e os pesados investimentos em infra-estrutura favorecem essa desconcentração, que compreende uma interiorização das atividades, sobretudo no Estado de São Paulo.

Apesar da longa manutenção das políticas de arrocho salarial a partir de 1964, a notável expansão quantitativa do emprego urbano e a elevada diversidade da estrutura ocupacional - aumentando consideravelmente os postos de trabalho mais qualificados e mais bem remunerados - possibilitaram, mais uma vez, a contenção das reformas sociais estruturais requeridas, notadamente a agrária. Contudo, o Censo Demográfico de 1980 revelaria notável piora dos níveis pessoais da distribuição da renda e considerável aumento do emprego informal (Cano, 1994:595).

A partir de 1979, com a "crise da dívida externa", a restrição de financiamento externo e a implementação de ajustes macroeconômicos de cunho ortodoxo - "cortes do gasto público, 
restrições monetárias, altos juros, arrocho salarial, câmbio 'realista', etc" (Cano, 1994:595) aprofundou-se a crise econômica, ao mesmo tempo em que se agravou ainda mais a concentração de renda, e a crise social do país cresceu em intensidade e visibilidade. Contribuindo para amenizar essas adversidades, os esforços exportadores compensaram parte da redução da demanda interna e contribuíram tanto para uma desconcentração espacial da agricultura e da agroindústria, bem como para o surgimento de focos de intenso progresso técnico. Outro fator que mitigou os efeitos da crise foi a redução da pressão demográfica (a taxa anual de crescimento populacional baixou de 2,48\% na década de 70, para 1,89\% entre 1980 e 1991) (Cano, 1994, p. 597).

$\mathrm{Na}$ reconstrução histórica que Cano oferece, nesse artigo, de alguns movimentos importantes do mercado de trabalho em um recorte nacional, percebe-se a importância das variáveis político-institucionais e demográficas, bem como da dimensão espacial, ladeando os marcadores mais propriamente econômico-produtivos que elege. Em seu livro de 1985, essa perspectiva dá espaço a um exercício de análise bem mais extenso, quando dedica um capítulo de seu estudo sobre industrialização e desequilíbrios regionais no Brasil à temática "Emprego, produtividade, salário-produto e excedente".

$\mathrm{O}$ autor examina essas quatro variáveis nas três fases em que periodiza a história da industrialização brasileira, subdividindo os gêneros industriais em três grupos (bens de consumo não-durável; bens intermediários; bens de consumo durável e bens de capital). A partir das 36 "unidades" que (potencialmente) resultam das combinações desses três critérios analíticos é que Cano empreende a sua análise regional, em uma abertura que utiliza ora Estados; ora a reunião de dois ou mais deles, como o par Maranhão-Piauí; muitas vezes as Grandes Regiões, como CentroOeste, raramente desagregada; com freqüência, a construção "Brasil exceto São Paulo", com que operacionaliza a discussão da centralidade do "pólo" e suas relações com a periferia.

Como não poderia deixar de ser, o tratamento, fortemente calcado em dados estatísticos, privilegia em cada passo aquelas evidências mais relevantes, mas não abre mão de tentar contemplar a vastidão dos cruzamentos que mobiliza. Não arrisco uma síntese desse ambicioso panorama, exercício que tampouco Cano se propõe, ao encerrar seu capítulo. Destaco, somente, que fatores como a inovação tecnológica, capacidades ociosas dos parques produtivos, políticas cambiais, decisões privadas ou governamentais de alocação de novos investimentos, economias e deseconomias de aglomeração, vigor das organizações sindicais, entre muitos outros, são acionados, alternativamente, pelo autor, para explicar comportamentos das variáveis acompanhadas nas situações (temporais e espaciais) específicas. Chama a atenção, ainda, a plasticidade dos recortes que aplica ao território, conforme a natureza do fenômeno sobre o qual se detém em cada momento de seu percurso de análise.

Claramente, o mercado de trabalho é, em Cano, um dos níveis em que se opera a articulação espacial mais abrangente a interessá-lo, a "integração do mercado e constituição da 
periferia nacional", título do quinto e último capítulo desse livro de 1985, que ocupa metade do volume.

De uma situação que perdura até 1920, quando "era pequena a integração do mercado nacional (...) [e] a produção industrial do país não apresentava suficiente dinâmica de crescimento que lhe obrigasse a romper o 'arquipélago' nacional e cativar para si o mercado nacional" (1985:158), o autor reconstrói uma trajetória em que a afirmação da hegemonia da economia paulista é, claramente, o eixo que organiza a exposição. Passando pelas controvérsias sobre a crise de 1929, seus antecedentes e sua recuperação, Cano expõe a mudança no padrão de acumulação que se opera ao longo da "industrialização restringida". A sua leitura deixa claro que a "saída para dentro" da economia brasileira (p.181) tem protagonistas sociais, setoriais e, inequivocamente, a eles corresponde um território, um espaço.

Recapitulemos as precondições para o novo padrão. $\mathbf{O}$ capitalismo brasileiro nasceu com o assalariamento da economia cafeeira do Oeste Paulista, em meados da década de 1880. Deu importantes passos desde o final do século e, principalmente, nos períodos 1905-1913 e 1920-1925, quando o investimento industrial sobrepassou de muito a demanda então específica da indústria nacional. $O$ setor cafeeiro superacumulou capacidade produtiva, principalmente na segunda metade da década de 1920; o de transportes ferroviário e o de cabotagem praticamente já estavam implantados já antes de 1930; o bancário nacional já sobrepassara o movimento dos bancos estrangeiros instalados no país e mostrava plenas condições para uma decisiva expansão, que ocorreria nas décadas de 1930 e de 1940. Quanto ao Estado, também já dera algumas demonstrações de capacidade de intervir na economia, experiência que lhe seria bastante útil após 1929 (Cano, 1985:184 -grifo meu).

Nesta fase da industrialização, a integração do mercado nacional dizia respeito fundamentalmente ao comércio inter-regional de mercadorias. Porém, "além disso, deve-se reconhecer a importância das migrações humanas inter-regionais e as decisões macropolíticas de alocação espacial de determinados investimentos de grande vulto" (p.186).

Outro excerto reforça essa articulação das dimensões envolvidas na performance - e, do ponto de vista que discuti no capítulo anterior, na própria constituição - de uma realidade regional:

O novo padrão de acumulação seria dominado pelo capital industrial e este, majoritariamente, estava sediado em São Paulo; era ali onde se concentravam seus maiores interesses, maior mercado, maior capacidade de articulação inter-setorial, maiores ganhos de escala e de economias externas, e o mais bem constituído mercado de trabalho (Cano, 1985:187 - grifos meus).

Para os "estados periféricos não cafeeiros", debilitados na capacidade exportadora para o estrangeiro, a integração do mercado nacional oferecia a potencialidade de novos destinos para a produção e, portanto, de crescimento, via exportações para o mercado interno (p. 191). Contudo, nesse mesmo movimento, é necessário "abrir o mercado regional" (aspas de Cano) e restringir o leque de produtos em que parece viável competir. 
$\mathrm{Na}$ visão do autor, o momento inaugural dessa integração, ainda que inquestionavelmente ancorado em uma miríade de ferramentas institucionais operadas pelo Estado, assenta-se fundamentalmente na lógica dos riscos e oportunidades do intercâmbio em um mercado. Isso viria dar o sentido, não apenas à consolidação de uma esfera propriamente nacional, mas, igualmente, à própria densificação das economias e das identidades das regiões, lançadas a essa articulação que lhes cobra um posicionamento em um sistema mais amplo. Os inúmeros espaços que compõem o "Brasil exceto São Paulo" vêm-se diante de uma variedade de possibilidades contraditórias, que o autor tipifica como efeitos de "estímulo, de inibição ou bloqueio e, até mesmo, de destruição" (p.191), categorias que o apóiam em diferentes momentos de suas análises regionais.

Dentre as potenciais determinações que arrola para que uma região sofra mais fortemente ou menos os efeitos de destruição, uma vez mais se percebe a natureza multidimensional desses espaços, incluindo-se a variável física da proximidade:

(...) quer por sua proximidade geográfica, por sua disponibilidade e grau de ocupação de determinados recursos naturais e, principalmente, por sua capacidade em 'assimilar e propagar internamente' o desenvolvimento de relações capitalistas de produção mais avançadas emanadas a partir do 'pólo', uma região poderá se beneficiar mais que outra, durante o processo de integração (1985:207).

Os fluxos humanos são permanentemente evocados e analisados por Cano, compondo a mesma integração que se plasma a partir dos circuitos das mercadorias. $\mathrm{O}$ autor assinala que, em 1940, 6,7\% população brasileira era de brasileiros vivendo fora de sua região de nascimento; em 1950, essa participação sobe para 8,2\% e continua ascendente, chegando a 12,8\% em 1970 (Cano, 1985:241; 288).

São Paulo mantém-se a partir de 1940 como o maior receptor líquido de migrantes, enquanto Minas Gerais e o Nordeste despontam como principais expulsores, no cômputo geral do período.

A observação desses deslocamentos populacionais conforme as origens e os destino rurais ou urbanos articula-se com a recorrente problematização que Cano faz do "atraso periférico" (p.259), especialmente a dominação que, no plano dessas regiões, o capital mercantil local impõe às populações, de que a agricultura e a estrutura fundiária são as maiores vítimas (idem) ${ }^{34}$.

Essas "burguesias regionais", como o autor indica, notadamente nas regiões integradas de forma periférica ao "pólo", encontram-se submetidas a um "novo padrão de dominação do mercado nacional" (p.252), que se consolida ao longo da "industrialização pesada" (1956-70). É, aqui, digna de relevo a leitura que Cano faz do papel dos incentivos e programas públicos de apoio

\footnotetext{
34 “Concluindo, não se pode dizer que não tenha havido desenvolvimento capitalista na periferia. Ele ocorreu e continua se expandindo; porém a passos mais curtos e demorados. Tanto é que ali subsiste, até hoje, a dupla subordinação do capital industrial do pólo e a do capital mercantil regional, este concorrendo acentuadamente para a manutenção da estrutura política, social e econômica regional, destacando-se a perversa estrutura fundiária” (Cano, 1985:313).
} 
às regiões periféricas, que, pode-se perceber, o autor identifica mais como instrumento do que como contraposição a essa nova forma de hegemonia:

Assim, parte do excedente gerado no pólo, que não tinha condições de ser convertido em novo capital produtivo no próprio pólo, graças ao sistema de incentivos fiscais (primeiro os regionais, em seguida também os setoriais) pode vazar em direção às regiões incentivadas, facilitando a transição para a forma mais avançada de dominação do mercado nacional: aquela que se manifesta via acumulação de capital.

A partir do momento em que se instaura predominantemente no pólo, o processo de industrialização pesada, é nesse espaço econômico que seriam centralizadas as decisões de 'onde', 'quando' e 'em que setor' o capital que domina a dinâmica de acumulação à escala nacional deverá investir. Assim - a despeito dos incentivos regionais -, a partir desse momento não teria sentido falar-se em 'industrialização autônoma' em qualquer outra região.

Dito de outra forma, a partir desse momento, as decisões privadas de inversão (incentivadas ou não) na periferia nacional, do capital industrial sediado no 'pólo', seriam tomadas quase que independentemente de decisões da tecnocracia e das burguesias regionais (Cano, 1985:253).

Nas conclusões desse livro, Cano sustenta que a análise do período 1930-70 permite assegurar que os efeitos de estímulo superaram largamente os de destruição. E deriva das evidências: "Com isso, torna-se cada vez menos sustentável pensar o relacionamento comercial entre São Paulo e o resto do país como no clássico modelo “centro periferia"” (1985:304).

Refutando a estagnação de qualquer região brasileira, Cano vê-se diante da tarefa, que proclama, de compreender a persistência da "miséria e do desemprego regional", e afirma que o "problema migratório [é] (...) verdadeiro translado espacial desses dois problemas", que termina por creditar, predominantemente às "atrasadas formas de produção e intermediação agrícola", à estrutura fundiária e à "intensificação tecnológica da agricultura” (p.311-12). As regiões em que a economia urbana se expandiu em grau suficiente para acolher o (próprio) êxodo rural sofreram menores perdas líquidas de população, por conseguirem reter em suas cidades a maior parte dos migrantes. As demais contribuem para o inchamento de metrópoles como São Paulo, movimento típico das décadas de que Cano trata nesse livro ${ }^{35}$.

Posteriormente (Cano, 1997), o autor integrará a discussão sobre certa tendência à desconcentração econômica, especialmente industrial, que estaria se verificando no Brasil, entre as décadas de 1970 e 1990. Analisando o período 1970 a 1995, enumera movimentos contraditórios

\footnotetext{
${ }^{35}$ Em outro trabalho, que guarda bastante proximidade com o livro "Desequilíbrios regionais (...)" que aqui priorizo, Cano dedica uma seção específica à "urbanização descontrolada". Numa formulação sintética de sua percepção do fenômeno, afirma: "Se a urbanização da década de 1950 foi 'suportável', a da década seguinte passou a ser problemática e, a de 1970 'caótica', com perda da qualidade do padrão de vida que as cidades ofereciam, com a perda de qualidade e a 'privatização' da maior parte dos serviços públicos e a incapacidade política - face ao autoritarismo e à baixa politização do povo - das populações reclamarem seus direitos de cidadãos". Na continuidade da análise, o autor alerta para o erro que seria "atribuir essas mazelas, com exclusividade, à concentração industrial", e propõe que se comparem as condições de metrópoles como Fortaleza e São Paulo, para que não se incorra no equívoco. Para ele, "a questão, na verdade, tem a ver fundamentalmente com os baixos salários com que se paga a força de trabalho no país, com a má forma da administração pública do urbano e com a voragem da especulação mercantil imobiliária" (Cano, 1991:23-26).
} 
de desconcentração e reconcentração e procura organizar os fatores que teriam contribuído em cada uma dessas direções. Antes, torna a asseverar a condição de núcleo conquistada por São Paulo, e apresenta essa formulação, que merece menção, por ser ainda mais cristalina do que as recolhidas na obra de 1985: “(...) [entre 1930-70] a economia paulista, sendo o núcleo da acumulação produtiva do país, ao crescer imprimia também determinações (regionalmente diferenciadas, é claro), de crescimento aos seus complementos econômicos espaciais (as demais regiões)" (Cano, 1997:106 - grifo meu).

O autor subdivide o intervalo de tempo em dois períodos: 1970 a 1985 e 1985 a 1995 . No primeiro, a perda de participação de São Paulo na indústria de transformação é efetiva, mas está longe de ser vertiginosa (de 58,2\% para 51,9\%). Cano identifica no plano interno desse Estado o movimento mais relevante: uma transferência importante de peso da Região Metropolitana em favor do restante do território paulista. No plano nacional, nesse primeiro subperíodo, somente o Rio de Janeiro acompanha São Paulo na perda de participação no valor da produção industrial, havendo avanços, evidentemente diferenciados, para as demais regiões.

O subperíodo seguinte é mais equívoco, do ponto de vista tendencial, o que contamina, na visão de Cano, o conjunto do intervalo 1970-95. Nesse segundo momento os fatores que apontariam para uma continuidade da desconcentração seriam: a alocação de grandes investimentos petrolíferos; o prosseguimento de um movimento de desconcentração agrícola; algumas políticas estadualizadas (em especial de "guerra fiscal"); políticas, mesmo que tímidas, de fomento ao turismo, com efeitos sobre áreas específicas, especialmente do Nordeste; um arrefecimento das migrações para São Paulo, por ser esse o epicentro da crise econômica que domina boa parte desse decênio 1985-95, o que contribui para "uma nova 'inchação urbana' em várias capitais e grandes cidades periféricas, além do conhecido fenômeno que ocorre com o notável crescimento de cidades médias brasileiras entre 1980 e 1991" (Cano, 1997:119-120).

A sinalizar reconcentração, Cano aponta "o desmantelamento do Estado Nacional", com "um 'ocaso' das políticas de desenvolvimento regional”; a abertura, que classifica de irresponsável, do comércio exterior; o esgotamento de efeitos dos investimentos do II PND, já maturados; debilidade fiscal e financeira dos governos para os investimentos infra-estruturais; pressões sobre as oportunidades e preços das exportações brasileiras; a tendência de investimentos vinculados à "informática, microeletrônica, telecomunicações e automação" localizarem-se em São Paulo.

Nesse texto, Cano remete a discussão sobre as tendências de espacialização da atividade econômica nacional aos processos evocados pelo termo globalização; denuncia "engodo aos países subdesenvolvidos", "efeitos perniciosos da Terceira Revolução Industrial” sobre essas mesmas nações, a "busca ideológica por um 'Estado Mínimo”” consagrada internacionalmente (1997:103), 
dentre outras posições correlatas. Interessa, aqui, enfatizar uma preocupação específica que manifesta:

O outro ponto se refere ao debilitamento proposital do Estado nacional, com seu enfraquecimento fiscal, financeiro e executivo e as tentativas de sua substituição por poderes locais (regionais, estaduais e municipais). Esse 'culto ao poder local' parece não se dar conta, de um lado, de que ele coopera ativamente para o maior debilitamento do Estado nacional, única instituição capaz de enfrentar a questão internacional; de outro, parece também não se dar conta de que o poder local não faz câmbio, nem moeda, nem juros, e só administra tributos locais (1997:104 - grifos meus).

Mesmo frente a esses "cultos" ou "ideologias" que detecta, o autor explicita que não compartilha a apreensão de pesquisadores que visualizam risco de fragmentação da nação, "pelo fato de que apenas porções de cada região estão (ou estarão) tendo melhor inserção internacional ou se beneficiando de investimentos privados (estrangeiros ou não) nelas especificamente localizados" (1997:104). Cano declara-se, aqui, convicto de que permanecem fortes os "elos entre o núcleo da acumulação (São Paulo) e o restante da nação". Seu temor era, então, que, em seu conjunto, o país marchasse para a desindustrialização, o que o leva a aventar "o indesejável caminho da regressão mercantil do país, e não apenas de uma ou outra região” (1997:104).

Com todas as diferenças que os três autores selecionados guardam entre si, alguns pontos comuns emergem da discussão. Mesmo com a diferença temporal entre os trabalhos que deles abordei, um dos elementos que os unifica é a permanente atenção ao caráter processual, à constituição de mercados, tanto de produtos quanto de trabalho - duas das faces de uma trajetória de integração e de hierarquização das porções territoriais distintas de que se compõe a nação. Interessam-lhes a dinâmica, os fluxos, as hierarquias - simbólicas, políticas, comerciais, produtivas - e suas mutações no tempo.

No que diz respeito ao trabalho, as migrações são o aspecto precípuo dessa articulação entre os espaços: uma "população para as regiões" transforma-se em uma "população para a nação", nas palavras de Oliveira. Os deslocamentos da força de trabalho são evidenciados pelos três autores como elemento fundante do mercado de trabalho brasileiro. No entanto, isso não implica uma naturalização desse movimento: tais fluxos humanos são produtos históricos de transformações sociais profundas, mais do que um atributo intrínseco e rotineiro que venha cumprir o requisito de "mobilidade" apontado na matriz mercantil. De qualquer modo, as ênfases interpretativas, nesse ponto, se distinguem: Lopes fala da "desintegração" de uma "ordem tradicional", às "custas" da qual se desenvolve o "Brasil novo"; Oliveira vê a forja de uma "divisão regional do trabalho" como chave de uma nova hierarquia de classes, que é também uma hierarquia de espaços, pela qual, numa posição extrema, o Nordeste brasileiro se transforma em 
"reserva do exército industrial de reserva". Cano, por sua vez, identifica como fundamento de "desequilíbrios" regionais uma "concentração automática de capital, através da concorrência capitalista que se processa em forma livre". Neste sentido, ele é o que maior determinação concede a mecanismos classicamente "mercantis", ainda que valorize um sem-número de fatores institucionais e políticos que cercam a hegemonia econômico-produtiva do núcleo do desenvolvimento brasileiro, que é o Estado de São Paulo.

A problematização do papel desse núcleo ou centro encravado no território paulista é um ponto de afinidade entre as análises de Oliveira e Cano, que, por outro lado, têm marcadas diferenças na avaliação que dele fazem. O primeiro fala de "drenagem" de capitais do Nordeste; o segundo contesta, quando discute o "mito do imperialismo paulista sanguessuga". Mais importante do que essa querela - também ela um tanto "regional" -, são as posições que esses autores externam quanto às tendências que derivam da centralidade de uma região (que é também uma fração do capital) sobre o conjunto das regiões e sua diversidade. Mesmo com inúmeras ressalvas que repelem o determinismo, Oliveira subscreve a conviç̧ão de que "regiões", no sentido que lhes empresta (formações "fechadas" por uma peculiar configuração da estrutura de classes), tendem a desaparecer com o movimento inerente ao capital. Cano, embora não se coloque o problema nos mesmos termos, expressa a crença de que São Paulo continua - mesmo sob as ameaças que ele identifica na globalização - sendo capaz de reger os elos com seus "complementos" (as outras regiões brasileiras) e operar como fator de propulsão da economia brasileira em seu conjunto. Lopes, por sua vez, deixa margem a uma leitura evolucionista da visão que construiu sobre a "crise do Brasil arcaico". Nessa perspectiva, com todos os tensionamentos de adaptação, o que parece indicado tendencialmente é uma transição generalizada para o "moderno", no sentido weberiano de impessoalidade e burocracia, que, eu acrescentaria, têm no mercado uma instância fundamental.

Isso posto, é compreensível que as escalas regional e, especialmente, local - nesse legado que aqui esbocei, com trabalhos produzidos entre as décadas de 1950 e de 1990 -, apareçam subordinadas a esquemas explicativos em que o chamado "nacionalismo metodológico" é dominante.

Por certo, como destaquei, não poucos estudos mais recentes perseguem uma perspectiva regionalizada do mercado de trabalho brasileiro ou enfrentam problemáticas que possuem escala marcadamente local, nas quais o mercado de trabalho torna-se um eixo de manifestação ou um recurso de análise do fenômeno estudado - como Kon (1995), no primeiro caso, ou Noronha e Turchi (2007), no segundo. O que me parece claro é que, mesmo nos casos em que o nexo prático entre território e mercado de trabalho é evidenciado, é escassa a teorização sobre ele.

$\mathrm{Na}$ minha investigação empírica, a tentativa foi de apontar nessa direção. A exposição dos procedimentos e resultados, que inicio a seguir, é realizada de uma forma que busca valorizar em detalhe o caso selecionado, para nele apoiar-se, procurando cercar, por sucessivas aproximações, 
dimensões analíticas que se mostraram relevantes na discussão que empreendi nesta primeira parte da tese. 


\section{PARTE II - POSSÍVEIS LIÇÕES DE UM CASO "LONGÍNQUO"}




\section{RUMO À FRONTEIRA: A ESTRATÉGIA METODOLÓGICA DA PESQUISA}

A investigação que embasa esta tese começou a ser concebida após o término de uma pesquisa anterior sobre essa região nucleada pelo município de Santa Rosa, no noroeste do Rio Grande do Sul, fronteira do Brasil com a Argentina. Aquela primeira aproximação se deu no âmbito de um projeto coletivo ${ }^{36}$. Embora, do ponto de vista analítico, o referido trabalho tenha sido bastante despretensioso, sua execução suscitou parte das questões que estiveram na origem do meu projeto de doutorado, em cujo enfrentamento incorporei gradativamente as referências teóricas que venho de discutir na primeira parte desta tese.

Neste capítulo busco, primeiramente, justificar o interesse que atribuo ao estudo de caso de mercados regionais de trabalho, destacando, ainda, o ganho que visualizo na escolha de uma realidade sócio-territorial que oferece um nítido contraste com as configurações metropolitanas, mais fartamente investigadas. Em um segundo passo, procuro reconstituir, ao mesmo tempo em que a problematizo, a estratégia de pesquisa. Neste momento, minha expectativa é que o percurso empírico que relato - ou anuncio, já que seus resultados serão apresentados nos capítulos seguintes - possa ser compreendido em sua associação com as questões que sobressaíram dos primeiros capítulos, nos quais, apoiado na bibliografia, procurei destacar os limites que cercam a matriz teórica de "mercados", especialmente quando está em questão o trabalho social, bem como a escassa tradição de conferir à dimensão espacial o necessário relevo, ao se tratar esse tradicional objeto de interesse da sociologia.

\subsection{A relevância de estudos em profundidade de mercados regionais de trabalho, para além das metrópoles e dos distritos}

Há vinte anos, Bagnasco (1988), em seu esforço de interpretar a emergência e a diversidade dos distritos industriais italianos, defendia a importância de que se empreendessem estudos monográficos, empíricos, sobre mercados de trabalho bem circunscritos. Já então, apontando para a importância de se compreender a natureza eminentemente social da construção dos mercados, encontrava no mercado de trabalho um objeto especialmente eloqüente para pavimentar essa posição teórica. No último capítulo de seu livro, a partir da comparação de duas áreas do território italiano (Bassano e Napoli), lançava luz sobre a diversidade dos arranjos

\footnotetext{
${ }^{36} \mathrm{O}$ projeto "Mercados Regionais de Trabalho no Rio Grande do Sul: manifestações da reestruturação produtiva nos anos 90" foi executado pelo Núcleo de Estudos do Trabalho (NET) da Fundação de Economia e Estatística (FEE), tendo parceiros da Universidade Federal do Rio Grande do Sul (UFRGS) e da Universidade de Caxias do Sul (UCS). Alguns resultados encontram-se em Xavier Sobrinho et alii, 2003. Os colegas do núcleo que empreenderam toda a pesquisa foram Maria Isabel Jornada, Sheila S. W. Sternberg, Walter Pichler e Ilaine Zimmermann. Participaram de diversas etapas Raul Luis A. Bastos e Gabriele dos Anjos. Os parceiros da UCS foram Vânia M. Heredia e Sandro R. dos Santos. Pela UFRGS, Sônia Larangeira e Fernando Cotanda. Agradeço a todos - especialmente ao Walter, que compartilhou comigo o estudo da Grande Santa Rosa - pela discussão conjunta, de que esta pesquisa se nutriu.
} 
institucionais, dos fatores culturais e das estratégias, individuais e empresariais, envolvidas na configuração de cada mercado de trabalho.

Bagnasco vale-se de um argumento epistemológico: diante da novidade de muitos dos fenômenos com que se defrontavam os analistas da emergente Terceira Itália, as construções teóricas precisariam se submeter a um intensivo aporte de trabalho empírico para restabelecer seu alcance, desestabilizado por transformações ainda escassamente visualizadas para serem compreendidas.

\begin{abstract}
Modelos macro como os acima relembrados mantêm sua validade, seja para uma aproximação dos aspectos agregados do problema do mercado de trabalho em nível nacional, seja para direcionar pesquisas sobre a variedade de situações concretas. Em uma fase de desenvolvimento na qual parece crescer a diferenciação social, velhas ordens (assetti) são desafiadas por novas condições de incerteza, estabelecem-se acomodações parciais e experimentam-se novas combinações institucionais, recupera também uma importância particular a análise micro. A pesquisa em uma escala mais delimitada (ravvicinata) não aplica, simplesmente, esquemas teóricos gerais - que, usualmente, mantêm-se presentes -, mas reconstrói estruturas e mecanismos latentes e específicos, que, de outro modo, não seriam visíveis. $O$ objetivo desse tipo de pesquisa consiste em colocar o mercado de trabalho no seu contexto institucional mais imediato; isso requer, em geral, que o contexto seja reconstruído com suficiente fôlego (respiro), de modo a definir um modelo interpretativo que funcione (Bagnasco, 1988: 184-5 - grifo meu).
\end{abstract}

Dificilmente alguém afirmará que, nessas últimas duas ou três décadas, a potência da mudança nos mercados de trabalho, em boa parte do mundo, tenha arrefecido, ou, analogamente, que "esquemas teóricos gerais" já tenham recobrado capacidade explicativa. Assim, permanece na ordem do dia a tarefa de realizar um sistemático esforço de apreensão e elaboração teórica dos fenômenos que se processam no âmbito da ocupação, do emprego, dos rendimentos do trabalho, especialmente quando essa agenda se nutre - e, a seu turno, alimenta - um programa de pesquisa como o da "sociologia dos mercados".

Não menos tempestivas para estimular esforços nessa direção são a força e a complexidade com que a dimensão espacial dos fenômenos sociais passa a reclamar seu status no mundo contemporâneo. A sobreposição de condicionantes em "escalas" ou "níveis" territoriais diversos - global, nacional, subnacional, regional, local - potencializa um processo de diferenciação das configurações sócio-espaciais e de suas trajetórias.

Uma das razões pelas quais os estudos de campo têm importância decisiva para a reflexão sobre a realidade dos mercados de trabalho encontra-se, assim, na heterogeneidade, aparentemente progressiva, de realidades regionais ou locais, mesmo no nível interno aos países. Banaliza-se a ocorrência de trajetórias discrepantes, com "sinais" opostos - de crescimento e retração - entre "formações sociais regionais" muito próximas, fisicamente. Por certo, o grau de novidade de que se reveste uma tal dispersão nas dinâmicas regionais precisa ser submetido a testes, mas tem se consagrado a posição de que os espaços subnacionais desfrutam - ou precisam desfrutar - de um 
papel de protagonistas no enfrentamento de muitos dos problemas sociais contemporâneos, a julgar, por exemplo, pela ênfase que lhes vêm sendo atribuída por instituições multilaterais.

Essa problemática emerge em clara articulação com o movimento de "desorganização" de um padrão anterior de desenvolvimento (Coriat, 1997; Bottazzi, 1996), que parecia apontar para a convergência, tanto tecno-produtiva quanto institucional, de "sistemas" eminentemente nacionais, sempre mais regulados, tendencialmente, por seus Estados - quer pela ação normativa direta desses, quer por seu papel na chancela e fiscalização de acordos entre as representações mais relevantes dos atores sociais.

Novas territorialidades na produção, estabelecidas no bojo da globalização econômica, associam-se a redesenhos institucionais nos quais se articulam ou se sobrepõem as intervenções de agentes sociais com diferentes níveis de abrangência - transnacionais, nacionais e subnacionais (regionais ou locais), como na imagem do "ninho" de Hollingsworth e Boyer (1997c).

Não devem restar dúvidas de que, embora tenha sido atiçado por essa ordem de transformações, o interesse pela análise de mercados de trabalho recortados local ou regionalmente não se subordina à agenda deste presente imediato e, no dizer de Robertson (1990/1999), incerto. A percepção de um enfraquecimento relativo do "nacionalismo metodológico" - e da força unificadora que a ele se associou - não deve obscurecer, primeiramente, que as "formações sociais regionais" mantiveram sempre algum grau de diversidade (mesmo quando negligenciada na agenda das ciências sociais), e, em segundo lugar, que os mercados de trabalho - quando mais não seja, pela circunstância dos limites à mobilidade física da força de trabalho -, sempre tiveram raios finitos de alcance territorial. Tampouco a validade de tratamentos espacialmente mais plurais havia sido desconhecida, como as análises de Oliveira tão bem exemplificaram, no capítulo anterior. É, talvez, uma determinada concepção de organização hierárquica entre escalas espaciais que aparece subvertida por fenômenos novos.

A idéia de um mercado nacional de trabalho, em um caso como o brasileiro, poderia ser então reposta, contemplando-se o lugar que compete ao seu caráter de articulação (com um alcance a ser melhor conhecido) de realidades regionais bastante distintas. Seria interessante moiblizar o numeroso (e capilarizado) contingente de estudiosos do mercado de trabalho, no país, na direção de valorizar, acumular e explorar analiticamente especificidades das instâncias locais e regionais, de uma forma nacionalmente integrada. Isso possibilitaria, partindo-se da multiplicidade, identificar padrões e avançar na compreensão dos condicionantes, tanto das estruturas desses muitos mercados de trabalho quanto das suas evoluções recentes, frente a fenômenos claramente associados à escala nacional - que não se trata de negar ou subestimar -, como a abertura comercial, a reestruturação produtiva, a estabilidade monetária etc. 
Acredita-se que o estudo de um mercado de trabalho regional terá melhores condições de aportar elementos proveitosos a essa discussão à medida que se elege, para o trabalho de campo, uma formação não-metropolitana.

Evidentemente, essa classificação definida pela negação ("não-metropolitano"), não é suficiente para compor uma categoria analítica com a devida consistência. A proliferação, no país, das "aglomerações urbanas" - definidas e regulamentadas por atos legais, tais como as regiões metropolitanas - é uma dentre tantas indicações de que se complexifica e se diferencia a realidade urbana e regional brasileira, para além das capitais das unidades da federação e de suas conurbações.

Ainda assim, dadas as possibilidades objetivas de fôlego (o respiro de Bagnasco), apostei na escolha intencional de um caso que favoreceria o contraste com traços tipicamente associados às realidades metropolitanas, já que sobre elas parece ter se produzido um acúmulo de conhecimento que insinua uniformidade e convergência. Não sem razão, arraiga-se no senso comum a referência aos problemas dos "grandes centros urbanos", quando se fala de fenômenos próprios aos mercados de trabalho, como desemprego e precarização, ombreando com problemas de naturezas muito diferenciadas, como degradação ambiental, violência, consumo de drogas, solidão, entre tantos outros.

Parece haver aí uma dupla mensagem. De um lado, boa parte das questões que têm visibilidade e que são revestidas de interesse social - que têm, portanto, um reconhecimento como desafios "nacionais" - é "delimitada", circunscrita a determinados territórios: quando se explicita que se trata dos "grandes centros urbanos", está-se assumindo que não se fala do "todo". De outro lado, as formações sociais que não são alcançadas por esse "critério" tornam-se como que relegadas a uma condição residual, a um desconhecimento que é falta de reconhecimento. Essa depreciação simbólica legitima-se, aparentemente, no argumento da representatividade estatística - ou da "complexidade" que a tradição teórica da sociologia historicamente priorizou. Com isso, as realidades a que não se confere relevância "desaparecem", e o que havia sido assumido como "parte" passa a equivaler ao todo. A cada mês, os resultados da Pesquisa Mensal de Emprego, do IBGE, divulgados amplamente em todo o país, são um exemplo dessa "nacionalização" dos resultados obtidos com base nas áreas mais "significativas".

O pressuposto implícito de que as realidades regionais "manifestam", representativamente, um estado de coisas que é eminentemente nacional induz a que se priorizem objetos empíricos de maiores dimensões, de maior "escala".

As metrópoles oportunizam a confluência dessa dupla ambição, latente na agenda de pesquisa sobre o mercado de trabalho: "representativas" e "complexas", elas favoreceriam uma compreensão do que se passa no nível territorial considerado digno de atenção pelo "nacionalismo metodológico". 
Um golpe na dominância dessa perspectiva veio com a influência das pesquisas sobre os distritos industriais, sistemas localizados de produção e assemelhados. Ao menos em um primeiro momento, a revalorização da dimensão territorial nos estudos sobre desenvolvimento econômico (que raramente priorizaram, mas geralmente incluíram a problemática do mercado de trabalho) esteve subordinada a essa nova "ortodoxia", de que falam Benko e Lipietz (1994). Como esses autores sugerem, um conjunto de pesquisas, em diversas nações, tratou de identificar, não raro com alto grau de artificialidade, traços "distritais" em formações regionais específicas. Se esse procedimento não chegasse a bom termo, o interesse pela multiplicidade dos arranjos locais se dissipava.

Quando pouco pelo risco presente da "desconexão forçada" (Chesnais, 1994/1996) de muitas formações sociais regionais, a realidade de espaços pouco "visíveis" na literatura sobre mercados de trabalho merece atenção. A multiplicidade de cenários desenhada por Bottazzi (1996), mesmo que especulativa ou limitada, sugere a coexistência de trajetórias locais muito variadas qualitativamente.

A perspectiva que estimulou esta investigação aponta para uma outra ordem de justificativa quanto à escolha de seu objeto empírico: o nível "agregado" típico do "nacionalismo metodológico" pode ter contribuído para obscurecer algumas fragilidades da perspectiva teórica que, historicamente, pôs sob a égide da categoria "mercado" a estruturação do trabalho social.

Antes de qualquer coisa, o volume populacional e a dimensão do tecido produtivo e empresarial nas metrópoles - tipicamente mais elevados, na comparação com o restante do território - favorecem a percepção de que são efetivos os princípios "mercantis" anteriormente discutidos - atomicidade, homogeneidade, permeabilidade etc. O grande número de "ofertantes" e de "demandantes" de trabalho se coaduna com um tratamento agregado e estatístico, em que mais facilmente se dispersa o interesse pelos padrões efetivos de "mobilidade" nesses mercados, que limitam a "permeabilidade" de seus diferentes circuitos, e assim por diante.

Do ponto de vista institucional, uma maior complexidade de representações de interesses coletivos e uma presença mais visível de agências do poder público tendem, nas realidades metropolitanas, a eclipsar a vertente interpretativa das relações sociais que tecem as situações de trabalho e de não-trabalho - normas informais, tradições culturais, as relações interpessoais, a confiança etc. Isso não significa (ao menos, não requer) um alinhamento com a perspectiva que identifica os espaços locais - pouco representados pelas metrópoles - com "comunidades", em oposição à idéia de "sociedade". Fatores como a própria escala, bem como o perfil produtivo e empresarial de algumas formações sociais locais não metropolitanas podem contribuir para esse contraste, em aspectos bastante influentes, no que tange à estruturação e à dinâmica dos mercados de trabalho, impondo sua marca nas relações de trabalho e nas perspectivas de ocupação. É importante que se explore, na evolução presente das formações sociais regionais, a variedade que 
elas consagram, que escapa sempre mais a uma interpretação como a que, opondo territórios do arcaico e do moderno, sugeria uma linha evolutiva e unidirecional de transformação -abordagem associada à reflexão de Lopes (meio século atrás), que discuti acima.

\subsection{A região estudada: uma escolha induzida pelo interesse analítico}

Correndo o risco de sacrificar informações potencialmente úteis, opto por não detalhar o desenho da pesquisa, acima referida, que, em 2002, me levou pela primeira vez à região da Grande Santa Rosa. Procuro evitar, com isso, uma sobreposição indesejada dos focos e objetivos de estudos diferentes. Parece-me suficiente registrar que, naquele momento, identifiquei nessa formação regional uma combinação muito particular - e, a meu ver, eloqüente - de elementos espaciais, sociais, culturais e econômicos que considerei especialmente apropriados para a discussão teórica sobre mercados de trabalho e sua espacialidade. A descrição propriamente dita do "caso" será feita, com considerável grau de detalhamento, a partir do próximo capítulo. Destaco, aqui, em um nível mais abstrato, algumas características que julguei analiticamente relevantes, ao ponto de justificar a realização desta pesquisa na Grande Santa Rosa:

Como primeiro ponto, alguns indicadores relativos ao mercado de trabalho da região já a credenciam quase de imediato a um olhar mais detido, por contrastarem com resultados ubiquamente destacados nos estudos regularmente produzidos no país. O fenômeno do desemprego aberto, por exemplo, é muito pouco reconhecível na região, quer se considerem os instrumentos oficiais de medição (o Censo Demográfico do IBGE é o único que atinge esses municípios), quer se tome por base os depoimentos dos atores sociais regionais. Ademais, o perfil da ocupação mostra um nível de assalariamento sensivelmente mais baixo do que no agregado do Rio Grande do Sul. Esses são apenas dois exemplos das "particularidades" que, desde as primeiras aproximações, indicaram que o "caso" regional selecionado permitiria buscar outras chaves de entrada para a problemática teórica dos mercados de trabalho, notadamente no que diz respeito ao seu alcance, frente à pluralidade de fenômenos que caracterizam o trabalho social.

Um segundo aspecto refere-se à dimensão ou "escala". A região estudada compõe-se de vinte municípios que, em seu conjunto, pouco ultrapassam os 200 mil habitantes; a população da cidade-pólo, Santa Rosa, não chega a 70 mil; apenas quatro das vinte municipalidades têm mais de 10 mil moradores. Esse elemento pode parecer, à primeira vista, pouco relevante, mas investigar como se manifestam, em semelhantes configurações, as dinâmicas da oferta e da demanda por trabalho, os canais de busca de ocupação, a circulação da informação, entre outros aspectos, abre possibilidades de um diálogo bastante provocador com a matriz mercantil de entendimento que discuti no primeiro capítulo desta tese, especialmente com o princípio, ou "condição", de atomização. 
Por outro lado, e esse é um terceiro elemento de grande interesse, essas localidades inserem-se em uma configuração que interconecta, de forma analiticamente promissora, diferentes escalas espaciais. É bastante reconhecível nesse conjunto de municípios - aos quais conferi o estatuto de instâncias locais - a configuração de um arranjo regional, seja pela efetiva circulação de mão-de-obra entre eles, seja pelo vasto elenco de instituições que assumem tal territorialidade, seja, ainda, pelo caráter recente das emancipações que fragmentaram administrativamente esse espaço que, até os anos 1950, constituía um único município, Santa Rosa. A pertinência dos níveis estadual e, sobretudo, nacional se mostram, quando pouco, pela sensibilidade às políticas econômica e públicas. Em meu trabalho de campo, surpreendi-me, por exemplo, com a freqüência com que a relação cambial entre o Real e o Dólar era objeto de consideração e censura, na boca de líderes políticos, pequenos agricultores ou estudantes, geralmente em um contexto de conversa sobre a conjuntura de preços altos da soja (principal cultura agrícola da região), que teria seus efeitos benéficos neutralizados pela valorização de nossa moeda. Esse exemplo remete, assim, à notável inserção da Grande Santa Rosa em circuitos tipicamente globais. Essa pode ser reconhecida já nessa especialização agrícola da região em uma commodity (a soja); merece destaque, ademais, a presença de duas unidades produtivas de grandes empresas industriais norteamericanas de máquinas agrícolas. Juntas, elas concentram uma considerável parcela do emprego formal regional e, mais ainda, uma fatia invejável do mercado nacional e das exportações brasileiras desses produtos. Ocioso dizer que a subordinação dessas unidades fabris a matrizes estrangeiras e a grupos fortemente internacionalizados "globaliza" a dinâmica econômica, ocupacional e institucional de dois dos maiores municípios da Grande Santa Rosa, o que transborda para o conjunto da região.

Esses exemplos apontam para mais um elemento: a estrutura produtiva da Grande Santa Rosa. Mesmo com sua dimensão reduzida (na comparação, mesmo espontânea, com as realidades metropolitanas), a região possui um tecido produtivo cuja relativa diversificação é analiticamente atraente. O peso considerável da agropecuária e, mais especificamente, o caráter familiar e minifundiário da produção primária, favorecem a problematização de aspectos geralmente ausentes dos estudos contemporâneos produzidos na arena acadêmica especializada em mercados de trabalho. Por outro lado, a presença sólida de uma economia urbana complexifica as possibilidades de inserção e de trânsito ocupacional.

Em quinto lugar, é muito presente, na Grande Santa Rosa, a representação que atribui à população da região uma tradição de cooperação e uma disposição acentuada para a ação coletiva. Isso tornaria mais consistente o tecido institucional, aspecto de interesse analítico, pela potencial contraposição à dinâmica estritamente mercantil ${ }^{37}$.

37 Uma percepção de "isolamento" da região aparece com freqüência no discurso que justifica essa característica associativa, comunitária ou cooperativa da população. Embora, como venho de salientar pouco acima, sejam reconhecíveis as conexões da Fronteira Noroeste com outras escalas espaciais superiores, regionalmente é sentido um distanciamento com relação ao restante do território gaúcho, ao Estado vizinho, 
A dimensão étnica é outra a despertar atenção e apresentar-se fértil nesta experiência regional. Celebrada no discurso de lideranças da Grande Santa Rosa, uma suposta diversidade contrasta com a flagrante predominância dos descendentes de alemães - o que não anula, mas qualifica um vetor muito rico de diferenciação e de negociação, social e simbólica.

Por fim, a dinâmica demográfica é também ricamente provocadora: a região tem tido estagnação ou decréscimo de sua população, nos intervalos censitários das últimas décadas. Esse caráter "expulsor" não se articula com indicadores econômicos agregados menos favoráveis do que os do agregado do Rio Grande do Sul, ao passo que o Estado segue mantendo crescimento populacional declinante, mas cadenciado. Esse fenômeno diferencia a região de boa parte dos mercados de trabalho - uma vez mais: essencialmente os metropolitanos - que vêm merecendo o interesse predominante das ciências sociais.

Outros elementos que particularizam a formação social regional escolhida certamente virão à tona na apresentação dos resultados da pesquisa. A escolha da Grande Santa Rosa, vinculada aos traços que venho de expor, objetivava um aproveitamento analítico bastante preciso. As dimensões da realidade regional que acionei na caracterização acima possivelmente já indicam que almejo, no estudo de caso, avançar na articulação dos condicionantes sociais e culturais que, em consonância com a discussão empreendida na primeira parte desta tese, permitem tensionar um entendimento estrito do trabalho social a partir da matriz teórica "clássica" de mercados. São assim chamadas a contribuir para esse esforço analítico uma série de vertentes da realidade social cuja principal riqueza encontra-se, precisamente, em sua articulação.

É nesse sentido que a escolha intencional de um caso "atípico" - se tomarmos como ponto de referência a copiosa produção sobre mercados de trabalho no Brasil e suas "escolhas" sócioterritoriais - tem um duplo interesse. Em primeiro lugar, parece auto-evidente a validade de se consolidar conhecimento sobre essas realidades espacialmente "periféricas", em um momento em que a discussão sobre economia regional aponta a clara desarticulação de padrões hierárquicos de organização e de dinamização do desenvolvimento sócio-econômico. Em segundo lugar, e dessa vez sob uma perspectiva teórica, a produção desse "conhecimento" ultrapassa a mera coleta de informações e a mera identificação de especificidades, para servir a uma reflexão sobre o alcance das próprias ferramentas analíticas com que se concebeu e com que se opera socialmente a noção mesma de "mercado de trabalho".

Sob essa perspectiva, uma configuração social não metropolitana, eivada pela marca convencionalmente associada ao arcaísmo - do "rural", de acanhadas dimensões (seja sob o critério populacional, seja pelo volume do produto), pareceu servir com muito mais propriedade

Santa Catarina, ou à nação argentina, com que faz fronteira. Essa visão é geralmente associada à distância física de centros urbanos mais vultosos, que poderiam favorecer conexões dinamizadoras para a economia regional. Várias vezes me foi apresentada alguma comparação que identificava condições mais favoráveis de desenvolvimento em outros municípios próximos à Região Metropolitana de Porto Alegre, atribuindo a esse fator de proximidade a vantagem. 
para que se visualizassem fatores que "estouram" o modelo estritamente mercantil de entendimento dos processos sociais que se tecem ao redor da problemática da ocupação e do trabalho. Mais do que os fenômenos empiricamente constatados em campo e analiticamente reconstruídos - que são, ex ante, admitidos como "idiossincráticos" -, interessam os "ruídos" que os mesmos podem produzir no entendimento da noção mesma de mercado de trabalho, bem como as sugestões que podem aportar para o aprimoramento dessa matriz teórica. Idealmente, os resultados procuram contribuir para a reflexão e a pesquisa sobre qualquer outra configuração específica, uma vez cumprida a tarefa de retornar, do nível do caso, ao tratamento teórico.

Em decorrência do que foi dito, uma insistência sobre a dimensão espacial é importante: a ênfase que confiro ao caráter regional da Grande Santa Rosa está longe de se restringir a um mero partido operacional. Como a discussão do capítulo 2 procurou estabelecer, o espaço é aqui concebido como uma dimensão inextrincável da realidade social e, em certa medida, uma construção analítica que sintetiza e particulariza experiências concretas. Longe de oferecer o conforto de delimitações seguras, embasa os exercícios - necessariamente parciais e provisórios de reconhecimento de "unidades" de tratamento de fenômenos sociais. Isso ultrapassa largamente os critérios físicos, para, justamente, propor a articulação das múltiplas dimensões que conformam e dão especificidade a uma configuração social específica.

\subsection{Um risco assumido}

Desde a concepção deste estudo, esteve presente um risco que, identificado, foi assumido como necessário.

Em um primeiro momento, pode-se considerar que a estratégia de pesquisa parte de duas delimitações bastante precisas: concentro-me numa pequena porção do território do Rio Grande do Sul e, ancorado nela, focalizo fenômenos e processos atinentes ao mercado de trabalho.

No entanto, uma vez que a motivação teórica é fundamentalmente a de, tomando a inspiração da bibliografia recente com que dialoguei no primeiro capítulo, cercar processos que indiquem e substantivem a "construção social" desse (ou "de um") mercado de trabalho, tornou-se indispensável adotar uma atitude de grande abertura para apreender as múltiplas dimensões da realidade social que potencialmente incidem sobre tal objeto.

Mesmo uma formulação bem anterior à (re)emergência da chamada "sociologia econômica" já indica a obrigatoriedade de se contemplar uma ampla gama de níveis da análise quando se quer fazer frente a um objeto complexo e sintético como o "mercado de trabalho". Basta relembrar a definição de Kalleberg e Sorensen, citada, aqui, no primeiro capítulo:

Definimos mercados de trabalho, abstratamente, como as arenas em que os trabalhadores negociam (exchange) sua força de trabalho tendo por retorno salários, status e outras recompensas derivadas do trabalho (other job rewards). O conceito, portanto, refere-se 
amplamente às instituições e práticas que regem a compra, a venda e a formação dos preços dos serviços do trabalho. Essas estruturas incluem os meios pelos quais os trabalhadores são distribuídos entre os postos (jobs) e as regras que regem o emprego, a mobilidade, a aquisição de qualificações e de treinamento e a distribuição de salários e outras recompensas obtidas em função da participação no sistema econômico (1979:351 grifo meu).

Como se percebe, mesmo que abstratamente aludidos, estão necessariamente implicados nessa conceituação fenômenos de ordens muito diferentes, que vão desde um plano eminentemente simbólico, como impõe o tratamento do "status", até aspectos mais estritamente "econômicos", passando-se pela miríade de estruturas sociais que podem servir de base às "instituições e práticas que regem a compra, a venda e a formação dos preços dos serviços do trabalho".

Os mesmos autores sustentam, como também foi acima reproduzido, que os mercados de trabalho envolvem cinco atores principais: o trabalhador individual, o empregador individual, as associações de trabalhadores, as associações de empregadores e o governo (Kalleberg, Sorensen, 1979:353).

Antes mesmo de qualquer ambição de trazer à cena outros condicionantes que extrapolem a matriz mercantil de entendimento do objeto, o estudo de mercados de trabalho implicaria, a rigor, a conexão de múltiplos planos de análise, que reivindicam abordagens metodológicas e técnicas de pesquisa distintas entre si (e complementares). A compreensão do que possa ser "o" trabalhador individual, a partir de uma perspectiva que se pretenda sociológica (Guimarães, 2002), não pode em hipótese alguma compartilhar o reducionismo economicista de limitar esse "termo" da equação a uma determinada dotação de "capital humano" e a uma racionalidade maximizadora dedutivamente atribuída. Há que se buscar ao menos uma aproximação sobre a constituição dos valores que condicionam suas "preferências"; há que se cercar os fatores sociais que conformam a subjetividade desses indivíduos e aqueles que os localizam em posições estruturalmente reconhecíveis, empreendendo o movimento que permanentemente contrapõe os níveis do idiossincrático e das identidades coletivas. Analogamente, enfrentar a questão do que possa ser "o empregador individual" e de como ele se coloca concretamente em mercados de trabalho específicos implica uma vastidão de dimensões sociais, econômicas, culturais e técnicas que dificilmente pode ser satisfatoriamente atendida. Ocioso dizer que tão ou mais múltiplos são os caminhos que se abrem para o tratamento das institucionalidades evocadas pelas figuras das associações e do governo, chamadas à definição de mercado de trabalho por Kalleberg e Sorensen.

Como os primeiros capítulos desta tese evidenciaram, investi em uma aproximação com a produção de disciplinas "vizinhas" - notadamente a economia e a geografia -, na busca de referências teóricas que são constitutivas de meu objeto. Essa apropriação, necessariamente parcial, da reflexão de outros campos científicos traz, por si mesma, algumas dificuldades. Não é a elas, entretanto, que me refiro, quando explicito, neste momento, a percepção de um "risco": 
independentemente das contribuições disciplinares envolvidas, precisei fazer frente ao amplo leque de dimensões envolvidas na compreensão desse "mercado de trabalho" concreto. Isso impôs uma investigação com um número elevado de eixos de interesse, cada qual requerendo um aporte bibliográfico e, especialmente, uma "atenção" o mais extensiva possível ao longo do trabalho de campo.

Foi o próprio desenrolar da pesquisa que permitiu hierarquizar as vertentes mais significativas para compor o quadro analítico almejado. É, por certo, possível que determinados fenômenos não tenham sido satisfatoriamente aquilatados; mais do que isso, mesmo naqueles que priorizo na análise que se segue, há sempre a sensação de que haveria muito mais a aprofundar ou, mesmo, a contemplar -, tanto no que concerne ao meu próprio trabalho de reflexão quanto no que diz respeito à exposição (e à extensão que convencionalmente pode ser considerada razoável para ela).

Em termos mais específicos: vi-me confrontado com dúvidas tão díspares que envolveram desde a viabilidade tecno-econômica da produção de soja em minifúndios até a noção de "etnia", passando pela conceituação de complexo industrial ou pela reconstrução histórica do processo de colonização do país e do Rio Grande do Sul. Fenômenos demográficos, condicionantes agronômicos, normas jurídicas referentes à previdência rural ou à herança de terras, sazonalidade e tempo de vida útil de máquinas agrícolas são alguns dos pontos que, a cada momento, precisei desenlear, não raro com a sensação de fragilidade de meu domínio sobre aspectos que poderiam ser melhor conhecidos para bem da realização das entrevistas e das observações em campo, bem como da análise.

A alternativa de fechar mais o foco de interesse, ao longo do trabalho de campo, não chegou a me tentar, uma vez que, ao longo de todo o processo, visualizava um resultado em que um mercado de trabalho pudesse ser compreendido com maior profundidade justamente pela densidade e pela riqueza dos condicionantes que compõem o tecido social em que ele se encontra enraizado. Quanto ao outro lado da moeda, referente à consolidação dos resultados, vali-me do recurso a dois "destaques" dentro do caso: após uma análise relativamente panorâmica do mercado de trabalho da Grande Santa Rosa, que apresento no capítulo 6, estendo-me com um pouco mais de detalhe sobre duas configurações que se demonstraram mais eloqüentes do ponto de vista dos meus objetivos. No capítulo 7, dedico-me a uma interpretação da realidade de um "local" dentro do recorte regional, e exploro os efeitos da desproporção entre uma grande firma global e uma pequena municipalidade que lhe serve de sede. No capítulo 8 , esmiúço um pouco mais detidamente a condição dos trabalhadores dos minifúndios, o sentido de sua inserção no mercado e a forma como seus projetos de vida emergem, cunhados pelo contexto sócio-cultural e pelos fatores que constrangem a produção primária familiar. Dentre tantos outros possíveis, esses fenômenos escolhidos para um tratamento mais circunstanciado ressaltaram das primeiras 
incursões a campo, nesta conjuntura de elaboração do doutorado, e já haviam tido sua importância anotada nas minhas incursões de 2002 à Grande Santa Rosa.

\subsection{O desenho da investigação - fontes e procedimentos}

Evidentemente, essa primeira experiência de pesquisa na região escolhida, que venho de referir, representou um valioso acervo de informações e intuições que muito contribuiu para a realização da pesquisa que embasa esta tese. Na ocasião - segundo semestre de 2002 -, fiz cerca de 20 entrevistas, em três visitas, de dois dias cada, aos municípios de Santa Rosa e Horizontina. Ademais, um parceiro de pesquisa, também sociólogo - Walter Arno Pichler - realizou outras 10 entrevistas, algumas nos municípios pesquisados, outras na Região Metropolitana de Porto Alegre (RMPA). Na ocasião, priorizamos as chamadas "lideranças" regionais - ocupantes de postos de chefia em instituições ligadas ao Sistema Público de Emprego, integrantes dos Executivos Municipais, dirigentes sindicais e de associações empresariais, pesquisadores das Universidades que atuam na região.

Dessa forma, alguns dos principais traços da "fisionomia" da região já eram, por mim, visualizados, quando iniciei a pesquisa para a tese. Ademais, tive a oportunidade de contar com esse intervalo de quatro a cinco anos entre minhas primeiras visitas e esse segundo momento, o que se demonstrou especialmente proveitoso por oferecer elementos para comparação entre duas conjunturas econômicas diversificadas e também para vivenciar de forma nítida certa "temporalidade", pela qual agentes em posições institucionais propõem - e, mesmo, reciclam determinadas ações, reiteram diagnósticos, ou precisam confrontar-se com as próprias percepções de tempos atrás, uma vez que essas lhes são "devolvidas" por um "estrangeiro".

Em 2006 e 2007, pude realizar um trabalho de campo bem mais aprofundado, em que eu destacaria, especialmente, a incorporação de uma nova e mais diversificada gama de sujeitos sociais negligenciados na experiência anterior: superando a amarra metodológica de tomar como base da investigação os discursos de "lideranças" institucionalmente "autorizadas", busquei o contato mais amiudado possível com a população local, com trabalhadores. Muitos deles entrevistei de modo "formal" - acompanhando um roteiro, utilizando a gravação como registro, após ter-me apresentado e exposto minha condição de "forasteiro" e de pesquisador. Não menos ricos, entretanto, foram os contatos que mantive em uma perspectiva mais próxima de um método etnográfico, o qual me fez compartilhar situações rotineiras da sociabilidade nos municípios visitados - a utilização dos transportes coletivos, a freqüência "regular" a bares e restaurantes, o recurso ao comércio e aos serviços locais, entre tantas outras. Apenas como uma ilustração anedótica: antes de viajar para uma estada de alguns dias em campo, necessitando de um corte de cabelo, optei por fazê-lo em Santa Rosa. Não sem humor, mas com certa convicção, justifiquei a decisão evocando a loquacidade popularmente atribuída aos barbeiros: se assim fosse, eu poderia 
ter um excelente "informante", em um contexto de interação "espontânea". Pois bem: essa expectativa se confirmou de modo lapidar. Ao lado de um "depoimento" pessoal muito rico, o barbeiro, quando expus os meus interesses de pesquisa, telefonou, por conta própria, para um exprefeito da cidade - seu cliente, já idoso -, e obteve para mim uma entrevista das mais produtivas.

Não desperdicei oportunidades de diálogo com os moradores da região, e vários trechos de conversas fortuitas revelaram-se muito úteis para aprimorar roteiros de entrevistas, além de favorecer, cumulativamente, meu repertório de temáticas "nativas" que em muito facilitavam a abordagem de interlocutores almejados. A pequena dimensão populacional dos municípios, de resto, demonstrou-se uma "aliada" - surpreendente para alguém que, como eu, só viveu em metrópoles - na facilitação de contatos. Um exemplo extremo: num ônibus entre os municípios de Santa Rosa e Porto Mauá, ao meu lado, estava um adolescente. Usei seus livros de computação como pretexto para conversar. Em poucos minutos, tendo eu mencionado minha pesquisa, ele disse que eu estava falando "com a pessoa certa" (ele), uma vez que seu pai era secretário municipal. Desembarcamos e ele fez um sinal para que eu o acompanhasse: levou-me a sua casa, na qual, de portas abertas, a família estava à mesa. Após me apresentar - o que o jovem nem cogitou fazer - fui insistentemente convidado pelos adultos a almoçar. Preferi recusar - o que pode ter sido uma indelicadeza -, combinando que retornaria mais tarde. Em pouco tempo, eu estava sendo apresentado, pelo secretário, pai do menino, ao prefeito - o que sequer estava em meus planos, naquela tarde, em que realizava uma visita com pretensões meramente exploratórias.

A forma como facilmente ingresso nessa "casuística", ao reconstituir o processo de pesquisa, trai o entusiasmo, que não hesito em assumir, por uma metodologia que me transmitiu a sensação de efetiva renovação na forma como concebi e abordei até recentemente o objeto "mercado de trabalho" - cuja análise, no nível estadual ou da Região Metropolitana de Porto Alegre, muito me ocupou, em minha atividade profissional, sempre apoiada quase exclusivamente nas séries estatísticas oficiais.

Reproduzo, no anexo que encerra este capítulo, um quadro sintético das minhas estadas na Grande Santa Rosa, ao longo do trabalho de campo (restringindo-me à etapa de 2006 e 2007). Ele se encontra descarnado da riqueza que venho de destacar, fornecida pelos prosaicos "acontecimentos" e contatos do meu "cotidiano" em campo. Ainda assim, consolida as entrevistas realizadas com um controle técnico mais rigoroso, sempre semi-diretivas, mantendo a maior receptividade possível às "surpresas" aportadas pelos interlocutores.

Visitei oito dos 20 municípios, com clara e deliberada concentração do tempo em dois deles - Santa Rosa (a cidade pólo, mais populosa) e Horizontina (sede da maior empresa de toda a região e objeto de interesse destacado, no capítulo 7).

Realizei quatro "estadas", de quatro a seis dias cada, na região. 
Entrevistei empresários ou produtores dos setores primário, secundário e terciário; integrantes dos Executivos municipais e de instituições associativas, de ensino e do Sistema Público de Emprego, entre outras; trabalhadores de diversas atividades e em situações distintas no mercado (ocupados, desempregados, aposentados).

Tive oportunidade de presenciar e registrar eventos muito ricos do ponto de vista da produção de discursos sobre a realidade regional e sua realidade econômica e ocupacional. Um exemplo foi o ato público em "defesa" (sic) do setor metal-mecânico da região, que ocorreu no dia 29 de junho de 2006. Quando soube, por uma notícia de um jornal (semanal) de Santa Rosa, da iminência desse evento, acomodei a minha agenda de viagens à região de modo a presenciá-lo, o que se demonstrou muito acertado.

Ao lado dessas duas vertentes, até aqui destacadas - o trabalho de campo mais "etnográfico", que rendeu um volumoso "diário de campo", e as entrevistas e observações mais estruturadas -, meu estudo buscou o aporte, indispensável, das séries estatísticas sobre o mercado de trabalho da região - notadamente a Relação Anual de Informações Sociais (RAIS) do Ministério do Trabalho e os Censos Demográficos do IBGE -, bem como as referentes a outros indicadores econômicos ou sociais relativos aos 20 municípios abrangidos na regionalização. Esta, por sua vez, é mais detidamente justificada no próximo capítulo, por conveniência do ordenamento da exposição.

Ainda que essa vertente não tenha sido abundante, obtive algum material documental sobre a Grande Santa Rosa, na forma de publicações de entidades regionais, e alguns trabalhos de cunho acadêmico. De resto, busquei acompanhar o mais sistematicamente possível a imprensa local, tendo, em 2006, me tornado assinante de um semanário de Santa Rosa.

Ainda nessa abertura de fontes de pesquisa, consultei e cheguei mesmo a intervir, com questionamentos, em comunidades virtuais do site de relacionamentos "Orkut" dedicadas tematicamente a municípios da região.

Quando utilizo - fartamente - excerto das entrevistas que gravei ou referências a anotações de conversas, optei por identificar os informantes, como regra geral. Se em algumas vezes deixo de fazê-lo é porque me impus o dever de arbitrar situações em que a exposição de um relato ou posicionamento específico poderia gerar constrangimento ou prejuízo a algum de meus informantes.

Acredito que essas diferentes técnicas e fontes de pesquisa adquirirão maior concretude para o leitor a partir do próximo capítulo, em que inicio a exposição e a análise do "caso" regional estudado. Saliento, como uma consideração final deste capítulo, que minha estratégia metodológica que recende a ecletismo se demonstrou, mais do que adequada, necessária ante a pluridimensionalidade do meu objeto de pesquisa e, mais do que isso, ao meu interesse em 
tensionar e expandir as fronteiras dos fenômenos que "merecem" integrar uma abordagem sociológica de mercados de trabalho. 


\section{ANEXO \\ QUADRO 4 - Entrevistas gravadas e eventos observados no trabalho de campo, no período 2006-2007}

\begin{tabular}{|c|c|c|}
\hline DATA & MUNICÍPIO & ATIVIDADE/ ENTREVISTADOS \\
\hline 18 JUL 06 & SANTA ROSA & $\begin{array}{l}\text { (O) (=Observação) "Dia do Povo", no bairro Jardim Petrópolis: Prefeitura "dá expediente" em } \\
\text { bairros }\end{array}$ \\
\hline 18 JUL 06 & SANTA ROSA & $\begin{array}{l}\text { (E) (=entrevista) Presidente da Associação Comercial, Industrial, de Serviços e Agropecuária } \\
\text { (ACISAP), dono de empresa metalúrgica }\end{array}$ \\
\hline 19 JUL 06 & PORTO MAUÁ & (E) Secretários Municipais e Prefeito \\
\hline $20 \mathrm{JUL} 06$ & SANTA ROSA & (E) Presidente do Conselho Regional de Desenvolvimento (Grande Santa Rosa) \\
\hline $20 \mathrm{JUL} 06$ & SANTA ROSA & (E) Cooperativa São Luiz (Cootrimil) / Agência de Desenvolvimento \\
\hline 20 JUL 06 & SANTA ROSA & $\begin{array}{l}\text { (O) Visita do Ministro Luiz Marinho, do Trabalho para anunciar extensão do seguro-desemprego } \\
\text { aos metalúrgicos - cerimônia no Centro Cívico }\end{array}$ \\
\hline 21 JUL 06 & ALECRIM & (E) Prefeitura - Chefe de Gabinete \\
\hline $1^{\circ} \mathrm{AGO} 06$ & SANTA ROSA & (E) Secretário de Desenvolvimento \\
\hline $1^{\circ} \mathrm{AGO} 06$ & SANTA ROSA & (O) Cerimônia de aniversário de Santa Rosa - Centro Cívico \\
\hline 02 AGO 06 & $\begin{array}{l}\text { SÃO JOSÉ } \quad \text { DO } \\
\text { INHACORÁ }\end{array}$ & (E) Diretor de Ensino, responsável (sic) pela Secretaria de Planejamento \\
\hline 02 AGO 06 & $\begin{array}{l}\text { BOA VISTA DO } \\
\text { BURICÁ }\end{array}$ & (E) Ex-Prefeito, atual secretário de Imprensa \\
\hline 03 AGO 06 & SANTA ROSA & Aniversário do Corede - Cerimônia na UNIJUÍ (com assembléia ordinária) \\
\hline 03 AGO 06 & SANTA ROSA & (E) Ex-prefeito e advogado, pesquisador (diletante) da história regional \\
\hline 04 AGO 06 & SANTA ROSA & (O) Visita à Casa da Xuxa (memorial de objetos pessoais da apresentadora) \\
\hline 04 AGO 06 & SANTA ROSA & (O) Visita ao Mercado de Hortigranjeiros \\
\hline $28 \mathrm{NOV} 06$ & SANTA ROSA & $\begin{array}{l}\text { (E) Microlins - empresa que ministra cursos de "qualificação" (informática etc), após receber } \\
\text { panfleto de divulgação na rua }\end{array}$ \\
\hline $29 \mathrm{NOV} 06$ & SANTA ROSA & $\begin{array}{l}\text { Ato-público de rua promovido por dez entidades regionais, em "defesa" da indústria metal- } \\
\text { mecânica }\end{array}$ \\
\hline $29 \mathrm{NOV} 06$ & SANTA ROSA & (E) SINE- funcionário de carreira \\
\hline $30 \mathrm{NOV} 06$ & SANTA ROSA & (E) SINE - coordenador \\
\hline $30 \mathrm{NOV} 06$ & SANTA ROSA & (E) SINE - desempregado 1 \\
\hline 30 NOV 06 & SANTA ROSA & (E) SINE - desempregado 2 \\
\hline $30 \mathrm{NOV} 06$ & SANTA ROSA & (E) SINE - desempregado 3 \\
\hline $30 \mathrm{NOV} 06$ & SANTA ROSA & (E) Coordenador da "Etnia Afro", da "Festa das Etnias" \\
\hline $1^{\circ} \mathrm{DEZ} 06$ & SANTA ROSA & (E) Presidente da Comissão da Festa das Etnias da $17^{\mathrm{a}}$ Fenasoja \\
\hline 07 MAI 07 & HORIZONTINA & (E) Secretaria de Indústria e Comércio da Prefeitura, integrante do PDT \\
\hline 07 MAI 07 & HORIZONTINA & (E) SINE - desempregado 1 \\
\hline 07 MAI 07 & HORIZONTINA & (E) SINE - Coordenadora \\
\hline 08 MAI 07 & HORIZONTINA & (E) FAHOR - Faculdade Horizontina - vice-reitor de Ensino Superior \\
\hline 08 MAI 07 & HORIZONTINA & (E) Competência Humana - consultoria de RH, subcontratada pela empresa John Deere \\
\hline 09 MAI 07 & HORIZONTINA & (E) John Deere - entrevista e visita à fábrica \\
\hline 09 MAI 07 & HORIZONTINA & (E) Pró-Ativa Consultoria (intermediação privada) \\
\hline 09 MAI 07 & HORIZONTINA & (E) SENAI \\
\hline 10 MAI 07 & HORIZONTINA & (E) Sindicato dos Metalúrgicos - presidente \\
\hline 10 MAI 07 & HORIZONTINA & (E) trabalhador metalúrgico aposentado (no sindicato) \\
\hline 11 MAI 07 & HORIZONTINA & (E) Empresa metalúrgica MSL \\
\hline 11 MAI 07 & HORIZONTINA & (E) trabalhador metalúrgico aposentado (no sindicato) 2 \\
\hline 11 MAI 07 & HORIZONTINA & (E) trabalhador metalúrgico (no sindicato) \\
\hline $11 \mathrm{MAI} 07$ & HORIZONTINA & (E) trabalhador desempregado no SINE \\
\hline 12 MAI 07 & HORIZONTINA & $\begin{array}{l}\text { (O) Assembléia do sindicato dos metalúrgicos; } \\
\text { (O) almoço de filiação (de metalúrgicos e outros indivíduos) ao PC do B; } \\
\text { (O) encontro, em um bar, com metalúrgicos, a convite deles (após o almoço acima referido) }\end{array}$ \\
\hline 29 MAI 07 & TUPARENDI & (O) Encontro de Lideranças do Sindicato dos Trabalhadores Rurais / almoço \\
\hline 29 MAI 07 & TUPARENDI & (E) Trabalhadora rural (no evento do sindicato) \\
\hline 29 MAI 07 & TUPARENDI & (E) Trabalhadora rural 2 (no evento do sindicato) \\
\hline 29 MAI 07 & TUPARENDI & (E) Comerciante, plantador (diálogo que começou casualmente, na rua, e pedi para gravar) \\
\hline 30 MAI 07 & SANTO CRISTO & $\begin{array}{l}\text { (E) Sindicato dos Trabalhadores Rurais - integrantes da Comissão de Jovens; presidente do } \\
\text { sindicato }\end{array}$ \\
\hline 30 MAI 07 & SANTO CRISTO & (O) Visita a propriedades rurais (acompanhado por líderes sindicais) \\
\hline 30 MAI 07 & SANTO CRISTO & (E) Produtores rurais - família \\
\hline 30 MAI 07 & SANTO CRISTO & (O) Visita a escola rural (acompanhado por líder sindical rural) \\
\hline 30 MAI 07 & SANTO CRISTO & (E) Aluno da escola rural \\
\hline 30 MAI 07 & SANTO CRISTO & (E) Aluno da escola rural 2 \\
\hline 30 MAI 07 & SANTO CRISTO & (E) Aluno da escola rural 3 \\
\hline 30 MAI 07 & SANTO CRISTO & (E) Produtora rural \\
\hline
\end{tabular}




\begin{tabular}{|l|l|l|}
\hline 31 MAI 07 & SANTA ROSA & (E) AST - empresa terceirizada de RH dentro da empresa AGCO \\
\hline 31 MAI 07 & SANTA ROSA & (E) ACISAP - Presidente \\
\hline 31 MAI 07 & SANTA ROSA & (E) AGCO - funcionária do RH da empresa \\
\hline 31 MAI 07 & SANTA ROSA & (E) AGCO - trabalhador metalúrgico com 37 anos de trabalho na empresa \\
\hline 01 JUN 07 & SANTA ROSA & (E) Consultora de RH - escritório privado de intermediação mão-de-obra \\
\hline 01 JUN 07 & SANTA ROSA & (E) Empresa De Conti Alimentos \\
\hline 01 JUN 07 & SANTA ROSA & (E) Produtora rural, no Mercado de Hortigranjeiros \\
\hline 01 JUN 07 & SANTA ROSA & (E) Produtor rural no Mercado de Hortigranjeiros \\
\hline 01 JUN 07 & SANTA ROSA & (E) Produtor rural no Mercado de Hortigranjeiros, presidente da Associação que gere esse Mercado \\
\hline
\end{tabular}




\section{A GRANDE SANTA ROSA: A CONSTRUÇÃO HISTÓRICA E A CONSTRUÇÃO ANALÍTICA DE UMA REALIDADE REGIONAL}

Expus no capítulo anterior a forma como foi concebido e realizado este estudo em que as noções de mercado de trabalho e região são discutidas a partir de sua articulação mesma. Destaquei, também, os ganhos analíticos esperados da escolha de uma experiência que se diferencia do mainstream das pesquisas sobre ocupação, por abordar uma realidade regional que contrasta em muitos pontos com a configuração típica das metrópoles.

Neste capítulo eu me dedico a apresentar o caso: a Grande Santa Rosa é aqui abordada a partir de algumas dimensões, que vão permitir recuperar, na discussão que se inicia no próximo capítulo, os condicionantes analiticamente relevantes. A caracterização da Grande Santa Rosa quer ser, aqui, fundamentalmente espacial - não em seu aspecto físico (que, de resto, desenvolvo muito pouco), mas na perspectiva que vincula os fenômenos sociais e históricos a um território.

Principio o capítulo estabelecendo, muito brevemente, um cotejo entre alguns indicadores sócio-econômicos da Grande Santa Rosa e os da Região Metropolitana de Porto Alegre (RMPA), para fundamentar meu interesse contrastivo. Trato, a seguir, de aspectos da história dessa região, focalizando a formação de sua população no próprio ato de ocupar uma área que foi quase totalmente tomada por florestas até o início do século XX. A procedência desse contingente humano que coloniza o território é associada à situação contemporânea das identidades e relações étnicas.

A terceira seção apresenta um panorama, novamente socorrido pelos recuos históricos mais indispensáveis, da estrutura produtiva e das atividades econômicas que sustentam a vida material dessa região. O universo empresarial, seu perfil e evolução recente, irão subsidiar, logo adiante, a compreensão das oportunidades de trabalho assalariado, ao passo que um circuito paralelo ao da mercantilização da força de trabalho - o minifúndio familiar - aparece aqui como o substrato da produção agropecuária, central na vida econômica da região, conquanto permanentemente desafiado em sua viabilidade.

Essas dificuldades do setor primário são a fonte mais visível de um forte êxodo, que configura a Grande Santa Rosa como uma região expulsora de população, o que me leva a desenvolver um pouco mais a problemática demográfica na quarta seção deste capítulo.

$\mathrm{Na}$ seção final deste capítulo, retomo a discussão sobre o caráter regional do conjunto de 20 municípios que compõem conjuntamente esse território. Busco mostrar que eles se diferenciam fortemente mas, nem por isso, deixam de constituir uma instância espacial efetiva, e complemento a caracterização do caso apresentando elementos da rede institucional que articula essa pluralidade e, dentro da região, integra atores sociais os mais diversos. 


\subsection{O contraste com a metrópole}

A Grande Santa Rosa tem pequena expressão quantitativa no Estado: ao final da década de 90 (Tabela 1), detinha 2,3\% da População Economicamente Ativa (PEA); 2,1\% da População em Idade Ativa (PIA); 2,0\% da população total; 1,9\% do Valor Adicionado Bruto (VAB); e 1,4\% do emprego formal do Rio Grande do Sul. A dimensão da Região Metropolitana de Porto Alegre é, pelo menos, 15 vezes superior nesses indicadores.

Qualitativamente, diversos aspectos merecem destaque: primeiramente, a Grande Santa Rosa tem na agropecuária um pilar inequívoco de sua economia e de seu mercado de trabalho, o que a destaca no Estado e a diferencia radicalmente da RMPA. A participação do Setor Primário no Valor Adicionado atingia, em 1999, 24,7\% naquele território, superando largamente o parâmetro estadual (13,3\%); na Região Metropolitana, por sua vez, a agropecuária era uma atividade residual, representando 1,2\% do VAB. Esses contrastes se repetem na distribuição da ocupação: em 2000, quase a metade (47,2\%) dos trabalhadores ocupados da Grande Santa Rosa exerciam atividades primárias, enquanto o percentual se limitava a 20,1\% no Rio Grande do Sul e a apenas $2,1 \%$ na RMPA.

Essa diferença estrutural básica se prolonga em uma feição bastante distintiva do mercado de trabalho da Fronteira Noroeste ${ }^{38}$. O nível de assalariamento é acentuadamente menor do que na Região Metropolitana de Porto Alegre (41,5\% versus 73,1\%). Ainda mais destacável é a forte presença do trabalho não remunerado, situação de 24,3\% dos ocupados da Grande Santa Rosa participação superior, na região, à dos empregados com carteira de trabalho assinada (22,5\%). O contraste não poderia ser mais agudo com a Região Metropolitana, onde os não-remunerados são $1,0 \%$, enquanto os assalariados com carteira são $50,0 \%$ dos ocupados.

O peso do trabalho não remunerado na região estudada é o efeito não apenas do seu perfil agrícola, mas de uma atividade primária baseada na produção familiar em minifúndios, a qual ajuda a compreender também a elevada taxa de participação na Grande Santa Rosa: em 2000, $68,4 \%$ da PIA integravam a PEA, proporção muito superior aos 61,2\% do agregado gaúcho e aos 60,6\% da RMPA (Tabela 1). A agricultura familiar condiciona ainda o patamar da desocupação: no agregado desses 20 municípios, a taxa, em 2000, era de 7,3\% - menos da metade dos 15,0\% da Região Metropolitana de Porto Alegre e também muito inferior ao parâmetro estadual (12,2\%).

\section{Tabela 1 - Estrutura produtiva e mercado de trabalho na Grande Santa Rosa, na RMPA e no RS - 1989-2000}

GRANDE RMPA (1) RS

\footnotetext{
${ }^{38}$ Reitero que utilizo a designação Fronteira Noroeste como sinônimo de Grande Santa Rosa. Esse é o nome dado ao mesmo conjunto de 20 municípios, na divisão do Rio Grande do Sul em Conselhos Regionais de Desenvolvimento (Coredes), vigente desde 1994 - como se verá neste capítulo.
} 


\begin{tabular}{|c|c|c|c|}
\hline & SANTA ROS & & \\
\hline POPULAÇÃO & & & \\
\hline Total $(2000)$ & 210366 & 3739250 & 10187798 \\
\hline Variação \% 1991-00 ............................. & $-0,3$ & 16,1 & 11,5 \\
\hline Taxa de urbanização (\%) (2000) ......... & 61,1 & 95,6 & 81,6 \\
\hline PRODUTO (Valor Adicionado Bruto - VAB) & & & \\
\hline 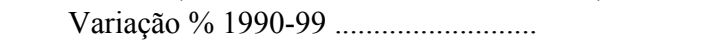 & 30,3 & 38 & 28 \\
\hline Participação \% no VAB do RS (1999) & 1,9 & 39,4 & 100 \\
\hline Setor Primário & & & \\
\hline Variação \% 1990-99 ............................ & 13,1 & $-16,1$ & 30,9 \\
\hline Participação \% no VAB total (1999) ... & 24,7 & 1,2 & 13,3 \\
\hline Setor Secundário & & & \\
\hline Variação \% 1990-99 ............................ & 63,4 & 53,8 & 32,4 \\
\hline Participação \% no VAB total (1999) ... & 25,6 & 48,3 & 37,5 \\
\hline Setor Terciário & & & \\
\hline 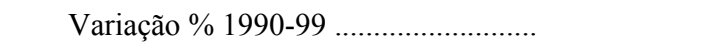 & 12,4 & 29,5 & 21,5 \\
\hline Participação \% no VAB total (1999) ... & 49,6 & 50,6 & 49,2 \\
\hline OCUPAÇÃO EM 2000 & & & \\
\hline PIA & 176950 & 3020947 & 8445139 \\
\hline PEA & 121116 & 1831343 & 5164528 \\
\hline Taxa de participação (\%) ..................... & 68,4 & 60,6 & 61,2 \\
\hline Taxa de desocupação (\%) .................. & 7,3 & 15 & 12,2 \\
\hline Ocupados / Posição na ocupação & 112262 & 1556623 & 4533777 \\
\hline 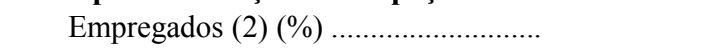 & 41,5 & 73,1 & 61,7 \\
\hline Com carteira/empregados ................. & 54,4 & 68,4 & 63,7 \\
\hline Sem carteira/empregados ............... & 32,1 & 23,8 & 26,7 \\
\hline $\begin{array}{l}\text { Funcionários públicos estatutários e militares/ } \\
\text { empregados .... }\end{array}$ & 13,5 & 7,8 & 9,6 \\
\hline Conta própria $(\%)$ & 29,6 & 21,6 & 26,2 \\
\hline Não remunerados $(\%)$ & 24,3 & 1 & 7 \\
\hline Distribuição setorial em 2000 (\%) & & & \\
\hline 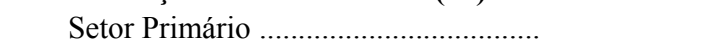 & 47,2 & 2,1 & 20,1 \\
\hline 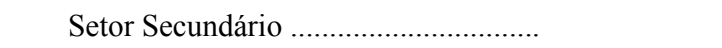 & 13,5 & 29,5 & 24,4 \\
\hline Indústria de transformação/Setor Secundário & 66,3 & 72 & 70,3 \\
\hline 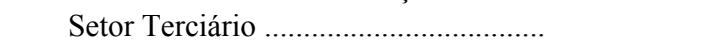 & 38,1 & 67,5 & 54,5 \\
\hline EMPREGO FORMAL & & & \\
\hline Participação \% no RS (1999) .................. & 1,4 & 49,7 & 100 \\
\hline Variação \% 1989-99 ................................ & 11,6 & $-16,3$ & $-3,4$ \\
\hline Emprego formal na indústria de transformação & & & \\
\hline Participação \% no total do emprego regional (1999) & 26,7 & 22,8 & 26,5 \\
\hline Variação \% 1989-99 .............................. & 15,5 & $-29,9$ & $-18,2$ \\
\hline
\end{tabular}

FONTES: IBGE, 1991; 2001. MTE/RAIS, 1990; 2000; Núcleo de Contabilidade Social-FEE.

\section{NOTAS}

(1) A variação populacional incorpora o ajuste do IBGE, que compatibiliza o dado de 1991 com a área metropolitana de 2000. Procedimento análogo foi adotado para a variação do VAB. (2) Inclui os empregados domésticos; em 2000, incluem-se os aprendizes e os estagiários.

Outro aspecto decisivo a incidir sobre os níveis de desemprego é demográfico: essa região teve variação negativa de população entre 1991 e 2000. Enquanto o Rio Grande do Sul apresentou elevação de $11,5 \%$ e a Região Metropolitana cresceu 16,1\%, a Grande Santa Rosa perdeu 0,3\% de seu contingente. A imagem de uma "válvula de escape" - em face de pressões fundiárias e/ou de escassez de oportunidades de inserção ocupacional alternativa - adquire, aqui, um sentido perturbadoramente literal. 
Entretanto, a evasão populacional não reflete um desempenho econômico especialmente adverso, quando se tomam os indicadores regionais agregados de fontes secundárias. A variação do Valor Adicionado Bruto da Grande Santa Rosa, entre 1990 e 1999 (30,3\%), embora inferior à obtida na Região Metropolitana de Porto Alegre (38,0\%), superou a do Estado (28,0\%). O emprego formal cresceu, na região, 11,6\% — percentual, em si mesmo, satisfatório; excepcional quando cotejado com os do agregado do Rio Grande do Sul $(-3,4 \%)$ e da Região Metropolitana $(-16,3 \%)$.

Esboça-se, assim, a distância que separa estrutural e dinamicamente os mercados de trabalho da Grande Santa Rosa e da Região Metropolitana de Porto Alegre. Os fenômenos que atravessam aquela região parecem ter, em alguns casos, outra natureza, e não apenas outra dimensão.

Nesse sentido, a escolha desta configuração regional como suporte deste estudo - como "caso" - se mostra pertinente, à medida que desafia uma teorização que tem, historicamente, se "acomodado" a um leque de fenômenos mais diretamente associados às metrópoles e outros grandes centros urbanos.

\subsection{A constituição de uma população: colonização e etnias}

Um espaço, segundo as lições coligidas no capítulo 2, só é espaço a partir de sua apropriação e da sua incorporação como elemento de uma experiência social. Assim sendo, começo a adentrar o caso apresentado empreendendo uma síntese histórica da colonização da Grande Santa Rosa, em que destaco a origem nacional da população que ali se localiza, base de uma clivagem étnica que sobressaiu na pesquisa de campo, interessa ao entendimento de processos de construção de identidades e, sobretudo, terá importância para uma compreensão mais ampliada da dinâmica da ocupação.

\subsubsection{O processo da ocupação do território e seus personagens}

A região estudada integra a porção do atual território brasileiro que, até 1801, esteve em disputa com a Coroa espanhola. Até a década de 1820, continuou sendo alvo de investidas de caudilhos uruguaios e constituiu-se em

centro de atração de novos estancieiros que recebiam terras das autoridades locais (na maioria militares) ou as compravam por preços irrisórios, alvo das preocupações dos estrategistas oficiais do governo brasileiro com a defesa do território, local de refúgio para índios missioneiros ou aqueles que resistiam aos aldeamentos e ainda espaço onde se desenvolveu a atividade extrativa acompanhada de uma agricultura de subsistência (Rotta, 1999:27). 
Martini $^{39}$ (apud Rotta, 1999:27-28), descrevendo o povoamento da porção Norte do Rio Grande do Sul ao longo do século XIX, destaca: a) caldeamento cultural entre missioneiros e kaigangs - até que esses passassem pelo processo de aldeamento - gerando o caboclo, caracterizado como "em princípio, itinerante e heterogêneo"; b) a presença de tropeiros, paulistas e descendentes de açorianos, que mantinham cultivos de subsistência em posses abertas no desbravamento das florestas, paralelamente ao comércio de muares e à exploração de erva-mate, atividade essa em que exploravam mão-de-obra dos caboclos; c) e, como um "adversário comum" aos dois primeiros grupos, o "militar-estancieiro, sesmeiro, que visava anexar os ervais, impedindo a passagem dos ervateiros para chegarem às florestas reservadas, em suas terras ou adjacências".

No entendimento de Rotta, "formou-se [no Rio Grande do Sul] (...) uma sociedade onde conviviam dois modelos diferenciados, o das estâncias e o da atividade extrativa, que, por vezes, complementavam-se, tensionavam-se ou ainda estavam em oposição frontal" (1999:29). Ao final do século XIX, a região do "reverso do Planalto", na expressão de Roche (1969), que engloba a Grande Santa Rosa, é a última fronteira agrícola do Estado a passar pelo processo de colonização, imprimindo-se uma sistemática distinta daquela adotada até então. O principal diferencial é a estratégia de formação de "colônias mistas”. O poder público gaúcho, desde 1889 sob o comando do PRR (Partido Republicano Rio-grandense), direciona o povoamento dessas áreas - ou o adensamento populacional e a intensificação da exploração econômica - de forma a que elas sejam partilhadas por múltiplas etnias, o que significava: imigrantes europeus de diferentes países nãoibéricos; descendentes "puros" desses imigrantes, nascidos em território nacional nas "colônias velhas" ${ }^{40}$ - como as da Serra e dos Vales, na porção leste do Rio Grande do Sul -; e o assim chamado "elemento nacional" ("os nacionais"), representado, na área em estudo, especialmente pelos caboclos, mas abarcando as demais etnias presentes no Estado - ibéricas, indígenas e africanas e as miscigenações entre elas.

Essa política visaria a diversos objetivos: a) integração ao "projeto nacional de fortalecimento de um mercado interno comprador de produtos industrializados e vendedor de alimentos para abastecer as regiões agro-exportadoras", com a expansão da produção agrícola (Rotta, 1999:30-35); b) criação de forças políticas capazes de estabelecer um contraponto ao poder das oligarquias vinculadas à pecuária e ao latifúndio, concentradas no sul do Rio Grande do Sul (Targa, 1996:42-46); c) a defesa do território, nas áreas de fronteira nacional; d) consolidação de um sentimento patriótico de nacionalidade brasileira que integrasse as diferentes etnias sob os princípios de "paz social" e de "ordem", indispensáveis, na doutrina positivista, para o progresso.

\footnotetext{
${ }^{39}$ MARTINI, Maria L., "Sobre o caboclo-camponês, "um gaúcho a pé”, Porto Alegre: UFRGS-PPGS, 1993 (dissertação de mestrado).

${ }^{40}$ Trata-se do processo conhecido por "enxamagem" - o "transbordamento", via migrações internas, de áreas coloniais precursoras, em decorrência do crescimento demográfico, da exigüidade dos lotes familiares e da indisponibilidade de novas terras (Schallenberger; Hartmann, 1981:65).
} 
Desde a proclamação da República, a colonização do território nacional estava a cargo exclusivamente dos Estados (Schallenberger, Hartmann, 1981:64). Devido aos custos elevados do processo, o governo gaúcho, ao lado da criação de colônias oficiais, pelas quais se responsabilizava, apostou nas empresas particulares de colonização e nas "sociedades coloniais". Essas últimas celebravam contrato com o poder público, prevendo preços e condições de venda. Os integrantes da sociedade repartiam entre si a terra ("começando assim a especulação"). As colônias particulares, por sua vez, resultaram do loteamento de fazendas ou áreas de mata, promovido pelos próprios donos (Schallenberger, Hartmann, 1981:64).

Nessa fase, que avança para o início do século XX, o "lote colonial", tratado como unidade de extensão territorial para delimitação das propriedades, estava estabelecido em 25 hectares, e a terra era vendida, não mais concedida.

A região da atual Grande Santa Rosa integra, inicialmente, o município de Santo Ângelo, instalado em 1874. Em 1891, estabelece-se, abrangendo parte dessa área, a colônia oficial Guarani - em seu núcleo homônimo, concentraram-se poloneses e seus descendentes; a partir de 1902, constitui-se, por meio de "sociedade colonial", o núcleo Cerro Azul, com predominância de alemães. Em 1912, a colônia Boa Vista, particular, surge como uma "extensão" do povoamento das anteriores (Schallenberger; Hartmann, 1981:80-1). Essas áreas - cada qual colonizada sob uma modalidade diferente (oficial, sociedade colonial e privada) - vieram a ser englobadas na colônia Santa Rosa, criada em 1915, pelo governo do Estado.

O núcleo principal - e sede - desta última, no entanto, foi o povoado "14 de Julho"41, que começou a se formar em 1914. Em 1913, o coronel Bráulio de Oliveira, "sediado em Santo Ângelo (...) e chefe político da região", solicitou e obteve do então interventor do Estado, General Flores da Cunha, a criação dessa colônia. Seu objetivo era de que só se radicassem nela "elementos de origem nacional" (Schallenberger; Hartmann, 1981:89).

Os caboclos vinham sendo gradativamente deslocados pela instalação das primeiras colônias do Planalto, concentrando-se nessa área da Fronteira Noroeste. Para a aquisição dos lotes mais próximos à sede da Colônia Santa Rosa, foi dada prioridade aos "nacionais". "O incentivo aos nacionais era uma postura estratégica para viabilizar a proposta de uma colônia mista" (Rotta, 1999:39). Da mesma forma, os lotes mais próximos à fronteira nacional (até $30 \mathrm{~km}$ ) deveriam ser ocupados por brasileiros natos casados com brasileiras natas; na faixa entre 30 e $150 \mathrm{~km}$ da divisa, aceitavam-se brasileiros solteiros e famílias cujo chefe fosse brasileiro ou tivesse filho brasileiro vivo (Rotta, 1999: 39-40).

Rotta recolhe de $\operatorname{Cardoso}^{42}$ a informação de que os primeiros colonizadores da região estavam assim distribuídos: $40 \%$ de descendentes de imigrantes alemães, $30 \%$ de descendentes de

${ }^{41}$ Conforme destacou, em entrevista, Erni Friderichs, ex-prefeito de Santa Rosa, advogado e pesquisador diletante da história local, essa denominação foi escolhida em homenagem à França, mais precisamente a Augusto Comte, criador da doutrina positivista, abraçada fervorosamente pelo PRR.

${ }^{42}$ CARDOSO, Vicente. "Município de Santa Rosa". Porto Alegre: Livraria do Globo, 1947. 
italianos e $10 \%$ de descendentes de poloneses; "os $20 \%$ restantes estariam distribuídos entre os colonos genuinamente nacionais, estrangeiros natos e descendentes de outras nacionalidades. A maioria absoluta (cerca de $80 \%$ ) deles era proveniente das Colônias Velhas do estado e das primeiras colônias do planalto (...)" (Rotta, 1999:41). O processo de colonização da Grande Santa Rosa é gradual, completando-se somente na década de 1940; ao lado do afluxo de novos contingentes de colonos, foi significativa a realocação interna de população, com a constituição de novas famílias (Rotta, 1999:42).

Essas rápidas referências históricas sobre a realidade regional pesquisada - sob esse ponto de vista mais basilar, que é a constituição de uma população - permitem compreender a presença constante, nas falas dos atores sociais entrevistados, bem como na produção discursiva consolidada em documentos consultados, da referência à composição étnica da Grande Santa Rosa. Duas passagens da obra de Schallenberger e Hartmann (1981) favorecem a rápida apreensão de uma ambigüidade que cerca essa temática:

A convivência de várias etnias imprimiu, na Colônia, uma maior dinâmica social, o que de certa forma, repercutiu sobre o desenvolvimento global da nova área de colonização (p.91).

O processo de ocupação colonial indicou, no entanto, que a maior qualificação para o trabalho agrícola, o emprego de tecnologia mais apropriada e o afã progressista dos colonos de descendência ( $\mathrm{sic}$ ) européia suplantou as vantagens conferidas aos colonos nacionais. Assim, à medida que se consolidou a colonização, o processo de produção marginalizou, em grande parte, os colonos nacionais e suas propriedades foram, progressivamente, absorvidos pelos novos contingentes de imigrantes alemães, italianos e poloneses (p.91)

Os colonos "nacionais" contaram com regras diferenciadas, bastante vantajosas, para o pagamento de seus lotes. Ainda assim, não se constituíram em maioria no momento da fundação; ademais, de acordo com os referidos autores, foram gradativamente levados a abandonar a região. A celebração da pluralidade de origens não encobre, assim, uma hierarquização simbólica de méritos e características atribuídas às diferentes etnias que compuseram a Grande Santa Rosa, como se terá oportunidade de identificar a partir dos depoimentos colhidos em campo.

\subsubsection{Manifestações presentes da clivagem étnica}

$\mathrm{Na}$ pesquisa de campo, foi externado com uma freqüência muito elevada, pelos entrevistados, esse entendimento de que a multiplicidade de ascendências étnicas representou um trunfo para a região e incentivou, desde os primórdios, a capacidade da população para articular-se em ações coletivas, num exercício de convivência harmoniosa que se sobreporia às diversidades. Essa posição, no entanto, convive com uma (re)afirmação, recorrente - ora mais explícita, ora mais velada -, da superioridade tecno-econômica dos indivíduos de origem européia não-ibérica, notadamente os de ascendência germânica, claramente predominantes na região. 
Os 20 municípios reunidos na Grande Santa Rosa, que já foram um só, têm distinções prontamente enunciadas pela população em geral - quanto à sua origem étnica. A "sede" da colônia, em seguida município pólo, é, por um lado, o espaço em que se realizaria mais plenamente a diversidade, celebrada no discurso:

O forasteiro, de certa forma - e eu digo isso com orgulho -, a sociedade de Santa Rosa é bastante aberta, ela recebe as pessoas de fora com muita facilidade, ao contrário de outros municípios da região, aqui, onde predomina só uma etnia, que são mais fechados. Santa Rosa não: aqui é a miscigenação dessas 14 etnias $^{43}$, e também porque aqui o elemento nacional já era o primeiro... Aqui, o sujeito que vem de fora, em 60 dias ele tem uma roda de amigos pra comer churrasco... (Ex-prefeito, advogado - ago/06).

Por outro lado, é nesse espaço da principal cidade, no qual se concentra o poder local, que tendem a aparecer com maior intensidade alguns conflitos. Em 2002, uma historiadora, professora de uma das universidades de Santa Rosa, destacou um passado de forte conflito entre os "brasileiros" e os "alemães" (a mais representativa dentre as ascendências presentes na região) e "italianos" (que vêm a seguir). Durante o primeiro período Vargas, especialmente, todos os cargos públicos e benesses distribuídas pelo Estado eram outorgados aos "nacionais", segundo ela. Isso teria se refletido num razoável descolamento entre poder político e poder econômico: muito embora houvesse várias famílias "nacionais" bastante prósperas (em decorrência, até mesmo, de seu acesso privilegiado às concessões do poder público), a riqueza material se concentrava no segmento de ascendência não ibérica.

Cabe registrar que essa professora nasceu no nordeste do Brasil e fixou-se em Santa Rosa apenas na idade adulta, em razão do casamento. Esse fator pode ter sido decisivo para que ela expusesse elementos geralmente obliterados nas falas dos atores locais, que justificam a transcrição um tanto longa:

Santa Rosa é meio sui generis. Eles mantêm uma sociedade, que na década de 1930 e 1940 houve o predomínio do elemento de origem portuguesa nacional; o coronelismo era fortíssimo aqui - o coronel Bráulio Oliveira [fundador da colônia], com os seus parentes, daquele tipo que, se eles deviam pra ti, e tu fosses cobrar, tu levavas um tiro. E os alemães e os italianos eram "colonos" [termo depreciativo]. [Exemplifica com sobrenomes de pessoas importantes, presentemente, na cidade]. Então, eles ["nacionais"] faziam a hegemonia, os políticos fortes, os amigos dos governadores, aquela história. Na década de 40 veio a guerra, aquela perseguição violenta, e isso dividiu muito a comunidade, sabe? Então, os alemães ficaram pra lá, os italianos pra cá, aquele clube ali é só de alemão; aquele clube ali é só de italiano, sabe?, tinha essa coisa. (...) queimavam os livros, houve arbitrariedades, porque já existia aquela coisa entre os nacionais daqui, que eram os portugueses de origem, que eram os donos da terra...

P: Mas a senhora falou na colonização já com várias origens...

R: Várias etnias. Mas quando essa colônia foi fundada pelo coronel Bráulio de Oliveira, que era o intendente de Santo Ângelo. Ele tinha terras que vêm de Santo Ângelo a Cruzeiro, por isso que ele conseguiu com o Borges de Medeiros fundar uma colônia aqui.

${ }^{43} \mathrm{O}$ entrevistado havia aludido anteriormente a um estudo que mencionava 14 etnias na formação de Santa Rosa, mas não soube indicar referências sobre ele: "Na verdade a grande região é formada (...) por 14 etnias que se fixaram aqui, entre russos, ucranianos, poloneses, e aí vai. São 14 etnias, algumas das quais desapareceram miscigenadas com outras de origem européia também” (Ex-prefeito, advogado - ago/06). 
Imagina só, né: rolou dinheiro. E aí, quem continuou mandando na colônia era o coronel

Bráulio de Oliveira e seus asseclas.

P: Certo: que eram da turma dos portugueses.

R: Dos portugueses.

P: E esses outros, alemães e italianos, ficavam mais à margem do poder político...

R: Reservados. Com certeza...

P: Como é que foi essa...?

R: Só... Deixa eu te dizer, só na década de 1960 acho que teve o primeiro candidato a deputado que ganhou que era de origem alemã. Os prefeitos eram quase todos eles de origem portuguesa.

P: E isso hoje está diferente?

R: Não, hoje não é mais assim, hoje tem Vicini [prefeito - sobrenome italiano], tem [sobrenome - inaudível]... Hoje não tem mais...

P: Mas ainda repercute na memória, de alguma forma?

R: Na memória está presente!

P: Seguidamente alguém deve lembrar: "ah..."

R: Essa coisa assim: "aquele alemão, aquele pêlo-duro, aquele italiano de merda, aquele alemão-batata" - isso existe ainda assim, mas meio... A minha sogra era alemã da Alemanha e tinha os cafés da tarde na casa dela, e tal, e vinham todas aquelas frau, e só se falava em alemão o tempo todo. Eu não sabia falar alemão, mas [faz gesto de indiferença]. Isso é muito comum, ainda tem aí... Um dia desses me convidaram para uma tal de [palavra em alemão]. Vou não! Só falam em alemão! (Historiadora, out/02).

De forma ainda mais clara, um secretário da administração municipal de Santa Rosa enunciou, em 2006, que há um certo "racismo velado" na cidade. Segundo ele, até pouco tempo atrás, era comum que ofertas de emprego (que são até hoje divulgadas, principalmente, nas emissoras de rádio) viessem com a exigência "que fale alemão", para postos como os de balconistas ou mesmo domésticos. Mesmo reconhecendo que isso poderia ser necessário para atender idosos que nunca se familiarizaram com a língua portuguesa, levantou a suspeita de que houvesse também um componente discriminatório.

A professora e o secretário municipal, porém, foram minoria. O ex-prefeito já citado representa a maioria de meus interlocutores, que não reconheceram na dimensão étnica qualquer clivagem com efeitos dignos de nota na vida local. Após consentir que houve tensionamentos durante a II Guerra Mundial, o ex-Prefeito saiu-se com uma frase muito interessante: "uma coisa que tem aparecido de uns tempos para cá, e que eu acho que pode ser muito ruim para nós, são essas tais de etenias ( $\mathrm{sic}$ ). Isso nunca teve, por aqui, mas de tanto ficarem falando...”. Essa perspectiva, que parece identificar na própria tematização da questão étnica um risco à unidade ou à harmonia da sociedade local, pode ser um dos fatores que condicionam a pouca abertura dos meus entrevistados a essa temática - aspecto a que retornarei a seguir.

Há, na grande Santa Rosa, municípios em que a maioria esmagadora dos habitantes descende apenas de imigrantes alemães, sem qualquer miscigenação com outras origens. Santo Cristo ou São José do Inhacorá são exemplos notórios. A região, em seu conjunto, apresenta, para quem nela circula, flagrante predominância de pessoas com fenótipos como o de Gisele Bündchen, nascida em Horizontina, ou os dos santa-rosenses Xuxa e Taffarel - figuras públicas que são 
evocadas com freqüência (e orgulho) pelos moradores locais ${ }^{44}$. Mas há também muitos "pêlosduros" - termo que ouvi em campo muito poucas vezes, mas que, no Rio Grande do Sul, evoca, no falar popular, esse tipo humano predominantemente "branco", mas com algum traço reconhecível da ascendência moura ibérica e/ou de índios, e/ou de negros - bem mais característico da porção sul do Rio Grande do Sul.

Apenas um exemplo de uma situação que se repetiu diversas vezes. Um jovem com que conversei em um ônibus intermunicipal da região - vendedor ambulante de DVDs piratas, após ter sido demitido de uma grande empresa metalúrgica -, integrava esse contingente "mestiço" (e "nacional"). Apostei em minha afinidade étnica com ele para, com um quê de chiste, tatear a questão racial, dizendo que eu me impressionava com a quantidade de alemães na região. Ele se limitou a concordar, serenamente. Perguntei, então, se os alemães eram "fechados", se havia algum tipo de dificuldade de eles fazerem amizade com "todo o mundo"... O rapaz assegurou, com ênfase, que não existia nada disso, que "todo mundo se dá com todo mundo".

Como esse relato sugere, ao longo das entrevistas, vi-me permanentemente entre, de um lado, o risco de forçar a emergência de uma problemática que não tivesse efetividade na realidade pesquisada; de outro, o de subestimar um eixo de compreensão das relações sociais potencialmente relevante - nesse caso, cercado de silêncios frente a um "observador" externo.

Quando visitei o município de Santo Cristo, ao menos, o temor de supervalorizar o componente étnico desapareceu. Em consonância com diversas outras conversas não gravadas que mantive com a população de lá, a transcrição da entrevista que registrei no Sindicato dos Trabalhadores Rurais não deixa dúvidas sobre a força da clivagem étnica na sociabilidade local. Num primeiro momento, falando-se de oportunidades de emprego - tema a que retornarei no próximo capítulo -, um dos dirigentes do sindicato mencionou: “(...) emprego para quem quiser trabalhar aqui na cidade, tem; ainda mais para os nossos aqui, né - que o povo conhece, tem toda essa relação de confiança, questão de etnia, que é muito valorizado aqui, a questão de ser alemão, e trabalhador, e filho de agricultor". Logo que o fluxo do diálogo oportunizou, procurei retornar a essa temática mencionando que, na região, Santo Cristo é mencionado como um município quase exclusivamente "alemão". Os dois entrevistados contestaram esse grau tão elevado de homogeneidade. De acordo com um deles:

\footnotetext{
${ }^{44}$ Numa das entradas da cidade de Santa Rosa, há um imenso portal multicolorido com os dizeres "Santa Rosa, terra da Xuxa" e a foto da apresentadora de televisão. A via pública que se inicia nesse marco de entrada tem seus postes decorados com outras imagens da apresentadora, até o ponto em que se chega à residência em que ela viveu na infância - hoje transformada na "Casa da Xuxa", com um acervo de objetos pessoais para visitação. Os direitos de uso de sua imagem foram cedidos sem ônus pela apresentadora, mas há uma tutela quanto ao uso que a municipalidade lhe dá. Essas iniciativas integraram um projeto da Prefeitura, no início desta década, visando a atrair turistas à cidade. O jogador de futebol Taffarel, por sua vez, é homenageado em uma estátua em um ponto privilegiado do centro de Santa Rosa. Quanto à modelo Gisele Bündchen, sua cidade natal, Horizontina, começou, há algum tempo, a estampar sua imagem em prospectos de divulgação institucional.
} 
(...) A colonização inicial, uns 90 anos atrás, ela foi basicamente coordenada pela Igreja Católica, que, então, coordenou a venda das terras. E ela permitia apenas a compra da terra para alemães católicos apostólicos. E depois, como a procura de outras religiões e de outras raças foi aumentando, foi destinado áreas do nosso município - que são as piores terras, né, ali no canto -, para outras etnias. Não italiano: italiano não entrou aqui, nem polonês. Eram brasileiros... Carvalho, Borges, Silva, que foram entrando nas piores áreas do município (líder do sindicato de trabalhadores rurais, Santo Cristo, mai.07).

Quando procuro cercar a problemática da integração social desses "brasileiros", fica claro - como nas demais conversas em que tive condições de abordar esse tema, no município - que o critério étnico de diferenciação é cotidianamente reposto, embora haja sempre comparações com um passado em que essa convivência teria sido mais fortemente (ou mais explicitamente) conflituada. O termo "racismo" não foi, em geral, elidido - mas apareceu sempre remetido a um pretérito que não é localizado com precisão no tempo.

Sindicalista 1 - No começo não se permitia, por exemplo, troca - começando lá na origem -, de um casar com o outro. Troca de famílias. De um alemão casar com... um brasileiro. $\mathrm{Na}$ verdade, aqui se chama, ainda hoje, se chama de negro, embora não seja negro, mas se chama de negro.

$\mathrm{P}$ - Todo mundo que não é alemão?

Sindicalista 1 - É, isso: é negro, é "Saturno" [nome da localidade em que se concentraram os "brasileiros", no município]. Assim que se chama.

$\mathrm{P}$ - Saturno já é um nome que usam como...

Sindicalista $1-$ É.

$\mathrm{P}-$...como adjetivo?

Sindicalista 1 - Como da Rocinha [Rio de Janeiro], ou como da...

Sindicalista 2 - Fala Saturno, já... o pessoal - mesmo morando alemão lá - o pessoal fala "lá tem negro morando, tem brasileiro morando".

Sindicalista 1 - Então no começo, por exemplo, um da Saturno casar com um da Belinha [localidade das mais "nobres" do município], ou aqui, da Linha Alma, isso não podia, imagina! Mas, aos poucos, isso aí foi quebrando. E hoje, embora exista esse preconceito e tudo, mas em questão de... de religião, de festa, de cultura, há integração normal. Faz festa, os alemão vão; eles [brasileiros] vêm para cá. São associados aqui do Sindicato, e muitos da Cresol [cooperativa], normal...

Sindicalista 2 - Quando dá briga numa festa, geralmente os caras... os alemão falam: "isso foi algum negro"... É assim que funciona ainda, né.

Esse menosprezo aos "negros", "brasileiros" ou "nacionais" aparece de várias outras formas, não apenas nos municípios mais "puramente" germânicos. No livro de Schallenberger e Hartmann (1981:95) encontrei menção a um "adágio" que me havia sido referido, com pequena variação, pelo ex-prefeito de Santa Rosa, pesquisador da história local: nos primeiros tempos da colonização, os "alemães" costumavam provocar os moradores de Santa Rosa e Boa Vista do Buricá - localidades mais "mistas", do ponto de vista étnico - com o dito: "Santa Rosa, Buricá, quem não presta vai pra lá” (ou “quem é burro vai pra lá”, na versão do ex-prefeito).

Esses dois autores, de resto, parecem esposar a visão de que a capacidade de trabalho e de êxito econômico seria (ou, ao menos, teria sido) menos presente nos "nacionais", como atesta a passagem referida anteriormente sobre "a maior qualificação para o trabalho agrícola, o emprego 
de tecnologia mais apropriada e o afã progressista dos colonos de descendência (sic) européia" (Schallenberger; Hartmann, 1981:91 - grifo meu).

$\mathrm{O}$ interesse por esse eixo da pesquisa foi estimulado, adicionalmente, pelo fato de que, como vim a saber em campo, Santa Rosa realiza, desde 2001, a "Festa das Etnias", um evento bienal que teve sua origem no processo de organização da Fenasoja (Feira Nacional da Soja desde 1966, a grande "estrela" do calendário turístico e de negócios da região) e hoje ocorre em anos alternados a ela. Celebrações semelhantes, que têm lugar em municípios próximos, como Ijuí, em outras unidades da Federação e na vizinha Argentina ${ }^{45}$, inspiraram a iniciativa, como declarou o presidente da comissão responsável pela edição de 2007 da festa de Santa Rosa. Além dele, integrante da "Etnia Polonesa", entrevistei o coordenador da "Etnia Africana", recentemente constituída. Esses dois personagens, cujos perfis sociais e biografias são muito contrastantes entre si, deram-me depoimentos em que pelo menos um ponto de convergência relevante se destacou.

Quando você está de fora disso aí, você não dá, talvez, o devido valor pras coisas. Mas quando você entra, começa a se envolver, daí parece que o sangue parece que começa a correr mesmo nas veias. Porque, na verdade, tu começa a buscar, em primeiro lugar, as próprias origens. Eu, por exemplo, desde que eu comecei a me envolver nisso, eu passo horas em Internet aí, e buscando... (integrante da Etnia Polonesa, coordenador da Festa das Etnias de 2007, nov.06).

Particularmente, fui a algumas escolas e comecei a perguntar: "Bom: quantos alunos negros vocês têm?"

$\mathrm{P}-$ Quando tu fizeste isso? Depois de assumir a...

$\mathrm{R}$ - É, isso aí faz um ano e pouco que eu fiz - eu já estava envolvido com a Festa e daí... Aí começou a me surgir pra mim isso como curiosidade. "Qual é a população? Eu não consigo saber. Eu trabalho com a questão da etnia e não sei, não consigo saber!”. Aí no IBGE me deram aproximadamente esse número. E eu comecei a ir nas escolas, então, fazer uma pesquisa aí (...) (coordenador da Etnia Africana, nov.06)

Efetivamente, a participação desses indivíduos na organização coletiva de suas "etnias" e esse tornou-se o termo "nativo", invariavelmente utilizado para designar cada uma dessas associações que, sobretudo a partir da Festa, se constituíram ${ }^{46}$ - despertou neles uma forte motivação para informar-se e refletir sobre os significados de sua ascendência e o componente identitário a ela associado, bem como iniciativas de ação, à semelhança da que relata o coordenador da Etnia Africana, que manifesta um sentimento de dever ("eu trabalho com a questão e não sei!").

\footnotetext{
${ }^{45}$ A cidade argentina de Oberá, bastante próxima a Santa Rosa, realiza há 26 anos a "Fiesta Nacional del Inmigrante", cuja organização enviou delegação para participar da última Festa das Etnias (Jornal Noroeste, 07 de abril de 2007).

${ }^{46}$ Ambos os entrevistados manifestaram a ambição de expandir as "atribuições" de suas respectivas "etnias", mas reconhecem que essas associações ainda têm sua existência muito restrita ao cumprimento das "tarefas" que lhes cabem para participar da Festa das Etnias e, nos anos em que essa não ocorre, do pavilhão gastronômico que ocupam durante a Fenasoja. As edições da Festa das Etnias, segundo o presidente da edição 2007, envolvem essencialmente um "jantar-baile" (com a apresentação de uma "rainha" escolhida por cada etnia), gastronomia e mostras culturais, em geral focadas na música e em danças folclóricas.
} 
A proposta de harmoniosa celebração da diversidade, que (a própria designação não deixa dúvidas) fundamenta uma iniciativa como a da "Festa das Etnias", não deixa de gerar desconfianças e controvérsias, permitindo entrever um substrato possivelmente menos idílico nas relações raciais. Aparentemente, há quem veja risco em mobilizar, ou constituir, identidades étnicas - aspecto inescapável quando se trata dessa problemática. O depoimento a seguir indica, de forma indireta, essa posição, de resto presente na já citada fala do ex-prefeito, sobre as "tais de etenias".

$\mathrm{Eu}$ acho, assim, um ganho muito grande, cultural, né. Eu acho isso fantástico. Tem pessoas, assim, e até de um nível cultural bastante elevado, eu diria, e que são contrários ao processo.

$\mathrm{P}$ - Aqui na cidade?

$\mathrm{R}$ - Sim. Eu me surpreendi. Foi essa semana, inclusive, semana passada, que eu ouvi isso aí, pessoalmente.

$\mathrm{P}$ - E como é que o senhor vê? Quais são os argumentos que estão em jogo?

$\mathrm{R}$ - Pela contrariedade, eles dizem que, na verdade, não vai haver união, e sim, cada vez mais, um movimento contrário. Por exemplo, assim como teve os problemas de guerra antigos, né, que talvez a gente está suscitando isso aí. Que o movimento étnico seria propulsor disso. Daí eu me apavorei quando eu ouvi isso aí, sabe? Porque quando a gente participa desses eventos aí, mas tá louco!, não existe qualquer conotação nesse sentido! (integrante da Etnia Polonesa, coordenador da Festa das Etnias de 2007, nov.06).

A entrevista com o coordenador do segmento "africano" merece uma atenção mais detida, não apenas por se tratar da única etnia "nacional" (no sentido êmico) organizada na cidade ${ }^{47}$, mas, sobretudo, por trazer à luz a problemática dos negros - possivelmente, o conjunto mais presente na reflexão daqueles que temem "suscitar" tensões raciais por dar visibilidade a essa dimensão das diferenças sociais.

Conforme a tabela 2 atesta, o perfil étnico do Rio Grande do Sul, com sua forte predominância dos que se auto-identificam como pertencentes à "cor ou raça" branca, é bastante diferente do nacional. Na Grande Santa Rosa, essa característica é ainda mais acentuada. A diferença entre o agregado gaúcho e o da região não envolve a categoria "pardos", cuja proporção é idêntica nos dois níveis. É na categoria "pretos" que o conjunto de municípios estudado ostenta os resultados relativamente mais discrepantes dos do Rio Grande do Sul. Por outro lado, tendo o conjunto do Brasil como referência, é a presença comparativamente pequena de pardos que mais destaca a realidade do sul, em seus dois recortes geográficos.

Tabela 2 - População residente por cor ou raça - municípios da Grande Santa Rosa, Rio Grande do Sul e Brasil, 2000

\begin{tabular}{lccccccc} 
& Total & Branca & Preta & Amarela & Parda & Indígena & s/ decl. \\
\hline Alecrim & 100,0 & 85,9 & 2,7 & 11,2 & 0,1 \\
Alegria & 100,0 & 77,7 & 1,6 & 20,5 & 0,1
\end{tabular}

${ }^{47}$ As "etnias" que integravam essa organização eram a alemã, a italiana, a polonesa, a russa e a árabe, vindose somar a africana Encontrava-se em processo de articulação a "etnia portuguesa", quando entrevistei o presidente da Edição 2007, ao final de 2006. 


\begin{tabular}{|c|c|c|c|c|c|c|c|}
\hline Boa Vista do Buricá & 100,0 & 89,2 & 4,3 & & 6,0 & 0,2 & 0,3 \\
\hline Campina das Missões & 100,0 & 97,2 & 0,1 & & 2,6 & 0,1 & 0,0 \\
\hline Cândido Godói & 100,0 & 98,5 & 0,4 & & 1,0 & & 0,1 \\
\hline Doutor Maurício Cardoso & 100,0 & 89,1 & 2,1 & & 8,7 & & 0,1 \\
\hline Horizontina & 100,0 & 87,9 & 4,6 & & 7,3 & 0,1 & 0,2 \\
\hline Independência & 100,0 & 92,7 & 2,6 & 0,1 & 4,5 & & 0,1 \\
\hline Nova Candelária & 100,0 & 96,2 & 3,2 & & 0,7 & & \\
\hline Novo Machado & 100,0 & 93,5 & 0,6 & & 5,7 & & 0,1 \\
\hline Porto Lucena & 100,0 & 91,1 & 0,9 & & 8,0 & & \\
\hline Porto Mauá & 100,0 & 97,0 & 0,3 & & 2,7 & & \\
\hline Porto Vera Cruz & 100,0 & 87,7 & & & 12,3 & & \\
\hline Santa Rosa & 100,0 & 87,7 & 2,5 & & 9,4 & 0,1 & 0,2 \\
\hline Santo Cristo & 100,0 & 93,6 & 1,8 & 0,1 & 4,4 & & 0,1 \\
\hline São José do Inhacorá & 100,0 & 97,5 & 0,2 & & 2,0 & & 0,2 \\
\hline Senador Salgado Filho & 100,0 & 85,9 & 1,9 & & 11,1 & & 1,1 \\
\hline Três de Maio & 100,0 & 89,4 & 2,8 & & 7,7 & & 0,1 \\
\hline Tucunduva & 100,0 & 91,6 & 0,9 & & 7,4 & & 0,2 \\
\hline Tuparendi & 100,0 & 96,3 & 0,2 & & 3,3 & & 0,2 \\
\hline Total da região & 100,0 & 90,0 & 2,2 & 0,0 & 7,5 & 0,1 & 0,2 \\
\hline Rio Grande do Sul & 100,0 & 86,6 & 5,2 & 0,1 & 7,5 & 0,4 & 0,3 \\
\hline Brasil & 100,0 & 53,7 & 6,2 & 0,4 & 38,5 & 0,4 & 0,7 \\
\hline
\end{tabular}

Fonte: IBGE - Censo Demográfico

Numericamente mais restrito, o contingente de pretos (e, presumivelmente, a parcela dos pardos socialmente amalgamada a ele) parece enfrentar na região a mesma desvantagem estrutural que se verifica no nível nacional. Primeiramente, cabe registrar que a organização da Etnia Africana foi incentivada (ou solicitada) pelos idealizadores da Festa das Etnias:

Tipo assim... tanto que a etnia afro só se organizou porque as etnias, algumas etnias, já estavam organizadas lá. No momento em que eles se reuniram, bom, sentiram necessidade de chamar o negro também a participar (coordenador da Etnia Africana, nov.06).

O coordenador da Etnia Africana não é natural da região, mas de um município próximo. Instalou-se em Santa Rosa para cursar Educação Física (que concluiu) e residiu no município por vários anos, tendo, a seguir, vivido em outros estados do Brasil. Em Minas Gerais, usando a expressão dele, "descobriu-se" negro, já que em sua infância o pai era, praticamente, o único "não branco" com que convivia: a mãe é filha de "alemã com brasileiro", e o círculo social - e ele destaca as escolas, privadas, que freqüentou -, exclusivamente branco. Nesse processo de autoreconhecimento como negro, interessou-se pela capoeira e passou a estudá-la, trabalhando, hoje como instrutor dessa prática, em academias privadas, no SESC e em atividades voluntárias em bairros pobres. Ao que seu relato permite deduzir, seu status social - escolaridade superior, redes sociais e ambientes profissionais mais "brancos" - diferencia-o da imensa maioria dos negros da cidade:

É, isso. Então, aqui... negros empresários a gente tem... Eu conheço dois, conheço dois. Alguns professores...

$\mathrm{P}-\mathrm{E}$ esses dois são de quê?

$\mathrm{R}$ - Na área de revenda de automóveis, um trabalha. E outro trabalha na área de "xerocadora". Mas, assim: micro-empresários.

P - Sim, sim. Professores, então, tem poucos? 
$\mathrm{R}$ - Professores negros, que eu conheço, dois, três; comigo, quatro. Fica aí, então.

O entrevistado relatou um momento anterior - "há oito anos, mais ou menos" - em que uma dessas professoras tentou promover a articulação dos negros de Santa Rosa. O alcance teria sido relativamente pequeno, e os êxitos, efêmeros. Mesmo visualizando que a organização atual é até certo ponto heterônoma, vindo em resposta a uma demanda das lideranças locais que objetivavam reforçar a representatividade da Festa, o coordenador da Etnia Africana demonstra que tomou a si não apenas a tentativa de buscar informações sobre os negros da cidade, conforme foi referido, como, em certa medida, inclusive, o exercício de um papel fiscalizador. Ele narrou a queixa que lhe foi feita por uma jovem negra, sua conhecida, a qual foi preterida, na seleção para um emprego de digitadora, por outra moça, branca, com a qual havia compartilhado toda a formação profissionalizante. Uma vez que o teste foi feito em conjunto, a candidata que não foi escolhida dizia ter constatado que seu próprio desempenho havia sido superior. O entrevistado tomou a iniciativa de ir à unidade do SINE para pedir os dois currículos e compará-los.

E eu pedi o currículo dessa pessoa, das duas. E conferi: iguais. Inclusive elas tinham diferença de dois meses de data de nascimento. Porque elas se criaram praticamente juntas. E daí eu conversei com o pessoal do SINE. Eu disse: "Olha, não é a primeira vez". Não é a primeira vez que ocorre... (coordenador da Etnia Africana, nov.06).

Instado a falar sobre a discriminação racial na realidade local, o coordenador da Etnia Africana não hesitou em reconhecê-la e enunciá-la:

Eu sempre vejo a discriminação de uma forma implícita, né. Implícita até porque é crime. Hoje fica complicado, né. Eu, particularmente, por exemplo, assim, passei por vários tipos, né; alguns abertos, outros fechados, que depois tu acaba sabendo. Que, claro, no momento que as pessoas te dão um nozinho lá, uma desculpa, e depois tu vai saber, às vezes, que, pô, não foi por esse motivo, né. (...)

Aí, no currículo, a foto eu considero hoje como um elemento discriminatório. (...) E se for um negro e um branco, a tendência é de o branco conseguir um espaço, tendo a mesma qualificação, mesma capacidade (coordenador da Etnia Africana, nov.06).

Mesmo externando uma tal visão - que reitera que discriminação racial é crime, ao mesmo tempo em que visualiza as formas disfarçadas com que ela ocorre -, o entrevistado avança uma interpretação um tanto complacente do fenômeno. Ela se demonstra muito especial, para meus interesses, por vincular diretamente a percebida discriminação racial com o fechamento de oportunidades de trabalho:

É algo que, como eu digo: às vezes, a pessoa que contratou, não é porque ela seja racista, nada: ela... a tendência é você - no momento em que você faz essa contratação, ou que você vá ter uma relação -, a tendência, às vezes, é você dar a oportunidade pros seus iguais. Iguais, que eu digo, então... Aí, serem iguais na cor da pele, vamos...

$\mathrm{P}$ - "Eu vou dar emprego a um igual a mim"?

$\mathrm{R}$ - Isso. É algo um pouco subjetivo. 
Esse "algo subjetivo" de que fala o entrevistado, quando especula sobre as razões que levam um empregador a fazer escolhas com critérios no mínimo "deslocados", segue sendo pouco abarcado nos modelos analíticos sobre mercados de trabalho, como venho tentando destacar.

Um último elemento aportado pelo coordenador da Etnia Africana em sua entrevista revelou-se de grande importância para minha reflexão. Ele externou uma percepção sofisticada e, sobretudo, persuasiva - da coexistência e da hierarquização dessas múltiplas "etnias", que se afirmam permanentemente como identidades (portanto, estabelecem contrastes) para, a partir dessa clivagem, celebrar sua conjugação e a unidade da população regional. Especificamente, o entrevistado brindou-me com uma interessante hipótese sobre a ambivalência que cerca a forte predominância germânica na região e o discurso da pluralidade. Com pequenos cortes, reproduzo sua formulação literal:

\footnotetext{
Porque essa questão da etnia germânica que tem aqui - a grande maioria... Então acabam sendo uma boa parte dos empresários também. E até é mais fácil de se juntar, né. Então eu não sei se já te disseram ou não - e que eu não sei se é verdade. Que eu vejo assim: como eles já são um grupo grande, de repente, um líder chama eles lá. De dez que vão ir, a tendência é que sete sejam da mesma [etnia]. Então isso torna mais fácil você aglutinar, que é aquilo que eu te falei: Santo Ângelo [município próximo, fora da região - do qual o entrevistado é natural], de repente, não conseguiu ter isso: pela diversificação, eles não conseguiram fazer uma diversidade, vamos dizer assim. Aqui, por ter essa força, de uma grande maioria ser essa colonização, de repente é provável, é possível que isso influencie nessa capacidade de...

$\mathrm{P}-\mathrm{E}$ ao mesmo tempo, o argumento que é dito é quase o contrário: "por sermos muito diversificados, todo mundo precisou falar a língua um do outro" - entende, no sentido figurado. Mas tu estás me dando um outro lado...

$\mathrm{R}$ - Veja bem... assim, oh, não invalida isso que foi dito pra ti. Não invalida pelo seguinte: por que você... Se você tem um grupo muito forte, esse mesmo grupo vê a necessidade de chamar os outros. E como eles já estão forte, aí os outros (...) aqui já pensam: "Pô, mas eles já estão fortes; vou me juntar com eles também".

(...) entra bastante essa questão da mesma formação. Se já tem um grupo grande... É como se você tem um time de futebol lá, quatro, cinco anos, o mesmo time. Se botar um, ou dois, ele vai; ele vai. Agora, se tu chama um de cada pedacinho fica mais difícil, sabe.

(...) Então, eles lá, também eles... como eles sentem essa necessidade de aglutinar com eles. Eles já têm a força, então eles vão agregando. Só que vão agregando, vão agregando, e daí se consegue formar um bolo maior.
}

Efetivamente, a capacidade de articulação dos mais diversos segmentos sociais é universalmente reconhecida, e positivamente destacada, nos depoimentos colhidos na região. Essa hipótese de uma "diversidade hegemonizada" (pelos "alemães"), à falta de outra formulação, aproximou-se de minha própria sensação, ao menos no que se refere aos aspectos culturais da realidade local. Por outro lado, não tenho elementos para verificar até que ponto a afinidade de origem ou ascendência efetivamente interfere na disposição de agentes - como, na fala do entrevistado, os empresários - para uma ação coletiva.

\subsection{A vida econômica: a base agrícola e um peculiar tecido industrial}


Para bem se compreender a configuração atual da economia da Grande Santa Rosa, há que recorrer novamente à história, a sua formação. Ainda que de forma seletiva, faço-o, a seguir.

\subsubsection{Uma trajetória econômica em "ciclos"}

Conforme já foi referido, no início do século XX, o poder público deixara de conceder os subsídios e benefícios oferecidos nas experiências iniciais de colonização do Estado, de modo que os primeiros habitantes que acorreram à Colônia Santa Rosa, fundada em 1915, enfrentaram o isolamento nas matas, falta de infra-estrutura de transportes e de comunicações e escassez de recursos monetários.

Rapidamente multiplicaram-se os comerciantes - presentes já dentre os primeiros colonizadores (Rotta, 1999:52) -, e expandiram-se os laços mercantis da colônia. Como indica Roche, priorizaram-se cultivos com melhores possibilidades de escoamento:

De começos relativamente rápidos, pois a produção se restringia aos produtos mais lucrativos, como o milho, o feijão, a batata-inglesa, a cana-de-açúcar, [a colônia Santa Rosa] teve desenvolvimento, entretanto, menos acelerado que o de Erechim, porque a via férrea só atinge Santa Rosa em 1940 (Roche, 1962/1969:283).

Outro estudo destaca os vínculos da agricultura da região com o mercado, mas, ao invés de enfatizar a orientação aos "produtos mais lucrativos", afirma que "a policultura foi o instrumento básico para a liberação de produtos para o mercado, o que, sem dúvida, propiciou a maior circulação monetária e veio requisitar uma maior demanda de produtos manufaturados" (ACISAP, 2001, s/pág, grifo nosso). As atividades comerciais floresceram rapidamente, de forma que, à época que o município foi constituído (emancipando-se de Santo Ângelo), em 1931, havia um dinamismo econômico considerável:

Os estabelecimentos comerciais, de pequenas vendas, passaram a ser verdadeiros centros de compra e revenda de mercadorias, não só para a clientela local, mas também para outros postos comerciais da região (...). No ano de 1930, Santa Rosa contava com 168 casas comerciais, sendo 132 lojas de artigos variados e 36 de gêneros alimentícios.

As atividades comerciais concentravam-se basicamente na compra de tecidos, ferragens, louças, perfumarias, açúcar, gasolina e óleos, sendo que as vendas aconteciam em torno de produtos como madeiras, banha, erva-mate, fumo, aguardente, vinho, salame, milho, feijão, cera e óleos vegetais. Nessa época, os melhores mercados encontravam-se nas praças de Porto Alegre e na Província de Misiones, na República Argentina (ACISAP, 2001, s/pág).

Os excedentes gerados com essas transações comerciais - que já incluíam produtos beneficiados, ou agroindustrializados, como se vê na enumeração de mercadorias vendidas por Santa Rosa para outros mercados, acima transcrita - e a condição de relativo isolamento do município, que dificultava ou encarecia o suprimento de bens provenientes de outras praças, oportunizaram um incremento de atividades de tipo industrial, a que Roche, no entanto, reconhece muito pequena expressão: 
Santa Rosa possuía (...); em 1937, 98 serrarias, 34 ferrarias, 46 marcenarias, 15 fábricas de tijolos, 22 alfaiatarias, 15 sapatarias, 16 cervejarias, 9 fábricas de limonada ou gasosa e 9 padarias. A brevidade dessa enumeração mostra a simplificação do artesanato numa colônia moderna: apesar dos progressos da sede e da prosperidade da construção, apesar do aparecimento de atividades de tipo urbano (como a panificação, a torrefação de café, a confeitaria e a tipografia), o essencial do artesanato continuava consagrado à transformação dos produtos agrícolas (Roche, 1962/1969:491).

Pode-se considerar esse primeiro período, entre a fundação da colônia e o final da década de 30, como uma fase de consolidação da economia regional, com boa performance de crescimento econômico (Rotta, 1999; Roche, 1962/1969).

A chegada da ligação ferroviária à região, no contexto nacional pós-revolução de 30 , caracteriza o início de uma segunda fase de sua história econômica. Embora a sede municipal de Santa Rosa só venha a contar com acesso direto às linhas em 1940, já em 1928 o serviço chegava a Passo das Pedras (atual município de Giruá) e, em 1937, ainda mais perto, à localidade de Cruzeiro, dentro das fronteiras do município de Santa Rosa. "Verificou-se então um súbito progresso, graças às novas possibilidades de saída dos produtos. A influência da guerra foi apenas secundária, visto que a prosperidade da agricultura continuou a elevar-se mesmo depois do retorno à economia de paz. De 1939 a 1950, seu volume global passou de 177780 toneladas para 332080 (...)" (Roche, 1962/1969: 283-4).

Roche ressalta a "orientação essencialmente comercial" da agricultura de Santa Rosa, e ainda classifica como "notável" o fato de que a região não tinha, no período entre 1939 e 1950, menos de nove produtos importantes em seus fluxos comerciais para fora da região, enquanto as demais "colônias", com a exceção de Estrela, não ultrapassavam "quatro ou cinco" (Roche, 1962/1969: 283-4).

O "surto de prosperidade" associado à chegada da ligação ferroviária se fez sentir fortemente. Em Santa Rosa, em apenas três anos, entre 1934 e 1936, o preço das terras já havia sextuplicado (Rotta, 1969:58), na medida em que a malha de transportes chegava às suas imediações. Os principais produtos agrícolas dessa fase eram o milho, o feijão, a linhaça, a mandioca e o fumo (Rotta, 1999:58).

Ao mesmo tempo, segundo ACISAP (2001), "na região da Grande Santa Rosa, este período vai caracterizar-se pela supremacia da pecuária sobre a agricultura, constituindo-se esta, como uma atividade subsidiária". Ao destacar o impulso gerado nos anos 40 pela ferrovia, Roche destaca como itens importantes nas remessas para o mercado de Porto Alegre "manteiga, queijo, banha, carne, etc." (Roche, 1962/1969:491-2), o que também indica o peso de produtos da pecuária e seus derivados.

O gado leiteiro manteve uma presença significativa, especialmente a partir da fundação dos Laticínios Mayer, em 1949, que impulsionou a produção das unidades familiares e, gradativamente, incentivou a melhoria da qualidade genética do rebanho, obtendo, essa empresa, 
uma boa performance no mercado nacional e mesmo internacional (ACISAP, 2001; Rotta, 1999:84). Mas o eixo da atividade pecuária, nas décadas de 1940 e, especialmente, 1950, estava na suinocultura, que se tornou a principal fonte de renda da agricultura familiar e garantia um caminho para agregar valor à produção. Havia demanda elevada, e, além de comerciantes do interior do município, vários frigoríficos de outras regiões do Rio Grande do Sul - Rizzo, Swift, Wilsons, Serrana - mantinham em Santa Rosa compradores autorizados (Rotta, 1999:59). A suinocultura fez convergir as culturas agrícolas: milho, abóbora e batata-doce eram os produtos essenciais. A criação era desenvolvida "sem aprimoramento técnico nenhum", mas foi "uma boa fonte de rendas" (Schallenberger; Hartmann, 1981:126).

Com o ingresso da região no circuito do mercado nacional em consolidação, se, por um lado, é decisivo o empuxo dado pela agropecuária à economia regional, há uma atrofia do que Roche denomina o "artesanato rural": "salvo a fabricação de tijolos e a ferraria, o fornecimento de artigos correntes foi eliminado pela difusão das usinas da Depressão Central; a transformação dos produtos agrícolas já escapa ao artesão, para passar à refinaria de banha, aos estabelecimentos de moagem e às leitarias industriais" (Roche, 1962/1969: 491-2).

Esse excerto alude a dois fenômenos complementares. De um lado, há o impacto concorrencial que a incipiente indústria da Grande Santa Rosa sofre, devido à facilitação da entrada de produtos de outras regiões - como destaca Rotta, não apenas da Depressão Central, mas de Porto Alegre, Pelotas, Rio Grande e de outros estados do país. De outro, a reorganização interna à região, que "esteriliza", na expressão de Roche, o artesanato rural, na medida em que se consagram novos padrões de eficiência produtiva, com requerimentos tecnológicos, gerenciais e de escala que inviabilizavam as empresas que não cumprissem o imperativo de "tornarem-se 'nacionais' (não necessariamente pela conquista de mercados extra-regionais e sim pela adoção de padrões de tecnologia, comercialização, etc. similares a seus concorrentes)" (Castro, apud Rotta, 1999:62 $)^{48}$.

Poucas indústrias santa-rosenses superaram esse desafio. Ao mesmo tempo, novas empresas do setor secundário surgiram, entre os anos 1940 e os anos 1960, já confrontadas, ao nascer, com esse novo quadro concorrencial. O conjunto delas representou a consolidação da vocação da região para o agronegócio, pois englobavam a produção de máquinas e implementos agrícolas, laticínios, óleos vegetais, erva-mate e frigorífico de suínos. Toma-se por base, para essa consideração, o elenco de sete empresas regionais analisadas por Rotta (1999) como representativas e indutoras de uma nova concepção de gestão e de inserção no mercado. A mais antiga delas, a ervateira Vier, foi fundada em $1944^{49}$.

${ }^{48}$ CASTRO, Antônio Barros de. Sete Ensaios sobre a Economia Brasileira. V.II. Rio de Janeiro: Forense, 1971.

${ }^{49}$ As firmas são: Laticínios Mayer (hoje Avipal/Elegê), Ervateira Vier, Indústria de Máquinas Ideal (hoje AGCO), Indústria Gaúcha de Óleos Vegetais (hoje Camera), SLC (hoje John Deere), Irmãos Fankhauser Ltda e o Frigorífico Prenda (hoje Alibem). Voltarei a tratar desse conjunto de empresas, neste capítulo, 
Nesse grupo, o frigorífico Santa-rosense S.A, posteriormente denominado Prenda, recebe de Rotta a mais detida atenção, por ter sido decisivo para potencializar o chamado "ciclo do suíno" na economia da região e por representar a consagração de "uma nova visão de empresa" (Rotta, 1999:100). A par disso, a reconstrução histórica que Rotta faz do processo de instalação do frigorífico merece um especial interesse, por revelar uma experiência muito particular de articulação da sociedade regional em torno de objetivos vinculados à planificação e à indução de seu desenvolvimento. Segundo Rotta, nos anos 50, o Sr. Pedro Carpenedo, que trabalhava no frigorífico Costi, de Passo Fundo, identificou, num desentendimento entre os proprietários daquele estabelecimento, a oportunidade de tentar convencer os sócios que estavam deixando a empresa a implantar uma unidade em Santa Rosa - que já era a origem de boa parte da matéria-prima, o que implicava custos de transporte e perdas por mortalidade dos animais no deslocamento.

O importante peso que a suinocultura vinha adquirindo em Santa Rosa tornava bastante atraente a possibilidade de se contar com a presença de um frigorífico local. Conforme me relatou, em 2006, um entrevistado, naquele tempo "esses suínos, para tu ter uma idéia, eram levados para Montenegro (...). Dois, três dias de viagem!" (dirigente de cooperativa).

A tentativa de estimular a implantação de um empreendimento com know-how e capital de fora malogrou, e o próprio Sr. Carpenedo teria mobilizado as lideranças locais, especialmente os integrantes da Associação Comercial e Industrial (ACI), para buscar alternativas visando a estabelecer um frigorífico local. A idéia teve crescente adesão, evoluindo-se para um "consórcio" de 170 acionistas que, com apoio do poder público municipal (isenções fiscais e subsídio para a aquisição de terreno), constituiu a empresa em 1956, realizando-se o primeiro abate em 1957. Representantes de empresas tradicionais do setor (como Rizzo, de Caxias do Sul) tentaram evitar que o Prenda se concretizasse, oferecendo "alternativas" aos santa-rosenses, como abertura de novas cotas para acionistas ou mesmo instalação de filial na região. Também os comerciantes que intermediavam a venda de suínos para fora da região opuseram-se ao apoio da Prefeitura. Mas a Câmara de Vereadores aprovou o suporte público, e a assembléia de (futuros) acionistas decidiu por unanimidade criar a empresa. A listagem de acionistas é apresentada por Rotta. A variedade das profissões (que é a única informação "pessoal") dos indivíduos que se articularam, a pulverização na distribuição das ações entre eles e o próprio número total de participantes no empreendimento demonstram a relevância da iniciativa e sua forte base social. Um grande número de comerciantes, muitos agricultores e algumas pessoas jurídicas, além de bancários, contadores, médicos, motoristas e funcionários públicos, dentre outras categorias, integram a relação, de acordo com a qual ninguém adquiriu menos de 25 ações e apenas 20 subscritores compraram 100 ou mais unidades. O número máximo foi 500 (caso de apenas dois acionistas) (Diário Oficial do Estado do Rio Grande do Sul, 08.06.1956, p.11-3, apud Rotta, 1999: 182-187).

ocasião em que essas empresas poderão ser mais bem visualizadas. 
Com o impulso do Prenda - cuja gestão é reconhecida, nos depoimentos colhidos em Rotta (1999), por seu caráter arrojado, pela seriedade e pela parceria com os suinocultores -, o ciclo do suíno em Santa Rosa vive seu apogeu nos anos 50.

Ao mesmo tempo, é nessa década que começa a eclodir a crise da pequena propriedade rural familiar, que desafiará o conjunto da economia regional. Associando-se à principal produção pecuária, a agricultura expandira fortemente a participação da cultura do milho, produto que exemplifica o principal fator da crise: a produtividade desse grão, que era de $2.100 \mathrm{~kg} / \mathrm{ha}$, em 1920, chegaria, em 1966, a $1.200 \mathrm{~kg} / \mathrm{ha}$. A falta de manejo agronômico - fertilização, correção dos solos -, a prática das queimadas na origem das explorações e a pouca rotatividade de culturas vinham esgotando a fertilidade das terras da região, e o recurso, preteritamente muito utilizado, de abrir novas áreas à exploração, quando o problema se colocava, não era mais viável, pela extensão já atingida de sua utilização e pelo crescimento demográfico. A população, que era de 110 mil habitantes em 1940, passara a 150,3 mil em 1950 e chegaria a 194,2 mil, em 1960 (Rotta, 1999:71).

Já nessa época, a cultura de soja começa a se tornar expressiva,

exigindo maiores áreas para o plantio e desenvolvimento da produção. As famílias numerosas não tinham terras disponíveis para os seus filhos, então, testemunha-se na região um forte movimento de migração. Levas e levas de colonos dirigiram-se ao oeste de Santa Catarina e sudoeste do Paraná e até mesmo para o Paraguai. Essa busca incansável de mais terras fez com que o meio rural da Grande Santa Rosa sofresse um processo de descapitalização de recursos financeiros e humanos (ACISAP, 2001, s/pág).

Ante a necessidade de superação desse impasse, os atores regionais articularam-se, conseguiram conceber alternativas e buscar sua implementação. As saídas esboçadas no âmbito da Grande Santa Rosa vieram a se beneficiar de um ambiente institucional favorável, na medida em que convergiam com interesses do governo federal, afinado, por sua vez, com um modelo de modernização agrícola intensivo em insumos químicos e mecanização, que vinha sendo difundido mundialmente, no bojo da "revolução verde".

A chamada "Operação Tatu" inicia-se como programa de recuperação do solo da região, por iniciativa da Associação Rural de Santa Rosa, envolvendo a Faculdade de Agronomia da UFRGS e contando com orientação de especialistas da Universidade de Wisconsin, a partir de convênio da UFRGS com a USAID (United States Agency for International Development). É deflagrada em 1965, envolvendo a $\operatorname{ACISAP}^{50}$ e a Associação dos Municípios da Grande Santa Rosa - duas instâncias em que a Associação Rural tinha assento - e contando com financiamento em condições muito favoráveis oferecidas pelo Banco do Brasil, que teria sido alvo de um "convencimento" muito tenaz da USAID, segundo depoimento colhido por Rotta (1999:76-7). A

${ }^{50}$ Na gestão 1961-1962, a Associação Comercial e Industrial (ACI) de Santa Rosa, fundada no mesmo ano da criação do município, 1931, muda sua designação para Associação Comercial, Industrial, Serviços e Agropecuária (ACISAP) (ACISAP, 2001, s/pág.). 
operação iniciou com diagnósticos das terras, tendo havido grande mobilização dos produtores 1.300 deles enviaram amostras. Em muitos casos, o investimento para recuperar o solo era mais elevado do que o valor das propriedades. Ainda assim, houve um grande esforço em experimentos e difusão do uso de fertilizantes, com resultados rápidos e animadores, expressos na arrecadação de tributos municipais, que tem forte elevação entre 1964 e 1967 (Rotta, 1999:79).

A "Operação Tatu" teria como fito a viabilização da produção de "soja, milho, suínos, aves e gado leiteiro, que eram apontados como indutores do desenvolvimento econômico da região" (Rotta, 1999:78, referindo depoimento de líder da operação). Os preços internacionais da soja, em fase de forte expansão, induziram uma virada no perfil da produção primária da Grande Santa Rosa, que na década de 60 esboça a sua guinada para tornar esse cultivo uma monocultura. Para isso, contribuíram os incentivos do poder público federal, que, especialmente nos anos 70, apoiou pesadamente a produção de commodities agrícolas, visando a gerar saldos na balança comercial.

O original da região da Grande Santa Rosa é o seu pioneirismo em introduzir o processo de modernização na agricultura familiar, adaptando o que já vinha sendo feito pelos granjeiros de trigo no Rio Grande do Sul e por outras experiências em nível de Brasil e exterior. As lideranças regionais aproveitaram bem a conjuntura favorável em nível nacional, que possibilitava a entrada de pequenos proprietários nos mecanismos de financiamento e incentivo governamental (...) (Rotta, 1999:81-2).

Ainda que a produção agrícola estivesse, nos anos 60, iniciando essa "conversão" para a monocultura, as lideranças regionais tinham em mente uma estratégia que buscava a diversificação e a integração das atividades econômicas. Em 1964, a ACISAP de Santa Rosa e outras lideranças dos municípios vizinhos provocam um processo de discussão sobre o desenvolvimento regional que está na origem da constituição da Associação dos Municípios da Grande Santa Rosa. Essa nova entidade, tão logo surge, contrata o IEPE-UFRGS para realizar um diagnóstico dos pontos críticos da economia regional. Os resultados apontam para a minifundiarização $(90 \%$ das propriedades encontravam-se abaixo do módulo rural), baixa produtividade, renda familiar insuficiente e expulsão de população. As alternativas, por sua vez, estariam na modernização da agricultura e na agroindustrialização, como forma de elevar o valor agregado da produção regional (Rotta, 1999: 82-83).

Assim, a modernização da agricultura empreendida no bojo da "Operação Tatu” viabilizou e foi viabilizada por atividades a montante e a jusante da produção primária: as máquinas e implementos agrícolas e as diferentes empresas "processadoras" de alimentos (Rotta, 1999:83). Os esforços dessas empresas no sentido de implementar as transformações identificadas como necessárias - incorporação de novas tecnologias e novos processos, qualificação da mão-de-obra, profissionalização da gestão, inserção competitiva no mercado, entre outros (Rotta, 1999:83) - 
tiveram resultados efetivos segundo Rotta, que se apóia na análise do grupo de sete firmas já referido acima, do qual voltarei a tratar.

Com essa nova inflexão na trajetória do desenvolvimento regional, os anos 70 têm um saldo de prosperidade, nucleado, inequivocamente, pela cultura da soja.

Logo em seguida a isso, veio o chamado milagre econômico brasileiro dos governos militares, liderado pelo Delfim Neto, e o Banco do Brasil passou a dar dinheiro subsidiado a rodo, pra agricultura, pra quê? Primeiro pra tirar os tocos da lavoura, (...) o colono antes derrubava a mata e deixava aquele toco de dois diâmetros de largura [sic], as raízes profundas, e ele ia com os boizinhos dele lavrando no meio, e plantando no meio disto, a mão - aí, pra mecanizar isso, tinha que vir o destocamento. E o Banco do Brasil começou a dar dinheiro pro colono contratar trator de esteira e isso e aquilo, pra fazer destocamento, pra fazer as curvas de nível, e aí fazer o quê? Aí comprar um trator pra lavrar, e aí comprar uma colheitadeira para colher e aumentar a produtividade e a produção, porque nos anos 70 o soja virou ouro pro mundo. Foi quando Santa Rosa teve um boom de crescimento muito grande (Ex-Prefeito de Santa Rosa, ago/06).

Na década de 1980, esse processo arrefece, embora ainda seja reconhecível. De qualquer forma, a expansão que tem seu ápice nos anos 1970, demonstrou-se, como destaca Rotta (1999), ainda mais excludente do que a de fases anteriores, pois

(...) excluiu do acesso ao trabalho e à terra aqueles que não conseguiram, por motivos diversos, incorporar os princípios da racionalidade industrial moderna, ou os relegou a atividades 'marginais'. Isso ocorreu em nível de agricultores familiares e assalariados urbanos, mas atingiu, com menor intensidade, os comerciantes e os industriais (Rotta, 1999:127).

Mesmo os produtores rurais que conseguiram se posicionar favoravelmente e se integrar no novo padrão de produção estariam enveredando em uma aposta perigosa, como, no presente, procuram demonstrar alguns depoimentos:

Aí veio a mecanização da agricultura que muda, né, muda a concepção, muda um sistema. Por fatores internacionais o soja dispara, tem um valor muito alto, o trigo também, nós tínhamos uma produtividade muito boa e nos preocupamos em produzir bastante na década de 70. E tinha subsídio, né? Na década de 80 começa a cair o subsídio, começamos a nos ressentir e a nossa propriedade, do sistema que nos levou à mecanização, houve um... Além do êxodo rural, houve também uma degradação do solo. (...) E aí, na década de 80, começa a diminuir a nossa produtividade. E na década de 90 sem subsídio, com baixa produtividade, passamos a ser castigados por anos de seca, né, e aí complicou a vida do agricultor, né? (liderança de Sindicato de Trabalhadores Rurais, 2002).

Depois veio a modernização da agricultura, a chamada operação Tatu, na década de 70 mudou completamente o panorama de Santa Rosa, porque veio o grande 'boom' da soja, todo mundo ficou rico, os primeiros anos da década de 70 foram anos de muita prosperidade e crescimento... Aí depois veio a cobrança das dívidas, aí foi um tal de colono se matando por aqui, viu? Então, Santa Rosa entrou num processo de decadência... não é decadência, mas uma estagnação. (...) Aí também tem a história do agrotóxico que entrou violentamente, e aí teve o êxodo rural que foi violento a partir de então. Porque com 25 hectares você não produz soja. Soja é para latifúndios; então os grandes foram engolindo os pequenos. Tanto que aqui, que é uma região de minifúndio, hoje tem 
propriedades de 1.200 hectares, isso aqui é uma exorbitância na estrutura fundiária dessa cidade, porque é 25 hectares [o padrão]. E aí começou o grande êxodo rural. Mas o grande êxodo mesmo! Santa Rosa de repente tinha 70, 80 vilas... (...) Os colonos vendiam as suas terras porque não dava mais para sobreviver - de dívidas até aqui - e vinham para a cidade. Aí aqui o que faziam? Engrossavam o cinturão de miséria na periferia, porque Santa Rosa tem vilas terrivelmente pobres (professora universitária, historiadora, 2002).

Os depoimentos citados exemplificam uma percepção generalizada dentre os atores entrevistados, de que efetivamente houve um surto de crescimento muito acentuado, no contexto que combinou modernização da agricultura e fortalecimento do setor industrial a ela vinculado, mas que esse impulso dependia muito fortemente de fatores instáveis, notadamente o favorável preço internacional da soja e os subsídios oferecidos pelo governo para a produção primária, em geral, e para os cultivos de exportação de forma especial. A seletividade — ou excludência dessa "original" experiência de tecnificação da agricultura familiar ocorrida na Grande Santa Rosa se expressa no êxodo rural, que redunda na constituição de bolsões de pobreza no eixo urbano da cidade-pólo e, também, na dinâmica demográfica da região em seu conjunto, que se demonstra expulsora de população. Esses fenômenos, que, nos anos 70 já estão presentes como contra-face da prosperidade, então no seu auge, passam a ganhar dimensão quando o eixo dinâmico da economia regional se fragiliza.

No diagnóstico elaborado em 1993( $\left({ }^{51}\right)$ para embasar o Plano Diretor de Santa Rosa, citado por Rotta (1999:111) o problema é expresso de forma contundente:

O crescente esvaziamento populacional da região de influência do município de Santa Rosa poderá configurar uma estranha situação: aquela de uma cidade que polarizaria o vazio. (...) Estabelecendo-se a relação entre o número de habitantes da cidade de Santa Rosa e o restante da população da região, tem-se para 1970 a relação de 1 para 14,4 "habitantes polarizados", já em 1991 a relação é de apenas 1 para 5,9.

A constante referência à evasão populacional põe em relevo a centralidade da dimensão demográfica na compreensão da dinâmica sócio-econômica região, o que será tratado na seção 5.4. Mas é preciso, primeiramente, caracterizar alguns aspectos da vida econômica da região em seu presente, em que a tensão expressa no excerto acima aparece de forma nítida, embora não sem ambivalências: vazio populacional e vazio econômico, aparentemente uma associação direta, nem sempre se verificam ou se prenunciam de modo linear. A economia da Grande Santa Rosa segue enfrentando desafios, mas em diferentes momentos alguns setores econômicos experimentam trajetórias ascendentes e imprimem novidades na estrutura dessa região.

\subsubsection{O quadro econômico presente}

${ }^{51}$ FIDENE/PREFEITURA MUNICIPAL DE SANTA ROSA. Plano diretor de desenvolvimento urbano. Ijuí: Fidene, 1993. 
Ao trazer a caracterização da economia regional para o período mais próximo, é interessante observar a dinâmica dos diferentes municípios que compõem a Grande Santa Rosa. Esse conjunto foi se constituindo gradativamente pelo desmembramento do ente municipal original, instituído em 1931. Nesse sentido, em que pese à fragmentação administrativa, o recorte desse espaço obedece a uma continuidade histórica flagrante.

Como procurei demonstrar acima, a região mantém uma "personalidade" econômica fortemente primária, tanto na geração da riqueza regional (comparativamente aos outros recortes geográficos utilizados na análise), quanto, sobretudo, na ocupação de sua força de trabalho. No agregado dos 20 municípios da Grande Santa Rosa, a agropecuária concentrava, em 2000, praticamente metade de todos os indivíduos que, conforme os critérios do Censo, trabalhavam.

Ainda assim, constituiu-se um parque industrial significativo - o qual teve um desempenho destacável, na década de 1990, como já foi também registrado - em que avultam as empresas produtoras de alimentos e, em especial, o "pólo metal-mecânico" - expressão que se consagrou na fala quotidiana da região, a julgar pelas entrevistas, pela leitura dos jornais locais e pelas conversas lá mantidas. Não é decisivo para os propósitos desta pesquisa discutir a apropriação do conceito de "complexo", também muito utilizado na região, à produção metalmecânica realizada na Grande Santa Rosa, mas o conjunto de empresas nela envolvido parece mostrar, efetivamente, crescente articulação, nucleado por duas grandes empresas. Uma delas, a AGCO, localiza-se em Santa Rosa; a outra, John Deere, em Horizontina. Ambas são unidades de empresas norte-americanas, que representam a continuidade - e a alienação - de duas firmas de grande significado econômico, histórico e simbólico, formadas há décadas com um caráter eminentemente local.

Antes de tratar desse segmento industrial específico, é interessante ter uma visão geral dos estabelecimentos instalados no território pesquisado, tomando-se por base dados da RAISEstabelecimentos.

\section{Tabela 3 - Número de estabelecimentos nos municípios da Grande Santa Rosa, em 2005, segundo o setor de atividade}

\begin{tabular}{|c|c|c|c|c|c|c|c|c|c|}
\hline & $\begin{array}{c}\text { EXTR } \\
\text { MINERAL }\end{array}$ & $\begin{array}{c}\text { IND } \\
\text { TRANSF } \\
\end{array}$ & $\begin{array}{c}\text { SERV } \\
\text { IND UP }\end{array}$ & $\begin{array}{c}\text { CONSTR } \\
\text { CIVIL } \\
\end{array}$ & COMERC & SERVICOS & $\begin{array}{c}\text { ADM } \\
\text { PÚBLICA }\end{array}$ & AGROPEC & TOTAL \\
\hline Alecrim & ( & 0 & 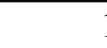 & 1 & 54 & 23 & 1 & 10 & 96 \\
\hline Alegria & ( & 6 & ( & 1 & 31 & 8 & 1 & 6 & 53 \\
\hline Boa Vista do Buricá & ( & 45 & & 26 & 102 & 43 & 1 & 3 & 221 \\
\hline Campina das Missões & ( & 16 & & 7 & 61 & 25 & 3 & 1 & 114 \\
\hline Candido Godói & ( & 20 & & 9 & 61 & 25 & 3 & 7 & 126 \\
\hline Doutor Mauricio Cardoso & ( & 8 & & 6 & 47 & 18 & 1 & 5 & 86 \\
\hline Horizontina & 1 & 67 & & 25 & 238 & 140 & 3 & 18 & 493 \\
\hline Independência & ( & 7 & & 1 & 34 & 16 & 2 & 39 & 100 \\
\hline Nova Candelária & ( & 8 & ( & 3 & 33 & 9 & 1 & 1 & 55 \\
\hline Novo Machado & ( & 1 & ( & 0 & 17 & 7 & 1 & 8 & 34 \\
\hline Porto Lucena & c & 7 & & 0 & 32 & 17 & 2 & 9 & 68 \\
\hline
\end{tabular}




\begin{tabular}{|c|c|c|c|c|c|c|c|c|c|}
\hline Porto Mauá & 0 & 1 & 0 & 0 & 24 & 8 & 2 & 4 & 39 \\
\hline Porto Vera Cruz & 0 & 0 & 0 & 0 & 11 & 4 & 1 & 1 & 17 \\
\hline Santa Rosa & 1 & 233 & 4 & 103 & 781 & 499 & 6 & 86 & 1.713 \\
\hline Santo Cristo & 1 & 58 & 1 & 13 & 157 & 98 & 1 & 38 & 367 \\
\hline São Jose do Inhacorá & 0 & 7 & 1 & 2 & 17 & 5 & 1 & 3 & 36 \\
\hline Senador Salgado Filho & 0 & 6 & 0 & 0 & 10 & 5 & 1 & 11 & 33 \\
\hline Três de Maio & 1 & 110 & 2 & 25 & 274 & 170 & 1 & 22 & 605 \\
\hline Tucunduva & 0 & 11 & 1 & 2 & 67 & 26 & 1 & 17 & 125 \\
\hline Tuparendi & 0 & 29 & 1 & 2 & 74 & 43 & 3 & 23 & 175 \\
\hline Total da região & 4 & 646 & 18 & 226 & 2.125 & 1.189 & 36 & 312 & 4.556 \\
\hline
\end{tabular}
FONTE: MTE/RAIS (2005)

A par da forte concentração da atividade econômica no município de Santa Rosa coadjuvado por Três de Maio e Horizontina -, a qual tem como reverso a acanhada estrutura empresarial em localidades como Porto Vera Cruz, Senador Salgado Filho etc., podem-se destacar, a partir dos dados da tabela, algumas evidências. O comércio é o setor que reúne praticamente metade dos estabelecimentos da Grande Santa Rosa (46,6\%), seguido dos serviços (26,1\%). A indústria de transformação vem em terceiro lugar (14,2\%).

As diferenças na distribuição setorial dos estabelecimentos em cada município são bastante elevadas. Tomando-se alguns exemplos: os agropecuários chegam a atingir participação de 39,0\%, em Independência, tendo como mínimo 0,9\% de representatividade em Campina das Missões; a indústria de transformação oscila de zero, em Porto Vera Cruz, a 20,4\% dos estabelecimentos, em Boa Vista do Buricá; o comércio tem como parcela mais baixa os 30,3\% que ostenta em Senador Salgado Filho, chegando ao máximo de 64,7\%, em Porto Vera Cruz.

Esses dados só adquirem seu alcance mais efetivo - sem que se esqueçam também seus limites, uma vez que se restringem ao universo de estabelecimentos formalizados que apresentaram declaração ao Ministério do Trabalho - quando se incorporam os contingentes de trabalhadores empregados. Optei por abordar apenas no próximo capítulo os indicadores e questões relativos à ocupação da mão-de-obra, o que implica um tratamento breve, aqui, das informações da RAIS Estabelecimentos.

Um dos aspectos que mais interessa reter é essa dimensão tão reduzida, em termos relativos - vale dizer: quando se pensa no contraste com os recortes territoriais tradicionalmente utilizados para a observação e a análise de mercados de trabalho -, do universo de potenciais empregadores, tanto no agregado da região quanto, sobretudo, na esmagadora maioria das unidades municipais que a compõem. Com esse intuito, a análise dos dados desagregados por porte do estabelecimento (conforme o número de empregados) é indispensável.

Em primeiro lugar, quando se excluem aqueles estabelecimentos que, mesmo tendo declarado a RAIS em 2005, não tinham nenhum empregado, o total regional reduz-se em 14,2\% (passa a 3.909). Esse estrato de declarantes com "zero empregados" ultrapassa $20 \%$ em Alegria e 
Novo Machado, os casos extremos, encolhendo ainda mais um conjunto de firmas que já havia se demonstrado bastante exíguo.

Estabeleci um segundo corte nesse universo de estabelecimentos, arbitrando um valor mínimo de 50 empregados. Esse procedimento visa não apenas a dimensionar o conjunto resultante, mas a localizá-lo espacialmente e a identificar as atividades econômicas que, uma vez ancoradas em firmas mais robustas, podem ser tomadas como mais representativas do tecido produtivo regional (Tabela 7, anexa a este capítulo).

Novamente, uma primeira observação pode ser feita a respeito da concentração espacial dos estabelecimentos de "maior" porte (50 empregados ou mais): metade dos vinte municípios integrantes da Grande Santa Rosa não contavam com nenhum, salvo o poder público municipal. Das dez municipalidades que o critério permitiu incluir, cinco compareceram com apenas um estabelecimento acima da dimensão mínima fixada ${ }^{52}$. A cidade-pólo detinha mais da metade (35) dos 66 empregadores regionais que atingiam a magnitude definida. Somando-se Três de Maio e Horizontina, constata-se que três municípios, dentre os 20 , sediavam $85 \%$ desses estabelecimentos. Sendo propositalmente redundante: dez dos vinte municípios não contavam com um estabelecimento, sequer, em que trabalhassem 50 empregados ou mais (salvo a administração pública).

Quanto às atividades desenvolvidas, é fácil identificar os três destaques: o único estabelecimento regional com mais de mil empregados localiza-se em Horizontina e produz máquinas agrícolas (trata-se, inequivocamente, da John Deere); no mesmo gênero industrial encontra-se uma das duas únicas empresas entre 500 e 999 trabalhadores (a AGCO, em Santa Rosa, classificada como fabricante de tratores). Até por isso, o "pólo" das máquinas agrícolas será objeto de algumas considerações mais detidas, a seguir. Acompanha a AGCO nesse segundo maior estrato de porte, a completar o trio dos maiores empregadores, um estabelecimento de "abate de reses (...)", no qual não é difícil reconhecer o Frigorífico Alibem - empresa que sucede o lendário "Prenda", que antes passou por outras reviravoltas patrimoniais, como se verá adiante.

Dois terços dos estabelecimentos com mais de 50 empregados encontram-se no intervalo até 99 trabalhadores, e os totais recuam progressivamente, até se chegar a um único representante

\footnotetext{
${ }^{52}$ Cabe registrar que o único estabelecimento que, presumivelmente, propiciou a inclusão de Boa Vista do Buricá - vinculado à empresa Reichert, fabricante de calçados - foi fechado, no segundo semestre de 2007, como todas as plantas daquela firma, que tinha matriz na serra gaúcha e produzia em diversos municípios do Estado, tendo sete décadas de atividade. Em entrevista que realizei em agosto de 2006, um integrante da Administração Municipal de Boa Vista do Buricá declarou, a respeito da presença dessa empresa na cidade: "eles preferem as pessoas daqui, porque nós temos muitas pessoas de origem italiana, alemão... Eles acham, sei lá, que tem mais dedicação a isso aí". E ainda: "Em 1975, acho, que veio pra cá. Pequeno, na época, mas foi crescendo. Hoje, se fechar isso aí, é complicado, né. (...) Apesar que ganham pouco. Mas a questão é assim: às vezes, trabalham cinco, quatro pessoas, de uma família, e conseguem sobreviver, até viver mais ou menos bem. E essa empresa também tem um sistema de mão-de-obra de casa em casa (...). As pessoas fazem em casa; casais já de mais idade, que não têm emprego, aposentados, inclusive". Segundo o entrevistado, esses trabalhadores no sistema à-la putting-out não eram contabilizados no efetivo da Reichert local, o qual ele estimava, naquele momento, em 400 empregados.
} 
no grupo de "mil ou mais". No que diz respeito às atividades que esses 66 estabelecimentos desenvolvem, há uma considerável variedade: os serviços - especialmente ligados à educação e à saúde, mas ainda os financeiros e outros - têm uma representatividade digna de nota, ladeando os estabelecimentos industriais (em que, sem surpresa, se destacam produtores e fornecedores da metal-mecânica e a produção de alimentos) e um bom número de estabelecimentos comerciais, em diversas especialidades.

Nesse segmento de estabelecimentos, é marcante a ausência de empresas estritamente agropecuárias. De fato, prolongando a marca histórica da colonização, a região se caracteriza por propriedades bastante pequenas e pelo trabalho familiar. Dos 312 estabelecimentos que a RAIS identificou, no setor primário da região, em 2005, quase $90 \%$ - nada menos do que 274 - tinham até quatro empregados, sendo que 49 compareciam na declaração sem nenhum trabalhador contratado.

É elucidativo caracterizar o elenco das principais firmas do município de Santa Rosa pelo critério de geração de ICMS, não apenas por se tratar de uma indicação de "dianteira" empresarial, na cidade-pólo, mas também porque permite indicar - a pretexto de uma matéria do principal jornal local - um aspecto simbólico recorrente nas falas dos entrevistados e demais habitantes da região, bem como realçar um ponto que unifica a trajetória recente de praticamente todas as empresas de maior porte (e significado histórico) da região.

Começando-se pelo aspecto simbólico: na edição que assinalava os 76 anos da fundação do município, em 2007, o jornal Noroeste estampou em sua contracapa a matéria "Nossas grandes empresas foram criadas por gente daqui", que trazia como abertura: "Vale a pena continuar sonhando (sic) com grandes empreendimentos para sacudir a economia do município. Porém, a história prova que ao longo de mais de sete décadas e meia os grandes projetos empresariais de Santa Rosa tiveram origem no empreendedorismo local" (Noroeste, 09.08.07, p.24).

Esse caráter local das firmas aparece muito freqüentemente nas falas, mesmo quando contraria a tendência recente - inegável - de alienação, que exporei abaixo. A reportagem, ao abordar essas onze empresas, termina por deixar evidente que o "empreendedorismo local" não foi suficiente para evitar que os principais estabelecimentos passassem para mãos "não-locais"; conclui que "alguns dos grandes projetos apenas trocaram de donos, mas permanecem aqui" (idem, grifo meu).

Não resta dúvida de que a presença desses estabelecimentos geradores da riqueza é um componente central da própria constituição da instância local - e regional -, e que a "localização" (ou "origem") dos detentores desses capitais, por si mesma, tem um alcance limitado no que diz respeito aos efeitos econômicos de tais empreendimentos sobre essa formação espacial. O que está em questão no discurso parece muito menos alguma problemática relativa à apropriação (e à 
localização) dos ganhos da atividade econômica do que uma afirmação identitária de autonomia e capacidade de realização da população da cidade - presumivelmente combalida.

Por outro lado, na Grande Santa Rosa é reconhecível - para além dessa "troca de dono" de empresas que, de fato, tiveram origem em iniciativas locais - que nenhuma implantação de firmas "de fora" tem acontecido. Esse elemento tão central, contemporaneamente, nos projetos de desenvolvimento local, aparece com freqüência no debate público que ocorre na região estudada e é muitas vezes contraposto a um sentimento que se poderia associar a um "orgulho autárquico", que contorna as evidências contrárias.

Na verdade, assim: novas empresas, a gente vê abrir e fechar todo dia, que nem em qualquer lugar. Pessoas com um sonho na cabeça; muitas dão certo, e muitas mais não dão certo (...). Eu estava numa entrevista na rádio, esses dias, e o radialista me perguntou se eu sabia de algum novo empreendimento em Santa Rosa, que não sei quê, pro desenvolvimento do município. Eu digo: "Tchê, que eu saiba, coisas de impacto não tem". Disse assim: "Mas tu está triste, tu acha ruim?"; - "É, porque lá em Carazinho [município de outra região] eles estão fomentando um não sei o quê de leite lá"; - "Não, eu até acho legal. Mas pergunta se Carazinho troca essa usina de leite por uma AGCO a pleno, uma Alibem [firma "local"] a pleno e um Camera [idem] expandindo. Vê se ele troca!".

Não tem um incremento de novos investimentos, mas sim a consolidação dos empreendimentos daqui, muito forte. (...) Claro, todo mundo adoraria, uma vez por mês, conseguir divulgar: "Ó, vai vir uma empresa, de não sei aonde, para abrir 50, 60 postos de trabalho em Santa Rosa". Qual é o município, qual é o prefeito, qual é a associação industrial que não corre atrás disso todo dia? Te pergunto. Pede se alguém vai divulgar aí no estado: "Ah, uma firma de não sei o que está procurando um município para se instalar". Quantos por cento dos municípios do estado tu acha que se candidatariam? Cem por cento! Lógico, então isso é muito... atirar muito confete para cima. (...) Só um pouquinho: vamos olhar para os lados! Se, pelo menos, não teve grandes empreendimentos, os que tem estão se consolidando e aumentando. Nós estamos crescendo (presidente da ACISAP, Santa Rosa, mai.07).

Essa fala do presidente da associação empresarial de Santa Rosa alude diretamente a três das onze empresas líderes na arrecadação de ICMS no município, que eu passo a reproduzir. São elas:

Frigorífico Alibem,

AGCO do Brasil,

Rio Grande Energia (RGE),

Pioneer Sementes,

Camera Agroalimentos,

Steffen Bebidas,

Brasil Telecom,

Avipal,

Corsan,

Coopermil,

Cotrirosa (Noroeste, 09.08.07, p.24) 
Convém, inicialmente, pôr à parte três dessas firmas, prestadoras de serviços de utilidade pública - uma estatal (Corsan) e duas sucedâneas de empresas públicas privatizadas (Brasil Telecom e RGE) $)^{53}$.

Uma segunda "secção" desse rol de empresas poderia reunir as duas últimas cooperativas, fundamentalmente de pequenos produtores rurais, as quais têm assumido um perfil cada vez mais próximo ao de empresas privadas, no que diz respeito à gestão. A Coopermil foi fundada em Tuparendi, em meados dos anos 1950, e teria, hoje em torno de 4 mil associados, de acordo com entrevista que realizei na empresa em julho de 2006. A Cooperativa Tritícola Santa Rosa (Cotrirosa) foi criada em 1968, por 77 agricultores, e atualmente tem 5.400 sócios, segundo a página da empresa na internet ${ }^{54}$. A mesma fonte informa que "a cooperativa está implantando um projeto de reestruturação, adequando-se à realidade econômica implantada no país". Muitos depoimentos que colhi afirmaram que é bastante similar a forma de gestão das principais cooperativas que atuam na região - conjunto que inclui ainda, a Cootrimaio, originária de Três de Maio, e a COMTUL, de Tucunduva, entre outras (todas com presença em diversos municípios da Grande Santa Rosa). Algo próximo a essa "reestruturação" aludida no site da Cotrirosa vem sendo implementado de forma progressiva em todas elas, como testemunharam líderes de sindicatos rurais e mesmo um prefeito, ressentidos pelo caráter excludente de algumas decisões operacionais que visam à elevação da qualidade e da produtividade, que os associados menos capacitados ou menos dotados de recursos não conseguiriam acompanhar ${ }^{55}$.

A empresa Steffen Bebidas é comercial, distribuidora dos produtos da AMBEV, e, como informa o jornal, é recente.

A Pioneer Sementes, por sua vez, nem volta a ser mencionada no texto da reportagem, quando se qualificam os onze empreendimentos, possivelmente por não ter laços mais sólidos com o "empreendedorismo local": integra uma multinacional de origem norte-americana que opera no Brasil desde 1970. Em 1999, celebrou-se a "completa aquisição da Pioneer Hi-Bred International pela tradicional empresa da área química E. I. DuPont de Nemours \& Company, com sede em

\footnotetext{
${ }^{53}$ A Corsan (Companhia Rio-grandense de Saneamento) é estatal, vinculada à Secretaria da Habitação, Saneamento e Desenvolvimento Urbano do Governo do Estado do Rio Grande do Sul. A Brasil Telecom, no Rio Grande do Sul, foi a primeira empresa a assumir a telefonia fixa após a privatização da Companhia Riograndense de Telecomunicações - CRT -, em 1998; de modo semelhante, a RGE, vinculada ao grupo CPFL, abastece de energia elétrica o norte e o noroeste do Rio Grande do Sul, responsabilidade que até 1997 estava a cargo da Companhia Estadual de Energia Elétrica - CEEE -, empresa pública.

${ }^{54} \mathrm{http}: / /$ www.cotrirosa.com.br/, acessado em 27 de outubro de 2007.

${ }_{55}$ Esse prefeito me disse, em julho de 2006, que a principal cooperativa que atua em seu (pequeno) município "virou empresa", e "não ajuda mais o pequeno produtor". Segundo ele, a funcionar nesses moldes, deveria perder as vantagens fiscais que a legislação concede às instituições cooperativas. Transcrevo partes do depoimento tomado na Coopermil: "Eu acho que o benefício do pequeno, ele se dá muito mais, vamos dizer assim, na prestação de serviço da cooperativa do que no retorno [financeiro]. (...) Nós achamos que a cooperativa tem que trabalhar o lado econômico, tu tem que ter visão econômica. (...) Se não, se tu vais começar a olhar o lado social, vai ter reunião para ouvir um monte de choradeira, de "quero isto, quero aquilo", acho que a cooperativa não é este o... (...) P - E qual é o aspecto cooperativo desse supermercado [que responde por $30 \%$ do faturamento da cooperativa]? R - Eu não tenho, eu não acredito que ele tenha uma função cooperativa: é um negócio...” (dirigente de cooperativa, jul. 2006).
} 
Wilmington, Delaware, que já detinha uma participação de $20 \%$ da Pioneer desde agosto de 1997", como informa a home-page da Pioneer ${ }^{56}$.

Chega-se, então, às "últimas" quatro grandes geradoras de ICMS ${ }^{57}$. Essas têm em comum atributos relevantes: são estabelecimentos industriais, com décadas de atividade contínua no município; nasceram de iniciativas (e capitais) genuinamente locais e, em algum momento após sua consolidação, passaram por mudanças patrimoniais que as retiraram do controle dos personagens da região.

Essas quatro empresas, ademais, se constituem em uma intersecção entre o grupo de que venho tratando - as onze principais geradoras de ICMS do município de Santa Rosa - e o elenco de sete empreendimentos, anteriormente aludido, que Rotta (1999) toma como exemplares do processo de modernização e do êxito empresarial (neste caso, no âmbito da região) logrado a partir da "Operação Tatu", deflagrada nos 1960. A elas:

- O Grupo Eleva (que tem origem na fundação da empresa Avipal, em 1959, em Porto Alegre) detém hoje, com a designação Elegê, uma planta cuja história se inicia em 1949, em Santa Rosa: a Laticínios Mayer teve um papel chave na modernização da cadeia regional do leite; foi adquirida em 1981 pela Cooperativa Central Gaúcha de Leite (CCGL). Em 1996, o Grupo Avipal comprou a CCGL, alterando sua denominação para Elegê Alimentos. Atualmente, a Avipal e a Elegê são marcas da Eleva, designação adotada em 2007 para o Grupo;

- A Camera Agroalimentos S/A opera em Santa Rosa desde 1998; entre outras atividades, retomou a industrialização de óleos vegetais que havia principiado com a Indústria Gaúcha de Óleos Vegetais (IOL), fundada no município em 1955. Esta cresceu e diversificou-se, originando o grupo Olvebra, que, nos anos 70, se consolidou no Brasil e no Exterior. A sede foi transferida para Porto Alegre nos anos 80, e a unidade de Santa Rosa foi desativada, em 1993, assim permanecendo até a aquisição pelo Camera (que tem origem no município de Tucunduva, na região da Grande Santa Rosa);

- O Frigorífico Alibem é o dono atual do lendário Frigorífico Santa-rosense S.A., a seguir denominado Prenda, cuja constituição em Santa Rosa, nos anos 1950, foi tratada no item anterior. Ostentando, segundo Rotta, solidez e inovatividade - e tendo chegado a contar com 1,6 mil funcionários (Rotta, 1999, p.104) - o Prenda foi vendido, no final da década de 1990, ao grupo Chapecó - que, por sua vez, havia sido adquirido pelo grupo argentino Macri. Em meio a uma crise da suinocultura e a problemas financeiros da empresa, a presente década iniciou-se com muitas demissões, e, em 2003, ocorreu o fechamento da unidade. O Grupo Chapecó faliu, e o Alibem (fundado no ano 2000, em Porto Alegre) é, desde 2003, o locatário da planta de Santa Rosa, enquanto não vai a leilão a massa falida - que o Alibem demonstra interesse em comprar

${ }^{56} \mathrm{http}$ ://www.pioneersementes.com.br/InstitucionalPioneerBrasil.aspx , acessado em 27 de outubro de 2007. ${ }^{57} \mathrm{~A}$ ordem em que as empresas são tratadas, aqui, obedece ao interesse da exposição, não a critério quantitativo. $\mathrm{O}$ jornal não informa se sua listagem segue o montante do tributo gerado - tampouco disponho desse dado. 
(Noroeste, 22.06.07). É hoje o maior empregador de Santa Rosa. Se, na RAIS 2005, se podia deduzir que não atingia a marca de mil trabalhadores, em abril de 2007 já contava com 1,2 mil empregados (Noroeste, 13.04.07).

- A AGCO do Brasil, subsidiária da transnacional norte-americana, é a atual detentora do espólio de outra empresa que teve grande significado histórico na Grande Santa Rosa. A Indústria de Máquinas Agrícolas Ideal foi constituída em 1963, a partir da Fábrica de Moinhos Santa Rosa Ltda., de 1953. Em 1973, tornou-se S/A, e a alienação foi progressiva. Nos anos 80, o controle pertencia ao grupo Iochpe, que adquiriu e nacionalizou a Massey Perkins S/A, detendo a marca mundial Massey Ferguson no Brasil. A razão social foi alterada para Maxion S/A. Em 1996, a norte-americana AGCO adquiriu parte da Maxion, passando a deter $100 \%$ da unidade de Santa Rosa. Pouco antes dessa mudança mais recente de titularidade, iniciara-se uma política de terceirização na empresa.

O depoimento de um empresário do segmento metalúrgico, também dirigente da ACISAP, colhido em julho de 2006, permite reconstituir em grandes linhas o processo que se desencadeou:

[A Iochpe/Maxion decide] "Vamos terceirizar. Nós temos uma previsão de produção grande, nós precisamos ampliar a linha de montagem. E pra nós ampliar, de repente nós abrimos espaço interno tirando parte da fabricação, da produção de peças pra terceiros, pra pequenas empresas que já estão instaladas em Santa Rosa hoje”. Santa Rosa já tinha, na época, sei lá, dez, 12 empresas pequenas, micro-empresas, metalúrgicas que faziam qualquer segmento. (...) Claro que nos bastidores aconteceu toda uma negociação, toda uma articulação. Mas, enfim, a idéia central foi essa. (...) Primeiro foi fortalecidas aquelas pequenas empresas que estavam aí, que se dispuseram a receber esse equipamento, a ser fornecedor. E segundo momento, algumas pessoas de dentro da empresa que se dispuseram a sair da empresa e começar o negócio. E naquela oportunidade se formaram 13 "parceiros", que se chamava na época - os parceiros da Maxion. (...) Um dos fatores pra fazer isso, o que era? Era ter redução de custos. Se pensava em pequenas empresas familiar, né, tocada lá pelo pai, pela mãe, pelo filho, pelo tio, pelo primo, enfim, pequenos grupos familiares que pudessem conduzir a empresa com uma mão-de-obra mais barata, né, uma mão-de-obra que pudesse ser competitiva, e tornar a montadora competitiva. Empresas num fundo de quintal, num fundo de garagem, né - esse era o modelo que se enxergava. E foi assim, mais ou menos, que começou o negócio. O desenvolvimento desse pólo se deu porque, no mesmo momento em que essas empresas eram familiares e pequenas, a Maxion crescia no mercado e vinha as exigências. Por exemplo: começou a entrar o boom da certificação, de ter qualidade, aquela coisa toda. E a Iochpe também se qualificou, entrou na qualificação de ISO, e, conseqüentemente, os fornecedores precisaram seguir o mesmo caminho (proprietário de empresa metalúrgica, dirigente da ACISAP de Santa Rosa, jul. 2006)

Constituiu-se um conjunto que atualmente soma algo em torno de 30 firmas. Algumas dessas empresas metalúrgicas menores chegam a 100 empregados, e muitos relatos são de que elas vêm ampliando seu mercado para além da $\mathrm{AGCO}$ e da região. Evidentemente, dessa primeira turma de "parceiros" de que fala o entrevistado, vários não conseguiram se manter no mercado. Porém, de maneira geral, essa trajetória típica do ex-funcionário que começa em "fundo de quintal" e consegue gradativamente fazer crescer sua empresa, por meio de uma vinculação quase de dedicação à Maxion/AGCO, foi confirmada por inúmeros testemunhos. 
A AGCO em Santa Rosa possuía, em junho de 2007, 410 empregados e 40 estagiários (Noroeste, 13.07.07). Nos meses seguintes, sucessivas levas de admissões foram anunciadas, sendo previsto um aumento de 100 funcionários ao longo do ano (Noroeste, 03.08.07). Os anos de 2005 e 2006 foram de aguda crise para os produtores de máquinas agrícolas, em todo o país. Inversamente, em seu auge, na primeira metade da presente década, a AGCO teria atingido, em Santa Rosa, a marca de "mil e poucos" funcionários, segundo a funcionária do departamento de Recursos Humanos que entrevistei na planta, em maio de 2007.

Esse grupo de quatro empresas que venho de destacar, dentre as onze maiores geradoras de ICMS em Santa Rosa, evoca o elemento, acima anunciado, que unifica a trajetória das firmas mais emblemáticas da região: os processos de transferência patrimonial foram uma constante, especialmente no contexto da reestruturação da economia brasileira da década de 1990, expondo o processo pelo qual o território estudado é atravessado pelos "vetores" (se quisermos usar a imagem de Milton Santos) que provêm de outras escalas espaciais. As firmas locais são adquiridas por grupos sediados em outras regiões do Rio Grande do Sul ou do restante do país e, com destaque muito especial, por grandes transnacionais - caso específico das duas grandes empresas produtoras de máquinas e equipamentos agrícolas. Como já foi indicado, ao lado da AGCO - e com dimensões bastante superiores -, desde o final dos anos 1990 a John Deere do Brasil, líder mundial na produção de equipamentos agrícolas e florestais, está sediada na região, após concluir a aquisição gradativa da histórica SLC, empresa de Horizontina - de que tratarei com algum vagar no capítulo 7.

Como já disse, há considerável superposição entre esse conjunto das onze maiores geradoras de ICMS no município de Santa Rosa e o elenco de sete firmas que Rotta utiliza em seu estudo (1999) como epítome da pujança e das transformações empresariais ocorridas no conjunto da região, notadamente a partir da "Operação Tatu”. São justamente as quatro últimas que venho de abordar - o laticínio, o frigorífico, a metal-mecânica e a processadora de óleos - que se repetem nos dois grupos. Complementando a seleção feita por Rotta, tem-se mais uma empresa de Santa Rosa, outra de Tuparendi e, evidentemente, a grande fábrica de colheitadeiras de Horizontina. A elas.

- Irmãos Fankhauser Ltda., sediada em Tuparendi, tem início como uma oficina de consertos de equipamentos mecânicos, em 1948. Acompanhando-se o histórico apresentado na home-page da empresa:

Por volta de 1960, demonstrando seu pioneirismo, projetam e passam a produzir ferramentas manuais. Porém, um acordo governamental entre Brasil e Japão permite que sejam importadas ferramentas daquele país, sem impostos. Isso faz com que a produção local seja interrompida, ocorrendo um duro revés para a empresa, que havia investido seus recursos no projeto. (...) Seu gênio inventivo, porém, os leva a produzir uma pequena plantadora adubadora de tração animal, no ano de 1961, a qual vem a tornar-se o carro chefe do crescimento da empresa na década. 
A firma prossegue sua trajetória especializando-se na produção de implementos agrícolas de menor complexidade, como as plantadeiras - especialmente os não-motorizados. Pelos dados apresentados acima, da RAIS 2005, deduz-se que, naquele ano, a Fankhauser tinha entre 100 e 249 empregados. Tanto em 2002 quanto em 2006-7, todas as vezes em que essa empresa foi mencionada em entrevistas e conversas, atribuíram-lhe uma situação de grande fragilidade. Em maio de 2007, um jovem operário de Horizontina, falando sobre seu município natal, Tuparendi, disse-me que "com a queda de produção [de 2005 e 2006] ela [a Fankhauser] quase foi à falência. (...) Eu acho que eles tinham uns 150 [empregados], um tempo atrás, mas daí demitiram um eito. Não sei se tem 100". Em contato com a empresa, fui informado, em outubro de 2007, que a Fankhauser tinha então 88 empregados efetivos e quatro estagiários.

- A Ervateira Vier, com sede em Santa Rosa, fundada em 1945, que produz erva-mate, dando prosseguimento a um cultivo cuja tradição, na região, precede a própria colonização, como se viu acima.

- A John Deere, que englobou a antiga SLC (Schneider, Logemann e Cia.). Sediada em Horizontina, esta última teve vigorosa expansão desde sua fundação, em 1945. Conquistou cerca de um terço do mercado nacional e metade das exportações brasileiras de colheitadeiras (Rotta, 1999:87). Sua associação com a Deere \& Company, nos anos 70, impulsionou-a. A participação da empresa norte-americana, de 20\%, inicialmente, elevou-se para $40 \%$, em meados dos anos 90 , atingindo $100 \%$ no final da década, quando a empresa teve alterada sua denominação. Segundo entrevista que realizei no departamento de recursos humanos, em 2002, a empresa tinha aproximadamente 1,8 mil funcionários efetivos e mais de 200 trabalhadores com vínculos de estágio ou contratos temporários, naquela época. Em maio de 2007, entrevistando a mesma funcionária, fui informado de que o auge da empresa, em contingente, deu-se em 2004, quando 2,1 mil empregados efetivos encontravam-se em atividade. Na crise de 2005 e 2006, teriam sido demitidos quase 600 deles, e o movimento, no momento dessa minha segunda visita, em que a retomada dos negócios parecia se consolidar como horizonte, era de cautelosa recomposição do quadro, com sucessivas levas de contratações. O contingente estaria retornando ao nível de 2002, próximo aos 1,8 mil funcionários efetivos ${ }^{58}$.

Encerrada com a John Deere essa caracterização - duplamente informada (pelo livro de Rotta e pelo Jornal Noroeste) - de empreendimentos-chave na economia regional, convém que se digam duas palavras a respeito do chamado "pólo metal-mecânico". Esse é muito valorizado pelos atores regionais como foco de dinamismo, o que, de resto, é bastante constatável: a RAIS mostra

${ }^{58}$ Conforme o site da empresa, a unidade de Horizontina teria 2,5 mil empregados, total que ultrapassa qualquer menção recolhida em campo, incluída aí duas entrevistas realizadas na planta, em 2007. De qualquer forma, é avassalador o vulto desse estabelecimento em município do porte de Horizontina, e é igualmente inequívoco que o movimento recente é de retomada do emprego no segmento. No capítulo 7 , retomo a caracterização dessa planta, a partir do ponto de vista de sua relação com a localidade de Horizontina. 
que a soma dos empregos dos subsetores "indústria metalúrgica" e "indústria mecânica" cresceu de modo muito significativo: em 1989, no total regional, ele era de 2.965; em 1999, chegava a 3.055, o que se poderia considerar digno de nota, tendo em vista a forte desverticalização por que passou, naquela década, a Maxion/AGCO, com centenas de postos de trabalho eliminados. Chegando-se a 2005, a soma dos dois subsetores, no agregado da Grande Santa Rosa, era de 4.824 trabalhadores declarados ao Ministério do Trabalho - um incremento de 58\% nesse intervalo mais recente de seis anos.

Dentre outros fatores, segundo inúmeros depoimentos, o "Programa de Modernização da Frota de Tratores Agrícolas e Implementos Associados e Colheitadeiras" (Moderfrota), criado ao final da década de 90, pelo Governo Federal, repercutiu muito favoravelmente sobre esse segmento produtivo.

Uma rápida olhada na distribuição dos postos de trabalho da indústria metal-mecânica, segundo os municípios e os portes dos estabelecimentos, permite deduzir que a soma de AGCO e John Deere (as maiores, nos respectivos municípios) atinge 58\% do emprego setorial regional. Mesmo que, em vários casos, ostentando "estoques" desprezíveis (sete deles com menos de dez empregados), é interessante observar que 17 dos 20 municípios apresentaram declarações de emprego formal nessas atividades econômicas. Ainda assim, Horizontina atinge praticamente a metade (48,7\%) do total; nela, a John Deere, sozinha, ostenta 43,5\% do emprego no "pólo" metalmecânico da Grande Santa Rosa.

Tabela 4 - Empregados nos subsetores indústria metalúrgica e indústria mecânica, nos municípios da Grande Santa Rosa, conforme o porte do estabelecimento - 2005

\begin{tabular}{lrrrrrrrrrrr} 
& até & 5 & $5-9$ & $10-19$ & $20-49$ & $50-99$ & $100-249$ & $250-499$ & $500-999$ & 1000 ou + Total \\
\hline Alecrim & 1 & 0 & 0 & 0 & 0 & 0 & 0 & 0 & 0 & 1 \\
Alegria & 2 & 0 & 0 & 0 & 0 & 0 & 0 & 0 & 0 & 2 \\
Boa Vista do Buricá & 9 & 17 & 0 & 24 & 0 & 0 & 0 & 0 & 0 & 50 \\
Campina das Missões & 5 & 6 & 0 & 0 & 0 & 0 & 0 & 0 & 0 & 11 \\
Candido Godói & 3 & 5 & 0 & 46 & 0 & 0 & 0 & 0 & 0 & 54 \\
Doutor Maurício Cardoso & 2 & 0 & 0 & 0 & 0 & 0 & 0 & 0 & 0 & 2 \\
Horizontina & 17 & 22 & 23 & 44 & 146 & 0 & 0 & 0 & 2.098 & 2.350 \\
Independência & 0 & 0 & 0 & 0 & 0 & 166 & 0 & 0 & 0 & 166 \\
Nova Candelária & 1 & 0 & 0 & 0 & 0 & 0 & 0 & 0 & 0 & 1 \\
Novo Machado & 1 & 0 & 0 & 0 & 0 & 0 & 0 & 0 & 0 & 1 \\
Santa Rosa & 62 & 61 & 191 & 279 & 426 & 147 & 0 & 696 & 0 & 1.862 \\
Santo Cristo & 17 & 0 & 51 & 0 & 0 & 0 & 0 & 0 & 0 & 68 \\
São José do Inhacorá & 0 & 0 & 0 & 22 & 0 & 0 & 0 & 0 & 0 & 22 \\
Senador Salgado Filho & 0 & 5 & 0 & 0 & 0 & 0 & 0 & 0 & 0 & 5 \\
Três de Maio & 17 & 14 & 16 & 43 & 0 & 0 & 0 & 0 & 0 & 90 \\
Tucunduva & 7 & 0 & 0 & 0 & 0 & 0 & 0 & 0 & 0 & 7 \\
Tuparendi & 4 & 0 & 0 & 0 & 0 & 128 & 0 & 0 & 0 & 132 \\
\hline Total da região & $\mathbf{1 4 8}$ & $\mathbf{1 3 0}$ & $\mathbf{2 8 1}$ & $\mathbf{4 5 8}$ & $\mathbf{5 7 2}$ & $\mathbf{4 4 1}$ & $\mathbf{0}$ & $\mathbf{6 9 6}$ & $\mathbf{2 . 0 9 8}$ & $\mathbf{4 . 8 2 4}$ \\
Fonte: MTE/RAIS 2005. & & & & & & & & &
\end{tabular}


Por outro lado, quase 1,6 mil empregos desses subsetores encontram-se distribuídos entre estabelecimentos de até 99 trabalhadores. Ainda assim, mesmo quando se tomam apenas essas plantas de tamanho menor, a concentração espacial é flagrante: $80 \%$ dos empregos nesse "estrato" de empresa localizam-se em Santa Rosa ou Horizontina. Esse aspecto é coerente com as informações levantadas nas entrevistas, que enfatizam que as externalizações progressivamente efetuadas pelas duas grandes empresas envolveram, em um número significativo de casos, a formação de novas empresas. Trabalhadores até então empregados em cada uma delas foram incentivados e apoiados para constituírem estabelecimentos e se tornarem fornecedores, como atesta o depoimento há pouco apresentado. Esse tipo de estratégia me foi descrito já em 2002, quando se tratava da AGCO. À época, a John Deere ainda se mantinha bastante verticalizada. Em minha segunda etapa de incursões à região, encontrei essa firma avançando claramente na linha da terceirização e da formação de "parceiros", aspecto que exploro um pouco mais no capítulo 7.

Até aqui, até mesmo pelas fontes utilizadas - a RAIS, o histórico e o quadro atual das maiores e mais representativas empresas -, essa caracterização da economia regional talvez sobrevalorize a indústria de transformação, em detrimento da agropecuária, que imprime uma marca muito forte na fisionomia da região, invariavelmente destacada nos documentos e entrevistas. Para além dos 24,8\% que detinha no Valor Adicionado Bruto (VAB) regional de 2004 (FEEDados, on-line), a agropecuária é vista como o fator por excelência que irradia, seja dinamismo, seja dificuldades. Nunca é demais lembrar o seu papel na ocupação de praticamente metade dos habitantes da região que trabalham.

Dentre incontáveis exemplos, um empresário do setor terciário, diretor da ACISAP, declarou, em 2002: "Quando tem uma safra boa, passa um ano totalmente diferente de quando é uma safra ruim. Infelizmente, ainda está atrelado. Pega tudo. O único que está fora talvez seja a metal-mecânica, que não vende aqui. Fora isso, o comércio, os serviços, tudo depende de uma agricultura boa".

O "ciclo da soja", como vimos acima, encontrou seus limites já nos anos 80 , pondo em relevo a inadequação daquela cultura à estrutura fundiária da região, em que $76,3 \%$ das propriedades rurais tinham menos do que 25 ha, e $96,9 \%$, menos de 50 ha (IBGE, 1998). Sobre esse aspecto fundiário é importante marcar uma tensão permanente, até mesmo uma contradição, na forma como esses processos são relatados e avaliados pelos informantes e como aparecem em materiais como os jornais e documentos. Se, por um lado, ao narrar as dificuldades vivenciadas pela agropecuária nas últimas décadas, é corrente que se aluda à concentração de terras, por outro, a face minifundiária é sempre muito destacada em qualquer perfil que se faça da Grande Santa Rosa, seja na conversa com o cidadão comum que em mim identifica alguém de fora, seja na entrevista com as autoridades locais de diversos municípios. Inclino-me a supor que algumas ocorrências de aquisições mais numerosas tenham causado um impacto simbólico e ajudado a 
difundir uma versão em que a estrutura da propriedade estaria se alterando de modo digno de nota, ao passo que a realidade cotidiana indica o contrário, também expresso pelos mesmos sujeitos. Como não contei com um novo Censo agropecuário posterior ao realizado em 1996, não foi possível ver a tendência mais recente. Os técnicos do escritório de Santa Rosa da Emater (Associação Riograndense de Empreendimentos de Assistência Técnica e Extensão Rural), que entrevistei em 2002, não percebiam alteração significativa na distribuição da terra, no nível regional. Registre-se que, especificamente no que diz respeito ao município de Independência, tive informação, em conversa rápida com o prefeito municipal, de que a presença de propriedades rurais de maior extensão era um fenômeno significativo.

Quanto à cultura da soja, não é muito diferente o que ocorre no nível do discurso. Considerada portadora de muitos malefícios econômicos, sociais e ambientais, até mesmo por sua alegada incompatibilidade com a exploração em pequenas propriedades, ela continua se constituindo na cultura central dos minifúndios da Grande Santa Rosa. Conforme declarou um técnico da Emater de Santa Rosa: “(...) se dissessem 'amanhã não tem mais soja, não precisa mais plantar', ia ser um caos aqui na região, porque [a economia] ainda está baseada". Volto a tratar esse ponto, no capítulo 8 . Por ora, vale ressaltar que não poucas alternativas de reconversão da produção agropecuária foram estimuladas, nas últimas duas décadas, por diversas instituições da região, envolvendo, por exemplo, olericultura, fruticultura, apicultura, piscicultura e prevendo formas alternativas de agroindustrialização, com o intuito de agregar valor à produção e, ao mesmo tempo, de contornar circuitos de cadeias produtivas que foram se afunilando, excluindo pequenos produtores.

Esse último elemento remete a uma importante transformação que se deu, a partir dos anos 1990, no Rio Grande do Sul, onde as empresas do agronegócio passaram por uma onda de concentração patrimonial, desnacionalização e mudanças logísticas (Benetti, 2000). Difundiu-se o paradigma da "produção integrada", no qual as indústrias estabelecem a produtores primários quotas de fornecimento, via de regra elevadas, e rigorosas especificações técnicas; a atualização de insumos e equipamentos é imposta periodicamente, acarretando endividamento cíclico do produtor e aumento de sua dependência aos contratos; os controles de qualidade e eficiência são rígidos. É generalizada a percepção de que o produtor primário perde autonomia e lucratividade, tornando-se tão subordinado quanto um empregado. Ademais, só os que atingem a escala permanecem no circuito. A Grande Santa Rosa viu reverter-se uma característica do "ciclo do suíno", quando a maioria dos produtores, fornecendo um pequeno número de porcos ao Frigorífico Prenda, obtinha uma fonte fundamental de renda monetária.

Já a bacia leiteira da região teve expansão continuada, sendo forte o contraste entre uma apreciação bastante negativa dos produtores, quando de minhas primeiras visitas à região, e um clima de relativa satisfação e otimismo, nesse período de 2006 e 2007. Um aumento de preços, 
originado em elevação de demanda, bem como a ampliação do leque de potenciais compradores operando na Grande Santa Rosa, têm garantido maior lucratividade e uma aposta mais continuada nessa atividade, em um crescente número de pequenas propriedades.

Retornando a essa preocupação, tão amplamente expressa na região, de diversificação da produção primária: os depoimentos que ouvi em 2002 sugeriam que várias iniciativas nesse sentido ganhavam alguma efetividade, embora ainda incipientes. $\mathrm{O}$ meu retorno à Grande Santa Rosa, em 2007, deixou-me a sensação de que os cinco anos transcorridos não haviam marcado qualquer avanço digno de interesse, no que diz respeito a essa meta: as mesmas alternativas foram evocadas (e com menos freqüência), como se estivessem por ser iniciadas. Se recorro a minha percepção subjetiva é porque não parece haver informações seguras sobre esses movimentos (ou estabilidade). Nesse sentido, vale referir a uma controvérsia a que Jornal Noroeste serviu de arena.

Na edição de 05.10.2007, o hebdomadário traz uma matéria em que reproduz avaliação do agrônomo Sérgio Schneider, vinculado à Coopermil, sobre a "matriz produtiva" agrícola da região. A reportagem relata sua posição, segundo a qual "apesar de algumas ações práticas e um amplo discurso em defesa da diversificação", cinco atividades mantêm a "frente": "o plantio de soja, milho e trigo, produção de leiteira (sic) e suinocultura". A seguir, cita diretamente o técnico: "Nossa matriz produtiva não mudou e nem mudará. O máximo que ocorreu nesse período [ele trata de 10 anos] foi uma acentuação maior do leite". Adiante, a reportagem menciona uma segunda ressalva do agrônomo: a produção de hortigranjeiros - "mas sem um grande impacto no contexto" (p.03).

Na edição da semana seguinte (11.10.07, p.17), Jorge Lunardi, veterinário, técnico da Emater de Santa Rosa, sustenta que "a diversificação é considerável no setor primário regional”. Apresenta valores da produção agropecuária, nos quais, entretanto, utiliza uma regionalização mais ampla (englobando a região Missões, contígua). Confirma que a soja, com R\$ 650 milhões gerados, é líder absoluta, seguida da pecuária leiteira ( $\mathrm{R} \$ 300$ milhões), milho (R\$ 160 milhões) e trigo (R\$ 135). Porém, (com esse recorte territorial que emprega), encontra a cultura de mandioca à frente da suinocultura, e complementa a listagem com outras atividades, que reputa importantes. Com no mínimo R\$ 6 milhões de faturamento anual são citadas: gado de corte, cana-de-açúcar, fumo, alfafa, fruticultura e avicultura. Abaixo desse valor/ano, ainda outras culturas são mencionadas, mas, partindo-se dos próprios dados desse técnico, é lícito limitar o interesse àquelas que geram pelo menos $1 \%$ do produto que é o carro-chefe inequívoco - a soja.

Mesmo com toda a importância da agropecuária na região, o setor destoou, nos últimos anos, do movimento de ganho de participação que a economia da Grande Santa Rosa obteve nos dados da contabilidade social gaúcha: entre 2000 e 2004, a participação desses 20 municípios elevou-se de 1,94\% para 2,22\% do Valor Adicionado estadual; na indústria, o passo foi de 1,66\% para 2,22\%; nos serviços, de $1,73 \%$ para $1,77 \%$; já a agropecuária, em que a região obtém 
tradicionalmente sua mais elevada participação no agregado, teve queda, de 3,75\%, em 2000, para $3,38 \%$, em $2004\left({ }^{59}\right)$.

Esse dado, sintético e abstrato, vem ao encontro de uma série de fatores históricos e técnicos, já esboçados - bem como, seguramente, de múltiplos condicionantes extra-econômicos (que procurarei explorar no capítulo 8) -, para configurar o meio rural e o setor primário como um foco de constante preocupação dos habitantes da Grande Santa Rosa, que localizam nesse espaço a origem principal de um dilema candente na realidade regional: o êxodo, de que passo a tratar na próxima seção.

Em uma última palavra sobre a estrutura produtiva regional, percebe-se que sua ligação com o chamado agronegócio extrapola a produção primária e envolve os setores industriais que ostentam relevância nesse espaço. Isso, todavia, não conduz à articulação de um "complexo agroindustrial" em seu sentido modelar. Embora dois grandes empregadores do secundário - o frigorífico e a produtora de óleos vegetais - abasteçam-se da produção da região, o principal ramo industrial, o de máquinas agrícolas, não se encadeia com o setor primário da Grande Santa Rosa, o qual, como comprador, representa uma demanda insignificante. A presença de duas grandes multinacionais nesse arranjo é o prolongamento de uma trajetória endógena de ação empresarial, que forjou as duas firmas locais, mais recentemente alienadas.

Com uma história econômica em que se destacam dois ciclos - o ciclo do suíno e o ciclo da soja -, a região, hoje, ainda se ressente de depender de um leque relativamente estreito de atividades - situação que pode ser associada à própria escala espacial e demográfica -, mas sua população percebe o valor que um certo grau de diversificação pode ter. Para mim, foi muito interessante ter vivenciado duas conjunturas bem distintas, em campo: em 2002, o frigorífico estava fechado, enquanto o setor metal-mecânico vivia um excelente momento; em 2006, o revés estava com a produção das máquinas agrícolas, ao passo que o abate de suínos mostrava vigor. Um professor universitário citou-me, então, a frase de um empresário local: “em 2001, 2002, o pessoal deixava de desmontar porco para montar colheitadeira; agora o pessoal deixa de montar colheitadeira para desmontar porco".

\subsection{A dinâmica demográfica}

Em 2000, apenas quatro dos 20 municípios da Grande Santa Rosa tinham mais de 10.000 habitantes. A população regional atingia 210 mil habitantes, assinalando uma virtual estagnação frente a $1991\left({ }^{60}\right)$, como já foi mencionado.

\footnotetext{
${ }^{59}$ No momento em que redijo, o IBGE e as instituições estaduais que são suas parceiras ainda não oferecem séries do VAB e do PIB municipais que compatibilizem os dados anteriores a 1999 aos posteriores.

${ }^{60}$ Nessa variação, utilizaram-se os dados de 1991 recalculados e publicados na Sinopse Preliminar do Censo de 2000 (a divisão territorial dos dois anos é compatibilizada). Sem essa correção, medir-se-ia um crescimento de $1,5 \%$. Os dados municipais aqui apresentados não foram corrigidos, para possibilitar a sua abertura em categorias para as quais a Sinopse não efetua a mesma correção.
} 
Tanto em 1991 quanto em 2000, a participação da população rural era, na região, mais de duas vezes superior à verificada no Estado. A taxa de urbanização passou de 52,7\% para 61,1\%, bem inferior à do Estado, que era de 81,6\% em 2000. Entre esses anos censitários, a variação da população urbana na Grande Santa Rosa foi similar à do Rio Grande do Sul (17,5\% e 18,9\% respectivamente); nas áreas rurais, a Fronteira Noroeste teve perdas mais acentuadas $(16,4 \%$ versus $12,7 \%$ do Estado).

O município mais populoso é Santa Rosa, que, em 2000, contava com 30,9\% dos habitantes da região. Sua variação demográfica foi idêntica à do Estado (11,5\%) e a mais elevada da região, onde apenas mais um município - Horizontina - teve crescimento $(4,0 \%)$. Os outros municípios já constituídos em 1991 chegaram a 2000 com perdas entre 1,7\%, em Santo Cristo, e 49,7\%, em Tucunduva. No período, foram constituídos seis novos municípios ${ }^{61}$, o que justifica parte das perdas dos demais, que lhes cederam áreas. Isso não afeta a tendência do agregado regional, já que todas as emancipações se deram internamente a ele - com a única exceção de Senador Salgado Filho -, e, em 2000, os novos municípios detinham apenas 8,6\% da população da Grande Santa Rosa.

O segundo município em população era Três de Maio, com participação de 11,5\%, em 2000. Horizontina era o terceiro, com $8,4 \%$. Os três maiores municípios abarcavam, conjuntamente, $50,8 \%$ da população total e $68,0 \%$ da população urbana.

Quando Santa Rosa foi fundada, em 1931, seu território correspondia ao do agregado dos 20 municípios aqui abordados. Essa área teve crescimento demográfico em taxas superiores às do Estado até 1960. Depois, é claríssima a condição de zona de expulsão populacional. Entre 1960 e 2000, o número de habitantes do Rio Grande do Sul aumentou 87\%, enquanto o da Grande Santa Rosa, 23\%, apenas. Se - num exercício ultra-simplificador - aplicássemos a variação populacional do Estado à região, essa chegaria ao ano 2000 com 318 mil residentes. Se assumíssemos a hipótese de que os demais componentes demográficos (mortalidade, fecundidade) não tenham tido diferenças decisivas nos dois recortes territoriais, poderíamos creditar à emigração a perda de mais de 100 mil "potenciais" moradores, nessas quatro décadas - já que a população efetiva, em 2000, era de 210 mil. Isso equivale a dizer que, se tivesse crescido a taxas idênticas às do Estado, no período, a população da Grande Santa Rosa seria hoje 50\% superior ao que é.

\section{Tabela 5 - População total dos municípios da Grande Santa Rosa e do Rio Grande do Sul, 1940 a 2000, e variações inter-censitárias}

\footnotetext{
${ }^{61}$ Nova Candelária, originada de Boa Vista do Buricá; Novo Machado, de Tucunduva; Porto Mauá, de Tuparendi e Tucunduva; Porto Vera Cruz, de Porto Lucena, Alecrim e Santo Cristo; São José do Inhacorá, de Três de Maio; Senador Salgado Filho, de Giruá.
} 


\begin{tabular}{|c|c|c|c|c|c|c|c|}
\hline & 2000 & 1991 & 1980 & 1970 & 1960 & 1950 & 1940 \\
\hline Alecrim & 8.487 & 10.379 & 13.916 & 15.412 & & & \\
\hline Alegria & 5.367 & 6.247 & & & & & \\
\hline Boa Vista do Buricá & 6.587 & 9.086 & 8.827 & 8.747 & & & \\
\hline Campina das Missões & 7.014 & 8.056 & 8.272 & 7.801 & & & \\
\hline Cândido Godói & 7.092 & 7.454 & 8.005 & 7.690 & & & \\
\hline Doutor Maurício Cardoso & 6.329 & 7.208 & & & & & \\
\hline Horizontina & 17.699 & 17.023 & 24.670 & 20.996 & 19.588 & & \\
\hline Independência & 7.308 & 7.491 & 8.317 & 9.046 & & & \\
\hline Nova Candelária & 2.883 & & & & & & \\
\hline Novo Machado & 4.718 & & & & & & \\
\hline Porto Lucena & 6.398 & 9.415 & 12.204 & 13.007 & 11.016 & & \\
\hline Porto Mauá & 2.802 & & & & & & \\
\hline Porto Vera Cruz & 2.464 & & & & & & \\
\hline Santa Rosa & 65.016 & 58.287 & 52.231 & 39.550 & 45.871 & 120.012 & 84.528 \\
\hline Santo Cristo & 14.890 & 15.147 & 15.312 & 15.076 & 28.088 & & \\
\hline São José do Inhacorá & 2.402 & & & & & & \\
\hline Senador Salgado Filho & 2.927 & & & & & & \\
\hline Três de Maio & 24.136 & 26.535 & 33.036 & 31.363 & 38.555 & & \\
\hline Tucunduva & 6.305 & 12.538 & 13.856 & 15.289 & 14.020 & & \\
\hline Tuparendi & 9.542 & 12.481 & 13.899 & 14.639 & 13.273 & & \\
\hline Total da região & 210.366 & 211.081 & 212.545 & 198.616 & 170.411 & 120.012 & 84.528 \\
\hline Rio Grande do Sul & 10.181 .749 & 9.138 .670 & 7.773 .837 & 6.664 .891 & 5.448 .823 & 4.164 .821 & 3.320 .689 \\
\hline \multicolumn{8}{|c|}{ VARIAÇÃO (\%) sobre o período anterior } \\
\hline Região & $-0,34$ & $-0,69$ & 7,01 & 16,55 & 41,99 & 41,98 & \\
\hline Rio Grande do Sul & 11,41 & 17,56 & 16,64 & 22,32 & 30,83 & 25,42 & \\
\hline
\end{tabular}

FONTE: FEE (2000 - CD ROM)

Nota 1: O universo de municípios muda, a cada Censo, em função de emancipações, que alteram a área de municípios precedentes (o que incide, evidentemente, na população). Entretanto, o conjunto de municípios considerado corresponde, em todos os Censos, à mesma área territorial.

Nota 2: o total apresentado para a região, em 1991, não corresponde exatamente à soma dos municípios, porque ele incorpora uma revisão feita pelo IBGE e apresentada em 2000, na Sinopse Preliminar do Censo 2000. Não aplico essa correção aos dados municipais, porque, em outras tabulações,os contingentes são abertos por atributos, o que os dados revisados não comportam.

A evasão populacional foi central na fala dos entrevistados. Muitos reconhecem um traço cultural "nômade" na população, relacionado com o processo de colonização:

(...) a nossa formiguinha é cortadeira, esse pessoal adorava mato. Eles saíram da região e foram para o norte de Santa Catarina, Paraná, foram devastando, subindo, tipo uma formiguinha, que foi cortando o mato. Eles tinham uma cultura de fazer plantio em áreas novas, e isso prosperou por muito tempo. Acho que tem umas quatro 'Nova Santa Rosa' no Brasil (...) já tem uma tradição de ser um pouco ousados no sentido de ser imigrantes mesmo (Professor universitário, integrante de Conselho Regional - agosto de 2002).

As motivações econômicas, sociais ou técnicas do êxodo não se obscurecem sob a idéia de uma propensão cultural, como o mesmo entrevistado evidencia: “(...) são plantios em escala, áreas maiores. Então, sempre queriam terras mais baratas".

Os movimentos de emigração são invariavelmente associados à falta de alternativas de trabalho e renda, sobretudo para os jovens rurais.

No interior (...) a nossa turma de colégio vivia sempre junto, era 15 ou 20. Não se enxerga mais, hoje, porque estão todos - uns em Três de Maio, outros em Santa Rosa, outros não sei aonde. Está tudo espalhado. Isso sem contar os que não foram pra outros estados, porque fizeram [curso de] Técnico Agrícola e foram trabalhar pra longe. E mesmo esse tempo, estando em Tuparendi, em Tuparendi mesmo, o pessoal sai bastante pra fora, pra 
trabalhar, porque não tem emprego. Então o pessoal sai bastante, sai pra trabalhar em Santa Rosa, sai pra outras cidades, para os outros estados - a maioria da juventude (...).

$\mathrm{P}$ - E acaba perdendo esse contato?

R - Perde (jovem de 19 anos, natural de Tuparendi, entrevistado na agência do Sistema Nacional de Emprego - SINE - de Santa Rosa, nov.06).

Como o testemunho desse jovem aponta, as zonas urbanas dos maiores municípios da própria região absorvem parte do êxodo rural. Fica clara, especialmente - no conjunto de entrevistas, bem como nos dados censitários -, a atração que Santa Rosa exerce. Mas parece se configurar uma tendência de migração "em dois tempos", envolvendo basicamente a mão-de-obra rural e jovem, pouco "qualificada" frente aos requisitos do mercado de trabalho urbano.

Os filhos dos agricultores que não vêem muita expectativa (...) não esperam muito: vêm para Santa Rosa. Aliás, são advindos dos municípios da região (...) essencialmente agrícolas. Filho de agricultor (...) vem para Santa Rosa à procura de emprego. Ele fica um mês ou dois aqui, não localiza trabalho, ele vai embora, vai para o grande centro. E aí a gente perde referência desse jovem, dessa família, desse trabalhador (Integrante do Sistema Público de Emprego (SPE), agosto de 2002).

Dessa forma, embora uma parte do contingente que se desloca para as principais cidades da região ali permaneça, outra parcela prossegue sua trajetória migratória.

Também os jovens que nasceram ou se fixaram nos espaços urbanos da região - e, dentre esses, em especial aqueles de famílias com recursos superiores ao padrão dos pequenos produtores rurais -, ao obter uma formação educacional mais elevada, notadamente o nível superior, tenderiam a deixar a Grande Santa Rosa, na busca de oportunidades ocupacionais compatíveis com a titulação conquistada; outros, ainda, partiriam em busca de cursos universitários não oferecidos nos municípios da Grande Santa Rosa. Esses condicionantes se associam a outras ordens de fatores, para conformar uma também alta propensão a migrar.

Com razões para acreditar que adentraria um "território" predominantemente jovem, urbano e de classe média - embora seja notória a progressiva difusão do uso da internet -, busquei no Orkut, site de relacionamento, subsídios sobre as representações que esse segmento social formula a respeito de suas perspectivas de vida e de trabalho na região pesquisada. Mais do que isso, filiei-me à "comunidade" (como são chamados os grupos de discussão desse site) intitulada "Santa Rosa", que tem 6.368 integrantes (em outubro de 2007), e nela propus um "tópico" (tema para a intervenção dos participantes) intitulado "Ficar em Santa Rosa ou sair". Ali expus telegraficamente meu interesse de pesquisa e pedi opiniões e depoimentos. Com assumido fascínio pela riqueza que representa essa nova fonte de pesquisa, transcrevo sete "posts" (manifestações) houve 29 , nem todos pertinentes - que julgo comporem uma "amostra" razoavelmente fiel do conjunto $^{62}$ :

${ }^{62}$ Evidentemente, esse recurso impõe muitas cautelas. Não pretendo discuti-las - somente lembrar que os usuários do Orkut podem criar identidades fictícias (e múltiplas) e que, se não há como se ter um "perfil" minimamente confiável dos indivíduos, é impossível ter-se uma apreensão - por que não dizer - sociológica do conjunto que compõem, em cada comunidade. Até por isso, optei por não identificar os autores dessas manifestações que transcrevo. Achei mais adequado, também, manter a grafia das intervenções, pois ela é 
- caara santa rosa foi onde nasci e tal.. mas cara , a cidade ta morta... ta certo que é geral. . mas aki ta geral de mais... trabalho aki ta dificil, cidades do mesmo porte ou porte parecido, como ijui por exemplo, tem pouco mais possiblidades... infelizmente naum fico...

- Não tenho ânsia por ir embora daqui...

Acho Sta Rosa uma cidade tranqüila, com boa gente...

É claro que as oportunidades de emprego não são as melhores, mas as vezes penso que pesa mais vc estar num lugar onde pode sair tranqüilo a noite do que estar numa grande empresa.

A maioria das pessoas não avalia que, numa cidade como Caxias (por exemplo) que é onde já tive possibilidade de ir morar, vc ganha melhores salários, mas tb ganha de brinde um custo de vida mto mais alto.

Em termos de entretenimento aqui tb não é o bicho... mas eu tenho bons amigos, e faço a festa com eles sempre que a gente se reúne... não importa o lugar, nem se está bombando... importa que a gente ri mto qdo está junto!

Além disso, preciso admitir... sou um pouco apegada a família... não a ponto de me amarrar num lugar, mas sei que sentiria falta das pessoas que aqui estão sempre por perto... e isso tb pesa na minha balança.

Enfim, se surgiu uma BOA oportunidade, não vou desperdiçar... mas não tomo nenhuma decisão sem antes analisar os prós e contras.

Não quero fugir de Sta Rosa... quero ter oportunidades e se elas estiverem aqui, eu agradeço...

- Sair... infelismente!

Sou muito ligado a minha família, meus avós, tios tias, amigos e amigas... mas sinceramente assim q me formar, minhas malas estarão prontas! Pra onde? Puts... tá cheio de lugares por esse Brasil, muito... mas muito melhor que nossa Sta. Rosa. Infelismente é assim, muitos amigos meus já foram embora... estão indo... querem vencer na vida!

- [mesmo usuário, dois meses depois - nos quais não houve manifestações alheias] Porque ficar em Sta. Rosa?

Volto a escrever minha indignação neste tópico, puts... será que nenhuma "autoridade" ou "liderança" desta cidade percebe a quantidade de jovens (e não apenas jovens) que estão saindo de Sta. Rosa em busca de realização pessoal e profissional?

Hoje, mais um amigo meu está "vazando" dessa cidade... e por que? Alguns motivos em destaque: Falta muito EMPREGO e muitas OPÇÕES DE ENTRETENIMENTO em Sta. Rosa! FALTAM OPORTUNIDADES!

$V c$ que está lendo este texto certamente conhece alguém que já tenha ido embora em busca de "novas conquistas", Sta. Rosa pode ser boa pra se morar, dependendo do seu ponto de vista... mas a realidade é cruel, e não vejo possibilidades de uma verdadeira "mudança" de comportamento e atitudes de pessoas que "decidem" pelo municipio! Sta Rosa "Terra da Xuxa" mais conhecida pela terra das "bandinhas" (estilo musical) hahaha... nada contra ao estilo de bandas, mas na minha opinião se não mudarmos a nossa postura, esta cidade continuará neste caminho... existem algumas incógnitas inexplicáveis e tradicionais que estão levando uma enorme galera embora daqui.

Atenção: é impossível fazer as coisas do mesmo jeito esperando resultados diferentes! É hora de reavaliar o que está acontecendo... e mudar! Mudar o pensamento e as atitudes! Caso contrário, Sta. Rosa já eras.

Alguma opinião?

- também já sai de santa rosa há um certo tempo.. to com 22 anos, fui embora aos 17. o único motivo pelo qual volto ainda algumas vezes por ano é rever meus pais/família/amigos, mas não pretendo voltar a morar lá. os motivos pra sair são diversos, mas acho que vale destacar:

- falta de opções de lazer/entertenimento

- população provinciana (no sentido depreciativo mesmo)

um elemento metalingüístico relevante - ao qual algum tempo de "navegação" ensina a atentar. 
- inexistência de vida acadêmica

- Santa Rosa foi sempre assim e não vai mudar tão fácil não.

Essa cidade me anoja!!!

Vou me mandar daqui assim que puder! hehehhehe!

- Sou de Santa Rosa, mais ja sai dae a mais de 10 anos, e hoje tenho 20 hehehehehehe meus pais tinham fazendo ae na região, Santo cristo, 150 hectares, dae eles venderam e foram pra Goiás e depois pro Mato Grosso, e graças a Deus hoje a gente vive tri bem, e foi porque a gente saiu de Santa Rosa, ou seja, falo bem de Santa Rosa e tudo mais em todos os lugares que vou, mais voltar prai???

Só pra velar parente morto.

Alguns aspectos chamam a atenção nessa sucessão de intervenções, que aqui ilustrei um tanto longamente. Em primeiro lugar, é marcante a justaposição entre, de um lado, considerações de ordem profissional e econômica, e, de outro, razões sentimentais ou familiares, sendo recorrente o conflito entre essas duas fontes de motivação; em segundo, meu questionamento sobre a perspectiva de permanência na cidade conduz a uma avaliação em que aspectos como custo de vida e oportunidades de emprego se vêem acompanhados, em igualdade de importância, por apreciações de ordem cultural ("população provinciana", "Terra da Xuxa"), bem como pela expressão de insatisfações quanto ao estilo de vida e à oferta de lazer ou de "vida acadêmica"; em terceiro, revolta e lástima são sentimentos expressos com intensidade e, mesmo, alguma violência, diante de uma percepção da saída como destino inevitável.

Após hesitar, não resisto a apresentar, como "bônus", um último "post" desta mesma série, o qual, com óbvias pretensões humorísticas, toca vários aspectos culturais de inegável relevância nessa formação regional:

axon q mora no colonha é feio... non non... os colonho non son tuto purro non... uahsiuahsiu;;; iso non eh feio fla q mora no colonha... non pote $t$ ferconha ...

Já que ela procura reproduzir graficamente o que seria um sotaque local, "traduzo" a frase: "acham que morar na colônia é feio. Não, não. Os colonos não são todos burros, não! (risos). Isso não é feio - falar que mora na colônia. Não pode ter vergonha”. Santa Rosa é, assim, associada (mordazmente) a uma identidade germânica, que - embora positivamente valorada em outros contextos - é aqui ressignificada pela experiência colonial, à qual adere o estigma da mediocridade, da "burrice". Isso geraria constrangimento aos sujeitos - e o alvo da ironia eram, evidentemente, os integrantes da comunidade que até ali haviam desabonado a vida em Santa Rosa.

Em qualquer estrato social, pelo que pude observar, os pais e mães de jovens demonstram grande naturalidade frente à migração de seus filhos, quer ela já tenha ocorrido, quer lhes pareça iminente. Em Alecrim, uma mulher taxista, divorciada - perfil claramente atípico, em seu contexto social, como ela fez questão de valorizar - exaltou sua "luta" para criar duas filhas e comemorou o 
fato de que a mais velha estava formada e bem empregada, na região serrana do Rio Grande do Sul, e que a caçula deveria colar grau dali a poucos dias. Essa segunda filha já havia ficado três anos em Porto Alegre e retornado; fez formação superior em Santa Rosa, residindo com a mãe em Alecrim, e tinha a perspectiva de voltar a mudar-se para a capital muito proximamente. Exaltando "o estudo", a taxista disse que, se tivesse tido dez filhos, faria tudo para que todos cursassem uma faculdade. Arrisquei uma réplica "feminina": "pena é que depois de formados tenham de ir embora!...". Ela reagiu com surpresa e declarou, quase em tom de censura, que queria que seus filhos tivessem "sucesso", "trabalho", não importando onde. Destacou que conhecia a vida da "roça" (sic), "muito sacrificada", e que havia se casado muito jovem, sobretudo para sair "daquela vida". ${ }^{63}$

Dada a ênfase que conferi às conversas com os habitantes da região, tive condições de atentar a um aspecto que me escapara na minha primeira incursão à Grande Santa Rosa: a recorrência das partidas e retornos da população. Pelo quadro que os depoimentos me indicaram, em que pese a um claro saldo negativo, os movimentos migratórios não se reduzem ao simples êxodo.

Dentre as diversas pessoas que conheci que haviam vivido algum(ns) períodos fora da região e retornado, impressionou-me o fato de que, salvo engano, nenhuma associou a volta à identificação de oportunidades de trabalho ou de ganho na Grande Santa Rosa. Um operário aposentado que regressa de uma região vizinha para cuidar de sua filha adolescente, após a morte da mãe da menina; um microempresário que abandona Porto Alegre e passa a trabalhar como taxista em Santa Rosa, após romper um casamento de modo algo embaraçoso; um jovem que se gradua na Região Metropolitana, lá obtém um emprego que valoriza muito, mas, após duas crises de stress, prefere assumir a gestão da propriedade rural da família - esses foram alguns dos prosaicos relatos que, em seu conjunto, se impuseram em claro contraste com as determinações estritamente econômicas ou com expectativas de "maximização" por parte desses indivíduos que empreenderam a migração de retorno. "Acidentes" biográficos, razões sentimentais e compromissos familiares adquiriram muito mais visibilidade, justamente por embasarem decisões que contrariam o sentido predominante do fluxo de deslocamentos.

Evidentemente, demissões sofridas em outras localidades são responsáveis por inúmeros casos de regresso, mas isso não contradiz a idéia de que as voltas são muito raramente motivadas pela identificação de oportunidades: nesses casos, é, nitidamente, a busca de uma rede social de apoio que move os indivíduos de volta para o município de origem. Em Alecrim, conversei com dois jovens agricultores, em uma lancheria. Um dos rapazes, de 27 anos, voltava de Novo Hamburgo (no vale do Sinos, Região Metropolitana), após ter perdido o emprego que tivera por vários anos em uma empresa de calçados. Encontrava-se na pequena propriedade rural dos pais,

${ }^{63}$ Seu ex-marido é taxista, razão que a fez, no passado, se iniciar nessa ocupação. Compartilham, hoje, o mesmo ponto de táxi, junto à rodoviária desse município de 6,5 mil habitantes. 
"ajudando" ${ }^{64}$. O dono da lancheria, que aderiu à conversa, também havia ficado 23 anos naquele mesmo município e retornado devido a uma demissão. Lembrou que se deslocara para lá num tempo em que "davam aumento para a gente não sair" - referindo-se ao final dos anos 70, época de forte demanda de mão-de-obra nas indústrias do entorno de Porto Alegre. Comentei com meus interlocutores que, na cidade de Alecrim, a grande maioria dos relatos de migração envolvia Novo Hamburgo. Relataram-me que, naquele município, há um bairro (Vila Rincão) que "só tem alecrinense. Deve ter 40 a 50 mil habitantes".

Seguramente, a indicação, aos empregadores, de conterrâneos, por indivíduos já empregados, tem um papel importante nesses deslocamentos, assim como a (re)construção de redes sociais, no novo local de residência, estimula decisões de partida e suaviza as dificuldades de adaptação. Entre muitos exemplos, um operário que trabalhava, em Santa Rosa, numa empresa de óleos vegetais, relatou-me que, quando esta fechou (posteriormente reabriu, sendo hoje a citada Camera), muitos de seus ex-colegas foram tentar conseguir emprego em Itaqui (município de outra região do Estado), em uma indústria da mesma especialidade. Como eles tiveram êxito, começaram a "puxar" (sic) o meu entrevistado, que acabou se deslocando para lá.

Recentemente, as dificuldades por que passou o segmento metal-mecânico da Grande Santa Rosa - entre final de 2004 e 2006 -, fizeram com que houvesse uma forte emigração de operários desse segmento para diversos municípios gaúchos e catarinenses em que sua qualificação e/ou experiência era demandada.

De mil, em torno de mil desempregados, talvez, aí do setor metal-mecânico (...) esse pessoal, uma parte, foi pro Vale do Rio das Antas - ali pra Serra, que é Caxias, Bento, e tal, que a indústria metalúrgica de Caxias tem outras alternativas que não se buscou [aqui] na região.

(...) E, depois, eles encaminhavam o seguro-desemprego, de todo esse pessoal ainda tem uns 300 desempregados aqui. Setecentos foram embora. Pra região de Canoas [Região Metropolitana], pra região de Criciúma, em Santa Catarina, e pra Serra [gaúcha].

$\mathrm{P}-\mathrm{E}$ a maioria foi já com perspectiva, ou com colocação, ou eles vão se arriscar?

$\mathrm{R}$ - Eles sempre têm aquele precursor, que vai na frente, faz o caminho e daí chega lá e... grande parte deles estão empregados. [funcionário do SINE Santa Rosa, nov.2006]

Muitas vezes, nas conversas que mantive, ouvi a opinião de que as pessoas procedentes das "colônias" da Grande Santa Rosa são muito bem vistas por potenciais empregadores, em outras regiões. Em geral, o contexto indicava que se tratava de alocação, em ocupações operárias, de indivíduos com passado de agricultores. A imagem dessa população estaria associada à "responsabilidade" (compromisso, disciplina). Não me foi possível aprofundar a investigação dos fundamentos dessa representação - mas nele toma parte, inquestionavelmente, o componente étnico. Um exemplo, dentre as muitas indicações nesse sentido, foi a forma como um integrante da Administração Municipal de Boa Vista do Buricá analisou a escolha de seu município para a

${ }^{64}$ Embora um tanto desolado com suas perspectivas imediatas, salientava que era bom retornar para sua terra, onde podia confiar ( $\mathrm{sic}$ ) nas pessoas. Claramente, sua "socialização" no meio operário em que viveu foi difícil. Declarou que "a gente tem que ser duas pessoas: uma quando está lá e outra quando está aqui”. 
localização de uma unidade da empresa calçadista acima referida (que veio a fechar, em todo o Rio Grande do Sul): “eles preferem as pessoas daqui, porque nós temos muitas pessoas de origem italiana, alemã. Eles acham, sei lá, que tem mais dedicação a isso aí" (novembro de 2006).

A par da tendência expulsora de população da Fronteira Noroeste, outro aspecto importante que os depoimentos explicitam é que ocorre uma forte circulação de força de trabalho em nível regional, movida pela busca de inserção no mercado de trabalho. O testemunho do prefeito de Três de Maio, segundo maior município da Grande Santa Rosa, é representativo:

Três de Maio recebeu muito migrante aqui das cidades vizinhas, e por isso temos hoje algumas áreas de concentração. Tipo... não chega a ser favela, né. Mas umas vilas mais empobrecidas e essa coisa toda. Então é por isso que nós... Mas a procura por emprego de municípios vizinhos é relativamente grande. Assim como o pessoal daqui sai e vai procurar emprego em Horizontina, Santa Rosa (prefeito de município da região, 2002).

Essa circulação de mão-de-obra entre os municípios foi bastante destacada, por exemplo, em Horizontina, onde assume características peculiares, que serão abordadas no capítulo 7. Mais do que a transferência de domicílio para outros municípios, que configura a migração, testemunhase uma mobilidade de espectro efetivamente regional dessa força de trabalho. Essa entrevista que fiz com um integrante da administração municipal de São José do Inhacorá não apenas explicita a prática, como testemunha sua difusão.

Nós, inclusive, nós estamos hoje subsidiando uma lotação que sai daqui e vai trabalhar em Três de Maio. Vinte e poucos moradores aqui de São José que trabalham (...) numa fábrica de móveis em Três de Maio. (...) Essa é uma... Na verdade, aquela que faliu aqui e foi adquirido por um de Três de Maio, que...

$\mathrm{P}$ - Ele levou o pessoal?

$\mathrm{R}-$ Que levou o pessoal. (...)

$\mathrm{P}$ - Mas e por que a empresa não banca esse transporte?

$\mathrm{R}$ - É, a empresa bancava. E aí chegou aí uma hora dessas, pediu uma ajuda... "não sei o que, não sei o que", porque era um custo alto...

$\mathrm{P}-\mathrm{E}$ o retorno pra vocês é o fato de ter os cidadão daqui empregados?

$\mathrm{R}$ - Morando aqui e... seu emprego. Não é... Eu sei lá! Às vezes fica meio... Mas muitos municípios da região fazem isso (ago.06).

Essa é uma das tantas razões pelas quais há uma unânime concordância entre os atores sociais das mais diversas posições no tabuleiro institucional quanto à necessidade de uma abordagem e de um enfrentamento articulado dos problemas que atravessam esse conjunto de localidades. Esse aspecto eu procuro explorar na próxima seção, que finaliza este capítulo.

\subsection{A Grande Santa Rosa como região e sua institucionalidade}

Tenho até aqui justificado a regionalização que adotei sobretudo pelo fato de o conjunto de vinte municípios com que trabalho corresponder - ou recompor - o território de Santa Rosa, quando de sua emancipação, há pouco mais de 75 anos. Destaco, ademais, que, seja em minha primeira incursão à região, seja no período 2006-2007, meus interlocutores sempre explicitaram, quando consultados, sua concordância quanto à adequação desse recorte; de resto, 
independentemente de meu questionamento a respeito, sempre que as entrevistas ou conversas tratavam do fluxo de busca de trabalho ou de serviços, os municípios mencionados convergiam quase exclusivamente para o elenco que aqui tomo por referência. Um exemplo mais "bem acabado":

P - (...) Algumas coisas como hospital, para o teu pai, como tu disseste, tem de ir pra Santa Rosa... Essa interação entre os municípios, tu acha que ela é importante, que ela é real? É comum esse vai-vém?

$\mathbf{R}$ - É. É real. É muito importante. É comum, porque é...

P - Como é que funciona? Quem vai pra onde e por quê - assim, mais ou menos? De que cidades as pessoas vão buscar $0 . .$.

R - No caso a região aqui é: Tuparendi e Porto Mauá procuram mais Santa Rosa; já Tucunduva e Horizontina procuram mais Três de Maio; assim como Santa Rosa e Três de Maio se procuram. E Porto Lucena, Porto Xavier, Porto Vera Cruz, Alecrim - que são mais interior - procuram Santo Cristo ou Santa Rosa...

$\mathbf{P}$ - E "procuram" pra que?

$\mathbf{R}$ - No caso, pra tudo - desde medicina até procurar emprego ou simplesmente pra fazer compras e lazer (jovem de 19 anos, morador de Tuparendi, em entrevista no SINE de Santa Rosa, nov.06).

O depoimento demonstra que mesmo um rapaz que sempre habitou um dos menores municípios da região visualiza e enuncia com clareza o circuito - e os subcircuitos - que transformam esse conjunto de espaços locais em uma formação regional, na qual a constância dos fluxos consagra interações sociais que se inscrevem no espaço e, na perspectiva de Milton Santos, produzem espaço (1978/2002, p.203).

Algumas considerações, entretanto, permitem qualificar um pouco melhor essa opção metodológica pelo conjunto de 20 municípios.

Conforme foi visto no capítulo 2, estaria ultrapassada a noção de região quando tributária a uma perspectiva meramente hierárquica de sucessivas escalas territoriais. Essa visão teria sido desafiada pela multiplicidade de articulações espaciais que se sobrepõem e que atravessam constituindo-a - uma mesma formação local, que, dessa forma, não pode ser reduzida a uma - e única - relação de subordinação ou ascendência com o nível superior ou inferior de uma seqüência de espaços de progressiva centralidade.

Ainda assim, encontro, em meu estudo, uma configuração que sigo a considerar regional.

\subsubsection{Aglutinação a partir da diversidade}

Em primeiro lugar, é interessante enunciar as razões que me desaconselharam a tomar a Grande Santa Rosa, simplesmente, como escala local - o que, de resto, seria confortável, tendo-se presente a tendência da literatura contemporânea, anteriormente revisada, de contrapor permanentemente uma instância local a uma dimensão global, eximindo-se de tratar teórica e analiticamente das escalas que podem mediar, e geralmente mediam, os "vetores" que provêm desses dois níveis. 
Sobejamente testemunhada e, até por isso, aceita a articulação entre os municípios, saltam aos olhos (e aos ouvidos, nas falas da população regional) as diferenças entre as múltiplas localidades que compõem a Grande Santa Rosa. Antes de trazer um ou dois exemplos dos testemunhos recolhidos, apresento um conjunto de indicadores selecionados que permitem visualizar as profundas diferenças sócio-econômicas e demográficas que particularizam as "unidades" de minha regionalização, impondo que se prefira tomar esse nível municipal como mais apropriado para servir de referência operacional à noção de "local".

Além da radical diferença de tamanhos populacionais, que já foi indicada anteriormente, chamam a atenção outros contrastes muito intensos. Há municípios com parcelas quase residuais de seus contingentes vivendo em áreas urbanas - sendo o caso mais extremo o de Nova Candelária, em que essa taxa fica em apenas 12,1\%. Na maioria (doze) dos 20 municípios, mais da metade dos habitantes vive no meio rural, segundo a estimativa para 2006; entretanto, somada a população total dessas doze localidades, não se atinge sequer uma quarta parte da população regional - cuja cidade-pólo, Santa Rosa, tem, por sua vez, taxa de urbanização superior à do agregado do Rio Grande do Sul. O PIB per capita assinala disparidades tão ou mais agudas, trazendo desde resultados que se situam próximos à metade do obtido no conjunto do Estado (Alecrim e Porto Lucena - os mais baixos) até um caso isolado em que o município supera em 3,5 vezes o parâmetro gaúcho ${ }^{65}$. Mesmo se desconsiderarmos essa excepcionalidade, temos uma distribuição em que o extremo mais bem posicionado (Nova Candelária) ostenta um PIB per capita quase três vezes superior à municipalidade mais pobre (Alecrim).

\section{TABELA 6 - Municípios da Grande Santa Rosa e RS - indicadores sócio-econômicos e demográficos selecionados, 2000 - 2006}

\begin{tabular}{|c|c|c|c|c|c|c|}
\hline & $\begin{array}{l}\text { POPULAÇÃO } \\
\text { TOTAL (1) }\end{array}$ & $\begin{array}{c}\text { RAZÃO } \\
\text { DE } \\
\text { SEXO } \\
\end{array}$ & $\begin{array}{l}\text { EXPECT. DE } \\
\text { VIDA AO } \\
\text { NASCER } \\
\end{array}$ & $\begin{array}{l}\text { IDESE } \\
\text { (2) }\end{array}$ & $\begin{array}{l}\text { PIB PER } \\
\text { CAPITA }\end{array}$ & $\begin{array}{c}\text { TAXA } \\
\text { URBANIZ. }\end{array}$ \\
\hline & 2006 & 2006 & 2000 (anos) & 2003 & $2004(\mathrm{R} \$)$ & $2006(\%)$ \\
\hline Alecrim & 7.180 & 102,0 & 69,47 & 0,64 & 6.843 & 30,3 \\
\hline Alegria & 4.719 & 102,7 & 70,59 & 0,68 & 8.542 & 36,5 \\
\hline Boa Vista do Buricá & 5.894 & 100,2 & 76,16 & 0,75 & 10.325 & 62,7 \\
\hline Campina das Missões & 6.095 & 101,4 & 69,40 & 0,75 & 9.134 & 39,2 \\
\hline Cândido Godói & 6.309 & 102,5 & 72,63 & 0,75 & 10.972 & 28,6 \\
\hline Doutor Maurício Cardoso & 5.257 & 101,3 & 69,97 & 0,70 & 11.191 & 48,7 \\
\hline Horizontina & 19.852 & 94,6 & 72,47 & 0,79 & 47.632 & 82,3 \\
\hline Independência & 7.441 & 102,1 & 72,63 & 0,72 & 10.977 & 61,8 \\
\hline Nova Candelária & 2.863 & 103,5 & 75,49 & 0,69 & 18.823 & 12,1 \\
\hline Novo Machado & 4.092 & 102,2 & 72,63 & 0,74 & 9.875 & 38,4 \\
\hline Porto Lucena & 5.690 & 94,2 & 69,47 & 0,70 & 7.134 & 44,9 \\
\hline Porto Mauá & 2.625 & 97,5 & 77,05 & 0,69 & 8.261 & 39,8 \\
\hline Porto Vera Cruz & 2.123 & 110,2 & 72,63 & 0,65 & 10.060 & 25,6 \\
\hline Santa Rosa & 68.345 & 95,2 & 74,94 & 0,79 & 13.888 & 89,2 \\
\hline Santo Cristo & 14.256 & 101,5 & 72,60 & 0,77 & 12.848 & 56,3 \\
\hline São José do Inhacorá & 2.186 & 108,8 & 77,76 & 0,72 & 9.048 & 36,9 \\
\hline
\end{tabular}

${ }^{65}$ Essa situação, a de Horizontina, é determinada pela pujança da planta industrial da John Deere, claramente "desproporcional" ao restante da economia e ao tamanho da população - o que será mais bem caracterizado no capítulo 7. 


\begin{tabular}{lrrrrrr} 
Senador Salgado Filho & 2.962 & 96,9 & 75,66 & 0,68 & 14.459 & 27,0 \\
Três de Maio & 25.233 & 95,1 & 77,35 & 0,75 & 9.238 & 78,8 \\
Tucunduva & 5.376 & 95,6 & 77,64 & 0,76 & 11.339 & 67,8 \\
Tuparendi & 9.290 & 94,4 & 72,72 & 0,73 & 10.784 & 60,8 \\
\hline Rio Grande do Sul & $\mathbf{1 0 . 8 6 7 . 1 0 2}$ & $\mathbf{9 6 , 0}$ & $\mathbf{7 2 , 0 5}$ & $\mathbf{0 , 7 6}$ & $\mathbf{1 3 . 3 2 0}$ & $\mathbf{8 4 , 9}$
\end{tabular}

FONTE dos dados brutos: FEE-Dados (on-line)

Notas (1): utiliza-se a projeção de população feita pela FEE para 2006, na medida em que os dados da Contagem Populacional de 2007 encontram-se sob revisão; (2) O Idese é o Índice de Desenvolvimento Sócio-econômico, calculado pela FEE aos moldes do Índice de Desenvolvimento Humano (IDH) da ONU. Contempla quatro blocos de variáveis: renda; educação; saneamento e domicílios; e saúde. Seu valor se situa entre zero e 1.

Mesmo as razões de sexo são muito desequilibradas, evidenciando uma considerável concentração de mulheres nas três maiores cidades - Santa Rosa, Três de Maio e Horizontina -, mas também em dois pequenos municípios (Tuparendi e Porto Lucena), enquanto o relativo excesso de homens é notável em alguns dos menores municípios, caracterizados, de modo geral, por taxas de urbanização muito baixas e posições desvantajosas no ordenamento regional do Idese (Índice de Desenvolvimento Sócio-Econômico) - caso de Porto Vera Cruz, São José do Inhacorá e Nova Candelária.

Essa heterogeneidade - que bem pode ser chamada de desigualdade - apareceu com muita clareza nas falas dos habitantes da região, e comporta, nada surpreendentemente, uma clivagem territorial. Geralmente, quando desejam assinalar "problemas sociais" em geral - destacando-se o êxodo e a pobreza -, os interlocutores costumam apontar os municípios da costa do Rio Uruguai fronteira física com a Argentina - como os mais desfavorecidos. Essa indicação foi mais freqüente por parte dos meus entrevistados mais "autorizados" - localizados em algum espaço institucional de prestígio, nas maiores cidades -, possivelmente porque participem de instâncias regionais de discussão da realidade regional e compartilhem informações disseminadas nesses eventos. Exemplificando-se:

Na região Costeira, municípios que fazem divisa com o Uruguai - Alecrim, Porto Vera Cruz, Porto Lucena, Porto Mauá, Novo Machado... Maurício Cardoso -, se você pega a população ribeirinha, você tem uma parte da população quase desempregada. É o pescador, que vive de pequenos cultivos e faz da pesca também uma atividade de busca de uma renda um pouquinho maior. Talvez aí poderia se identificar um pouquinho um conjunto de pessoas que tenha um aspecto crítico de desemprego. Não sei se poderia se chamar de bolsões de miséria, mas ao menos de não-ocupação efetiva... Mas, como eu disse, isso já aconteceu no final da década de 80 (professor universitário, 2001).

Observando-se, mesmo das poucas variáveis apresentadas na tabela acima, os indicadores referentes aos seis municípios listados pelo professor, que formam a linha do território banhado pelo Rio Uruguai, constata-se que, de fato, o conjunto se localiza geralmente próximo aos extremos menos positivos. Não chegam a constituir uma realidade à parte no quadro da região basta exemplificar com Alegria e Nova Candelária, que, na porção oposta (leste) da Grande Santa Rosa, detêm números comparavelmente ruins. Ainda assim, os municípios "ribeirinhos" formam 
uma faixa do território reconhecível - e, mais do que isso, reconhecida socialmente - como menos favorecida.

Essa configuração intra-regional expressa bem a articulação de dimensões históricas, econômicas, naturais, etc., na conformação de um fenômeno espacial, se à categoria espaço for dado o alcance que lhes emprestam contemporaneamente os geógrafos. A beira do rio Uruguai distingue-se por razões geológicas: tem solos mais pedregosos e desgastados por erosão, parte significativa dos quais apresenta forte delicividade, o que tem importantes efeitos técnicos e econômicos ${ }^{66}$. Historicamente, encontram-se em Schallenberger e Hartmann (1981:108-114) referências ao fato de o povoamento, tanto de Alecrim quanto de Porto Lucena, ter se associado a empreendimentos extrativos, conduzidos por 'nacionais' (o segundo desses municípios leva o nome atribuído a um lendário primeiro morador, que seria descendente de índigenas). Nessa clivagem étnica, cabe ressaltar que Alecrim foi das últimas porções da Grande Santa Rosa a ser desmatada e ocupada, num momento em que muitos moradores de origem ibérica e "brasileira" haviam sido deslocados dos núcleos originais de colonização por terem obtido menor eficiência, conforme a passagem de Schallenberger e Hartmann citada anteriormente (1981:91). Outro aspecto a incidir sobre esse conjunto de municípios envolve a regulação estatal, especificamente a legislação ambiental: segundo o secretário municipal de turismo de Porto Mauá, que entrevistei em julho de 2006, o Código Florestal brasileiro, de 1965, proíbe qualquer cultivo em terras com declive de mais de 45 graus; transformou, ademais, em Áreas de Proteção Permanente (APPs) faixas de terra nas margens dos rios, que devem ser reflorestadas se necessário (a extensão da zona costeira preservada varia conforme a do curso de água). A atenção a essa regulamentação, ocioso dizer, tem sido crescente.

Mais do que detalhar as particularidades desse subconjunto de municípios, quis ilustrar, aqui, pelo interesse metodológico, a pluralidade de dimensões analíticas que se articulam para conformar uma problemática espacial - neste caso, intra-regional. Não deixa de ser importante ter presente, ademais, que algumas pressões e problemas que são sentidos na Grande Santa Rosa tendem a ser vinculados de forma um tanto direta com essa área específica formada pelos municípios costeiros:

Hoje, aqui, Santo Cristo, tem algumas vilas, e que sofreram... que são oriundas aí do êxodo rural, principalmente dos outros municípios, da costa do Rio Uruguai. Naqueles anos aí que não tinha nenhum crédito para agricultura, aquele povo saiu, e Santo Cristo foi o primeiro lugar onde essas famílias pararam. Depois é Santa Rosa, e os outros é Novo Hamburgo, é Porto Alegre. Mas Santo Cristo recebeu a primeira leva, o êxodo rural de pessoas, a maioria não-alemãs, que vieram da costa do Rio Uruguai (Sindicalista rural, Santo Cristo, mai.07).

\footnotetext{
66 "Antes tu plantava o soja e tu colhia ele tudo manual, com a foice: cortava, colhia ele, amontoava num determinado lugar; encostava a trilhadeira, colocava ele dentro, trilhava, ensacava ele e levava. E essa prática ainda é usual aqui na costa do Rio Uruguai, onde as terras são muito em declive. Então, tu não consegue... Porque a automotriz trabalha num terreno mais ou menos plano ou semi-plano" (funcionário do SINE de Santa Rosa, nov.06).
} 
Em meio a tantos outros, talvez esse processo da migração de curta distância - ou, mesmo, a mera percepção da possibilidade de sua ocorrência ${ }^{67}$ - seja suficiente para afirmar uma articulação inequívoca das diferentes localidades, o que aponta para a necessidade e para a pertinência dessa "segunda" escala, de tipo regional.

É oportuna uma palavra sobre as emancipações. A instauração de novos municípios, que recortaram administrativamente o território da Grande Santa Rosa, teve dois "surtos": o primeiro se inicia nos anos 1950, com a autonomização de Três de Maio, Horizontina e Santo Cristo (hoje os municípios de maior porte, seguindo a cidade pólo), além de Porto Lucena, entre 1955 e 1956; mais para o final daquela década, seguem-se Tucunduva e Tuparendi (Schallenberger; Hartmann, 1981:103-120). Nos anos 1960 um novo rol de emancipações se processa. A fragmentação é detida ao longo do regime militar: uma única municipalidade é constituída na região: Alegria. No início da década de 1990, uma nova enxurrada de plebiscitos e de emancipações traz à Grande Santa Rosa seis novos integrantes.

A cada lote de instalações de municípios, perdem território alguns dos que haviam sido instaurados no surto anterior. A partir de um exemplo que me foi narrado, chamou-me a atenção o fato de que, muitas vezes, a fragmentação administrativa não é, do ponto de vista regional, um jogo de soma-zero. A municipalidade "mãe" sofre alguma retração na arrecadação de tributos ou nas transferências estaduais e federais, em decorrência da perda populacional. Entretanto, a sistemática do Fundo de Participação dos Municípios no ICMS - que contempla mecanismos redistributivos $^{68}$ - pode fazer com que determinadas cisões contemplem os interesses de ambas as partes. Segundo me foi dito em uma entrevista na Prefeitura de Horizontina, a "saída" de Doutor Maurício Cardoso foi apoiada pela Prefeitura, que teria favorecido seu ex-distrito na partilha de maquinário e da dívida municipal que caberia à nova cidade.

Mesmo que a segmentação administrativa possa não gerar disputas, nem por isso deixa de ser reconhecido que o pequeno porte de quase todas essas municipalidades as deixa com escassos recursos financeiros e, sobretudo, políticos, o que estimula uma ação articulada em nível regional, segundo o entendimento unânime de meus entrevistados, como pretendo detalhar um pouco.

\subsubsection{Uma articulação real, convergente e - por que não? - hierárquica}

Se é verdade que uma parte significativa da literatura consultada, proveniente da geografia, rejeita a construção estática e meramente hierárquica de regionalizações, nem por isso

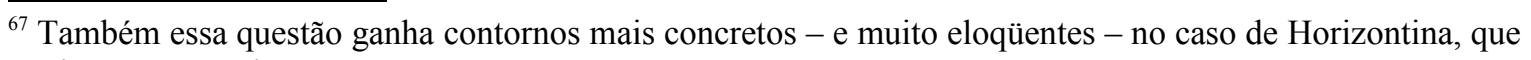
exploro no capítulo 7.

${ }^{68}$ GASPARINI, Carlos Eduardo e MELO, Cristiano Santos Lúcio de. Equidade e Eficiência Municipal: Uma Avaliação do Fundo de Participação dos Municípios - FPM. http://www.tesouro.fazenda.gov.br/Premio_TN/VIIIPremio/1 premio tfdp.pdf, acessado em 04.11.2007.
} 
os estudos dessa disciplina abandonam a perspectiva de ordenar e encadear vínculos entre distintas classes de formações urbanas. Um exemplo obrigatório a ser, mesmo que rapidamente, tratado aqui é o estudo das redes urbanas no Brasil, de que o IPEA, o IBGE e parceiros lançaram um produto muito robusto em 2002 (IPEA, IBGE, UNICAMP, 2002). Em sua revisão teórica, esse trabalho questiona e busca avanços a partir do legado da "teoria dos lugares centrais", cujos fundamentos, salvo melhor juízo, continua a esposar:

A hierarquia urbana inscreve-se, cada vez mais, num contexto econômico internacional que transforma a natureza das relações entre as cidades e seus hinterlands, entre as cidades de mesmo nível e entre os centros urbanos de diferentes categorias. A estrutura da rede urbana aparece menos piramidal (...).

Entre os diferentes níveis urbanos, as relações tradicionais de hierarquia dos mercados do centro para a periferia permanecem; e também se pode notar a multiplicação dos fluxos de bens e serviços de alto nível das redes urbanas inferiores em direção às redes urbanas superiores (IPEA, IBGE, UNICAMP, 2002, v.6, p.30).

Com uma abordagem tributária à idéia de "regiões de influência das cidades" (Regic), o estudo combina a avaliação das dotações de cada cidade (volume populacional, infra-estrutura, oferta de serviços especializados em áreas como educação e saúde, etc.) com medidas de fluxos entre municípios: transportes e, em casos específicos, como no Centro-Oeste do país, fluxos migratórios (v.1. p.45-50).

Indo diretamente ao meu interesse empírico: na p.158 do segundo volume, em graus sucessivos e decrescentes de centralidade, parte-se de Porto Alegre e, dentre as cidades de segundo nível, segue-se para Santa Maria (no centro do Estado). Dentre os municípios por ela "influenciados", consta Ijuí, já no noroeste do Rio Grande do Sul. No "passo" seguinte, encontrase Santa Rosa, cujo nível de centralidade é tipificado como "forte para médio" na referência à metrópole gaúcha.

Nessa perspectiva de mapear "interações espaciais e níveis de centralidade", que norteia aquele estudo, vinculam-se a Santa Rosa, em nível inferior, duas classificações de municípios: (a) aqueles de centralidade "muito fraca" cuja relação é direta com Santa Rosa: Alecrim, Campina das Missões, Cândido Godói, Porto Lucena, Porto Mauá, Porto Vera Cruz, Santo Cristo e Tuparendi; (b) municípios em um grau intermediário de centralidade, sucedendo Santa Rosa, mas precedendo outros: Três de Maio comparece como um nível "médio", e a ele se vinculam Horizontina (em nível "fraco") bem como, no último degrau da classificação ("muito fraco") as cidades de Alegria, Boa Vista do Buricá, Independência, e São José do Inhacorá. Por fim, vinculados por intermédio de Horizontina a Três de Maio (e, a seguir, Santa Rosa), tem-se Doutor Maurício Cardoso, Novo Machado e Tucunduva.

Percebe-se que dos 20 municípios que compõem a regionalização que adotei, 18 estão, de acordo com o referido estudo, articulados, de forma hierárquica, com Santa Rosa e, em alguns casos, entre si. Deixam de comparecer a esse desenho apenas duas municipalidades, Senador 
Salgado Filho e nova Candelária. Todavia, não os localizei em outro ponto qualquer da rede urbana do Rio Grande do Sul ${ }^{69}$.

A existência de alguma hierarquia entre os municípios - de resto, recomendada pelo bomsenso -, foi indicada em diversas oportunidades da pesquisa de campo, em formulações que apontam, por exemplo, para níveis sucessivos de distâncias físicas a percorrer, conforme a complexidade de algumas demandas. O exemplo da saúde - sobretudo quando colocado a partir do ponto de vista de um dos menores municípios da Grande Santa Rosa - é bastante apropriado:

P - E desses mais idosos, alguns também vão para outras cidades, para "pólos" - por razões de saúde, às vezes?

$\mathbf{R}$ - Muito difícil. Porque o atendimento de saúde que nós temos aqui não pode ser melhor. Aqui se faz de tudo. Se não tem recurso no município, se leva a Três de Maio; se não tem em Três de Maio, se leva a Santa Rosa; se não tem em Santa Rosa, se leva a Porto Alegre ou a Passo Fundo [integrante da administração municipal de São José do Inhacorá, ago/06].

Ao mesmo tempo - e o caso de Horizontina, que será discutido no capítulo 7, deve contribuir para iluminar esse ponto -, o reconhecimento de que determinadas hierarquias organizam o espaço e os deslocamentos, ao longo de uma rede de lugares, não autoriza a que se tomem os "níveis de centralidade" - ponto de chegada do estudo do IPEA, IBGE, UNICAMP como indicações inequívocas e suficientes das posições relativas de cidades ou regiões. Seja por critérios econômico-produtivos, seja pelos níveis de bem-estar, seja pela inserção em cadeias qualificadas (contínuas ou - especialmente - descontínuas, no espaço) de intercâmbio e de geração de valor, uma localidade classificada como "nível fraco", como é o caso de Horizontina, pode rivalizar com muitas das formações que lhe são antepostas no quesito "centralidade". Aí, salvo engano, reside um dos fulcros da discussão dessa literatura mais recente sobre região.

Em paralelo aos deslocamentos no espaço determinados pelas necessidades, pelos recursos, preferências e mesmo pelo grau de informação de que dispõe uma miríade de indivíduos ou agências relativamente isolados - bem ilustrado no depoimento acima, ouvido em São José do Inhacorá -, corre a formalização de incontáveis arranjos institucionais que recortam - e articulam - porções de território, funcionando como fator de "criação" de entes regionais. Na Grande Santa Rosa foi possível identificar a coexistência de inúmeras regionalizações diversas. A título de exemplo: o escritório da Emater em Santa Rosa é responsável por 45 municípios; o Comando Regional de Policiamento Ostensivo da Secretaria de Segurança Pública do Estado coordena, a partir dessa cidade, 55 outras; a regional do Sindicato da Indústria da Construção Civil abrange sete municípios; a Coordenadoria Regional da Secretaria Estadual de Educação engloba 22.

\footnotetext{
${ }^{69}$ Ademais, dois outros municípios - Giruá (encravado entre Santa Rosa, Senador Salgado Filho e Independência) e São Martinho (contíguo a Alegria), níveis fraco e muito fraco, respectivamente, na classificação do estudo - apareceram na rede que se abre a partir de Santa Rosa. Entretanto, eles constituem dois dos (poucos) casos em que há duplicidade (ou multiplicidade) de "enquadramentos" das influências sofridas por uma mesma cidade, no referido estudo.
} 
Isso não impede que o conjunto das vinte municipalidades com que trabalho tenha uma "existência" amplamente reconhecida e tradicionalmente replicada, no universo sócio-institucional da região. Recorro a um dos depoimentos, colhido em 2002, o qual já antecipa um fator importante a condicionar a convergência para esse "desenho" regional específico:

Por exemplo, nós temos aqui uma regional dos empresários que está ligada à questão da ACISAP [Associações Comerciais e Industriais, que incluem outros setores, como Agropecuária e Serviços, dependendo do município] (...) mas eles têm um fórum regional de coordenação. (...) Outro detalhe: tem uma regional dos sindicatos de trabalhadores rurais. (...) Então esses atores que têm suas organizações de categoria acabam...(...) E aí têm os sindicatos urbanos, também estão articulados. Aqui nós temos duas ou três articulações, uma pelo núcleo do CPERGS Sindicato [professores públicos estaduais], por exemplo, outra pelo núcleo dos bancários, outra pelo núcleo dos metalúrgicos, e assim vai indo. Essas entidades, elas conseguem ter mais presença no município, nos 20 municípios daqui, do que a efetividade do conselho municipal de desenvolvimento. (...) E essa associação dos municípios ela é histórica, quer dizer, ela tem uma presença muito forte aqui na região em termos de articulação. Depois eles têm também um fórum regional de vereadores. Então você vai ter assim, praticamente todas as organizações têm fórum regional (professor universitário, integrante de uma instância regional, 2002).

Neste segundo tempo da pesquisa, procurei, regularmente, em meus contatos com representantes de instituições da Grande Santa Rosa, verificar a existência e a abrangência de fóruns ou associações de tipo regional, vindo a confirmar o quadro apontado quatro ou cinco anos antes pelo professor acima citado. Conforme ele sintetiza, os vinte municípios são a territorialidade de base para a articulação tanto de sindicatos rurais e urbanos quanto do empresariado e dos poderes públicos. Mais recentemente, como relatarei, emergem instâncias que, a partir da mesma configuração espacial, buscam ultrapassar a organização por categoria e promover fóruns de ampla representatividade social, visando à discussão de problemas e ao encaminhamento de ações coletivas de interesse dessa coletividade construída a partir da perspectiva regional.

\subsubsection{Alguns recursos institucionais e um traço da auto-imagem}

Ao apresentar, rapidamente, algumas balizas institucionais que contribuem para constituir a Grande Santa Rosa como uma região - na linha do que Milton Santos denomina "sistema de ações", se quisermos -, cabe destacar de imediato a existência, no Rio Grande do Sul, dos Conselhos Regionais de Desenvolvimento (Coredes). Eles foram oficialmente criados e regulamentados por decretos do governo estadual em 1994, mas começaram a ser articular já em 1991. 
As atribuições e, mesmo, o número dos Coredes variaram bastante, desde então ${ }^{70}$. Em meu "tempo 1" da pesquisa, o território gaúcho era recortado em 22 Coredes. Posteriormente, mais quatro deles foram criados, refletindo a dinâmica política e rearticulações de interesses nas porções envolvidas, conforme já havia acontecido em momentos passados, com outras frações do território, incluindo-se a Grande Santa Rosa, como veremos.

Os Coredes, dessa forma, significam tanto uma regionalização no sentido de subdivisão territorial - cuja oficialidade tem induzido certo grau de progressiva padronização - quanto uma criação institucional relativamente "anfíbia", no terreno que marca a afirmação de uma esfera pública não exclusivamente estatal. Têm uma composição (regulamentada) cujo propósito manifesto é o de ser amplamente representativa, socialmente. Na lei de sua criação, suas atribuições são definidas como segue:

\footnotetext{
Art. $3^{\circ}$ - Compete aos Conselhos Regionais de Desenvolvimento, dentre outras, as seguintes atribuições:

I - promover a participação de todos os segmentos da sociedade regional no diagnóstico de suas necessidades e potencialidades, para a formulação e implementação das políticas de desenvolvimento integrado da região;

II - elaborar os planos estratégicos de desenvolvimento regional;

III - manter espaço permanente de participação democrática, resgatando a cidadania, através da valorização da ação política;

IV - constituir-se em instância de regionalização do orçamento do Estado, conforme estabelece o artigo 149, parágrafo $8^{\circ}$ da Constituição do Estado;

$\mathrm{V}$ - orientar e acompanhar, de forma sistemática, o desempenho das ações dos Governos Estadual e Federal na região;

VI - respaldar as ações do Governo do Estado na busca de maior participação nas decisões nacionais (Lei Estadual no 10.283, de 17 de outubro de 1994).
}

Em agosto de 2006, tive oportunidade de assistir (e gravar) à comemoração dos quinze anos de existência do Corede "Fronteira Noroeste" - designação que é dada ao exato conjunto de vinte municípios da Grande Santa Rosa.

A cerimônia de aniversário contou com o discurso de um professor universitário que tomou parte das primeiras articulações para essa "criação" institucional, na região. Ele historiou o processo político de demarcação das fronteiras entre os Conselhos, exaltando a unidade dos municípios da Grande Santa Rosa, que obtiveram à força de pressão e mobilização um recorte territorial que os livrou do "casamento forçado" com a zona contígua polarizada pelo município de

\footnotetext{
${ }_{70}$ No que diz respeito às atribuições, não me refiro a alterações na legislação, mas na forma como o Executivo Estadual, a cada mandato, lança mão dessa criação institucional que são os Coredes. Durante a gestão do Partido dos Trabalhadores (1999-2002), por exemplo, os Coredes foram o recorte territorial para a implantação do Orçamento Participativo estadual - tentativa de transpor para a gestão de uma Unidade da Federação a sistemática que já tinha certa tradição em Prefeituras do país. No mandato seguinte, do PMDB, é desativado o Orçamento Participativo e criado um mecanismo de Consulta Popular (com votações de prioridades de investimento, inclusive, via internet). Também aqui, a base de regionalização acompanha a subdivisão do Rio Grande do Sul em Coredes, que passam a ser também, institucionalmente, os responsáveis pela condução do processo.
} 
Ijuí, resultando na reprodução exata da delimitação da Associação dos Prefeitos da Grande Santa $\operatorname{Rosa}^{71}$.

No esquema do governo estadual de então, nos idos de 1991, a Região Noroeste foi incluída na Região Colonial, sob a liderança da cidade de Ijuí. Para a formatação dessa região, que teria um Conselho Regional de Desenvolvimento, o governo estadual, ao que consta, não buscou nenhuma informação prévia.

Sob a batuta do secretário [nome do Secretário de Planejamento], o Estado foi loteado (...) obliterando completamente o espírito democrático (...). Este pecado de autoritarismo provocou reações em várias partes do estado, sobretudo na Região Noroeste, inconformada com o casamento forçado com a Região Colonial.

As lideranças políticas regionais da época, tendo à frente o empresário [nome], líder da grei política do governo estadual na região, se empenharam a fundo para tentar demover [sic] o secretário, a desvincular a Região Noroeste da Região Colônia, criando outro Corede. Toda a argumentação foi frustrada, até o momento em que o dito secretário aceitou a sugestão de vir a Santa Rosa e convencer as lideranças regionais a juntar-se com a Região Colonial de Ijuí. (...) O debate foi acalorado e as argumentações das lideranças locais - presentes vários prefeitos municipais da região - convenceram o secretário da necessidade de criar mais um Corede. O homem acabou cedendo, ao perceber a unidade da região em torno do [inaudível]. Deixou, porém, um compromisso a ser assumido pela região: tornar-se o melhor Corede do Estado [articulador do Corede Fronteira Noroeste, em 1991, e integrante da Diretoria em exercício em agosto de 2006 - evento de aniversário do Conselho].

Essa idéia de mobilização e unidade, que ressalta da fala acima transcrita, remete a uma característica auto-atribuída com muita freqüência pelos meus interlocutores inscritos em instituições da Grande Santa Rosa, a que já me referi anteriormente: uma propensão para a negociação, para a ação coletiva, para a articulação de interesses diversos, exaltada como traço cultural da população regional. Essa visão aparece mesmo quando os entrevistados advertem contra uma leitura "panglossiana" da realidade social local:

\begin{abstract}
'Capital e trabalho se dão muito bem'. Não se dão tão bem, não. Porque já teve boas greves, bons movimentos... Tem sindicatos aqui fortes, né, e o PT é forte aqui. (...) Essa é uma região extremamente conservadora. (...) Uma cidade com 70.000 habitantes e três lojas maçônicas? Isso a gente tem que pensar, o que é isso? São disputas internas e locais. O caso do CTG [Centro de Tradições Gaúchas] — tem o grande CTG Sepé Tiaraju, mas já tem mais dois. Isso é comum nessa região, esse esfacelamento das instituições. (...) eu acho que isso tem a ver com a fogueira das vaidades. [...]

Agora, uma coisa: existem umas lideranças aqui que têm procurado reverter essa situação. Isso é uma verdade. Eles buscam desenvolvimento daqui, eles buscam de lá... sabe? Eu, particularmente, tenho uma grande admiração por essa comunidade nesse sentido de eles serem assim... Vão buscar, vão atrás, eles não se entregam, sabe? (...) há uma busca permanente, porque é uma comunidade extremamente trabalhadora (professora universitária, historiadora, 2002)
\end{abstract}

Desde a Fundação do Frigorífico, nos anos 1950, passando pela "Operação Tatu" e pela criação da Associação dos Municípios da Grande Santa Rosa, em 1964, no âmbito de uma

\footnotetext{
${ }^{71}$ Entre 1991 e 1994, a delimitação dos Coredes foi objeto de ajustes e discussões nas regiões. O decreto que finalmente os define, em 1994, omite da "Fronteira Noroeste" dois dos 20 municípios que aqui considero Senador Salgado Filho e Nova Candelária -, ambos com apenas dois anos de emancipação. Todavia, eles não tardam a ser incorporados.
} 
discussão sobre o desenvolvimento regional - anteriormente referidos -, ou a criação, em 1966, da Fenasoja - que é gerida com uma complexa organização de que toma parte um grande número de entidades locais de Santa Rosa, com trabalho voluntário e várias formas de apoio -, depoimentos de diversos entrevistados em posição de "liderança" evocaram com freqüência episódios em que os atores sociais demonstrariam capacidade de organização e iniciativa.

Na década de 90, conforme levantei nas entrevistas de 2002, houve alguns esforços de articulação para a planificação de ações de desenvolvimento. Destacou-se o Plano Estratégico de Desenvolvimento da Região Noroeste do Rio Grande do Sul - realizado no bojo do Programa de Emprego e Renda (Proder), do Sebrae -, que teria mobilizado as representações mais diversas da região em torno de diagnósticos e proposições, segundo um de seus articuladores. Foram mencionados ainda o Plano de Desenvolvimento Sustentável da Bacia do Rio Uruguai e o Plano Integrado do Desenvolvimento do Médio e Alto Uruguai. Os três ultrapassam os limites territoriais do Corede e foram conduzidos por esferas de governo e instituições supra-regionais. A visão de muitos entrevistados, na época, foi que eles teriam ficado "no papel", por não terem obtido a devida mobilização da sociedade regional.

Também nos anos 1990, a terceirização da Iochpe-Maxion (hoje AGCO) assinala esse tipo de ação conjunta: a ACISAP, a Prefeitura de Santa Rosa e o Sindicato dos Metalúrgicos atuaram de diversas formas, pressionando e favorecendo a empresa, para que se mantivessem, na região, os elos da cadeia produtiva, dando suporte à constituição do conjunto de pequenas fornecedoras, como me narrou o presidente da ACISAP em 2002. Outras instituições aparecem na fala de seu sucessor - ele próprio um empresário, em decorrência desse processo -, em entrevista que realizei em 2006:

O início - [falando-se] bem simplório da coisa -, foi aquele do prefeito vai lá, desafia [a empresa], forma, "tá, vamos formar" [as empresas fornecedoras]. Ok, aí, depois, a prefeitura começou a participar. Participar com o quê? (...) máquinas pesadas, precisava vir de Panambi, de Caxias, a prefeitura ajudava com uma parte desse transporte. A própria Maxion ajudava [as terceiras] com o apoio técnico. (...) E a ACISAP apoiando todo esse processo de articulação entre empresa, prefeitura e novas empresas se formando. Mas ajuda financeira não teve. Ninguém veio aqui e disse assim: "Ah, toma lá cinco mil reais pra te ajudar na tua empresa". Incentivos fiscais tiveram por parte da prefeitura naquela oportunidade - mais pro ISSQN (...). Então, depois, quando veio a qualificação [certificação, etc], aí veio o projeto através da Iochpe-Maxion, juntamente com a ACISAP, juntamente com a prefeitura e com as empresas. Então era dividido o pacote, né. A IochpeMaxion pagando metade dos custos, o SEBRAE pagando metade dos custos; a prefeitura, dessa outra metade, (...) [confunde-se], aí sobrava um percentual pequeno pras empresas [pagarem].

(...) o grupo dos fornecedores, o grupo dos parceiros. E nós tínhamos reuniões todas as semanas. E lá naquelas reuniões, a gente trocava informações, até porque nós estava todos praticamente aprendendo. (...) Então, eventualmente, eu poderia ter uma máquina aqui que uma outra empresa não tinha. (...) Eu fazia essa operação pra essa empresa, vice-versa, e assim foi acontecendo. Foi acontecendo uma ajuda mútua (líder empresarial, empresário da metalurgia, ex-funcionário da Maxion - Santa Rosa, jul/06). 
Naquele mesmo período de minhas primeiras visitas à região, novas iniciativas dessa natureza - concepção e implementação de planos de desenvolvimento para a região - estavam sendo postas em marcha. O Programa de Recuperação Econômica da Região Noroeste (Reconvernoroeste), cuja principal agência era o BNDES, estava, então, em fase de deflagração. Avançava também um projeto para o incentivo da fruticultura, para o qual, informavam-me, teriam sido obtidos R \$ 5 milhões em emenda parlamentar. Ambos abarcavam porções mais amplas do Estado, mas haviam sido articulados por lideranças da Grande Santa Rosa; envolviam a captação de recursos federais, com uma trajetória, nesse sentido, mais "tradicional" de condução de políticas regionais.

Em uma outra vertente de iniciativas, ganhou relevo, na ocasião, o Fórum Regional de Desenvolvimento, do qual se pretendia que tivesse caráter permanente, que foi impulsionado pela principal universidade que atua na região (Unijuí), mas envolvia um amplo leque de instituições e mantinha cinco comissões: agroecologia; agricultura familiar e agroindústria; ensino técnico; ensino superior; e empreendedorismo. No bojo das discussões desse fórum, fundou-se a Agência de Desenvolvimento de Santa Rosa.

Quanto ao Conselho Regional de Desenvolvimento, a ampla maioria dos entrevistados testemunhou problemas para que ele, como instituição, assumisse a função de instância articuladora que lhe é reservada. Algumas manifestações se limitaram à falta de visibilidade de ações; outras, numerosas, indicaram que ele não conseguiu ser plural e mobilizador.

Ao retornar, pude constatar que as iniciativas que pareciam promissoras cinco anos antes não haviam gerado resultados que meus interlocutores demonstrassem reconhecer. Como tais projetos não aparecessem espontaneamente nas falas, vez por outra eu questionei diretamente, obtendo respostas como essa: "A fruticultura, né, na verdade não vingou. (...) Não deu em nada, não se plantou um pé de figo, pra dizer a verdade" (Secretário Municipal de prefeitura da região, maio/07).

Quanto ao Fórum capitaneado pela Unijuí, em um texto de dois professores que nela atuam, foram listados alguns resultados:

Resultaram desse processo, várias iniciativas. Ressaltam-se algumas: (1) realização de fóruns de debate de alternativas em várias áreas; (2) realização de cursos de capacitação e a "feira do empreendedor"; (3) iniciativas de valorização do Ensino Técnico na região, mais adequado às necessidades regionais; (4) apoio à estruturação de cooperativas de agricultores familiares e implantação da Cooperativa Central de Agricultores Familiares do Noroeste e, (5) realização de estudo de novas alternativas para a agricultura familiar regional, do que resultou o indicativo da viabilidade de ampliação da cadeia produtiva da cana-de-açúcar, inclusive para produção de álcool num sistema de micro-usinas integradas à produção leiteira, (6) realização de um encontro das instituições de ensino superior e representantes estudantis, para estudar a ampliação das possibilidades de acesso ao ensino superior, e de ensino técnico, bem como, a constituição do Comitê pró-instalação da Universidade Estadual-UERGS no estado e na região (Dallabrida, Büttenbender, s/d). 
O alcance que possam ter tido os resultados elencados como destaque - de resto, claramente tópicos e, quando muito, preparatórios de futuras ações - não impede que a experiência não seja muito lembrada, nas falas dos atores regionais ouvidos em 2006 e 2007. De qualquer modo, a própria implantação, na Grande Santa Rosa, de um campus dessa universidade que esteve à frente do Fórum, a Unijuí foi bastante destacada como um dos fatos relevantes da década de 1990 para o desenvolvimento regional ${ }^{72}$. A região conta com outras três instituições de ensino superior, de menor porte, criadas - em pelo menos dois casos - a partir das estruturas de escolas tradicionais de ensino fundamental e médio: uma localiza-se, também, em Santa Rosa, outra em Três de Maio e a mais recente em Horizontina. A presença dessas quatro instituições é muito valorizada nas nas falas sobre os potenciais de desenvolvimento da região.

Segue sendo relativamente limitada a capacidade de essa instância chamar a uma mesma arena todos os segmentos sociais e as instituições potencialmente pertinentes para uma discussão continuada da realidade regional e encaminhamento de ações que beneficiem seu desenvolvimento. O presidente da Agência de Desenvolvimento de Santa Rosa alfinetou:

É que tem que ter um pouco de cuidado: essa questão acadêmica, às vezes, se tu só olha o lado acadêmico da coisa e não vai na parte prática - que é aqueles que estão lá na ponta, como dizem o cara do chão-de-fábrica, que está executando -, fica um troço muito "elevado". Então o cara olha e diz: "não é assim". O Corede tem um pouco esse sentimento, pelo que eu ouço - do que eu ouço, ouço muito disso, né? Então, na verdade, “... ah, o diagnóstico está aqui, está pronto". Mas quem é participou da confecção, quem é que discutiu? Existe esse questionamento (dirigente de cooperativa, presidente da Agência de Desenvolvimento de Santa Rosa, jul.06).

De quebra, ele diz que nenhuma das duas universidades sediadas na cidade tem se engajado nas atividades da Agência de Desenvolvimento, embora sejam a elas associadas, e termina por indicar que há uma disputa entre elas, depois de ter sido rompido um "acordo de cavalheiros" pelo qual elas evitariam sobreposição na oferta de cursos de graduação.

Não é possível detalhar, mas, a par dos percalços na tentativa de instaurar essas arenas multi-institucionais de tipo "estratégico", é muito recorrente se ouvir o relato de intervenções que articulam mais de uma entidade. Nas iniciativas voltadas à produção primária, uma boa interação da Emater e dos Sindicatos de Trabalhadores Rurais foi testemunhada por ambas as partes; o Sebrae teve sua atuação referida por diferentes entrevistados; Senai, Senac e Senar tiveram reconhecida sua atuação na formação de mão-de-obra, configurando-se uma parceria muito clara com a empresa John Deere e com instituições escolares do município de Horizontina; a intervenção da Unijuí foi relatada em inúmeras iniciativas, desde o suporte técnico à produção de ervas medicinais no pequeno município de Tuparendi até a coordenação do Programa Pólos de

\footnotetext{
${ }^{72}$ A Universidade assumiu uma série de parcerias com o Governo Estadual, como a condução do núcleo regional do programa Pólos de Modernização Tecnológica, da Secretaria de Ciência e Tecnologia, ou do Programa Extensão Empresarial. Vinculados à universidade, são mantidos o Instituto de Políticas Públicas e Desenvolvimento Regional, (IPD), que fomenta a modernização das administrações públicas, e o Instituto Regional de Desenvolvimento Rural voltado à gestão ambiental e à tecnologia agrícola.
} 
Inovação Tecnológica, cujos núcleos setoriais mobilizam esforços conjuntos com sindicatos patronais e com outros programas públicos.

Uma das questões que parecem mais candentes do ponto de vista das condições sócioeconômicas da região é a necessidade percebida de diversificar a produção primária. Como nos indica esse entrevistado, tal é um campo em que o esforço conjunto de muitas entidades vem sendo empreendido:

Por volta de 2003, 2004, alguns produtores já estavam indo pro leite, criando a vaca. "O grão está bom". Voltam tudo pro grão de novo. Porque daqui a pouco plantar, sei lá eu, dez, 20 hectares de grão, um ano bom, com preço bom, ele rende mais, na média, e com menos trabalho do que tu ter uma série de hortigranjeiros, e coisas do tipo assim. Então o pessoal acaba querendo esse negócio. Então há uma dificuldade muito grande desse entendimento por cultura. Agora, no caso da piscicultura, mesmo, nós estamos juntos: além do apoio do Sebrae, o apoio da própria Emater. Está trabalhando junto; não é um trabalho isolado da ACISAP, ou do Sebrae; é um trabalho conjunto, em que as entidades estão buscando, estão indo lá no produtor, conversando, trazendo pra reunião - uma hora vem, outra hora não vem; agora questiona, agora não questiona. É uma coisa que custa muito a ver resultado lá na frente (presidente da ACISAP, jul.06)

$\mathrm{O}$ equacionamento da sustentabilidade da agricultura famililar aparece como um eixo fundamental tanto para conter a perda populacional, quanto para garantir o impulso econômico que possa ativar as atividades urbanas. Essa tarefa é considerada, em larga medida, uma responsabilidade da própria região. Na fala de um líder empresarial, em 2002: "Nós estamos a 500 quilômetros de Porto Alegre. Nós temos que ser - entendeste? - os geradores do nosso desenvolvimento".

A preocupação recorrentemente explicitada se defronta com o desafio de gerar oportunidades de trabalho, apontando simultaneamente para a retenção de agricultores familiares em seus minifúndios - retirados, portanto, da arena de oferta de mão-de-obra para o assalariamento - e de oportunidades de emprego em atividades urbanas. A forma que assume a problemática do mercado de trabalho na região é o centro do interesse dos próximos capítulos.

$* * * *$

Antes de começar a problematizar diretamente o mercado de trabalho da Grande Santa Rosa, o que inicio no próximo capítulo, procurei aqui assentar algumas referências que serão, nesse segundo passo, de grande importância.

Se mercados não "operam" por si mesmos e tampouco têm leis próprias, mas são construídos socialmente, é imperioso saber-se de "quem" se trata, quando se trabalha com uma experiência histórica - e territorial - precisa. No caso da Grande Santa Rosa, a trajetória da constituição mesma da região traz alguns elementos importantes: a colonização é muito recente (o tempo de um ciclo médio de vida: pouco mais de 75 anos), tendo sido promovida deliberadamente sob a égide da multiplicidade de origens étnicas. Ainda assim, houve e há uma expressiva predominância dos descendentes de alemães. Tais ascendências são claramente um elemento 
mobilizado com destaque na constituição das identidades, tendo emergido exemplos de tensionamento e mesmo de discriminação, ao mesmo tempo em que a diversidade é positivamente valorada no discurso que "funda" a região, tendo como expressão acabada a "Festa das Etnias".

Do ponto de vista produtivo, a "vocação" primária persiste, mas esteve desde cedo associada a movimentos - com êxitos e reveses - de industrialização. O tecido empresarial é exíguo e relativamente pouco diversificado (o contraste com a Região Metropolitana, evidentemente, amplifica tal característica), concentrando-se, ademais, em três municípios, o que deixa 17 deles muito distantes - se tratados isoladamente - de uma representação de mercado de trabalho, em que um número mínimo de agentes é condição lógica para que operem as interações e se viabilizem os "mecanismos" de equilíbrio. Não obstante, especificamente no segmento produtor de máquinas agrícolas, a Grande Santa Rosa detém duas grandes empresas, hoje multinacionais, porém fundadas por empreendedores locais e por eles alçadas a posições de destaque no mercado nacional e mesmo mundial. A presença dessas firmas - especialmente no caso da John Deere, em Horizontina, que é detalhado no capítulo 7 - inscreve essa região, em que não faltam queixas quanto ao "isolamento" geográfico, em circuitos globais de intercâmbio de mercadorias, informação, recursos humanos, tecnologia, etc., que têm efeitos muito destacados na literatura contemporânea sobre espaço e governança.

Ao gosto da literatura da sociologia econômica, a trajetória da Grande Santa Rosa é lapidar para evidenciar que a economia não "evolui" como um subsistema autônomo e descarnado da vida e da ação social: da fundação de um importante frigorífico (que serviu de base a um ciclo de prosperidade regional, a partir dos anos 50) à terceirização de uma empresa mecânica de grande porte (que é hoje multinacional), na década passada, são inúmeros os exemplos que mostram a permanente influência da ação coletiva, da política, sobre a configuração do tecido produtivo e das relações econômicas.

Também no nevrálgico problema da evasão populacional, a abordagem parece falha se ficar restrita ao discurso, um tanto difundido regionalmente, que a confina ao contingente de jovens rurais, restringindo, ademais, a determinação do êxodo a restrições de lucratividade ou de acesso à terra. É possível verificar que as oportunidades no meio urbano - mesmo da cidade pólo da região - são consideradas escassas e/ou insatisfatórias por indivíduos que não têm passado de vida rural. Além disso, a par de qualquer problema ligado à escala dos mercados urbanos de trabalho e/ou à sustentabilidade da agricultura familiar, fatores culturais não podem ser negligenciados, e parecem operar tanto na construção de uma identidade de povo propenso a migrar - "a formiguinha cortadeira" -, quanto na atração nutrida por centros maiores, frente a uma apreciação negativa da vida "provinciana". Pode contribuir para isso a crescente oferta de educação superior na região, que vem produzindo sempre mais recursos humanos credenciados a buscar trabalho em outros espaços. 
A composição da Grande Santa Rosa por 20 municípios, por fim, não deve obscurecer a heterogeneidade que não é abrandada pela proximidade ou pela relativa continuidade que, em vários aspectos, se estabelece entre eles. Por isso mesmo o conceito de região aparece como pertinente, ao partir de elementos que possuem uma identidade espacial própria - mais próximos à noção de local - e indicar uma articulação entre eles. 


\section{ANEXO \\ Tabela 7 - Número de estabelecimentos com 50 empregados ou mais nos municípios da Grande Santa Rosa, segundo o porte e a atividade econômica ("Classe CNAE 95"), 2005}

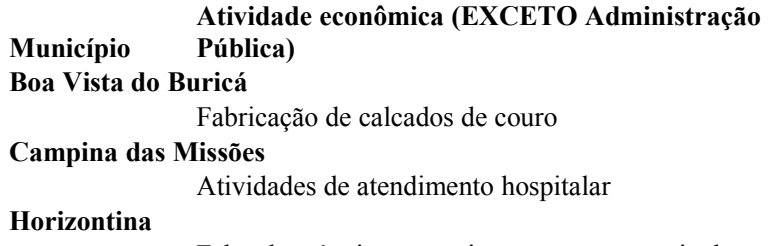

Fabr. de máquinas e equipamentos para agricultura, avicultura.

Transporte rodoviário de cargas, em geral

Ensino médio

Atividades de atendimento hospitalar

Outras atividades associativas, não especificadas anteriorm

Total

Independência

fabr. de máquinas e equipamentos para agricultura, avicultura

Santa Rosa

Cultivo de cereais para grãos

Abate de reses, preparação de produtos de carne

fabricação de produtos do laticínio

fabricação de embalagens de papel

Execução de outros serviços gráficos

fabricação de artefatos diversos de plástico

fabricação de pecas fundidas de ferro e aço

fabr. de estruturas metálicas para edifícios, pontes,

torres de tr.

fabr. de artigos de funilaria e de artigos de metal para usos domes.

fabricação de outras maquinas e equipamentos de uso geral

fabr. de máquinas e equipamentos para agricultura,

avicultura

fabricação de tratores agrícolas

Distribuição de energia elétrica

Com. atacadista de matérias primas agrícolas e produtos semi-acabados

Comércio atacadista de bebidas

Com. varejista de mercadorias em geral, com

predominância de produt..

Com. varejista de material de constr., ferragens,

ferramentas

Transporte rodoviário de passageiros, regular, urbano

Transporte rodoviário de passageiros, regular, não urbano

Transporte rodoviário de cargas, em geral

Crédito cooperativo

Ensino fundamental

Ensino médio

Educação superior - Graduação e Pós-Graduação

Atividades de atendimento hospitalar

Outras atividades relacionadas com a atenção à saúde

Atividades de organizações religiosas

Outras atividades associativas, não especificadas anteriorm.

Total

Santo Cristo

Obras para geração e distribuição de energia elétrica

Com. varejista de material de constr., ferragens,

ferramentas

Outras ativ. de intermediação financeira, não
50- 99 100- 249 250- 499500 -999 mil ou + TOTAL

$\begin{array}{llllll}0 & 0 & 1 & 0 & 0 & 1 \\ 1 & 0 & 0 & 0 & 0 & 1 \\ & & & & & \\ 2 & 0 & 0 & 0 & 1 & 3 \\ 2 & 0 & 0 & 0 & 0 & 2 \\ 1 & 0 & 0 & 0 & 0 & 1 \\ 1 & 0 & 0 & 0 & 0 & 1 \\ 1 & 0 & 0 & 0 & 0 & 1 \\ 7 & 0 & 0 & 0 & 1 & 8\end{array}$

$\begin{array}{llllll}0 & 1 & 0 & 0 & 0 & 1 \\ 1 & 0 & 0 & 0 & 0 & 1 \\ 0 & 0 & 0 & 1 & 0 & 1 \\ 1 & 0 & 0 & 0 & 0 & 1 \\ 1 & 0 & 0 & 0 & 0 & 1 \\ 1 & 0 & 0 & 0 & 0 & 1 \\ 1 & 0 & 0 & 0 & 0 & 1 \\ 1 & 0 & 0 & 0 & 0 & 1 \\ 1 & 0 & 0 & 0 & 0 & 1 \\ 0 & 1 & 0 & 0 & 0 & 1 \\ 1 & 0 & 0 & 0 & 0 & 1 \\ 3 & 0 & 0 & 0 & 0 & 3 \\ 0 & 0 & 0 & 1 & 0 & 1 \\ 1 & 0 & 0 & 0 & 0 & 1\end{array}$


especificad

Atividades de atendimento hospitalar

Total

Senador Salgado Filho

Três de Maio

fabricação de outros produtos alimentícios

fabricação de produtos do laticínio

fabricação de calcados de couro

fabricação de moveis com predominância de madeira

Distribuição de energia elétrica

Com. atacadista de matérias primas agrícolas e produtos semi-acabados

Crédito cooperativo

Ensino fundamental

Ensino médio

Educação superior - Graduação

Educação profissional de nível técnico

Atividades de atendimento hospitalar

Total

Tucunduva

Com. atacadista de matérias primas agrícolas e produtos semi-acabados

Tuparendi

fabr. de máquinas e equipamentos para agricultura, avicultura

TOTAL da Região

Cultivo de cereais para grãos

Abate de reses, preparação de produtos de carne fabricação de produtos do laticínio

fabricação de outros produtos alimentícios

fabricação de calcados de couro

fabricação de embalagens de papel

execução de outros serviços gráficos

fabricação de artefatos diversos de plástico

fabricação de pecas fundidas de ferro e aço

fabr. de estruturas metálicas para edifícios, pontes,

torres de tr...

fabr. de artigos de funilaria e de artigos de metal para usos domésticos

fabricação de outras maquinas e equipamentos de uso geral

fabr. de máquinas e equipamentos para agricultura, avicultura

fabricação de tratores agrícolas

fabricação de moveis com predominância de madeira

Distribuição de energia elétrica

Obras para geração e distribuição de energia elétrica

Com. atacadista de matérias primas agrícolas e produtos semi-acabados

Comércio atacadista de bebidas

Com. varejista de mercadorias em geral, com predominância de produt..

Com. varejista de material de constr., ferragens, ferramentas

Transporte rodoviário de passageiros, regular, urbano

Transporte rodoviário de passageiros, regular, não

urbano

Transporte rodoviário de cargas, em geral

Crédito cooperativo

Outras ativ. de intermediação financeira, não

especificad

Ensino fundamental

Ensino médio

Educação superior - Graduação

Educação superior - Graduação e Pós-Graduação

Educação profissional de nível técnico

Atividades de atendimento hospitalar

Outras atividades relacionadas com a atenção à saúde

Atividades de organizações religiosas

Outras atividades associativas, não especificadas

$\begin{array}{rrrrrr}1 & 0 & 0 & 0 & 0 & 1 \\ 2 & 0 & 2 & 0 & 0 & 4 \\ 0 & 1 & 0 & 0 & 0 & 1 \\ 0 & 1 & 0 & 0 & 0 & 1 \\ 0 & 0 & 1 & 0 & 0 & 1 \\ 2 & 0 & 0 & 0 & 0 & 2 \\ 0 & 1 & 0 & 0 & 0 & 1 \\ 2 & 0 & 0 & 0 & 0 & 2 \\ 0 & 1 & 0 & 0 & 0 & 1 \\ 1 & 0 & 0 & 0 & 0 & 1 \\ 0 & 1 & 0 & 0 & 0 & 1 \\ 1 & 0 & 0 & 0 & 0 & 1 \\ 1 & 0 & 0 & 0 & 0 & 1 \\ 0 & 1 & 0 & 0 & 0 & 1 \\ 7 & 5 & 1 & 0 & 0 & 13\end{array}$




\section{anteriorm}

Total sem Administração Pública

Administração pública em geral

Total com Administração Pública

$\begin{array}{rrrrrr}\mathbf{4 3} & \mathbf{1 5} & \mathbf{5} & \mathbf{2} & \mathbf{1} & \mathbf{6 6} \\ 3 & 14 & 1 & 2 & 1 & 21 \\ \mathbf{4 6} & \mathbf{2 9} & \mathbf{6} & \mathbf{4} & \mathbf{2} & \mathbf{8 7}\end{array}$

FONTE: MTE/RAIS (2005)

Nota: os municípios que não constam da tabela não possuíam sequer um estabelecimento declarante com 50 empregados ou mais, em 2005 - desconsiderada a atividade "Administração Pública em geral". 


\section{O TRANSBORDAMENTO DO MERCADO: NEXOS SOCIAIS DO TRABALHO NA EXPERIÊNCIA ESTUDADA}

Conhecidas, no capítulo anterior, algumas das principais características sócio-econômicas, culturais e institucionais da Grande Santa Rosa, o foco deste capítulo coincide com o cerne empírico da tese, o mercado de trabalho da Grande Santa Rosa, suporte para a discussão que proponho.

Optei por desdobrar essa apresentação em dois movimentos. No primeiro, valho-me de dados secundários, recorrendo às duas bases estatísticas que recobrem a totalidade dos municípios brasileiros fornecendo informações sobre ocupação da força de trabalho: a RAIS, do Ministério do Trabalho e Emprego, e os Censos Demográficos, do IBGE. No segundo, trago resultados de minha pesquisa de campo para incorporar aquelas dimensões analíticas que, em consonância com a idéia de espaço abordada no capítulo 2, concorrem para conferir a esse mercado de trabalho sua fisionomia regional, com as dimensões, cultural, institucional, histórica que isso implica.

Acredito que esse procedimento de exposição permitirá delinear duas idéias centrais para esta tese, as quais se apóiam nos resultados do trabalho de campo. Em primeiro lugar, e de modo mais evidente, fazer com que os dados secundários dialoguem com a realidade viva de uma formação regional e com as representações que dela fazem seus agentes potencializa em muito a capacidade de (re)dimensionar e corrigir a percepção de diversos fenômenos captados estatisticamente e, sobretudo, de avançar na compreensão de suas causalidades e interconexões. Em segundo lugar, ao incorporar as representações dos indivíduos e a dinâmica das instituições - a sociedade, em uma palavra -, amplia-se o arco de questões e dimensões requeridas para enfrentar a problemática de um mercado de trabalho, histórica e espacialmente concreto, ao menos da perspectiva disciplinar da Sociologia.

Lidando especificamente com a questão do desemprego, conforme referido no Capítulo 1, Guimarães (2002) chama a atenção para a agenda propriamente sociológica que o tratamento desse fenômeno reclama:

\footnotetext{
Com isto, estou chamando a atenção para o fato de que uma sociologia do desemprego deve ter a responsabilidade de analisar, conciliando, duas dimensões que são caras (porque constitutivas) da nossa tradição disciplinar: por um lado, a construção institucional e normativa do fenômeno; por outro, a sua significação subjetiva, tecida ao longo dos percursos no mercado de trabalho e ressignificada pela interpretação subjetiva das biografias individuais.
}

Trata-se, aqui, de alguma forma, de seguir essa proposição, de um modo ao mesmo tempo mais amplo e mais modesto. Mais amplo, porque meus resultados de campo fazem com que me volte a diversas categorias analíticas que tradicionalmente integram os levantamentos e análises sobre mercado de trabalho, das quais o desemprego é apenas uma. Outro aspecto a ampliar o escopo é a busca de considerar dimensões que transbordam o foco nos aspectos institucionais, 
normativos e subjetivos (no nível individual) indicados por Guimarães, como é o caso, por exemplo, de compromissos de solidariedade familiar ou construções coletivas de identidade étnica. Mais modesto, por outro lado, na medida que não espero contribuir com mais do que um exercício de articulação desses múltiplos níveis da vida social na abordagem do objeto "mercado de trabalho". É nesse sentido que o espaço - o recorte regional - opera, aqui, mais do que como uma dimensão analítica entre outras, como um produto e uma síntese delas.

\subsection{O mercado de trabalho delineado pelos indicadores estatísticos}

Para explorar as fontes secundárias sobre o mercado de trabalho da Grande Santa Rosa, restrinjo-me ao período entre o início dos anos 1990 e os dados mais recentes disponíveis. No caso dos dados da RAIS, trabalho com três pontos no tempo: 1989, 1999 e 2005, lembrando que as medições se referem ao último dia útil de cada ano. Quanto aos Censos, utilizo os dois últimos, concentrando-me no mais recente, mesmo porque mudanças metodológicas implementadas pelo IBGE restringem as comparações entre os resultados de ambos.

Principio a análise pela base estatística que apreende somente a forma mais "pura" de inserção num mercado de trabalho: o emprego assalariado "típico", com registro formal. Esse segmento da ocupação, conforme já antecipei anteriormente, é, nessa realidade regional, especialmente restrito, mesmo quando se tem em mente os padrões brasileiros e gaúchos. A RAIS de 2005 captava, ao final do ano, um total de 31,5 mil empregados formais, no somatório dos 20 municípios da Fronteira Noroeste. Esse número é bastante exíguo quando se considera que o Censo de 2000 computava mais de 112 mil ocupados na região.

Após um panorama geral do universo do emprego "com carteira", incorporo as informações censitárias para caracterizar tanto a ocupação quanto o desemprego regionais, bem como algumas problemáticas específicas do mercado de trabalho, para as quais combinarei informações da RAIS e dos Censos (notadamente a caracterização de situações específicas de inserção conforme atributos dos trabalhadores, como idade, sexo e escolaridade).

\subsubsection{Volume, distribuição espacial e setorial do emprego formalizado}

O emprego formal na Grande Santa Rosa concentra-se no Terciário, que respondia por 64,7\% dos postos, ao final de 2005, participação próxima à verificada em 1989 (64,1\%) e pouco superior à de 1999 (61,3\%). Os três setores que compõem o Terciário mantêm o mesmo ordenamento, nessas três medições: o Comércio é o primeiro, em número de trabalhadores $(25,9 \%$ do emprego total e 40\% do emprego terciário, em 2005), seguido dos Serviços e da Administração Pública. 
As atividades primárias são, nesse segmento formal do mercado de trabalho, muito pouco relevantes. Sua participação havia marcado um significativo avanço entre 1989 e 1999, passando de 3,4\% para 5,3\%, mas chega a 2005 com acentuado recuo, limitando-se a 2,6\%. O Secundário, por seu turno, representava, nessa medição mais recente, aproximadamente um terço do emprego formal (32,7\%), patamar que mostra estabilidade com relação a 1999 (33,4\%), quando registrava ganho de participação de 4 pontos percentuais, na comparação com o final da década anterior. Saliente-se que, desagregando-se os oito setores apresentados pela RAIS, a Indústria de Transformação detinha a primeira posição nos três anos selecionados, tendo sua participação se expandido moderadamente (de $25,8 \%$ para $26,7 \%$, e finalmente para $28,8 \%$ ).

A concentração dos empregos não é apenas setorial, como também espacial, no interior da região. Em 1989, três dos 20 municípios detinham, em conjunto, 75,6\% do total dos postos computados pela RAIS: Santa Rosa, isoladamente, representava 45,7\%; Três de Maio, 15,6\%; e Horizontina, 14,3\%. Em 1999, a soma das participações desses três municípios no emprego se reduz sensivelmente, limitando-se a 68,4\% do emprego (42,6\% em Santa Rosa; 13,5\% em Horizontina, que assume o segundo lugar; $12,4 \%$ em Três de Maio). Ao se chegar a 2005, observase pequena reconcentração, com um percentual de 70,2\%. Santa Rosa volta a sofrer perda, recuando para 40,9\%; Horizontina recupera e supera sua marca do início dos anos 1990, atingindo 15,9\% do emprego regional; a participação de Três de Maio $(13,4 \%)$ encontra-se agora num nível intermediário comparativamente aos seus resultados na década anterior.

A concentração do emprego formal nos três maiores municípios fica mais nítida quando se considera que os aproximadamente $70 \%$ que ela atinge superam largamente o percentual que reúnem da população total da Grande Santa Rosa - 49,1\%, em 1991; 50,8\%, em 2000.

Dentre os principais setores de atividade, essa concentração nos referidos municípios se faz sentir de forma mais acentuada na indústria de transformação. Neste caso, ela se mostra descendente, nas três medições aqui consideradas: de 87,8\%, em 1989, passa para 82,3\%, dez anos depois, e chega a 81,0\%, em 2005.

Tomando-se esse último ano, percebe-se que Santa Rosa (com 40,3\%) e Três de Maio (com 12,0\%) tinham, no emprego industrial, pesos próximos aos que ostentavam no total dos vínculos formais. Já Horizontina quase dobrava sua participação, alcançando 28,7\%. Cabe lembrar que Horizontina abrigava apenas $8,2 \%$ da população da Fronteira Noroeste, em 1991, e 8,4\%, em 2000.

A evolução do volume de emprego na Grande Santa Rosa, ao longo dos anos 90 e na primeira metade da presente década, foi bastante positiva, no contexto do Rio Grande do Sul. Entre 1989 e 1999, o Estado sofreu estreitamento de seu mercado de trabalho formal, ao passo que a região teve uma variação positiva de 11,6\% (2.574 empregos adicionais). Entre 1999 e 2005, o 
acréscimo, na Fronteira Noroeste, foi de $26,9 \%$, ou 6.689 postos, superior ao desempenho do agregado gaúcho, que cresceu $23,2 \%$.

Conforme foi indicado acima, entre 1989 e 1999 houve alguma desconcentração intraregional do emprego, parcialmente revertida no período 1999 a 2005. Nesse segundo intervalo, dos três maiores municípios, apenas Santa Rosa ostenta taxa de crescimento menor do que o agregado regional (22,0\%, versus 26,9\%); Horizontina tem um desempenho especialmente favorável (49,7\%), e Três de Maio, com 37,0\%, também supera o índice da Grande Santa Rosa.

Nesse mesmo período, 1999-2005, alguns municípios muito pequenos apresentam percentuais elevados de crescimento relativo do emprego. É o caso de Nova Candelária, Boa Vista do Buricá e Senador Salgado Filho, cujos estoques totais, entretanto, chegam ao final do período em patamares tão pequenos que oscilam entre 213 e 1184 empregados.

Esse crescimento do emprego, na primeira metade da presente década, manifestou-se tanto no secundário $(24,2 \%)$ quanto no terciário $(34,0 \%)$. Este, que já era o maior setor em força de trabalho, agregou $3 / 4$ do emprego "novo" (5.172 de 6.689 postos).

A indústria de transformação da Grande Santa Rosa, como mostrei no capítulo anterior, concentra-se em dois subsetores (na terminologia da RAIS): a indústria mecânica e a indústria de produtos alimentícios, de bebidas e álcool etílico. O primeiro perdeu participação no emprego industrial da região, ao longo da década de 90 , passando de $46,7 \%$ do total, em 1989, para 38,9\%, em 1999; em 2005, reconquistava praticamente o espaço perdido, com 45,0\% do emprego setorial. A indústria de produtos alimentares e bebidas, ao contrário, teve um pequeno ganho de participação na década de 1990, (de 26,4\% para 27,4\%), mas nos últimos anos perdeu 10\% de seu contingente, e sua parcela no emprego retraiu-se para 17,9\%. Juntos, esses dois subsetores representavam quase dois terços $(62,9 \%)$ do emprego setorial em 2005, após terem ostentado $73,1 \%$ de participação em 1989. Dois outros subsetores industriais merecem ser destacados: a indústria da madeira e do mobiliário - com 5,3\% dos empregados industriais da região, em 1989, e 8,4\%, tanto em 1999 quanto em 2005 - e a indústria metalúrgica - com 4,9\%, 7,1\% e 8,1\%, respectivamente.

Somando-se o emprego da mecânica e da metalúrgica, encontram-se $53,2 \%$ do contingente de trabalhadores industriais, em 2005.

$\mathrm{Na}$ indústria metalúrgica regional, o município de Santa Rosa detém um peso muito acentuado. Sua participação cresceu, na década de 1990 - de 59,0\% para 72,6\%, recuando para $66 \%$ em 2005. Com $106,0 \%$ de crescimento em seu contingente na década passada (que, como foi visto no Capítulo 4, marcou a terceirização da AGCO), continuou vendo aumentar seu contingente, entre 1999 e 2005, porém com menos intensidade que o conjunto da região (41,9\%, versus 55,9\%). Horizontina chega a 2005 com 70 empregados na metalurgia, número suficientemente pequeno para evitar entusiasmo com o percentual de variação, que atinge $900 \%$. 
Também na indústria de alimentos, o peso da cidade-pólo é muito elevado, situando-se em $66,5 \%$, no ano de 2005. Observa-se, entretanto, um recuo expressivo, pois em 1989, Santa Rosa, detinha 88,4\%, e, em 1999, 73,6\%.

Nos dois outros subsetores industriais aqui destacados, Santa Rosa não repete a condição de maior empregador. A indústria mecânica, principal subsetor em número de empregos industriais da Fronteira Noroeste, tem como líder inconteste Horizontina, que, com sua John Deere, inicia os anos 90 com $54,8 \%$ dos postos desse segmento e termina aquela década com 60,6\%. Em 2005 observa-se um recuo dessa participação, a qual segue, ainda assim, majoritária: $55,8 \%$.

$\mathrm{Na}$ indústria da madeira e do mobiliário, por fim, Santa Rosa encontrava-se em terceiro lugar em 2005. Após haver iniciado a década de 1990 na liderança, já em 1999 era superada por Três de Maio e Santo Cristo, situação que se mantém.

Assim como no emprego formal total, elevados percentuais de variação do emprego industrial ocorreram em municípios pequenos, entre 1999 e 2005, sobressaindo-se Nova Candelária, Boa Vista do Buricá e Doutor Maurício Cardoso, com aumentos de 528,6\%, 474,4\% e $250,0 \%$, respectivamente. A pequena dimensão de seus contingentes, mesmo após essa elevação, recomenda cautela: em 2005, os totais de trabalhadores do setor eram 44, 517 e 14, respectivamente.

No Comércio - que vem logo após a indústria, em estoque de postos formais da Grande Santa Rosa -, o contingente teve, entre 1999 e 2005, a maior elevação, dentre os principais setores: praticamente $50 \%$. Esses empregos mostravam, também, concentração no município de Santa Rosa, a qual se acentuou um pouco, na década passada, elevando-se dos 44,6\% de 1989 para 46,0\%, em 1999; já em 2005, assinalava-se o retorno para 44,7\%. A segunda posição ficava com Três de Maio, que detinha $13,8 \%$ do total do emprego no comércio. O crescimento do setor foi generalizado na região, com uma única exceção (Porto Mauá).

No setor Serviços, uma vez mais, a maior concentração do emprego formal na região encontra-se em Santa Rosa - 49,6\%, em 1989; 53,4\%, em 1999; 48,6\% em 2005. O segundo maior estoque de ocupados formais se encontra em Três de Maio - 21,2\%, em 1989; 16,5\%, em 1999; $18,1 \%$, em 2005.

A Administração Pública, quarta colocação em volume de empregados, não ostentava a concentração intra-regional verificada nos demais: o maior número de empregos formais localizava-se em Santa Rosa - 26,4\%, em 1989; 23,9\%, em 1999; 25,9\% em 2005. Seguia-se Horizontina, com 11,4\% em 2005, superando pela primeira vez Três de Maio (10,6\%), que se mantinha na segunda posição em 1989 e 1999 - com 12,0 e 10,7\%, respectivamente, enquanto Horizontina tinha $10,2 \%$ e $10,3 \%$. 
Observe-se que, na Administração Pública, registrou-se um aumento de 957 empregos no período 1989-1999. Desses, 508 constituíam, em 1999, o contingente de empregados dos municípios criados na região ao longo da década passada: Nova Candelária, Novo Machado, Porto Mauá, Porto Vera Cruz, São José do Inhacorá e Senador Salgado Filho. Vale destacar que o setor atinge participação muito elevada no total do emprego formal das localidades de menor porte, e que, no total da região, continuou crescendo vigorosamente $(21,4 \%)$ na primeira metade da presente década. Em 2005, a Administração Pública ostentava mais de 50\% dos empregados registrados na RAIS em cinco dos 20 municípios da Fronteira Noroeste. Nesse conjunto, estavam os quatro últimos colocados da região em número de empregos formais - Porto Vera Cruz, Porto Mauá, Novo Machado e São José do Inhacorá, além de Alegria (15 $5^{\mathrm{a}}$ posição em estoque de empregos). O grau de predominância da Administração Pública no mercado formal chegava ao seu ponto máximo em Porto Vera Cruz, com nada menos do que 79,0\%. Mais uma vez, é importante que se "desça" para os números absolutos, para aquilatar esse dado: aquela municipalidade contava com 98 empregados na Administração Pública e tão-somente 26 em outros setores (19 no comércio, 6 nos serviços e 1 na agropecuária).

Até mesmo por essa diminuta participação do segmento formalizado da ocupação, em localidades cuja população total já é muito pequena, é indispensável uma análise dos dados que englobam o conjunto da força de trabalho, na qual outras formas de inserção, que não o assalariamento com vínculo legalizado, mostram-se tão ou mais relevantes para uma compreensão da estruturação e da dinâmica do trabalho social. Os Censos Demográficos do IBGE se constituem na fonte por excelência para esse exame.

\subsubsection{A ocupação no Censo Demográfico de 2000}

A Grande Santa Rosa possuía, em 2000, 112.262 indivíduos ocupados, o que correspondia a 2,5\% do total da ocupação do Rio Grande do Sul. Santa Rosa detinha a maior parcela dos ocupados (25,4\%), seguida de Três de Maio (11,5\%), Santo Cristo $(8,2 \%)$, Horizontina $(7,6 \%)$ e Tuparendi (5,1\%).

Setorialmente, o mercado de trabalho era fortemente concentrado: quase metade $(47,1 \%)$ dos ocupados exercia atividades de Agropecuária, Extração Vegetal e Pesca, cujo contingente atingia 52.931 indivíduos. A participação desse setor era, na região, mais do que o dobro da verificada no agregado do Estado (20,1\%). O maior município da região, Santa Rosa, era o menos agrícola: apenas $16,0 \%$ dos ocupados exerciam atividades primárias. Horizontina, o quarto município em número de ocupados, detinha o segundo menor percentual de ocupação primária (27,1\%), o qual, no entanto, já ultrapassava o do Rio Grande do Sul. A seguir, encontrava-se Três de Maio, onde as atividades agropecuárias já saltavam para 38,1\%. Em apenas outros dois municípios, além desses, o setor primário detinha uma participação inferior à metade da ocupação 
total (Boa Vista do Buricá, 44,7\% e Tucunduva, 41,1\%). Nas quinze localidades restantes, a parcela de trabalho primário abarcava a maioria absoluta dos ocupados, variando de 57,9\%, em Tuparendi, a nada menos que $82,2 \%$, em Nova Candelária.

Nesse setor, os municípios da região com maior número absoluto de trabalhadores eram, em 2000, Santo Cristo, Três de Maio e Santa Rosa, nessa ordem.

A segunda "seção", como classifica o IBGE, em volume de força de trabalho, na região, era o "Comércio, reparação de veículos automotores, objetos pessoais e domésticos", que contava com 13.339 postos de trabalho, ou $11,9 \%$ do total, ao passo que, no Estado, o setor atingia 15,9\%. Em nível regional, essas atividades tinham sua participação máxima no município de Santa Rosa (19,1\%), seguindo-se Três de Maio (17,0\%). Santa Rosa detinha 40,8\% da ocupação da região nesse setor, enquanto Três de Maio respondia por 16,4\%. Somando-se Horizontina, que abarcava $8,4 \%$ dos postos comerciais, tem-se três municípios concentrando $65,7 \%$ da força de trabalho setorial.

A Indústria de Transformação - que, dentre as desagregações setoriais apresentadas no Censo, era, em 2000, o segundo setor em número de ocupados, no Rio Grande do Sul, com participação de 17,2\% -, possuía, na Grande Santa Rosa, uma representatividade bem menor, apenas 9,0\% (10.079 indivíduos), terceira posição no ranking dos setores. Horizontina era o único município da região em que o trabalho nesse setor ostentava participação um pouco superior à verificada no agregado do Rio Grande do Sul (19,6\%). Em Santa Rosa, o percentual era pouco inferior (14,2\%). Santa Rosa detinha 40,1\% dos postos de trabalho da indústria de transformação da região. Seguiam-se Horizontina (16,6\%) e Três de Maio (12,1\%). Juntos, esses três municípios respondiam por quase $70 \%$ da ocupação setorial na Fronteira Noroeste.

As três principais "seções" setoriais respondiam, conjuntamente, por $68 \%$ da ocupação regional. Observa-se que o grau de concentração nos maiores municípios é acentuadamente inferior ao que se verificou, acima, no tocante ao emprego formal, tendendo a se manter mais harmônica com a distribuição populacional, como voltarei a tratar.

Cumpre reter que a dimensão do segmento formalizado frente ao conjunto da ocupação é bastante restrita, na Grande Santa Rosa. No final de 1999, a RAIS registrava 24.837 empregados na região; o Censo de 2000 apontaria 112.262 ocupados, sendo 31,6 mil a soma dos empregados com carteira assinada e dos funcionários públicos e militares. Esse segmento (que inclui 2,7 mil empregados domésticos com registro formalizado) representava $28,1 \%$ da ocupação total. Se a idéia é cotejar resultados do Censo com os da RAIS - com a cautela que requer essa licença, tratando-se de duas bases tão distintas, em todos os quesitos, inclusive as datas de coleta e referência -, constata-se que o volume apurado nos registros administrativos do Ministério do Trabalho correspondia a $22,1 \%$ do total da população trabalhadora levantada pelo IBGE. Para o total do Rio Grande do Sul, essa razão ficava próxima de 40\%. Seguindo-se esse cotejo, 
meramente aproximativo, constata-se que em 13 dos 20 municípios da Grande Santa Rosa o estoque da RAIS não atingia 15\% do número de ocupados detectados pelo Censo.

O mercado de trabalho era mais formalizado em Santa Rosa, Horizontina e Três de Maio. Esses são, justamente, e nessa ordem, os municípios com menor peso da agropecuária na ocupação total apreendida pelo Censo, o que sugere uma relação inversa entre o grau de formalização das relações de trabalho e o peso da produção primária, nessa região caracterizada pela agricultura familiar.

\subsubsection{Posição na ocupação}

A estrutura do mercado de trabalho da Grande Santa Rosa pela ótica da posição na ocupação parece espelhar a elevada participação das atividades primárias, já assinalada. Inicialmente, chama a atenção o baixo percentual de empregados (41,5\%), dentre os ocupados que o Censo identifica na região, comparativamente ao que se verifica no agregado do Estado $(61,7 \%)$.

Essa diferença tem como contrapartida uma maior participação, não tanto do contingente de trabalhadores por conta própria $(29,6 \%$ dos ocupados, na Fronteira Noroeste; 26,2\%, no Rio Grande do Sul) quanto, especialmente, do de trabalhadores não remunerados: essa posição na ocupação representava, em 2000, nada menos do que $24,3 \%$ dos ocupados da região, quando, na ocupação gaúcha, limitava-se a 7,0\%.

Em nove dos vinte municípios a soma desse contingente de não-remunerados e dos "trabalhadores na produção para o próprio consumo" representava mais de $40 \%$ do total de ocupados, atingindo seu patamar mais elevado em São José do Inhacorá, único caso em que representava mais da metade dos ocupados $(50,3 \%)$. Em apenas seis municípios essa agregação de categorias representava menos de uma terça parte do total de ocupados.

Somente em Santa Rosa a soma das categorias "não-remunerados" e "trabalhadores na produção para o próprio consumo" tinha peso inferior ao observado no agregado do Estado (7,9\%, contra $8,6 \%$ ).

Quanto aos conta-própria, sua participação no total dos ocupados de cada município apresentava menor variação, mas esta era, ainda assim, bastante significativa. O menor percentual era observado em Santa Rosa (24,0\%), seguindo-se de perto Horizontina $(24,4 \%)$ - únicos resultados inferiores, ainda que pouco distantes, aos 26,2\% do agregado do Estado; o maior, registrava-se em Novo Machado (37,4\%).

Apenas em Santa Rosa o assalariamento ultrapassava o patamar do Rio Grande do Sul (64,5\% dos ocupados contra 61,7\%). A participação dos empregados atingia níveis muito baixos em inúmeros municípios da região: em oito deles, não chegava a uma quarta parte do total de 
ocupados, sendo que, em quatro, era inferior a 20\% (Nova Candelária, com 14,4\%; Alecrim, 15,0\%; São José do Inhacorá, 15,4\% e Novo Machado, 16\%).

Nesse segmento de empregados - excetuados os domésticos -, o Censo de 2000 aponta que $26,3 \%$ não tinham carteira assinada, proporção um pouco mais elevada que o parâmetro do Estado $(23,4 \%)$. Apenas três municípios ostentam percentuais igual ou menores: Santa Rosa $(20,8 \%)$, Boa Vista do Buricá(21,3) e Horizontina $(23,4)$. Em Porto Mauá e Novo Machado, esse patamar excedia os $40 \%$.

Quanto ao emprego doméstico, ele representava $15,7 \%$ do conjunto de assalariados da Grande Santa Rosa, participação bem mais elevada do que os $10,6 \%$ aferidos no total do Rio Grande do Sul. Entretanto, a participação desse segmento de trabalhadores no universo de ocupados era bem próxima em ambos os recortes - em torno de $6,5 \%$-, uma vez que a região estudada ostenta menor grau de assalariamento de sua força de trabalho. As mulheres representavam 95\% do emprego doméstico, no Rio Grande do Sul, e 99\%, na Fronteira Noroeste, em 2000. Em ambos os casos, cerca de $15 \%$ da ocupação feminina encontravam-se nesse segmento.

Grosso modo, os municípios em que a ausência de registro em carteira mais pesava no contingente de empregados eram aqueles em que o assalariamento tinha menores participações sobre o total da ocupação. Dessa forma, conjugam-se dois fenômenos ligados à precariedade da inserção do trabalhador no mercado de trabalho.

\subsubsection{A oferta de trabalho: PIA e PEA}

Assim como no agregado do Rio Grande do Sul, é reconhecível, na Grande Santa Rosa, um estreitamento da base da pirâmide etária, que se traduz numa elevação da proporção da população total que se encontra em idade ativa. Em 1991, a população em idade ativa (PIA) da Fronteira Noroeste correspondia a $79,9 \%$ da população total, percentual que se eleva para $84,1 \%$, em 2000. No Rio Grande do Sul, essa relação se alterou menos: dos 79,9\% de 1991 - idênticos aos da Grande Santa Rosa - para 82,9\%, em 2000.

Dessa forma, entre os dois Censos, a PIA regional cresceu 6,8\%, em contraste com a variação praticamente nula de sua população total, já mencionada anteriormente. $\mathrm{O}$ aumento da PIA da Grande Santa Rosa foi bem menos intenso do que o verificado no agregado do Estado (15,7\%), e concentrou-se em poucos municípios, liderados por Santa Rosa (16,5\% de elevação) e Horizontina (10,4\%). Afora esses, apenas Santo Cristo (4,7\%) e Independência (2,8\%) tiveram acréscimos na PIA. Cândido Godói mostrou estagnação $(0,2 \%)$, e os outros nove sofreram perdas, que variaram de 4,2\%, em Três de Maio, a 47,0\%, em Tucunduva ${ }^{73}$.

${ }^{73}$ Cabe lembrar que a análise dos dados municipais perde acuidade em função das emancipações já referidas. 
A distribuição da PIA regional por município acompanha de forma bastante similar aquela verificada para a população total. Um exemplo dessa convergência: os três principais municípios (Santa Rosa, Três de Maio e Horizontina), que detinham, conjuntamente, em 2000, 50,8\% da população total, abarcavam, no mesmo ano, 50,3\% da PIA.

Quanto à população economicamente ativa (PEA), em 2000, 121,1 mil indivíduos a integravam, o equivalente a $2,3 \%$ do total estadual, naquele ano, percentual mais elevado do que o que a região apresentava na PIA do Estado (2,1\%). Esse diferencial expressa uma taxa de participação mais elevada da força de trabalho na Grande Santa Rosa: 68,4\% dos seus habitantes em idade ativa tomavam parte do mercado de trabalho, ao passo que no Rio Grande do Sul essa parcela era de $61,2 \%$.

Tal discrepância está fortemente associada ao perfil rural da região: tomadas só as áreas urbanas, a taxa de participação na Grande Santa Rosa era pouco superior à do Estado $(62,1 \%$ versus 59,9\%); já o percentual nas áreas rurais era bem mais elevado na Fronteira Noroeste $(78,1 \%)$ do que no Rio Grande do Sul (66,5\%). Tendo em vista que os habitantes de zonas rurais tinham peso muito superior na PIA da região $(39,8 \%)$ do que no total do Estado $(18,4 \%)$, o efeito de sua elevada taxa de participação se amplificava. Devido a esse maciço engajamento na atividade econômica, a participação da população rural no total da PEA regional era muito superior ao que ostentava na PIA, atingindo $45,4 \%$. Os integrantes rurais eram mais da metade da PEA em 14 dos 20 municípios, ficando o percentual extremo em Nova Candelária (91,2\%).

Dentre os municípios da região, as taxas de participação da população rural variavam de 63,9\% em Santa Rosa, a 88,1\%, em São José do Inhacorá; nas áreas urbanas, o mínimo ocorria em Porto Lucena (53,0\%); o máximo, 76,4\%, em Nova Candelária. Consideradas conjuntamente as situações de domicílio (rural e urbana), constata-se que apenas um município da Grande Santa Rosa tinha taxa de participação inferior à do agregado do Estado: Tucunduva, com 60,6\%, próxima aos 61,2\% do Rio Grande do Sul. O indicador atingia seus maiores valores em São José do Inhacorá, Nova Candelária e Campina das Missões - todos com taxas superiores a 80\%. Com relação ao município de Santo Cristo, merece menção o fato de que, dada sua elevada taxa de participação, ele galgava a condição de terceira maior PEA da região, embora na dimensão de PIA ficasse em quarto lugar, deslocando Horizontina (terceira maior PIA) para a quarta posição na distribuição dos economicamente ativos.

\subsubsection{Atributos dos trabalhadores: gênero}

$\mathrm{Na}$ população residente da Grande Santa Rosa, verifica-se suave predominância das mulheres, a qual se acentuou discretamente entre os dois Censos, passando de 50,2\% do total para $50,4 \%$. O crescimento da população feminina no período, de $2,0 \%$, superou o da masculina $(0,9 \%)$. Nos dois pontos do tempo, o desequilíbrio demográfico entre os sexos era menos 
pronunciado na região do que no total do Estado, cuja população tinha 50,8\% de mulheres, em 1991, e 51\%, em 2000.

Ainda assim, nos dois anos censitários considerados, o número de municípios da Grande Santa Rosa em que os homens eram majoritários superava a metade. Em 1991, a predominância masculina era mais acentuada em Alegria (razão de sexo $^{74}$ de 106,0); a feminina, em Santa Rosa e Três de Maio (razão de sexo de 95,6 para ambos). Em 2000, o valor máximo eleva-se para 110,4, em Porto Vera Cruz (município criado na década de 90). O mínimo recua para 94,8, em Horizontina - a que se seguem Três de Maio e Santa Rosa $(95,1$ e 95,8). Confirma-se, assim, o padrão pelo qual a predominância masculina tende a ocorrer em municípios mais rurais, e a feminina, nos mais urbanos.

Efetivamente, a superioridade numérica das mulheres ancora-se nas áreas urbanas. Nas zonas rurais, os homens eram maioria: representavam, considerada a Grande Santa Rosa em seu conjunto, 51,3\%, em 1991, e 51,1\%, em 2000 - menos do que no agregado do Rio Grande do Sul (52,2\%, nos dois momentos). Já nas áreas urbanas da região, a participação das mulheres atingia $51,5 \%$, em 1991, e 51,4\% em 2000, comportamento bastante semelhante ao verificado no Rio Grande do Sul (51,7\%, nos dois anos considerados).

Apenas três municípios da região tinham, em 1991, predomínio masculino nas áreas urbanas, e pouco significativo (razões de sexo de 101,1 em Cândido Godói; 100,4 tanto em Alegria quanto em Boa Vista do Buricá). Em 2000, esses casos eram quatro: em Porto Vera Cruz a razão de sexo da população urbana atingia 103,2; seguia-se Porto Mauá (101,7); Boa Vista do Buricá e Cândido Godói, por fim, tinham mínima superioridade do contingente de homens $(100,2)$. As zonas urbanas em que a participação feminina era proporcionalmente mais elevada, em 1991, eram as dos municípios de Três de Maio, Independência e Alecrim (razão de sexo muito próxima a 90). No ano 2000, Tuparendi e Porto Lucena estavam nesse patamar; seguiam-se Senador Salgado Filho e Três de Maio, com 90,9 e 91,8, respectivamente.

Quanto às áreas rurais, todos os municípios, em 1991, tinham mais homens do que mulheres. Em nenhum deles, entretanto, a razão de sexo da população rural atingia a do agregado do Estado $(109,4)$; na Fronteira Noroeste, em seu conjunto, o indicador ficava em 105,4. No ano 2000, diferentemente, dois municípios tinham pequena predominância de mulheres nas zonas rurais (Senador Salgado Filho, com razão de sexo de 98,7, e Porto Mauá, com 99,4). Dessa vez, ademais, dois municípios tinham a população rural mais desequilibrada do que o agregado do Rio Grande do Sul: em Porto Vera Cruz e São José do Inhacorá as razões de sexo superavam os 109,3 do Estado (com 112,3 e 110,8, respectivamente). Cabe destacar que se trata de pequenas populações, e que essas razões se referem a diferenças que, em números absolutos, são pouco

\footnotetext{
${ }^{74}$ Número de homens para cada 100 mulheres.
} 
expressivas. No caso de Porto Vera Cruz, em 2000 o número de homens na zona rural superava o de mulheres em 114 indivíduos.

Em 2000, a razão de sexo das áreas rurais da Grande Santa Rosa em seu conjunto havia recuado um pouco, frente a 1991 (de 105,4 para 104,6).

Quanto à PIA regional, coerentemente com o que ocorreu com a população total, o contingente feminino elevou-se, entre 1991 e 2000, mais do que o masculino: 7,3\% de variação, contra 6,3\%. A distância entre as taxas é mais ampla do que a verificada para o total do Estado (16,0\% versus $15,5 \%)$. Ainda assim, mesmo no final do período, o predomínio relativo das mulheres era, na PIA regional, menos acentuado do que na do agregado do Estado. Na PIA da Grande Santa Rosa, elas representavam 50,5\% do total, em 1991, e 50,8\%, em 2000, enquanto no Rio Grande do Sul esses percentuais eram de 51,3\% e 51,4\%.

Esse padrão não se verificava de modo uniforme dentre os municípios: no ano 2000, nove deles tinham mais homens em idade ativa do que mulheres. A PIA com maior peso masculino era a de Porto Vera Cruz (razão de sexo de 109,8), único município em que o número de homens superava o de mulheres mesmo na faixa etária de 60 anos ou mais, na qual a preponderância feminina atinge seus mais altos patamares (razões de sexo de 79,4, na região, e de 74,3, no Estado). Quanto a esse cruzamento por estratos etários, observa-se, tanto na Fronteira Noroeste como no Rio Grande do Sul, a mesma tendência: a razão de sexo é decrescente, conforme avançam os intervalos de idade. Exceto nos grupos de 10 a 17 e de 18 a 24 anos (de maioria masculina), a região tende a ter sempre maior equilíbrio entre os gêneros do que o agregado do Estado.

Os três únicos municípios da região em que o predomínio feminino na PIA superava ou igualava o do agregado do Estado (razão de sexo 94,7) eram, em 2000, Horizontina (94,4), Santa Rosa $(93,4)$ e Três de Maio $(92,7)$, precisamente os mais populosos, confirmando-se a tendência de que a população feminina se destaque nos maiores centros.

Quando se parte para as variáveis propriamente concernentes ao mercado de trabalho, as discrepâncias entre os gêneros se acentuam, configurando uma presença menor e, em geral, relativamente desprivilegiada das mulheres.

A razão de sexo da PEA, em 2000, atingia, na Grande Santa Rosa, 129,3, evidenciando que, embora majoritário na população e na PIA, o contingente feminino era significativamente menos expressivo no mercado de trabalho. Em todos os municípios da Fronteira Noroeste a PEA era majoritariamente masculina. A menor razão de sexo ocorria em Tuparendi: 111,4. Essa desigualdade era, regionalmente, mais amena do que no agregado do Estado, em que a razão de sexo atingia 137,2. Porém, em três dos 20 municípios da Grande Santa Rosa, a razão de sexo excedia a da PEA gaúcha - Alegria, Tucunduva e Independência, esta última com o valor máximo, 176,2. Santa Rosa era a quinta colocada nesse ranking de predomínio masculino na PEA, embora 
fosse, junto com Três de Maio, o município com mais acentuado predomínio das mulheres na população total. Tal discrepância relaciona-se com a taxa de participação das mulheres no mercado de trabalho daquele município (50,6\%), a segunda mais baixa da Fronteira Noroeste, muito inferior à do agregado regional $(58,8 \%)$.

No conjunto da região, tanto homens quanto mulheres superavam as taxas de participação aferidas no agregado do Estado. No caso da força de trabalho feminina, esse diferencial era, proporcionalmente, ainda mais acentuado: $58,8 \%$ das mulheres em idade ativa, na região, integravam a PEA, versus 50,2\%, no Rio Grande do Sul. Do contingente masculino, as taxas eram, respectivamente, de $78,4 \%$ e $72,7 \%$.

$\mathrm{Na}$ comparação entre os municípios, as taxas de participação das mulheres eram bem mais heterogêneas, oscilando de 43,0\% em Tucunduva até 74,7\% em Nova Candelária. Da PIA masculina, o menor percentual de indivíduos economicamente ativos se observava em Santa Rosa, $73,2 \%$; o maior, em São José do Inhacorá - praticamente 90\% (89,8\%).

Quando se passa à distribuição da ocupação segundo os sexos, constata-se que ela não era, na Grande Santa Rosa, muito discrepante da verificada para o conjunto do Estado: em 2000, as mulheres detinham, na região, uma parcela um pouco mais significativa do total de postos $(43,0 \%$, contra os 40,5\% do Rio Grande do Sul).

No Estado, a razão de sexo dos ocupados era significativamente mais elevada do que a razão de sexo da PEA - 146,8 e 137,2, respectivamente -, o que expressa maior dificuldade das mulheres, comparativamente aos homens, para lograr a inserção pretendida no mercado de trabalho. Na Fronteira Noroeste, em contraste, as duas razões eram mais próximas (132,7 e 129,3). De forma geral, nos municípios, a participação das mulheres dentre os ocupados atingia níveis muito próximos aos que elas representavam na PEA, o que irá se traduzir em taxas de desemprego relativamente equilibradas entre os gêneros, como assinalarei adiante. As maiores discrepâncias encontravam-se em Horizontina, desfavoravelmente à ocupação feminina, e em São José do Inhacorá, favoravelmente. No primeiro caso, a razão de sexo na ocupação era 146,0, enquanto, na PEA, ficava em 136,7; no segundo, as razões eram de 124,5 e 127,3, respectivamente.

Dos cinco maiores municípios, em nenhum a razão de sexo do contingente ocupado superava a do Estado, embora Santa Rosa e Horizontina ostentassem resultados muito próximos àquela. Tuparendi destacava-se com o indicador mais próximo ao equilíbrio $(112,9)$; no extremo oposto, Tucunduva era o município com menor proporção de mulheres dentre os trabalhadores em atividade (razão de sexo de 186,7).

Os dados do emprego formal indicam que o ingresso das mulheres nesse segmento positivamente diferenciado do mercado de trabalho era mais restrito do que seu acesso à ocupação em geral. A razão de sexo do emprego formal da Fronteira Noroeste, em 1989, atingia 210,0 bem superior aos 164,5 observados no conjunto de ocupados e também na PEA aferidos pelo 
Censo de 1991; em 2005, a razão de sexo do emprego formal da Grande Santa Rosa havia recuado para $159,3 \%$, novamente superando o indicador para o universo de ocupados recenseado em 2000 $(132,7)$ e para a PEA regional $(129,3)$. Em ambos os momentos, a desigualdade de gênero no emprego formal era mais acentuada na Fronteira Noroeste do que no agregado do Estado, cujas razões de sexo eram de 159,2, em 1989, e 131,4, em 2005. Ademais, como a razão de sexo da PEA gaúcha em 1991 era 175,1, e, em 2000, encontrava-se em 137,2 a participação das mulheres no emprego formal pode ser estimada (aproximativamente, para os anos de 1989 e 1999) como mais do que proporcional à sua presença no contingente economicamente ativo. Nesse caso, as mulheres teriam uma vantagem relativa no acesso aos "bons" empregos, diferentemente do que ocorria na Fronteira Noroeste. Cabe destacar que a razão de sexo do emprego formal recuou tanto no Estado quanto na Grande Santa Rosa, e que esse movimento rumo a um maior equilíbrio foi proporcionalmente mais acentuado na região.

Em síntese, a Fronteira Noroeste mostrava menor desequilíbrio de gênero do que o agregado do Estado, seja na população; seja na PIA, na PEA e na ocupação. Entretanto, o emprego formal era proporcionalmente menos acessível às mulheres da região.

\subsubsection{Atributos dos trabalhadores: idade}

A distribuição etária da PIA da Grande Santa Rosa era, tanto em 1991 quanto em 2000, bastante semelhante à do agregado do Estado. Os movimentos observados obedeceram à mesma tendência de "envelhecimento", constatando-se, entretanto, que esta se deu de forma mais acentuada na região do que no Rio Grande do Sul.

A participação dos indivíduos com idade entre 10 e 17 anos era um pouco superior na região à observada no Rio Grande do Sul, mas a distância diminuiu, ao mesmo tempo em que, nos dois recortes geográficos, esse intervalo etário teve perda de participação: em 1991, representava 20,1\% da PIA da Fronteira Noroeste, e 19,1\% da gaúcha; em 2000, 17,8\% e 17,6\%, respectivamente.

A dispersão das participações desse segmento mais jovem da PIA, nos municípios da região, também não era muito elevada, em 2000: o ponto mínimo verificava-se em Doutor Maurício Cardoso (15,0\%), e o máximo, em Alecrim (19,6\%).

A faixa etária seguinte, de 18 a 24 anos, ao contrário da primeira, tinha, na Fronteira Noroeste, participação um pouco inferior à verificada no agregado do Estado. A diferença era mínima, em 1991 (15,1\% versus 15,2\%), mas em 2000 mostra-se mais significativa (13,4\% contra $14,8 \%$ ). A pequena perda de importância relativa desse segmento é verificada em ambos os casos.

Considerando-se conjuntamente as duas faixas mais jovens, as diferenças entre a Grande Santa Rosa e o Estado são mínimas, já que os diferenciais para cada uma delas se dão em sentidos opostos. 
No que diz respeito à faixa etária seguinte, de 25 a 39 anos, uma vez mais ocorre, tanto no Rio Grande do Sul quanto na Fronteira Noroeste, perda de participação, entre um Censo e outro: de $30,0 \%$ para $27,1 \%$, na região; de $31,0 \%$ para $28,0 \%$, no Estado.

As faixas etárias de 40 anos em diante são aquelas que têm acréscimo de participação: a de 40 a 59 anos aumenta, na Grande Santa Rosa, de 23,6\% para 28,1\%; no Estado, de 23,6\% para $27,0 \%$. Observe-se que, na Fronteira Noroeste, esse movimento faz com que a referida faixa etária supere, em 2000, a de 25 a 39 anos, diferentemente do que ocorre no agregado do Estado, no qual se verifica uma aproximação do peso desses dois grupos etários, sem que o ordenamento se altere.

Também na faixa de idade mais elevada, 60 anos ou mais, o movimento de ganho de participação se verifica nos dois recortes, mostrando-se mais acentuado na região. Em 1991, esse contingente representava $11,1 \%$ da PIA da Grande Santa Rosa, mesmo percentual registrado para o Estado; já em 2000, tal participação se eleva para 13,7\% e 12,6\%, respectivamente.

Em uma medida mais sintética desse "envelhecimento", corta-se a PIA em dois grupos menos de 40 anos; 40 anos ou mais -, observando-se que a participação do segundo passou, na região, de 34,7\%, em 1991, para 41,8\%, em 2000, elevação mais pronunciada do que a verificada no agregado do Estado (que, de 34,7\% - ponto de partida idêntico ao da Fronteira Noroeste -, ascende para 39,6\%).

Considerando-se a evolução dos contingentes, constata-se que o número de indivíduos com 40 anos ou mais aumentou 31,9\%, no Estado, enquanto o de até 39 anos teve elevação muito menos expressiva: 7,1\%. Na Grande Santa Rosa, a discrepância do comportamento dos dois grupos etários é ainda mais radical: o primeiro tem acréscimo de $28,4 \%$; já o segundo tem variação negativa, de 4,7\%, o que representa uma diminuição de 5.085 indivíduos no segmento.

Em 2000, na região, os municípios em que se registravam as maiores participações do segmento de 40 anos ou mais na PIA eram Porto Lucena, Novo Machado e São José do Inhacorá $49,2 \%, 47,6 \%$ e 47,5\%, respectivamente. As menores ocorriam em Santa Rosa, Horizontina e Boa Vista do Buricá $(36,8 \%, 40,4 \%$ e 40,9\%).

A elevação dessa participação do grupo com idade igual ou superior a 40 anos se deu de forma mais acentuada em municípios pequenos, tendo no extremo Cândido Godói, Campina das Missões e Porto Lucena.

A distribuição por sexo varia fortemente, quando se desagrega a PIA por faixas etárias. $\mathrm{Na}$ Grande Santa Rosa, como no agregado do Estado, a razão de sexo é decrescente conforme avança a idade. Nos grupos de 10 a 17 e de 18 a 24 anos, há predominância dos homens e, nas faixas a partir de 25 anos, a superioridade numérica das mulheres é progressiva. Ressalte-se que, na região, as faixas jovens têm a predominância masculina um pouco mais elevada do que no Rio Grande do Sul; já nos grupos etários seguintes, a vantagem das mulheres mostra menor intensidade do que no Estado. O desequilíbrio mais acentuado verifica-se dentre os indivíduos de 60 anos ou mais: para 
cada 100 mulheres, havia, em 2000, apenas 79,4 homens, na Grande Santa Rosa (74,3, no agregado do Estado).

Quanto à situação de domicílio, cabe destacar que a forte retração da PIA rural da Fronteira Noroeste $(-11,8 \%$, um decréscimo de 9.416 indivíduos) envolveu especificamente as faixas etárias mais jovens. A mais drástica redução percentual se deu na faixa de 18 a 24 anos $(-27,8 \%)$, seguida da de 10 a 17 anos (-24,6\%). Também a faixa de 25 a 39 anos mostrou, no meio rural, encolhimento de intensidade muito próxima $(-25,4 \%)$. Nas faixas a partir de 40 anos, a PIA rural cresceu: $8,0 \%$ no segmento de 40 a 59 anos e $17,9 \%$ no de 60 anos ou mais. A retração da PIA rural jovem foi generalizada dentre os municípios da região. A PIA urbana, por sua vez, teve crescimento em todas as faixas etárias, porém bem mais acentuado naquelas a partir de 40 anos.

No que tange às taxas de participação desagregadas por idade, os contrastes mais marcantes, dentre os municípios, se davam, como seria de esperar, nas faixas extremas da distribuição etária. Os indivíduos de 10 a 17 anos, cujo peso na PIA dos municípios da Fronteira Noroeste oscilava pouco - entre 15,5 e 20,1\% -, representavam, nas PEAs, parcelas que iam de 6,9\%, em Santa Rosa, até 14,5\%, em Porto Mauá. Nesse grupo etário, o percentual de economicamente ativos variava de 23,3\%, em Santa Rosa, a 63,4\%, em São José do Inhacorá. No agregado dos 20 municípios da região, situava-se em 37,4\% - bastante superior aos $23,7 \%$ observados no agregado do Estado.

No extremo oposto, os indivíduos de 60 anos ou mais representavam, nas PIAs dos municípios, parcelas entre 11,0\% (em Santa Rosa) e 17,2\%, em Doutor Maurício Cardoso, no ano 2000, assinalando uma elevação importante frente a 1991, quando essa participação oscilava de 9,7\% a 13,3\%. Nas PEAs, em 2000, a dispersão era maior: esse intervalo de idade chegava a um peso máximo de 12,6\%, em São José do Inhacorá, e tinha como mínimo 3,4\%, no maior município, Santa Rosa. Esses municípios eram também os extremos regionais no que tange às taxas de participação dessa faixa etária no mercado de trabalho: 19,3\% eram economicamente ativos em Santa Rosa; 65,0\% em São José do Inhacorá. A este último, seguiam-se, com os mais elevados percentuais, Nova Candelária e Porto Mauá (58,1 e 57,9\%, respectivamente). No conjunto da Fronteira Noroeste, a taxa de participação dessa faixa de idades mais avançadas atingia $35,4 \%$, mais de 10 pontos percentuais superior à do Estado (23,9\%). Verifica-se que os patamares das taxas da região, bem como de suas diferenças com relação ao agregado do Rio Grande do Sul, são semelhantes entre os dois grupos etários "extremos".

Também nos segmentos intermediários da distribuição por idade as taxas de participação da região superavam as gaúchas, embora as distâncias se demonstrassem menores: na faixa de 18 a 24 anos, eram economicamente ativos 82,2\% dos indivíduos da Fronteira Noroeste, e 77,1\% dos do Estado; de 25 a 39 anos, essas taxas eram de 87,4\% e 82,6\% respectivamente; de 40 a 59 anos, de $79,4 \%$ e $72,0 \%$. 
O exame do emprego formal na Fronteira Noroeste revela que também houve "envelhecimento" desse segmento do mercado de trabalho. Entre 1989 e 1999, o total de indivíduos com 40 anos ou mais abarcados pela RAIS teve acréscimo de $43,3 \%$, enquanto o daqueles com idades inferiores aumentou apenas 3,8\%. De 1999 a 2005, o crescimento do emprego total foi de $26,9 \%$, enquanto o dos indivíduos com 40 anos ou mais aumentou 47,6\%. Com isso, a participação desse grupo mais maduro subiu de 20,9\% para 26,9\% do total, entre 1989 e 1999 - elevação proporcionalmente mais intensa do que a verificada na PIA, em que o mesmo estrato etário passou de uma participação de $34,7 \%$ para $41,8 \%$-, vindo atingir $31,3 \%$ dos registros da RAIS, em 2005.

No contingente com idades inferiores a 40 anos, encontra-se a maior faixa da distribuição etária do emprego formal, os trabalhadores de 25 a 39 anos. Em 1989, eles representavam 47,2\% de todos os vínculos formais da região. Essa participação elevou-se, ultrapassando a metade $(50,6 \%)$, ao final da década. O número de empregados nesse intervalo de idade cresceu, nos anos 1990, 19,6\% - bem mais do que os 11,6\% do mercado formal regional, em seu conjunto -, invertendo o sinal observado na PIA, na qual o total de indivíduos de 25 a 39 anos reduziu-se em 1,4\%. Em 2005, esse grupo marcava perda de participação no universo do emprego formal, recuando para $46,7 \%$.

A faixa de 10 a 17 anos, em que pese à sua pequena expressão, teve o estreitamento mais notável: perdeu 53,9\% de seu contingente, entre 1989 e 1999, retraindo-se, sua participação, de 5,7\% para 2,3\%. Em 2005, chegava a apenas 1,2\%. Na faixa seguinte, de 18 a 24 anos de idade, a década de 1990 marcou redução absoluta, 12,5\% no contingente, bem superior à perda de 5,6\% observada na população dessa faixa etária, entre os censos. Sua participação no mercado formal de trabalho da Grande Santa Rosa baixou de 25,7\% para 20,2\%, entre 1989 e 1999. Nos últimos anos, entretanto, houve certa estabilidade, pois o percentual estava em 20,9\%, em 2005.

\subsubsection{Atributos dos trabalhadores: escolaridade}

A escolaridade dos trabalhadores ocupados na Grande Santa Rosa é, inquestionavelmente, baixa: a participação dos indivíduos com educação formal inferior ao Fundamental Completo (menos de 8 anos de estudo) nesse universo, segundo o Censo 2000, chegava a 61,2\%, bem superior à verificada no Estado, de 52,2\%.

Dentre os municípios, a pior posição era a de São José do Inhacorá, em que 80,5\% dos ocupados tinham no máximo sete anos de estudo, em 2000; segue-se Alecrim (com 79,1\%). 
Horizontina e Santa Rosa detinham os melhores resultados, sendo os únicos dos 20 municípios em que os indivíduos com pelo menos o Ensino Fundamental ultrapassavam a metade dos ocupados.

A partir do Fundamental completo, em todas as faixas de escolaridade a região tinha um percentual menor de seus ocupados do que o Estado.

Nas faixas mais elevadas dessa distribuição por escolaridade dos ocupados, dos municípios da região apenas Santa Rosa e Horizontina superavam ou se equiparavam aos percentuais do Rio Grande do Sul. No estrato com Fundamental completo (que inclui Médio incompleto), Santa Rosa tinha 20,0\%, e Horizontina, 19,7\% de seus ocupados, vis-à-vis aos 18,5\% do Estado. Na faixa de Médio completo (e Superior incompleto), encontravam-se $21 \%$ dos ocupados gaúchos; $21,9 \%$ dos de Santa Rosa e 25,7\% dos de Horizontina; por fim, os indivíduos com escolaridade superior respondiam por 7,7\% da ocupação estadual e 9,4\% da de Santa Rosa. Horizontina, com 5,9\%, não atingia, nesse caso, o padrão do agregado do Rio Grande do Sul.

A evolução dos níveis de escolarização dos trabalhadores da região pode ser também abordada a partir dos dados do mercado formal de trabalho. Esse segmento é qualitativamente diferenciado, em sentido positivo, dentro do universo da ocupação. O padrão de educação dos indivíduos que o integram é mais elevado, configurando uma clara seletividade por esse quesito.

A RAIS demonstra que, na Fronteira Noroeste, verificou-se, como no agregado do Estado, a mesma tendência de elevação do patamar de educação formal dos empregados com vínculo legalizado. Houve considerável perda de participação dos trabalhadores com ensino fundamental incompleto, que atingiu, em 1999, 33,9\% - uma retração de 12,7 pontos percentuais frente a 1989. Em 2005, esse grupo resumia-se a 21\% dos trabalhadores formais da Grande Santa Rosa.

Diferentemente do que se observou quanto ao conjunto dos ocupados, no emprego formal a Fronteira Noroeste detém um nível de escolaridade próximo - e até ligeiramente melhor - do que o agregado do Estado, se for considerada a proporção de trabalhadores nesse intervalo amplo de mais baixa escolaridade: em 1989, eles eram 46,6\%, na região, contra 51,0\%, no Estado; em 1999, $33,9 \%$ versus $36,8 \%$; em $2005,21,0 \%$ e $24,4 \%$.

\subsubsection{Rendimentos}

O rendimento médio real no mercado formal de trabalho da Fronteira Noroeste era, em 1989, R\$ 645,11, enquanto, no agregado do Estado, atingia R\$ 736,08, configurando um diferencial negativo de $12 \%$ para a região. Ao final da década, a distância se amplificou, pela combinação de forte queda do valor real dos salários na Grande Santa Rosa $(-13,1 \%)$, de um lado, e, de outro, estabilidade no Rio Grande do Sul em seu conjunto (variação de 0,3\%). Com isso, os 
rendimentos médios chegaram a $\mathrm{R} \$ 560,62$, na Fronteira Noroeste, e $\mathrm{R} \$ 738,35$, no Estado, e a desvantagem da região passou para $24 \%\left({ }^{75}\right)$

Em 2005, tomando-se a magnitude das remunerações em salários mínimos (SM), vê-se que a desvantagem prossegue: enquanto o agregado gaúcho afere um rendimento médio de 3,79 SM, a Grande Santa Rosa chega a 3,03 SM - uma diferença de cerca de 20\%. Na indústria de transformação, essa medição mais recente mostra um valor médio praticamente idêntico $(3,40$ e 3,41 SM, respectivamente), enquanto a distância mais marcante, dentre os principais setores, encontra-se na Administração Pública, em que o rendimento na Fronteira Noroeste representa menos de $60 \%$ do valor praticado no conjunto do Estado.

Quanto aos rendimentos médios totais por município, observa-se, em primeiro lugar, que havia uma dispersão considerável entre eles, embora ela tenha arrefecido na década. Em 1989, a diferença entre o salário médio mais elevado e o mais baixo era de 3,5 vezes. Essa amplitude se reduz, e, em 1999, a diferença fica em 2,6 vezes. Em 2005, ela fica em 2,3.

Em todos esses pontos do tempo, o maior rendimento médio real foi registrado em Horizontina, o que tenderá a ficar mais claro na análise que faço no capítulo 7.

A Indústria de Transformação era o setor no qual a dispersão dos salários era mais elevada. Em 1989, a diferença entre os valores extremos atingia 8,5 vezes, ampliando-se para 8,9 vezes, em 1999. Em 2005, caiu para 5,1 vezes. Horizontina - cuja participação no emprego regional do setor era de 28,0\%, em 1989; 26,8\%, em 1999; e 28,7\%, em 2005 - diferencia-se fortemente, pelas mais altas remunerações, sobretudo no início da década: em 1989, os salários industriais eram 2,1 vezes superiores aos da região em seu conjunto. Em 1999, essa razão mostra recuo, mas se mantém elevada, atingindo 1,7, patamar que mantinha em 2005, com 1,8. Na comparação com Santa Rosa - município que concentrava 48,7\% do emprego industrial da região em 1989; 44,2\%, em 1999; 40,3\% em 2005 -, a diferença é ainda mais acentuada: no início da década, os rendimentos do setor, em Horizontina, eram 3,3 vezes maiores; no final da década, 1,9 vez; em 2005, 2,3 vezes.

É importante não perder de vista o peso dos benefícios da previdência social na renda das famílias da região, especialmente no meio rural. Tomados os valores históricos do acumulado de 2005, esses recursos, nos municípios da Grande Santa Rosa, totalizaram 17,2 milhões de reais, sendo pouco inferior à metade $(8,1$ milhões) a parcela destinada a habitantes das zonas rurais, segundo o site do Ministério da Previdência Social ${ }^{76}$. Esse dado não permite identificar as modalidades de benefício, mas, ainda assim, são relevantes algumas relações: o cotejo entre o número de benefícios e a população (estimativa de 2006 - FEEDados on-line) atinge 21,5\%, no

\footnotetext{
${ }_{75}$ Valores monetários a preços de dezembro de 2000, para todas as cifras citadas no parágrafo.

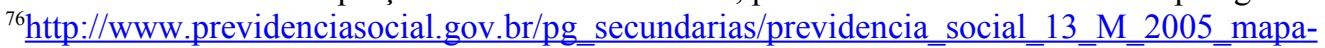
acumulado.asp. O site apresenta dados municipalizados até 2007, mas optei por utilizar a série de 2005 para ter uma comparação mais adequada com os dados de PIB, dos quais, nessa abrangência territorial, 2005 é a informação mais recente.
} 
total da Grande Santa Rosa. Considerados apenas os indicadores referentes às zonas rurais, esse percentual sobe para $42,1 \%$, ao passo que se restringe a $11,8 \%$ no meio urbano. Como termo de comparação, para o agregado do Rio Grande do Sul os resultados são 17,6\%, 14,6\% e 34,6\%, respectivamente.

Em outra comparação - entre grandezas bastante díspares, o que a torna apenas aproximativa -, o valor dos benefícios previdenciários totais, em 2005 , correspondeu a $0,7 \%$ do PIB (FEEDados on-line), na Grande Santa Rosa. Esse resultado é bastante próximo ao que se obtém para o conjunto do Rio Grande do Sul (0,64\%). Dentre os municípios, entretanto, essa relação variou muito, tendo como pontos máximos Alecrim (1,68\%) e Porto Lucena $(2,1 \%)$.

\subsubsection{Desocupação}

Em 1991, havia, na Fronteira Noroeste, 1.423 indivíduos desocupados, o equivalente a 2,2\% da PEA da região. Essa taxa de desemprego era significativamente inferior à do agregado do Estado, de 3,42\%. Em 2000 - sabendo-se que houve mudanças metodológicas no recenseamento e na categorização do trabalho - o diferencial se mantém pronunciado: a taxa de desemprego da Grande Santa Rosa encontra-se em 7,3\% (8.854 indivíduos) contra 12,2\% do Rio Grande do Sul.

Dentre os municípios, o desemprego tinha magnitudes bastante diferentes, em 2000: as taxas variavam de 0,5\% em Porto Vera Cruz, a 13,4\% em Santa Rosa, única unidade em que a desocupação ultrapassa o percentual do Estado. Sete municípios ostentavam resultados inferiores a 2\%. Na outra ponta, seguindo a cidade-pólo, as taxas mais elevadas são dos municípios que também a sucedem em tamanho da população - Três de Maio (7,6\%) e Horizontina (9,5\%).

Como as taxas eram, de modo geral, baixas, e os municípios eram majoritariamente de pequeno porte, observa-se que os números absolutos de desempregados não alcançavam grande expressão: Santa Rosa tinha o maior contingente, 4.405 pessoas (49,8\% do total regional); seguiase Três de Maio, com 1.066 (12,0\%), e Horizontina, com 898 (10,1\%). Na seqüência, baixa-se para um patamar significativamente inferior, encontrando-se os municípios de Tucunduva e Alegria, ambos com 232 indivíduos desempregados.

Em 1991, o desemprego, na região, atingia de forma equilibrada homens e mulheres, registrando-se a mesma taxa $(2,2 \%)$. O número de mulheres em desemprego era menor e elas eram $38,0 \%$ do total dos desocupados, obedecendo à proporção que elas detinham na PEA $(37,8 \%)$. Em 2000, a situação alterou-se: a taxa feminina encontrava-se em 8,7\%, bem acima dos 6,3\% observados entre os homens. Elas eram então 51,8\% dos desempregados, embora sua participação na PEA se limitasse a 43,6\%.

Entre os municípios, os diferenciais de desemprego por gênero tinham diferenças de sinal: em quatro deles, todos muito pequenos, os homens tinham taxas superiores às das mulheres; quando se trata dos números absolutos, a quantidade de indivíduos do sexo masculino em 
condição de desemprego era maior do que a de mulheres em sete municípios, incluindo-se Santa Rosa.

Campina das Missões e Porto Lucena são casos extremos, em que a taxa de desocupação feminina equivalia a 3,6 vezes a masculina. Cabe atentar, evidentemente, para uma "peculiaridade" que atravessa toda essa apreciação estatística: os contingentes envolvidos, em boa parte desses municípios, são muito pequenos. Nesses dois exemplos, o número de mulheres desempregadas era de 126 e 77, respectivamente.

Vale destacar que, nas três maiores e mais urbanizadas cidades, as taxas de desemprego femininas superavam as masculinas - moderadamente, em Santa Rosa (14,8 e 12,3, respectivamente); de forma acentuada, em Três de Maio (10,8\% versus 5,1$)$ e Horizontina $(7,6$ e $4,7 \%)$.

Uma síntese dos dados que venho de apresentar faz emergir algumas das características desse mercado regional de trabalho: uma participação quase dominante das atividades agropecuárias; assalariamento como condição minoritária (cerca de $40 \%$ dos ocupados); presença muito elevada do trabalho não remunerado (uma quarta parte dos ocupados); taxas muito altas de participação na atividade econômica; salários significativamente mais baixos do que a média do Rio Grande do Sul; taxas de desemprego muito inferiores às do agregado do Estado. Alguns processos e fenômenos que são bastante generalizados aparecem, aqui, em manifestações mais agudas (quando se toma a comparação com o agregado do Rio Grande do Sul): acesso relativamente mais difícil das mulheres ao emprego formal; envelhecimento da população, fundamentalmente nas áreas rurais; baixa escolaridade, confrontada com a seletividade dos vínculos formais pelo critério de educação formal.

Esse quadro abriga acentuadas diferenças internas, quando se cotejam os 20 municípios que integram a região. Apenas para exemplificar: $70 \%$ do emprego formal se concentram nos três maiores municípios, cuja participação na população regional é bastante inferior (50\%); as taxas de desemprego formavam, em 2000, um arco tão amplo que oscilava de 0,5\% a 13,4\%; as razões de sexo da população em idade ativa evidenciam que a predominância masculina ou feminina se alterna - e discrepâncias semelhantes ocorrem em boa parte das variáveis.

A força dessas especificidades evidencia a pertinência de uma análise que não perca de vista a dimensão local, a qual, como procuro explorar especialmente no capítulo 7 , não pode ser subsumida ante os condicionantes de nível regional. A articulação entre essas duas escalas espacialmente mais reduzidas (ravvicinate, na expressão de Bagnasco) é um dos elementos que o trabalho de campo que realizei na Grande Santa Rosa permitiu apreender de um modo que os indicadores estatísticos não oportunizam - mesmo em um tratamento mais pormenorizado e extensivo do que a caracterização assumidamente panorâmica que venho de fazer. 
Antes de apresentar resultados que provêm de minha pesquisa qualitativa, realço um aspecto que merece ser enunciado. Nas análises de mercado de trabalho, reconhece-se a dominância de um estilo que, em certo sentido, reproduz um elemento chave da matriz herdada das ciências econômicas, que discuti no primeiro capítulo desta tese: o trabalho social, não importa o quanto escape da forma modelar do assalariamento, é interpretado e problematizado fundamentalmente a partir de sua conexão - ou mais apropriado seria dizer derivação - da estrutura produtiva e de fatores como escalas, patamares tecnológicos e pressões concorrenciais que pesam sobre as atividades econômicas, e ainda da disponibilidade de recursos (ou "fatores") como crédito, infra-estrutura, eventualmente terra, entre outros. A problematização mais reconhecivelmente social costuma, também ela, aparecer sobretudo como derivação: no mais das vezes, enunciam-se (ou denunciam-se) a posição relativa ou as condições de vida dos trabalhadores nesse mercado, concentrando-se os esforços de interpretação nos condicionantes econômicos.

Por certo, fatores político-institucionais não estão ausentes dessas análises. Todavia, também nesse eixo, a abordagem típica tende a restringir sua atenção àqueles aspectos diretamente associados a externalidades que incidem sobre a atividade econômica, aí compreendidos a atuação do poder público; as relações de trabalho e os conflitos entre atores coletivos definidos pela sua inserção no mundo da produção; a oferta de mão-de-obra na quantidade e com os requisitos adequados à demanda da esfera produtiva. Inegavelmente, todas essas dimensões analíticas são cruciais para a compreensão das condições concretas de um mercado de trabalho. Por outro lado, a contribuição da sociologia, ao tratar desse objeto, tem sido acanhada em ampliar o leque de questões reconhecidas como pertinentes.

É justamente nesse ponto que uma inspiração como a da nova sociologia econômica, de que tratei no primeiro capítulo, estimula investigações que apontem no sentido de afirmar uma agenda disciplinar que ultrapasse a "colonização" exercida pela economia na construção analítica dos mercados de trabalho.

\subsection{Algumas características do mercado de trabalho, à luz da pesquisa de campo}

Nesta seção, abordo alguns aspectos, dentre tantos que concorrem para a compreensão da problemática do trabalho na formação regional estudada, que emergiram a partir da metodologia qualitativa que utilizei. Como não poderia deixar de ser, retorno a alguns desses traços mais marcantes do mercado de trabalho da Grande Santa Rosa que os dados secundários revelaram de forma eloqüente, procurando contribuir para a compreensão de seu significado na realidade concreta estudada, com suas particularidades sociais, culturais e institucionais. Além disso, busco trazer à luz outros fenômenos que não se associam de modo tão direto à arquitetura analítica dos indicadores consagrados pelos levantamentos estatísticos. 
Evidentemente, minha seleção procura servir à problematização teórica que motiva essa tese, priorizando os processos e achados que possam contribuir para um tensionamento, quiçá um aprimoramento, da apropriação que é feita pela sociologia da categoria mercado de trabalho.

Algumas dimensões dessa análise já foram antecipadas no capítulo anterior; outras serão mais detidamente tratadas nos dois próximos. De qualquer modo, não tenho qualquer pretensão de esgotar nesta tese as possibilidades do tratamento que abracei, dando-me por satisfeito se o exercício que apresento trouxer sugestões metodológicas interessantes. Começo por acrescentar alguns elementos a questões já lançadas anteriormente.

Primeiramente, o perfil primário do mercado de trabalho da Grande Santa Rosa - tanto a preponderância desse setor, quanto a característica da exploração, familiar em pequenas propriedades - tem inequívoca associação com as baixas proporções do assalariamento na região. Ainda assim, houve crescimento do emprego formal nesse setor, nos anos 1990 (tendência revertida na primeira metade da presente década), o qual aparece associado a segmentos bem específicos da produção, notadamente a integração com a indústria de alimentos, para a suinocultura e a atividade leiteira, como atesta esse depoimento de um líder de sindicato de trabalhadores rurais da região:

Assalariado rural aqui... assim, é muito pouco o que tem (...) aqui é um dos municípios que nós não temos nenhum trabalho com assalariado rural. Pelo fato da gente não ter assim... não ter muita... Não tem muito esse tipo de trabalho aqui.

P: (...) Empregador entra também [no Sindicato]?

R: Não, não, não. Na verdade, nós temos... Mas são poucos também, que lidam aí... Tipo... principalmente na área da suinocultura e no leite, o pessoal que... eles passaram a ser empregador pra questões legais, né, pra evitar qualquer problema, né. Então eles passaram a ser empregadores rurais com mão-de-obra especializada, né, já um pouco mais. Isso existe (Presidente do Sindicato dos Trabalhadores Rurais de Santo Cristo, entrevista em 2002).

Esse testemunho de que o assalariamento rural é uma excepcionalidade foi partilhado por todos os entrevistados que se manifestaram sobre o tema. O que fica indicado no excerto acima é que, quando ocorre, está associado à produção pecuária, mais do que à agrícola, e à agroindustrialização.

Afora a pequena capacidade de investimento que a maior parte dos produtores rurais tem para a contratação de força de trabalho suplementar à de sua família, há, no entendimento de muitos dos entrevistados, alguma apreensão, por parte de potenciais empregadores, frente às exigências da legislação trabalhista. Nas palavras de um pesquisador de uma universidade da região, que entrevistei em 2002:

(O assalariamento rural) É uma prática que tem alguns empecilhos. Até porque hoje a legislação é bastante drástica - porque hoje qualquer um que entrar na Justiça aí acaba ganhando. (...) A maioria dos agricultores tem receio de contratar pessoas trabalhadoras. Até porque o horário de trabalho da agricultura às vezes é diferenciado do horário de uma indústria. Época de plantio você planta vários dias a fio ou noite adentro. Época de 
colheita, a mesma coisa: quando está bom para colher, tem que colher. Então, algumas pessoas - já é de praxe isso na região -, (...) o que tem acontecido é uma prática de um trabalho mais - como eu vou te explicar isso? ...

P: Informal?

R: Informal. Bem informal, ou de parceria - de ele trabalhar por percentual, não como contratação direta. Alguns sim, têm (empregados), mas é muito difícil isso. O pessoal tem aí os chamados agregados - pessoas que moram na propriedade, por exemplo; muitas vezes o proprietário não mora ali, mas ele recebe um percentual da colheita, e aí então...

A concentração da atividade econômica da Grande Santa Rosa no chamado agronegócio, como indiquei no capítulo 5 , não conduz à constituição de um arranjo aos moldes de um complexo produtivo, uma vez que seu braço industrial (em especial a fabricação de máquinas agrícolas, segmento dominante) não se articula de forma relevante seja com a oferta, seja com a demanda dos minifúndios da região. $\mathrm{Na}$ industrialização de alimentos, esses laços são mais reconhecíveis, embora o número de unidades primárias conectadas às cadeias seja bastante restrito. Isso não impede que a população represente a agropecuária - que, diretamente, contribui com uma quarta parte do produto interno - como fator absolutamente determinante para as condições mercado de trabalho regional. Expressa-se, assim, a percepção de que os condicionantes para o desempenho do setor têm um alcance espacial bem mais amplo, envolvendo desde "conjunturas" climáticas (favoráveis ou desfavoráveis), que geralmente incidem sobre amplas extensões territoriais, até a política econômica nacional, em variáveis como o câmbio, taxa de juros, políticas de preço ou de financiamento e garantias à agricultura, entre outros.

O mercado de trabalho aqui... Já basicamente por ser base de agricultura, então se a agricultura melhorasse tudo iria melhorar, né, porque já vende... O setor... Loja de roupa já não vai vender tanta roupa, até porque - claro, o pessoal da cidade que tem emprego, que recebe, digamos assim, não tem problema com as suas contas. Agora, o pessoal que vive do leite, ou vive do soja, como é que vai começar a...? Não pode esbanjar dinheiro, tem que ser aquele dinheiro contado, para poder... Agora, se a agricultura melhorasse um eito, melhoraria um eito, porque daí a AGCO volta a funcionar, a John Deere volta a funcionar, fábricas de implementos que tem aqui voltam a funcionar, as metalúrgicas... Então tudo volta ao normal, porque antes de começar essa crise, há dois ou três anos atrás, não se tinha queixa praticamente de desemprego. Isso era pouco comum, aqui nessa região, a meu ver (Oberdan, 19 anos, natural de Tuparendi, inscrito no Sine de Santa Rosa, nov.06).

Os resultados da pesquisa de campo referentes ao significado do minifúndio na construção do mercado regional de trabalho serão explorados com mais detalhe no capítulo 8. Um dos elementos que destaco é o trânsito entre a atividade na unidade rural familiar, cujos vínculos mercantis "para fora" são restritos, e o assalariamento. Em São José do Inhacorá, ao falar de uma indústria metalúrgica que tem 25 empregados (e é a segunda fonte de ICMS, nesse pequeno município), o representante da Prefeitura me disse que "muitos agricultores deixam de trabalhar na lavoura para vir trabalhar na indústria". Quando lhe perguntei a razão dessa escolha, declarou:

É, a agricultura hoje está numa situação muito difícil. (...) O preço do produto agrícola é muito baixo, então está todo mundo assim... desestimulado, sem vontade, meio deprimido, 
né. Trabalham, trabalham e não vejam rentabilidade (sic). Enquanto o pessoal vai trabalhar por mês, né, numa indústria, chega no fim do mês não tem muito, mas tem um rendimento satisfatório (Eliseu, Secretário do Planejamento de São José do Inhacorá, ago.06).

Mesmo nesses casos em que um vínculo de emprego no meio urbano retira um indivíduo da atividade primária, a interpenetração desses dois "universos", do ponto de vista da composição da renda e das estratégias familiares, bem como da alocação dos tempos de trabalho, é um elemento que reaparece de várias formas. Essas evidências indicam a importância de avançar as análises desses processos para além das estatísticas concebidas com foco no trabalhador individual, sobretudo quando restritas ao "trabalho principal" que executam.

Uma das constatações interessantes que fiz é que a família rural, na região, não opera necessariamente com um compartilhamento dos haveres de seus integrantes: correndo em paralelo com laços de dever e reciprocidade, muito freqüentemente estabelecem-se, entre parentes de primeiro grau, contratos formais (especialmente de arrendamento de terra), ou mantém-se uma "contabilidade" individualizada de propriedade e de retornos monetários, dentro de uma mesma unidade produtiva. Um exemplo é narrado por um operário de 63 anos, de Santa Rosa, que relembra o tempo em que, jovem, já casado, deixou a colônia, em que viviam seus pais, para empregar-se na grande empresa metalúrgica da cidade:

GERALDO - Eu morei oito meses com uma tia da minha esposa. Aí era um problema também. Ela era uma viúva, quer dizer, separada. E era boca braba, também. Então, sem dinheiro, eu tinha... Ainda eu tinha que pagar 120 reais de aluguel, e eu ganhava 180 reais [confunde a unidade monetária, pois refere-se a 1970]. Eu tinha que... os primeiros meses, eu tinha que emprestar dinheiro para poder viver. (...) Então o meu pai me emprestava. Eu tinha um pouco de gado lá.

$\mathrm{P}-\mathrm{O}$ senhor tinha gado onde?

GERALDO - Eu tinha lá onde morava o pai.

$\mathrm{P}$ - Com o pai?

GERALDO - É.

$P$ - E era seu? Era separado?

GERALDO - É. Aí fui vendendo pra poder botar comida na... (mai.07)

O aluguel pago à tia e a discriminação entre o gado próprio e o paterno (ao mesmo tempo em que esse pai se responsabilizava pelo manejo de todos os animais da unidade) exemplificam a sobreposição das lógicas de "negócio" e de rede de apoio, confluindo na trama das relações familiares.

Um segundo ponto que quero realçar - a ser mais bem explorado no próximo capítulo, em que trato do município de Horizontina e do papel da empresa John Deere - é a circulação de mãode-obra (vale dizer, de indivíduos e famílias) no raio territorial da Grande Santa Rosa (o que não elimina a recorrência de migrações para fora dela). Os relatos dos trabalhadores que ouvi trazem, quase unanimemente, esse traço, seja nas trajetórias dos próprios entrevistados, seja na de seus pais, irmãos ou filhos. Apresento, aqui, apenas um exemplo, recolhido na pequena cidade de Boa 
Vista do Buricá, que, como referi no capítulo anterior, sediava, ainda na ocasião dessa entrevista, uma fábrica de calçados, que fechou pouco tempo depois:

$\mathrm{P}$ - O que houve, que essa preponderância [da cultura alemã] diminuiu [como o entrevistado vinha de declarar]? Veio mais gente de...

ELOI - É, eu acho que foi a miscigenação de raças, e veio muita gente de outra raças, então...

$\mathrm{P}-\mathrm{E}$ veio de onde?

ELOI - Veio de tudo que é lado. Acho que é a indústria que traz isso aí. (...) Vamos ao caso Reichert Calçados: no mínimo 2 mil famílias já vieram pra cá e foram de novo [a planta é de 1975]. Não deu certo. Às vezes não era aquilo que eles pensavam, então eles vão embora, vão para outro serviço, de novo.

$\mathrm{P}$ - Mas vêm de outras regiões?

ELOI - Vêm de outros lugares para cá. Até na nossa região, principalmente da nossa região.

$\mathrm{P}$ - Os municípios próximos?

ELOI - Exato (Ex-Prefeito, funcionário da Prefeitura de Boa Vista do Buricá, ago.06).

Essa circulação entre a condição de assalariamento e outras formas de ocupação (ancoradas de forma mais ou menos direta na subsistência e no domicílio assegurados pela família minifundiária) teve, historicamente, um papel decisivo no sentido de garantir flexibilidade numérica aos grandes estabelecimentos industriais. Essa inaudita plasticidade da oferta e da demanda por postos de trabalho particulariza fortemente a dinâmica de semelhante mercado.

GERALDO - (...) Então sempre, todos esses anos, tinha... para mim, que a gente está há anos aqui, essa era a coisa mais triste. Por exemplo, porque colheitadeira é o seguinte: geralmente tem seis meses de produção alta, seis meses baixa. Então, quando chegava o mês de abril, maio, todo mundo já estava, assim, com as orelhas apontadas, porque maio, junho, era aquela demissão.

$\mathrm{P}-\mathrm{Todos}$ os anos?

GERALDO - Todos os anos.

P - E isso já no tempo da Ideal? [primeira designação da planta da AGCO]

GERALDO - No tempo da Ideal... Não nos primeiros anos, mas aí, de 1979, 80 em diante, já era isso aí. (...) Então era aquelas demissão, aqueles colegas indo embora. Isso dói para a gente. (...)

$\mathrm{P}$ - E essas pessoas, às vezes, eram as mesmas que saíam e entravam?

GERALDO - Sim, a maioria das vezes era...

$P$ - Era um vai e volta?

GERALDO - É. Porque aqui... Por exemplo, nessa região, aqui em Santa Rosa, nós temos, só aqui, de máquinas agrícolas, só temos a John Deere, que é Horizontina, aqui - é mais perto. Então, justamente quando aqui estava maré baixa, lá também estava baixa. Então não tinha como...

P - Como compensar (Geraldo, operário da AGCO de Santa Rosa, 63 anos, mai.07).

Não podem ser subestimadas as conseqüências dessa concentração do emprego assalariado em poucas empresas sobre o significado que elas adquirem na vida local e regional, o que tem implicações claras no vínculo que trabalhadores e instituições com elas estabelecem, do ponto de vista simbólico e político. Esse aspecto é bastante evidenciado no exemplo limite da John Deere, em Horizontina, que abordo no próximo capítulo. Trago, aqui, um depoimento que trata da posição 
da AGCO em Santa Rosa, que antecipa, por homologia, alguns dos principais pontos de interesse analítico:

CRISTINA- Nós sentimos que o funcionário tem orgulho de vir trabalhar aqui. E que nas outras, tipo Canoas, é mais uma empresa, a AGCO é mais uma empresa. E aqui não, aqui a AGCO é reconhecida como a AGCO. Porto Alegre o mercado de trabalho é bem mais aberto, e aqui não é. Então aqui reflete muito, assim, "a AGCO está demitindo" - isso reflete em todo o município. Porque abrange muitas famílias. E o comércio reflete, o mercado reflete, reflete em tudo. Então quando a AGCO está balançando, a cidade inteira fica em alerta.

(...)

CRISTINA - Aqui ela é tranqüilo, o sindicato, se for comparar com o nosso pessoal de Canoas - lá eles têm mais conflitos, mais reivindicações. Aqui parece que tudo é mais amigável, tudo é mais no entendimento mesmo.

$\mathrm{P}-\mathrm{E}$ por que será?

CRISTINA - Talvez pelo mercado de trabalho mesmo, né, que oferece mais oportunidade, que eles batem mais... que o sindicato já é mais forte (Psicóloga do RH da AGCO Santa Rosa, mai.07).

Esse depoimento indica, com base na experiência de uma mesma empresa em dois pontos diversos do território gaúcho, que as relações de trabalho são muito diferentes com o operariado de Santa Rosa e com o de Canoas, na Região Metropolitana de Porto Alegre. A hipótese da psicóloga aponta para um elemento muito destacado pelos entrevistados, a reverência que a população nutre por esses estabelecimentos fabris de maior porte e de origem local, que se constituem num contraponto, muitas vezes idealizado, ao trabalho rural, suas agruras e seu desprestígio simbólico.

Seguindo-se a mesma fala, o estado de "alerta" quanto à saúde dos negócios dessas firmas expressa a condição de relativa dependência que esses municípios vivem em relação a elas - neste caso, cabe frisar, plantas pertencentes a corporações multinacionais. Na Grande Santa Rosa, constatei recorrentemente a disposição que um conjunto muito variado de instituições demonstra para se mobilizar em favor dessa atividade industrial. Uma manifestação extrema desse laço tão particular entre a esfera pública (em sentido lato) e as empresas privadas que pontificam nesse mercado regional de trabalho foi um ato público, ocorrido em 29 de junho de 2006, que teve sua organização compartilhada por dez instituições, em "defesa" (sic) do setor metal-mecânico da região, à época fazendo frente a uma violenta crise.

Esse evento ocupou, bloqueando-as, duas das principais ruas de Santa Rosa, tendo contado com o apoio de quase todos os estabelecimentos comerciais dessa área, que, durante o ato, como pude testemunhar, fecharam suas portas. Fizeram uso da palavra representantes de cada uma das entidades promotoras do evento - a Associação dos Municípios da Grande Santa Rosa; a Associação Comercial, Industrial, de Serviços e Agropecuária (ACISAP) de Santa Rosa; outras cinco associações empresariais (incluído o sindicato rural); três sindicatos de trabalhadores (trabalhadores metalúrgicos, rurais e da indústria de alimentação); bem como deputados estaduais e federais com base eleitoral na região e o Prefeito Municipal. Cada um deles expressou sua percepção sobre a alegada crise setorial e sobre o significado desse segmento produtivo para a 
região e/ou para a categoria específica que integravam. Um exemplo eloqüente vem do pronunciamento do presidente do Sindicato dos Trabalhadores da Alimentação, também vereador em Santa Rosa:

\begin{abstract}
Vocês podem estar pensando neste momento: "O que o sindicato da Alimentação tem a ver com este momento? O que os vereadores, os políticos, têm a ver com este momento?". Bom, pra nós é um momento muito complicado porque é uma situação em que não só trabalhadores metalúrgicos estão sendo desempregados. É a cadeia... Nós também tivemos demissões no setor da alimentação, em conseqüência da crise que está se passando hoje no setor metal-mecânico. Então, por isso, o nosso apoio, por isso nós estarmos aqui prestigiando e apoiando vocês.

Também dizer que, enquanto vereador, deputado, as pessoas nos encontram na rua e dizem: "Vereador, pelo amor de Deus, me arruma um emprego". São jovens que querem começar a carreira de trabalho, profissionalismo, pessoas qualificadas, formadas, são pessoas que estão por se aposentar e que foram demitidos em conseqüência dessa crise que estamos vivendo no nosso município. (...) Então, não dá pra nós ficarmos parados, não dá pra nós ficarmos esperando que alguma coisa venha acontecer. Que nós temos que fazer a pressão! (Presidente do Sindicato dos Trabalhadores da Alimentação de Santa Rosa, pronunciamento em ato-público, jun.06).
\end{abstract}

Pude acompanhar um pouco os bastidores deste ato, que incluíram tensões políticopartidárias (estava-se a três meses de uma eleição estadual e nacional). Alguns discursos veiculados isoladamente - como uma nota emitida por um partido político, distribuída sob a forma de panfletos, rapidamente recolhidos - associavam a crise da metal-mecânica regional à atuação governamental, em esferas comandadas por agremiações (localmente) adversárias. Esse episódio é lateral, porém ilustra os dissensos, que não impediram a manifestação conjunta - que, em praça pública, soou uníssona - dos principais atores coletivos e lideranças políticas locais e regionais.

Duas características dessa região, que têm clara influência na configuração de seu mercado de trabalho, foram discutidas no capítulo anterior, e dispenso-me, aqui, de comentários adicionais. Refiro-me, em primeiro lugar, à sua dinâmica demográfica, fortemente expulsora, e, em segundo, ao complexo tabuleiro que se constrói em torno das identidades étnicas.

Destaco, agora, algumas questões que o campo trouxe à tona, no que diz respeito a categorias específicas de trabalhadores, segundo seus atributos ou formas de inserção na ocupação.

Inicio pelo trabalho doméstico. Nos últimos anos tem mudado o perfil desses serviços, nas maiores cidades da Grande Santa Rosa (nos quais se concentram), obedecendo a transformações na estrutura das famílias que os contratam. Na agência do SINE de Horizontina, em 2002, a coordenadora declarou:

[Emprego] para doméstica eu acredito que não diminua, pelo simples fato de que hoje toda mulher vai em busca de uma profissão. Então, (...) ela não sendo doméstica, vai precisar de alguém que vai fazer esse trabalho em sua casa. Não é mais como há oito, dez anos atrás, quando numa casa você via duas, três, ou às vezes até quatro.

P: As famílias mais ricas tinham muitos empregados?

R: Isto. Hoje não, hoje tem uma que é babá, é cozinheira, é faxineira. (...) mas não é que com isto deixa do pessoal pegar. É uma constante, é difícil o dia que não se coloca uma, 
duas, todo dia acontece entrevista. Mas hoje, mesmo a doméstica ela precisa ter uma qualificação (Coordenadora do SINE de Horizontina, 2002).

Por um lado, reduz-se o número de empregados por família, nos segmentos de maior poder aquisitivo - e, conforme outros depoimentos, a tendência é a uma significativa substituição de emprego doméstico (de tempo integral) por contratação de serviços (faxineiras diaristas, em especial). Por outro, uma proporção mais elevada de famílias passa a contratar trabalho doméstico e esse segue sendo uma importante forma de inserção para as mulheres da região.

Essa parece ser uma das razões da maior retenção do contingente feminino nas principais cidades da Grande Santa Rosa, comparativamente ao que ocorre com os homens, o que se reflete na razão de sexo desses municípios. Ao comentar a mudança no perfil da emigração na região, um entrevistado, funcionário do SINE de Santa Rosa declarou:

Há muitos anos eles [migrantes dos demais municípios] estão indo, em vez de virem aqui pra Santa Rosa, muita gente também vai pro Vale Real, Bom Princípio, para a Região Metropolitana. Aí vale destacar a empregada doméstica, que vem pra Santa Rosa. Nós temos aí, da região, de pequenos municípios, muitas mulheres, principalmente, que trabalham aqui em Santa Rosa de empregadas domésticas. E muitas delas inclusive intermediadas pelo sistema SINE (funcionário do SINE de Santa Rosa, 2002).

Mesmo que, no trabalho doméstico, o emprego tendencialmente seja substituído por contratação de serviços autônomos, ele ainda é significativo e oferece uma estratégia para que mulheres dos municípios menores permaneçam nas cidades maiores e estudem, conforme atesta esse depoimento de uma professora universitária:

E aqui tem uma questão interessante: nós temos uma escola normal - (...) formação de professores a nível de segundo grau, professores de $1^{\mathrm{a}}$ a $4^{\mathrm{a}}$ série -, e muitas meninas vindas da colônia estudar. Aí existe o seguinte: a menina vem da colônia, consegue se colocar numa casa, porque ela estuda, vamos dizer, de tarde; aí, de manhã ela faz o serviço, tem onde morar e pela comida. Isso é muito comum nessa região aqui. E mesmo na própria universidade, eu tenho uma aluna que estava me dizendo: "olha, professora, eu só estou conseguindo estudar porque eu cuido um senhor de oitenta e poucos anos". Ela trabalha o dia todo cuidando dele e de noite vai estudar (Professora universitária, Santa Rosa, 2002).

Em uma das descobertas que o trabalho de campo me reservou, deparei-me, na rodoviária de Santa Rosa, com um pequeno quiosque, envidraçado, que, como vim a saber, é uma cabine de transmissão de uma das emissoras de rádio de maior audiência, na região. Uma secretária e um locutor mantêm-se nesse espaço durante boa parte do dia, e o principal objetivo, segundo me declararam, é realizar a divulgação de vagas e a auto-oferta de trabalhadoras para serviços domésticos. As mulheres que vêm das zonas rurais ou das sedes dos municípios menores da Fronteira Noroeste, dispostas a fixar-se na cidade-pólo, têm, assim, uma informação imediata de vagas em residências de Santa Rosa e podem, igualmente, ser apresentadas e "descritas" pelo radialista, no ar, para potenciais empregadores. Nas diversas vezes em que me utilizei de ônibus 
intermunicipais, na região, pude testemunhar que esse serviço de "intermediação" da rádio é bastante procurado.

Não surpreendentemente, é radical a distinção de gênero na configuração dos projetos e trajetórias laborais, o que fica especialmente patente quando se trata de uma mesma família. Especialmente no ato de deixar o meio rural, o movimento esperado das mulheres parece ser as cidades próximas, e a inserção via trabalho doméstico é identificada como típica:

CLÁDIS - O meu irmão mais velho teve, assim, coragem, até porque ele teve amigos que muita gente já tinha migrado para o Paraná, e lá pra cima... Então ele foi a Cascavel (...). Trabalhou tipo carregar mala em hotel, essas coisas que não depende de estudo (...) depois foi batalhando.

(...) Aí ficamos nós irmãs, né, em casa. A minha irmã mais velha, daí, também, logo em seguida, foi para a cidade [de Horizontina, em cuja zona rural a família habitava], mas trabalhar, tipo assim, babá. O que a mulher vai fazer? Vai trabalhar babá, ou emprego doméstico. Então ela foi trabalhar de babá (proprietária de consultoria privada de recursos humanos, Santa Rosa, jun.07).

É interessante ressaltar a força que evidenciam as relações familiares e as redes sociais nesses percursos, o que se observa na migração de longa distância do irmão da entrevistada que venho de citar, bem como em inúmeros casos que me foram relatados, referentes a essa passagem do campo para a cidade. No caso das mulheres, o engajamento no trabalho doméstico, não poucas vezes, situa-se nessa fluida fronteira entre a relação de emprego e a reciprocidade devida ante uma acolhida por pessoas do círculo familiar:

CRISTIANE - Até depois eu saí um tempo de casa, porque quando eu fui fazer o Ensino Médio, eu não tinha transporte aqui de casa [na zona rural, para a qual retornou]. Ou eu teria que ir à noite. Então eu até estudei um ano de noite, mas era um pouco complicado eu tinha que embarcar muito cedo e voltava muito tarde. E aí eu fui morar na cidade.

$\mathrm{P}$ - Aqui mesmo, em Santo Cristo?

CRISTIANE - Em Santo Cristo. Eu fui morar com a minha madrinha. Lá eu fazia uns serviços domésticos e cuidava de uma criança, o meu priminho, que pela parte da tarde nós ia para o colégio, eu levava ele comigo, pela parte da manhã nós ficava em casa, e à noite também - até porque de noite ela estudava e meu tio viajava (produtora rural, 22 anos, Santo Cristo, mai.07).

São recorrentes nesses depoimentos os esforços realizados visando à escolarização, no nível do Ensino Médio, e também à formação universitária. Esse é mais um aspecto que quero abordar, em alguns de seus nexos, com base na pesquisa de campo. Os dados do Censo de 2000, anteriormente apresentados, evidenciando a desvantagem da Grande Santa Rosa frente ao agregado do Estado, no que tange à educação formal, e um percentual majoritário $(61,2 \%)$ de ocupados que não haviam concluído sequer o Ensino Fundamental, conflitam, em um primeiro momento, com a posição praticamente unânime, de que a região tem tido, desde os anos 1990, um grande dinamismo na área educacional, com destaque para o Ensino Superior. Em 2002, um professor da Unijuí de Santa Rosa detalhou esse movimento: 
Existe (...) uma preocupação maior atualmente com o ensino técnico. Mas o grande processo de qualificação de mão-de-obra aqui ocorreu pelo aumento da população que ingressa nos cursos superiores. Só vou te dar um exemplo para te mostrar um pouco o que isso significa na década de noventa. Quando a Unijuí fez um convênio com o Instituto Educacional Dom Bosco para vir para Santa Rosa, para instalar um campus aqui, nós tínhamos 590 alunos no Dom Bosco - eu já trabalhava lá. Hoje nós temos 2300 aqui (na Unijuí). O Machado de Assis [FEMA], nessa época, começo da década de noventa, não passava de 100, 150 alunos. Hoje eles têm mais de seiscentos. A CETREM, de Três de Maio, também não passava de 200 alunos. Hoje eles têm quase mil. Então houve uma procura muito grande para o ingresso no ensino superior. E isso também se faz presente no ensino médio. Eu trabalho numa escola pública estadual, onde, quando eu entrei nesta escola, em 1991, nós tínhamos duas turmas de ensino médio no primeiro ano. Hoje temos onze turmas. Quer dizer, então, esse processo de qualificação foi muito forte na década de 90.

A essas três instituições de ensino superior, veio somar-se, mais recentemente, a Faculdade de Horizontina (FAHOR), de que voltarei a tratar no próximo capítulo, elevando ainda mais a oferta de vagas universitárias. Não é difícil propor uma solução para a aparente contradição entre a permanente expansão do contingente de graduados e um escasso reflexo dessa tendência no perfil educacional dos ocupados (lembrando-se, de qualquer modo, que o último Censo já se encontra um tanto recuado no tempo). Os processos migratórios e o aumento da participação dos indivíduos mais idosos na região (ocupados, em grande parte, no trabalho agrícola familiar) contribuem para neutralizar - ou alienar - os resultados obtidos pela Fronteira Noroeste, no que tange à formação de seus recursos humanos.

É a "migração em dois tempos" a que me referi no capítulo anterior que se mostra com força nessa equação. No município de São José do Inhacorá (de 2,4 mil habitantes, 63\% dos quais em zonas rurais), o representante da Prefeitura me declarava, em agosto de 2006, ao tratar da evasão de jovens:

Vão para os centros maiores. Uns procura de serviço, né; outros para estudar, e não retornam mais. Mas, principalmente, é aquela massa jovem que procura estudar. Vamos supor, vamos usar assim: um dentista, um médico, vamos supor, ou um engenheiro, não têm espaço aqui; então, eles procuram, estudam e procuram um trabalho já nos centros maiores, onde eles conseguem o seu espaço pra isso.

Uma parte considerável da clientela dessas universidades regionais é formada por essa juventude dos municípios menores, muitos dos quais se transferem de zonas rurais para as cidades que sediam as instituições de ensino. Nelas, o contingente que se forma é crescente e configura uma pressão de saída da própria região, percepção que pode ser ilustrada por dois entrevistados de minha primeira incursão à Grande Santa Rosa, em 2002. Um empresário da metalurgia me disse, então, após esmiuçar a situação de suas duas filhas: "Geramos os filhos; se formam e vão embora. E isto é uma tônica constante. Não muda”. Já uma professora universitária declarou:

Aqui tem "fábricas" de advogados, de professores, de tudo, porque Santa Rosa tem duas faculdades de Direito, uma de dia e outra de noite; Santo Ângelo, a $50 \mathrm{~km}$, tem faculdade 
de Direito, duas; Ijuí, a 100 km, tem; Cruz Alta, a $200 \mathrm{Km}$, e Santa Maria. Então, essa turma está largando gente aí de monte, para trabalhar aonde? Não tem. E assim é com outras profissões - o próprio professor... Sabe? Há nisso um retrocesso, não tem, não tem emprego, tem mão-de-obra de excelente qualidade, mas não tem emprego.

Posta à frente da análise essa permanente drenagem de mão-de-obra, sobretudo nesse segmento de elevada escolaridade, é lícito que se questione em que medida a Grande Santa Rosa constitui, de fato, um mercado de trabalho, ou representa, sobretudo, uma região que sobrevive com base em trabalho não mercantilizado e se articula com outros territórios na condição de "fornecedora" de trabalhadores qualificados ${ }^{77}$.

Todavia, os indicadores apresentados na primeira seção deste capítulo e a caracterização das atividades econômicas da Fronteira Noroeste, no anterior, parecem suficientes para que se identifiquem, primeiramente, a efetividade e a trajetória claramente ascendente de um segmento formalmente assalariado, no universo da ocupação. Ademais, em que pese a todas as especificidades que o trabalho rural, familiar, não remunerado apresente, não parece uma boa opção analítica extirpá-lo da noção de mercado de trabalho, se esta ambiciona dar conta de uma realidade social enquanto totalidade, e, ao fazê-lo, abarcar problemáticas como a reprodução material da vida social, o papel do trabalho na formação de identidades e constituição de hierarquias de status, dentre outras. Tal como tenho procurado demonstrar, e abordarei com mais vagar nos próximos capítulos, o trânsito de indivíduos e a imbricação proporcionada pelas redes sociais e familiares não permite que se aplique uma cisão entre essas diferentes esferas da ocupação.

Termino esse capítulo com uma última consideração que também será melhor esclarecida nos dois outros que o seguem. Ao investigar as formas como os indivíduos procuram trabalho e como as empresas recrutam, sobressaiu, na pesquisa de campo, a importância das redes sociais e familiares. Esses laços interpessoais, os fluxos de informação que por eles circulam e as formas de apoio e chancela que se baseiam na confiança têm sido crescentemente valorizados pela sociologia - notadamente no estudo de mercados, como assinalei no capítulo 1. Se alguma particularidade parece revestir uma formação regional como a estudada, ela está na nitidez com que esses mecanismos aparecem, associados à pequena escala populacional e à baixa complexidade do universo produtivo e institucional.

Oberdan: Eu fui começar a procurar emprego, assim que meu pai ficou doente. (...) Minha irmã já trabalhava na cidade (...) eu senti necessidade de ajudar em casa, né, então tive que buscar um emprego pra... e daí, como a Cooperativa, um dos fundadores da Copermil foi o meu vô, em Cinqüentenário [localidade de Tuparendi], né, a primeira sede -, então meu tio, irmão gêmeo do meu pai, até ele fazia parte da diretoria. Então eu procurei, já larguei currículo, conversei com ele e tal, e através do meu tio eu consegui entrar, né. Meu tio deu

\footnotetext{
77 A pista para tal interpelação aos dados que recolhi devo-a ao Prof. Álvaro Comin, em sua estimulante argüição quando de meu exame de Qualificação, em dezembro de 2005.
} 
uma mão, e a gente já conhecia o presidente da cooperativa - até por ser agricultor, já conhecia; então foi mais fácil através disso, e eu comecei a trabalhar aí.

$\mathrm{P}: \mathrm{Tu}$ chegaste a largar outros currículos noutros lugares?

Oberdan: Naquela época, cheguei a largar em dois ou três lugares, assim... onde tinha amigos nossos, assim, da família, no caso, que a gente largava, deixava...

Em praticamente todos os depoimentos de trabalhadores, há a referência à obtenção de algum trabalho já exercido por intermédio de parentes ou amigos; as migrações intra-regionais ou de maior alcance contam quase sempre com o apoio de membros de grupos familiares ou sociais que fizeram o mesmo percurso anteriormente. Nesses municípios de pequeno porte que compõem a Grande Santa Rosa, a expressão de confiança nas pessoas da cidade, e mesmo da região, é muito freqüente, sugerindo que a expectativa de cumprimento de normas de conduta é estendida, de um circuito pessoal, para um circuito social que é, fundamentalmente, espacial.

P - E a história de currículos com informações falsas? Vocês chegaram a ter situações desse tipo, a identificar?

CLÁDIS - Olha, como é só pessoas daqui da região, dificilmente elas fazem isso.

Especialmente nas localidades com menores tamanhos populacionais, essa "proximidade" entre os indivíduos - vale dizer, a reiteração de laços interpessoais, vinculada à sobreposição de circuitos de sociabilidade que envolvem desde a família até as diferentes transações mercantis, passando pelas interações nas esferas política e cultural - ostenta claras conseqüências na vida social, de que uma leitura sociológica dos mercados de trabalho não deveria se descuidar. Em 2002, entrevistando um integrante da Comissão Municipal de Emprego de Horizontina, pergunteilhe sobre o grau de conflito entre as bancadas dessa arena tripartite. Sua resposta ilustra com muita propriedade esse "efeito escala" que mostra sua força em campos tão distintos quanto as relações de trabalho no interior de uma empresa quanto nos diferentes espaços institucionais:

Até por ser assim uma cidade considerada pequena, sabe que a gente, todo mundo é amigo, né. Então é difícil de ter essas... Porque tu é amigo do futebol, tu é amigo do... Existe uma... Não, em termos assim, o funcionamento dela [Comissão], a maneira, é muito harmoniosa, o que eu senti até hoje, é pacífica, não tem "puxar muito para o meu lado" ou... (secretário municipal, integrante da Comissão Municipal de Emprego, Horizontina, 2002).

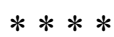

As formas como a metodologia qualitativa utilizada nessa pesquisa de campo permitiu avançar na compreensão da dinâmica do mercado de trabalho da Grande Santa Rosa se desdobram. Há fenômenos que o conhecimento da realidade regional permitiu captar, que seriam elididos a tomar por apoio apenas as bases estatísticas, as quais, no limite, induziriam a equívocos de interpretação. Esse é o caso da problemática da escolarização, em que os dados secundários não 
expressam a elevada "produção" de recursos humanos (sobretudo de terceiro grau), devido à permanente e rápida evasão desses. Em uma linha um pouco diferente, situações tradicionalmente quantificadas adquirem uma nova dimensão de complexidade, como as múltiplas situações que quebram a classificação binária de ocupados $\mathrm{x}$ desempregados com que se subdivide a PEA: a periódica contratação e demissão dos mesmos indivíduos na grande empresa mecânica de Santa Rosa é um exemplo disso, quando se tem uma indicação, ao menos, de trajetórias muito mais matizadas. A forma como essas situações ocupacionais se enraízam no tecido social e regional já emergiram neste capítulo, em que a interveniência das redes sociais e familiares se demonstram especialmente relevantes para viabilizar projetos pessoais, como o estudo de minifundiários na zona urbana, ou para abrandar situações de dificuldade, por desemprego ou restrições associadas a baixos salários. Elementos tipicamente associados a particularidades da região, como o recurso ao domicílio e ao trabalho rural, como alternativa periódica a penúrias no meio urbano, ou a influência do porte das cidades, impactando a força de princípios como a confiança, também compareceram de forma rica.

Se neste momento algumas dessas evidências surgiram de forma um pouco desconectada, busco aprofundar o que aqui teve um tratamento panorâmico destacando e analisando com um pouco mais de vagar, nos dois próximos capítulos, duas configurações bastante eloqüentes da conexão entre mercado de trabalho e sua espacialidade, na experiência estudada: a localidade de Horizontina é o recorte territorial da primeira; a seguir, um critério ao mesmo tempo setorial e social: a categoria dos minifundiários, no conjunto da região. 
TABELA 8 - Indicadores selecionados do mercado de trabalho, Grande Santa Rosa e Rio Grande do Sul, 2000

Distribuição etária da PIA (\%)

Taxa de participação Taxa de desocupação

\begin{tabular}{|c|c|c|c|c|c|c|c|c|c|c|}
\hline 10 a 17 & 18 a 24 & 25 a 39 & 40 a 59 & 60 ou mais & Urbana & Rural & Total & Homens & Mulheres & Total \\
\hline 14,4 & 13,2 & 27,6 & 36,1 & 8,7 & 55,3 & 76,0 & 71,8 & 1,2 & 2,1 & 1,6 \\
\hline 11,7 & 14,1 & 30,2 & 35,4 & 8,6 & 67,0 & 88,1 & 82,0 & 6,8 & 8,2 & 7,3 \\
\hline 11,8 & 14,7 & 34,5 & 33,3 & 5,7 & 64,3 & 82,1 & 76,6 & 5,8 & 5,7 & 5,7 \\
\hline 13,0 & 13,9 & 28,3 & 36,4 & 8,4 & 74,9 & 77,0 & 76,5 & 1,6 & 5,7 & 3,4 \\
\hline 14,1 & 11,3 & 31,6 & 33,6 & 9,4 & 76,4 & 81,8 & 81,3 & 2,9 & 3,2 & 3,1 \\
\hline 9,0 & 14,2 & 31,2 & 33,7 & 11,9 & 58,4 & 80,4 & 73,4 & 4,7 & 6,5 & 5,5 \\
\hline 8,2 & 18,9 & 37,7 & 30,1 & 5,2 & 59,0 & 75,2 & 70,4 & 7,0 & 13,0 & 9,5 \\
\hline 7,8 & 15,0 & 31,7 & 36,3 & 9,3 & 57,1 & 65,9 & 60,6 & 4,7 & 7,6 & 5,9 \\
\hline 13,0 & 13,3 & 27,0 & 37,2 & 9,4 & 56,8 & 71,6 & 63,7 & 0,8 & 1,1 & 0,9 \\
\hline 10,7 & 13,4 & 29,9 & 35,4 & 10,5 & 53,0 & 82,9 & 71,9 & 2,0 & 1,3 & 1,7 \\
\hline 12,0 & 11,7 & 29,5 & 36,9 & 9,9 & 66,7 & 79,1 & 74,2 & 1,2 & 4,4 & 2,6 \\
\hline 14,5 & 11,8 & 29,5 & 32,2 & 12,0 & 69,9 & 76,4 & 72,9 & 1,9 & 1,3 & 1,7 \\
\hline 9,8 & 10,9 & 32,7 & 39,1 & 7,4 & 68,0 & 82,1 & 78,9 & 0,0 & 1,3 & 0,5 \\
\hline 6,9 & 19,8 & 40,2 & 29,7 & 3,4 & 65,8 & 86,9 & 80,0 & 12,3 & 14,8 & 13,4 \\
\hline 13,5 & 13,1 & 33,9 & 32,9 & 6,5 & 58,6 & 80,6 & 75,1 & 3,4 & 4,6 & 3,9 \\
\hline 12,8 & 13,0 & 26,2 & 35,6 & 12,6 & 70,1 & 79,3 & 74,4 & 2,2 & 0,0 & 1,2 \\
\hline 8,7 & 15,5 & 33,7 & 33,7 & 8,4 & 59,2 & 73,7 & 62,6 & 1,4 & 2,0 & 1,7 \\
\hline 9,4 & 16,1 & 34,5 & 31,4 & 8,7 & 65,1 & 85,3 & 75,6 & 5,1 & 10,8 & 7,6 \\
\hline 7,5 & 14,2 & 35,8 & 34,1 & 8,5 & 64,1 & 80,7 & 68,6 & 5,2 & 10,5 & 7,1 \\
\hline 7,9 & 15,0 & 34,1 & 34,1 & 8,9 & 61,1 & 63,9 & 61,5 & 4,6 & 5,8 & 5,2 \\
\hline 9,8 & 15,9 & 34,6 & 32,6 & 7,0 & 62,1 & 78,1 & 68,4 & 6,3 & 8,7 & 7,3 \\
\hline 6,9 & 18,6 & 37,9 & 31,8 & 4,9 & 59,9 & 66,5 & 61,2 & 9,7 & 15,6 & 12,2 \\
\hline
\end{tabular}

Fonte: IBGE, Censo Demográfico 2000 
Tabela 9 - Ocupados, por posição na ocupação e a categoria do emprego no trabalho principal (\%) - Grande Santa Rosa e RS, 2000

\begin{tabular}{|c|c|c|c|c|c|c|c|c|c|}
\hline \multirow[b]{3}{*}{ Alecrim } & \multicolumn{4}{|c|}{ Empregados } & \multirow[b]{2}{*}{ Empregadores } & \multirow[b]{2}{*}{$\begin{array}{l}\text { Conta } \\
\text { própria }\end{array}$} & \multirow[b]{2}{*}{$\begin{array}{c}\text { Não } \\
\text { remunerados }\end{array}$} & \multirow{2}{*}{$\begin{array}{l}\text { Produção } \\
\text { para o } \\
\text { próprio } \\
\text { consumo }\end{array}$} & \multirow[b]{2}{*}{ Total } \\
\hline & $\begin{array}{l}\text { Com } \\
\text { carteira }\end{array}$ & $\begin{array}{l}\text { Militares e } \\
\text { funcionários } \\
\text { públicos }\end{array}$ & $\begin{array}{l}\text { Sem } \\
\text { carteira }\end{array}$ & Total & & & & & \\
\hline & 4,6 & 5,5 & 4,9 & 15,0 & 0,1 & 35,9 & 45,7 & 3,3 & 100,0 \\
\hline Alegria & 5,5 & 6,1 & 10,2 & 21,8 & 1,6 & 34,6 & 41,8 & 0,2 & 100,0 \\
\hline Boa Vista do Buricá & 26,3 & 7,0 & 12,4 & 45,7 & 3,4 & 29,4 & 20,8 & 0,6 & 100,0 \\
\hline Campina das Missões & 10,0 & 4,3 & 11,9 & 26,2 & 1,9 & 32,2 & 36,5 & 3,2 & 100,0 \\
\hline Cândido Godói & 8,7 & 5,2 & 7,5 & 21,4 & 2,2 & 33,1 & 40,6 & 2,7 & 100,0 \\
\hline Doutor Maurício Cardoso & 10,1 & 5,5 & 12,0 & 27,6 & 1,5 & 33,9 & 36,7 & 0,3 & 100,0 \\
\hline Horizontina & 34,2 & 5,3 & 17,6 & 57,2 & 3,2 & 24,4 & 13,6 & 1,6 & 100,0 \\
\hline Independência & 15,0 & 9,4 & 15,4 & 39,8 & 2,0 & 32,4 & 25,2 & 0,7 & 100,0 \\
\hline Nova Candelária & 5,2 & 4,7 & 4,5 & 14,4 & 1,4 & 36,5 & 47,4 & 0,3 & 100,0 \\
\hline Novo Machado & 3,9 & 2,2 & 9,9 & 16,0 & 0,5 & 37,4 & 44,7 & 1,4 & 100,0 \\
\hline Porto Lucena & 7,4 & 4,7 & 8,7 & 20,9 & 1,3 & 36,0 & 40,9 & 1,0 & 100,0 \\
\hline Porto Mauá & 9,7 & 3,1 & 13,3 & 26,1 & 2,5 & 30,5 & 38,7 & 2,3 & 100,0 \\
\hline Porto Vera Cruz & 3,5 & 10,4 & 7,5 & 21,4 & 0,0 & 35,5 & 42,2 & 0,9 & 100,0 \\
\hline Santa Rosa & 40,2 & 7,8 & 16,4 & 64,5 & 3,7 & 24,0 & 6,5 & 1,3 & 100,0 \\
\hline Santo Cristo & 19,5 & 2,5 & 11,9 & 34,0 & 2,0 & 26,9 & 35,8 & 1,3 & 100,0 \\
\hline São José do Inhacorá & 6,4 & 2,8 & 6,2 & 15,4 & 0,7 & 33,6 & 47,8 & 2,5 & 100,0 \\
\hline Senador Salgado Filho & 11,8 & 6,6 & 11,5 & 29,9 & 1,3 & 29,8 & 31,7 & 7,3 & 100,0 \\
\hline Três de Maio & 26,1 & 3,3 & 16,7 & 46,1 & 3,7 & 30,8 & 16,5 & 3,0 & 100,0 \\
\hline Tucunduva & 20,2 & 8,6 & 15,3 & 44,2 & 2,8 & 34,6 & 17,8 & 0,6 & 100,0 \\
\hline Tuparendi & 15,3 & 4,3 & 12,5 & 32,1 & 1,9 & 33,0 & 25,3 & 7,7 & 100,0 \\
\hline Total da região & 22,5 & 5,6 & 13,3 & 41,5 & 2,5 & 29,6 & 24,3 & 2,1 & 100,0 \\
\hline Rio Grande do Sul & 39,3 & 5,9 & 16,5 & 61,7 & 3,5 & 26,2 & 7,0 & 1,6 & $\overline{100,0}$ \\
\hline
\end{tabular}

Fonte: IBGE, Censo Demográfico 2000

(1) inclusive os trabalhadores domésticos (2) inclusive os aprendizes ou estagiários sem remuneração 
Tabela 10 - Emprego formal: Indicadores Selecionados - Grande Santa Rosa e Rio Grande do Sul - 1989-2005

Empregados sem Fundamental Empregados com 40 anos ou mais Razão de sexo dos empregados

\begin{tabular}{|c|c|c|c|c|c|c|c|c|c|}
\hline & \multicolumn{3}{|c|}{ Completo (\%) } & \multicolumn{3}{|c|}{$(\%)$} & \\
\hline & 1989 & 1999 & 2005 & 1989 & 1999 & 2005 & 1989 & 1999 & 2005 \\
\hline Alecrim & 43,2 & 36,8 & 19,8 & 21,5 & 33,9 & 47,1 & & 127,5 & 118,2 \\
\hline Alegria & & 33,8 & 22,1 & 0,0 & 43,2 & 47,8 & & 114,7 & 98,3 \\
\hline Boa Vista do Buricá & 37,9 & 25,5 & 21,4 & 19,5 & 26,5 & 27,8 & 174,1 & 124,5 & 93,8 \\
\hline Campina das Missões & 21,0 & 29,7 & 22,7 & 19,0 & 33,2 & 41,7 & 133,1 & 151,4 & 100,9 \\
\hline Cândido Godói & 35,0 & 38,0 & 21,9 & 16,9 & 28,6 & 36,5 & 178,9 & 163,4 & 119,5 \\
\hline Doutor Maurício Cardoso & & 31,1 & 23,4 & 0,0 & 28,3 & 34,9 & & 110,5 & 100,5 \\
\hline Horizontina & 51,5 & 19,0 & 12,4 & 22,6 & 24,5 & 25,5 & 331,0 & 236,5 & 235,7 \\
\hline Independência & 52,0 & 48,4 & 33,3 & 23,8 & 35,5 & 36,4 & 196,9 & 204,6 & 199,1 \\
\hline Nova Candelária & & 19,4 & 13,6 & 0,0 & 28,0 & 23,9 & & 89,8 & 156,6 \\
\hline Novo Machado & & 18,4 & 17,3 & 0,0 & 19,7 & 41,1 & & 194,0 & \\
\hline Porto Lucena & 29,8 & 31,3 & 23,9 & 21,6 & 36,6 & 45,4 & 134,4 & 125,2 & 111,7 \\
\hline Porto Mauá & & 25,9 & 26,7 & 0,0 & 28,9 & 31,7 & & 145,5 & \\
\hline Porto Vera Cruz & & 34,9 & 30,6 & 0,0 & 25,7 & 35,5 & & 172,5 & \\
\hline Santa Rosa & 48,5 & 39,4 & 23,4 & 21,2 & 26,8 & 31,5 & 215,0 & 172,1 & 167,1 \\
\hline Santo Cristo & 39,8 & 37,6 & 25,1 & 16,7 & 20,7 & 27,0 & 193,2 & 212,8 & 193,4 \\
\hline Sao Jose do Inhacorá & & 35,6 & 26,5 & 0,0 & 27,3 & 35,3 & & 232,3 & 168,4 \\
\hline Senador Salgado Filho & & 24,2 & 25,7 & 0,0 & 18,3 & 23,3 & & 75,2 & 94,9 \\
\hline Três de Maio & 46,3 & 31,3 & 15,5 & 20,1 & 28,0 & 30,2 & 172,2 & 135,9 & 121,5 \\
\hline Tucunduva & 45,3 & 35,3 & 30,8 & 21,9 & 32,9 & 42,3 & 195,9 & 164,3 & 221,3 \\
\hline Tuparendi & 46,0 & 28,0 & 25,3 & 21,8 & 25,3 & 40,0 & 223,1 & 157,7 & 108,3 \\
\hline Total da região & 46,6 & 33,9 & 21,0 & 20,9 & 26,9 & 31,3 & 210,0 & 170,1 & 159,3 \\
\hline Rio Grande do Sul & 51,0 & 36,8 & 24,4 & 25,4 & 32,5 & 35,8 & 159,2 & 139,5 & $\overline{131,4}$ \\
\hline
\end{tabular}

FONTE: MTE/RAIS - diversos anos.

(*) Número de homens para cada 100 mulheres. 


\section{A FORJA DE UM MERCADO LOCAL DE TRABALHO: INSTITUIÇÕES, ESPAÇO E OPORTUNIDADES OCUPACIONAIS EM HORIZONTINA}

\subsection{Diferenciação (articulada) de uma localidade, no contexto regional}

Horizontina não possui um semáforo, sequer. Horizontina tem oito táxis em atividade. Sua área urbana abriga 16,3 mil habitantes, sendo a população total de 19,9 mil. O município, entretanto, ostenta um PIB per capita 3,5 vezes superior ao do Rio Grande do Sul, equivalente a 2,5 vezes o valor do segundo colocado, dentre os municípios da Grande Santa Rosa, nesse indicador $^{78}$. O ambiente e o quotidiano de Horizontina se diferenciam amplamente do padrão das demais cidades da região, o que fica nítido logo que se chega ao município - quando se ocupa, por exemplo, um dos quartos do tradicional hotel, cujas instalações e serviço superam em muito os do melhor hotel do centro de Santa Rosa, e em cujo saguão registra-se, permanentemente, uma intensa movimentação de pessoas comunicando-se em idiomas estrangeiros.

Mesmo com toda a pluralidade de dimensões que se procure apreender, é impossível não identificar de imediato o elemento que nucleia tantas particularidades, de resto prontamente apontado por qualquer morador do município ou, mesmo, da região: a presença de uma portentosa planta industrial da corporação multinacional John Deere, sob controle norte-americano, líder mundial na produção de equipamentos agrícolas e florestais. Atualmente, segundo o website da empresa, esta unidade é responsável por $60 \%$ do total das exportações brasileiras de colheitadeiras; as máquinas ali produzidas respondem por $50 \%$ da colheita de grãos no País. Ainda segundo o site, 2,5 mil pessoas trabalham na John Deere de Horizontina ${ }^{79}$.

Rica, urbanizada, assalariada e industrial, na comparação com seu entorno, Horizontina possui com essa empresa uma relação de impressionante densidade, que faz d" "a firma" - como normalmente é evocada, com o artigo definido a dispensar que a John Deere seja nominada - algo próximo a um "fato social total". Esse laço não é livre de ambivalências. O reconhecimento da dependência praticamente absoluta que a economia do município apresenta frente ao empreendimento é fonte de apreensão, exponencialmente alimentada pela transferência do controle acionário à norte-americana John Deere ${ }^{80}$, o que ocorreu gradualmente entre os anos 1980

\footnotetext{
${ }^{78}$ Em 2004, conforme a base de dados da Fundação de Economia e Estatística (FEE) do Rio Grande do Sul, o PIB per capita de Horizontina atingia R\$ 47,6 mil; o do Estado, R\$ 13,3 mil; os das demais cidades da Grande Santa Rosa oscilavam entre R \$ 6,8 mil (município de Alecrim) e R\$ 18,8 mil (Nova Candelária).

${ }^{79} \mathrm{http}: / / \mathrm{www}$. deere.com.br/pt_BR/ag/about us/horizontina.html. Nas entrevistas realizadas no município, incluindo-se uma com representante dos Recursos Humanos da John Deere e outra com o presidente do sindicato dos trabalhadores, esse número varia um tanto - o que, seguramente, expressa diferenças de contagem (e de visibilidade) de situações contratuais heterogêneas, que vão desde a existência de setores terceirizados dentro da própria planta, até contratos de aprendizes e (poucos) temporários, aos quais retornarei neste texto.

${ }^{80}$ Em termos internacionais a companhia tem 52 mil empregados, opera em 17 países e comercializa seus produtos em mais de 110 países.
} 
e 1990. Afinal, a planta que hoje é "dos americanos", nasceu em 1945, no município que havia recentemente sido emancipado, pelas mãos de dois empreendedores que não poderiam ser mais "locais", no reconhecimento simbólico que isso implica: um dos sócios era justamente o responsável pela colonização do que inicialmente foi um distrito de Santa Rosa, e seu primeiro habitante. A atual fábrica da John Deere foi, por cinco décadas, SLC - Schneider, Logemann e Cia. Ltda, carregando dois dos sobrenomes mais proeminentes - e ubíquos - na história da cidade. É curioso observar como, na percepção dos habitantes de Horizontina, as mudanças gerenciais experimentadas pela John Deere decorrem, fundamentalmente, da nacionalidade - estrangeira - de seus proprietários atuais; os condicionantes concorrenciais ou as transformações técnicas e logísticas que afetaram todo o tecido produtivo nacional nas últimas décadas raramente são evocados.

Para os habitantes de Horizontina, trabalhar na SLC, no passado, e, hoje, na John Deere, é também uma condição percebida com ambigüidade: a palavra "sonho" aparece com uma freqüência elevadíssima, nos depoimentos; não são raras, no entanto, as indicações de que essa é uma fatalidade, pois a ausência de alternativas ocupacionais é permanentemente reiterada.

Em torno dessa "fatalidade sonhada", um desenho muito particular de mercado de trabalho se organiza. De um lado, o volume de trabalho propriamente operário tem tido oscilações relativamente acentuadas, tendo mostrado ascenso na primeira metade desta década e forte retração entre final de 2004 e o início de 2007, quando começa novamente a se expandir. Essas sístoles e diástoles foram equacionadas com uma série de recursos capazes de dotar a empresa de flexibilidade numérica. A utilização de contratos temporários foi experimentada na última fase de aumento do emprego, tendo sido abandonada no momento mais recente de contratações, que está em curso; a terceirização de processos dentro da planta e a externalização da fabricação de componentes, paralelamente, vêm sendo implementadas gradualmente ao longo dos últimos anos.

Ainda mais interessantes, entretanto, do ponto de vista deste estudo, são mudanças nas políticas de recursos humanos da empresa que condicionam diretamente a própria "oferta" de trabalho dos habitantes do município. A mão-de-obra feminina, por exemplo, foi por muitos anos desconsiderada para aproveitamento nas tarefas produtivas. Isso se refletiu na inserção - então, praticamente nula - das mulheres em toda a "cadeia" de formação para o ingresso na empresa em que se destacam um curso técnico de Mecânica, em uma escola particular, e o Programa de Aprendizagem Industrial do SENAI. Nas contratações do ano de 2007, passam a ser contratadas mulheres (muitas das quais sem a formação tradicionalmente requerida, o que também se verifica no caso dos homens: um sinal - complementar? - de uma conjuntura de escassez de mão-de-obra, a que se retornará neste texto).

De forma semelhante, os trabalhadores aposentados pelo INSS constituem uma reserva estratégica, tanto nos momentos de elevação quanto de enxugamento do contingente. Geralmente, 
a companhia não rescinde automaticamente os contratos desses trabalhadores, mas, quando há necessidade de reduzir o quadro de empregados, oferece, recorrentemente, vantagens - na forma de Planos de Demissão Voluntária (PDVs) - para que eles deixem o emprego. Por outro lado, em momentos como o atual, de recrutamento expressivo, há uma procura pessoal e direta a muitos desses indivíduos, para que assumam um novo contrato com a empresa.

Esses(as) trabalhadores(as) tendem a se "tornar" economicamente ativos, do ponto de vista da tradicional categoria de análise dos mercados de trabalho, ou deixar de sê-lo, ao ritmo da permeabilidade oferecida pela John Deere à sua incorporação aos coletivos de trabalho, tendo em vista o restrito leque de ocupações alternativas e a condição culturalmente construída para o trabalho feminino como reforço acessório à renda familiar. Quanto aos aposentados, de resto, a constância de um rendimento monetário assegurado pela Previdência atenua a necessidade de novo trabalho, prevalecendo sobre o desejo ou disposição desses indivíduos para tal.

Para se compreender a "regência", por parte da empresa, da "oferta" local de mão-de-obra - que procurei antecipar a partir de duas categorias de trabalhadores a ela expostos de forma mais "extrema" - outra dimensão de análise é, do ponto de vista desta tese, fundamental, e revela fenômenos muito interessantes. O município - e aqui não se trata da empresa de máquinasagrícolas, mas o conjunto de suas instituições - mantém um permanente controle sobre o potencial de atração imigratória que "a firma" traz consigo. Isso se expressou de modo exemplar em 2002, quando Horizontina obteve o primeiro lugar - excetuada a capital do Estado - em um índice de desenvolvimento social elaborado pela FEE-RS para os municípios gaúchos ${ }^{81}$. O então-prefeito mandou confeccionar uma placa com os dizeres "Bem-vindo a Horizontina, primeiro lugar em qualidade de vida no interior do Rio Grande do Sul” (ou algo assim). Presenciei inúmeras críticas a essa iniciativa - inclusive uma dirigida ao próprio prefeito, quando eu o entrevistava -, por parte de pessoas que demonstravam temor de que a cidade fosse "invadida" por migrantes. Na ação cotidiana das instituições, tal perspectiva se reflete em uma filtragem bastante "fina" que é exercida, seja na agência local do SINE, seja no setor responsável pelas matrículas no SENAI, dentre outros, como terei oportunidade de relatar.

No entanto, com sua escassa população, Horizontina não consegue fornecer suficientes braços para a companhia, em momentos de forte expansão do emprego. O mecanismo utilizado pela empresa, tradicionalmente, tem sido o de estabelecer (e custear) rotas diárias de ônibus que buscam, no início do turno, e levam, ao final, trabalhadores de diversos municípios vizinhos, que neles continuam a residir. Todos os testemunhos apontam que, nas conjunturas em que é necessário demitir, esses operários "de fora" formam o primeiro contingente a ser dispensado.

${ }^{81}$ A produção desse indicador - O Índice Social Municipal Ampliado (ISMA) - foi descontinuada, tendo ele sido substituído pelo IDESE - Índice de Desenvolvimento Sócio-Econômico. No dado mais recente da série deste último, Horizontina figura na $19^{\mathrm{a}}$ posição (FEE - homepage). 
A força de trabalho da empresa, todavia, possui um segundo nível, de status e requisitos técnicos mais elevados, cujo provimento obedece a uma lógica bastante diferente - em certo sentido, oposta. Embora os representantes da John Deere não externem essa preocupação, dois entrevistados "estratégicos" - de um lado, uma funcionária do escritório que, por terceirização, realiza o recrutamento de pessoal para a unidade local da corporação; de outro, um diretor da Faculdade Horizontina (FAHOR), instaurada em 2002 - asseguraram que é, historicamente, bastante difícil atrair (e/ou reter) profissionais altamente capacitados de nível superior, dentre os quais se destacam, pelo número de postos, os engenheiros. Em ambos os casos, os testemunhos enfatizaram aspectos relacionados ao "estilo de vida" no município, especialmente seu pequeno porte, ao qual se associa a carência na oferta de serviços mais sofisticados típicos de centros urbanos maiores. Esse "gargalo" está, assumidamente, na origem do esforço que deu origem à instalação, nessa pequena cidade, da referida instituição de ensino superior. Uma vez mais, neste caso, a articulação de diferentes instituições para viabilizar a iniciativa expressa uma percepção muito presente dos agentes sociais locais no sentido de que a disponibilidade dos recursos demandados pelos "gringos" - como muitas vezes foram chamados - é uma questão decisiva para que não haja risco de deslocalização da planta hoje sediada em Horizontina, o que teria conseqüências evidentemente desastrosas para a localidade.

Esse aspecto referente ao pequeno porte do município evoca outro ponto de especial interesse analítico. Observa-se com nitidez nessa formação social uma espécie de hibridação entre duas "lógicas" que são muitas vezes contrapostas (outras vezes, articuladas) nos estudos mais recentes sobre mercados e sobre o "objeto local". Tipicamente, na bibliografia, associa-se com as localidades menores e menos diversificadas a relevância, na vida social, de mecanismos de tipo "comunitário" - em que fatores como tradição, lealdades, afetos e outros dessa natureza são determinantes. Em Horizontina, efetivamente, foi possível reconhecer a importância de que se revestem, na rotina das instituições e nas vidas laborais dos indivíduos, relações sociais altamente pessoalizadas, alimentadas pela proximidade espacial e pelo número relativamente pequeno de atores sociais envolvidos nas interações cotidianas. A racionalidade impessoal, burocrática e hierarquizada que se poderia esperar de uma companhia multinacional, entretanto, limita e contamina a potência dessa "lógica" comunitária, ao mesmo tempo em que, inequivocamente, é por ela eivada. Sob diferentes formas, é muito freqüentemente verbalizada pelos moradores de Horizontina a percepção de que sediar empreendimentos econômicos transnacionais do porte da planta da John Deere é objeto de concorrência de localidades em um âmbito propriamente global. Paralelamente, os efeitos concretos de decisões corporativas tomadas nos Estados Unidos, sede da matriz "d'a firma", repõem, regularmente, a distância, em todos os sentidos, que se impôs entre a cidade e sua sustentação econômica ${ }^{82}$.

${ }^{82}$ O exemplo mais candente disso, neste ano de 2007, foi a decisão de interromper, na fábrica de Horizontina, a produção de tratores, que passará a ser realizada em uma unidade nova da John Deere, em 


\subsection{A cidade e a empresa: uma imbricação genética}

As terras que vieram a formar o município de Horizontina mantiveram-se tomadas por mata nativa até que, em 1928, tiveram sua propriedade conferida oficialmente pela Diretoria de Terras e Colonização do Rio Grande do Sul à firma Rosa \& Logemann, como contrapartida a serviços prestados em obras públicas de infra-estrutura no Estado.

Frederico Jorge Logemann, um dos titulares dessa empresa, foi quem efetivamente conduziu, a partir de 1927, o processo de ocupação do que seria a colônia Belo Horizonte e, posteriormente, o município de Horizontina. Nascido em 1884, na cidade alemã de Bremen, fixouse, aos 30 anos de idade, no Brasil. Trabalhou, inicialmente, para uma companhia belga que construía estradas de ferro em diversos pontos do território nacional, o que o levou, em mais de uma oportunidade, ao noroeste do Rio Grande do Sul. Em 1919, casou-se com Nelly Dahne - irmã de João Dahne, "Comissário de Terras e Colonização para o Alto Uruguai" e responsável, desde 1916, pela chefia da Colônia Santa Rosa. Os dois cunhados, juntamente com um terceiro sócio, estabeleceram uma "empresa de construção de obras, colonização de terras e outros negócios" (Christensen, 2007:28), que está na origem da transação que envolveu o território em questão.

Num primeiro momento, a designação da colônia foi Belo Horizonte. Diferentemente de outros empreendimentos de colonização privada que ocorriam no mesmo período,

$\mathrm{O}$ engenheiro Logemann iniciou o loteamento do povoado e foi oficialmente o primeiro morador. Logo iniciou a construção de uma ampla residência de três andares, com acomodações para a família, para os empregados e um escritório na parte térrea. $\mathrm{O}$ fato de Frederico, como responsável pela colonização, fixar residência na sede, encorajava colonos de lugares distantes a virem se estabelecer na nova colonização (Christensen, 2007:32).

A força simbólica desse ato fundador permanece reconhecível no presente, uma vez que a evocação à "família Logemann” é invariavelmente cercada de reverência, no município.

Na década de 1920, conforme já se assinalou anteriormente, as novas colônias eram ocupadas predominantemente por população excedente das "Colônias Velhas", já então sofrendo significativa saturação demográfico-fundiária. Como no caso de Santa Rosa, o principal contingente que povoou a colônia Belo Horizonte acorreu de regiões gaúchas de colonização alemã (Venâncio Aires, Santa Cruz do Sul, Estrela e Lajeado, entre outras), mas houve significativo afluxo de descendentes de italianos. Uma década depois do início da colonização, acresce-se a esses dois principais grupos uma primeira leva de poloneses (Christensen, 2007:33).

outro município gaúcho, bem mais próximo da capital. Essa decisão gerou, mais do que temor, incompreensão, mas o principal argumento tranqüilizador é que em nenhum lugar do mundo a John Deere produz colheitadeiras e tratores em uma mesma unidade. Tal "explicação" consagra uma certa aceitação de que determinações que afetam a vida local emanam de uma instância longínqua; ao mesmo tempo, abranda temores de que a medida tomada pela matriz pudesse representar um enfraquecimento da posição da unidade horizontinense na rede que a corporação possui na América do Sul. 
Em 1938, Horizonte torna-se o oitavo distrito de Santa Rosa - que, por seu turno, havia se tornado município sete anos antes, incluindo em seu território aquela colônia. A emancipação política de Horizontina ocorreu em 1954. A Comissão que conduziu a campanha para a aprovação, em plebiscito, da criação do novo município foi presidida pelo único filho do casal de fundadores do município, Jorge Antônio Logemann, então com 32 anos. A ele também foi conferido o primeiro mandato de prefeito: um acordo entre os principais partidos políticos com representação no nascente município desembocou em uma candidatura única, que foi encabeçada pelo PSD, partido dos Logemann.

Quando a emancipação se concretizou, já se encontrava em plena consolidação a empresa que viria a se constituir na grande planta industrial presentemente controlada pela norte-americana John Deere. Ela foi criada em 1945, com o nome Logemann associado ao de Balduino Schneider, na Schnedeir, Logemann \& Cia Ltda - a SLC. A primeira motivação do empreendimento foi reparar e produzir ferramentas - ainda bastante rudimentares - utilizadas no trabalho agrícola pelos habitantes do distrito, evitando deslocamentos longos, então necessários. Os sócios começam por adquirir uma oficina mecânica que já operava, e passam a trabalhar com "consertos de motores de automóveis, de geradores de energia elétrica, de reparos de peças e de ferramentas utilizadas pelos colonos. Vale lembrar que, na época, o local mais próximo para trabalhos de fundição era a cidade de Ijuí, distante aproximadamente $350 \mathrm{~km}$ da colônia Belo Horizonte", afirma Christensen (2007:77).

A mesma autora continua: "em seguida, construíram um moinho, montaram uma serraria, uma ferraria, uma carpintaria rudimentar e um gerador de energia elétrica que fornecia luz ao povoado" (p.77). Em 1947, começa a produção de trilhadeiras estacionárias e picadores de forragem; em 1949, a SLC instala uma fundição de ferro e bronze, que impulsiona a diversificação da oferta de implementos agrícolas.

Em 1951, morre o patriarca da cidade e da empresa - Frederico Jorge Logemann. Seu filho, que havia retornado dois anos antes de Porto Alegre, onde estudara e estivera baseado desde os 11 anos de idade, assume a direção da empresa.

Já no final da década de 50, inicia a industrialização de trilhadeiras automotrizes - que já não eram novidade, mas praticamente não eram empregadas no município. Do ano de 1958 datam as primeiras colheitadeiras rebocadas e, em 1965, a SLC lança as primeiras colheitadeiras automotrizes do país, com índice de nacionalização de 98\% dos componentes (Christensen, 2007:107). O desenvolvimento do primeiro produto foi um processo clássico de engenharia reversa, tendo partido de uma colheitadeira de 1955 fabricada, justamente, pela John Deere, com a qual não havia ainda qualquer acordo ou contato.

Esses se iniciam em 1979, apenas, pois, como relata Eduardo Logemann - terceira geração da família - em depoimento colhido por Christensen (2007:107-8), 
Apesar do orgulho que sentimos de termos aqui desenvolvido a primeira colheitadeira do país, sabíamos, olhando em comparação ao que já existia no exterior, que estávamos [com] uma década, ou quem sabe alguns anos, de defasagem tecnológica. Primeiramente pela capacidade de pesquisa (...). Nós sabíamos que não teríamos capacidade para concorrer nem tecnológica nem financeiramente com máquinas importadas com desempenho superior (...). Fábricas como a Massey Ferguson, Class e New Holland vieram para o Brasil (...). Fomos à procura da empresa que, na época, já era considerada a primeira do mundo, e continua sendo até hoje.

A associação com a John Deere foi, a partir de então, gradual: naquela conjuntura do final dos anos 70, a companhia norte-americana recebeu $20 \%$ do controle, em troca do aporte tecnológico.

Em 1987, a SLC transformou-se em Sociedade Anônima, presidida, naquele momento, por Jorge Eduardo Logemann. Na diretoria, seu filho Eduardo, ao lado de Romeu Schneider. Outras duas famílias locais já integram essa sociedade e tomam lugar nessa diretoria: os Ulmann e os Montigny da Silva.

Em 1995, a produção de uma nova linha de tratores fez com que a SLC transferisse outros 20\%. Por fim, nas palavras de Eduardo Logemann:

Finalmente, assinamos um acordo de multi-interesse. Porém, a John Deere tinha interesses que não representavam a nossa linha de ação, como, por exemplo, abrir o mercado para exportação, o que para nós não era conveniente. (...) Após 20 anos de uma convivência frutificante, vendemos, em 1999, 100\% do controle para a John Deere (IN: Christensen, 2007:108).

Quando essa transferência patrimonial total se materializou, a segunda geração dos Logemann já não estava mais presente, pois Jorge Antônio havia falecido em 1987. A terceira geração permaneceu na titularidade de empreendimentos portentosos, fortemente alimentados pelos recursos obtidos na venda da fábrica. A SLC Participações controla várias empresas, enquanto sua subsidiária SLC Agrícola tem sido uma importante player na atual fase de expansão da fronteira agrícola brasileira: possui explorações agrícolas marcadamente modernas e extensas em estados como o Maranhão, Mato Grosso, Mato Grosso do Sul e Goiás. Da família Ulmann, a empresa Weisul realiza um trabalho bastante semelhante.

Também de propriedade da família fundadora são, hoje, em Horizontina, uma concessionária de máquinas - que vende os produtos John Deere, entre outros - e o Hotel Ouro Verde, que historicamente foi como uma extensão da fábrica, vinculado diretamente às viagens de negócios em torno do empreendimento.

No entanto, nenhum dos descendentes diretos dos Logemann vive hoje em Horizontina, fato que é invariavelmente assinalado pelos habitantes do município, ao recontar o processo de transferência patrimonial da planta industrial. 


\subsection{A mudança patrimonial da fábrica na percepção dos atores locais}

$\mathrm{P}-\mathrm{E}$ esse pessoal que veio, qual é a sensação que vocês têm?

LAUDÍLIO - Ah, dos gringos, né?

$\mathrm{P}$ - É.

LAUDÍLIO - Eles... aqui o pessoal comenta: eles querem ver dólar na frente. Mudou, sabe, a... Antes era... antes chamava a família Logemann, família SLC, hoje não é mais...

$\mathrm{P}$ - ...tão "família"?

LAUDÍLIO - Tão família. É, isso que o pessoal comenta. É mais cobrança, é mais e mais e mais coisa.

P - E o senhor chegou a pegar um período em que... assim, por exemplo, situações particulares dos trabalhadores, as gerências, ou o próprio senhor Jorge Logemann lá, se envolviam, ou ajudavam, existia um pouco isso? [esse tipo de prática foi referido por outros entrevistados].

LAUDÍLIO - Não, não. Eu sei até... Depois já não era mais tão família, porque nós tinha... uma vez foi feita uma reunião, deu uma crise, e foi feita uma reunião. O Dr. Jorge fez uma reunião, chamou todos os funcionários, "Bah, porque a SLC tem dinheiro pra pagar os funcionários cinco anos. Podemos parar cinco anos, né. E não vamos dispensar ninguém". Foi numa quarta-feira. Isso o Alcindo [presidente do sindicato] sabe disso. E na segunda foi 380 pra rua (operário aposentado da JD, 50 anos, integra cooperativa de aposentados que presta serviço de vigilância no parque da Fundação John Deere).

Como o excerto exemplifica, a grande maioria dos entrevistados costuma associar causalmente mudanças na forma de gestão da fábrica - "cobranças" em especial, no caso dos trabalhadores - à mudança de propriedade da SLC. A nacionalidade norte-americana é, quase invariavelmente, mencionada de forma espontânea.

MARLENE - Mas é assim, ó; pode ver, Guilherme, ó: americanos. Aqui os donos eram... $\mathrm{P}$ - Eram daqui, fundadores da cidade...

MARLENE - Fundadores. Eles agiam bastante com a emoção e não com a razão, muitas vezes, entende? (coordenadora do SINE de Horizontina).

A figura do "Dr. Jorge", Jorge Eduardo Logemann, o "capitão-de-indústria" da segunda geração do empreendimento, é muito evocada, até hoje, na cidade - no mais das vezes, com bastante reverência. Entre os operários mais antigos, é comum que se exalte sua presença cotidiana na fábrica e seu hábito de circular por todos os setores e conversar com os "peões". Entretanto, o episódio relatado por Seu Laudílio - da promessa de estabilidade seguida por demissões - foi mencionado por vários outros entrevistados. No mesmo sentido, um operário narrou, no intervalo de uma assembléia do sindicato, que em outro momento de crise a empresa prometeu não dispensar os empregados, mas, como não havia produção a realizar, manteve-os por um mês fazendo "trabalho de escravo" no terreno e no prédio da fábrica - escavações para obras de saneamento, por exemplo. Ao final de um mês, todos teriam sido demitidos.

Outro aspecto muito lembrado nas formulações sobre a gestão Logemann na SLC foi a vinculação da família a agremiações partidárias - PSD, Arena e PDS, nas sucessivas conjunturas 
políticas - e a pressão que exerciam sobre os trabalhadores para que apoiassem candidatos de sua preferência ${ }^{83}$.

ANTÔNIO - Eles traziam pra dentro da empresa essas pessoas que eram de interesse deles, de colocar lá na prefeitura, tanto o candidato a prefeito quanto os candidatos a vereador, principalmente os que trabalhavam lá dentro. Mas existia uma certa pressão sim. Isto... certamente.

$\mathrm{P}-\mathrm{E}$ aí o pessoal levava mais na...

ANTÔNIO - É, tinha... como eu disse anteriormente, tinha aquele lado: "Bah, mas eu tenho que trabalhar na SLC. Se eu não vou votar nele, está sujeito, amanhã ou depois, de repente, eles me botarem pra rua". Pressionavam mesmo. Havia essa pressão (operário aposentado da JD, 53 anos, ex-dirigente sindical, atualmente eletricista predial autônomo).

Um poder político e econômico de tipo "caciquista", exercido, especialmente, pela família Logemann, mas também pelas outras famílias que participavam da sociedade, foi fortemente rechaçado por um dos entrevistados, segunda geração de uma família de comerciantes, que é militante do PDT, partido que se encontra à frente da prefeitura de Horizontina atualmente, na qual ele integra o secretariado.

EGON - (...) Até talvez a minha adesão à política... Nós temos uma loja que tem 60 anos de existência em Horizontina. Eu nasci em Horizontina - tenho 56 anos hoje. E aquele medo, aquele temor de se contrapor ao poder econômico de Horizontina, que era a família Schneider e a família Logemann, eu, como comerciante, fui praticamente um dos primeiros comerciantes que, em $88 \ldots$ Em 85 , já, a primeira eleição direta, eu acabei me envolvendo assim, mas superficialmente, na política. E aí em 88 eu já defendi uma candidatura do MDB, na época, acho que era [não era]. E em 1992 eu me expus totalmente, né. Botei placa na frente da minha casa. Eu acho que eu acabei incentivando as pessoas a se libertar um pouco também da... desse medo, desse temor, da perseguição política, que havia. Isso havia... Porque o Schneider, na véspera de eleição ele ia passar nos setores da fábrica e dizer: "Olha, vocês têm que votar nesse candidatos, porque esses são os nossos candidatos. Se os outros ganhar, vocês podem perder o emprego." Isso era usado. Então acho que assim, a minha exposição... Como depois aí, com isso, veio, vieram outras, é lógico. Isso é um efeito que se dá no decorrer do...

$\mathrm{P}$ - Do ponto de vista dos funcionários, é bem claro, mas... E os demais? Tipo assim: comerciantes são empresas à parte. Que tipo de sanção, entre aspas, estaria minimamente esboçado pra vocês?

EGON - É, mas acho que é aquele temor, né. Pô. Porque eles detinham todo o poder econômico. As famílias, né, Schneider, Logemann, Ulmann, também eram sócios. Então aquele medo de... "Pô, os caras vão nos boicotar, vamos ficar de fora." (Secretário Municipal da Indústria e Comércio, comerciante, militante do PDT).

Por outro lado, a "prodigalidade" da empresa SLC era demonstrada, e é até hoje referida, em iniciativas comunitárias, como o financiamento de festividades ou atividades culturais, e, de forma mais nítida, na gestão do pessoal empregado. Um entrevistado, atualmente proprietário de uma pequena empresa metalúrgica que produz quase exclusivamente para a John Deere, conta que, no período em que trabalhou na SLC, nos anos 1990, cursou durante 5 anos uma faculdade de

${ }^{83}$ Durante a ditadura militar, não eram eleitos os prefeitos, pois, até o desmembramento que deu origem ao município de Doutor Maurício Cardoso, há aproximadamente 20 anos, Horizontina era área de fronteira com a Argentina, sendo considerada "área de segurança". O executivo municipal era nomeado pelo governo estadual. A Câmara Municipal, no entanto, era eleita, bem como os deputados e senadores do Rio Grande do Sul. 
engenharia, em um município relativamente próximo a Horizontina - fora da Grande Santa Rosa -, tendo seu salário integralmente mantido e várias formas de auxílio.

E, então, nós tínhamos um salário, ajuda de custo, tinha vale-refeição, vale-transporte, ela comprava todos os materiais necessários para a gente estudar, tipo livros - livros, calculadora, tudo. E nós era registrado, décimo-terceiro, tudo. É uma bela de uma oportunidade. E não tinha nenhum vínculo, assim, nenhuma obrigação de ficar depois. É óbvio que ela fazia porque queria que ficasse. Mas muitos não, alguns: encerrou a graduação... (Rosnei, empresário da metalurgia, ex-funcionário da SLC/JD).

Rosnei afirma que essa era uma política "mais da SLC", e que a John Deere, atualmente, ainda presta apoio à formação superior de funcionários, porém de forma bem mais restrita. $\mathrm{O}$ mesmo foi dito em uma roda de conversa de que participei, em um bar, com um grupo de aproximadamente 8 jovens, todos trabalhadores ou ex-trabalhadores da empresa. Segundo eles, os auxílios monetários no pagamento das mensalidades dos cursos hoje se restringem aos empregados mais bem colocados nos vestibulares de cada faculdade da região.

Ao comentar a vida na empresa, esse grupo de operários e ex-operários enfatiza muito a pressão por produtividade e um "clima" ruim. Especialmente as cobranças ligadas ao cumprimento do "DPS - Deere Production System", que incluem "sabatinas"-surpresa com os funcionários sobre as normas e procedimentos operacionais, geram grande revolta. "Hoje tem gente que prefere ganhar 500 'pilas' no interior [agricultura] a agüentar o DPS", diz um deles. Quando pergunto o que significa a sigla, responde: "é as metas dos americanos". Relatam que o grau de tensionamento na fábrica tem aumentado, e que o número de atestados médicos e de faltas está elevado como nunca se vira. Pergunto se os trabalhadores não ficam receosos de perder o emprego. Resposta: "os caras já não estão nem aí, mais".

Ao mesmo tempo, elogiam a melhora da organização do ambiente fabril. Um deles relata, com hilaridade: "no tempo da SLC, cada posto tinha um radinho, para ouvir música".

Em outra roda de conversa, durante assembléia do sindicato, os trabalhadores discutem, a partir de algumas perguntas que faço. Como estão tratando de um acordo sobre o banco de horas, questiono se a empresa costuma respeitar os termos negociados. Um operário mais velho diz que "eles sempre querem ganhar", e emenda: “empresa americana, né?". E começa a externar sua opinião de que no tempo da SLC as coisas eram diferentes. Outro, mais jovem, interrompe, contestando: "É tudo a mesma coisa. Era outra época, isso sim".

O fato de a John Deere - que, diferentemente da SLC, não tem raízes consolidadas em Horizontina - se manter no município precisa ser compreendido a partir de fatores que sejam favoráveis à empresa. A localização da planta, do ponto de vista logístico, e o porte extremamente reduzido da cidade são reconhecidos por todos como elementos pouco atraentes. Uma possibilidade bastante plausível é que a corporação identifique, nessa configuração local, 
vantagens que devem envolver capacitação, perfil e custos da mão-de-obra, bem como um tecido social e institucional que, em Horizontina, tem na fábrica um eixo inequívoco.

\subsection{A grande empresa e seu entorno produtivo e institucional}

$\mathrm{Na}$ visita que realizei à fábrica, conduzido pelo gerente industrial, discutimos, em certo momento, a decisão da John Deere de retirar da planta de Horizontina a produção de tratores, transferindo-a para Montenegro (RS), numa nova unidade produtiva. $\mathrm{O}$ argumento que $\mathrm{o}$ engenheiro apresentou foi, fundamentalmente, que em nenhum outro dos inúmeros países em que a John Deere produz máquinas agrícolas a produção de tratores e colheitadeiras se dá na mesma planta. Alegou, ademais, razões de espaço físico para a expansão das instalações, haja vista uma expectativa de elevação da venda de ambas as linhas de produtos. Questionei-o sobre as impressões que essa decisão produzia na população da cidade, e ele confirmou o que eu já havia percebido desde as primeiras conversas com os habitantes de Horizontina: é grande o temor de que isso represente uma progressiva desativação da unidade local. Assegurou que tal apreensão é totalmente infundada, pois deve haver forte ampliação da produção de colheitadeiras (bem como de plantadeiras - produto com menor valor - e plataformas - que são acessórios das colheitadeiras, em verdade). Mencionei, então, que, em 2002, em uma entrevista na empresa, haviam me destacado o cuidado da John Deere com sua imagem junto à "comunidade", o que levaria a empresa, inclusive, a realizar pesquisas de opinião no município. O gerente industrial, então, afirmou desconhecer isso e, com certa ironia, declarou:

MÁRIO - Aqui é uma comunidade pequena. Como a cidade é uma extensão da ... [interrompe-se e retifica] A fábrica é uma extensão da cidade... [retoma] ou a cidade é uma extensão da fábrica - como tu quiser olhar -, as conversas lá fora e aqui dentro são muito integradas. Então a percepção do que está acontecendo na cidade é muito fácil de se ter. $\mathrm{Na}$ própria família da gente a gente sabe o que a mulher fala, o que que não fala. Então não há a necessidade de uma pesquisa, assim,...

Essa idéia, primeiramente auto-censurada e a seguir assumida, de que Horizontina é uma extensão da John Deere, como já fora da SLC, parece ganhar consistência em diversos planos institucionais que se observam.

A empresa John Deere é responsável por aproximadamente $80 \%$ da arrecadação de ICMS do município, o que foi declarado tanto em 2002 quanto em 2007, pelos representantes da Prefeitura entrevistados. No final dos anos 70, a prefeitura municipal implantou um distrito industrial, justamente no momento em que a SLC inaugurava sua "Fábrica 2", uma vez que a sede original - ainda hoje utilizada para alguns processos -, na região mais central da cidade, encontrava-se no limite de sua capacidade física. Segundo o prefeito municipal entrevistado em 2002 - que havia ocupado, por nomeação, o mesmo cargo, ao longo de dois mandatos, incluído aí 
o período de instauração do distrito -, a empresa se beneficiou da isenção fiscal, por cinco anos, e das demais vantagens, como energia elétrica, terraplenagem, etc. Na fábrica, outra versão foi apresentada: a escolha da localização do distrito teve o intuito de aproximar da SLC as empresas que ali viessem a se instalar, mas aquela não teria se valido de incentivos.

De qualquer forma, o distrito, na avaliação colhida nos dois momentos junto ao Executivo municipal, teve pouca adesão, de empresas sem expressão econômica. Esse fato reforça a impressão de que os ganhos teriam sido especialmente para a SLC, sobretudo se tiver razão a versão apresentada por um entrevistado, de que os prefeitos eram designados pelo governo estadual a partir da indicação do líder partidário da situação, na localidade - o Sr. Logemann, no caso de Horizontina.

Se algumas dessas relações se transformaram bastante, não apenas pela redemocratização do país, mantêm-se bastante fluentes alguns mecanismos de interpenetração entre a vida da empresa e o tecido institucional local. Isso é marcante do ponto de vista da formação profissional e da capacitação de recursos humanos. Em primeiro lugar, há uma vinculação plena entre o SENAI do município e a demanda da John Deere - desde os tempos de SLC - por mão-de-obra.

Na verdade, o Senai, o que... Ele preparava o pessoal pra trabalhar na SLC, ou John Deere. (...) Era só ali. Já vinha... Já era preparado desde o início, desde... praticamente da adolescência, 14, 15 anos. Vamos dizer, já era preparado pra pensar a empresa nas 24 horas por dia. Que a gente até, de certo modo, não concordava muito, porque o Senai podia ser pra... outras empresas também, pra preparar pra trabalhar em outras empresas - mas aqui não era o que ocorria (Antônio, 53 anos, operário aposentado da JD, ex-dirigente sindical, atualmente eletricista predial autônomo)

O programa de Aprendizagem Industrial do SENAI foi iniciado no município em meados dos anos 70. Admite jovens de 14 anos, para uma formação de dois anos de mecânica básica. Em sua esmagadora maioria, esses alunos desenvolvem suas atividades práticas curriculares na John Deere e, por determinação desta, cursam, simultaneamente, o Ensino Médio - especificamente, o Curso Técnico em Mecânica, com duração de quatro anos - em uma escola particular, chamada, não surpreendentemente, Frederico Jorge Logemann, que é mantida por uma instituição de confissão evangélica (religião daquela família).

MELO - Então aqui funciona uma parceria: a empresa, ela dá todo o maquinário e material de consumo. A comunidade, o Colégio, entra com a parte física. E o Senai com a parte de professores e metodologia de ensino, que é a Aprendizagem. (...) A iniciativa, na época [1976], [foi], pela... falta de mão-de-obra que tinha na região. E a empresa, grande como era, em expansão, viu a necessidade de ter um curso de extensão do Senai, né, e daí foi... aperfeiçoando. Na época, um grande incentivador, na pessoa... responsável pela empresa foi o Jorge (Kruel) - esse foi um cara que, na época, que... Ele era o gerente industrial na época (Coordenador da "Extensão Horizontina” do SENAI de Santa Rosa). 
O curso técnico da Escola Logemann deixou de ter vinculação oficial com o SENAI nos primeiros anos da década de 90, segundo o representante local do Serviço. Entretanto, desde a década de 1970, a associação foi íntima, e ela hoje se recoloca da seguinte forma: com base na estrutura do Colégio Frederico Jorge Logemann, foi instituída, em 2001, a Faculdade Horizontina (FAHOR), em cujo campus uma área foi cedida, por um acordo, à unidade do SENAI. As instalações físicas - tornos, máquinas em geral - são compartilhadas entre a Aprendizagem Industrial do SENAI e os cursos da FAHOR e da Escola Técnica. Os equipamentos, por sua vez, foram oferecidos em comodato pela SLC, num primeiro momento, e continuam a ser atualizados e repostos pela John Deere.

Segundo o coordenador do SENAI,

MELO - Quando é cursos mais ou menos fechados com a John Deere, para a Aprendizagem, ela pode fazer a seleção, ela faz a seleção e ela monta turma fechada fechada, que eu digo, é 30 . E daí nós aproveitamos para fechar 40, nós selecionamos mais dez e fechamos a turma. Daí, digamos, a John Deere vai financiar esses cotistas, né, pela lei, esses 30, 40 cotistas; e o Senai vai arcar com as despesas dos outros dez. (...) Porque o normal é o Senai bancar toda a Aprendizagem. Nenhuma empresa paga a Aprendizagem, isso é o Senai que paga - porque tem uma receita, né, porque as empresas, né... (...) Mas daí isso é o normal. Aqui é um acordo diferente, né.

$\mathrm{P}$ - Por que só uma empresa vai se apropriar?

MELO - Exato. Mas isso não quer dizer que desses alunos, outras empresas não podem...

Não ficou claro se esse "acordo diferente" que ocorre em Horizontina entre o SENAI e a John Deere prevê a remuneração ao SENAI pelo processo de formação dos aprendizes. Aparentemente, o custo que a empresa assume é a manutenção desses "cotistas". Esses, durante o primeiro ano da Aprendizagem, são auxiliados pela Fundação John Deere, vinculada à empresa. No segundo ano, eles são contratados pela empresa, em conformidade com a legislação relativa ao menor-aprendiz, por prazo determinado. Conforme declarou uma funcionária do setor de Recursos Humanos da John Deere, em 2002: "Os de primeiro ano (...) têm seguro de vida, eles têm colégio $100 \%$ pago e eles têm... E os cotistas de segundo ano, eles já são considerados nossos funcionários. É um contrato por prazo determinado".

Segundo o coordenador do SENAI, de aproximadamente 110 aprendizes, hoje, 62 são “cotistas" da John Deere. Algumas outras vagas estão sendo financiadas por empresas menores recentes, como se verá - do setor metal-mecânico da cidade, e as demais o SENAI oferece para "a comunidade" (sic).

A seleção é feita conjuntamente pela empresa e pelo SENAI, que formula e aplica as provas. Quanto aos "quotistas" da John Deere, eles passam, inclusive, pela avaliação psicológica de um escritório de consultoria em recursos humanos, que é também o responsável pelo recrutamento de trabalhadores efetivos para a unidade de Horizontina da companhia. 
A FAHOR, por sua vez, é o desdobramento natural de uma progressão na demanda por especialização da mão-de-obra, como declarou em entrevista o diretor da instituição (que se encontra há poucos anos em Horizontina). Nas palavras do responsável pelo SENAI,

MELO - (...) No ano passado, se formou a primeira turma de engenheiros da FAHOR. Dessa primeira turma (...) em torno de $80,90 \%$, eram todos ex-aprendizes de Senai e excurso técnico.

$\mathrm{P}$ - E funcionários da John Deere?

MELO - É, e funcionários da John Deere, a grande maioria.

A FAHOR começou seu primeiro curso superior em 2002. Inicialmente, ofereceu uma turma por ano de uma única graduação: Engenharia Mecânica. Em 2005, iniciou-se a oferta de Engenharia de Produção e de Economia. O Diretor estima que $80 \%$ dos alunos de Mecânica sejam empregados da John Deere, e que, do total de discentes dos três cursos, $60 \%$ o sejam. A empresa financia uma parcela muito significativa das mensalidades (cujo valor, no caso da Engenharia Mecânica, é de $\mathrm{R} \$ 850,00$ ) para os alunos que lá trabalham, obedecendo a critérios internos que não foi possível detalhar.

Quanto à deflagração dessa iniciativa, o Diretor entrevistado declarou:

PROF. CÉSAR - Foi um movimento, um primeiro movimento que aconteceu no final do século pela mão da prefeitura, que sentiu a necessidade e mobilizou, naquela época, para formar um curso - mas não teve êxito. Aí, depois esse movimento já, depois de dois, três anos, já no início do novo século, aí então o colégio encampou o processo, né, a direção. E como ele é comunidade evangélica, né, encampou o processo motivado também por pessoas ligadas à John Deere, e que sentiam essa necessidade e que proporcionaram o ambiente adequado. Motivaram esse caldeirão aí que foi a FAHOR. Mas ela surgiu, vamos dizer, da indústria - pessoas que... Não dá pra dizer John Deere, assim, a empresa, mas pessoas, vamos dizer, da John Deere, de postos de comando e de decisão da John Deere, que visualizaram essa possibilidade. Então, junto com a comunidade evangélica da qual faz parte o Colégio Frederico Jorge Logemann, e também a Prefeitura Municipal que incentivou no início.

Observa-se, neste depoimento, que os interesses da empresa em dispor de força de trabalho com determinada qualificação aparecem eclipsados pela "percepção" que a prefeitura tem de uma "necessidade". A ligação histórica entre a empresa (quando SLC), a comunidade evangélica e a Escola, é, também, um caminho indireto pelo qual se enuncia o vínculo entre John Deere e FAHOR. O mais interessante, por fim, é a forma como a atuação da empresa é personalizada: "não dá para dizer a John Deere”, mas, sim "pessoas da John Deere em postos de comando".

\subsection{A pessoalização das relações sociais}


A fala, acima citada, do diretor da FAHOR oportuniza que se aborde a força que as relações interpessoais ostentam na atuação de instituições e nas práticas mais variadas que envolvem o mercado de trabalho de Horizontina.

É interessante tomar esse tema dando continuidade ao depoimento do referido professor:

P - (...) dentro da John Deere. Qualquer instituição, às vezes tem quem ache mais importante um projeto, quem não ache. Haveria ali divisões ou diferenças em termos de pessoas que... que dão menos importância, ou mais importância [à FAHOR]?

PROF. CÉSAR - Ah, com certeza tem, só eles nunca deixaram transparecer. (...) O que a gente tem que saber é com quem está lidando. Então, por exemplo, o nosso canal de ligação sempre foi com a direção, aqui. Então a diretoria local [da empresa] sempre foi muito ligada à Escola, então... O próprio [nome], no início, era o [cargo] [da empresa], e está aqui todo o dia, enchendo o saco. $\mathrm{O}$ [nome] também. $\mathrm{O}$ [nome] hoje contribui com... um aluno ele paga todo mês do bolso dele - o diretor industrial. É, praticamente toda a diretoria está no dia-a-dia.

(...) Hoje quem... vamos dizer, a figura de maior poder, vamos dizer, hoje aqui, é o [nome] - aqui na fábrica; que é uma espécie de cara...

$\mathrm{P}-\mathrm{E}$ o gerente?

PROF. CÉSAR - É o "gerentão-geral" aí. E que também é da casa. Então, vamos dizer, o canal... ele está fortemente centrado nas relações com as pessoas. Eu acho importante isso. E até num mundo em que o papel tomou conta, a gente preserva a relação de sentar, expor a dificuldade, o que vamos fazer juntos, o que nós precisamos, e aí os caminhos. Mas existe muito respeito nessa relação também. Então, de fato, quando a gente faz o nosso planejamento, a gente senta com eles: "Olha, nós estamos pensando isso. O que vocês têm pra contribuir com isso?". E, logicamente, eles dão as idéias, mas não interferem.

Essa relação não diz respeito apenas à alta hierarquia da companhia. Quando perguntei sobre a adequação dos currículos da Engenharia Mecânica às novidades introduzidas nos processos de transformação industrial da John Deere, o "canal" prontamente apontado foi a quantidade de alunos-funcionários que aportam cotidianamente suas vivências e dificuldades no ambiente produtivo.

Nos conselhos da FAHOR, tampouco, a empresa tem presença. Não a empresa: "pessoas da empresa". Essa fluidez se encontra em vários níveis da vida local, e consagra um terreno muito nítido para que laços sociais, familiares, e outros níveis de lealdade ou reciprocidade, desloquem ou, ao menos, se associem - a critérios burocráticos e impessoais na rotina institucional.

Do ponto de vista da obtenção de trabalho, esse substrato formado pelas relações pessoais mostra muito nitidamente a sua força, na definição dos percursos dos indivíduos. Uma primeira evidência: dos 7 funcionários e ex-funcionários da John Deere que eu entrevistei mais detidamente, todos tinham ou haviam tido parentes empregados na fábrica. Quatro mencionaram que seu ingresso no estabelecimento deveu-se à intermediação de algum familiar que já trabalhava na SLC ou na John Deere - sendo o mais extremo o caso de um trabalhador que foi admitido aos 18 anos, "na vaga que era" de seu pai, que, naquele momento, estava se aposentando.

A prática de chefias imediatas pedirem indicações aos empregados bem avaliados prossegue, na fase multinacional da planta.

SILVANA - Aqui, na cidade de Horizontina, existe aquela coisa assim... o pai trabalhou e se aposentou [na empresa], sabe; o avô trabalhou, fundou a empresa. Então eu também 
quero trabalhar. A família quer que ele vá trabalhar. Então aí tem, numa mesma família... Às vezes têm empresas que têm essa política de não colocar pessoas da família. E a empresa, aqui na John Deere, não existe isso. Até é um referencial, né, positivo, digamos: "Ah, mas ele já tem um irmão que é engenheiro, um ótimo engenheiro; então vamos dar oportunidade". Claro que não no mesmo setor, né (...). Então existe muito essa cultura assim de que é um lugar muito bom de se trabalhar, em que o funcionário é bem... é valorizado (Psicóloga da empresa Competência Humana, terceirizada pela John Deere para o recrutamento de mão-de-obra).

Essa associação feita pela psicóloga entre a valorização do funcionário e a abertura de possibilidades de emprego para sua família - em especial, os filhos - aparece nas falas dos operários. Há uma clara manifestação de reconhecimento, sobretudo quando os filhos têm uma inserção com mais status mais elevado do que a do pai.

A própria psicóloga citada e sua colega de trabalho, ainda graduanda de psicologia - a que se resume a equipe local da empresa especializada em recrutamento na qual trabalham -, afirmam lançar mão de seus canais pessoais, quando precisam de um profissional mais específico que não conseguem facilmente encontrar.

Já há alguns anos, a inscrição de trabalhadores que desejam trabalhar na unidade de Horizontina da John Deere é feita através da home-page da empresa, pelo preenchimento de um currículo eletrônico, que é direcionado automaticamente para essa firma de RH. Ainda assim, muitos currículos eram entregues na sede da empresa, que, hoje, os redireciona, também, ao escritório da Competência Humana. De resto, há uma oferta constante e direta de mão-de-obra para a firma por meio do contingente de aprendizes que concluem seus contratos - já familiarizados e avaliados à exaustão -, o que costuma suprir as necessidades, salvo em conjunturas de excepcional expansão do emprego na planta - como começava o ocorrer quando de minha estada no município, em 2007. Até por isso, o anseio de trabalhar na SLC e, hoje, na John Deere, encontra no ingresso no curso de Aprendizagem do SENAI uma primeira e decisiva possibilidade de realização. Em grande medida, todo o processo de disputa por esses empregos é deslocado para a etapa anterior da carreira típica. No passado, portanto, a "valorização" dos filhos de funcionários acompanhava essa tendência, como relata o diretor da unidade do Serviço:

MELO - Acontecia. Assim, uma época atrás tinha uma... bem, tudo amparado em lei, né. O Sistema S na empresa, tudo que... para beneficiar o funcionário, né, digamos - de 100 alunos, 30\% da vaga teria que ser filho de funcionários. (...) Teria uma preferência... Faz o processo normal, e se na hora da seleção empatou, então tem que ter $30 \%$. Hoje não tem mais. Hoje eliminou tudo isso. Tem condições, vai entrar. Até, o que acontecia? Que eu vivi essa época também, né, de uns anos atrás, que colocavam filho de funcionário porque tinha que ter a cota, e ele não rendia tanto quanto um outro... (...) Mas, então, hoje não tem mais essa separação: filho de funcionários.

Com esse forte peso do ingresso via Aprendizagem Industrial - e, também, por uma preferência da empresa -, a unidade local do SINE não tem grande conexão com o recrutamento para a John Deere. Os maiores volumes de postos intermediados pela agência pública ligam-se ao 
emprego doméstico e a assalariados rurais que saem do Rio Grande do Sul contratados pelas empresas agrícolas, já referidas, que foram fundadas por integrantes das famílias anteriormente proprietárias da SLC. Somam-se a esses a força de trabalho para empresas que prestam serviços (de vigilância, limpeza e restaurante) dentro da John Deere, e, mais recentemente, a um nascente conjunto de empresas metal-mecânicas locais de que a multinacional tem comprado componentes.

Nesse escritório do SINE, constatei uma sistemática muito surpreendente da coordenadora da unidade - que, em verdade, é a única funcionária propriamente lotada na agência, contando com o auxílio de duas estagiárias. Próximos à sua mesa, inúmeros lembretes em papel, colados em um painel, traziam nomes e telefones. De resto, todas as informações que poderiam constituir um sistema de informações - telefones e nomes de demandantes e ofertantes de emprego - encontramse em um caderno espiral, escrito a mão por ela própria, que mais de uma vez ela consultou, com dificuldade, para me indicar outros possíveis entrevistados. Perguntada sobre os sistemas de cadastramento, a funcionária, D. Marlene, queixou-se de que sua unidade ainda não se encontrava informatizada. O mesmo me havia sido dito cinco anos antes, por ela própria. Desta vez, no entanto, eu visualizava um moderno computador ligado, junto à mesa de uma das estagiárias.

Perguntei-lhe o que seriam esses bilhetes - num dos quais, li o nome de uma moça seguido da observação "Filha do [Fulano]", e um telefone.

MARLENE - Ah, esse aqui, sabe por que eu coloco aqui, rapidinho? Porque daí assim, ó: quando eu vejo que é alguém que... Por exemplo, eu preciso de uma babá urgente, ou preciso de alguém que vá fazer uma faxina - você não vai... até que eu vou procurar; eu só olho aqui: "A fulana”. Aí já pego o telefone e já ligo. Então boto nome dela aqui. (...)

$P$ - E vem cá, se eu venho aqui e se eu estou procurando pra babá, também... Não dá ciumeira isso?

MARLENE - Não, não dá porque é assim, muito pouco a gente tem dentro da... Por exemplo, essa aqui, até ela... provavelmente vai sair, porque ela, na sexta-feira, ela foi encaminhada. Eles não deram o retorno pra nós hoje ainda. Então são as pessoas, assim, como é que eu vou te dizer... "Bah, Marlene, eu vim aqui. Mas tu me arruma, eu preciso, pá, pá, pá”. Tá, coloco aqui. Se não, às vezes, tem um recadinho, colo. Então são as pessoas que... Mas nunca ninguém, assim, que se queixou. Porque às vezes eu preciso de alguém pra fazer uma faxina - me ligam, ó.

$\mathrm{P}-$ Mas deve ter várias faxineiras inscritas?

MARLENE - Tem, bastante, né.

$P$ - Aí, se alguém chamar, a senhora vai indicar esta [do bilhete]?

MARLENE - É, a primeira ali, que eu preciso rapidinho. Então... eu olho ali, tá. Já mando. Então... Mas assim, a gente procura, dentro da...

A fala indica que a coordenadora do SINE tem dificuldade de explicar claramente tal metodologia. Vários elementos chamam a atenção: em primeiro lugar, a alegação de urgência é surpreendente, numa agência pública de intermediação de mão-de-obra. O mesmo vale para a hierarquização de "necessidades", seja de quem "precisa" trabalhar como de quem "precisa" contratar. Um outro elemento interessante é a alusão que a funcionária faz - teatralizando o diálogo - ao ato pessoal de quem "lhe" pede uma colocação. 
Procurei, diplomaticamente, explorar essas questões. O recurso aos bilhetes foi adicionalmente justificado pela dificuldade que a funcionária sente de interromper (!) seu trabalho para consultar os fichários de inscritos. Pedi para conhecer esse cadastro: os currículos são armazenados em pastas suspensas, com apenas dois critérios de organização: a separação entre homens e mulheres, e, a seguir, ordem alfabética - como se a inicial do nome pudesse ajudar a encontrar o perfil adequado para uma vaga de emprego.

Não apenas para o trabalho doméstico opera esse "critério" de seleção. No fluxo de nosso diálogo, D. Marlene volta a exemplificar seu "método", relatando o caso de uma vaga para secretária:

Então eu sou uma só. Daí surge a vaga. Quem que eu vou procurar? Foi o que aconteceu sexta. Chegou um empresário, sentou ali: "Ah, Marlene, eu quero uma secretária. O perfil é esse, esse. E você pode me indicar ela. Pode me indicar, e eu estou indo, e você manda lá assim-assim, tal hora, eu estou aguardando ela no escritório". Eu, na hora, me veio na mente a menina. Porque a menina está presente sempre.

$\mathrm{P}$ - E ela aparece e vem dar um oi?

MARLENE - Sim. Então o que eu teria que fazer? Ele pediu. Então se eu não tenho... Daí eu vou ter que ir lá, no banco de dados, tem que deixar tudo que eu estou fazendo aqui e sentar lá. "A fulana [simula consultar ficha], ah, ótima essa aqui. A fulana... taratátá". E assim não. Então o que eu faço? "Liguem", digo [para os inscritos ]; "Fiquem em contato". [E eles:] "Ah, mas aí a gente fica enchendo". [Ela novamente] "Não, a gente está aí pra isso".

Aqui entra um aspecto fundamental do procedimento da funcionária do SINE. Em várias oportunidades, ela frisou sua dedicação à tarefa - encontrava-se, oficialmente, em férias, por exemplo, no dia em que a entrevistei. O trabalho que realiza, até por isso, é altamente associado ao seu crivo pessoal e à sua avaliação do grau de "interesse" dos desempregados que se inscrevem no serviço público de intermediação. E a mensagem é clara: os indivíduos que não visitam o SINE (ou sua coordenadora) regularmente não serão "imediatamente lembrados". Tive a sorte de transcorrer em Horizontina uma semana da qual metade D. Marlene compareceu à agência. Na outra metade, como estava efetivamente em férias, viajou a Porto Alegre, por motivos familiares, conforme informaram as estagiárias. Nos dias em que a coordenadora do SINE se encontrava, o saguão do escritório estava repleto. Nos outros dias - e pude observar bastante, pois o hotel fica a 100 metros -, era muito raro ver algum trabalhador nas cadeiras destinadas à espera.

Esse engajamento pessoal que a funcionária ostenta com orgulho é especialmente perceptível nos casos em que levas de trabalhadores são contratadas para as plantações no CentroOeste e Nordeste do país:

MARLENE - Assim, por exemplo, a pessoa vai sair daqui; os familiares ficam pensando: "Poxa, mas meu filho foi..." E aquela dúvida. Inclusive, esse pessoal que foi pra Bahia, nós temos contato com eles toda semana.

P - Por quê? Ligam pro...

MARLENE - Ligam... Mas quem liga não são os funcionários (...), é o pessoal responsável lá, nos dando notícia pra passar pros familiares. Entende? Então a gente não faz um trabalho, assim, duvidoso, que fica... Que nem a gente sabe: "ah, mas pra onde é 
que foram?"... (...) A gente acompanha até a rodoviária. Inclusive, porque o embarque sai daqui, o pessoal sai daqui do Sine.

Também no SINE, outra face da pessoalização das relações emergiu. Na medida em que todos os moradores de Horizontina tendem a, ao menos, se identificar uns aos outros (D. Marlene, de qualquer forma, declara-se capaz disso), é imediato o reconhecimento de indivíduos "de fora" que procuram o serviço. Já em 2002, quando a entrevistei uma primeira vez, ela declarou que, ao me ver, concluiu que se tratava do pesquisador que agendara um encontro com ela para aquela tarde.

(...) então, como a gente é natural daqui, é automático de que você conhece todos os rostos, tanto que eu comentei que quando eu te vi entrando no restaurante eu sabia que... E quando você entrou aqui você chamou a atenção: isto é gente de fora, entende. Então o mesmo acontece aqui no SINE. Isso é todos os dias (D. Marlene, SINE, entrevista realizada em 2002 - quando o coordenador da Agência era outro profissional).

Nem em 2002 nem em 2007 foi possível obter um relato claro do procedimento que é tomado com esses trabalhadores de outras localidades. Aparentemente, a primeira providência é obter deles as informações sobre onde estão "parando", se têm parentes na cidade, etc. Presumivelmente, trata-se de filtros para indicar-lhes a dificuldade de permanecer na cidade. Um pouco mais transparente, nesse mesmo sentido, foi a posição do coordenador do SENAI:

\footnotetext{
Nós temos alunos aqui de Tucunduva, Três de Maio, tem - mas tem que ser muito bom, ter onde morar, ter tudo isso, porque isso vai gerar uma parte social também. Pegar um aluno de Três de Maio, que ele vai ter que pagar pensão, sair de casa, tudo, aqui, ele não vai ter como sobreviver.

$\mathrm{P}$ - Aí vocês já não selecionam?

MELO - Daí, então... é, já se vê isso aí. Então vamos pegar um outro daqui, que é nosso, daqui da cidade, né, vamos dar preferência para esse daqui, que vá... Então também tem isso, né. Mas temos alunos dessas regiões.

$\mathrm{P}$ - Dessa região. Mais para longe não chega?

MELO - Não, mas não, não chega, não tem como. Porque ele tem que trazer... onde está estudando, tudo. Então tu já sabe, de outra região, daí...

$\mathrm{P}$ - Não é para aceitar porque...?

MELO - Não é [inaudível] a empresa fazer a parte social para outro município longe.
}

Esse mesmo entrevistado enuncia uma percepção que tive ocasião de constatar em vários interlocutores, nas conversas que mantive na cidade. Perguntado sobre eventuais pontos negativos de viver em Horizontina, respondeu: “Ah... hoje tem bastante gente de fora. Tu não pode já deixar mais... se tiver um filho pequeno, sair de noite, tem que ter um cuidado. Já tem, né, então não dá para dizer que não tem. É bom, mas não é mil maravilhas, né”. Aparentemente, do seu ponto de vista, alguns problemas sociais chegam à cidade por uma "contaminação" desde fora.

Outro aspecto dessa pessoalização das relações sociais me foi destacado numa conversa com trabalhadores, na ocasião da assembléia a que assisti. Um dos operários, depois que foram levantados aspectos de "endurecimento" das exigências da empresa, após a mudança de 
propriedade, elogia alteração na escolha das chefias: "hoje tem que ter estudo - não é assim!”. Anteriormente, segundo ele, o "cara que ia pra zona com o chefe, virava chefe". Ele diz ter tido chefe "analfabeto", porque era "amigo do gerente". Conclui: "isso melhorou". Outro colega, no entanto, salienta que ainda tem muito "puxa-saquismo". No setor dele, recentemente, "veio" um chefe que tinha como hobby fazer trilhas de motocicleta. Sete subordinados compraram motos, para compartilhar o tempo de lazer com o superior. Este, agora, foi transferido - "e as motos estão lá, paradas".

Esse ponto remete de volta à John Deere e à sua realidade "interna", que de interna tem pouco, uma vez que transborda e condiciona as perspectivas ocupacionais de toda a localidade, bem como as representações em torno do mundo do trabalho.

\subsection{O trabalho na (ou para a) John Deere: sonhos, "quebras"}

Nesse município pequeno, em uma região que tem um perfil predominantemente agrícola e minifundiário, a emergência e a gradativa pujança dessa planta industrial consagrou um "destino" ocupacional que se tornou referência pétrea para todos os projetos e trajetos da população trabalhadora - muito especialmente, no caso dos homens.

A associação entre ingressar na empresa e um "sonho" foi referida incontáveis vezes, nas entrevistas e diálogos fortuitos. Apenas para exemplificar:

SILVANA - Então existe muito essa cultura assim de que é um lugar muito bom de se trabalhar, em que o funcionário é bem... é valorizado. Tem um plano de carreira. Tem pessoas, assim, que entram como soldador e dizem para nós assim: "Eu quero me aposentar aqui dentro, sabe, é o meu sonho é me aposentar aqui dentro". Então a gente vê que existe... Além de toda essa questão, assim, do dinheiro, dos benefícios, é o amor, assim, pela empresa, sabe, é o respeito, a valorização pela empresa, por isso que a empresa significa aqui para cidade.

MARCIANE - Com quem tu conversar, enfim, for conversar aqui com o pessoal do município, aqui o sonho dos pais é os filhos trabalhando dentro da empresa, todo mundo tem que entrar (funcionárias da empresa Competência Humana, terceirizada pela John Deere para o recrutamento de mão-de-obra).

Esse "sonho", claro está, é fortemente condicionado por um realismo de "mercado", pela visualização das escassas oportunidades ocupacionais que se abrem para os indivíduos que habitam e desejam permanecer em Horizontina.

RAFAEL - Eu nunca tinha entrado dentro da empresa até então.

$\mathrm{P}$ - Mas qual era a tua visão do trabalho lá, a partir da tua experiência como filho? [o pai era operário da empresa]

RAFAEL - É diferente, né, o cara trabalhar em... O sonho de todo mundo até hoje, né, o pessoal que vem de fora aí, é ingressar dentro da John Deere.

$\mathrm{P}$ - Tu já tinha te proposto a isso quando tu era mais moço?

RAFAEL - Sim, porque em Horizontina a alternativa que tem é essa.

$\mathrm{P}-\mathrm{E}$ já tinham conversado alguma vez, antes do teu pai te indicar?

RAFAEL - Não. Nunca.

P - Vocês, em casa, nunca assim: “ah, quero trabalhar"... 
RAFAEL - Ah, o pai sempre falava, porque o pai se aposentou, né, como soldador. Dizia: "Ah, eu queria que vocês seguissem como soldador", e coisa assim - que é um pensamento pequeno também, né, só que...(ri) (Desempregado, 28 anos, com duas passagens pela empresa - uma com contrato pleno, que rompe por vontade própria, pelo desejo de tentar vaga no Pólo Petroquímico da Bahia; a segunda, como temporário, da qual se demite por revolta gerada pela diferença salarial frente aos colegas efetivos).

Em uma conversa (não gravada) com um ex-funcionário da John Deere, que hoje trabalha em uma empresa terceirizada, que fez o caminho "típico" de Aprendizagem Industrial no SENAI combinada com Escola Técnica na Jorge Logemann, perguntei se, quando chegava a idade de concorrer a essa formação, todos os meninos de 14 anos tentavam ingressar. Ele foi enfático: "Todo mundo! Quem não fizer é burro", pois "se aprende muito no SENAI". Pergunto-lhe, então, sobre o gosto, ou a vocação, para aquele tipo de trabalho, pois supostamente nem todos os teriam. Ele reconhece esse "detalhe", mas insiste: alguns colegas seus não queriam fazer, mas acabaram entrando e "aprenderam a gostar". Um, especialmente, tinha aversão à idéia, por ver seu pai estagnado desde sempre, trabalhando "na graxa". Acabou ingressando na empresa, "cresceu, está bem". Meu interlocutor credita a má situação do pai de seu colega à incapacidade de "fazer por si”, e encerra reiterando: "Muitos entram sem vontade e aprendem a gostar".

Do lado de quem oferece a formação, problemas relacionados à ausência de pendor para esse tipo de trabalho, em alguns alunos, foram relatados pelo coordenador do SENAI e pelo diretor da FAHOR. Da mesma forma, um operário aposentado, cujos dois únicos filhos trabalham hoje na John Deere, relatou: "O meu mais novo, sabe, não se interessou tanto que nem o mais velho. É, ele foi, depois... Ele fez porque, sabe, ele já tinha... Depois, quando ele fez, era dos 14 aos 16. E daí não tinha outra opção. Daí ele pegou e disse: 'Olha, eu vou fazer, né'. Fez e ficou”.

Com vocação, contra ela ou sem se perguntar a respeito, os trabalhadores ingressam na empresa e, muitas vezes, desenvolvem com ela um vínculo bastante marcado pelo fascínio:

PAULO - Ah, na verdade, você cria uma imagem na tua mente. Você nunca... nunca aquilo que você vê é a expectativa que você tinha. E nesse caso, pra mim, surpreendeu - a expectativa ela foi menor do que aconteceu, do que... todos os fatos que cercaram o trabalho, e tudo o mais.

$\mathrm{P}$ - Fala um pouco desses fatos. O que te marcou?

PAULO - Ah, por exemplo, a estrutura da época, da fábrica. Claro, hoje a gente sabe que é antiquada, mas só que na época eu era uma pessoa diferenciada, assim, no sentido de que eu já tinha um contato maior com pessoas, e tal, não fui bem oriundo de uma agricultura. (...). Me trouxe... questão de estrutura, né, me trouxe surpresas. E coleguismo, e pessoal, e tudo era diferente, tudo era novidade. E a questão de você andar uniformizado dentro da empresa. Regras de seguranças - tudo isso pra mim era novidade.

$\mathrm{P}$ - E era novidade boa ou era novidade ruim?

PAULO - Não, novidade boa (Paulo, 35 anos, caminhoneiro em outro município, exfuncionário da John Deere, a procura de emprego em Horizontina).

Como o depoimento desse operário indica, espera-se dos trabalhadores provenientes do meio rural um estranhamento - positivo ou negativo - mais acentuado quando do ingresso no ambiente fabril. Dentre os trabalhadores que vieram da "colônia" - como costumam designar -, 
mais de um mencionou dificuldade de adaptação, sobretudo à hierarquia. Mas o reconhecimento à empresa parece mais prontamente conferido:

Mas eu penso assim: como eu vim do interior, lá, na época, com uma mão na frente e outra atrás, né. Eu conquistei bastante coisa. O que eu tenho hoje, dá pra dizer... Claro, com o meu trabalho, né, mas foi através da empresa. Caprichando, indo lá, consegui... poupando. $\mathrm{P}-\mathrm{E}$ isso lhe dá, tipo assim, um reconhecimento.

LAUDÍLIO - É um reconhecimento. Claro que o sindicato também teve as suas lutas, foi lá, né, e conseguiu bastante coisa que a gente não tinha na época, quando entrou na empresa. Depois foi criado o sindicato. Através do sindicato, tivemos muitas conquista... mas eu posso dizer, o que eu tenho hoje veio da... De repente, se tivesse ficado na colônia, não sabia como é que estava hoje. [Laudílio - operário aposentado da JD, 50 anos, integra cooperativa de aposentados que presta serviço de vigilância no parque da Fundação John Deere].

Abstraindo-se as motivações da SLC e da John Deere - e, como lembra o Sr. Laudílio, os efeitos da ação sindical -, há indicações abundantes de que a empresa manteve, tradicionalmente, políticas de gestão que contemplaram diversos interesses dos seus trabalhadores. Nesse sentido, uma experiência recente merece destaque: a contratação de trabalhadores temporários. Em 2002, quando estive na John Deere uma primeira vez, a funcionária dos Recursos Humanos declarou que haviam começado recentemente a recorrer a essa modalidade (também ela recente, na legislação). O objetivo da empresa seria "estabilizar" o quadro de "efetivos", e responder a oscilações na demanda por trabalho apenas com temporários, que permaneceriam no máximo 6 meses, de acordo com a regulamentação desses contratos. Perguntei, na ocasião, se era comum que, após essas interrupções, os mesmos indivíduos voltassem a disputar uma nova ocupação por tempo determinado, ao que ela respondeu afirmativamente. Quanto às formas de sobrevivência empregadas por esses trabalhadores entre uma saída da fábrica e um novo ingresso, respondeu: “Ah, eles trabalham na construção civil, eles trabalham por cesta básica...”.

A sistemática foi revertida, justamente em função da repercussão que ela causou, a médio prazo, no contingente da força de trabalho potencialmente envolvida nesse fluxo de "aproveitamento" intermitente pela empresa. Na entrevista de 2007, a mesma funcionária da John Deere declarou:

Veja bem, Guilherme, foi a nossa primeira experiência. E a nossa relação com o nosso funcionário é pra ser uma relação duradoura, né. Nós contratamos o nosso funcionário e ela é pra ser a mais duradoura possível. E aí essa imagem se quebrou um pouco.

$\mathrm{P}$ - Por causa do uso de temporários?

MARLISE - Por causa do uso dos temporários.

$\mathrm{P}$ - E se quebrou não só com os temporários, mas com os efetivos?

MARLISE - Sim, porque agora, quando a gente... Porque neste momento, quando a gente está recontratando, né, ou contratando, aumentando o nosso quadro, a nossa idéia é trazer, dentro, lógico, do perfil e das condições de performance, um maior número possível de exfuncionários. E, em função disso, a gente foi atrás de alguns funcionários... Logicamente que todo mundo procura refazer, reconstruir, ir pro mercado de trabalho, enfim. E algumas pessoas, a primeira pergunta que elas faziam é: "Qual é o tipo de contrato?" Porque... por mais simples, ou por menor que seja a empresa onde eles estão, eles não querem largar uma coisa certa por, daqui a pouco, uma coisa incerta ou não tão certa assim. Então a gente deixou de, inclusive, ter de volta alguns bons funcionários em função disso, né. 
$\mathrm{P}$ - Mesmo já oferecendo o contrato efetivo?

MARLISE - Mesmo oferecendo o contrato efetivo. Porque... "Ah, mas daqui a pouco dá uma crise de novo..." (Marlise, funcionária dos Recursos Humanos da John Deere em Horizontina).

É importante ter presente que, entre a entrevista de 2002 e a de 2007, ocorreu uma conjuntura de fortíssima retração das vendas de máquinas agrícolas em todo o país. Entre o final de 2004 e o início de 2007, o movimento foi de muitas demissões no setor, que atingiram fortemente a John Deere, na qual teria havido, segundo a representante dos Recursos Humanos, uma retração de 580 pessoas; segundo o presidente do Sindicato dos Trabalhadores, 1.300. Apenas nos primeiros meses de 2007 começa a haver novas contratações.

Os depoimentos de muitos entrevistados dão conta de que uma parte preponderante desses trabalhadores dispensados deixou a região, o que tem criado uma dificuldade para a John Deere de atender rapidamente sua demanda por mão-de-obra:

Porque a maioria do que foi demitido naquele período, aproximadamente $90 \%$ foi embora. Foi embora, foram pra região de Santa Catarina e Paraná.

P - Dizem que, inclusive, veio gente de Santa Catarina recrutar aqui. Vocês tiveram conhecimento disto?

ALCINDO - Sim, o pessoal da Motores [Weg?], é um dos que vieram pra cá... Tá? Buenas, tanto é verdade, que eles [a empresa] acabaram, né - só que isso eles não deixam transparecer porque, às vezes, eles têm um certo orgulho, que eu acho que é bobagem, né. Porque veja bem: imediatamente quando começa a dar sinais de retomada da produção,... verificando que tem grande parte dos profissionais soldadores que foram embora, e eles foram atrás deles - através de contato telefônico, cartas e etc. Não houve...

$\mathrm{P}$ - Retorno.

ALCINDO - Retorno (presidente do sindicato dos trabalhadores).

Uma atitude praticamente oposta é relatada pelas funcionárias da empresa responsável pelo recrutamento de pessoal para a John Deere - o que não necessariamente significa contradição entre os entrevistados, mas o testemunho de reações diferentes de diferentes subconjuntos de extrabalhadores da empresa, ante a possibilidade de recontratação - condicionadas, por sua vez, pela inserção obtida no (ou noutro) mercado de trabalho, após a demissão.

SILVANA - Isso aí, um aspecto que foi engraçado, que a gente até comentava aqui entre nós: pessoas que quando sabiam que a John Deere estava fazendo esse processo de buscar os profissionais - estavam trabalhando em Caxias, em... - largavam os empregos e vinham, achando que iam ter emprego certo. E aí a pessoa podia não passar, não ser selecionada, e aí diziam assim: "Ah, mas eu perdi o meu emprego achando que"... Então a gente sempre, quando a pessoa participava do processo seletivo, a gente aconselhava: "Ó, está trabalhando? Continua trabalhando. A gente ainda não sabe quem são as pessoas que vão ser selecionadas. Ainda tem toda a avaliação médica. Então com calma, né”.

$\mathrm{P}-\mathrm{E}$ isso é desespero de voltar ou é gosto pela empregadora ser a John Deere? Por que essas pessoas se desabalam?

MARCIANE - Acho que os dois. O que é... O que...

$\mathrm{P}$ - Os salários aqui não são mais altos do que nas outras regiões.

SILVANA - É.

MARCIANE - Só que o pessoal saiu da empresa e passou assim, foi contratado sem carteira, sem benefícios, sem nada. Eles voltam, se tu liga: "Está trabalhando?" "Estou, mas eu largo isso aqui para voltar para John Deere. Eu não quero nem saber por quanto, 
nada. Eu quero voltar para John Deere". Porque tu sabe tu tem uma estabilidade, tem um plano de benefícios para ti e para tua família, o teu salário certinho, né.

É consensual, todavia, um fenômeno radical, do ponto de vista de um mercado local de trabalho: a migração dos contingentes operários dispensados é um destino praticamente "natural", em resposta ao ciclo de negócios de uma única empresa.

Embora não constitua um contingente elevado, também ocorreu a absorção local de uma parcela dos demitidos da John Deere em um pequeno conjunto de empresas, cuja constituição, por si mesma, merece menção. Há alguns anos, especialmente após a conclusão da transferência patrimonial, a empresa tem procurado externalizar, de modo gradativo, alguns processos, bem como a fabricação de componentes de seus produtos.

Além da terceirização já mais antiga de serviços como vigilância, restaurante e limpeza, passou a manter, em um de seus prédios - a "fábrica 1" -, uma empresa subcontratada de grande porte, com atuação internacional, a Ceva, especializada em logística - que tem, no país, importantes clientes, como a Fiat. Processos de separação, embalagem e armazenamento de materiais para as diferentes seções da fábrica são realizados por essa parceira. Numa sistemática relativamente recente em todo o mundo, especialmente em uma cidade como Horizontina, temos a constituição de novas modalidades de relações de trabalho um tanto complexas. A Ceva, por exemplo, repassa a seleção de estagiários e temporários para um escritório privado de Horizontina, o qual, por sua vez, realiza a contratação por intermédio de uma empresa da Grande Porto Alegre, especializada em vínculos por tempo determinado. Dessa forma, é possível encontrar dentro da John Deere um empregado da Ceva, que foi escolhido pela Pró-Ativa e tem em sua carteira um vínculo registrado com a AST.

Mais impacto, do ponto de vista da estrutura produtiva da localidade, teve o estímulo, pela própria John Deere - com apoio de diversas instituições, como a Associação Comercial, Industrial e Agropecuária (ACIAP) de Horizontina, a Prefeitura Municipal e o SEBRAE -, para que fossem instaladas novas pequenas empresas, dedicadas, ao menos em um primeiro momento, ao fornecimento à unidade da multinacional. As estimativas são de que esse grupo de pequenas metal-mecânicas seja próximo a oito, sendo que cinco teriam sido formadas por ex-funcionários da John Deere que deixaram o emprego em função dessa oportunidade de estabelecerem um negócio próprio. Recentemente, o grupo de fornecedores tentou estabelecer uma associação de "sistemistas" - conceito usado um pouco livremente, de resto - da John Deere, a qual não prosperou, mas que visava a fortalecer uma atuação conjunta, sob inspiração do conceito de "arranjo produtivo local". Esse processo teve uma forte indução do SEBRAE, em função das "diretrizes nacionais" que regem a atuação daquele serviço, na percepção de um desses novos empresários, que entrevistei. 
Seu testemunho sobre a sua própria iniciativa empreendedora vem ao encontro do que abordei anteriormente, relativamente à pessoalização das relações na cidade. $O$ entrevistado indicou que houve, por parte da John Deere (ou "pessoas da John Deere") muitas "sinalizações" de que era possível subcontratar etapas, e tem havido um direcionamento preferencial de pedidos para os ex-colegas:

Então nós vislumbramos aí uma oportunidade. E... decidimos de abrir a nossa empresa. Só que isso já vinha acontecendo desde 97, mas nós conseguimos abrir a nossa em 2003 mas eu vinha acompanhando esse processo e esperando o melhor momento. E realmente, nós... nós abrimos nossa empresa, a John Deere logo começou a nos dar oportunidade. E foi o que nos alavancou até agora, né. Assim - tudo que aconteceu para nós ainda foi em torno da John Deere (Rosnei, engenheiro, dono de empresa metalúrgica fornecedora da John Deere).

Entre outras "cortesias" da John Deere - e talvez, aqui sim, valha a distinção acima recolhida entre "a empresa" e "pessoas da empresa" -, esse empresário teve informalmente direcionada para sua firma a demanda por um tipo de equipamento que a unidade da multinacional deixou de fabricar. Mais do que isso, recebeu o projeto.

ROSNEI- E o canal de distribuição desse produto é através dos concessionários, da rede de concessionários da própria John Deere. Como é um produto que a John Deere não fornece, os concessionários podem comprar e revender. Até para eles é bom, porque daí eles...

$\mathrm{P}$ - Se eu entendi, o projeto era o projeto que era utilizado na John Deere?

ROSNEI- Sim, igual. Eles nos passaram.

$\mathrm{P}$ - Mas passaram informalmente?

ROSNEI- Isso. Inclusive, eles tinham um estoque de peças lá, tudo, a John Deere nos vendeu - praticamente nos deu. Falou: "Para nós não serve mais, pode fazer". É bom. Toda vez que alguém entra em contato com eles, lá, que quer esse produto, eles recomendam nós.

Esse empresário reiterou enfaticamente a situação privilegiada de iniciar uma indústria em condições tão favoráveis, de demanda assegurada e aporte técnico. Tem bem claro o desafio de, gradativamente, desprender-se dessa vinculação umbilical com a John Deere. Relata, inclusive, a surpresa que teve nas primeiras tentativas de negociar com potenciais clientes de outras regiões:

Outro cliente, outro cliente, tem outras diretrizes, outras metas. Então muitas coisas que nós estava fazendo aqui com a John Deere, assim, na relação comercial, que eles eram um tanto tolerantes conosco. Às vezes algum atraso, alguma não-conformidade, assim, o pessoal era mais tolerante. Os outros clientes não são. Combinou, combinou, tem que cumprir. E tu já leva um baque, sabe: "Bah, mas tem que ser tanto assim?"

Mesmo com essas facilidades relativas, esse movimento de "empreendedorismo" pode ainda mostrar algum impulso, na realidade local, motivado por uma política da John Deere. Nesse sentido, se estaria caminhando para superar um traço cultural apontado por dois entrevistados, em dois momentos diferentes: a restrição dos projetos de vida e trabalho dos moradores de Horizontina à condição de assalariamento "n'a fábrica". 
O diretor da FAHOR declarou:

Uma característica do nosso aluno é o sonho do cara se formar e trabalhar na John Deere. Tem que respeitar esse sonho. Mas se tu pensar, estrategicamente pra região, nós temos que formar gente que seja empreendedor, se não, a dependência vai continuar. (...) a região precisa [saber] que não existe só a John Deere, que existem várias oportunidades e que eles podem não simplesmente participar, mas serem atores de transformação.

Cinco anos antes, o então presidente da Associação Comercial, Industrial e Agropecuária respondeu-me, quando lhe perguntei se Horizontina tinha imagem de "prima rica", na região:

Não. Não acredito que seja isso aí, porque nunca se deixou transparecer que Horizontina fosse uma cidade rica, né. Inclusive isso aí trazia um problema num outro sentido. Nós éramos uma cidade de empregados, enquanto nas outras cidades já existia mais empreendedorismo. E inclusive isso trazia um sentido pejorativo. E hoje já está mudando isso aí, com esse incentivo aí, pra criar mais empresas de pequeno e médio porte pra fornecer equipamentos para a John Deere. Isso já faz com que o pessoal seja mais considerado em Horizontina, né, como pessoal empreendedor e não mais um pessoal simplesmente preparado - como de fato era preparado por todos os colégios - para serem um bom empregado na firma... (Franck, proprietário de um panifício, presidente da ACIAP - entrevista realizada em 2002).

\subsection{Mecanismos de controle da oferta e da demanda de trabalho}

Como foi abordado, o momento atual "d'a empresa" de Horizontina, do ponto de vista de demandante de mão-de-obra, é um tanto inusitado ante o padrão afirmado há vários anos em suas relações com o mercado local. Um processo seletivo para reposição de mão-de-obra não chegou plenamente a termo, por falta de candidatos habilitados em número suficiente.

Reforçando a interpretação já apresentada em outros depoimentos, tem-se essa formulação lapidar de um operário aposentado:

$\mathrm{R}$ - Porque parece que ainda está faltando gente.

LAUDÍLIO - Está faltando. Porque uma época eles chamavam, tipo assim, dá uma chacoalhada num galho e saltavam mil. Hoje não. Hoje, pra arrumar 300 não foi fácil.

$\mathrm{R}-\mathrm{E}$ por que será que mudou?

LAUDÍLIO - Porque mudou? Porque quem estava já na empresa, uma ou duas vezes, e foi dispensado, não ficou aqui. Saiu: Santa Catarina, Caxias - saíram, né, o pessoal saiu.

$\mathrm{R}-\mathrm{E}$ antes ficavam? Enquanto...

LAUDÍLIO - Antes ficava, né, de repente... Com a esperança de voltar. Mas quem foi dispensado uma vez e foi chamado de novo, e depois dispensaram de novo, esse não ficou mais, né. Então esse pessoal foi, saiu mesmo, esses não ficaram. E lá pra cima tem serviço à vontade. Joinville, esses lados. Eu tenho três irmãos morando em Joinville.

Neste momento de escassez, aparecem estratégias de flexibilização que ganham sentido retroativamente, no contraste entre as diferentes conjunturas do match entre oferta e demanda de trabalho nessa configuração local específica, sob a égide dessa firma em particular.

Em primeiro lugar, houve um relaxamento na exigência de Ensino Médio completo para o ingresso na empresa. Após afirmar que era um requisito, a psicóloga da empresa de recrutamento admitiu que aceitaram quem tinha "pretensão" de cursar... 
Abrindo mão da usual preferência pelos integrantes ou egressos do Programa de Aprendizagem, a empresa encomendou ao SENAI, segundo informou o presidente do sindicato dos trabalhadores, um curso de 120 horas para soldadores, aberto aos interessados "independente de sexo, independente de idade, bastando ter o segundo grau completo, e ter algum tipo já de relação e de vocação empresarial no setor". O dirigente sindical considera que a John Deere não deseja demonstrar que essa iniciativa visa a socorrer uma lacuna emergencial em sua planta, e por isso estaria sendo divulgado que o objetivo é suprir as empresas "sistemistas".

Um aspecto de grande importância nessa fala do entrevistado é a ênfase que dá ao sexo dos alunos do curso emergencial. Ao que tudo indica, precisamente nesta conjuntura de escassez de mão-de-obra, a companhia volta a "valorizar" as mulheres, para usar o termo de uma das psicólogas da Competência Humana. Nessas contratações de 2007, que deveriam ter atingido 380 e ficaram em torno de 300, até o momento das entrevistas, teriam entrado aproximadamente 20 mulheres, para postos nos quais tradicionalmente elas não eram aceitas - no chão-de-fábrica.

Em 2002, foi-me relatado que havia sido feita uma primeira experiência, havia pouco tempo, mas o resultado não fora muito positivo. Não consegui obter uma versão mais precisa dos problemas que haviam se colocado. De modo geral, em todas as conversas que se travavam à época na cidade, era apontada a ausência de oportunidades de trabalho para as mulheres tomando-se como um dado que a John Deere não era lugar para elas. Um integrante da administração municipal da época falava na importância que teria ocupar as "esposas e filhas", já que os homens, de modo geral, tinham oportunidade na fábrica:

Fundamental para nós desenvolver mais o município é partir para a ocupação de esposas e filhas. Eu me refiro a uma mão-de-obra mais simples, mais leve, por isso eu penso em linha de calçados, confecções - porque normalmente o esposo trabalha na John Deere, ganha relativamente bem. Mas a mulher, nós não temos onde botar esse pessoal. (...) Estas fábricas que ocupem este pessoal também tem interesse de vir para cá, porque (...) quando o principal que se ganha numa fábrica não está na tua fábrica é bom. (...)E até em termos de salário não precisa ser tão alto, porque vai agregar uma renda ao esposo. Então eu vejo que este é o caminho nosso aqui, hoje é partir para este tipo de industrialização (presidente da Comissão Municipal de Emprego, funcionário da prefeitura - entrevista realizada em 2002).

A mulher é, assim, "localizada" nessa problemática antes pela condição familiar (pressuposta) do que por sua condição de trabalhadora. Até por isso, o entrevistado aventa a possibilidade de sub-remunerar as mulheres como uma vantagem para as empresas e reitera a tradicional associação entre mão-de-obra feminina e trabalhos "simples". Também nesta época, o presidente do sindicato dos trabalhadores - o mesmo de 2007 - declarou ${ }^{84}$ :

[a empresa] tinha mulheres no setor produtivo. E numa época que deu uma crise, preferiram demitir a mão-de-obra feminina ao invés da masculina. E depois não voltaram a

\footnotetext{
${ }^{84}$ Entrevista realizada, em 2002, pelo sociólogo Walter Arno Pichler, integrante da equipe da pesquisa.
} 
ter mais, diretamente. Porque o Senai oferece também vagas pra mulheres. Mas nós sabemos de antemão... dá pra dizer que $98 \%$ é rapaz que vai pro Senai. Mulher não vai.

Nas entrevistas mais recentes, perguntei ao coordenador do SENAI se a política para o ingresso nos cursos não reproduzia os critérios da John Deere - aceitando ou deixando de aceitar mulheres para capacitá-las conforme a sinalização de incorporá-las nos postos de trabalho.

MELO - Não, eles aceitaram. Nunca foi proibido. Mas só que o seguinte...

P - Mas a dona Marlise me disse em 2002: "Não trabalhamos com mulheres na produção". MELO - Exato. Por quê? Lógico, eles até podem dizer, mas assim... porque cria uma discriminação, e não é isso que eles queriam. Só que daí dentro... não vamos perder essa aplicação de estudo e tudo, porque nós não vamos aproveitar. Porque na época, eles não tinham estrutura física para manter as mulheres lá dentro: não tinham vestiário, sabe, toda essa parte física. E mesmo trabalhar em lugares... trabalhar em solda, na época não podia e tal - e ainda não pode. Então tem lugares que as mulheres...

P - Mas elas estão trabalhando.

MELO - Mas não é na solda. [Ele está equivocado]. Então como mudou - não posso falar para... Mas pelo o que eu estou sabendo, né, mudou o layout, a estrutura, o processo, então agora tem mulheres de novo. Porque tinha mulheres trabalhando, daí parou de se trabalhar com mulher, e daí voltou de novo.

Não posso deixar de registrar que, de modo velado, muitos trabalhadores ouvidos deixavam no ar algumas sugestões maliciosas, quando falavam dos supostos problemas que a presença de mulheres na produção teria causado, no passado. Com um entrevistado procurei induzir a uma explicitação da versão.

P - Que tipo de problema? Tu que vivenciou ali...

RAFAEL - Eu, assim... o cara ver, nunca vi nada. Só que o comentário tu sabe que corre solto.

$\mathrm{P}$ - Sim, claro. Mas seria... pode abrir o jogo.

RAFAEL - Mulher com... tipo, com os chefes, supervisores, esse negócio assim.

$\mathrm{P}$ - Mas os colegas, como é que era? Não foi colegas também que foram desrespeitosos? É mais essa idéia de que elas teriam... algumas... se valido de...

RAFAEL - Com a supervisão.

P - Tá. Supervisão também são colegas ali, também estão na produção.

RAFAEL - Estão na produção.

Ao contrário da declaração do coordenador do SENAI, há, sim, mulheres na solda, na John Deere. Entrevistei uma delas, junto com o seu marido. Ele tem 25 anos e está na empresa há sete; ela tem 24, e havia sido admitida poucos dias antes de nossa conversa. A soldadora - que teve como formação, afora o ensino médio, apenas dois módulos de um curso técnico em Santa Rosa não manifesta qualquer dificuldade em inserir-se no ambiente predominantemente masculino da fábrica. Menciona que sempre gostou da idéia de trabalhar "no chão-de-fábrica", pois não gosta da atividade de doméstica que realiza desde os doze anos de idade.

P - Então, na fábrica, ainda vocês são poucas? No teu setor tem mais alguma? YEDA - Nós trabalhamos em três.

$\mathrm{P}-\mathrm{E}$ tu acha que vocês ali, as mulheres, por terem entrado juntas e serem mulheres, tem uma camaradagem mais imediata entre vocês ou é indiferente?

YEDA - É indiferente, todo o pessoal recebe bem. Eles... são, assim... parece que eles querem te passar o teu trabalho. Eles são bem... todo mundo, assim, é bem profissional, mas eles são bem... 
$\mathrm{P}$ - Em termos de relacionamento está gostando?

YEDA - É. Com respeito.

MARCOS [marido] - É que assim, principalmente antes de vir os novatos, assim, o supervisor pede que é pra todo mundo ajudar.

Pode-se esperar que mais mulheres saiam da penumbra do emprego doméstico, ou da desocupação, rumo a ocupações fabris, se a unidade horizontinense honrar a política de "diversity" da John Deere, aludida, assim mesmo, em inglês, pela funcionária dos Recursos Humanos - a mesma que, cinco anos antes, declarou que a experiência de empregar mulheres não havia dado certo e, perguntada pela razão, respondeu apenas: "Isso é cultural".

A oferta de trabalho feminino em Horizontina aparece fortemente condicionada às decisões da grande unidade fabril local - afinada, claramente, a uma tradição cultural machista (se ainda se usa o termo). Os cursos do SENAI já apresentam significativa procura das mulheres, que, é lícito supor, saem de uma condição associável à do desemprego oculto pelo desalento, na qual uma pressão por trabalho não emerge por estar embotada por fatores percebidos como limitadores do êxito na procura.

Outra categoria claramente utilizada, ao menos na presente década, como variável de ajuste no equilíbrio de oferta e procura de emprego na John Deere é a dos trabalhadores que se aposentaram na empresa. Cumpre ressaltar que uma grande parcela dos operários conquista a aposentadoria com idade próxima - mesmo inferior - aos 40 anos, por beneficiar-se de tempo de trabalho agrícola (a partir de 12 anos de idade, em alguns relatos) e ainda devido à grande proporção de postos, na empresa, em que há aposentadoria especial por insalubridade.

No ano de 2007, em que se verificava insuficiência de oferta de trabalhadores com os requisitos buscados pela empresa, os aposentados eram assediados para retornar ao chão-defábrica. Ao mesmo tempo, por muito tempo foi mantido na John Deere um Plano de Demissão Voluntária específico para os aposentados pelo INSS cujos vínculos de trabalho com a firma não tivessem sido rescindidos. Essa política foi aprovada pelo presidente do sindicato dos trabalhadores, na entrevista realizada naquele ano: "Então é lógico, se eu tenho... se eu tenho um PDV e eu tenho um conjunto de aposentados, que eu posso demitir primeiro os aposentados".

Em minha conversa com o Sr. Antônio, aposentado da John Deere, acabei saindo do "personagem" de entrevistador para expressar uma opinião, que me parecia bem fundamentada nos depoimentos, e foi avalizada pelo interlocutor autorizado:

ANTÔNIO - Sim. Até, inclusive, teve pessoas que voltaram a trabalhar. Aposentados que voltaram.

$\mathrm{P}$ - Que eles foram buscar?

ANTÔNIO - Sim.

$\mathrm{P}$ - Então depende do que isso? Da conjuntura? Se está precisando de gente, busca o aposentado. Se querem tirar, tira o aposentado?

ANTÔNIO - É, exatamente, é isso. 
Sobre essa dificuldade em preencher as vagas ofertadas, cheguei a "sondar" a representante dos Recursos Humanos da John Deere quanto à avaliação que fazia do trabalho do escritório terceirizado, responsável pelo recrutamento. D. Marlise explicitou que a Competência Humana não estava estruturada adequadamente para atender a uma demanda volumosa e relativamente repentina como a que se configurou. Ainda assim, isentou-a de culpas, considerando a situação excepcional.

Se uma escassez de força de trabalho para ocupar vagas de chão-de-fábrica é, de fato, um fenômeno relativamente atípico na história recente de Horizontina, o mesmo não pode ser dito, a julgar por diversos depoimentos, dos cargos mais qualificados de nível superior. A própria instalação da FAHOR, como já foi sugerido, partiu da identificação de um gargalo. Uma vez que, usualmente, os filhos das famílias com melhores condições econômicas deixam a cidade para estudar - muitas vezes não retornando, pela falta de oportunidades ocupacionais ligadas às suas escolhas de carreira (que não necessariamente, neste caso, precisam ser a Engenharia Mecânica) -, não se trata meramente de garantir que alguns indivíduos possam realizar uma capacitação mais elevada, mas, isso sim, de fixar no município uma mão-de-obra que dê conta de uma demanda premente. Não é à toa que o diretor da FAHOR assim descreveu o perfil dos alunos da instituição:

Perfil: bom, quase que $100 \%$ trabalha durante o dia e estuda à noite. De famílias humildes, por incrível que pareça. A grande maioria a família tem uma situação classe média baixa. E a grande maioria estuda com auxílio - auxílio das suas empresas, da própria instituição que a gente criou esse ano uma fundação para 14 estudantes - que é a Fundação Capacitar.

$\mathrm{Na}$ entrevista junto à empresa "terceira", de recrutamento, a retenção de profissionais mais "gabaritados" se demonstrou um problema candente:

MARCIANE - Mas mesmo assim, com as especificações que a gente busca para a John Deere, é bem complicado a gente conseguir - a maioria do pessoal vem de fora. A não ser o pessoal...

$\mathrm{P}$ - E aí não gera muita rotatividade? Porque às vezes vem um pessoal... "eu estou matando cachorro a grito noutra cidade. Eu vou aonde for". (...) Já sai querendo voltar para o seu lugar, já sai com uma idéia de... "bom, é uma experiência, eu vou ficar um tempo". Não acaba ocorrendo muito entre-e-sai de alguns postos?

MARCIANE - Dificilmente. Isso a gente questiona bastante durante a entrevista individual. Por isso que é feito com psicólogas. E a gente pesquisa bem a fundo, aplica testagem. Nas testagens apresenta muito...

SILVANA - É, e a gente procura ver também a questão da família. Às vezes a mulher está bem colocada profissionalmente, vai vir para cá e não vai conseguir se colocar.

MARCIANE - Porque em algum momento da entrevista...

$\mathrm{P}-\mathrm{E}$ vocês evitam esses que possam causar essa descontinuidade?

SILVANA - É, a gente questiona...

P - Sim, mas vamos dizer: o cara veio porque ele quer. Só que ele quer, mas não quer. Vocês detectam isso?

SILVANA - Tentamos detectar. Claro que algumas vezes isso até pode passar.

A formulação do diretor da FAHOR aponta para o mesmo sentido: 
Aí já era outra: "Bom, como é que nós vamos segurar?" Só que eles não dizem essa... que tem uma rotatividade nessa área da John Deere. Isso eles jamais vão dizer, mas a gente sabe. Porque o pessoal fica dois, três anos e... sempre falta o convívio, quem está acostumado num grande centro, sente falta de algumas coisas que aqui não tem.

$\mathrm{O}$ que os dois excertos parecem apontar em comum é que a oferta de trabalho em um mercado de trabalho local não se resume aos elementos "mercado" e "trabalho": ela é, também, necessariamente, local, o que envolve diversos aspectos relativos à satisfação pessoal que condicionarão as decisões daqueles indivíduos que possuem alguma margem para deliberar sobre suas estratégias de inserção no mundo do trabalho.

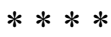

Pequena e repleta de signos facilmente associáveis ao mundo do "arcaico", se evocarmos Lopes, Horizontina, ainda assim, é atravessada pelas ultramodernas práticas de gestão de uma grande empresa multinacional, e a formulação segundo a qual cidade e empresa são extensão uma da outra, que colhi de um entrevistado, adquire concretude nos mais diferentes níveis da vida social.

O emprego na John Deere, como sonho ou como sina, domina tanto o plano subjetivo em que os jovens concebem projetos profissionais e de vida - sacrificando, muitas vezes, a própria idéia de vocação -, quanto o quadro objetivo de oportunidades, em um mercado em que o poder de determinação de um único agente ("a” empresa) atinge um grau extremo. Essa dominância é, inquestionavelmente, econômica, mas boa parte da riqueza analítica do caso se perderia se não fosse considerado o significado histórico e simbólico da SLC na construção identitária da localidade - bastando destacar que território e firma são "fundados" pelo mesmo personagem, o colonizador e capitão-de-indústria Frederico Jorge Logeman.

As instituições locais, historicamente, gravitam em torno dos interesses da fábrica, que o conjunto da população tende a perceber como seus - mesmo após o processo de alienação da planta, com sua incoporação pelo conglomerado norte-americano, que trouxe algumas tensões inéditas à vida local. Em uma análise típica de mercados de trabalho, raramente as relações entre os atores mostram-se tão fortemente enraizadas ou, mesmo, sobredeterminadas pela dimensão territorial. Horizontina surge assim, não como um "recorte" no espaço, ou uma mera unidade administrativa municipal, mas como uma referência - e um produto - das condutas, negociações e iniciativas dos diferentes grupos sociais locais.

Nesse sentido, as instituições locais, em seu conjunto, exercem, permanentemente, um fino monitoramento da permeabilidade do mercado de trabalho da cidade à mão-de-obra dos municípios vizinhos, a qual fornece à John Deere suporte para uma política de flexibilidade numérica. É difícil não reconhecer, impressas no território, práticas empresariais que evocam a teoria dos mercados duais de trabalho, anteriormente relembrados: aos habitantes de Horizontina 
cabe o papel de "setor primário", enquanto àqueles do entorno resta a inserção em um "setor secundário", instável e menos protegido.

Se Horizontina mostra com tanta nitidez as suas idiossincrasias locais, parte da riqueza analítica dessa evidência está no caráter que contemporaneamente se atribui ao "lugar", na reflexão teórica sobre o espaço: essa configuração territorial só adquire seu significado a partir da multiplicidade das conexões entre as diferentes escalas espaciais que a conformam. Acabo de enfatizar o caráter regional do recrutamento de força de trabalho, que se espraia necessariamente pela Grande Santa Rosa, ainda que de forma hierarquizada - e, acrescento, precisa recorrer a centros urbanos maiores, para determinados postos. Ao mesmo tempo, o intenso intercâmbio técnico e produtivo da planta da John Deere com outras unidades do grupo, bem como com fornecedores, compradores e prestadores de serviços de inúmeros países, torna volumosa e cotidiana a presença de estrangeiros na pequena cidade, o que atualiza permanentemente a natureza global dos circuitos econômicos em que ela se insere. Por fim, desafiando interpretações dualistas ou evolucionistas, as relações de estilo "comunitário", altamente pessoalizadas - marca de um espaço local em que "todos se conhecem" -, harmonizam-se e servem aos imperativos da racionalidade e da eficiência de um player como essa portentosa empresa. 


\section{O CAMINHO DA ROÇA E SEUS SENTIDOS: AGRICULTURA FAMILIAR VERSUS EMPREGO URBANO, NA PERSPECTIVA DOS MINIFUNDIÁRIOS}

Como já foi, anteriormente, bastante destacado, o setor primário exerce uma potente influência sobre o desempenho econômico agregado da Grande Santa Rosa; concentra praticamente metade dos trabalhadores ocupados; e é também um elemento central nas representações sobre a identidade regional - bastando destacar que o "slogan" da cidade pólo é "Berço nacional da soja". A forma social que o trabalho agropecuário assume no espaço estudado é, de modo praticamente exclusivo, a agricultura familiar em pequenas propriedades: três quartos dessas têm menos de 25 hectares.

Neste momento, retorno a esse grande "campo" para tentar pôr em destaque alguns pontos analiticamente relevantes para a discussão que atravessa este estudo. Eles dizem respeito à natureza do trabalho que se desenvolve no minifúndio, aos vínculos sociais que caracterizam essa configuração social e produtiva, à forma como os indivíduos e famílias que nela se encontram inseridos representam sua condição e a partir dela concebem projetos futuros de trabalho e de vida.

O contraponto com a concepção mais idealizada de "mercado" segue servindo como um recurso para organizar as evidências colhidas e a reflexão sobre elas.

Devido à ênfase que a população local invariavelmente confere à emigração de jovens associada à problemática de sua inserção ocupacional -, busquei privilegiar os depoimentos desse contingente e algumas questões que lhe dizem respeito de forma mais direta - embora, evidentemente, sejam indissociáveis das "balizas" mais amplas que se referem aos grupos familiares em seu conjunto e a alguns condicionantes tecno-econômicos que pesam sobre as atividades agropecuárias, na forma como essas se configuram na região.

\subsection{Agricultura familiar e sua relação com alguns outros mercados}

Tipicamente, a realidade dos minifúndios estudados permite identificar claramente os limites da operação de alguns outros "mercados", que não apenas o de trabalho. Não desejo aqui discutir se isso a aproxima do tipo-ideal da unidade "camponesa", ou se estamos diante, simplesmente, de manifestações historicamente singulares de "imperfeições de mercado", como se encontram em qualquer outro contexto social e produtivo. Saliento, aqui, três planos em que é nítido o desvio frente ao que se poderia esperar do "jogo" do mercado.

Em primeiro lugar, o mercado de terras tem sido marcado por uma significativa debilidade. A ociosidade e mesmo o abandono absoluto de inúmeras propriedades são, com freqüência, testemunhados por entrevistados das mais variadas extrações, quando relatam os impasses da produção agrícola, em termos de sua lucratividade, do financiamento ou, mesmo, da 
sucessão na propriedade familiar, quando o êxodo abarca toda a família. Classicamente, poder-seia esperar uma aquisição por outros agentes econômicos capazes de pôr em ação esse ativo econômico - sendo o preço, como convém, um fator do ajuste entre uma oferta e sua demanda potencial. No entanto, um elemento que inibe claramente a operação dessa virtualidade é a extrema fragmentação das propriedades e a dificuldade de que elas sejam vendidas de modo a permitir a formação de extensões contínuas mais significativas. Nesse quadro, o histórico de pulverização das propriedades, em sucessivos processos de herança, faz com que haja um padrão de vizinhança que se sobrepõe a redes de parentesco (a área que um dia compôs uma unidade familiar é hoje uma pluralidade de pequenas explorações independentes, de descendentes do primeiro proprietário).

Com isso, são correntes tanto a venda quanto a prática de arrendamento entre familiares incluindo-se pais e filhos; destacando-se irmãos (quando herdam frações). Do mesmo modo, a ausência de compradores contíguos leva a que uma parcela - significativamente relevante, em seu agregado - da terra agricultável fique longos tempos sem utilização.

No município de Santo Cristo, em maio de 2007, pude constatar a disseminação e o impacto que vem tendo um programa federal de crédito fundiário - especialmente uma de suas modalidades, intitulada "Minha primeira terra", voltada para jovens agricultores. Segundo um diretor do Sindicato dos Trabalhadores Rurais local, o município é, em nível nacional, líder em número de projetos concretizados.

$\mathrm{P}$ - Comprar aqui, para várias pessoas, implica ter gente vendendo. Como é que fica esse mercado? Como é que tem sido?

CLÁUDIO - A primeira leva de projetos feitos aqui foram vendas de áreas de pessoas que já estavam fora e que estavam empregadas em Teutônia, em Porto Alegre; ou que tinham ido se aventurar aí no Piauí (...); terras que estavam ociosas aqui no município, ou arrendadas para outros (...); ou que estavam empregados aqui nos municípios, né, já fora.

$\mathrm{P}$ - E essa pessoas já tinham vontade de vender? Houve algum estímulo?

CLÁUDIO - Já tinham vontade de vender. E daí como o crédito fundiário é um projeto aí que, no começo, demorou um pouquinho, mas que... que pagava à vista. E aí houve essa procura, no que começou a sair os primeiros, né, de vender, porque tu vende à vista. Teve muitos problemas aí de venda de terra para vizinho, para amigo, e tudo, e daí o cara dava o título da terra e depois não conseguia receber.

$\mathrm{P}$ - Isso antes do crédito fundiário?

CLÁUDIO - Antes do crédito fundiário. E hoje, difícil sair um negócio de terra fora do crédito fundiário. Porque aí tem uma segurança. Tu legaliza a área, tu bota tudo direitinho no papel, e aí tu recebe o pagamento da transmissão à vista.

$\mathrm{P}-\mathrm{O}$ cara está lá no meio de um monte de propriedades... Alguém, para comprar aquela, tem que ser vizinho?

CLÁUDIO - Sim. Mas existe bastante isso. Tipo aquela propriedade que a gente falou antes: aquela moça comprou uma propriedade do lado, cinco hectares, pequenininha, mas que vai ser anexada à propriedade familiar, para se viabilizar. E aquela proprietária era uma viúva que estava morando já em outros lugares.

Em segundo lugar, é curioso registrar a força que mantém - ainda que, presentemente, em grau menos acentuado - a utilização, na Grande Santa Rosa, da "saca de soja" como unidade de 
conta, nas transações econômicas - inclusive futuras. Essa "quase-moeda" 85 desafia a commoditização do grão, com a conseqüente volatilidade de seu preço. No auge da monocultura, essa prática teve seu ponto máximo, o que poderia se explicar, em parte, pelo fato de que praticamente todos os agentes econômicos compartilhariam de forma articulada as elevações ou quedas de valor do produto. Por outro lado, a economia da Grande Santa Rosa jamais foi "autárquica", para poder desconsiderar as relações entre seus preços internos e aqueles praticados por fornecedores e clientes de fora da região. Isso indica o caráter tradicional da "contabilidade" em soja, uma convenção eminentemente local.

O presidente do Sindicato dos Trabalhadores Rurais de Santo Cristo acentuou a temporalidade passada, ao afirmar: "o soja, aquilo que uma vez era referência, era moeda, pagava terra, fazia de tudo, né?, passa a não ser mais". Da mesma forma, um representante da Prefeitura de Boa Vista do Buricá declarou: "Se pesava, se vendia, se comprava, tudo pelo preço de soja. Era moeda corrente. Hoje já não se fala mais. O cara comprava um carro: 'Quanto você pagou?' 'Tantos sacos de soja'. Então você ainda tinha que fazer a conta. Era assim'.

Embora esses entrevistados tenham dado por superada essa prática, fiz uma entrevista com um comerciante (também agricultor) de Tuparendi - com um razoável patrimônio, entre imóveis e terra -, que insistiu em me demonstrar o quanto a plantação de soja rendia pouco. Trouxe-me uns cálculos que havia realizado, de custos de toda a ordem, a partir dos quais simulava cenários (todos sombrios) de retorno econômico. Em todas as "rubricas", a unidade "monetária" eram as sacas de soja. Em determinado momento, questionei:

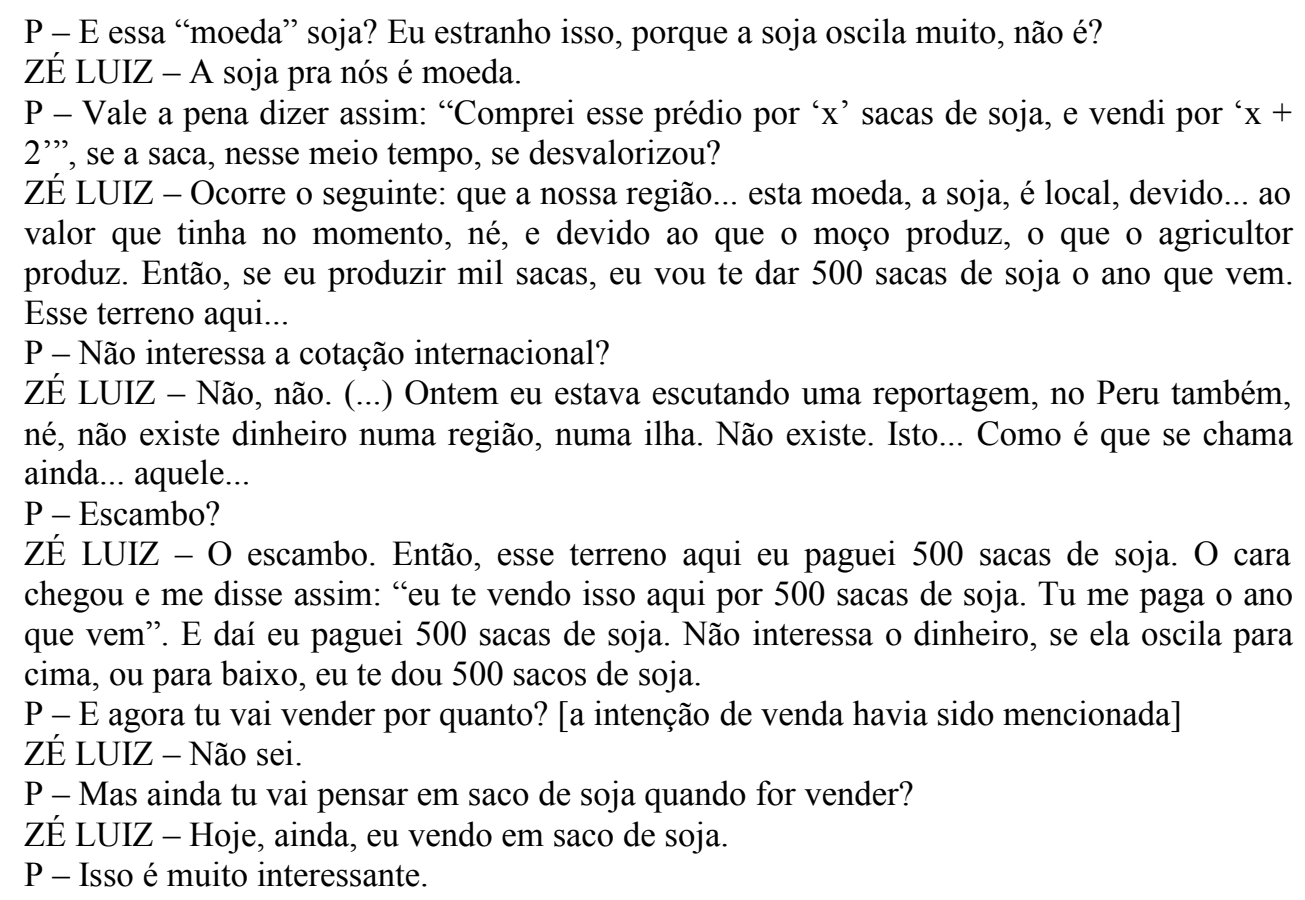

${ }^{85} \mathrm{O}$ interesse pelos significados e usos socialmente construídos para a(s) moeda(s) merece o interesse de alguns trabalhos da nova sociologia econômica, como, especialmente, os de Zelitzer (Zelitzer, 2002). 
ZÉ LUIZ - É porque... o que acontece: se eu vender para um cara de fora, que a moeda dele não é soja, tudo bem. Agora os negócios... Eu cheguei à conclusão que esse negócio, não existe... Se eu vender, vai ser para alguém daqui.

Em terceiro lugar, como já foi abordado, anteriormente, a relativa estabilidade que o próprio cultivo da soja ostenta - contrariando evidências muito claras de que ele se torna progressivamente anti-econômico, em pequenas propriedades - parece não se adequar a explicações fundamentadas numa visão estrita de mercado, especialmente no que diz respeito à racionalidade da maximização.

Porque até hoje nós temos dificuldade em mudar essa matriz produtiva, porque não achamos ainda uma... Mas até hoje nós sentimos dificuldade, porque o agricultor está arraigado na soja. E não deixa de ter certa... a sua razão também. Porque é um mercado... um mercado tranqüilo, né? Porque ele produz a soja e vende. Agora, produzir outras culturas como fruticultura, olericultura, essas aí, a hortigranjeira em si, eles já exigem um mercado que ainda não está organizado, enquanto que o da soja e do trigo está organizado, o mercado (Lírio, técnico da Emater, 2002).

Essa idéia de "organização do mercado", de que fala o técnico, põe em relevo as dimensões institucionais que extrapolam - e condicionam - o cálculo do produtor "atomizado". Outro técnico da Emater, à mesma época (2002), destacou que as "próprias" cooperativas de produtores rurais estimulavam a continuidade do cultivo da soja, "porque têm armazenamento e tudo mais adequado", evidenciando fatores inerciais nas decisões dos produtores.

Nessa conjuntura de cinco anos atrás, o preço da soja estava excepcionalmente alto, conforme já foi assinalado. Naquele momento, diversos integrantes de instituições que vinham tentando estimular um movimento de diversificação da produção dos minifúndios manifestaram-se desanimados com os sinais de reversão dos êxitos até então obtidos.

E destoa agora, por causa do preço da soja, mas é por causa do dólar, né, em parte. Quem é que ganha o dinheiro? Não sei, porque a turma aqui não ganhou. Porque, em primeiro lugar, foi seco. Produziu talvez $50 \%$, ou nem isso, do que devia ter produzido, venderam logo, quando estava a vinte e poucos reais. Hoje está trinta e poucos. Muito poucos venderam a esse preço. Agora, é um mal danado, porque todos eles vão se atirar na soja de novo pensando nos trinta reais, né, a saca. (Lírio, técnico da Emater, 2002).

E eles preferem... com esse preço da soja agora eles vão plantar até no fundo do quintal soja de novo, tá? (...) Então aí tem os extremistas que dizem que isso é um problema governamental, que isso o governo é que fez... Mas é que se o cara ganhar mais dinheiro com a soja o que eu vou fazer? Tu não pode proibir que ele plante soja. E obrigar que ele plante milho. O certo seria isso (Paulo Sérgio, técnico da Emater, 2002).

Em 2006-7, a pesquisa se deu em um contexto praticamente oposto: a conjunção dos preços internacionais da soja e do câmbio vinha de produzir dois anos largamente desfavoráveis a essa cultura, e a região vivia uma crise acentuada. Ainda assim, nenhum entrevistado testemunhou a percepção de um movimento significativo de reconversão da matriz produtiva. Cabe recuperar 
aqui a informação de que a área plantada com soja, no conjunto dos 20 municípios da Grande Santa Rosa, foi de 247 mil hectares, em 1991; de 234 mil, em 2000; e de 227 mil, em 2005, marcando estável uma participação entre $55 \%$ e $60 \%$ da terra utilizada para culturas temporárias na região (FEEDados, on-line).

Em quarto e último lugar, quero destacar um ponto que, de uma forma ou de outra, se associa com todos os fenômenos que serão abordados nos próximos itens, nos quais exploro mais diretamente a problemática do trabalho. Trata-se da presença ainda bastante relevante da produção de subsistência nas unidades agrícolas familiares. Seguramente, ela já foi bem mais representativa do consumo das famílias rurais da região.

\footnotetext{
Na minha época - eu sou filho de agricultor -, o pai vendia uma "caminhonada" de porco por ano e vivia tranqüilo, sobrava dinheiro. Mas também não precisava comprar praticamente nada. Comprava roupa, né, um pouquinho de açúcar... Se comprava o quê? Um arroz, alguma coisa - e fim. Hoje não, hoje tu tem que pagar luz, tem que pagar água, tem manutenção do carro, tem parabólica. Entende? Então as exigências... (...) Os jovens, por exemplo, hoje já querem ir pra cidade, participar da sociedade, tudo. Então realmente aumentou as despesas, os custos, né? Os desejos deles hoje são bem diferentes do que naquela época (Lírio, técnico da Emater, 2002)
}

Ainda são praticamente unânimes, dentre os trabalhadores dos minifúndios, os testemunhos dando conta de que uma parcela importante da terra e, especialmente, do tempo de trabalho são destinados a cultivos ou criação para "consumo próprio", como costumam dizer. Um pequeno número de animais de corte e algumas culturas agrícolas, mesmo que não muito variadas, são suficientes para justificar a percepção de muitos entrevistados segundo a qual, na "colônia", ao menos a alimentação dos indivíduos está garantida.

Ao mesmo tempo, como o excerto acima exemplifica, e já foi, de resto, apontado, os jovens que vivem nesse meio rural, marcado pela propriedade minifundiária com alguns traços "camponeses", têm sido vistos como um elemento de grande preocupação, no que diz respeito às possibilidades de preservação da agricultura familiar na região, haja vista a elevada parcela deles que têm migrado para as cidades - sejam as da própria região, sejam as de outras porções do Rio Grande do Sul ou do país. Essa atenção é justificada pelas evidências, mas eu a tomo aqui como uma questão "nativa", que me conduz, mais do que a uma tentativa de resposta, a investigar algumas especificidades do trabalho nessa configuração social, territorial e produtiva.

\subsection{A “opção" de ficar ou sair do minifúndio e as especificidades do trabalho e do mercado na agricultura familiar}

As características e desafios da propriedade rural familiar configuram-se como um contraponto ao esquema tradicional de análise dos grandes mercados de trabalho urbanos, em que a oposição binária entre ocupação e desemprego parece dar conta do que de mais importante há 
para ser medido e interpretado. Tal contraste aparece de duas formas: de um lado, os minifúndios são percebidos como a fonte por excelência dos fluxos de emigração - recomendando, assim, que se busquem formas de captar e analisar a escassez de oportunidades de trabalho e de renda por outras lentes que não a da desocupação aberta. De outro, o relativo "fechamento" dessas unidades produtivas frente a outros circuitos sociais e mercantis, a baixa rentabilidade que caracteriza boa parte delas e, mesmo, as particularidades dos ciclos produtivos da agricultura - que, em muitos casos, consagram períodos sazonais de ociosidade da mão-de-obra -, dentre outros fatores, levam a que o trabalho na pequena propriedade rural seja visto como uma condição que não equivale, social e simbolicamente, à ocupação sob a forma do emprego assalariado. Um excerto de entrevista condensa todas essas questões, expressas por um secretário municipal de Porto Mauá:

PARADA - Mas, enfim: a mola geradora de mão-de-obra ainda é a agricultura. E se você vai pegar os índices de desemprego...

$\mathrm{P}$ - São baixos.

PARADA - Não. É: eles são baixos porque, de certa maneira, as estatísticas de vocês consideram que quem está na lavoura é empregado. Agora, se tu saíres hoje por aí, pedires: "Tu quer sair de lá fora? Tu quer um emprego?" Todo mundo quer isso. Todo mundo quer sair da lavoura. E por quê? Porque hoje a produção primária não é mais rentável. Então o que nós temos aí hoje, no interior? Nós temos uma população envelhecendo rapidamente. E por que ela começa a envelhecer rapidamente? Porque está ficando o dono da terra, aquele filho, um ou dois mais velhos, ficaram na propriedade. E o resto foi pra onde? O resto foi pra cidade estudar e não voltou mais (secretário municipal de Turismo, Porto Mauá, jul.2006)

Embora os relatos e dados dêem conta de um êxodo rural mais diversificado - do ponto de vista das estruturas e estratégias familiares (e, por extensão, das idades dos indivíduos que emigram) -, a imagem mais reiterada e mais típica do problema remete ao abandono, pelos jovens, de seu meio social de origem, em busca de oportunidades de trabalho. A pressão demográfica advinda do tamanho das proles diminuiu sensivelmente, atenuando um dos fatores de expulsão, que se associa à estrutura fundiária. Da mesma forma, variações conjunturais no desempenho do setor agrícola interferem de forma muito evidente sobre esses movimentos. De qualquer modo, a entrada na idade adulta (ou a aproximação desta) é um momento crucial para uma definição quanto aos projetos e destinos ocupacionais dos jovens e - uma vez que se está tratando de unidades de produção familiar - também desse grupo de parentesco diretamente associado na atividade econômica, e do próprio "empreendimento".

Dois fortes fatores aparecem de imediato quando se trata de afirmar a propensão dos mais jovens a deixar o ambiente rural em favor do assalariamento urbano (via de regra, a alternativa aventada para a atividade agrícola na propriedade familiar): de um lado, o escasso retorno econômico, presente e esperado, da unidade produtiva em que se encontra; de outro, um conjunto de interesses (ou seduções) que o jovem teria por um estilo de vida que não tem como abraçar no seu meio de origem. Essas duas "vertentes" não têm nada de excludentes - ao contrário, aparecem 
por vezes um pouco confundidas, nas falas dos entrevistados, como esses integrantes da Comissão de Jovens do Sindicato dos Trabalhadores Rurais de Tuparendi:

Jovem 1 - O maior motivo que a juventude está fugindo da agricultura é por causa da... Jovem 2 (Coordenador da Comissão) - Falta de renda. Falta de renda.

Jovem 1 - Entende? Você trabalha, trabalha, não tem renda. Aí você senta com o jovem que nem lá na minha comunidade aconteceu. Agora, esses dias, eu liguei para os piás que estão lá em Florianópolis, matando cachorro a grito para comer. Só que eles disseram assim: "Não adianta for pra lá [voltar para Tuparendi], porque lá só tem comida". E o jovem não vive só de comida.

Jovem 2 - Ele quer festa, ele quer agito - você sabe, né.

Jovem 1 - Ele quer agito, ele quer se divertir.

$\mathrm{P}$ - Mas isso não é só a renda...

Jovem 1 - Mas chega no fim de semana, o pai não tem. A atividade que ele está fazendo não viabiliza para ele sobrar uns trocos, entende. E daí ali entra o negócio de preço. Nós não temos preços. Nós não temos sobrando nada da agricultura.

$\mathrm{P}-\mathrm{E}$ esses que foram para Florianópolis, tinham alguém já lá? Por que foram para Florianópolis?

Jovem 1 - Foram para Florianópolis porque... por exemplo, esses três jovens, eles tinham um amigo conhecido lá, daí foram lá fazer bico para sobreviver. Porque lá, daí, assim, pega 100 [assim] vai pra balada, e assim... (almoço com jovens agricultores de Tuparendi, mai.07).

Como se percebe, a exigüidade do rendimento monetário - intermediado pelo pai, na fala acima, aspecto ao qual se retornará - é uma primeira argumentação referente à disposição dos jovens para enfrentar até mesmo condições bastante adversas em outro ambiente (urbano e, no caso acima, na capital de outro Estado brasileiro). A isso se mistura uma demanda por diversão, "balada", que - mais do que representar um dos itens de consumo que se esperaria financiar com a remuneração pelo trabalho -, aponta para uma orientação subjetiva para um ambiente social diverso daquele dos minifúndios de remotas localidades do interior, como as que estão em questão.

Isso não significa que não opere, na reflexão dos jovens - e de suas famílias -, um cotejo eminentemente monetário de possibilidades ocupacionais, que poderia ser aproximado, com algum "conforto", de abordagens mais economicistas de mercado de trabalho. Como se poderia esperar, o resultado dessa "operação" tanto pode pender para a vantagem de um emprego urbano quanto para a permanência na agricultura familiar, como atestam os depoimentos abaixo:

Não, a agricultura hoje, do jeito que está... Esses dias nós tivemos uma reunião aí do Comude (Conselho Municipal de Desenvolvimento), daí eu falei, foi uma das coisas que eu falei (...): "hoje, com um salário de 380, é piada. Quem vai querer ficar na agricultura, né, para...?". Tu não tira isso. Por exemplo, eu e minha esposa, nós dois trabalhando, nós trabalhamos e nós não ganhamos 700 reais por mês, então não tem! (Valdenir, Coordenador da Associação dos Produtores do Mercado Municipal de Hortigranjeiros, Santa Rosa, pai de duas adolescentes que ele não deseja que sigam na atividade agrícola jun.07).

É bom mesmo trabalhar, é muito bom mesmo. Que nem muitos me falaram: "Ah, por que não vai trabalhar na cidade?". Eu trabalhar na cidade e ganhar 600 real por mês, manter luz, água, tudo mais, não sobra nada para mim. Mais comprar o rancho [compras para abastecer a residência] também, junto, e mais um aluguel ainda, não sobra nada. Então, na lavoura tu tem isso e te sobra mais ainda. 
(...) Eu tinha até pensado em ir para Dois Irmãos [município próximo a Porto Alegre], lá onde que está minha irmã, trabalhar em loja, em mercados, fábricas de calçados, roupas, né. Mas com a combinação do dólar, agora, que está caindo bastante, então está difícil, está difícil a situação lá (Ademir, 25 anos, mora e trabalha com os pais em Santo Cristo - mai. 07).

Observa-se que há uma inequívoca aritmética, com resultados divergentes - informados, esses, pelos ganhos presentes e pelas expectativas de remuneração no emprego assalariado -, que fundamenta uma tomada de posição no que tange ao trabalho. É curioso observar, no segundo depoimento, a apreciação até mesmo dos condicionantes macroeconômicos que afetam o mercado de trabalho urbano (o câmbio, neste caso). Também na fala de Ademir, nos dois trechos justapostos - em verdade um tanto distantes, no percurso da entrevista -, vê-se que as aparentes certezas de que vale a pena permanecer na agricultura mostram-se a seguir menos firmes. Isso foi bastante comum aos jovens: mesmo quando manifestam uma preferência por um desses dois grandes caminhos (seguir na atividade dos pais, no meio rural, ou buscar um emprego urbano), geralmente não descartam a outra possibilidade. Também é freqüente o relato de alternâncias entre essas duas condições, sejam vivenciadas pelos próprios jovens entrevistados, sejam por familiares seus. A agricultora Jaqueline, de Tuparendi, 16 anos, fala de seu único irmão, que tem 34 anos, há 15 deixou a propriedade familiar e vive na sede do município. Ela menciona o plano dele de comprar a terra de um tio, vizinha à propriedade em que Jaqueline vive com os pais.

\footnotetext{
$\mathrm{P}$ - E o teu irmão tem vontade de deixar o emprego?

JAQUELINE - Ele, por ele, ele estaria na roça. Ele não gosta da cidade.

$\mathrm{P}-\mathrm{E}$ ele veio por quê? [entrevistei-a na cidade].

JAQUELINE - Ele veio por não ter condições em casa. Ele querer sair, ter as coisas dele, e ele não tinha condições.

$\mathrm{P}$ - Ele trabalhou, veio jovenzinho... até os 19 na roça com os pais?

JAQUELINE - Sim.
}

Voltarei a tratar desses trânsitos, neste capítulo, que busca indicar, em aproximações sucessivas, o quanto essas tomadas de decisão, relativamente à permanência ou não no minifúndio, ainda que claramente "objetivadas" em expectativas de remuneração, envolvem uma série de outros fatores sociais e simbólicos. Antes, menciono outro aspecto bem ao gosto do raciocínio econômico: dentre as vantagens do trabalho assalariado, a segurança da remuneração mensal preestabelecida exerce uma atração sobre muitos dos jovens, acostumados às incertezas do retorno da produção primária.

Desde a morte de seu pai, Tiago vive com a mãe na zona urbana de Santa Rosa. Até então, era uma família de agricultores (e até hoje o menino ajuda o avô no trabalho rural, aos fins de semana); por outro lado, ele já teve experiências de trabalho urbano, em oficina mecânica, fez curso voltado à indústria mecânica e manifestou satisfação com essa área. Em certo momento, perguntei-lhe se o agradaria a possibilidade de comprar uma terra, no futuro, e voltar a trabalhar com agricultura. 
TIAGO - Gostar eu gosto, mas não é futuro.

$\mathrm{P}$ - Em que sentido, "futuro"?

TIAGO - Não é... os preços não estão... Para tu se manter no campo é muito caro.

$\mathrm{P}$ - Os preços. Das coisas que precisa comprar para produzir, é isso?

TIAGO - É. É agrotóxico e semente, e coisa.

$\mathrm{P}$ - Se tu fosse ter certeza que vai ganhar a mesma coisa, com tranqüilidade - só imaginando, uma situação imaginária mesmo -, trabalhando na graxa, que tu falou que gosta, ou na agricultura, o que tu preferiria?

TIAGO - Trabalhar na graxa.

P - É? Gosta mais?

TIAGO - É.

$\mathrm{P}-\mathrm{O}$ que tu acha legal no trabalho da metalúrgica?

TIAGO - É que tu sabe que no final do mês o teu dinheirinho está ali na conta, não precisa nada de... de estar... se dá zebra de safra, alguma coisa assim, tu sabe que tu perde. Além de gastar, tu está perdendo. E assim não. Assim aquele dinheiro é fixo, todo mês. Não tem problema (filho de agricultores, 16 anos, hoje instalado na zona urbana de Santa Rosa ainda assim, a mãe participa da associação dos produtores de hortigranjeiros, e comercializa alimentos caseiros no Mercado municipal, jun.07).

O exemplo de Tiago é interessante para expor a ambivalência com que alguns entrevistados se posicionaram ao tratar o seu futuro de trabalho a partir da perspectiva do desejo. Não acompanhou (talvez não tenha compreendido) o exercício de imaginação que lhe propus, e justificou pela garantia do salário o que seria uma preferência pelo conteúdo de uma atividade.

É oportuno mencionar alguns aspectos que caracterizam a atividade agropecuária na região pesquisada, e a forma como eles são representados pelos trabalhadores.

\subsection{Formas e conteúdos do trabalho na agropecuária, e um pouco das representações a respeito do rural}

O trabalho nos minifúndios da agricultura familiar é, tipicamente ("camponesamente"), gerido pela própria família, a qual estabelece a divisão interna das tarefas, as cadências, as estratégias de produção, de modos que tendem a refletir as hierarquias e os papéis extraeconômicos dos diferentes indivíduos que a compõem. Alguns aspectos referentes a esse caráter familiar do trabalho serão abordados adiante. No momento, quero, primeiramente, registrar algumas outras "modalidades" de trabalho agrícola reconhecíveis na região, que escapam a esse modelo mais "puro" de produção em unidades familiares relativamente "autônomas" do ponto de vista dos processos de trabalho. A seguir, tratarei um pouco das representações que os entrevistados constroem sobre sua inserção na atividade agrícola.

Uma primeira forma de trabalho a destacar é a criação de suínos (e, em alguma medida, a produção de leite) que emerge, agora, de forma integrada a grandes empresas - em sua maioria multinacionais - de alimentos. A suinocultura, como já foi abordado, teve centralidade na economia da Grande Santa Rosa, entre as décadas de 1950 e 1960, e, mesmo após a guinada da região para o "ciclo da soja", nunca deixou de ter uma representatividade significativa. 
Se, no passado, a criação de porcos era um elemento importante para aportar renda monetária a unidades produtivas ainda bastante "autônomas", graças aos cultivos de subsistência, e para isso bastava um pequeno número de animais, as mudanças concorrenciais das últimas décadas, no setor, consagraram a dominância de grandes empresas industriais como compradores virtualmente únicos para os produtores de suínos da região, e essas vêm impondo novos padrões de relacionamento com os "fornecedores" da matéria-prima.

A empresa traz os leitões, traz a ração, dá assistência técnica. E o produtor entra com a mão-de-obra. A mão-de-obra, despesa de água, luz, etc. Mas, basicamente, como eu falei, ele é um peão, sem direitos previdenciários nenhum. (...) Eu tenho um vizinho que tem um chiqueirão, que tem 500 porcos, que ele investiu 50 mil reais do Banco do Brasil. (...) Ele precisa, pela conta que eu fiz, seis anos pra pagar o investimento. Ele vai trabalhar seis anos para a empresa só pra pagar o investimento que ele tem na propriedade.

(...) O suíno é a empresa que fornece. Ela traz o leitão, ela dá um prazo pro agricultor de 105 dias pra engordar. O dia que eles trazem o porco eles já marcam o dia que eles vêm buscar. (...) O custo que o agricultor tem é só água e a luz e o serviço dele. Agora, se fosse contar a mão-de-obra que dá, ele não tem lucro. Ele vai empatar dinheiro. Mas a mão-deobra do agricultor a gente sabe que... Hoje nós não contamos, porque até é a nossa profissão. Mas se fosse contar, certamente ele não teria lucro, não (Pinzon, dirigente do Sindicato dos Trabalhadores Rurais de Três de Maio - 2002).

CRISTIANE - Vai fazer dois anos já. Nós achamos que é um bom negócio, porque, assim, nós não corremos risco, porque nós já criamos porco por conta nossa. Então tu corre o risco de quando o preço está baixo, tu ter um baita de um prejuízo, e tu ter que tirar de um outro lugar para conseguir pagar ali. Então desse jeito nós não corremos nenhum risco, assim.

$\mathrm{P}-\mathrm{O}$ risco é de não ter uma remuneração...

CRISTIANE - ...muito boa, né. Isso também depende do preço. Quando o preço está baixo, a nossa porcentagem fica baixa também. Além disso, para nós é uma vantagem, é o esterco, que fica aqui para nós. E como nós lidamos com vaca, pastagem, nós poupamos na uréia. Então para nós, no momento, assim, como também não temos dinheiro para investir - porque precisaria de dinheiro para tu comprar uma cota de suínos, para comprar ração, para engordar. Até que tu consiga vender... Porque isso demora três, quatro meses, isso dá todo um giro que tu tem que... teria que ter um dinheiro para investir para daqui a três, quatro meses, ter algum retorno, e tu não vai saber se tu vai tirar aquilo que tu investiu, se vai sobrar, se vai faltar. Porque, às vezes, em três, quatro meses, o preço muda muito. Então, no momento, nós achamos que...

$\mathrm{P}$ - Está valendo.

CRISTIANE - Está valendo assim, está melhor assim (Cristiane, 22 anos, produtora em Santo Cristo, mai. 07).

Tornar-se "peão" dos frigoríficos é uma condição que, a julgar por inúmeros depoimentos, avilta um imaginário de independência que parece acompanhar os trabalhadores dos minifúndios. Por outro lado, a "aversão ao risco", a falta de capital para implementar (e esperar amadurecer) investimentos e a dificuldade de inserção autônoma nos circuitos de comercialização justificam a entrada nesse tipo de arranjo, como atesta a fala de Cristiane. Já o depoimento do sindicalista evidencia que a "precificação" da mão-de-obra do produtor é algo absolutamente distante da cultura e da tradição, nessa configuração social e produtiva fundada na agricultura familiar. A se 
levar ao pé da letra sua formulação, não há remuneração ao trabalho do produtor integrado de suínos, muito embora ele seja um "peão".

Quanto à produção de leite, na minha primeira incursão à região (em 2002), era forte a reclamação quanto às condições de preços e às exigências técnicas e contratuais das duas grandes empresas multinacionais que, à época, dominavam o mercado regional, como compradoras. Em 2006-7, essa situação se alterou, favorecendo os pequenos produtores, que contam com um maior leque de opções de escoamento e com remunerações que consideraram mais adequadas, mesmo que bastante diferenciadas conforme o padrão técnico adotado na produção leiteira.

Uma segunda modalidade de trabalho que escapa ao modelo da agricultura familiar "camponesa" é a contratação de mão-de-obra pelos próprios minifundiários. $\mathrm{O}$ assalariamento em sua forma plena - envolvendo vínculos de trabalho por tempo indeterminado, com jornadas regulares e remuneração mensal - praticamente inexiste, mas é bastante corriqueiro o recurso à contratação de trabalhadores (homens, invariavelmente) que habitam a própria região para "empreitadas" de alguns dias, em momentos nos quais as tarefas agropecuárias requerem um aporte de mão-de-obra que supera a força de trabalho da família. Um contingente de trabalhadores retira dessas oportunidades eventuais de trabalho uma parte significativa de seu sustento, e, em alguns casos, a totalidade de sua renda monetária, como no caso da família de meu entrevistado Air. Ele, seu avô e dois tios, no entanto - que realizam esse trabalho -, além da avó, vivem em cinco hectares que pertencem à família. Da própria terra, retiram os cultivos de subsistência, tãosomente.

Segundo o presidente do Sindicato dos Trabalhadores Rurais de Santo Cristo, em entrevista de 2002, "a maioria quando trabalha [para outrem] ainda é meio no sistema informal. Tem a sua terrinha ainda e trabalha pra fora e não quer perder os direitos. Então eles evitam ter carteira assinada, essas coisas". Como se observa, as regras específicas para o trabalho rural, na legislação trabalhista e previdenciária, são percebidas como vantajosas por esses indivíduos, que preferem manter como extra-oficiais formas de trabalho que com aquelas conflitem. Na mesma entrevista, o sindicalista apontava claramente para essa combinação de "posições na ocupação" que envolve uma parcela dos trabalhadores rurais dos minifúndios, e que, em alguns casos, não se limita a atividades agrícolas:

$\mathrm{O}$ que que acontece muito no interior, assim? Tem o cara que durante uma certa época do ano ele é pedreiro. Quando ele não tem muito serviço na agricultura, na sua propriedade ele planta e daí limpou a roça... -, aí ele trabalha: constrói um galpão, constrói uma casa, constrói isso, constrói aquilo. Então esse povo tudo está na informalidade. E não são poucos, são bastante gente assim. Claro, se olhar pela quantia de agricultores que tem talvez não seja tanto assim em percentual. Mas tem inúmeros assim, ou vão trabalhar de peão. Mas estão, tipo assim... ele não perde, na verdade, a sua condição de agricultor. Mas ele busca alternativa naquele tempo que ele tem disponível.

Nas entrevistas que realizei foi possível encontrar alguns exemplos dessa realidade que tem sido evocada como "pluriatividade". Na família da jovem Franciele, por exemplo, as mulheres 
- sua mãe, suas tias, a avó e a própria moça - integram-se freqüentemente ("quando necessário"), de modo alternado, à produção de biscoitos, doces e salgados que uma das tias mantém, na zona urbana de Santo Cristo. A pequena fábrica tem empregadas, mas o número dessas é insuficiente quando há maior volume de encomendas. Com exceção da "empresária", todas as demais têm também trabalho permanente em suas propriedades rurais. Dentre os homens dessa família, um apenas combina atividades rurais e urbanas: possui uma oficina de automóveis, na "cidade", e participa das lidas agropecuárias na terra que a esposa adquiriu recentemente.

AVÓ DA FRANCIELE - [falando dos seus filhos] ...do outro lado do asfalto é o filho, o Rui - ele tem oficina (...).

FRANCIELE - A mulher dele tem também um crédito fundiário - também pegou, também tem terra. Ali também eles...

$\mathrm{P}$ - Aí a mulher é que cuida mais da terra, ou ele consegue dar conta da terra?

FRANCIELE - Os dois juntos.

AVÓ DA FRANCIELE - Os dois juntos. Ela ajuda a trabalhar na padaria [da cunhada]. E trabalha um pouco também o que é preciso na terra.

FRANCIELE - Fins de semana, ou domingo (Franciele, 17 anos, produtora rural em Santo Cristo).

Observa-se que essa combinação de trabalhos envolve, ao menos no exemplo, atividades que são desenvolvidas de forma voluntária - autônoma - pelos membros da família, os quais se desdobram entre elas de forma coletivamente articulada. A combinação de trabalho agrícola com formas de assalariamento em atividades urbanas não teve uma freqüência expressiva, nos depoimentos. Em experiências (de meus entrevistados, ou de seus irmãos e amigos) de emprego na sede urbana de seus municípios (ou em outros, vizinhos), o mais comum é que transfiram residência para lá, em função, até mesmo, da dificuldade para se deslocar diariamente entre a propriedade rural da família, na "colônia", e o local de trabalho.

Ainda assim, há casos em que a propriedade rural continua sendo residência - e ocupando parte do tempo "livre" - de jovens que têm vínculo de emprego na zona urbana.

ANDRÉA - Olha, eu conheço muitos amigos que trabalham na cidade e moram na colônia com os pais. Tanto que tem um vizinho nosso, (...) já é um irmão para mim, aquele rapaz. Então ele sai todo dia de manhã, pega a moto dele, e vai até Guia Lopes [localidade], na Vier [empresa de erva-mate], e volta de noite. Almoça lá, tudo. Tem um amigo meu, que é ali do Ipê [localidade], que ele também pega a moto dele, vai trabalhar na Fankhauser [metalúrgica], ali em Tuparendi, e volta. (...)

$\mathrm{P}$ - Esses que fazem isso, em geral, ainda pegam algum trabalho na colônia, ou é poucos que ainda...?

ANDRÉA - Bastante. Bastante.

$\mathrm{P}$ - Os caras trabalham na fábrica e...

ANDRÉA - E, fim de semana, feriado, estão tudo com o pai e com a mãe na roça.

$\mathrm{P}-\mathrm{E}$ tu acha que eles ficam por quê? Em vez de sair para, por exemplo, pegar uma casa na cidade, ou alugar uma coisa, fazer uma república?

ANDRÉA - No meu ponto de vista, que nem esse amigo do meu irmão, ele está pegando todo o salário dele e botando no banco. Parte no banco e parte para uso pessoal: baile, roupas... Tudo. E esse outro, meu amigo, também. (...) vão guardando um dinheiro.

$\mathrm{P}-\mathrm{E}$ tu acha que aí, com esse dinheiro, o que eles fariam?

ANDRÉA - Ah, mas se eu fosse eles, comprava um pedaço de terra e morava em cima.

$\mathrm{P}-\mathrm{E}$ tu acha que eles também fariam isso? 
ANDRÉA - Eu acho que sim (Andréa, 18 anos, expositora do mercado de hortigranjeiros de Santa Rosa - jun.07).

Chama a atenção, no depoimento de Andréa, a menção ao desejo de utilizar os rendimentos do trabalho urbano para alavancar um empreendimento rural. Voltarei a esse apreço, no prosseguimento do capítulo. Cabe observar, desde já, que o salário que vem de fora da propriedade familiar é tratado de modo diferenciado daquilo que poderia ser a "quota-parte" do rendimento da propriedade, proporcional ao trabalho de um jovem que permaneça integrado exclusivamente à produção familiar. Como também se verá, não existe a prática de repartir os retornos monetários da atividade do minifúndio, enquanto o jovem que tem um emprego, a par de assumir seus gastos pessoais, "pode" dispor (ou acumular) o dinheiro que deixa de despender por manter-se na residência paterna.

Neste momento, é interessante abordar um componente tecno-produtivo que subjaz a essas considerações que venho fazendo sobre as formas de trabalho nos minifúndios da Grande Santa Rosa. As mudanças tecnológicas na produção de grãos - notadamente, de soja -, que se consagraram progressivamente desde os anos 70 , são acentuadamente poupadoras de mão-de-obra. Esse fato é muito evocado quando se trata de explicar o desemprego (ou seu "dublê", a emigração).

E aí o desemprego vem dentro dum... Ele começou na década de 70, com a agricultura se modernizando, né, e indo pra mecanização. E na década de 90 entrou os agrotóxicos, tirando a mão-de-obra. Então hoje é mais prático pegar uma máquina, botar ali dentro um herbicida, passar aí um secante - eu estou fazendo a limpa da lavoura, né, a capina, que seria a mão-de-obra de quatro, cinco ou dez pessoas, né, e simplesmente em meio dia eu faço toda a capina que levaria um mês. Então está sendo uma mão-de-obra ociosa. E aí vai criando costumes (Itálico Cielo, presidente do Sindicato dos Trabalhadores Rurais de Tuparendi, 2002).

Jovem [Coordenador da Comissão dos Jovens Tuparendi - não anotei o nome!] - Todo piazinho, criança, gosta - ou carro... que nem a gente lá no interior: é a colheitadeira, é o trator, né, porque é motorizado. Só que se tu vai lá na lida manual, que é o que sobraria um pouco, e o que precisa...

$\mathrm{P}$ - E o que é essa lida? Me ajuda porque eu sou uma besta com a agricultura.

Jovem - A manual?

$\mathrm{P}$ - É, o que é o trabalho mais braçal?

Jovem - Mais braçal? Você tem... tipo, a gente trabalha com leite. Você tem que tirar o leite, lavar a vaca, você tem que tratar, levar a vaca pro pasto. (...) Daí você tem suíno pro teu consumo. (...) Daí você tem frango, que também você ocupa pro consumo, de corte, para produção de ovos. Daí você tem que se dedicar, além disso: você quer ter um peixe? Você quer ter a batata-doce? Você quer ter mandioca? Você quer ter a fruta?

Esposa dele - $\mathrm{O}$ amendoim, por exemplo, é totalmente manual. Então não tem condições de ter...

$\mathrm{P}$ - Mas essa plantação mais de soja, milho e trigo, está tudo mecanizado?

Jovem - Isso a gente dedica...

Esposa - Uma pessoa pode fazer.

Jovem - ...vamos supor, $10 \%$ do nosso trabalho é para isso aí, $10 \%$ ou $20 \%$.

$\mathrm{P}$ - Do trabalho da família ou de um?

Esposa - Da família. 
Jovem - Assim, acho que dá para dizer... mas nem de toda a família, porque seriam mais de dois, ou três. Porque assim: a gente lida com trator. Daí, tipo uma pessoa, ou duas quando é época da semeadura, um está dirigindo e o outro está cuidando a plantadeira; época de passar tratamento, é uma pessoa só que lida com o trator, com o pulverizador, para passar para insetos, ou para inço. É uma pessoa. E é praticamente toda mecanizada.

$\mathrm{P}-\mathrm{E}$ a colheita também?

Jovem - A colheita nem se fala (mai.07).

Numa formulação altamente sintética, o presidente do Sindicato dos Trabalhadores Rurais de Santo Cristo arrematou: "Dá para plantar soja por telefone. Não precisa botar a mão". E, como se observou, uma parte ainda central do rendimento das propriedades da Grande Santa Rosa vem dessas culturas de grãos e leguminosas - soja, milho e trigo. Nesse sentido, os resultados da modernização tecnológica, que foram sentidos fundamentalmente como propulsores da emigração, pela redundância de força de trabalho, são, no presente, aliados da permanência, no meio rural, de famílias com escassa potência produtiva. Conversei com pelo menos dois casais bastante idosos que vivem, cada qual em sua propriedade, sem mais nenhum integrante de suas famílias. Nos momentos em que é preciso "limpar" a terra, semear ou colher, contam com "peões" contratados. No restante do tempo, dedicam-se, extensivamente, a outras atividades mais leves, como criação de galinhas ou cultivo de hortigranjeiros. No caso dos idosos, a aposentadoria rural, com que praticamente todos contam, é um fator decisivo de fixação no campo.

Nas famílias mais numerosas e que não contam com o ingresso monetário dos fundos previdenciários, esse tempo que "sobra" dos cultivos de lavoura é intensamente aplicado nas outras atividades, que fornecem produtos de subsistência e, não raro, excedentes comercializáveis.

A criação de animais - seja para a venda de leite, seja para o próprio consumo - é especialmente associada a um trabalho que é, invariavelmente, representado como penoso, "pesado". Um dentre tantos exemplos possíveis de enunciações dessa percepção eu colho na fala de uma mulher:

Porque eu sei a diferença, eu morei na cidade. O serviço que eu fazia lá não tem nem comparação do que eu faço aqui em casa, é totalmente diferente. Como eu te falei: hoje de manhã estava -2 graus; não deu para ficar aqui dentro, a gente teve que enfrentar o frio, sair lá, lavar úbere de vaca. Então, isso é uma coisa que se tu for trabalhar numa loja, de babá, de doméstica, é um serviço totalmente diferente, que é menos pesado, menos judiado, porque não é fácil (Cristiane, 22 anos, produtora em Santo Cristo).

Esse caráter árduo do trabalho na "colônia" é claramente positivado em alguns discursos, e isso não se limita à autovalorização dos indivíduos que a ele se dedicam. Muitas vezes me foi dito, pelos mais diferenciados agentes sociais, inclusive por empresários de Santa Rosa, que os trabalhadores "do interior" (agricultores das zonas rurais) são muito bem vistos por empregadores urbanos, seja na própria região, seja fora dela (quando ocorrem migrações de mais longo alcance).

Jovem 1 (o tal coordenador!) - E até, assim, um detalhe que conta bastante: que tanto o rapaz quanto a moça do interior é mais valorizado na cidade pela cultura que ele tem.

Esposa - Isso é verdade. 
Jovem 1 - Porque assim, não desprezar a questão da pessoa da cidade, mas ela tem mais chance de se envolver com questões negativas.

Esposa - Ela tem uma vontade de trabalhar, a pessoa que sai do interior, né, porque ela vai só para isso.

Jovem 2 - O jovem do interior, ele, desde o relacionamento, ele leva mais a sério (Almoço com jovens agricultores, Tuparendi - mai.07).

O reverso dessa medalha, entretanto, aparece nessa mesma conversa que travei com um grupo de agricultores, ligados ao Sindicato dos Trabalhadores Rurais de Tuparendi, no almoço de que participei.

Jovem 2 - (...) A mãe diz assim: "Ó, minha filha, por que tu quer ficar aqui no interior? Tu não vê eu e o teu pai o que estamos sofrendo? Não temos nada, não conseguimos ter lazer, não conseguimos sair". Aí a fillha [inaudível]. Aí tem aquilo, tu conhece uma menina, aí tu diz assim: "Não, mas eu gosto de ficar no meio rural. A gente poderia formar.."..

Jovem 1 - Aí entra o detalhe da discriminação. Chega alguém ali, ó, chega uma moça bonita, vai te pedir: "Qual a tua profissão?".

Jovem 2 [simulando o diálogo] - "Agricultor".

Jovem 1[idem] - "Agricultor".

Jovem 2 - Se foi! [a moça]

Jovem 1 - Se foi! É, tem várias, várias questões aí que...

Tanto em Tuparendi como em Santo Cristo, alguns homens jovens mencionaram a dificuldade de encontrar mulheres dispostas a um relacionamento conjugal com agricultores e a se fixarem no meio rural ${ }^{86}$.

Prosseguindo nesse mesmo diálogo de que venho tratando, reproduzo mais um trecho, em que o Jovem 1 (coordenador da comissão de jovens) e o outro rapaz expressam essa percepção de celibato forçado, que faz pensar no baile dos argelinos de Bourdieu:

Jovem 1 (casado) - Mas provavelmente ele - você, no caso [dirigindo-se ao jovem2] - já teria, se você tivesse tido uma oportunidade, estaria já com uma companheira há muito mais tempo, né? Ou você não quis, no caso?

Jovem 2 - Não, [tive] dois relacionamentos que... podia hoje estar casado, ter filhos, só, [inaudível], porque elas estavam na cidade e não concordavam em voltar na agricultura. $\mathrm{E}$ eu tinha... E eu, para morar aqui na cidade, e todo dia, praticamente, voltar a trabalhar na agricultura, não viabilizava.

$\mathrm{P}$ - Então tu namorou essas duas que estavam na cidade por algum tempo mais longo?

Jovem 2 - É.

$\mathrm{P}$ - Mas ficava tu indo e vindo, porque elas não queriam...

Jovem 2 - ...Elas não aceitaram em voltar na agricultura.

$\mathrm{P}$ - Elas eram de agricultura?

Jovem 2- Eram de agricultura, vieram na cidade, arrumaram trabalho e não quiseram mais voltar.

Outra manifestação eloqüente do estigma que pesa sobre o trabalho agrícola e sobre o meio rural - da perspectiva do ethos urbano da região mesma -, colhi por acaso. Eu acabara de entrevistar o presidente da associação que congrega os agricultores que comercializam sua

${ }^{86}$ O Censo de 2000 não chega a dar suporte a uma percepção tão extrema, mas mostra que todos os municípios da região tinham, na zona rural, razão de sexo superior a 100, o que expressa maior quantidade de homens do que de mulheres. A mais elevada, na Grande Santa Rosa, era a de São José do Inhacorá $(112,3)$. 
produção no Mercado Municipal de Santa Rosa, o que fiz na banca dele, onde estavam, também, duas de suas filhas, adolescentes de 13 e 14 anos (ele tem mais uma filha, adulta, que se casou e deixou a região). Esse produtor, Valdenir, abandonou um emprego que considerava bom, em uma empresa metalúrgica, para comprar terra e voltar a trabalhar "na roça". Esse relato se deu quase ao final de nossa entrevista, e motivou-lhe a seguinte colocação: "É que a gente se criou... A gente gosta do que faz. Nós somos colonos. Nós se 'criemos' na agricultura e gostaria de poder ficar na agricultura".

Em seguida, ele precisou encerrar nossa conversa, pois uma reunião da associação que ele preside estava por se iniciar. Na minha "aproximação", eu havia comprado um lanche em sua banca e, após desligar o gravador, permaneci ao balcão, para terminar de comer. No exato instante em que Valdenir se retirou, deu-se o seguinte diálogo, que não foi gravado, mas transcrevi o mais fielmente possível, minutos depois:

Menina (filha de 14 anos do Valdenir, dirigindo-se à irmã, de 13) - Eu detesto quando ele fala assim, "colono"!!

[pausa em que aguardei resposta, que não veio]

$\mathrm{P}$ - Desculpa, eu estava conversando com o teu pai sobre isso, posso te perguntar por que tu detesta quando ele fala "colono"?

Menina - Porque ele não é colono!

$\mathrm{P}-\mathrm{E}$ o que seria um colono?

Menina - Colono é quem só trabalha na terra, e ele não trabalha só na terra [referindo-se, provavelmente, à confecção caseira de alimentos que a família comercializa nesse Mercado Municipal]. Colono quer que os filhos continuem na agricultura. Eu estudo em colégio particular, o Dom Bosco [prestigiado]. Essa aqui [aponta a irmã] estuda no [escapou-me o nome da outra escola].

P - Não sei se eu entendi: o que o colégio tem a ver com isso de colono ou não colono?

Menina - Colono não põe filho em colégio particular!

$\mathrm{P}$ - Certo. E então, como é que seria certo dizer em que o teu pai trabalha?

Menina - Ele é agricultor.

$\mathrm{P}-\mathrm{E}$ no teu colégio tem muitos colegas teus que são filhos de agricultor?

Menina - Tem uma, na outra turma, que o pai dela é de Tuparendi [...].

$\mathrm{P}$ - Só uma?

Menina - Acho que é.

$\mathrm{P}-\mathrm{E}$ os outros colegas? Tu acha que eles fazem alguma diferença com quem é filho de agricultor?

Menina - Ah! Tem umas brincadeirinhas, né, o tempo todo! "Tu não mora: tu te esconde!”. Ou então “Teu pai é colono!”... (jun.07).

O que me pareceu interessante no diálogo foi o caminho relativamente longo que a jovem percorreu para explicitar as razões pelas quais a incomoda a designação "colono". Ela própria trai, de resto, o quão inútil é tentar afirmar diferenças entre subgrupos de produtores rurais: a distância que, tão veementemente, ela reivindica para seu pai, relativamente à "categoria de acusação", é absolutamente irrelevante para os colegas que ministram o estigma.

Como se percebe, a articulação entre o rural e o urbano, entre o agrícola e o não agrícola, nessas pequenas e médias cidades que compõem a região estudada é reconhecível, do ponto de vista da circulação de mão-de-obra ou do provimento de produtos e serviços, mas está longe de consagrar um "continuum" tão dúctil como sugeririam as formulações sobre o "rurbano". 
A própria circulação dos moradores das zonas rurais da Grande Santa Rosa pela cidade pólo - o máximo da urbanização, no contexto regional - era bastante restrita, há algumas décadas. O técnico Lírio, da Emater, contava-me, em 2002, que havia muita gente de 40, 50 anos de idade, nos municípios da beira do Rio Uruguai, que nunca havia visitado Santa Rosa. Já em 2007, um jovem de 15 anos (Air) encaixou, em uma frase, que seu tio tinha muitos amigos que haviam ido embora, "para cidade grande, assim que nem Tucunduva" - município que, no último Censo, tinha uma população urbana de 3,8 mil habitantes. Na mesma linha, conversando, no "interior" de Santo Cristo, com uma família de produtores, perguntei se a família da mulher era "daqui mesmo", e tive como resposta: "Não. Eles moram em Santo Cristo" - revelando que a localidade onde nos encontrávamos, embora integrando o município, não era o mesmo "aqui" que a sede urbana.

Em certo sentido, parece que "cidade grande" seria um pleonasmo, para alguns desses indivíduos, cuja existência está bastante circunscrita a uma pequena propriedade rural e suas imediações. As representações de alguns jovens sobre o trabalho e a vida na cidade, anteriormente referidas, indicam a permanência de uma contraposição bastante acentuada entre os estilos de vida urbano e rural: a necessidade de se pagar pelo "rancho" ou pela moradia parece estabelecer uma diferença muito sentida; as possibilidades de se envolver com "questões negativas" na cidade já foram também mencionadas...

Outro aspecto que merece ser registrado é o isolamento social que muitos dos jovens - e adultos de todas as idades - vivenciam, em seu cotidiano. Minha atenção foi despertada para esse aspecto na entrevista com Franciele, que tinha 17 anos e havia concluído o Ensino Médio no ano anterior. Ela começou recentemente a participar das atividades da Comissão de Jovens do sindicato de Santo Cristo, e celebra:

FRANCIELE - Eu estou começando a me envolver mais, assim, na comunidade, por que nós temos a comissão. E daí nós temos reuniões, e daí eu participo bastante. Antes não, sabe, era só em casa, assim, e agora não - agora eu saio com o Cláudio, eles têm cursos para fazer. Tem mais oportunidade com isso.

$\mathrm{P}$ - E quando tu estavas na escola, em geral terminava a escola, vinha direto, não tinha uma convivência mais assim...

FRANCIELE - Não, terminava a escola, vinha para casa. E no outro dia para escola de novo, aí voltava de meio-dia.

$\mathrm{P}$ - Em termos de sair com o pessoal do colégio, não tinha muito?

FRANCIELE - Não, não tinha isso.

$\mathrm{P}$ - Então no cotidiano é mais a família mesmo que tu convive?

FRANCIELE - Sim.

$\mathrm{P}-\mathrm{E}$ antes do sindicato, tu participou de alguma coisa, de igreja, ou de clube, ou de qualquer outro círculo de convivência?

FRANCIELE - Não, não participava.

O grupo populacional que enfatizei nesse tópico da pesquisa, os jovens dos minifúndios, tem efetivamente encolhido. No meio urbano da própria região, encontram-se, o tempo todo, exagricultores, com quem tratei, regularmente, sobre essa transição. Neste momento, no entanto, acho mais proveitoso, analiticamente, apresentar o ponto de vista dos jovens que dizem apreciar o 
trabalho agrícola e o meio rural, e nele desejam permanecer. Uma tal disposição fica, em geral, encoberta pela representação genérica de que as novas gerações anseiam por um estilo de vida urbano e, de resto, não têm perspectiva de prosperidade na atividade agropecuária.

\section{4. O gosto pela atividade rural, estímulos versus dificuldades e os trânsito ocupacionais}

Embora seja inegável a expressiva emigração de jovens do meio rural, isso não necessariamente se associa a uma apreciação negativa, por parte desses, frente à atividade agropecuária. Em geral, o argumento acionado pelos agricultores de menos idade, quando mencionam a perspectiva de deixar "a colônia", é a dificuldade de sobrevivência. Um coro de negativas foi a resposta que obtive de um grupo de adolescentes, com que conversei em um ônibus escolar que percorre a zona rural de Alecrim, quando perguntei se pensavam em seguir o mesmo trabalho de seus pais. Um deles declarou que ficar significava "passar fome".

Ainda assim, um número mais expressivo de jovens manifesta o desejo de permanecer no campo, e, mais do que isso, o gosto pela "lida".

Terei oportunidade, adiante, de discutir um pouco mais a posição das mulheres nesse universo, mas presumo que a firme presença delas dentre os produtores que entrevistei já deve ter chamado a atenção do leitor. Até por isso - e também porque, como vimos, parte dos depoimentos atribui uma maior aversão das mulheres ao trabalho e ao meio rural -, escolho aqui duas trabalhadoras para ilustrar o apreço que muitos jovens manifestam pelo trabalho agropecuário.

$\mathrm{P}-\mathrm{E}$ como é que... tu planeja seguir na atividade agrícola?

FRANCIELE - E com certeza.

$\mathrm{P}$ - Está se vendo, né [ela acaba de ser contemplada com o crédito fundiário e é titular de 5 hectares contíguos aos dos pais]. E tu, desde guria, tu tem essa vontade, como é que foi isso para ti?

FRANCIELE - Sim, desde pequena, sempre. Que nem no colégio, as minhas amigas: "Ah, tu quer ficar no interior. Tá louca!". Eu: "Por que não? É um trabalho que nem os outros, que na cidade".

$\mathrm{P}-\mathrm{E}$ as tuas amigas diziam isso pensando em quê? Elas pensam que tipo de...

FRANCIELE - Para muitos é tipo uma vergonha ficar no interior. Por que vergonha? É um trabalho que nem outro. Que nem tu fizer uma faculdade, alguma coisa.

$\mathrm{P}$ - Isso tu até pode fazer. Tu está seguindo ainda a escola?

FRANCIELE - Não, por enquanto ainda não. É que ano passado eu terminei o segundo grau.

$\mathrm{P}$ - Olha aí! Aplicada, ainda por cima.

FRANCIELE - É.

MÃE DA FRANCIELE - Aplicada, mas ela passou "assim", porque ela gostava mais de trabalhar de dia do que estudar. (...) Só de noite, estudar.

FRANCIELE - Ou de manhã. Eu levantava às cinco para fazer o tema rapidinho.

(...)

FRANCIELE - Eu odeio limpar casa. Eu prefiro ficar assim, fora, ajudando o pai, alguma coisa. Mas dentro, eu... A mãe sempre diz: "Aprende a cozinhar". Eu sei cozinhar o básico, mas eu também não gosto de fazer isso.

$P$ - Não se interessou?

FRANCIELE - Não. 
P - E o que tu gosta de fazer no trabalho, na lida aí do...

FRANCIELE - Eu gosto mais de trabalhar na horta, assim, ou vir cortar pasto, alguma coisa assim (17 anos, Santo Cristo).

Franciele é a primeira de duas filhas mulheres. Pode-se pensar que seu engajamento em atividades mais "tipicamente" masculinas tenha sido favorecido pela ausência de irmãos homens com quem partilhar tarefas de apoio aos pais. Por outro lado, um testemunho semelhante é apresentado por Cristiane, que tem um irmão, dois anos mais velho.

CRISTIANE - Olha, eu, na minha opinião, eu acho assim: muitas vezes... Porque eu morei na cidade, eu sei a diferença de morar na cidade de que morar no interior. Na cidade, você também tem hora para cumprir, também não é moleza, né. Só que no interior é outra realidade: você trabalha, muitas vezes, num serviço sujo, um serviço pesado, um serviço no calor, no frio, na chuva. Então, principalmente as mulheres, eu acho que é por isso que elas optam a ir trabalhar numa loja, a ir trabalhar de doméstica, de babá, porque elas sabem que é um serviço mais leve. Não deixa de ser um serviço, que também tu tem que cumprir horário e também tem que ser feito com responsabilidade, só que... (...) Eu acho assim: para trabalhar na agricultura tem que ter vontade, tem que ter interesse, porque se não... (...)

$\mathrm{P}$ - No teu caso, tu, desde que idade tu assumiu tarefas aqui na propriedade, na criação, na lavoura?

CRISTIANE - Desde muito pequena, assim. Até, no tempo que nós estudava, ia para o colégio... Meu irmão saiu muito cedo de casa, com 16 anos. Mas até esses 16 anos, ele também sempre trabalhou em casa. (...) Na sétima, oitava série, a gente, de manhã, eu acordava, ajudava a tirar leite - porque naquele tempo nós tirava leite a mão - hoje nós temos a ordenha. Então desde muito pequena, nove, dez, 11 anos, a gente já ajudava. Claro, fazendo o que conseguia. Não era obrigado, não tinha tarefas, assim, que tinha que fazer naquele dia - ia fazendo o que conseguia. E coisas mais leves, nada exagerado. Mas assim, desde... (...) Muitas vezes, assim, não era bem um serviço, mas só, assim, a gente estava junto, então a gente ia buscar alguma coisa... (...) Eu desde bem pequena, eu sempre gostei bastante de gado. Que nem, desde pequena, ajudava a tirar leite, quando nós tirava leite a mão (produtora em Santo Cristo, 22 anos).

O depoimento de Cristiane apresenta essa "comparação" entre o trabalho pesado, e os compromissos, no "interior" e na "cidade". Ela argumenta que já teve as duas experiências. Sua situação não é muito diferente da de muitos jovens de pequenas propriedades rurais: durante a idade de cursar o Ensino Médio, ela se transferiu para a sede urbana de seu município. Trabalhou como doméstica e babá, na casa de sua madrinha, e, segundo diz, teve propostas de emprego lá. Preferiu voltar para a propriedade familiar e para o trabalho agropecuário, mas, segundo muitos dos depoimentos, se constituiria, por isso, em uma exceção.

Quando eu conversei, por exemplo, com funcionários e assessores do Sindicato dos Trabalhadores Rurais de Tuparendi, eles enfatizaram muito o êxodo de jovens, e utilizaram o problema da escola como um sintoma e como um fator indutor desse fenômeno. Segundo eles, o município já teve 20 escolas no interior, e hoje tem duas ou três (hesitaram). Devido à redução da população em idade escolar - efeito do êxodo e da transição demográfica - nas diferentes localidades, concentram-se os alunos na sede urbana, dando a eles uma "cultura de cidade" (sic), 
que os desmotiva a retornar (ou se estabelecer) na propriedade agrícola familiar. Opiniões muito semelhantes eu colhi, tanto em 2002 quanto nessa segunda temporada, dos mais diferentes agentes.

Tampouco os pais, aparentemente - em especial após o advento da aposentadoria rural cujo radical impacto sócio-econômico tem merecido muitos estudos, em nível nacionl -, insistem em reter seus filhos na atividade primária.

Jovem 1 - E outro detalhe: a escola ensina para a profissão no meio urbano. A escola não ensina profissão pro meio rural.

Esposa - Não é só na escola: é em casa! As mães educam pros filhos ir embora - os pais. É incrível, eu perguntava para... [inaudível]. "Ah, não - vou dar estudo pro meu filho para ele não ficar aqui no interior". Por quê? Porque não está dando. Os pais vêem que não dá (almoço com jovens agricultores, Tuparendi, mai.07).

O "estudo" é, claramente, um recurso que fornece aos jovens uma alternativa ao trabalho no minifúndio, mais do que uma meta em si mesmo. Uma forte indicação nesse sentido me foi dada ao visitar a "Casa Familiar Rural", ONG que oferece para jovens cursos de três anos, direcionados à prática da agricultura familiar. Embora inclua conteúdos de escolarização, não fornece certificação. Dentre os alunos com que conversei ou entrevistei, a maioria havia evadido a escola. No caso de Air, 15 anos, o avô (que é o responsável pelo rapaz) decidiu que ele deveria deixar de estudar:

AIR - Eu parei na sétima.

$\mathrm{P}-\mathrm{Na}$ sétima do Primeiro Grau. E por que tu parou?

AIR - Por causa que assim, não tava dando muito... lucro, assim, estava gastando com mais material, né, e não tinha futuro, o meu avô que achou... Eu moro com o meu avô, né, ele achou que não tinha futuro continuar num colégio, assim, que... Nós que moramos no interior, assim, eles não falavam sobre os assuntos do... do que devia ser tratado mesmo, daí eu...

$\mathrm{P}-\mathrm{E}$ tu achou que o teu avô tomou a decisão correta?

AIR - Achei.

Contrariando a versão bastante generalizada na região, em especial dentre "lideranças", de que o Ensino Médio está praticamente universalizado, não foram poucos os exemplos que encontrei de jovens abandonando precocemente a formação escolar. Outro aluno da "Casa Familiar Rural”, Sanair, não apenas exemplifica esse fenômeno, como expõe sua percepção de que ele não é raro.

$\mathrm{P}$ - E o [irmão] anterior a ti fez até que escolaridade?

SANAIR - Fez a oitava também.

$\mathrm{P}-\mathrm{E}$ aí parou também?

SANAIR - Parou.

$\mathrm{P}$ - Eu achei que o Segundo Grau quase todos estavam fazendo, mas pelo que eu vim a conversar, não é bem assim: muitos estão deixando?

SANAIR - Muitos estão deixando.

$\mathrm{P}$ - É mais pelo tempo que o cara perde de trabalho, ou por que tu acha que não estimula, assim, que não dá vontade de fazer? 
SANAIR - (...) o jovem, como... se ele está mal em casa, com a família, ele quer se divertir, ele quer sair. Tu vai na escola, no fim de semana tu não pode trabalhar fora. $\mathrm{E}$ trabalhando em casa não dá muito lucro. Como agora: muita gente está procurando ["peão" - trabalho por diária] - como lá, onde que eu estou, eu podia trabalhar em três, quatro lugares. E daí, eles estão procurando empregado, o cara escolhe para trabalhar agora, que tem o dinheiro no final de semana. Tu vai na escola, ali, uma semana inteira, chega o fim de semana tu não tem dinheiro? Como é que fica daí? Não pode também, né.

$\mathrm{P}$-Mas o gosto por estudar, como é que foi enquanto tu estudou? Tu tinha dificuldade, gostava, não gostava, como era a tua relação com o colégio?

SANAIR - Olha, era até... Dá para dizer, até uma sexta série, por aí, eu gostava muito, eu queria ir, queria fazer o segundo grau. Eu fiz a oitava série, daí eu comprei livro, tinha que comprar livro. Paguei 150 reais. Daí eu estudei meio ano no primeiro, daí eu vi que eu não ia passar, que era mais difícil do que eu esperava, e daí...

$P$ - Isso era escola estadual?

SANAIR - É. E daí apareceu serviço - se eu podia trabalhar lá. Daí acabei deixando a escola e fui trabalhar. E depois, agora, foi que apareceu isso aqui [a Casa Familiar] (Sanair, 16 anos, Santo Cristo).

Uma evidência que não surpreende, mas de qualquer modo perturba, é que a evasão escolar se concentra no segmento de minifundiários mais pobres, que não têm expectativa de obter um retorno financeiro razoável trabalhando com suas famílias e/ou assumindo tarefas de "peão"; que, na eventualidade de herdarem algum pedaço de terra, essa será de dimensão desprezível; e, ademais, se vêem privados também das credenciais escolares mínimas para pleitear uma ocupação no espaço urbano. Para os jovens agricultores com que almocei em Tuparendi, essa polaridade aparece invertida: citam o exemplo de um jovem que, por ter condições financeiras e gostar da atividade agropecuária, não precisaria estudar para ter êxito econômico. Na opinião de meus interlocutores, o futuro de trabalho desse conhecido deles, na propriedade da família, não requereria formação escolar para encontrar êxito. Ironicamente, nesse caso a mãe força o jovem a estudar.

$\mathrm{P}$ - E tem os que querem ficar também, não é?

Jovem 1 - Que gostam. Lá na minha comunidade, tem gente, assim, ó: tem uma mãe que é professora, ela obrigou o filho a estudar, porque ele não queria. Por quê? Porque ele gosta de caça, pesca, lidar com trator, maquinário. Só que daí tem um detalhe: os pais dele têm mais condições, têm maquinário, trabalham com áreas maiores de lavoura, daí têm condições. O piá com... Ele, sozinho, ele praticamente, ele vai conseguir, porque tem condições. Agora você pega uma família com menos estrutura, menos condições, ele não vai se viabilizar financeiramente.

Jovem 2 - Não vai se manter na agricultura.

Jovem 1 - Ele vai trabalhar, trabalhar, e não vai encontrar renda.

O valor econômico da escolarização é inequivocamente considerado por essas famílias. Mais de um depoimento - em geral, quando se alude a uma prosperidade que não existe mais no meio rural da região - indicou que os pais de família costumavam beneficiar cada filho com um lote de terra (comprado especialmente, e não subtraído da propriedade familiar)... "ou o estudo":

Jovem 1 - Assim: o vô, no caso, foi comprando as terras e dando pros filhos.

(...)

$\mathrm{P}$ - Mas eles tinham ganho o seu lote?

Jovem 1 - Ganharam. Ou o estudo. 
$\mathrm{P}$ - Ah, "ou o estudo".

Jovem 1 - Ou o estudo. Porque com o trabalho deles, eles conseguiam pagar o estudo, porque daí tinha renda.

São dois aspectos que transparecem nessa alternativa: ou terra ou estudo significa que os "herdeiros" estarão pondo em equivalência os ganhos esperados por receber um ativo produtivo ou uma formação (que qualifica para o trabalho urbano). Por outro, o investimento dos pais tenderia a ser similar em ambos os casos - e eu não saberia dizer em que medida é "contabilizado" o tempo que o indivíduo que resolve estudar "subtrai" à força produtiva da família ou apenas os custos estritos de escola, material, etc.

Tendo ou não concluído a escolarização, estando ou não ainda a obtê-la, gostando ou não do trabalho na "colônia", os jovens com que conversei parecem nunca fechar as possibilidades de alterar seus planos ou percursos de trabalho. Penso que essa "disposição" reflete a experiência de outros indivíduos - não apenas os da mesma faixa etária, como também, em muitos casos, os familiares de gerações anteriores - que, no seu círculo social, descreveram trajetórias ocupacionais bastante descontínuas.

Esposa do Jovem 1 - Os meus pais sempre viveram da cidade pro interior, do interior para cidade. "Ah, mas [está bom] no interior: vamos pro interior". Daí: “Ah, mas não estava dando: vamos pra cidade".

$\mathrm{P}-\mathrm{E}$ a cidade é Tuparendi mesmo?

Esposa - Não, Guarani das Missões [muito próxima].

$\mathrm{P}$ - Guarani das Missões. E a terra, também lá?

ESPOSA - Eles têm, mas não é muito. E daí eles fazem tipo... Ficam naquele pouquinho lá, e daí não dá, sabe?

$\mathrm{P}-\mathrm{E}$ na cidade faziam o quê?

ESPOSA - A mãe trabalhava de empregada. O pai, [inaudível] pedreiro...

$\mathrm{P}-\mathrm{E}$ tem mais irmãos?

ESPOSA - Eu tenho mais três irmãos.

$\mathrm{P}-\mathrm{E}$ eles, onde é que andam?

ESPOSA - Eu tenho uma irmã que anda trabalhando por ali. Daí dois estão em casa. Só que, com certeza, um já é certo que não fica. E daí tem o pequenininho, de sete anos, mas daí vai saber se fica ou não fica.

MARIDO (JOVEM 1) - E até lá, esse, provavelmente, mais certo é que não vai ficar. Por quê? Do jeito que continua, quanto menos renda, menos as pessoas vão tender a ficar lá. Já os outros saíram, eles...

ESPOSA - Nós fomos obrigado a procurar um emprego, trabalhar de empregada doméstica, porque não dava. A gente queria uma roupa, o pai não tinha condições de dar para nós. Então o jeito era sair (almoço com jovens agricultores, Tuparendi, mai.07).

Essa moça, cujo nome não registrei, e com a qual não fiz uma entrevista sistemática, é filha de agricultores, trabalhou como metalúrgica em Santa Rosa (após fazer cursos preparatórios, também lá) e como doméstica (não sei onde), e desde que se casou mora com o marido na propriedade dos pais dele e voltou a se dedicar exclusivamente às atividades agropecuárias.

O pai de Andréa, por sua vez, tem um "currículo" altamente movimentado, entre localidades, da região e de fora, trabalhos agropecuários e urbanos. Poupo-nos de recompor as informações dadas pela moça; o que vale ressaltar é que em praticamente todas as mudanças de atividade, havia um ponto de apoio em algum parente. 
Uma impressão despertou-me interesse analítico, embora eu não tenha conseguido aferrála com segurança. Tanto nesse pequeno "mergulho" que fiz com o universo rural da região pesquisada, quanto nas entrevistas que fiz nas zonas urbanas, com indivíduos com permanência já longa na cidade, pareceu-me, que, nas biografias em que havia um histórico inicial de agricultura familiar, os trabalhadores tinham maior dificuldade de suportar a autoridade patronal/ gerencial. O principal sintoma são os relatos de abandono de empregos por iniciativa própria, em função de conflitos. Ainda assim, escolho como ilustração o exemplo de um dos operários que entrevistei em Santa Rosa, um homem de 63 anos que, há 37, encontra-se empregado na maior empresa industrial daquele município, de máquinas agrícolas. O trecho, mesmo com supressões, resulta longo, mas considero-o especialmente rico e interessante.

GERALDO - [sobre a entrada na fábrica, aos 26 anos, vindo do "interior"] - Muitas vezes eu estava, assim, de desistir. Porque a gente vir de um sistema de trabalho na colônia, e daí, na cidade, era... de manhã cedo, levantar cedo, era hora certa. (...) Eu chegava em casa, às vezes, de noite, digo: "Olha, eu vou desistir. Eu vou me embora". Aí o outro dia ela (esposa) ia lá... Enquanto eu estava trabalhando, ela ia lá falar com essa tia dela [cujo marido conseguiu o emprego para o Sr. Geraldo]. "Ah, o Geraldo está com isso..". "Não, mas deixa, que ele agüenta. Vamos dar um aumento para ele". E foi indo, foi indo, foi indo, e... durante os anos, né, então a gente foi... Trabalhava muito, assim, hora extra, então ganhava um dinheirinho extra. Então foi ajudando. Então...

$\mathrm{P}$ - O senhor tinha que acordar cedo - mas na colônia também acordava cedo.

GERALDO - Não, não era isso.

$\mathrm{P}$ - Era mais o tipo de trabalho, o ambiente, ou era ganhar pouco [ele havia se queixado do salário]?

GERALDO - É. Não, e muitas vezes, assim, por exemplo, no começo, como a gente não tinha muita prática, eles me botaram lá: "Tu vai fazer isso daqui”. Tinha que começar do zero. Então, só para te contar...

$\mathrm{P}$ - Um episódio.

GERALDO - É. Um episódio: tinha o meu chefe. Ele disse assim: "Olha, tu vai montar todos esses - tinha cinco plataformas de corte. (...) Tu vai... faz um pedaço com uma mão, a porca, e depois tu acerta com a chave". Daí eu comecei lá. Eu achei que tinha que apertar com os dedos. Quando eu vi, estava com os dedos cheios de bolhas. Aí, daqui a pouco, veio um cara, disse: "Como é que está indo, Geraldo?" Eu disse: "Tá bem, só que eu estou com as mãos cheias de bolhas". E ele disse: "Mas por que isso?" Eu digo: "É de apertar". Ele disse: "Não, mas é só para você pegar a ponta, depois aperta com a chave". [imita o riso do colega]

$\mathrm{P}$ - Então isso é que incomodava mais o senhor? Era esse tipo de situação de...

GERALDO - É. Aí chegava, às vezes, o chefe; porque o meu chefe era um dos patrão. (...) Então eles eram daqueles... tipo antigo, a maioria, uns alemão, assim, gringo. O que eles diziam, se isso aqui era uma pedra e ele dizia que era pau, era isso aí. Então, mais ou menos assim. Então eles olhavam... a gente... Nem que trabalhava bem, mas, assim, chegava ali, "o manguá pegava”!. (...) Aí tomava uma mijada, pô. Aí o cara se esforçava, daí a pouco tomava outra. Aí fiquei... Eu digo: "Bah, mas isso aí não me serve". Até que eu... o meu tio, muitas vezes, falava: "Não, Geraldo, isso é assim. Não adianta. Se eles estão... Nem que eles estão errado, mas o patrão é que manda. Se ele diz que é assim, tu tem que fazer assim". Aí fui me...

É o conselho (a autoridade) de um tio que pacifica, no Sr. Geraldo, a revolta que lhe causa a atitude do patrão. Essa intervenção repõe a ordem que ele conhecia em sua experiência de jovem trabalhador de minifúndio: tipicamente, o respeito que se deve, no trabalho, acompanha a 
hierarquia dos papéis familiares. Ao mesmo tempo, esse grupo familiar possui considerável grau de autonomia, ou mesmo de soberania, frente aos agentes que não o integram, ao menos no que diz respeito à condução dos seus processos produtivos e de trabalho. $\mathrm{O}$ mesmo vale para as estratégias de progresso e de enfrentamento das adversidades.

\section{5. O caráter familiar da vida econômica e dos projetos}

O minifúndio é tipicamente uma unidade de produção com uma força de trabalho exclusivamente familiar, o que em algumas situações a mantém relativamente apartada, inclusive no espaço, da interação cotidiana com outros sujeitos sociais. Embora, como tenho mostrado, a linha dominante nas trajetórias dos trabalhadores inclua a combinação ou a alternância de inserções no trabalho primário e em atividades urbanas, alguns membros das unidades, em especial - de acordo com o sexo e a idade -, desfrutam de poucas oportunidades de interação para fora do grupo familiar.

Tradicionalmente sob uma condução patriarcal - que vem sofrendo modificações, sem deixar de operar - o processo de trabalho vincula permanentemente relações (e "funções") sociais que, como característica básica da sociedade contemporânea, são separadas pela distinção das esferas do público (regido pelo trabalho) e do privado (sob a égide da família e do domicílio).

A particularidade do trabalho numa tal configuração - mais do que outras especificidades, como os aspectos técnicos da interação direta com a natureza - têm compreensível impacto na forma como os indivíduos vivenciam subjetivamente o próprio sentido de sua atividade laboral e concebem seus projetos de futuro.

$\mathrm{Na}$ pesquisa que realizei, chama a atenção, permanentemente, o quanto os planos - e mesmo os desejos - dos entrevistados, bem como os movimentos passados nas suas trajetórias ocupacionais, aparecem fortemente enredados às situações vividas pelos demais integrantes de suas famílias. Isso pode envolver vários aspectos, como a solidariedade - o sentido de parceria em uma potencial atividade, como no caso de Jaqueline.

$\mathrm{P}$ - E tu tem vontade, ou seria porque é uma continuação natural [seguir trabalhando na propriedade dos pais]?

JAQUELINE - Olha, vontade, vontade mesmo, eu não teria. Porque isso aí não... do jeito que está indo, também não tem muitas perspectivas. Mas, se todo caso, meu irmão volta [ele tem plano de comprar a terra ao lado, do tio], eu fico, por questão de companhia para minha cunhada, que nós se demos muito bem. Até, agora, eu quero fazer um curso ali através do sindicato, de processamento de frutas, que daí nós já estava pensando, né. Daí eu e ela fazer para vender (Jaqueline, 16 anos, que tem apenas esse irmão, de 34, há 15 anos fora da propriedade dos pais).

Muito freqüentemente, conforme já foi mencionado, é também no âmbito da família que se dá boa parte das transações fundiárias, que obedecem às necessidades e disponibilidades dos diferentes integrantes do grupo. 
ADEMIR - Nós tinha adquirido primeiro nove hectares. (...) onze ha foi com os herdeiros. Então dois herdeiros, daí foi comprado esses onze ha.

$\mathrm{P}$ - Os herdeiros seriam quem?

ADEMIR - Os irmãos do pai.

(...)

$\mathrm{P}$ - E o teu pai, esses nove que ele tinha antes, eram herança também, ou ele comprou?

ADEMIR - Não, esse foi comprado para... isso o pai dele deu de presente. A compra por família.

$\mathrm{P}$ - E os irmãos não queriam mais ou ele que quis expandir e propôs?

ADEMIR - Não, é que... assim, uma foi morar em outro... até no município de Santo Cristo, e a outra em outro lugar. Então não... (ajuntava) muito bem a propriedade. Então resolveram vender. Como nós já tinha instalação naquele lugar, né... é galpão, é casa, é tudo. Era só comprar e se manter ali.

Se, por um lado, a interdependência dos integrantes desses pequenos coletivos de trabalho viabiliza sua sobrevivência como empreendimento, uma eventual adversidade com algum deles e, nesse sentido, os episódios de saúde ganham destaque - pode comprometer toda a atividade econômica, não apenas porque o grupo precisa responder às necessidades de cuidado e de gastos com o familiar em questão, mas, muitas vezes, porque, a força de trabalho sendo tão exígua, a unidade produtiva não suporta sem traumas uma defecção.

ANDRÉA - A família da minha mãe, praticamente, moram tudo na cidade.

$P$ - Tiveram terra alguma vez?

ANDRÉA - Tiveram terra, só que tiveram que vender porque o falecido vô teve problema de saúde. Então foram morar pra cidade e venderam a terra.

$\mathrm{P}$ - Se vende para pagar os custos da saúde ou por que não tem como cuidar?

ANDRÉA - Não, é que é um tanto para pagar o custo e um tanto porque não tinha como ele chegar até na cidade, tivesse uma crise; que ele tinha problema no pulmão - ele fumava, bebia. Então deu câncer no pulmão. Daí eles foram morar na cidade, venderam as terras, compraram duas casas: uma eles alugaram. Agora, no momento, não está mais alugada, né. Compraram um carro, uma casa, e estão morando lá agora, na Sulina.

Em vários relatos, sente-se a força de uma obrigação moral com a continuidade da propriedade familiar, a partir da qual um balanço de compensações - especialmente entre irmãos leva a que a decisão de um familiar se paute pela iniciativa de outro. No depoimento abaixo, observa-se, igualmente, que as relações de parentesco têm uma efetividade que extrapola, por certo, os limites da unidade doméstica, envolvendo, da madrinha da cidade ao primo da Bahia.

CRISTIANE - Então eu fiquei lá [na cidade, na casa da madrinha] dois anos para terminar o Ensino Médio. Eu tive propostas de emprego, e outras, mas eu... não que eu não gostei, não que eu não me adaptei. Mas eu, quando eu voltei para casa, eu gostava de fazer o serviço em casa. E como aqui em casa também sempre faltou mão-de-obra, eu acabei ficando em casa. Se aqui em casa não tivesse serviço... Até, talvez, se meu irmão tivesse assumido ficar aqui em casa, se ele tivesse interesse, quem sabe eu teria saído. Mas como ele nunca teve muito interesse, e ele preferiu sair, então eu acabei ficando.

$\mathrm{P}$ - Quando ele saiu, que ele tinha 16 anos, ele foi para onde a primeira vez? CRISTIANE - Para Bahia. $P$ - E o que ele fez lá? Foi nesse esquema de ir para empresas também?

CRISTIANE - Ele foi trabalhar numa fazenda de um primo do pai. 
Na operação da vida econômica do minifúndio, os jovens relataram, invariavelmente, que o "caixa" é único, e que eles necessitam pedir - e, presumivelmente, justificar - aos pais os recursos para seus gastos pessoais com roupas, lazer, etc., muito embora tenham, em muitos casos, uma participação não menos intensa do que a dos seus genitores no trabalho familiar. Isso se prolonga mesmo quando os filhos já estão bem adentrados na vida adulta, como é o caso de Salef, 27 anos:

$\mathrm{P}-\mathrm{E}$ vocês, na família? O teu irmão tem 15 , é menor, tu já é maior. A história da grana que entra, da colheita, e tal. Em geral alguém centraliza, divide?

SALEF - É da família.

$\mathrm{P}$ - Da família. Mas aí... para gerenciar, por exemplo. Tu quer comprar uma coisa, ou tua mãe...

SALEF - Ah, tem que combinar em casa.

$\mathrm{P}-$ Quem é que fica com a chave do cofre?

SALEF - Ah, não sei. É o pai ou a mãe. Não sei.

$\mathrm{P}$ - Quando tu precisa, tu pede para eles?

SALEF - É, peço para eles.

$\mathrm{P}$ - A cada vez.

SALEF - Claro.

Essa hierarquia que confere aos pais - em especial ao pai - a autoridade maior sobre a alocação dos recursos ainda aparece com nitidez. Em alguns casos, isso se estende às decisões sobre o que e como produzir. Houve alguma menção à resistência dos mais velhos a inovar, bloqueando proposições dos mais jovens. Mas esse tipo de opinião eu ouvi sobretudo de agentes de instituições, mais do que dos próprios agricultores-filhos. Esses tenderam a conferir aos pais a disposição a, ao menos, ouvir e discutir as alternativas trazidas (em especial pelos três rapazes que cursam a Casa Familiar Rural de Santo Cristo). Mas também houve algumas queixas - neste caso, "compreensiva", até por partir do pressuposto de que a responsabilidade pela família é do(s) pai(s):

Jovem 1 - [A "gurizada"] (...) é bem mais aberta, porque... até num detalhe, assim, que a gente tem mais a facilidade de tu ver as coisas novas. Tu vê uma tecnologia: "Não, isso aqui vai ser bem mais fácil para mim". A gente consegue ver as coisas um pouquinho mais para frente. Daí tem bastante resistência. Até porque isso gera custo. E como o dinheiro está pouco, eles [pais] pensam: "Não, mas eu vou botar ali... Vamos dizer, eu tenho mil reais, vou botar 500. Se não der certo, como é que fica? Porque eu tenho a responsabilidade de dar a sustentação para essa família. E se eu não fizer correto?" (almoço jovens).

Arrisco a dizer que se processa, no meio rural da Grande Santa Rosa, um padrão de mudança nas relações intergeracionais não muito distinto, em intensidade, do que se observa no meio urbano. Porém, diferenças de natureza prosseguem, derivadas da natureza de um vínculo que não é apenas familiar: é também muito claramente um pilar da "empresa".

Quanto às relações de gênero, como já se observou e já foi enunciado, elas reservaram surpresas. Confesso que não esperava encontrar tantas jovens mulheres participando de modo tão ativo da gestão de suas propriedades ou de circuitos públicos como os sindicatos de trabalhadores 
rurais. Mantém-se uma divisão sexual do trabalho, talvez menos rígida, mas que prossegue se manifestando no fato, por exemplo, de que não há mulheres trabalhando como "peãs" (contratadas por diária para trabalhar nas propriedades alheias), e que seus destinos, quando ocupadas fora da terra da família, não têm grande variedade:

FRANCIELE - Ah, [as ex-colegas de escola] querem ir para cidade. Ah, mas na cidade não tem emprego para todos. Vai querer o que na cidade?

MÃE DA FRANCIELE - Porque agora elas estão em casa, porque dinheiro não têm para faculdade. Estão esperando uma oportunidade de emprego.

$\mathrm{P}$ - E alguma saiu da cidade já, das tuas amigas, ou a maioria está aqui?

FRANCIELE - Algumas estão aqui, mas umas foram para cidade já, estão trabalhando, acharam alguma coisa para fazer.

MÃE DA FRANCIELE - De empregada.

$P$ - E o que é, em geral - empregada e que mais?

MÃE DA FRANCIELE - Empregada ou balconista.

$\mathrm{P}$ - Basicamente empregada e balconista. Empregada em casa?

FRANCIELE - Sim, limpando casa, doméstica.

$\mathrm{P}-\mathrm{E}$, em geral, as gurias do teu conhecimento, elas pegam também no trabalho agrícola?

FRANCIELE - Não.

Franciele afirma que as meninas, em geral, não se integram ao "trabalho agrícola" expressão que eu próprio utilizei, na pergunta. Permito-me pôr em dúvida se sua resposta não espelha uma compreensão um pouco restritiva do que seja o "trabalho agrícola". Foi-me várias vezes referido que, nessas propriedades familiares pesquisadas, a divisão sexual do trabalho típica - independentemente da geração - põe a cargo dos homens as tarefas de lavoura, ao passo que hortas ou pomares, bem como o trato com os suínos, frangos e gado de leite - quando em pequeno número - seriam responsabilidade das mulheres. Uma dirigente sindical rural de Santo Cristo pioneira na organização nacional das mulheres, junto às organizações de trabalhadores da agricultura - contava-me, com hilaridade, que muitos homens, escorados nessa "tradição", vêm se beneficiando dos avanços tecnológicos acima referidos, no que tange ao cultivo de grãos, e não alocam o tempo liberado para "ajudar" as mulheres.

\section{$* * * *$}

A produção agrícola familiar distancia-se setorial, territorial e socialmente de uma concepção modelar de mercado de trabalho e reivindica - quando pouco pela sua dimensão quantitativa, no Brasil -, estatuto e reconhecimento nesse campo da reflexão sociológica. Essa configuração se demonstra profícua, ademais, para pôr em relevo dimensões analíticas que não têm recebido ênfase nos estudos sobre mercado de trabalho, independentemente de se tratar de formações sociais urbanas e/ou rurais.

A extensão em que se pode falar em mercantilização do trabalho é, nessas pequenas propriedades, particularmente limitada, seja pelo fato de que a "contratualidade" das relações de trabalho se eclipsa ante a força das relações familiares, seja pela ausência de remuneração monetária individualizada para os integrantes da unidade produtiva, seja, ainda, pelo peso 
(variável, mas praticamente generalizado), na alocação das capacidades laborais, de atividades voltadas para o chamado "auto-consumo", cujo produto se coloca à margem de qualquer transação. Em torno dessa forma de organização social e produtiva, outros mercados passam por uma refração, "localizando-se" - como pude observar no que diz respeito ao dinheiro, à terra e mesmo à escolha dos produtos cultivados para a comercialização, que obedecem a inércias cognitivas e institucionais.

Os minifundiários mantêm complexas e variadas conexões com o meio urbano e engajamse com freqüência em formas mercantilizadas de ocupação, que eles combinam ou alternam com a produção familiar, o que desaconselha qualquer tratamento dualista. Isso não impede, todavia, que - a despeito da continuidade física entre os territórios do rural e do urbano, na Grande Santa Rosa - as pequenas propriedades rurais conformem uma realidade diferenciada do ponto de vista espacial. O espaço, aqui, é compreendido em seu sentido multidimensional, anteriormente discutido, e isso se revela com clareza em um chiste que colhi em campo: quando os colegas de escola estigmatizam uma "filha de colono", um dos gracejos que utilizam é dizer que ela não "mora", mas "se esconde". Essa distância, por certo, não se estabelece em quilômetros: é eminentemente simbólica e, se esse depoimento, como tantos outros, aponta para uma depreciação da condição de agricultor familiar, não foi sem alguma surpresa que conheci um sem-número de "colonos", muitos deles bastante jovens, determinados a afirmar, por meio da continuidade de sua atividade produtiva, uma identidade que reivindicam e valoram muito positivamente.

Nos depoimentos, o conteúdo desse trabalho é contrastado, recorrentemente, às atividades urbanas. Tanto quem o aprecia quanto quem o deplora considera "pesado", "sacrificado", o trabalho na "roça"; destaca que não existem folgas (notadamente na lida com animais) e, nessa representação, é central a relação que se estabelece entre o trabalhador e a natureza, especialmente a meteorologia (trabalhar sob frio, calor ou chuva; perder cultivos por intempéries climáticas). $\mathrm{O}$ enfrentamento dessas adversidades serve de base a um sentimento de orgulho, proporcional ao desprestígio que é afirmado desde uma perspectiva "urbana". A essa "luta de classificações" associam-se diversas outras oposições que os minifundiários estabelecem entre a forma ou estilo de vida que conduzem e o meio urbano, tal qual o representam. Na apreciação que fazem de suas possibilidades de trabalho, cálculos "objetivos" com que cotejam ganhos (e despesas) que poderiam esperar, transferindo-se para a (alguma) cidade ou permanecendo em suas propriedades, misturam-se a fatores das mais diversas ordens, como compromissos de solidariedade com outros membros da família, comparações quanto à qualidade de vida em cada um desses espaços, considerações sobre relações hierárquicas no trabalho assalariado e, não menos importante, a vocação.

$\mathrm{Na}$ perspectiva de (re)construir, analiticamente, o mercado de trabalho da região pesquisada, o segmento que se encontra ocupado nos minifúndios impõe-se, em primeiro lugar, 
como uma parcela imponente (cerca de metade) da força de trabalho total, a produzir, a reproduzir-se e a "produzir espaço", na expressão de Milton Santos. Os resultados da pesquisa de campo desautorizam, por artificial, uma cisão dualista entre a pequena produção primária familiar e as atividades urbanas (ou, por outro corte, as ocupações assalariadas), já que esses circuitos se interpenetram, incontestavelmente, pela circulação dos indivíduos entre essas formas de trabalho (que eles alternam ou combinam) e, mais do que isso, pelo modo como, no interior das famílias, esses "trabalhos" diferenciados se distribuem entre os vários integrantes, como estratégia, mais deliberada ou menos, de compor uma unidade sustentável.

Essas evidências sobre os minifúndios estimulam que se questione se as pesquisas sobre os mercados de trabalho dos grandes centros urbanos não adotaram acriticamente a perspectiva da atomização, tributária da economia (neo)clássica, consagrando um desinteresse pelos arranjos familiares e microssociais que cercam a inserção dos indivíduos na ocupação e na geração de renda. No mesmo sentido, a afirmação de identidades e estigmas em torno de escolhas "vocacionais" e de trajetórias ocupacionais - que encontra um exemplo limite nos "colonos" seguramente pode ter correlatos analiticamente interessantes em outras configurações, aí compreendidas as metropolitanas. 


\section{CONCLUSÃO}

Neste estudo, a partir de uma investigação de assumida inspiração etnográfica, na região gaúcha nucleada pelo município de Santa Rosa, procurei articular duas vertentes bastante acesas na produção contemporânea das ciências sociais, as quais, curiosamente, têm estabelecido, até o momento, poucas intersecções analíticas.

A reflexão sobre mercados de trabalho persegue uma agenda repleta de novos desafios, mas nela tem se prolongado a tradição de delimitar espacialmente os objetos empíricos a partir das fronteiras político-administrativas ou institucionais tradicionais, bem como a de tomar formações sócio-espaciais de maiores dimensões como foco praticamente único de interesse. Duas convicções que poderiam justificar esse tratamento tornam-se crescentemente frágeis, e refiro-me, de um lado, a um princípio de representatividade - pelo qual os resultados obtidos nas grandes "praças", notadamente, as regiões metropolitanas, poderiam ser estendidos, mesmo que tendencialmente, ao conjunto das configurações sócio-espaciais que coexistem em uma mesma unidade nacional ou estadual -; de outro, a um critério, explícito ou implícito, de pertinência que só reconhece como objetos legítimos dos estudos de mercado de trabalho aquelas formações em que se reconheçam modelarmente os fenômenos (e escalas) confortavelmente abrangidos por uma abordagem mercantil.

Procurei discutir as fragilidades e as implicações que a adoção de tal matriz de pensamento pode ter sobre a cognição mesma das relações que se articulam em torno do trabalho social. Se está longe de ser verdade que o acervo acumulado de pesquisas sobre mercados de trabalho seja marcado por uma adesão majoritária à orientação da economia clássica e neoclássica, também é histórica a falta de teorizações alternativas que aprimorem ou disputem a representação que é feita dos mecanismos de mercado, e que permitam definir com maior rigor seu alcance e suas relações hierárquicas com outras ferramentas, em um sistema conceitual que tenha o trabalho como centro de interesse.

O direcionamento para semelhante tarefa encontra na nova sociologia econômica, quando pouco, uma conclamação. Um dos princípios que aglutina essa linha de pesquisas, reconhecida como uma "sociologia dos mercados", é sua ênfase à pluralidade, à historicidade, à subordinação que os mercados devem aos valores, interesses e estratégias que perpassam sociedades ou grupos sociais concretos. É neste ponto que se reconhece uma homologia e uma intersecção com a produção recente sobre o espaço - em que adentrei, em função de meu objeto, pelo caminho da categoria de região, para a seguir lançá-la a um "ninho", na expressão de Hollingsworth e Boyer, bem mais complexo.

Na realidade social contemporânea, estilhaça-se a visão estática de escalas espaciais e suas hierarquias, para afirmar-se a noção de um espaço em que múltiplos níveis ou escalas - global, supra-nacional, nacional, regional, local - imbricam-se, para dar contornos a configurações que 
são, por definição, históricas, portanto provisórias, e que só adquirem sentido nessa sobreposição de múltiplos recortes, apenas parcialmente coincidentes. Por certo referido a uma territorialidade em sentido físico, esse espaço define-se, também e necessariamente, a partir das dimensões econômicas, institucionais, culturais ou políticas da sociedade que o constitui como tal, no sentido em que Milton Santos fala do ato constante de "produzir espaço".

Ao eleger a Grande Santa Rosa como objeto de minha pesquisa empírica, valorizei, em primeiro lugar, essa orientação de diversidade e de irredutibilidade: essa formação regional concreta oferecia com nitidez essa multiplicidade de níveis de conexão espacial que venho de referir. Nela reconheci, ademais, ricos contrastes com os espaços tradicionalmente contemplados na reflexão sobre mercados de trabalho, nomeadamente as metrópoles.

Em um registro que se poderia dizer imediato, o caso da Grande Santa Rosa interpela a noção de mercado de trabalho de uma maneira interessante: uma parcela superior à quarta parte dos trabalhadores ocupados nessa região exerce trabalho não-remunerado ou enquadra-se na categoria "produção para o próprio consumo"; $40 \%$ da população vivem em zonas classificadas como rurais, e cerca de $50 \%$ da ocupação encontram-se na agropecuária; os tamanhos populacionais são muito pequenos, dentre tantas outras características que procurei destacar ao longo da exposição. Se as parcelas não-assalariadas do trabalho nas metrópoles são sobejamente reconhecidas e problematizadas na tradição brasileira de estudos do trabalho, o mesmo não parece valer para configurações como a que fui buscar. Também aqui, uma abordagem dualista não oferece interpretação satisfatória, demonstrando-se importante perseguir uma perspectiva de totalidade, nessa formação social concreta, que possui, como pude detalhar, uma significativa presença de atividades urbanas e industriais, com traços de modernidade inequívocos, o que deu oportunidade para uma integração analítica eloqüente com a dimensão espacial.

A experiência estudada propõe fenômenos sobre a configuração da problemática da ocupação que se distinguem qualitativamente dos que dominam os tradicionais estudos em realidades metropolitanas - o que talvez já a dote de algum interesse. Ela se revestiu, ademais, de uma segunda riqueza: devido à pequena escala populacional, às dimensões mais restritas de seu tecido empresarial, a uma certa "especialização" produtiva (no sentido de pouca diversificação) que também se associa ao porte, essa configuração favoreceu a experimentação de uma análise que tentou abranger e pôr em relação um leque mais amplo de eixos analíticos que recobram interesse em uma análise sociológica de mercado de trabalho, sem deixar de mirar a configuração territorial em seu conjunto. Isso não significa que os nexos sugeridos pelo estudo de caso sejam "transferíveis" para outras experiências concretas, mas que a pertinência de alguns deles possa ser melhor evidenciada, de modo a contribuir para o avanço da reflexão.

Se, por exemplo, a perspectiva "granovetteriana" sobre a força dos laços interpessoais e das redes sociais para condicionar as estratégias e oportunidades de trabalho foi afirmada com base 
em pesquisas com segmentos profissionais específicos, parece muito rico visualizar esses mecanismos operando em uma escala que recobre uma pequena localidade, na qual, como me disse um entrevistado, os conflitos são raros, na medida em que todo mundo é amigo e joga futebol junto.

É semelhante o que se poderia dizer sobre outras questões que, remetidas a configurações espaciais constituídas de modo muito particular, como se demonstrou a Grande Santa Rosa, podem - e talvez devam - ser repostas mais freqüentemente, nas investigações levadas a cabo em outros contextos: o peso, por exemplo, de que uma mega-empresa transnacional como a John Deere se reveste, em um município de 18 mil habitantes, como Horizontina, expõe, em um radical "concentrado", a importância de se atentar para a concepção de sonhos e projetos profissionais, por parte de jovens prestes a ingressar no mercado de trabalho, e para a forma como as seduções e restrições das oportunidades concretas condicionam, no nível mais íntimo, sua subjetividade. Quem não tentar ingressar na John Deere é "burro"; se não gostar do trabalho que há para ser feito nessa empresa, "aprende a gostar", disse-me um jovem metalúrgico. Aqui, novamente, o espaço se impõe como dimensão analítica de uma forma cristalina, como dificilmente ocorreria em um caso menos extremo.

A interveniência, nos projetos pessoais, de vida e de trabalho, dos fatores simbólicos associados ao prestígio do território e às representações sobre ele construídas, também ganhou um sentido muito preciso neste "caso". "Axon q mora no colonha é feio", escreveu, em um site de relacionamento, parodiando o falar alemão, um participante de uma comunidade que tem por temática Santa Rosa, ironizando as ácidas críticas que os demais haviam feito ao estilo de vida e às oportunidades que a cidade oferece.

A multiplicidade das questões cujo potencial interesse para o estudo eu procurei indicar foi muito grande. Para evitar que essa dispersão de interesses ultrapassasse um nível manejável, fechei o foco em duas configurações de muita importância na realidade regional pesquisada. Quando aprofundei a análise do município de Horizontina e, nela, o significado da empresa John Deere, o eixo espacial da pesquisa apareceu com uma solidez marcante. Aqui, a idéia de local que vem sendo avançada pelas teorizações recentes sobre território encontrou uma materialização exemplar: inserida em circuitos globais dos mais virtuosos e modernos, a cidade, se se contamina de surpreendente "cosmopolitismo", em alguns aspectos, convive com características que em nada cumprem as antecipações que, cinqüenta anos atrás, autores como Juarez Brandão Lopes faziam da trajetória dos espaços que "ainda" não eram "modernos", na concepção de então. A perspectiva de impessoalidade e racionalidade weberianas - que têm no mercado, de resto, uma pedra-detoque por excelência - seguramente não deslocou práticas que, em Sobrado ou Mundo Novo, o autor classificaria como pessoais, tradicionais ou patrimonialistas. Essas vão desde os critérios para pedir e conceder empregos na grande empresa até a ação do sistema público de emprego (de 
que se esperaria, naquela perspectiva teórica, a encarnação da burocracia em seu sentido mais asséptico). E no entanto, a localidade mantém-se próspera, sedia as práticas mais avançadas de gestão empresarial, com a planta industrial complexificando sua cadeia de suprimentos, utilizando sistemistas, trazendo uma globalidade palpável para dentro do município, e fazendo o caminho de volta. As articulações regionais, por sua vez, são múltiplas e analiticamente ricas, cabendo destacar a forma como, em Horizontina, a força de trabalho das outras localidades da região é mobilizada ou dispensada como recurso de flexibilidade numérica para a John Deere - sob um monitoramento que tem tal densidade institucional que muito se afasta da perspectiva clássica de mercados. Oferecendo o transporte para buscar e levar de volta muitos trabalhadores, ao início e ao término do expediente, nas cidades vizinhas - muitas vezes em propriedades rurais - , nos contextos de escassez de operários locais, a empresa e o município de Horizontina inscrevem no espaço da região uma inequívoca articulação, a qual é claramente hierarquizada, na medida em que a mão-de-obra "de fora" constitui nitidamente um setor secundário do mercado de trabalho, e sua fixação na cidade é permanentemente evitada. Para postos de trabalho de maior complexidade técnica, que exigem determinadas formações em nível superior e/ou alta especialização, a situação é oposta: atrair e reter profissionais provenientes de centros urbanos maiores é, muitas vezes, necessário, mas nem sempre fácil, pois a equação não se resolve, meramente, por uma oferta salarial "suficiente": o local impõe-se em toda a sua pluralidade de dimensões, em uma escolha como essa.

No outro destaque que fiz, a realidade dos minifúndios, especialmente de seus jovens, retoma alguns desses eixos de interesse, por manifestações diversas: se o corte espacial aqui mais relevante não é entre localidades, mas entre áreas urbanas e rurais, o olhar territorial sobre a região em seu sentido de configuração social e histórica localizada vai pôr em destaque outras imbricações, dessa vez entre as formas de trabalho primário e urbano, autônomo e ofertado, monetarizado e de subsistência. As diferenças, que não fundem essas formas do trabalho, se recriam diversamente e consagram uma considerável de circulação de indivíduos entre elas. $\mathrm{O}$ mercado aqui se afirma onde antes não penetrava, transformando, por exemplo, em "peão" o produtor familiar, integrado (muito seletivamente) a agroindústrias empresarialmente pujantes muito bem estruturadas e exigentes. Essa forma é representada por esses agricultores ambiguamente, como proteção ao risco e estabilidade de fluxos financeiros, mas também como um aviltamento da situação de autonomia que caracterizava seu trabalho. Ao mesmo tempo, outros mecanismos dos mais classicamente mercantis e universais se hibridizam, se "contaminam" pela cultura e pela tradição, como nos casos da persistência da saca de soja como moeda (unidade de conta, mais precisamente); do mercado de terras que impõe, pela fragmentação da estrutura fundiária, transações altamente personalizadas; da persistência das culturas de subsistência nos interstícios da produção para o mercado, e também o contrário. 
Laços de lealdade e obrigação familiar, o estigma contra o "colono" ou a valorização simbólica positiva do trabalho "sacrificado", emoções de encantamento ou aversão à vida urbana, oportunidades matrimoniais - todos esses fatores que apareceram articulados, a condicionar escolhas entre a "roça" e cidade compõem um ataque combinado às interpretações de corte utilitarista estreito. A espacialidade encontra-se nos conteúdos específicos que adquiriram, no tempo e nesse espaço, as representações simbólicas, a cultura, tanto quanto nas balizas tecnoeconômicas, fundiárias ou outras, a que acostumamo-nos a conferir maior objetividade.

$\mathrm{O}$ aporte que o universo rural traz, por meio desse estudo de caso, à discussão mais geral de mercados de trabalho parece-me residir, em parte, no fato de que, por não ter sido muito tematizado nos estudos sobre essa problemática, ultrapassa mais facilmente as camadas de tecnicalidade e as reificações que se constituíram em alguns níveis da reflexão sobre o trabalho que se construiu historicamente com base na realidade dos grandes centros urbanos.

A opção por tentar entender de modo articulado a multiplicidade de formas que assume o trabalho social parece bem mais conseqüente do que uma cisão em que a investigação de mercados de trabalho restrinja-se às situações mais tangíveis e quantificáveis de oferta e demanda de força de trabalho para a contratação sob a forma de emprego.

De qualquer forma, é importante que essas ambigüidades que têm sido carregadas em nossa reflexão sobre o trabalho sejam postas à prova, e, ao menos de uma perspectiva sociológica, isso não se faz sem o confronto com a realidade de sociedades que se diferenciam no tempo e no espaço. 


\section{BIBLIOGRAFIA}

ABBOT, Andrew. Sociology of Work and Ocupaccion. In SMELSER, Neil J., SWEDBERG, Richard (orgs). Handbook of Economic Sociology - 2a. Edição. Princeton University Press, 2005.

ABRAMOVAY, Ricardo. Entre Deus e o Diabo: mercados e interação humana nas ciências sociais. Mimeo, 2004.

ABRAMOVAY, Ricardo. Para uma teoria dos estudos territoriais (mimeo). Tradução do original, em espanhol, publicado em MANZANAL, Mabel, NEIMAN, Guillermo e LATTUADA, Mario. Desarrollo rural - Organizaciones, instituciones y territorios, Buenos Aires: Ciccus, p.51-70, 2006.

ABRAMOVAY, Ricardo. Paradigmas do Capitalismo Agrário em Questão. São Paulo/ Rio de Janeiro/ Campinas: Hucitec/ ANPOCS/ Editora da UNICAMP, 1992.

ACISAP - ASSOCIAÇÃO COMERCIAL, INDUSTRIAL, SERVIÇOS E AGROPECUÁRIA. ACISAP 70 anos: evolução que faz História (Edição especial 70 anos). Santa Rosa: ACISAP, 2001.

AMIN, Ash. ROBINS, Kevin. Regresso das economias regionais? A geografia mítica da acumulação flexível. In: BENKO, LIPIETZ. (org). As regiões ganhadoras - Distritos e redes: os novos paradigmas da geografia econômica. Oeiras, Celta. p.77-101. 1994.

AMIN, Ash; ROBINS, Kevin. Distritos Industriales y Dessarrollo Regional: Límites y Possibilidades. Sociología del Trabajo, Madrid, p.181-229, 1991.

BAGNASCO, Arnaldo. La Costruzione Sociale del Mercato. Bologna: Il Mulino, 1988.

BAGNASCO, Arnaldo. Tre Italie: la problematica territoriale dello sviluppo italiano. Bologna: II Mulino, 1977.

BALTAR Paulo E. de A., PRONI, Marcelo W. Sobre o Regime de Trabalho no Brasil: rotatividade da mão-de-obra, emprego formal e estrutura salarial. IN: OLIVEIRA, Carlos Alonso; MATTOSO, Jorge Eduardo (org.). Crise e Trabalho no Brasil - Modernidade ou volta ao passado? São Paulo: Scritta, 1996.

BANCO MUNDIAL. World Development Report 1999/2000: Entering the 21st Century: The Changing Development Landscape. Url: http://publications.worldbank.org/ecommerce/catalog/product?item_id=217053. 1999.

BARCELLOS, Tanya M. Roseta MAMMRELLA. Questões teóricas e metodológicas na pesquisa recente sobre as grandes cidades: notas para reflexão. Ensaios FEE, v. 22, n. 2, p.248-269, 2001.

BARON, James N., HANNAN, Michael T. The Impacts of Economics on Contemporary Sociology. Journal of Economic Literature, vol. XXXII, p.1111-1146, 1994.

BARQUERO, Antonio Vázquez. Desenvolvimento Endógeno em Tempos de Globalização. UFRGS. Porto Alegre, 280p.2001.

BARROS, Eliane Cruxên et alii.. RS: Imigração e colonização. Porto Alegre: Mercado Aberto, 1980.

BECATTINI, Giacomo. The Marshallian Industrial District as a Socio-economic Notion. In: PYKE, F.; BECATTINI G.; SENGENBERGER, W. Industrial districts and interfirm cooperation in Italy. Genebra: OIT, 1990.

BECK, Ulrich. O que é Globalização? Equívocos do Globalismo, Respostas à Globalização. São Paulo: Paz e Terra, 1999.

BENETTI, Maria D. Reestruturação do agronegócio no Brasil e no Rio Grande do Sul, nos anos 90. In: FLIGENSPAN, F. (Org.). Economia gaúcha e reestruturação nos anos 90. Porto Alegre: FEE, p. 63-116. 2000 
BENKO, Georges. LIPIETZ, Alain. O novo debate regional: posições em confronto. In: Benko, LIPIETZ. (org). As regiões ganhadoras - Distritos e redes: os novos paradigmas da geografia econômica. Oeiras, Celta. p.3-15. 1994.

BOTTAZZI, Gianfranco. On est toujours le 'local' de quelque 'global'. Pour une (re)définition de l'espace local. Espaces et Sociétés. Paris: L’harmattan. n. 82-83: Les échelles de l'espace social. P.69-92. 1996.

BOURDIEU, Pierre. O Poder Simbólico. Rio de Janeiro: Bertrand Brasil, (1989) 2004.

BOURDIEU, Pierre. The forms of capital. IN: BIGGART, Nicole W. (org). Readings in Economic Sociology. Oxford: Blackwell, 2002.

BOURDIN, Alain. A Questão Local. Rio de Janeiro, DP\&A, 2001.

BOYER, Robert. The Variety and Unequal Performance of Really Existing Markets: farewell to Doctor Pangloss? . IN: HOLLINGSWORTH, J. Rogers, BOYER, Robert (org). Contemporary Capitalism - The embeddedness of institutions. Cambridge: Cambridge University Press, p.55 a 93, 1997.

BREITBACH, Áurea C. M. Une dynamique régionale fondée sur la diversification industrielle: l'expérience de la région de Caxias do Sul, Brésil, tese de doutorado, Université de Paris I Panthéon - Sorbonne, 2003.

BRUSCO, Sebastiano. The Emilian Model: Productive Decentralization and Social Integration. Cambridge Journal of Economics, Londres, n.6, p.167-184, 1982.

CACCIAMALI, Maria Cristina, BRITTO, André. A flexibilização restrita e descentralizada das relações de trabalho no Brasil. Revista Brasileira de Estudos do Trabalho, v. 2, n.2, p.91-120, 2002.

CACCIAMALI, Maria Cristina. Política Social e Reforma Laboral no Brasil - Limites e Desafios. In: Anais do X Encontro Nacional de Economia Política, 2005.

CAMARGO, Cândido P.F. de et alii. São Paulo 1975: Crescimento e Pobreza. São Paulo: Loyola, 1976.

CANO, Wilson. (1994). Industrialização, crise, ajuste e reestruturação: algumas questões sobre o emprego e suas repercussões sobre a distribuição da renda. In: OLIVEIRA, Carlos A B. et alii (org.). O mundo do trabalho. São Paulo: Página Aberta.

CANO, Wilson. Brasil: desenvolvimento econômico e questão regional 1930-1990. Texto preparado para o 47th International Congress of Americanists, New Orleans, 7-11 jul.1991. mimeo, 41 p., 1991.

CANO, Wilson. Concentração e desconcentração econômica regional no Brasil: 1970/95. Economia e Sociedade, Campinas, (8):101-41, jun 1997.

CANO, Wilson. Desequilíbrios Regionais e Concentração Industrial no Brasil - 1930-1970. São Paulo: Global; Campinas: Ed. da Universidade Estadual de Campinas, 1985.

CARDOSO, Fernando Henrique, FALETTO, Enzo. Dependência e Desenvolvimento na América Latina - Ensaio de Interpretação Sociológica. Rio de Janeiro: Zahar, 1970.

CASTEL, Robert. As metamorfoses da questão social: uma crônica do salário. Petrópolis, Rio de Janeiro, Vozes, (1995) 2001.

CASTILHOS, Clarisse C. Sistemas locais de produção no RS: reflexões sobre seus limites e possibilidades enquanto política pública. In: CASTILHOS, Clarisse C. (org.) Programa de apoio aos sistemas locais de produção: a construção de uma política pública no RS. Porto Alegre, FEE, p.49-63, 2002.

CASTRO, Antônio Barros de. Sete Ensaios sobre a Economia Brasileira v. I - Rio de Janeiro: Companhia Editora Forense, (1969),1972. 
CHESNAIS, François. A Mundialização do Capital. São Paulo: Xamã. (1994) 1996.

CHRISTENSEN, Teresa N. de Sousa. Horizontina - História e Memória. Horizontina: Graficasa, 2007.

CORIAT, Benjamin. El taller y el Robot: Ensayos Sobre el Fordismo y Producción en Masa en la era de la Electrónica. México: Siglo XXI, 1992.

CORIAT, Benjamin. Globalization, Variety and Mass Production: the metamorphosis of mass production in the new competitive age. IN: HOLLINGSWORTH, J. Rogers, BOYER, Robert (org). Contemporary Capitalism - The embeddedness of institutions. Cambridge: Cambridge University Press, p.240-264, 1997.

COURLET, Claude. Novas dinâmicas de desenvolvimento e sistemas industriais localizados (SIL). Ensaios FEE, Porto Alegre, v.14, n.1, , p.9-35. 1993.

DALLABRIDA, V. Roque; BÜTTENBENDER, P. Luís, "A Organização Social para o Desenvolvimento: análise da experiência da região gaúcha "Grande Santa Rosa"” www.ucdb.br/coloquio/arquivos/65POR.doc, s/d.

DALLABRIDA, Valdir Roque. O Desenvolvimento Regional: a necessidade de novos paradigmas. Editora UNIJUÍ.152p. 2000

DOSI, Giovanni: MOGGI, Massino. Picccole e Medie Imprese e Innovazione in Italia. L'Industria, Bolonha, v.13 n.3, p.429-453, jul./set. 1992.

DUMONT, Louis. Homo aequalis: gênese e plenitude da ideologia econômica. Bauru: EDUSC, (1977) 2000.

ESPAÇO; DEBATES. Aliança e Competição entre Cidades. Revista de Estudos Regionais e Urbanos - Ano XVII - n.41, São Paulo, Editora NERU, 2001.

ESPAÇO; DEBATES. Nova Dimensão Regional. Revista de Estudos Regionais e Urbanos - Ano XIV - n.38, São Paulo, Editora NERU,1994.

FEEDados (banco de dados online) - disponível em www.fee.rs.gov.br.

FERNANDES, Florestan. Anotações sobre o capitalismo agrário e a mudança social no Brasil. IN: SZMRECSÁNYI, Tamás; QUEDA, Oriowaldo. Vida Rural e Mudança Social. São Paulo: Companhia Editora Nacional, págs: 131-150,1973.

FLIGSTEIN, Neil. Social Skill and the Theory of Fields. Mimeo, 2001(b).

FLIGSTEIN, Neil. The Architecture of Markets - an Economic Sociology of Twenty-First Century Capitalist Societies. Princeton/ Oxford: Princeton University Press, 2001(a).

GALVÃO, Carlos Antonio F., VASCONCELOS, Ronaldo R. Política Regional à Escala SubRegional: uma Tipologia Territorial como Base para um Fundo de Apoio ao Desenvolvimento Regional. Brasília. IPEA, Texto para discussão no 665.

GARCIA-PARPET, Marie-France. A construção Social de um Mercado Perfeito: o caso de Fontaines-en-Sologne. Estudos Sociedade e Agricultura, n. 20, p.5-44, 2003.

GARCIA-PARPET, Marie-France. Des outsiders dans l'économie de marché: Pierre Bourdieu et les travaux sur l'Algérie (mimeo). Versão revista da comunicação ao Colóquio "Histoire et Méthodologie de la sociologie économique", 2002.

GEREFFI, Gary. The Global Economy: Organization, governance and development. Mimeo, 2003 .

GOMES, Gustavo Maia. Desenvolvimento e Política Regional na União Européia. Brasília. D.F. IPEA, 119p. n. 483. (Texto para Discussão). 1997.

GORZ, André. Metamorfoses do Trabalho: Crítica da Razão Econômica. São Paulo: Annablume (1988), 2003. 
GRANOVETTER, Mark, SWEDBERG, Richard (org). The Sociology of Economic Life. Boulder, Westwiew Press, 2001.

GRANOVETTER, Mark. A Theoretical Agenda for Economic Sociology, (a ser publicado em GUILLEN et alii, "Economic Sociology at the Millenium", New York: Russell Sage Foundation, 2001) mimeo, 2000.

GRANOVETTER, Mark. Economic Action and Social Structure: the problem of embeddedness. The American Journal of Sociology, vol. 91, n. 3, p. 481-510, nov, 1985.

GRANOVETTER, Mark. The Sociological and Economic Approaches to Labor Market Analysis: a social structural view. IN , SWEDBERG, Richard (org). The Sociology of Economic Life. Boulder: Westview Press, p. 233-264, 2001.

GRAZIANO DA SILVA, José. O novo rural brasileiro. Nova Economia, 7(1):43-81, mai 1997 [versão em editor de texto, obtida na internet].

GUIMARÃES NETO, Leonardo. Dimensões, limites e implicações da desconcentração espacial no Brasil. Núcleo temático o equilíbrio federativo. FUNDAP, Instituto de Economia do Setor Público - IESP. 1995.

GUIMARÃES, Nadya A. Por uma Sociologia do Desemprego. Revista Brasileira de Ciências Sociais, vol. 17, n.50, p. 103-121, 2002.

GUIMARÃES, Nadya A. Transições Ocupacionais e Formas de Desemprego em São Paulo e Paris. Comunicação ao "Seminário sobre Estrutura Social e Segregação Espacial - São Paulo, Rio de Janeiro e Paris", CEBRAP, São Paulo, mimeo, 2004.

GUIMARÃES, Nadya, MARTIN, Scott (orgs). Competitividade e Desenvolvimento: atores e instituições locais. São Paulo: SENAC, 2001.

HAGE, Jerald, ALTER, Catherine. An evolutionary typology of interorganizational relationships and networks. IN: HOLLINGSWORTH, J. Rogers, BOYER, Robert (org). Contemporary Capitalism - The embeddedness of institutions. Cambridge: Cambridge University Press, p. 94 a 125, 1997.

HOFFMANN, Helga. Desemprego e Subemprego no Brasil. São Paulo: Ática, 1977.

HOLLINGSWORTH, J. Rogers, BOYER, Robert (org). Contemporary Capitalism - The embeddedness of institutions. Cambridge: Cambridge University Press, 1997a.

HOLLINGSWORTH,J. Rogers, BOYER, Robert. Coordination of Economic Actors and Social Systems of Production. IN: HOLLINGSWORTH, J. Rogers, BOYER, Robert (org). Contemporary Capitalism - The embeddedness of institutions. Cambridge: Cambridge University Press, p. 1-47, 1997b.

HOLLINGSWORTH,J. Rogers, BOYER, Robert. From National Embeddedness to Spatial and Institutional Nestedness. IN: HOLLINGSWORTH, J. Rogers, BOYER, Robert (org). Contemporary Capitalism - The embeddedness of institutions. Cambridge: Cambridge University Press, p. 433-484, 1997c.

IBGE. Censo agropecuário 1996-1996: Brasil. Rio de Janeiro: IBGE, 1998.

IBGE. Censo demográfico 1991: Rio Grande do Sul. Rio de Janeiro, IBGE, 1994.

IBGE. Censo demográfico 2000: características da população e dos domicílios - resultados do universo. Rio de Janeiro: IBGE, 2001.

IPEA, IBGE, UNICAMP. Caracterização e tendências da rede urbana do Brasil: configurações atuais e tendências da rede urbana. Brasília: IPEA, 2001.

KALLEBERG, Arne L., SORENSEN, Aage B. The Sociology of Labor Markets. Annual Review of Sociology, vol.5, p. 351-379, 1979. 
KAPLINSKY, Raphael. From Mass Production to Flexible Specialization: a Case Study of Microeconomic Change in a Semi-industrialized Economy. Word Development, Oxford, v. 22 n.3, p. 337-353, 1994.

KEYNES, John Maynard. A Teoria Geral do Emprego do Juro e da Moeda. São Paulo: Abril Cultural, (1936)1983.

KEYNES, John Maynard. A Teoria Geral do Emprego. IN: Keynes - coletânea organizada por SZMRECSÁNYI, Tamás. São Paulo: Ática, p. 167-179 (1937) 1978a.

KEYNES, John Maynard. O fim do "laissez-faire". IN: Keynes - coletânea organizada por SZMRECSÁNYI, Tamás. São Paulo: Ática, p. 106-126(1926)1978b.

KLARMANN, Herbert. Região e Identidade Regional: Um Estudo da Espacialidade e Representatividade Regional no Vale do Rio Pardo. Santa Cruz do Sul, UNISC - Tese de Mestrado, Programa de Pós-Graduação em Desenvolvimento Regional. 1999.

KON, Anita. A estruturação ocupacional brasileira: uma abordagem regional. Brasília: SESI, 1995.

KURZ, Robert. Com todo vapor ao Colapso. Juiz de Fora: UFJF - Pazulin. (2002) 2004.

LAMARCHE, Hughes (coord). A Agricultura Familiar - Comparação Internacional. v. I - Uma realidade multiforme. Campinas: Editora da UNICAMP, 1993.

LARANGEIRA, Sonia M. G. Fordismo e Pós-Fordismo. In: Cattani (org.). Trabalho e tecnologia. Petrópolis, Vozes, p. 123-127. 2002.

LAVINAS, Lena. GARCIA Eduardo H. e AMARAL, Marcelo R. Desigualdades regionais e retomada do crescimento num quadro de integração econômica. Rio de Janeiro: IPEA, Texto para discussão, nº 466, 1997.

LEBORGNE, Danièle; LIPIETZ, Alain. Idéss Fausses et Questions Ouvertes de I'Après-fordisme. COLÓQUIO: LES METROPOLES MONDIALES, 1990, Paris. Actes.Paris: [S.n.], 1990.

LENCIONI, Sandra. Região e Geografia. São Paulo: Editora da Universidade de São Paulo, 2003.

LEVINE, Donald N. Visões da Tradição Sociológica. Rio de Janeiro: Zahar (1995) 1997.

LIMA, Alessandro Dutra. Conselhos Regionais de Desenvolvimento: A participação da comunidade na elaboração do orçamento público no Rio Grande do Sul Porto Alegre, PUC, (Monografia). 1999.

LIPIETZ, Alain, O local e o global: personalidade regional ou inter-regionalidade? In: ESPAÇO; DEBATES. Nova Dimensão Regional. Revista de Estudos Regionais e Urbanos - Ano XIV n.38, São Paulo, Editora NERU,1994.

LIPIETZ, Alain. As relações capital-trabalho no limiar do século XXI. Ensaios FEE, Porto Alegre, FEE. V. 12, n.1, p. 101-130. 1991(a).

LIPIETZ, Alain. Verde que te quero verde. Entrevista a Ermínia Maricato, João Machado e Marco Aurélio Garcia. Teoria e Debate, São Paulo, p.64-71. 1991(b).

LISBOA, Armando de Melo. A crítica de Karl Polanyi à utopia do Mercado. Url: http://pascal.iseg.utl.pt/ socius/wp/wp002.pdf, 2000.

LOMBARDI, Mauro. L' Evoluzione del Distretto Industriale come Sistema Informativo: Alcuni Spunti di Riflessione. L'Industria, Bolonha, II Mulino, v.15, n.3, p.523-535, jul./set.1994.

LOPES, Juarez Brandão. Capitalism in the Periphery: Agrarian Conditions and The Development of the Working Classes in São Paulo (mimeo). São Paulo: CEBRAP, 1977.

LOPES, Juarez Brandão. Crise do Brasil Arcaico. São Paulo: Difusão Européia do Livro, 1967. 
LOPES, Juarez Brandão. Desenvolvimento e Mudança Social. São Paulo: Companhia Editora Nacional, (1968) 1972.

LYSON, Thomas A., FALK, William (org.). Forgotten Places: Uneven Development in Rural America. University Press of Kansas, 1993.

MAGGIOLINI, Piecarlo. As Negociações trabalhistas e a introdução de inovações tecnológicas na Europa. Petrópolis: Vozes, 1988.

MALERBA, Franco. The National system of innovation: Italy. In: NELSON, R. (Org.) National System of Innovation: a comparativa analysis. Oxford: Oxford University Press, 1993.

MANKIW, N. Gregory. Introdução à Economia: princípios de micro e macroeconomia. Rio de Janeiro: Campus, 1999.

MARSDEN, David. Sistemas de emprego: estratégias de gestão de recursos humanos no local de trabalho e instituições do trabalho. Tempo Social. São Paulo: USP, v. 16, n.2, p. 225-255, nov. 2004.

MARTINS, José de Souza. A Imigração e a Crise do Brasil Agrário. São Paulo: Livraria Pioneira Editora, 1973.

MARTINS, José de Souza. O Cativeiro da Terra. São Paulo: Hucitec, (1978) 1990.

MARTINS, José de Souza. Os camponeses e a Política no Brasil - As lutas sociais no campo e seu lugar no processo político. Petrópolis: Vozes, (1981) 1995.

MARX, Karl. O Capital - Crítica da Economia Política - Livro Primeiro. São Paulo: Nova Cultural (1867) 1988.

MATTOSO, Jorge Eduardo L. O novo e inseguro mundo do trabalho nos países avançados. In: OLIVEIRA, Carlos Alonso et alii (org.). O mundo do trabalho: crise e mudança no final do século. São Paulo: Página Aberta, 1994.

MINGIONE, Enzo. Sociologia della vita economica. Roma: Carocci Editore, (1997), 2003.

MOEN, Phyllis, DEMPSTER-McCLAIN, Donna, WALKER, Henry (org.). A Nation Divided: Diversity, Inequality and Community in American Society. Ithaca/ London: Cornel University Press, 1999.

MONTAGNER, Paula; BRANDÃO, S. M. C. Desemprego: novos aspectos de um mesmo problema. São Paulo em Perspectiva, v.10, n.1 São Paulo, p.36. 1996.

MOURA, Rosa. Dos espaços sem fronteiras às fronteiras dos espaços. IN: CASTELLO et alii (orgs). Fronteiras na América Latina: espaços em transformação. Porto Alegre: Editora da Universidade/UFRGS; Fundação de Economia e Estatística, 1997.

MTE - Ministério do Trabalho e Emprego. RAIS - Relação Anual de Informações Sociais. Brasília: MTE, diversos anos.

MÜLLER, Lúcia Helena A. Livre Mercado. Civitas - Revista de Ciências Sociais, v.3, n.2, p. 301-325, 2003.

NERI, Marcelo. Dynamics of Self-Employment Activities. ABET: VI Encontro Nacional de Estudos do Trabalho. Anais. (CD-Rom). 1999.

NOROESTE. Santa Rosa: Companhia Jornalística Noroeste. Semanário (diversos números).

NORONHA, Eduardo, TURCHI, Lenita. O pulo do gato da pequena indústria precária. Tempo Social, São Paulo: USP, v. 19, n.1., P.249-280, jun. 2007.

OFFE, Claus. Trabalho: a categoria-chave da sociologia? Revista Brasileira de Ciências Sociais, $\mathrm{n}$. 10, vol. 4, jun 1989. 
OLIVEIRA, Carlos Eduardo e MATTOSO, Jorge Eduardo (org.). Crise e Trabalho no Brasil modernidade ou volta ao passado? São Paulo: Scritta, 1996.

OLIVEIRA, Carlos W. de A. e GUIMARÃES NETO, Leonardo. Emprego Organizado e Regiões nos Anos 90: Quem perdeu mais? Estudos Econômicos, São Paulo, v.27, número especial, p. 37-64. 1997.

OLIVEIRA, Francisco de. Crítica à Razão Dualista. São Paulo: Vozes, (1972) 1981.

OLIVEIRA, Francisco de. Elegia para uma re(li)gião: Sudene, Nordeste, planejamento e conflito de classes. Rio de Janeiro, Paz e Terra, (1977) 1981.

OLIVEIRA, Francisco de. O elo perdido: classe e identidade de classe. São Paulo: Brasiliense, 1987.

PAOLI, Maria Célia P.M.. Desenvolvimento e Marginalidade: um estudo de caso. São Paulo: Livraria Pioneira Editora, 1974.

PÉREZ, Carlota. Mudança técnica, reestruturação competitiva e reforma institucional nos países em desenvolvimento. Discussion paper n. 4, Banco Mundial, 1989.

PIORE, M.; SABEL, C.The Second Industrial Divide. New York: Basic Books, 1984.

POCHMANN, Marcio. Emprego e desemprego juvenil no Brasil: as transformações nos anos 90 versão preliminar. Campinas: mimeo. 1998 a.

POCHMANN, Márcio. Velhos e novos problemas do mercado de trabalho no Brasil, Ensaios FEE, Porto Alegre: FEE, v.26, n.2, p. 119-139. 1998 b.

POLANYI, Karl. A Grande Transformação: as origens da nossa época. Rio de Janeiro: Campus, (1944) 1980.

PORTER, Michael A Vantagem competitiva das Nações. Rio de Janeiro: Campus, 1993.

PREBISCH, Raúl. Keynes: uma introdução. São Paulo: Brasiliense, 1998.

PUTNAM, Robert D. Comunidade e Democracia: a experiência da Itália moderna. Rio de Janeiro. FGV, 1996.

QUEIROZ, Maria Isaura Pereira de. Do rural ao urbano no Brasil. IN: SZMRECSÁNYI, Tamás; QUEDA, Oriowaldo. Vida Rural e Mudança Social. São Paulo: Companhia Editora Nacional, págs: 199-219,1973.

REICH, Michael, GORDON, David, EDWARDS, Richard. A Theory of Labor Market Segmentation. American Economic Review, v.63, n.2, p. 359-365, 1973.

REINECKE, Gerhard. Qualidade de emprego e emprego atípico no Brasil. IN: Abertura e ajuste de trabalho no Brasil: Políticas para conciliar os desafios de emprego e competitividade. São Paulo, Editora 34 Ltda. (p. 119 - 147), 1999.

RIO GRANDE DO SUL, Decreto-lei n. 35.764, de 28 de dezembro de 1994. Regulamenta a Lei ${ }^{\circ}$ 10.283, de 17 de outubro de 1994, que criou os Conselhos Regionais de Desenvolvimento CRDs. (a)

RIO GRANDE DO SUL, Lei n. 10.283, de 17 de outubro de 1994. Dispõe sobre a criação, estruturação e funcionamento dos Conselhos Regionais de Desenvolvimento e dá outras providências. (b)

ROBERTSON, Roland. Mapeamento da Condição Global: globalização como conceito central. IN: FEATHERSTONE, Mike (org). Cultura Global. 3ª edição Petrópolis: Vozes. P. 23-39. (1990). 1999.

ROCHE, Jean. A colonização alemã e o Rio Grande do Sul. t. I. (Coleção Província). Porto Alegre: Globo, (1962)1969. 
RODRIK, Dani. Has Globalization gone too far? Washington DC: Institute for International Economics, 1997.

ROSSETTI, José Paschoal. Introdução à Economia. São Paulo: Atlas, 2002.

ROTTA, Edemar. A Construção do Desenvolvimento. Análise de um "Modelo" de Interação entre Regional e Global. A experiência da Grande Santa Rosa. Editora UNIJUÍ, 1999.

SABEL, Charles F. Constitutional Orders: trust building and response to change. IN: HOLLINGSWORTH, J. Rogers, BOYER, Robert (org). Contemporary Capitalism - The embeddedness of institutions. Cambridge: Cambridge University Press, p. 154-188, 1997.

SABOIA, João. Desconcentração industrial no Brasil nos anos 90: um enfoque regional. Revista Pesquisa e Planejamento Econômico, Rio de Janeiro v.30,n.1, p.69-116. 2000.

SAMUELSON, Paul. Introdução à Análise Econômica. Rio de Janeiro: Agir, 1955.

SANTOS, Milton. A Natureza do Espaço - Técnica e tempo. Razão e Emoção. São Paulo: Editora da Universidade de São Paulo, (1996) 2004.

SANTOS, Milton. Por uma Geografia Nova - da crítica da geografia a uma geografia crítica. São Paulo: Editora da Universidade de São Paulo, (1978) 2002.

SASSEN, Saskia. As Cidades na Economia Mundial. São Paulo: Studio Nobel (1994) 1998.

SAYGILI, Seref. Is the efficiency wage hypothesis valid for developing countries? Evidence from the turkish cement industry. Mimeo, 1998.

SCHALlENBERGER, Erneldo, HARTMANN, Hélio Roque. Nova Terra, Novos Rumos - a experiência de colonização e povoamento no Grande Santa Rosa. Santa Rosa: Barcellos Livreiro e Editor, 1981.

SCHERER, André Luiz Forti. Globalização. In: Cattani (org.). Trabalho e tecnologia. Petrópolis, Vozes, p. 103-108, 2002.

SCHMITZ, Hubert. Industrial Districts: Model and Reality in Baden-Württemberg. In: PYKE, F.; SENGENBERG, W. Industrial districts and local economic regeneration. Genebra: Instituto Internacional para Estudos do Trabalho, 1991.

SCHMITZ, Hubert; MUSYCK, Bernard. Industrial Districts in Europe: policy Lessons for Developing Coutries? Word Development, Oxford, v. 22, n.6, p. 889-910, 1994.

SCHNEIDER, Sérgio. Teoria social, agricultura familiar e pluriatividade. Revista Brasileira de Ciências Sociais, vol. 18, n.51, fev. 2003

SEN, Amartya. Sobre ética e economia. São Paulo: Companhia das Letras (1987) 1999.

SILVESTRO, Milton Luiz et alii (coord). Impasses Sociais da Sucessão Hereditária na Agricultura Familiar. Florianópolis: Epagri; Brasília: NEAD/ Ministério do Desenvolvimento Agrário, 2001.

SMELSER, Neil J., SWEDBERG, Richard. The Sociological Perspective on Economy. IN. (orgs). Handbook of Economic Sociology. Princeton University Press, 1996.

SOUZA, Maria Carolina de A. F. A Especialização Flexível e as PMEs: Algumas Notas Sobre a Visão de Piore e Sabel. Ensaios FEE, Porto Alegre: FEE, v. 13. n.1, p.316-340, 1992.

SOUZA, Paulo Renato Costa. Emprego, Salários e Pobreza. São Paulo, Hucitec - Funcamp, 1980.

SOUZA, Paulo Renato Costa. Salário e Emprego em Economias Atrasadas. Campinas: Unicamp (1980), 1999.

STEINER, Philippe. La sociologie économique. Paris, La Découverte, 1999.

STEINER, Philippe. Le marché vu par la sociologie économique. Mimeo, 2004. 
STERNBERG, Sheila S. Wagner, JORNADA, Maria Isabel H. da; XAVIER SOBRINHO, Guilherme G. de F. O emprego formal no RS nos anos 90: diferenciais na retração. Indicadores Econômicos FEE, Porto Alegre: FEE, v.27, n.4, p.209-248, 2000.

STORPER, M. Industrialization, Economic Development and the Regional Question in the Third World. From Import Substitution to Flexible Production. Londres: Pion Limited, 1991.

STREECK, Wolfgang. Beneficial constraints: on the economic limits of rational voluntarism. IN: HOLLINGSWORTH, J. Rogers, BOYER, Robert (org). Contemporary Capitalism - The embeddedness of institutions. Cambridge: Cambridge University Press, p. 197 a 219, 1997.

STREECK, Wolfgang. The Sociology of Labor Markets and Trade Unions. In SMELSER, Neil J., SWEDBERG, Richard (orgs). Handbook of Economic Sociology - 2a. Edição. Princeton University Press, 2005.

SWEDBERG, Richard. Economic Sociology: Today and Tomorrow. Mimeo, 2004.

SWEDBERG, Richard. Max Weber e a Idéia de Sociologia Econômica. Rio de Janeiro/ São Paulo: UFRJ/Beca Produções Culturais, 2005.

TARGA, Luiz Roberto Pecoits, org. O Rio Grande do Sul: fronteira entre duas formações históricas. In: TARGA, L.R.P. Gaúchos; Paulistas: dez escritos de história regional comparada. Porto Alegre: FEE, 1996.

TICKAMYER, Ann R. Space Matters! Spatial Inequality in Future Sociology. Contemporary Sociology, vol. 29, n. 06, p. 805-813, nov. 2000.

TRIGILIA, Carlo. Economic Sociology: State, market and society in a modern capitalism. Oxford: Blackwell Publishers, 2002.

TROYANO, A et alii. A necessidade de uma nova conceituação de emprego e desemprego. São Paulo em Perspectiva. São Paulo. Fundação SEADE. 1985.

VEIGA, José Eli da. Destinos da ruralidade no processo de globalização. Estudos avançados, 18(51), 2004.

VERSCHOORE FILHO, Jorge Renato de Souza. Participação e cooperação: elementos para uma nova política de desenvolvimento regional. Ensaios FEE, Porto Alegre, v. 22 n. 1 p. 86-114, 2001.

VILLASCHI FILHO, A. CAMPOS, R.R. Sistemas/arranjos produtivos localizados: conceitos históricos para novas abordagens. In: CASTILHOS, Clarisse C. (org.) Programa de apoio aos sistemas locais de produção: a construção de uma política pública no RS. Porto Alegre, FEE, p. 11-48. 2002.

WALLERSTEIN, Immanuel. A Cultura como Campo de Batalha Ideológico do Sistema Mundial Moderno. IN: FEATHERSTONE, Mike (org). Cultura Global. 3ª edição Petrópolis: Vozes. P. 41-67. (1990). 1999.

WEBER, Max. Economia y Sociedad. México: Fondo de Cultura Económica, (1922) 1969.

WILKINSON, John. Sociologia Econômica, a teoria das convenções e o funcionamento dos mercados: inputs para analisar os micro e pequenos empreendimentos agroindustriais no Brasil. Ensaios FEE, v. 23, n.2, p. 805-824, 2002.

XAVIER SOBRINHO, Guilherme G. de F. et alii. Mercados de Trabalho Não-metropolitanos apontamentos sobre quatro experiências regionais no Rio Grande do Sul (Brasil). Anais do $4^{\circ}$ Congreso Latinoamericano de Sociología del Trabajo. ALAST (Asociación Latinoamericana de Sociologia del Tabajo) - Cd-Rom (ISBN 959-032-X). La Habana, Cuba, 9 a 12 setembro de 2003.

XAVIER SOBRINHO, Guilherme G. de F., STERNBERG, Sheila S. Wagner, JORNADA, Maria Isabel $\mathrm{H}$. da. Escolaridade do trabalhador formal no RS: evolução em um quadro de diversidades regionais. Indicadores Econômicos FEE, v. 28, n.3, 2000. 
XAVIER SOBRINHO, Guilherme G. de Freitas. Distritos Industriais. In: Cattani (org.). Trabalho e tecnologia. Petrópolis, Vozes, p. 76-82, (1997) 2002(b).

XAVIER SOBRINHO, Guilherme G. de Freitas. Especialização Flexível. In: Cattani (org.). Trabalho e tecnologia. Petrópolis, Vozes, p. 103-108, (1997) 2002(a).

XAVIER SOBRINHO, Guilherme G. de Freitas. Longe da metrópole: singularidades de um mercado regional de trabalho no Rio Grande do Sul dos anos 90. Indicadores Econômicos FEE, Porto Alegre, FEE, 3(32): 31-62, 2004.

XAVIER SOBRINHO, Guilherme G. de Freitas. Modelo Italiano. In: Cattani (org.). Trabalho e tecnologia. Petrópolis, Vozes, p. 183-190, (1997) 2002(c).

ZELIZER, Viviana. The social meaning of money. IN: BIGGART, Nicole W. (org). Readings in Economic Sociology. Oxford: Blackwell, 2002. 